\title{
RESPONSABILIDADE ESPECIAL DOS AGENTES ECONÔMICOS DOMINANTES
}

Tese de Doutorado

Orientador: Professora Dra. Paula Andréa Forgioni

\author{
UNIVERSIDADE DE SÃO PAULO - USP
}

FACULDADE DE DIREITO

São Paulo - SP 
BRUNO DE LUCA DRAGO

\section{RESPONSABILIDADE ESPECIAL DOS}

\section{AGENTES ECONÔMICOS DOMINANTES}

Tese apresentada à Banca examinadora do Programa de Pós-Graduação em direito, da Faculdade de Direito da Universidade de São Paulo, como exigência parcial para obtenção do título de Doutor em Direito, na área de concentração Direito Comercial, sob orientação da Professora Dra. Paula Andréa Forgioni.

UNIVERSIDADE DE SÃO PAULO - USP

FACULDADE DE DIREITO

São Paulo - SP 


\section{$\underline{\text { ÍNDICE }}$}

CAPÍTULO 1 INTRODUÇÃO AO TEMA

\section{CAPÍTULO 2 EVOLUÇÃO E IDENTIDADE DO DIREITO CONCORRENCIAL}

2.1. Processo Histórico-Evolutivo do Direito Concorrencial e o Tratamento do Poder Econômico.

2.1.1. Primórdios das Normas de Defesa da Concorrência: Caráter Imediatista e Autopreservativo do Mercado.... .29

2.1.2. Normas de Defesa da Concorrência como Regramento Institucional do Estado Contemporâneo.

2.2. Escopo das Normas de Defesa da Concorrência 43

2.3. Papel do Direito na Regulação dos Mercados .57

2.4. Teoria Econômica. .65

2.4.1. O papel e Relevância da Teoria Econômica.. 65

2.4.2. Falhas de Mercado e Correção do Sistema ..... .70

2.4.3. A Teoria da Regulação. .73

2.4.4. A Função Social Segundo a Teoria da Regulação 80

2.4.5. Mercado Relevante e sua Análise Dinâmica. 84

2.4.6. Monopólios, Poder de Mercado e Posição Dominante .96 
2.5.1. Externalidades de Rede e Efeitos Lock-in 108

2.5.2. Direitos de Propriedade Intelectual 110

2.5.3. Convergência Tecnológica 112

\section{CAPÍTULO 3 NOVO SISTEMA JUS-CONCORRENCIAL BRASILEIRO}

3.1. Garantias Constitucionais Jus-Concorrenciais do Estado e dos Administrados.. 114

3.1.1. Princípios Constitucionais Concorrenciais Consagrados. 118

3.1.2. Demais Princípios Constitucionais Aplicáveis. 120

3.2. A Concorrência Como Garantia Institucional 123

3.3. A Função Social na Atividade Empresarial 128

3.4. A Nova Lei de Defesa da Concorrência Brasileira. 135

3.4.1. A Antiga Lei n. 8.884/94 e sua Evolução. 135

3.4.2. O Novo Diploma Legal e seus Ajustes de Rumo. 137

3.4.3. A Presunção de Poder de Mercado sob o Novo Diploma. 138

3.4.4. O Novo Regramento de Penas Previsto.

\section{CAPÍtUlo 4 A TEORIA dO ABUSO DE POSIÇÃO DOMINANTE COMO ELEMENTO DE AMPARO ÀS RESPONSABILIDADES ESPECIAIS.

4.1. O Abuso de Posição Dominante.

4.1.1. Exploração do Estado de Dependência Econômica 145

4.2. Espécies de Infrações e Respectivas Qualificações

4.2.1. Efeitos Lesivos das Condutas Unilaterais. 
4.2.2. Espécies de Condutas Exploratórias e Tratamento Emprestado. 149

4.2.3. Espécies de Condutas Excludentes e Tratamento Emprestado. 152

4.2.3.1. Recusa de Contratação

4.2.3.2. Venda Casada 156

4.2.3.3. Preços Predatórios 159

4.2.3.4. Descontos de Fidelidade. 165

4.2.3.5. Exclusividade 167

4.3. Guias de Análise de Abuso de Poder. 169

4.4. Introdução às Formas de Defesa Garantidas aos Agentes Dominantes 174

\section{CAPÍtUlO 5 TRATAMENTO COMPARADO DO ABUSO DE POSIÇÃO DOMINANTE: ESTADOS UNIDOS .

5.1. Tratamento Normativo Norte-Americano 176

5.2. Organização do Sistema Legal Norte-Americano. 179

5.3. Construção Jurisprudencial e Doutrinária Norte-Americana 184

5.3.1. Formação e Aplicação Inicial da Seção 2 do Sherman Act. 184

5.3.2. Recusa de Contratação 188

5.3.3. Venda Casada 197

5.3.4. Preços Predatórios .202

5.3.5. Descontos de Fidelidade e Multiprodutos 205

5.3.6. Exclusividade 208 


\section{CAPÍtUlO 6 TRATAMENTO COMPARADO DO ABUSO DE POSIÇÃO DOMINANTE: UNIÃO EUROPEIA .................................................................................2212}

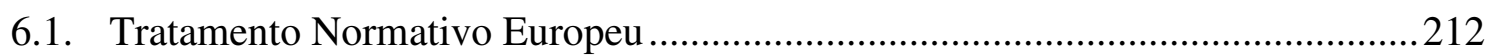

6.2. Organização do Sistema Concorrencial Europeu ............................................2 214

6.3. Construção Jurisprudencial e Doutrinária Europeia .........................................216

6.3.1. Formação e Aplicação Inicial do Artigo 82 .....................................216

6.3.2. Recusa de Contratação .................................................................2231

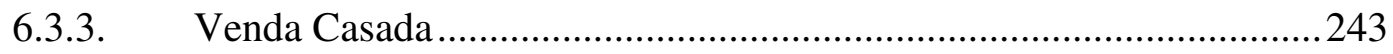

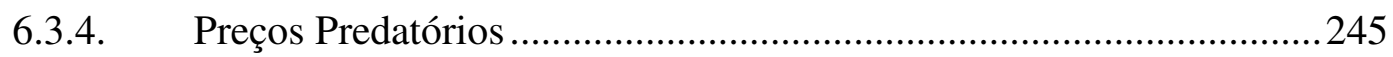

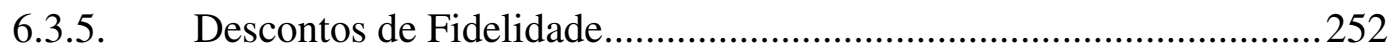

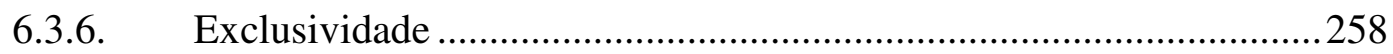

6.4. Tratamento da Doutrina Relativamente às Responsabilidades Especiais ............261

CAPÍTULO 7 TRATAMENTO NORMATIVO, DOUTRINÁRIO E

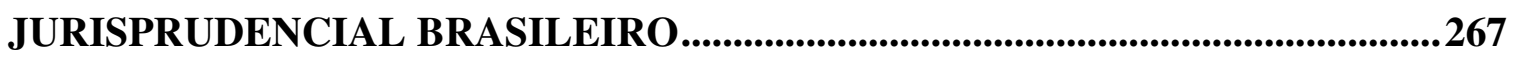

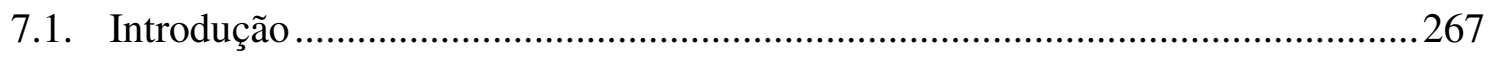

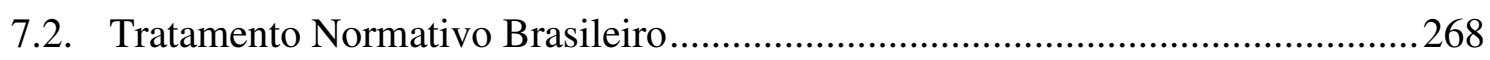

7.3. Organização do Sistema Jus-Concorrencial Brasileiro.....................................2278

7.4. Construção Jurisprudencial e Doutrinária Brasileira ..........................................221

7.4.1. Recusa de Contratação ............................................................... 281

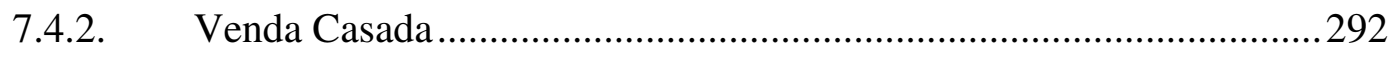


7.4.3. Preço Predatório 298

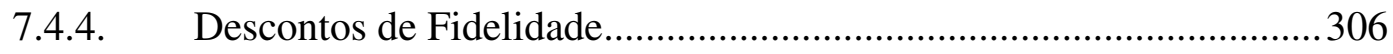

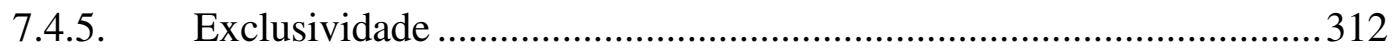

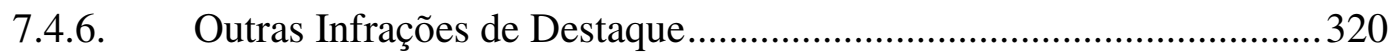

\section{CAPÍTULO 8 ANÁLISE APLICADA DA TEORIA DAS RESPONSABILIDADES

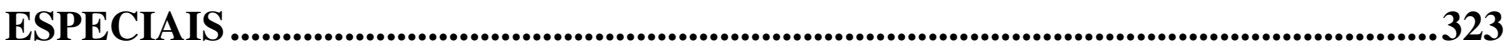

8.1. Análise Comparativa da Teoria do Abuso de Posição Dominante como Elemento de Apoio.

8.2. Os Casos Microsoft: Análise Comparativa Aplicada.

8.2.1. Caso Microsoft nos Estados Unidos.

8.2.2. Caso Microsoft na União Europeia 340

8.2.3. Caso Microsoft no Brasil. 344

8.3. Sistematização dos testes para determinação de abusos. 349

8.4. Ausência de Sistematização nas Decisões do SBDC e Influência dos Princípios Aplicáveis: o Dever-Ser do Sistema Jus-Concorrencial Brasileiro. 365

8.5. Análise Comparativa do Tratamento da Responsabilidade Especial ...... 371

8.6. Abuso de Poder e Responsabilidade Especial: Reconhecimento da Interdependência Das Teorias. 375

8.7. Teoria do Abuso de Poder Econômico: Concorrência no Mérito 377

8.8. Reconhecimento da Livre Concorrência como Garantia Institucional. 380

8.9. Aplicação Sugerida da Tese de Responsabilidade Especial. 386 
8.10. Defesas Disponibilizadas aos Agentes com Posição Dominante

393

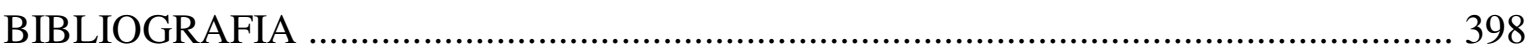


"It is excellent to have a giant's strength; but it is tyrannous to use it like a giant." William Shakespeare 
DRAGO, Bruno De Luca. Responsabilidade Especial dos Agentes Econômicos Dominantes. 2015. Doutorado - Faculdade de Direito, Universidade de São Paulo, São Paulo, 2015.

Resumo: Agentes econômicos com posição dominante são capazes de se conduzir de maneira independente na sua atividade comercial. Da mesma forma, possuem todos os incentivos para manutenção desta posição, em detrimento de seus concorrentes, fornecedores e clientes. O presente trabalho visa, inicialmente, em estudo comparado da doutrina e jurisprudência no Brasil, União Europeia e Estados Unidos, identificar os elementos de cognição da teoria do abuso de posição dominante para cinco modalidades de conduta. A partir daí traçamos seus elementos de correlação com o propósito de sugerir uma teoria aplicada ao ordenamento jurídico pátrio, que passa pelo reconhecimento da concorrência como garantia institucional, de forma a estabelecer-se igualdade material segundo a teoria da função social dos meios de produção. A presença constante da concorrência nos mercados deve ser tratada como presunção de bem-estar social. E finalmente, valendo-se destes elementos de suporte, propomos uma teoria da responsabilidade especial para agentes econômicos em posição dominante, que implicaria o dever de autoaplicação dos limites permitidos para sua conduta comercial, cujo descumprimento ensejaria presunção relativa de efeitos deletérios ao mercado, segundo os parâmetros propostos.

Palavras-chave: responsabilidade especial; abuso de posição dominante; recusa de contratação; venda casada; preço predatório; desconto de fidelidade; exclusividade; função social dos meios de produção; concorrência no mérito. 
DRAGO, Bruno De Luca. Special Responsibility of Dominant Firms. 2015. Doctorate Faculty of Law, University of São Paulo, São Paulo, 2015.

\begin{abstract}
Firms enjoying dominant position are able to conduct themselves independently in their commercial activities. Likewise, they hold all due incentives to maintain such position, in detriment of their competitors, suppliers and clients. The present work aims, initially, through a comparative study of the Brazilian, the European Union and the United States' legal doctrine and jurisprudence, to identify cognitive elements of the abuse of dominance theory, for five different natures of conducts. Subsequently, we identify their elements of connection with the purpose of suggesting a theory applicable to the local legal system, which includes the recognition of competition as an institutional guarantee, so to establish a material equality according to the theory of social function of productive assets. The constant presence of competition on the markets shall be treated as a presumption of social welfare. And finally, based on such supportive elements, we propose a theory of special responsibility for dominant firms that implies in a duty of self-application of the permitted limits for their commercial conduct, and which infringement would entail a relative presumption of harmful effects to the market, pursuant to the proposed parameters.
\end{abstract}

Keywords: special responsibility; abuse of dominance; refusal to deal; tying/bundling; predatory price; fidelity rebates; social function of productive assets; competition on the merits. 
DRAGO, Bruno De Luca. Responsabilité spéciale des agents économiques dominants. 2015. Doutorado - Faculté de Droit, Université de São Paulo, São Paulo, 2015.

Résumé: Les agents économiques avec une position dominante sont capable de se comporter de façon indépendente face a ses activités commerciales. En même temp, ils ont tout intérêt à maintenir cette position au détriment de ses concurrents, fournisseurs et clients. Le présent ouvrage, initialement, fait un étude comparative de la doctrine et de la jurisprudence au Brésil, a l'Union européenne et aux Etats-Unis, identifiant les éléments cognitifs de la théorie de l'abus de position dominante par cinq types de conduite. Aprés, nous identifiant les éléments de corrélation afin de proposer une théorie appliquée au système juridique brésilien, qui comprend la reconnaissance de la concurrence comme une garantie institutionnelle, d’une façon a établir une égalité matérielle selon la théorie de la fonction sociale des moyens de production. La présence constante de la concurrence dans les marchés devrait être traitée comme présomption de bien-être social. Et enfin, profitant de ces éléments de soutien, nous proposons une théorie de la responsabilité spéciale a être aplique aux agents économiques dans une position dominante, ce qui implique le devoir d'auto-application des limites autorisées pour sa conduite commerciale, dont la défaillance créerai une présomption relatif d'effets nocifs sur le marché, conformément aux paramètres proposés.

Mots-clê: responsabilité spéciale; abus de position dominante; refus de contractation; vente attaché; prix prédateur; abatiment de fidélité; exclusivité; fonction sociale des moyens de production; concurrence sur le mérite. 
"À minha amada Flor, que inspira minhas conquistas e suporta minha caminhada; e aos meus queridos pais, a quem devo toda oportunidade de vida, ética e perseverança." 


\section{CAPÍtULO 1 \\ INTRODUÇÃO AO TEMA}

Sabemos que o direito da concorrência não é algo novo; existe de longa data, sob formas talvez não tão explícitas na sua origem como as atuais, em modos mais rudimentares e não sistematizados, muitas vezes aplicados intuitivamente por um agente econômico ou Estado, porém ausente uma consciência do bem jurídico maior tutelado. No contexto histórico-evolutivo das normas de defesa da concorrência reconhecemos que este sub-ramo específico do sistema jurídico visa a regular o equilíbrio dos mercados que, muitas vezes, não são capazes de se autorregular. Neste sentido surge o direito da concorrência como um dos instrumentos corretivo das falhas de mercado.

Diversas seriam as razões identificadas na doutrina para tais falhas de mercado que demandam resposta positiva do Estado, as quais podem geralmente ser tratadas sob dois prismas. Primeiramente, podemos enfrentar a problematização de forma preventiva, ou ex ante, regulamentando-se comportamentos ou estruturas de maneira universal com o intuito de mitigarmos os efeitos distorcidos originados pelas falhas de mercado. Sob um segundo prisma, podemos ainda tratar tais efeitos distorcidos de forma repressiva, ou ex post, analisando-se o caso concreto e direcionando medidas de forma a corrigirmos o problema verificado. Inegável que tanto sob o primeiro formato como sob o segundo deve a autoridade em questão sinalizar de maneira transparente o rumo traçado para a atividade empresarial legítima, criando os incentivos econômicos estritamente necessários para tanto.

Ao longo do último século, o direito concorrencial veio ganhando força e importância, procurando adequar-se aos modelos de desenvolvimento econômico adotados pelas nações que progressivamente o introduzem. O direito da concorrência parece evidenciar-se sob a forma de um pêndulo, de maneira a acompanhar o grau de intervenção indireta que um Estado pretenda impingir na sua economia. Até mesmo economias de planejamento central, em que se faz mais presente a longa manus do Estado, começam a reconhecer a importância do direito da concorrência para o amadurecimento de suas instituições, de sua economia e do bem-estar dos seus cidadãos.

Não obstante reconheçamos o aludido desenvolvimento deste ramo autônomo do direito, ao longo de seu processo de maturação os limites e consequente extensão do seu objetivo finalístico sempre foram alvo de críticas mais ou menos severas, a depender das 
circunstâncias históricas em que se encontravam e da própria maturidade evolutiva das teorias econômicas desenvolvidas para dar suporte à intervenção estatal. Inegável ainda que estes embates teóricos têm servido ao fortalecimento do direito concorrencial em todo o globo, muitas vezes como elemento de ponderação para o devido balanceamento do peso da atividade intervencionista estatal, visto que ainda hoje tal limite não é colocado por quaisquer normas fundamentais ou diplomas legais em grande parte dos sistemas jurídicos encontrados.

Ao final, fortalecido pelos intensos debates legais, progressivamente incorporados pela teoria econômica, o direito da concorrência passou a representar importante e eficaz instrumento de política desenvolvimentista e social das nações que o adotam, promovendo efeitos concretos indiretos na dinâmica da sociedade, ao ponto de ser compreendido como uma garantia constitucional em alguns sistemas.

Vale repisar, a propósito, que o direito da concorrência visa a obter mais relevante papel funcional no contexto da econômica moderna, merecendo destaque seu objetivo de proporcionar aos consumidores preços mais baixos, melhor qualidade e maior variedade de bens e serviços, bem como a promoção de inovação tecnológica. Para tanto, presta-se ao papel preventivo de identificar estruturas concentracionistas que venham a facilitar comportamentos colusivos ou exercícios abusivos de posição dominante, em detrimento da promoção da livre concorrência e da livre iniciativa, bem como ao papel repressivo de efetivo combate a tais comportamentos colusivos ou exercícios abusivos, desestimulandoos e restaurando, sempre quando possível, o status quo da dinâmica concorrencial.

Neste sentido, tem-se instrumentalizado o direito da concorrência com os mais variados mecanismos de investigação, instrução e punição, de forma a permitir-se a devida e esperada resposta do Estado frente, principalmente, ao fortalecimento da atividade empresarial privada, ou mesmo diante de sua própria atividade intervencionista direta na economia, a qual não deve, em qualquer hipótese, restar imune à aplicação do direito da concorrência.

Diante das mais diversas falhas de mercado a que se pretende endereçar o tema do direito da concorrência, abordamos na presente tese aquela de maior controvérsia, visto que é campo fértil para as mais profundas divergências teóricas deste ramo do direito, e talvez por esta razão a que menos tem sido efetivamente enfrentada pelas autoridades de defesa da concorrência. Trata-se da problematização do tratamento que deve ser dispensado aos comportamentos de agentes econômicos que se encontram em posição 
dominante, entendendo-se por posição dominante o poder de mercado reconhecido ao agente na sua atividade econômica.

Muito se passou a dizer que esses agentes econômicos em posição dominante possuem uma responsabilidade especial de concorrer que não deve afetar, de forma deletéria, a estrutura e a dinâmica concorrencial dos mercados. Assim, o desafio que se coloca preocupa-se, de forma efusiva, em identificar o tratamento que tem sido emprestado a esta qualidade de agente por parte das autoridades, diante das mais variadas formas de atuação reconhecidas, e dos efeitos que se poderiam acarretar ao instituto da concorrência, de forma imediata, e aos consumidores, de forma mediata, para, ao final, concluirmos acerca da existência efetiva e justificada de um limite na sua atuação.

Não restaria suficiente a mera constatação de uma posição dominante que per se não deve configurar qualquer ilícito concorrencial. No plano do direito da concorrência, reforcemos com vigor, a conduta para ser considerada ilícita requer efetiva prática de um ato abusivo. Pensemos ainda que o conceito de posição dominante, também reconhecida como poder de mercado ou poder econômico, assim como a verificação, ainda que potencial, dos seus efeitos são indubitavelmente merecedores de maior atenção por parte da doutrina nacional, bem como das autoridades brasileiras que se dispõem a tutelar e interagir com o instituto da concorrência.

Em verdade, grande parte das ciências jurídicas nacionais preocupa-se em demasia com as práticas concertadas de mercado e mesmo com o controle das estruturas, sendo raras as reflexões mais profundas acerca das condutas unilaterais e seus efeitos lesivos às garantias institucionais do sistema normativo como um todo. Por esta razão é que o presente trabalho buscará alicerces em doutrina e jurisprudência do direito comparado que, há tempos, enfrentam o tema com maior robustez, podendo apresentar critérios objetivos para identificação dos problemas concorrenciais trazidos pela atuação autônoma dos agentes econômicos dominantes e, mais, conferir propostas inovadoras e eficientes para prevenção e solução de conflitos e problemas concorrenciais por eles causados.

A própria divergência teórica verificada no tratamento do tema por parte das jurisdições analisadas apresenta-se enriquecedora à observação do tratamento que é dado ao abuso de posição dominante no Brasil. Somam-se a isso fatores extrínsecos ao próprio tema, como a estruturação legal dos diplomas em análise e do próprio sistema institucional de controle, bem como a teoria econômica aplicada, ponderando-os de forma a se 
promover interpretação teleológica do tema e permitindo-se a identificação de elementos que possam vir a contribuir para sua aplicação no sistema nacional.

Para um estudo aprofundado é inevitável recorrermos a tradicionais instrumentos de análise concorrencial, discorrendo acerca de seus conceitos e aplicação, como o reconhecimento do mercado relevante, da análise estática da representatividade de participações de mercado por um agente, dos mais diversos fatores de pressão competitiva, das eficiências econômicas, dentre outros de relevo. Tais elementos reputam-se de indispensável valor ao presente trabalho uma vez que pretendem trazer alicerce ao pensamento revelado.

Prima facie, a doutrina nacional e internacional não divergem de forma relevante com relação aos passos que devemos trilhar para verificação concreta da existência de posição dominante de determinados agentes econômicos. Da definição e apuração de um mercado relevante e respectiva análise de sua concentração, examina-se, num segundo momento, sua dinâmica, através da observação da pressão competitiva exercida por seus fornecedores, a posição de mercado de seus concorrentes, as pressões de expansão de concorrentes efetivos, as pressões de entrada no mercado de potenciais concorrentes e, finalmente, as pressões exercidas pelos seus clientes e consumidores finais.

Concluída a análise sobre a dinâmica concorrencial do mercado, pode-se chegar à verificação de uma presuntiva condição especial que distancia o agente econômico em sabatina e o dissocia de seus concorrentes. O abismo entre sua permissiva atuação e de eventual infração concorrencial aprofunda-se e dá ensejo a responsabilidades especiais deste agente em relação aos seus clientes, aos seus fornecedores e aos seus concorrentes, no que tange a sua atuação no mercado.

Inegável que um agente econômico dotado de posição dominante, atuando de forma autônoma, é capaz de dinamizar a estrutura de mercado no qual interage, alterando o fluxo natural das relações através de levantamento de barreiras à entrada de novos agentes, balizamento de regular funcionamento de seus concorrentes ou, ainda, extração de ganhos supracompetitivos de seus clientes, dentre outros efeitos que podem impor ao mercado. $\mathrm{O}$ ulterior e inevitável resultado desta prática seria um prejuízo mediato ao bem-estar do consumidor, perdas imediatas para a concorrência enquanto instituição e, por fim, por que não dizer, consequente transferência indesejável de renda.

Por conta do dinamismo e novidade da atuação empresarial, que não prevê contorno específico, podendo se travestir de diversas formas, bem como em virtude da existência da regra da razão utilizada para interpretar condutas anticoncorrenciais em 
diversas jurisdições, que requer o balanceamento dos efeitos pró e anticompetitivos de tais práticas, não haveria fórmula objetiva ou precisa para se aplicar na apreciação do comportamento abusivo dos agentes econômicos dominantes. Trata-se, pois, de análise teleológica, isto é, de interpretação finalística aplicada caso a caso e que depende da coerência entre as premissas admitidas no sistema jurídico e os fins potencialmente verificados na conduta praticada. Não obstante, devemos questionar se algumas práticas que lhe são censuradas por conta de sua condição especial de mercado, diferentemente não o seriam caso não tivesse este agente econômico atingido posição dominante em determinado mercado relevante.

Nesta busca, diversas seriam as indagações que merecem profunda reflexão. Fundamentalmente, a dúvida que resiste gravita em torno das responsabilidades especiais impostas aos agentes dominantes, os quais se encontrariam impedidos de concorrer em toda sua extensão e, muitas vezes na mesma medida de seus concorrentes não dominantes, fato que poderia fadá-los à perda de participação de mercado, até mesmo impedindo eficiências econômicas e ganhos de bem-estar social e promovendo verdadeira punição a esses agentes. Deve-se pensar o limite desta responsabilidade à luz dos preceitos constitucionais e infralegais do ordenamento jurídico brasileiro, a fim de que não se promovam erros tipo dois, ou falso-positivos, prejudicando os agentes econômicos em questão. Da mesma forma, a exata medida desta limitação merece cuidadosa reflexão para que o oposto não se verifique, a fim de que não reste o próprio instituto da concorrência prejudicado pela imposição de responsabilidades especiais insuficientes ao agente dominante, que o permitam capitanear a dinâmica do mercado de maneira unilateral. Tratase, neste caso, de análise de erros tipo um, ou falso-negativos.

A complexidade do tema verifica-se em decorrência das diversas variáveis incidentes. Neste sentido, vale constatar a inexistência de rol taxativo de práticas abusivas, recaindo a qualificação de sua abusividade por conta de efeitos potencialmente verificáveis ao instituto da concorrência. Não obstante, após mais de cem anos de experiência concorrencial em outras jurisdições, permite-se reconhecer em determinadas práticas sua predisposição a efeitos lesivos. Poderíamos assim separá-las em duas modalidades, para fins metodológicos: comportamentos ou práticas abusivas de exploração e comportamentos ou práticas abusivas de exclusão. As autoridades historicamente têm focado suas atenções na segunda modalidade comportamental.

Por práticas abusivas de exploração reconhecemos uma atuação do agente econômico imediatamente focada no consumidor, e que são capazes de gerar efeitos 
diretos de peso morto -- "deadweight losses" -- e transferência de renda, como seria o caso de preços excessivos, royalties excessivos, estreitamento de margem, fixação de preço de revenda, dentre outros. Por sua vez, comportamentos de exclusão implicam práticas comportamentais voltadas imediatamente ao instituto da concorrência, de forma a prevenila, limitá-la ou expurgá-la, atingindo de forma mediata o próprio consumidor que se vê alijado de suas opções consumeristas. Aqui vale citar a venda casada, exclusividade negocial, recusa de contratação, discriminação, preços predatórios, entre tantas outras que podemos verificar. Desta forma, a cada modalidade de prática abusiva vislumbramos um padrão restritivo maior ou menor para a operação do agente dominante.

Outra questão que merece apurada reflexão, visto que impacta na análise finalística pretendida na presente tese, concerne à tese pacificada de que a existência de poder de mercado per se não constitui ilícito concorrencial. Para que se configure tal ilícito é necessário observar-se conduta abusiva por parte do agente dominante. Ao se considerar o fato de que um agente dominante pode ter atingido tal posição por consequência de sua maior eficiência no mercado, eleva-se à condição de dominante e adquire o estigma ora mencionado, passando a carregar consigo o fado das responsabilidades especiais sobre seus atos mercadológicos. Ao extremo poderia se tornar limitado, subitamente, nas práticas que o elevaram à condição de agente dominante, de onde viria indagação se o prêmio para sua maior eficiência seria a limitação de seu poder de concorrer no mercado.

Ainda que uma ulterior conclusão nos leve à tese de que esta limitação se deva verificar somente no que tange a condutas que ultrapassem o liame compreendido pelo conceito da concorrência no mérito, aí podemos encontrar um ponto de partida para outra questão de controvérsia na doutrina, e que implica o grau de segurança jurídica para o tratamento do tema.

A discussão ora pretendida não deve ser pautada segundo uma visão estática da concorrência e de seus incentivos. Pelo contrário, pretendemos empregar uma perspectiva predominantemente dinâmica, visto que não podemos pretender impingir ao direito da concorrência tal visão estática ao se reconhecer todo o dinamismo de seu instituto, em especial diante de todos os temas da nova economia que se colocam, sob pena de desconsideração de seus preceitos mais fundamentais.

Na esteira deste dinamismo que deve ser emprestado à presente análise, discussão indispensável viria no sentido do grau de limitação a ser eventualmente imposto àqueles agentes econômicos que, à luz de recentes julgados europeus, têm sido qualificados superdominantes, beirando o monopólio completo. Justificar-se-ia atuação mais restritiva 
por parte das autoridades na medida em que um agente se torne cada vez mais dominante, ainda que esta sua dominância esteja calcada em sua maior eficiência econômica? Argumentando nesta toada, qual deveria ser a interpretação das autoridades caso a maior eficiência produtiva alcançada se baseasse exclusivamente em economias de escala segundo uma estrutura monopolística herdada de um agente incumbente desestatizado, mas que, por outro lado, não traria qualquer eficiência dinâmica ao mercado? Qual deveria, portanto, ser a extensão da restrição que lhe seria imposta?

Vislumbramos ainda questões outras que clamam por apontamentos. Por vezes deparamo-nos com agentes monopolistas presentes em diversos mercados relevantes, alguns dos quais sem qualquer condição de dominância, sofrendo as respectivas constrições que seus fornecedores, concorrentes e consumidores lhe impõem. A discussão que decorre e que merece confronto é a extensão das responsabilidades especiais a mercados vizinhos, ainda que estes não estejam sob o poder do agente de mercado.

Em princípio, a presente tese preocupa-se com a análise do poder unilateral singular, ou seja, poder de mercado verificado por uma única empresa. Contudo, situações em que isoladamente não se vislumbra posição dominante, e mesmo assim tal posição pode ser exercida por duas ou mais empresas de forma conjunta, são tangenciadas. Trata-se da teoria da dominância coletiva, que poderia ser facilmente confundida com acordos colusivos restritivos à livre concorrência.

Os padrões presuntivos adotados para constatação de uma condição de poder de mercado por parte de agentes dominantes são igualmente tratados no presente estudo. De forma direta e significativa, as hipóteses de presunção influenciam a subsunção das normas relativas ao direito da concorrência nas mais diversas jurisdições, gerando embates filosóficos intensos. Interessante notarmos, por ora a título introdutório, que a própria legislação recentemente editada no Brasil, introdutora de um novo diploma concorrencial, ${ }^{1}$ altera os padrões presuntivos de posição dominante que vigoraram na jurisprudência pátria até pouco tempo atrás.

No tocante à sua essência, temos que o direito da concorrência fora, originalmente, concebido como resposta à busca universal pelo poder de mercado. Mais precisamente com relação ao Brasil, devemos reconhecer a estrutura tendencialmente monopolística dos seus mercados desde os primórdios da colonização, e que influenciaram de forma acentuada o nascimento desta disciplina no país. Importante ainda observar o

\footnotetext{
${ }^{1}$ Lei n. 12.529 , de 30 de novembro de 2011.
} 
significativo fortalecimento da economia brasileira na última década, e via de consequência do setor produtivo e de serviços privados, que requer aperfeiçoamento dos seus sistemas de regulação.

Novos agentes econômicos surgem a cada momento, desenvolvem-se os de pequeno e médio porte, observando-se ainda um contínuo natural processo concentracionista que, muitas vezes, com a complacência das autoridades responsáveis pela tutela concorrencial, acabam por criar agentes econômicos dominantes ou, por outras vezes, gigantes nacionais predispostos e preparados à concorrência globalizada.

O processo de globalização encontra-se consolidado, sendo sua natureza contínua e progressiva. Assim, tanto a entrada no país de novos agentes econômicos como a internacionalização de grandes empresas estruturadas pode alterar a dinâmica concorrencial no mercado nacional, gerando efeitos diversos aos quais devem sempre estar atentas as autoridades concorrenciais.

Neste sentido, se por um lado a entrada no país de grandes grupos multinacionais pode representar estímulo à concorrência e à própria eficiência produtiva e dinâmica do mercado, por outro o anseio do Estado em "patrocinar" a internacionalização de empresas nacionais e sua inserção em um contexto de concorrência global podem representar incentivos para tratamento mais leniente por parte das autoridades, permitindo-se a apropriação de ganhos de escala ou escopo que permitam estrutura mais robusta para uma concorrência internacional, sem necessariamente levarem-se em conta critérios distributivos e demais efeitos decorrentes no mercado nacional.

Outro fator que traz nova dinâmica à análise do tratamento do abuso de posição dominante relaciona-se com os temas da nova economia, dentre os quais merecem destaque os mercados multimodais, mercados de dois lados e mercados de inovação, em que se inserem temas complexos como os efeitos de rede e as barreiras de aplicações, dentre outros a serem tratados adiante.

Em razão de toda controvérsia que circunda a análise do tratamento do abuso de posição dominante nos mais diversos pontos do globo, o fato é que todos os dias, crescentemente, agentes econômicos deparam-se com situações cuja licitude é questionável. Da mesma forma que a matéria probatória torna-se cada vez mais complexa em vista de toda engenharia empregada pelos agentes dominantes, colocando em xeque o equilíbrio do sistema, espera-se, por outro lado, cada vez mais preparo técnico e celeridade por parte das autoridades em suas decisões. O limite da própria atuação Estatal é um dos grandes paradigmas que se coloca em discussão. 
Para enfrentar o tema proposto devemos inicialmente dissecar seu fundamento legal, de forma a estabelecermos as premissas que dirigem o construtivismo da atuação do sistema jus-concorrencial. Neste sentido, encontramos no artigo 170, incisos II, III, IV, V e parágrafo único, bem como no artigo $173, \S 4^{\circ}$, as pedras fundamentais sob as quais se edifica nosso sistema concorrencial. Segundo esclarece Calixto Salomão Filho, "[a] competência normativa e reguladora atribuída pelo Constituinte ao Estado é ampla o suficiente para incluir intervenções bastante brandas ou bem extremadas na ordem econômica". 2

Segundo este mesmo autor, para se compreender a extensão do conceito de "abuso de poder econômico" trazido por nossa norma fundamental, devemos entender a defesa da concorrência como garantia institucional. ${ }^{3}$ Da mesma forma, trata-se a ordem econômica de norma afirmativa, que demanda a atuação do Estado no sentido de garantir a correta atuação do mercado. Daí caracterizarem-se os direitos de ordem econômica, segundo a doutrina, de direitos fundamentais de segunda geração, direcionados à coletividade. Discute-se, portanto, segundo uma aplicação silogística, se o artigo 173, § $4^{\circ}$, da Constituição Federal, atribuiria ao poder econômico um cunho social, uma função pública, da mesma forma que atribui ao Estado um poder-dever de preservação do sistema.

Chegamos, desta forma, a uma das questões essenciais ao tema, na medida em que se admitir ao poder econômico uma função social implicaria estender-se, via de regra, o cunho da função social aos entes privados que detêm referido poder. Não obstante, o embate que se cria decorre do balanceamento de princípios aparentemente conflitantes, como a liberdade de iniciativa dos entes privados, do princípio da propriedade privada e outras garantias fundamentais reconhecidas.

As responsabilidades especiais ora referidas podem criar limitações para que agentes dominantes efetivamente concorram no mercado. A importância do tema, portanto, cresce a cada dia em que agentes econômicos observam o fortalecimento de sua posição dominante. Urge repensar-se o tema, em vista das novas teorias comportamentais do pensamento pós-Chicago, bem como em vista dos novos problemas que se colocam decorrentes da economia moderna, adaptando-as às especificidades do sistema jurídico pátrio. Um novo paradigma acerca das responsabilidades especiais inerentes aos agentes com posição dominante deve ser objeto de reflexão a fim de mitigarmos eventuais erros na sua disciplina.

\footnotetext{
${ }^{2}$ SALOMÃO FILHO, Calixto. Direito Concorrencial - As condutas. São Paulo: Malheiros, 2003. p. 106.

${ }^{3}$ Idem, ibidem, p. 108.
} 
O objetivo do presente trabalho centra-se, portanto, na impreterível reflexão acerca das circunstâncias em que se pode emprestar aos agentes de mercado alguma forma de responsabilidade especial na sua atuação no mercado, bem como na reflexão acerca da validade dos pressupostos existentes para sua determinação.

Em especial, a experiência brasileira na aplicação do ordenamento jurídico pátrio a situações de abuso de poder econômico unilateral é verdadeiramente carente e insipiente se comparada a outras jurisdições de tradição concorrencial. Daí a necessidade de aprofundamento do tema, segundo uma visão comparativa. Inicialmente, não nos parece possível o desenvolvimento de uma teoria das responsabilidades especiais sem que haja aprofundamento no tocante às teorias de abuso de poder econômico unilateral.

Assim, um passo atrás se fez necessário para construção da presente tese, visando a identificação ou sugestão do tratamento a ser dado pelas autoridades brasileiras ao tema dos abusos de poder econômico unilateral. Somente diante desta identificação é que poderíamos passar a tratar dos limites de imposição de responsabilidades especiais. A teoria dos abusos reconhecida aos sistemas jurídicos analisados é, portanto, elemento intrinsecamente ligado e complementar à responsabilidade especial reconhecida aos agentes econômicos.

Com base em premissas a serem estabelecidas e diante de uma base legal de sustentação da responsabilidade especial, a presente tese procura estabelecer metodologia de análise dedutiva para proposição de alternativas de intervenção do Estado na economia, sob a ótica estrita do direito da concorrência, bem como identificar os efeitos legais e econômicos resultantes da abordagem proposta, a partir da observação destes elementos em outras jurisdições.

Da mesma forma, vislumbra-se uma conclusão sobre a metodologia criada, de forma a determinar sua aplicabilidade para as mais diversas modalidades de abuso, partindo-se, desta forma, para uma customização dos elementos específicos a serem verificados para configuração de um abuso segmentado por cada conduta tratada, em contraposição a uma metodologia universal de reconhecimento da ilicitude das práticas.

O objetivo é, portanto, unir a teoria à prática, o direito à experiência, facilitando a todos os juristas o manuseio do texto legal. De nada adianta análise teórica sem que se obtenha, através dela, resultados concretos, no mundo real. Portanto, vislumbramos com o presente trabalho criar base teórica sólida sobre responsabilidades especiais dos agentes dominantes, e eventualmente sobre a teoria do abuso do poder econômico unilateral, de forma que possa servir como um guia não somente aos aplicadores do direito no 
embasamento de suas decisões, mais ainda como fonte informativa para os diversos agentes econômicos atuantes no mercado, que possuam ou não poder de mercado, tentando-se aumentar a previsibilidade acerca das práticas legítimas de concorrência.

Para se atingir o objetivo perseguido, a base jurídica de sustentação da presente tese será solidificada nos ditames constitucionais observados, principalmente no que tange à proteção da propriedade privada e de sua função social, bem como nos consagrados princípios da livre concorrência, livre iniciativa e defesa do consumidor. Elementos atinentes à teoria geral do Estado e formas de intervenção na economia serão ainda essenciais à análise do tema, que deverá seguir uma ótica positivista. Ainda vale considerar a aplicação dos princípios econômicos relevantes ao tema. Por fim, pretendemos ao longo do trabalho contextualizar a realidade fática em que se insere o problema, enunciando ainda os elementos econômicos, políticos e sociais que contribuem para o cenário atual.

Com base na tradição norte-americana e europeia, pretendemos ainda traçar o padrão de tratamento que tem sido dado ao tema, elucidando os elementos estruturais e dinâmicos a que reconheçamos uma justificação para tratamentos convergentes ou divergentes, tentando-se ainda aproximar a realidade fática nacional da verificada por qualquer destas orientações, com o intuito de identificar a que melhor se aplicaria. Isto para, num segundo momento, diante de uma análise de precedentes no sistema pátrio, verificar a ausência de maturidade e consistência do tratamento nacional empregado, sugerindo-se elementos que devem ser considerados para seu robustecimento.

Portanto, a teoria da responsabilidade especial que agentes dominantes possuem será avaliada e sistematizada de forma a identificarmos situações em que se possa reconhecê-la, bem como ao seu grau de maturidade, com base nas diferentes situações identificadas para as diferentes condutas tratadas. Discutiremos ainda a base legal de sustentação desta responsabilidade especial, o tratamento sugerido às diferentes circunstâncias identificadas e os efeitos legais e econômicos resultantes da abordagem proposta.

Ao final, pretendemos responder à indagação do que implicaria, propriamente, o reconhecimento desta responsabilidade especial aos agentes com posição dominante. Tratar-se-iam de limitações atreladas diretamente a sua conduta, em forma de testes universais ou específicos? Operaria diretamente em instituto jurídico no tocante ao procedimento investigatório? Traria contribuições ao estabelecimento de parâmetros mais claros acerca do conceito de concorrência no mérito? Somar-se-ia à teoria dos abusos de 
poder econômico na repressão às condutas ilegítimas? Tratam-se todas de questões fundamentais e carecedoras de profunda reflexão.

A proposta metodológica deve seguir o roteiro identificado no índice. Assim, o Capítulo 2 pretende abordar as origens das normas de defesa de concorrência, com a ulterior missão de demonstrar que seu surgimento, desde a história antiga, sempre esteve atrelado aos comportamentos oportunísticos dos agentes econômicos, segmentando-se tal análise com relação às normas imediatistas e autopreservativas dos mercados, até as normas modernas interpretadas e pretendidas de forma sistemática e institucional. $\mathrm{O}$ referido capítulo presta-se ainda a debater o escopo das normas de defesa da concorrência sob sua perspectiva finalística, tema de profunda controvérsia, ilustrando o relevante papel do direito na regulação dos mercados e a importância da teoria econômica para este ramo do direito, como elemento de apoio à atividade jurisdicional da concorrência, ilustrando-se os principais instrumentos de subsídio analítico. Ainda relacionado às teorias econômicas, discutimos conceitos introdutórios relevantes e indispensáveis para o estudo da disciplina, como as falhas de mercado, a teoria da regulação, a definição de mercado relevante, na sua acepção dinâmica e os conceitos de monopólio, poder de mercado e posição dominante. Por fim, traçamos breve síntese dos temas da nova economia e sua importância para o tema.

O Capítulo 3, por sua vez, pretende trazer panorama acerca do sistema jusconcorrencial brasileiro, traçando sistemática análise das garantias constitucionais do Estado e dos seus administrados e estabelecendo os princípios delimitadores da política de concorrência brasileira. Passamos então a situar tais garantias em função da nova lei de defesa da concorrência, bem como discutirmos brevemente seus novos elementos e efeitos decorrentes. Aqui tratamos ainda de tema de vital importância para as conclusões que pretendemos acerca do presente trabalho, discorrendo sobre a função social reconhecida à atividade empresarial, para ao final traçarmos o perfil e escopo da legislação pátria sobre o tema da concorrência.

O Capítulo 4 pretende aprofundar a análise do tema, incialmente debatendo a teoria do abuso de posição dominante, identificando as modalidades de abuso e espécies de conduta infringentes à livre concorrência, tratando-a de forma pormenorizada sob a ótica de cinco das principais práticas, que serão matéria de discussão ao longo do presente trabalho: recusas de contratação, venda casada, preços predatórios, descontos de fidelidade e exclusividade. O capítulo traz ainda considerações sobre os principais guias de análise do abuso de posição dominante, tratando, ao final, do tema das justificativas econômicas 
objetivas que trariam legitimidade a práticas, em princípio, identificadas como infrativas à ordem econômica.

Vale ressaltar que, pela necessidade fática de se estabelecerem paralelos de tratamento muito em razão da lacuna doutrinária e jurisprudencial do tema no Brasil, o presente trabalho adquire formato de estudo comparado, levando em consideração as duas jurisdições de maior relevo no tema da concorrência, de forma a extrairmos e propormos, segundo o escopo verificado de nossa legislação, a melhor perspectiva para o direito pátrio. Neste sentido, o Capítulo 5 pretende trazer preliminar análise da normativa incidente no tocante ao abuso de poder de mercado nos Estados Unidos, análise da aplicação inicial destas normativas aos casos concretos e, finalmente, revisão exaustiva dos precedentes de relevo para o tema, com foco nas modalidades identificadas acima. O Capítulo 6, por sua vez, destina-se ao mesmo propósito, contudo com o foco na doutrina e jurisprudência europeias.

O Capítulo 7 trata da análise dos precedentes encontrados no sistema jurídicoadministrativo brasileiro discorrendo acerca das recusas de contratação, vendas casadas, preços predatórios, descontos de fidelidade e exclusividade, mas não sem antes passar pela definição da normativa brasileira e organização do sistema jus-concorrencial brasileiro. Em razão dos diversos fatores apontados, verificaremos a ausência de uma linha mestre de atuação das autoridades ao longo dos últimos anos, bem como despreparo para enfrentamento dos temas.

Tais fatores, como se verá, trazem dificuldade para sistematização da atuação do Estado na regulação ex post no Brasil. Igualmente, esta realidade criou a necessidade de revisitação de uma teoria do abuso de posição dominante que se encaixasse no ordenamento jurídico brasileiro, a fim de complementar e permitir a aplicação efetiva da teoria das responsabilidades especiais.

O último capítulo, por sua vez, pretende extrair, da análise de precedentes levada a efeito no capítulo anterior, sistematização da metodologia de aplicação da norma pelas autoridades de defesa da concorrência no tratamento do abuso de posição dominante, em especial das modalidades ora identificadas. De forma a ressaltarmos os pontos de divergência entre a perspectiva norte-americana, europeia e brasileira, trazemos detalhamento descritivo das diversas batalhas enfrentadas pela Microsoft perante os tribunais e autoridades concorrenciais destas jurisdições. Com isso, pretendemos sistematizar os testes aplicados por estas autoridades às modalidades trazidas. Tratamos ainda de reconhecer a influência dos princípios inerentes ao direito da concorrência 
brasileiro para a aplicação dos referidos testes na atividade pátria do controle repressivo das normas de defesa da concorrência. Para finalmente reconhecermos, no mesmo capítulo, a existência de uma teoria da responsabilidade especial aos agentes com posição dominante em atividade no Brasil, explicitando os seus efeitos para os administradores e administrados. 


\section{CAPÍTULO 2 \\ EVOLUÇÃO E IDENTIDADE DO DIREITO CONCORRENCIAL}

\subsection{Processo Histórico-Evolutivo do Direito Concorrencial e o Tratamento do Poder Econômico}

Antecipadamente, a inegável conclusão que devemos alcançar diante de uma análise histórico-evolutiva do direito concorrencial é a de que o tratamento empregado no controle dos abusos de poder econômico, de agentes que possuíam posição dominante em mercados estratégicos à época em questão, caracterizou-se como a semente do direto concorrencial moderno.

Neste sentido, ainda que em estágio bastante inicial e desprovido de formato institucional, encontramos manifestações que remontam a princípios consagrados do direito da concorrência em fases muito anteriores da história da humanidade. Neste estágio insipiente, as normas eram postas visando aplicação pontual e não sistematizada. A consciência acerca da importância do controle dos mais diferentes mercados, bem como de seus mecanismos de funcionamento, para o bem ou para o mal, sempre existiu de forma intuitiva na cabeça daqueles envolvidos com o comércio.

Para que se remonte à história do direito concorrencial, sugere Paula Forgioni que “devemos abandonar a crença na necessária vinculação - feita por alguns - entre concorrência e o mercado do Estado liberal burguês (livre mercado)". Neste sentido, assevera a autora que regras de concorrência são muito anteriores ao surgimento de um conceito de livre mercado, fazendo, contudo, ressalva no que tange à natureza das regras analisadas. Assim, afirma que é preciso distinguir entre (i) regras que disciplinam a conduta dos agentes econômicos e (ii) regulação da concorrência correlata a um discurso técnico-econômico e mesmo à ideia de mercado liberal. ${ }^{4}$

Em sua obra, Forgioni ainda identifica os três passos principais da evolução do fenômeno da concorrência, que implicam a (i) determinação de regras para o comportamento dos agentes econômicos no mercado visando resultados eficazes e imediatos, eliminando distorções tópicas; (ii) regulamentação do comportamento dos agentes econômicos como contraponto a um sistema de produção entendido como ótimo, e

\footnotetext{
${ }^{4}$ FORGIONI, Paula A. Os Fundamentos do Antitruste. São Paulo: Ed. Revista dos Tribunais. 3. ed. 2008, 6. ed. 2013. p. 28.
} 
que visa proteger o mercado contra seus efeitos autodestrutíveis; e (iii) regulamentação da concorrência e, portanto, do comportamento dos agentes econômicos como instrumento de implementação de políticas públicas, sendo esta última a que mais nos importaria. ${ }^{5}$

Em quaisquer dos estágios verificados acima reconhecemos o tratamento dado a situações específicas e concretas, num primeiro momento, e gerais e abstratas posteriormente, rechaçando ou beneficiando-se o Estado das condutas de agentes dominantes e quase sempre monopolistas, por vezes o próprio Estado, como o cerne da celeuma concorrencial de diferentes períodos da história, até os dias de hoje. Para que se tenha mais clara a constatação acima, passemos a traçar breve histórico-evolutivo das normas de defesa da concorrência, segundo a divisão metodológica proposta, ou seja, do momento em que se consideravam para o fim de resultados pontuais e imediatos à sua sistematização e institucionalização.

\subsubsection{Primórdios das Normas de Defesa da Concorrência: Caráter Imediatista e Autopreservativo do Mercado}

Inicialmente, na esteira do exame das regras de concorrência reguladoras do comportamento dos agentes econômicos visando resultados imediatos, segundo uma intuição de autopreservação do mercado, encontramos inicialmente na Grécia antiga a cidade de Selimbria, com estratégia no sentido de reter provisões de fermento com exceção daquelas necessárias à população para consumo em um ano, visando a posterior revenda a preço mais elevado, inclusive no mercado externo. Ainda, as cidades de Pitocle e Atenas propuseram a instituição de monopólio estatal do chumbo das minas da região de Lauria, possibilitando, assim, a elevação dos preços praticados. ${ }^{6}$

Do relato feito por Aristóteles acerca da estratégia comercial de Tales de Mileto também se infere a ausência de regulamentação dos monopólios privados à época. Aquele tratou de alugar todos os lagares das cidades de Mileto e Chio prevendo safra abundante de azeitona e, quando da época da colheita, detinha exclusividade dos instrumentos necessários ao seu processamento, restando apto a cobrar os preços que bem determinasse. ${ }^{7}$

Ainda na Grécia antiga, na região de Ática, passaram a viger normas dispondo sobre a comercialização de grãos, raras commodities à época em decorrência da

\footnotetext{
${ }^{5}$ FORGIONI, Paula A. Os Fundamentos do Antitruste, cit., p. 28.

${ }^{6}$ Idem, ibidem, p. 34.

${ }^{7}$ Idem, ibidem, p. 35.
} 
infertilidade do solo, porém de vital importância ao seu povo. Tais normas visavam, antes de tudo, coibir os abusos praticados por comerciantes e importadores. Incentivava-se assim a importação de grãos, a limitação dos estoques dos comerciantes e o controle deste pelo governo, fixando-se ainda os lucros máximos que poderiam ser obtidos com a comercialização dos grãos. A penalidade prevista pela infração da lei era a morte. ${ }^{8}$

Com as guerras vivenciadas nos invernos de 388-387 a.C. na região, que impactavam no transporte de grãos, elevaram-se de forma acentuada os preços dos produtos derivados, como o pão, a ponto de funcionários encarregados pelo comércio do grão aconselharem os agentes econômicos a não concorrerem entre si, o que resultou na formação de uma associação com este escopo. Levado o fato ao conhecimento do Senado, houve julgamento segundo o argumento de que, em maus tempos, os comerciantes compravam grãos e recusavam-se a vendê-los ao público, estocando mais do que o permitido, de forma que, para haver o produto, pagava-se o preço exigido, ainda que alto. ${ }^{9}$

Da mesma forma, em Roma, por volta de 300 a.C., havia estrito controle de preços imposto pelo Imperador, na forma de fixação de preços máximos aplicados sobre o comércio de bens e serviços em decorrência de elevada inflação do período, sob pena de morte aos que violassem a determinação. A prática dos monopólios estatais era também verificada, assegurando, por exemplo, o monopólio do sal. Ao final do Império, visando aumentar os recursos do Estado, o número de concessões de monopólios passou a abranger quase que a totalidade da distribuição dos alimentos. ${ }^{10}$

A política de monopólios veio ainda a ser regulamentada pelo Édito de Zenão, de 483 a.C., demonstrando a preocupação das autoridades da época no combate aos abusos que invariavelmente decorriam de tais monopólios:

\begin{abstract}
That no one may presume to exercise a monopoly of any kind of clothing or fish or of any other thing serving for good or for any other use, whatever its nature may be, either on his own authority or under a rescript of an emperor already procured, or under an imperial decree or under a rescript signed by our Majesty; nor may any person combine or agree in unlawful meeting that different kinds of merchandise may not be sold at a less price than they may have agreed upon among themselves. ${ }^{11}$
\end{abstract}

Mais adiante na história de Roma, à época do Imperador Leone, estabeleceu-se a proibição per se dos monopólios. Às palavras de Paula Forgioni fazemos coro no sentido

\footnotetext{
${ }^{8}$ FORGIONI, Paula A. Os Fundamentos do Antitruste, cit., p. 36.

${ }^{9}$ Idem, ibidem, p. 36-37. A Professora ainda esclarece não ter havido registro do resultado do julgamento.

${ }^{10}$ Idem, ibidem, p. 37.

${ }^{11}$ Idem, ibidem, p. 37-38.
} 
de não parecer existir, à época, preocupação maior do que resultados imediatos da coibição de determinados comportamentos reputados nocivos à população e à nação, inexistindo qualquer visão dualística acerca do binômio concorrência-livre mercado. ${ }^{12}$

Curioso verificar-se, neste momento, que o próprio Estado utilizava-se, por vezes, de mecanismos de reserva de mercado através da instituição de monopólios, de forma a beneficiar-se do que viria a ser conhecido nos dias de hoje como falhas de mercado, da mesma forma que o faziam determinados agentes econômicos. Passou o Estado, contudo, a editar normas que evitassem o abuso na comercialização de grãos, promover regulação de preços e até mesmo reprimir os abusos cometidos. A concessão de monopólios a terceiros era ainda utilizada por Estados para auferir receita, prática que se intensificou mais adiante com o mercantilismo.

Em resumo, a atuação do Estado neste período verificou-se de certa maneira paradoxal, utilizando-se de mecanismos aptos a aumentarem sua receita em detrimento da população, num primeiro momento, mas aparentemente evoluindo para um regramento, ainda que pontual, da atuação de agentes econômicos privados em benefício dos seus administrados, num segundo instante.

Já na idade média, contudo, parece ainda mais acentuada a ligação entre o conceito de monopólio e as regalias concedidas principalmente pelo monarca, exercido, na maioria das vezes, por agentes privados. Verifica-se uma intervenção das autoridades na estocagem e distribuição de gêneros alimentícios, por razões de cunho social e político, ao lado da formação de autênticos monopólios privados, representados não somente pelas associações entre os pequenos artesões e as conhecidas corporações de ofícios, mas ainda pelas grandes empresas medievais que se formavam, usando como exemplo o Banco da Família Médici, em Florença. Aqueles, não se pode olvidar, foram os responsáveis por caracterizar a idade medieval como umas das mais ricas em termos de história do direito da concorrência. É nesse período histórico que nascem muitas das regras concorrenciais que se colocam até os dias de hoje.

Esta produção normativa coloca regras de condutas para os agentes econômicos da época que seriam seguidas por muitos séculos segundo a ideia de proteção dos interesses mercantis. Duas eram, portanto, as modalidades de normas disciplinando as atividades das corporações de ofício: os estatutos das corporações que deveriam disciplinar a atividade dos próprios artesãos e comerciantes, e o sistema da Comuna medieval, que

\footnotetext{
${ }^{12}$ FORGIONI, Paula A. Os Fundamentos do Antitruste, cit., p. 38-39.
} 
procurava regular a atividade das corporações de ofício através de imposição de normas de conduta obrigatória para seus membros. ${ }^{13}$

Já na época do Mercantilismo, de inspiração serviu o próprio Édito de Zenão, no sentido de proibirem-se os monopólios, somando-se ao coro das reações contra os regramentos das corporações de ofício. Os estatutos das cidades italianas vedavam o açambarcamento de mercadoria e buscavam controlar ou fixar os preços praticados pelos comerciantes, de forma a mitigar os efeitos dos monopólios. Em 1540, Carlos V promulga ainda legislação que proibia os pactos de monopólio. Desenvolvem-se discussões acerca do que poderíamos hoje chamar de justificativas objetivas para a concessão de monopólios, uma vez atendido o bem comum.

Durante este período, é sabido que os monopólios foram larga e essencialmente utilizados no comércio marítimo e colonial. A política mercantilista da época implicava um sistema de monopólio da compra e venda dos produtos da colônia, bem como monopólio do transporte marítimo efetuado pelos navios da metrópole, além de um sistema de decisão unilateral de preços por parte da metrópole, que garantia o saldo positivo da balança de pagamentos e proporcionava o aumento do estoque metálico das nações europeias. Ainda, era essencial que a colônia não oferecesse qualquer tipo de concorrência à metrópole, impedindo-se, desta forma, por longo período, o estabelecimento de qualquer atividade industrial ou de processamento de matérias-primas nas colônias americanas. O monopólio outorgado às companhias marítimas para exploração do comércio corroborava com os ditames do pacto colonial.

Assim, reconhecia-se que a possibilidade de conceder monopólios ou exclusividade de exploração de um setor da economia trazia vigoroso instrumento de poder aos monarcas, tendo sido objeto de contestações crescentes no tocante à sua legalidade, principalmente na Inglaterra, ao final do século XVI.

\footnotetext{
${ }^{13}$ FORGIONI, Paula A. Os Fundamentos do Antitruste, cit., p. 44-45. Dentre as regulamentações privadas estabelecidas pelos próprios artesãos, identificavam-se, em especial, normas que estabeleciam o monopólio da corporação, normas que fixavam regras de conduta para os membros da corporação e que acabavam por neutralizar a concorrência, por vezes até mesmo limitando a capacidade de produção de seus membros, e normas que estabeleciam o poder das corporações de fiscalizar e punir seus membros, privilegiando-se, assim, uma completa uniformização de preço e qualidade de produtos. Por sua vez, as regras de controle da atuação das corporações, ditadas pela Comuna, muitas vezes objetivavam a proteção do consumidor, como a vedação ao açambarcamento de mercadorias, a garantia de pão aos membros das Cruzadas a um preço não excessivo e a inspeção e corte da cauda de peixes colocados à venda pelos comerciantes, a fim de se evitar que no dia seguinte fosse este vendido como fresco. Ainda, talvez o controle mais significativo implementado fora a fixação por algumas cidades do lucro máximo para determinadas categorias de produtos. As próprias feiras medievais eram utilizadas de forma a se evitarem abusos de preços por parte dos comerciantes.
} 
O Caso dos Monopólios, como é conhecido, de 1603, é reputado como o primeiro pronunciamento judicial, sobre os princípios gerais do common law, acerca do tema dos monopólios. Tratou o caso de uma ação impetrada por um importador de cartas de jogo, perante o Tribunal Inglês, para fazer cumprir com o monopólio que the havia sido outorgado pela rainha para importação e fabricação de cartas de jogo em seu reino, direito que lhe foi negado pelo Tribunal. Os argumentos trazidos pelo Tribunal, no sentido de que monopólios seriam ilegais perante o common law, remetiam, basicamente, ao reconhecimento de que com o monopólio os preços das mercadorias tenderiam a aumentar, ao mesmo tempo em que a qualidade tenderia a diminuir. Da mesma forma, outras pessoas estariam impedidas de fabricar aqueles bens, sendo levadas ao empobrecimento. Argumentos que, de certa forma, emprestavam viés econômico ao caso. ${ }^{14}$

Das lições trazidas acima podemos tirar, corroborando com os ensinamentos de Forgioni, que:

\footnotetext{
onde quer que haja comércio, os agentes econômicos tendem a adotar determinados comportamentos que objetivam sua proteção, independentemente do governo (=poder externo) a que estão sujeitos. Este fenômeno pode ser compreendido e justificado levando-se em consideração o fato de que os agentes econômicos, em qualquer período histórico, estão sujeitos a leis econômicas, semelhantes às da física, [1]eis cuja existência independe de qualquer autoridade. ${ }^{15}$
}

Verifica-se, portanto, ainda neste período, o caráter pontual e paradoxal em que os mecanismos de mercado eram tratados, por vezes visando o Estado regrar os efeitos imediatos perante os consumidores, por outros se beneficiando dos próprios mecanismos como forma de captar renda proveniente da exploração dos monopólios, para si ou para os amigos do rei, em detrimento de sua população. Também se verifica que a disciplina do abuso de poder de mercado, naqueles períodos, possuía caráter consumerista na medida em que visava proteção imediata - e não mediata, como se faz atualmente - dos súditos.

De toda sorte, importante notar que o centro de disputa continuava sendo os abusos praticados pelos agentes dominantes, sejam estatais ou privados, na sua maioria voltados a práticas monopolistas unilaterais e sob regime de concessão.

\footnotetext{
${ }^{14}$ FORGIONI, Paula A. Os Fundamentos do Antitruste, cit., p. 53.

${ }^{15}$ Idem, ibidem, p. 56.
} 


\subsubsection{Normas de Defesa da Concorrência como Regramento Institucional do Estado Contemporâneo}

Já no período contemporâneo, em 1889, surge o primeiro diploma legal institucionalizado de direito concorrencial, promulgado no Canadá e denominado Act for the Prevention and Suppression of Combinations formed in Restraint of Trade. Não obstante seu pioneirismo, seguiu-se a ele a promulgação do notório Sherman Act, nos Estados Unidos, em 1890, ato efetivamente considerado como sendo o marco histórico do direito antitruste contemporâneo no mundo, cujo intuito girava em torno da repressão aos abusos praticados pelos grandes trusts norte-americanos. No contexto histórico do direito concorrencial acima apresentado, temos que este sub-ramo específico do sistema jurídico que regula o equilíbrio de mercado nasceu como resposta à busca universal de poder de mercado pelos agentes econômicos.

Alguns dos elementos que contribuíram para o nascimento do direito concorrencial contemporâneo seriam as grandes invenções que revolucionaram o final do século XVIII, tais como o telefone, a locomotiva e o telégrafo, e que promoveram verdadeira quebra do isolamento até então existente entre os mais diferentes e distantes mercados geográficos. Assim, verificou-se verdadeira redução das barreiras de entrada e atuação dos agentes econômicos, passando mercados geográficos antes distantes a exercerem pressão competitiva entre eles. Com maior e mais efetiva concorrência entre os diversos agentes econômicos atuantes nestes mercados, o resultado inevitável seria a queda nos preços praticados e, consequentemente, das margens dos produtos.

Contra esta "síndrome" da concorrência saudável iniciaram-se tentativas de ajustes entre produtores para regulação artificial do mercado, como se poderia racionalmente esperar. Contudo, uma coordenação verificava-se complexa e os incentivos às trapaças eram grandes e compensadores, o que demandou organização de estruturas mais rígidas para coordenação. O nascimento dos trustes veio nesse sentido, na medida em que permitiam, através de vínculos contratuais societários, a coordenação entre os centros decisórios da empresa por um mesmo grupo.

A rápida industrialização iniciada na metade do século XVIII também contribuiu para a criação de grupos industriais com relativo poder econômico. A população rural se viu cada vez mais dependente desses novos grupos para atividades de seu dia a dia, principalmente dos grupos controladores de ferrovias, necessárias ao transporte de seus produtos, bem como controladores de máquinas destinadas à agricultura. Pequenos 
fazendeiros e comerciantes passaram a se sentir discriminados por parte dos grandes grupos industriais, dos quais se tornaram economicamente dependentes.

Destarte, o Sherman Act, que efetivamente institui a primeira lei antitruste, passou a regular a atividade de monopolização ou tentativa de monopolização de mercado, bem como os acordos, combinações e conspirações que restringissem o livre comércio. $\mathrm{O}$ foco da lei criada era evitar a tentativa ou obtenção de concentração de poder por um grupo econômico, retornando-se ao status quo ante e encerrando-se a "intervenção estatal". A mão invisível de Adam Smith voltaria, então, a regular o mercado.

Desde então políticas de defesa concorrencial evoluíram à sombra do desenvolvimento econômico, passando a englobar diversas práticas reconhecidamente prejudiciais ao bem-estar social. A lei de proteção de defesa da concorrência passou a analisar, com cuidado, não somente restrições horizontais, mas também restrições verticais. O controle preventivo de concentrações também passou a ser matéria de escrutínio técnico com a edição de outro ato legislativo pioneiro norte-americano, o Celler Kefauler Act de 1950, posteriormente alterado pelo atualmente conhecido Hart-Scott Rondino Act de 1976.

Aqui novamente devemos pontuar que o nascimento do direito concorrencial contemporâneo encontra sua semente na necessidade de disciplinar os abusos praticados pelos agentes dominantes. Por certo, nesta fase da evolução industrial, política e social da humanidade, principalmente nas grandes nações da virada do século XX e décadas subsequentes, tais abusos eram capazes de afetar de forma mais profunda e ramificada os agentes econômicos dependentes e consumidores, com especial ênfase em alguns setores inteiros da economia, como o agrícola. Isso, por outro lado, potencializava o poder de reação institucional, o que acabou por gerar o próprio Sherman Act.

A União Europeia, ${ }^{16}$ por sua vez, teve sua primeira lei concorrencial supranacional com a edição do Tratado de Roma, em 1957, nos seus artigos 85 e 86 . Esse diploma foi reformado pelo Tratado de Maastrich, em 1994, e novamente pelo Tratado da Reforma, com vigência a partir de dezembro de 2009. Grande parte das preocupações elencadas pelos tratados dizia respeito à eliminação de obstáculos à livre movimentação de produtos, serviços, pessoas e capital dentro dos Estados-Membros. O racional por detrás das normas dos tratados vinha no sentido de que a própria remoção desses obstáculos inevitavelmente contribuiria para a promoção da livre concorrência naqueles países.

${ }^{16}$ Com a Edição do Tratado de Roma, a denominação estabelecida à época foi Comunidade Econômica Europeia. Esta denominação foi alterada em 1992, com o Tratado de Maastricht, passando a denominar-se Comunidade Europeia, e mais recentemente com a entrada em vigor do Tratado de Reforma, assinado em Lisboa em dezembro de 2007, passou a se chamar União Europeia. 
Anteriormente ao Tratado de Roma, vale menção à gênese do artigo 82, que nasceu na Constituição da Comunidade Europeia do Carvão e Aço ("CECA"), entabulado pelo Tratado de Paris, em 1951. O Tratado, desta forma, trazia normas que visavam combater a colusão, bem como a concentração entre empresas nos setores por ele abrangidos.

Interessante notar que as regras de concorrência inseridas no Tratado de Paris à época traziam uma ideia de consolidação dos interesses geopolíticos dos aliados pósguerra, com nítido objetivo de promover a desconcentração do poder nazista derrotado, em especial no que se referia à indústria de base, fundamentalmente os setores do carvão e ferro. ${ }^{17}$ Sustenta-se ainda que a própria política de descartelização e desconcentração foi imposta pelos Estados Unidos aos seus aliados ocidentais, salientando que Reino Unido e França encontravam-se em processo concentracionista com relação à sua indústria. ${ }^{18}$

Assim, o próprio plano aliado de reconstrução da indústria alemã previa medidas que se dirigiam a uma desconcentração econômica, através da dissolução dos grandes grupos empresariais até então existentes. Interessante, assim, notarmos o contexto de nascimento das regras de concorrência na Europa, que se assemelhava, em certa medida, aos propósitos norte-americanos, focada, portanto, na quebra dos grandes monopólios existentes no continente e, principalmente, na Alemanha, ao final da segunda guerra. ${ }^{19}$

Contudo, a aplicação do Tratado de Paris não permitiu qualquer alteração na realidade das discussões de preços do carvão e do aço, verificando-se pouca intervenção neste período. O controle de concentrações, também previsto naquele Tratado, não era aplicado à época. Ressalte-se que o Tratado de Paris ainda levava em conta outros fatores, como eficiência, pleno emprego e estabilidade dos mercados, política industrial e normas de infração às condições de concorrência. ${ }^{20}$

17 “Assim, a conformação das regras de concorrência do Tratado de Paris tem como pano de fundo os interesses geopolíticos das potências ocupantes, bem como a sua articulação com os representantes políticos e económicos da Alemanha ocupada, em particular nas zonas ocupadas pelos Estados Unidos, Reino Unido e França" (MOURA E SILVA, Miguel. O Abuso de Posição Dominante na Nova Economia. Teses de Doutoramento. Coimbra: Almedina, 2010. p. 26). O próprio Acordo de Potsdam, de 2 de agosto de 1945, já trazia objetivos de descartelização e desconcentração da indústria alemã, porém não receberam o mesmo empenho por parte das potências aliadas.

${ }^{18}$ MARENCO. The Birth of Modern Competition Law in Europe, p. 284. In MOURA E SILVA, Miguel. O Abuso de Posição Dominante na Nova Economia, cit., p. 29.

19 Deixemos de lado aprofundamentos especulativos acerca do verdadeiro interesse norte-americano na alegada imposição do artigo 82 aos países europeus, que por certo se revestia de um caráter políticoimperialista de extensão de sua área de influência, a exemplo de outros acordos à época assinados, como o próprio Plano Marshall.

${ }^{20} \mathrm{O}$ Controle de abusos de posição dominante, entabulado pelo item 7 do art. 66 daquele Tratado, era objeto de regime menos desenvolvido por comparação com as normas sobre acordos e concentração. Previa-se possibilidade de fixação de preço e estabelecimento de quotas de produção e repartição de recursos, sujeito a 
A previsão das regras de controle prévio no Tratado de Paris encontrava justificativa no fato de que os mercados da CECA possuíam níveis de concentração altíssimos. O Tratado de Roma, por sua vez, não possuía regras de controle de concentrações. Assim, verificou-se determinante influência dessa lacuna na lapidação dos conceitos de abuso de posição dominante, conforme verificado adiante. Da mesma forma, uma visão política da época do pós-guerra apregoava que os efeitos da aglomeração de poder econômico em domínios, principalmente no que tange ao carvão e aço, eram vistos como essenciais a um esforço de guerra, tendo sido as siderúrgicas alemãs apoiadas pelo regime nazista. ${ }^{21}$

Assim, reconhecemos na Europa que o nascimento do antitruste encontrava-se ligado não somente à percepção da quebra dos grandes monopólios para funcionamento eficiente dos mercados, mas talvez de forma ainda mais determinante, à percepção política - e em certa maneira imperialista - acerca da necessidade de segmentação do poder econômico dos grandes grupos, a fim de se evitar patrocínios políticos belicistas.

No que tange ao Brasil, vale breve exposição acerca do tratamento emprestado ao poder de mercado desde a sua colonização até os tempos modernos, para melhor conclusão acerca das diferenças atualmente existentes com outros sistemas jus-concorrenciais mundiais. Assim, o período que sucedeu a colonização do Brasil foi marcado pela relação colonialista estabelecida pela metrópole portuguesa segundo um caráter fiscalista, em que este impunha ao Brasil o pagamento de pesados impostos para sustentação financeira do Estado português. Assim, a coroa portuguesa utilizou-se, de forma intensa, de uma política de concessão de regimes de monopólio que visassem maximizar seus ganhos na exploração relativamente predatória da colônia. ${ }^{22}$

Para manutenção do regime colonialista pregado pelo mercantilismo, contudo, prezava-se a exclusividade nas relações comerciais entre colônia e metrópole, bem como continha-se qualquer tentativa de desenvolvimento industrial na colônia. ${ }^{23}$ Toda exploração econômica seguia os interesses do Estado português, através dos monopólios reais ou concedidos pela coroa, a exemplo da Companhia do Grão-Pará e Maranhão e tantas outras.

uma regulação assimétrica (MOURA E SILVA, Miguel. O Abuso de Posição Dominante na Nova Economia, cit., p. 36-41).

${ }^{21}$ Idem, ibidem, p. 42.

22 Neste sentido vide FORGIONI, Paula A. Os Fundamentos do Antitruste, cit., p. 94 e ss.; PRADO JUNIOR, Caio. História Econômica do Brasil. São Paulo: Brasiliense, 2008.

${ }^{23}$ Carta Régia de 1766 trazia vasta listagem de proibições às atividades industriais brasileiras, dentre as quais proibição às atividades dos ourives, da fabricação de mel de vinho e mesmo da cultura da uva. 
Foi somente com a vinda do rei de Portugal e sua corte ao Brasil em 1808 que se iniciou uma fase de maior desenvolvimento econômico do país, com a abertura dos portos às nações amigas e, no mesmo ano, fundação do Banco do Brasil, instituindo-se ainda a liberdade industrial.

Contudo, o maior efeito da abertura dos portos à época foi a exposição da incipiente industrialização e economia brasileira aos interesses das grandes nações internacionais, em especial aos interesses ingleses. Assim, o mercado brasileiro continuou a ser abastecido por mercadorias estrangeiras, não havendo qualquer forma de concorrência interna, salvo esporádicos surtos de industrialização de pouca duração, e logo esmagados por interesses imperialistas.

Podemos, portanto, dizer que o sistema econômico nacional foi formado, desde a colonização brasileira, em torno dos grandes monopólios estatais e privados, sendo esta a forma de exploração monopolística verificada posteriormente na economia agrícola cafeeira e na economia industrial subsequentemente. Daí decorre a origem do sistema concorrencial brasileiro muito atrelado à ideia de proteção da economia popular contra o poder econômico, sendo a legislação brasileira uma das poucas no mundo a trazer disposições expressas sobre abuso de preços - atualmente disciplinado por abuso de lucros.

O processo evolutivo sistematizado de controle dos abusos de poder de mercado iniciou-se no Brasil somente com a Constituição Federal de 1934, que em seu artigo 116 previa a possibilidade de monopolização de certas atividades econômicas por parte da União, a ser criado através de lei especial e contanto que houvesse "motivo de interesse público" justificador da medida. ${ }^{24}$ Não obstante a previsão na Carta Magna, o dispositivo nunca viria a ser regulamentado e aplicado, o que não retira, por sua vez, a qualidade de primeiro preceito constitucional pátrio em que o Estado se preocupou com os fenômenos econômicos que viessem a atingir a coletividade, relacionando ainda a dinâmica da ordem econômica com os princípios de justiça e necessidade de uma vida social digna, garantindo, contudo, como regra, a liberdade econômica. ${ }^{25}$

Apesar da vanguardista exteriorização dos princípios de intervenção indireta do Estado na economia e do momento político que se fazia favorável para tanto, não foi esta

24 “Art. 116. Por motivo de interesse público e autorizada em lei especial, a União poderá monopolizar determinada indústria ou atividade econômica, asseguradas as indenizações devidas, conforme o artigo 112, n. 17, e ressalvados os serviços municipalizados ou de competência dos poderes locais."

25 "Art. 115. A ordem econômica deve ser organizada conforme os princípios da justiça e as necessidades da vida nacional, de modo que possibilite a todos a existência digna. Dentro destes limites, é garantida a liberdade econômica." 
política de imediato verificada no país. ${ }^{26}$ Vale notar que a Carta Magna autorizava a intervenção tão somente para supressão das deficiências da iniciativa individual e coordenação dos fatores de produção, "de maneira a evitar ou resolver os seus conflitos e introduzir no jogo das competições individuais o pensamento dos interesses da Nação, representados pelo Estado". ${ }^{27}$

Percebemos, no dispositivo constitucional acima aludido, influência de um movimento social mais retórico, reflexo do momento histórico e político da época, principalmente ao tratar da função de coordenação dos fatores de produção pelo Estado, e mesmo ao aludir aos interesses da Nação na concorrência.

Subsequentemente, em 1945, houve a promulgação do Decreto-lei n. 7.666, influenciado pelo Deputado Agamenon Magalhães, Ministro da Justiça à época. O Decreto regulamentava os "atos contrários à ordem moral e econômica", tendo criado, dentre outras inovações, a Comissão Administrativa de Defesa Econômica - CADE, órgão que dispunha de competência para zelar pela aplicação do regramento instituído. Contudo, as reações provocadas pela promulgação do Decreto fizeram com que fosse rapidamente revogado, cerca de três meses após sua entrada em vigor, em $1^{\circ}$ de agosto de 1945 , não tendo chegado a efetivamente operar no ordenamento jurídico brasileiro. ${ }^{28}$

Já na Constituição Federal de 1946, a repressão ao abuso de poder econômico foi novamente consagrada em seu artigo $148 .^{29}$ Neste dispositivo se encontram disposições mais próximas de nosso atual sistema jus-concorrencial.

Vale ainda recordar que havia algumas leis esparsas, como o Decreto lei n. 869, de 18 de novembro de 1938, trazendo tratamento criminal a infrações - crimes contra a economia popular -, bem como as Leis n. 1.521 e 1.522, de 26 de dezembro de 1951, as quais alteravam dispositivos atinentes aos crimes contra a economia popular e autorizavam

26 FERREIRA, Waldemar Martins. História do Direito Constitucional Brasileiro. São Paulo: Max Limonad, 1954. p. 184-185.

27 “Art. 135. Na iniciativa individual, no poder de criação, de organização e de invenção do indivíduo, exercido nos limites do bem público, funda-se a riqueza e a prosperidade nacional. A intervenção do Estado no domínio econômico só se legitima para suprir as deficiências da iniciativa individual e coordenar os fatores de produção, de maneira a evitar ou resolver os seus conflitos e introduzir no jogo das competições individuais o pensamento dos interesses da Nação, representados pelo Estado."

${ }^{28}$ Instrumento de revogação foi o Decreto-lei n. 8.167, de 9 de novembro de 1945.

29 “Art. 148. A lei reprimirá toda e qualquer forma de abuso do poder econômico, inclusive as uniões ou agrupamentos de empresas individuais ou sociais, seja qual for a natureza, que tenham por fim dominar os mercados nacionais, eliminar a concorrência e aumentar arbitrariamente os lucros." 
o governo federal a intervir no domínio econômico para assegurar a livre distribuição de produtos necessários ao consumo do povo, respectivamente. ${ }^{30}$

Em paralelo, diversas foram as tentativas de regulamentar o dispositivo 148 da Constituição Federal, tendo o Deputado Agamemnon Magalhães apresentado Projeto de Lei que, segundo o próprio deputado, utilizava-se de diretrizes da legislação dos Estados Unidos com modificações impostas pela realidade brasileira. Contudo, ao que parece, houve intensa reação ao seu projeto, tendo recebido, após longo período de debate, um substituto pelo Deputado Aldo Sampaio, que reduzia o projeto original de 58 artigos para 21. Porém os projetos apresentados restaram por um tempo esquecidos, tendo sido recuperados somente a partir de 1956, após a morte do Deputado Agamemnon, por reapresentação de seu filho, também Deputado, Paulo Magalhães. Dessa forma, o Projeto foi desarquivado e esmiuçado, tendo sido alterado através de diversos substitutos, até aprovação final no Congresso em 1962, transformando-se na Lei n. 4.137, regulamentada pelo Decreto n. 52.025, de $1963 .^{31}$ Esta lei criava, ou recriava, por melhor dizer, a Comissão Administrativa de Defesa Econômica - CADE.

Por sua vez, a Carta Magna de 1967, com redação trazida pela EC 1/69, alterou a exposição antes genérico-exemplificativa do dispositivo constitucional predecessor. ${ }^{32}$ Verificamos que a Lei n. 4.137 tinha como pilar de sustentação o artigo 148 da Carta de 46; assim, ao eliminar o caráter exemplificativo, não taxativo das modalidades de abuso, críticas se insurgiram acerca da revogação de determinadas modalidades, como os incisos IV e V do artigo $2^{\circ}$ da Lei n. 4.137, discussão esta que, aparentemente, não se projetou do campo doutrinário ao campo jurisprudencial.

Durante este período da história brasileira, sujeita aos desmandos dos governos militares que se perpetuaram no poder e diante da administração centralizada - inclusive de preços - imposta ao país, de pouca utilidade se fez o instituto da concorrência.

Contudo, a partir de meados da década de 80, desenvolve-se a necessidade de reformulação das políticas de investimento público na atividade de produção de bens e

${ }^{30}$ FRANCESCHINI, José Ignácio Gonzaga; FRANCESCHINI, José Luiz Vicente de Azevedo. Poder Econômico: Exercício e Abuso. Direito Antitruste Brasileiro. São Paulo: Ed. Revista dos Tribunais, 1985. p. 9.

${ }^{31}$ Idem, ibidem, p. 10 e ss.

${ }^{32}$ Tal dispositivo constitucional predecessor dispunha que: "A lei reprimirá toda e qualquer forma de abuso do poder econômico, inclusive as uniões ou agrupamentos de empresas individuais ou sociais, seja qual for a natureza, que tenham por fim dominar os mercados nacionais, eliminar a concorrência e aumentar arbitrariamente os lucros". Este dispositivo foi alterado, com a Carta Magna de 1967, para: “Art. 160. A ordem econômico e social tem por fim realizar o desenvolvimento nacional e a justiça social, com base nos princípios (...) V - repressão ao abuso de poder econômico, caracterizado pelo domínio dos mercados, a eliminação da concorrência e o aumento arbitrário dos lucros”. 
serviços, mediante retirada gradativa do agente público da esfera econômica e da restrição às situações de monopólio. Pelos mais diversos motivos, como a constatação da excessiva oneração decorrente da manutenção do Estado na seara da produção e o reflexo da implantação de uma ideologia pautada no afastamento do Estado da atividade produtiva, inicia-se o processo de privatização em suas diversas modalidades. Até mesmo monopólios tradicionais, como regimes de exploração de petróleo e gás, cederam espaço aos atrativos do mercado e da potencialidade de otimização da produção e oferta, por intermédio da implementação de um regime de livre concorrência.

Funções antes desenvolvidas pelo Estado passaram a ser transferidas às empresas do setor privado, sujeitando-se à lógica da mais valia, ainda que de forma relativa, pois, em sendo serviço público, continuavam a interessar diretamente às políticas públicas. Isso conferiu novo impulso à simbiose entre direito comercial e direito econômico na disciplina dessas empresas e na construção do mercado no qual se inseriam.

A atuação estatal, por sua vez, passou a repousar sobre o aspecto "regulatório", disciplinador do comportamento dos agentes econômicos prestadores de serviços públicos. Em outras palavras, de Estado-empresário - atuação "na economia" - transformou-se em Estado-regulador - atuação "sobre a economia" - surgindo as denominadas agências reguladoras, cujo principal papel residia em normatizar de forma conjuntural cada setor regulado, assim como fiscalizar o comportamento das empresas que atuavam em tais setores.

Com a promulgação da Constituição Federal de 1988, houve alteração do dispositivo atinente ao controle do abuso de poder de mercado, identificando-se maior proximidade com o preceito trazido pela Constituição de 46, contudo ausente uma exposição exemplificativa de modalidade de abuso. ${ }^{33} \mathrm{O}$ foco do novo dispositivo passa a flutuar sobre os atos tendentes à dominação dos mercados e à eliminação da concorrência, nas acepções do controle das condutas bem como das estruturas. Ainda, tais dispositivos passam a ter caráter mais institucionalista e menos centrados na ideia de proteção mediata do consumidor, fato que se reconhecia nos dispositivos anteriores muito em razão da gênese do direito concorrencial nos dispositivos constitucionais e penais de proteção à economia popular. ${ }^{34}$

Ainda segundo o processo de redemocratização brasileiro ocorrido em 1989, que

\footnotetext{
33 "Art. $173, \S 4^{\circ}$ - A lei reprimirá o abuso do poder econômico que vise à dominação dos mercados, à eliminação da concorrência e ao aumento arbitrário dos lucros."

${ }^{34}$ SALOM $\tilde{A}$ O FILHO, Calixto. Direito Concorrencial - As condutas, cit., p. 107.
} 
implicou irresponsável abertura da economia brasileira - que, diga-se de passagem, nos faz recordar algo semelhante ocorrido com o Brasil com a abertura dos portos em 1808 houve a promulgação da Lei n. 8.158, em 8 de janeiro de $1991{ }^{35}$ segundo os ideais liberalistas de autorregulação do mercado. A referida normativa criou a Secretaria Nacional de Direito Econômico, com a função de fiscalizar e corrigir as anomalias de comportamento de setores econômicos, passando o CADE a funcionar junto a esta Secretaria.

Logo na sequência, em 1994, verificamos a edição da Lei n. 8.884, que visou sistematizar e aperfeiçoar os instrumentos de combate ao abuso de poder econômico nas suas várias acepções. A Lei n. 8.884/94 aprimorou o Sistema Brasileiro de Defesa da Concorrência, que passou a ser composto pelo Conselho Administrativo de Defesa Econômica, pela Secretaria de Acompanhamento Econômico, vinculada ao Ministério da Fazenda, e pela Secretaria de Direito Econômico, vinculada ao Ministério da Justiça.

Essa interferência do Estado na organização da economia, que tinha como propósito corrigir eventuais falhas de mercado, intensificou-se com a consolidação industrial brasileira e, subsequentemente, com a globalização a que foi exposta, especialmente em razão da dimensão dos impactos causados pela conduta de agentes econômicos em posição dominante no mercado.

Com a crescente investidura e inter-relacionamento das nações com economias de mercado tornou-se imperativo a adoção de leis de defesa da concorrência. Até mesmo organismos internacionais, como o Fundo Monetário Internacional e o Banco Mundial advogam para a edição destas normas, muitas vezes de forma condicionada aos auxílios fiscais prestados. Prova disso é o número crescente de jurisdições que adotam sistemas concorrenciais, mais ou menos eficientes, ao redor do globo. ${ }^{36}$

A se concluir, resta bastante evidenciada a ideia de que o direito concorrencial sempre esteve atrelado a preocupações acerca do abuso de poder de mercado, em especial abusos relacionados a condições monopolísticas dos agentes e, portanto, indicativas de condutas ilegítimas unilaterais. Esta sempre foi a motivação central desde as primeiras manifestações de normas de defesa da concorrência até os diplomas modernos. Inerente, portanto, à racionalidade do comportamento humano, o desenvolvimento de todo o sistema

\footnotetext{
${ }^{35}$ Medida Provisória n. 204, de 2 de agosto de 1990, convertida na Lei n. 8.158.

${ }^{36}$ Segundo o website do FTC, mais de 120 países possuem atualmente legislações de defesa da concorrência, além de órgãos supranacionais com regramento específico, como a União Europeia, a Comunidade Andina, a COMESA (Common Market for Eastern And Southern Africa), dentre outras (para mais detalhes vide: $<$ http://www.ftc.gov/policy/international/competition-consumer-protection-authorities-worldwide>).
} 
concorrencial das mais diversas nações, nos mais distantes pontos da história, sempre se deu a partir deste elemento de preocupação.

Um ponto aparentemente paradoxal a se considerar seria que a própria persecução ao abuso do poder econômico estrito senso, a que convencionamos aqui chamar de condutas unilaterais, e que parece ser atualmente o segmento de maior controvérsia e menor preocupação e atuação das autoridades de defesa da concorrência, muito em razão dos embates teóricos que se impõem e da complexidade que requer um estudo aprofundado e aplicação razoável de suas regras. Assim, antes a semente do direito concorrencial, as condutas unilaterais parecem ser hoje objeto de distanciamento ou aversão de muitas autoridades concorrenciais.

É necessária maior reflexão sobre os efeitos destas condutas de agentes econômicos com posição dominante nos mercados. Como veremos, teorias econômicas mais liberais têm contribuído com grande grau de influência na política de concorrência de algumas nações, as quais ecoam em outros sistemas, como o jus-concorrencial pátrio. Muito em razão da globalização dos mercados, há constante inter-relação com as práticas de multinacionais no exterior que acabam por afetar mercados locais.

Será frisada ao longo do presente trabalho a necessidade de pensarmos a formulação de um direito concorrencial próprio, analisando o ordenamento jurídico em que nos inserimos, de forma a criarmos ideologia de aplicação que atenda às realidades locais. Devemos partir de um estudo comparativo como instrumento de análise, e não como fim, a exemplo da sugestão de diversos autores, especialmente no tocante ao tema dos abusos de posição dominante. Para tanto, de vital importância que se reconheçam as origens destes sistemas e suas particularidades, a fim de se trazer a referida modelagem própria.

\subsection{Escopo das Normas de Defesa da Concorrência}

Grande discussão doutrinária entre os catedráticos do direito concorrencial reserva-se aos limites e objetivos deste ramo do direito. Vários poderiam ser os elencados objetivos da lei de defesa da concorrência, os quais podem variar diametralmente nas mais diversas jurisdições, influenciados por inúmeros fatores.

Esta discussão se faz relevante não somente à academia, mas acima de tudo para a aplicação do direito concorrencial. Determinar-se de forma equivocada o escopo das normas de defesa da concorrência pode implicar em atuação mais ou menos interventiva 
por parte do Estado, consequentemente desbalanceando a exata medida de incentivos a que deve se prestar a atuação regulatória interventiva.

Em particular, esta discussão se faz indispensável ao reconhecimento daquilo que seria um dos temas mais controversos - e importantes - atualmente no direito concorrencial: os limites da concorrência no mérito.

Verificamos, assim, determinação de escopos mais liberais, em que a eficiência econômica deve desempenhar papel fundamental, ao mesmo tempo em que diversos outros objetivos são reconhecidos, conforme tratemos a seguir. Inegável em nossa visão, contudo, ao se delimitar o escopo das normas antitruste, que o ordenamento jurídico em questão esteja sujeito a uma interpretação teleológica a fim de se retirar as bases jurídicas de aplicação das normas de defesa da concorrência.

Vale recordar a frustração de Ronald Coase com as regras do direito da concorrência, visto que, segundo o economista, quando os preços eram aumentados, juízes diziam se tratar de monopólio; quando os preços eram reduzidos, juízes diziam tratar-se de preços predatórios, e quando os preços permaneciam estáveis, diziam tratar-se de colusão tácita. $^{37}$

Se por um lado se espera que o escopo de uma norma posta se faça claro e objetivo, encontrando sustentação na norma fundamental do Estado, nem sempre se alcança o fim colimado. Talvez isto seja ainda mais verdade no que tange às normas de defesa da concorrência, geralmente firmadas sobre uma tipologia relativamente aberta.

E quando não se tem claro e delineado o objetivo fundamental a que deve se prestar um sistema de defesa concorrencial, diversos fatores podem influenciar na perspectiva que se dá a uma análise de concentração ou a um controle repressivo de conduta. A ser mais bem discutido ao longo deste trabalho, cabe somente mencionar alguns desses fatores de influência, como o sistema legal adotado e sua respectiva instrumentalização, objetivos supranacionais ou mesmo federativos de integração econômica, modelos econômicos adotados, tradição publicista ou privatista do corpo administrativo, dentre outros.

Certo está, para alguns autores, que a "política concorrencial" encontra-se atualmente mais relacionada à criação de padrões de conduta do que propriamente com a obtenção de metas atingíveis, encontrando-se, via de regra, ancorada em princípios de livre

37 ØSTERUD, Eric. Identifying Exclusionary Abuses by Dominant Undertakings under EU Competition Law: The Spectrum of Tests. International Competition Law Series. Great Britain. Wolters Kluwer Law \$ Business. 2010. p. 1-2. 
mercado capitalistas. ${ }^{38}$ A aplicação das normas de defesa da concorrência pode apresentar diferentes perspectivas, subsumindo-se a mercados extremamente liberalizados até aqueles em que o Estado desempenhe papel mais incisivo, ou mesmo a países que se encontram em fase de transição de políticas socialistas. As origens e respectivos motivos pelos quais são criadas as normas de defesa da concorrência podem - e de fato o fazem - direcionar o rumo da aplicação da norma, conforme pretendemos demonstrar adiante. Elementos extrínsecos à norma material, como os citados acima, podem ainda influenciar seu desenvolvimento de forma determinante.

No berço do direito concorrencial moderno constatamos os objetivos das normas antitrustes intensamente pautados pela influência das sucessivas escolas econômicas que, a partir da década de 50, passaram a modelar a aplicação destes ramos do direito, alastrandose por outras jurisdições ao longo das décadas.

Inicialmente, cabe enfatizar o conceito de que normas de concorrência seriam aquelas aptas a regulamentar, preventiva ou repressivamente, o comportamento dos agentes econômicos como instrumento de implementação de políticas públicas. Por sua vez, políticas públicas, neste contexto, visam proteger os mecanismos de mercado, prevenindo opressão econômica. ${ }^{39}$ Estaria aqui, portanto, a principal diferença entre as políticas públicas concorrenciais com a atuação direta do Estado ou sua atividade regulatória ex ante. No que pese o conceito acima, a discussão da natureza das normas de defesa de concorrência se coloca adiante, ao se inquirir tratar-se de uma política pública ou uma garantia institucional a ser perseguida pelo ordenamento.

As vantagens deste sistema, se comparado a um sistema de planejamento ou coordenação mais centralizado, estariam no constante ajuste que os agentes de mercado deveriam promover a fim de manterem seus negócios competitivos, sendo que aquele que não se adaptar corre imensos riscos de insucesso.

Diversos seriam os grupos de objetivos das políticas concorrenciais a que podemos nos referir. Sullivan e Grimes ponderam, neste sentido, que tais grupos podem incluir: (i) objetivo do bem-estar do consumidor, incluindo alocação eficiente de recursos e evitando transferência de renda entre os agentes econômicos que interagem; (ii) eficiência

\footnotetext{
${ }^{38}$ WILKS, Stephen. Competition Policy - Towards an Economic Constitution. In WALLACE, Helen; POLLACK, Mark A.; YOUNG, Alasdair R. (coord.). Policy-making in the European Union. Sixth Edition. Oxford Univesity Press. p. 134.

39 "Antitrust overriding goal is to maintain public confidence in the market mechanism by deterring and punishing instances of economic oppression. Antitrust preserves and protects markets as an alternative to more intrusive government regulation or control of the economy" (SULLIVAN, Lawrence A.; GRIMES, Warren S. The Law of Antitrust. An Integrated Handbook. Saint Paul, Minn: West Group, 2000. p. 10).
} 
dinâmica, com a promoção da inovação e progresso tecnológico; (iii) proteção de firmas individuais através de objetivos de justiça e equidade; e finalmente (iv) manutenção de poder econômico descentralizado. ${ }^{40}$

Em uma situação de monopólio, a quantidade produzida é menor e o preço mais elevado, sendo que aqueles que se propõem a adquirir o bem a um preço superior tornam a estratégia mais lucrativa. Neste cenário, verificamos que a alocação dos escassos recursos não seria eficiente, havendo inevitável transferência de renda do consumidor para o monopolista. $^{41} \mathrm{O}$ escopo das políticas concorrenciais estaria, desde já, justificado na prevenção a esta indesejável transferência de renda dos consumidores para os agentes monopolistas acima dos níveis concorrenciais normais. Isso equivale a impedir ou evitar a perda de bem-estar social do consumidor. ${ }^{42}$

A promoção de inovação e progresso tecnológico, ou eficiência dinâmica, referese aos melhoramentos ou evoluções da tecnologia de um produto ou serviço melhoramento ou criação de novos produtos ou mesmo de sua técnica de produção. $\mathrm{Na}$ seara da promoção da eficiência dinâmica é que talvez tenhamos os limites da concorrência menos compreendidos, e talvez aqui sejam mais incertos os limites de aplicação do direito concorrencial, no sentido de prover os necessários incentivos para que haja o indispensável investimento em pesquisa e desenvolvimento por parte dos agentes econômicos. ${ }^{43}$

Outros objetivos outrora considerados pela doutrina merecem menos destaque nos dias de hoje, como a proteção de concorrentes em detrimento da proteção do próprio instituto da concorrência. Poucos atualmente discordam que tal objetivo não deve se servir a promover a proteção de concorrentes ineficientes. O racional de um sistema de livre concorrência, não podemos esquecer, encontra-se no fato de que agentes econômicos

${ }^{40}$ SULLIVAN, Lawrence A.; GRIMES, Warren S. The Law of Antitrust. An Integrated Handbook. cit., p. 12.

${ }^{41}$ Eficiência alocativa implica produção e distribuição mais eficiente possível, através do uso de tecnologia existente.

${ }^{42}$ A Escola de Chicago defende que preocupações com transferência de renda deveriam ser reguladas via políticas fiscais ou quaisquer outros instrumentos apropriados para tal fim. Neste caso, situações em que houvesse transferência de renda, porém que gerassem eficiências que superassem tais transferência de renda, poderiam ser autorizadas. Assim, se discute se ambos os escopos - transferência de renda e potenciais reduções de bem-estar do consumidor - deveriam ser conjuntamente considerados.

${ }^{43}$ A questão da proteção patentária serve de estímulo à inovação na medida em que traz exceção ao princípio da livre concorrência, de forma a permitir a adequada remuneração do agente inovador. A presença de externalidades positivas criou a necessidade desta proteção aos inovadores. Vale notar que a exata dosagem de proteção é requerida, de forma que não haja maior proteção do que o necessário para que se dê a remuneração do agente inovador e que venha a restringir a atuação do princípio da livre concorrência além do necessário, promovendo maior transferência de renda, por exemplo. Da mesma forma, uma proteção insuficiente quer representar verdadeiro desincentivo para os necessários investimentos em pesquisa e desenvolvimento que visa a eficiência dinâmica. A aplicação do direito concorrencial estaria justificada na medida em que houvesse tal desalinhamento na intensidade da proteção concedida. 
devem estar sujeitos ao insucesso, e fatalmente o alcançarão quando ineficientes. Da mesma forma vale mencionar o escopo da prevenção do crescimento de grandes negócios em detrimento dos pequenos negócios, hoje objetivo sem força mesmo nos Estados Unidos.

Segundo Wilks, ${ }^{44}$ a política de concorrência deve ser levada em conta sob sua ótica política e econômica. A primeira implicaria compromisso dos governos de permitirem aos atores econômicos a liberdade de concorrerem no mercado, bem como de protegerem consumidores da exploração de grandes empresas. Mais recentemente a ótica econômica tem sido clamada a desempenhar regra mais atuante, desde os primeiros ensaios proferidos pela escola liberal de Chicago, através do estudo das eficiências econômicas resultantes da interação de seus agentes, englobando não somente eficiências estáticas, notadamente as produtivas e alocativas, mas ainda sua perspectiva dinâmica. Assim, temos que políticas de concorrência se prestariam ao papel de assegurar que a concorrência do mercado não seja restringida ou prejudicada de forma a reduzir o bem-estar econômico.

Podemos assim dividir o escopo de análise das teorias econômicas desenvolvidas em três grandes períodos de embate entre as visões: o período em que predominou a Escola de Harvard; o período de predominância da Escola de Chicago; e, finalmente, o período Pós-Chicago. Às teorias econômicas desenvolvidas a partir da década de 50 nos Estados Unidos visando a promoção de uma maior interação com o direito chamamos de Law and Economics, ou Teoria do Direito e Economia. Talvez tenhamos na aplicação de seus preceitos os principais instrumentos de suporte para análise da teoria da responsabilidade especial dos agentes dominantes.

A denominada Escola Estruturalista de Harvard, cujos principais representantes foram Carl Kaysen e Donald Turner, enfatizava o estudo das estruturas de mercado individuais. Segundo a teoria, a estrutura do setor era determinante para o desempenho da indústria. Em estruturas concentradas as empresas seriam protegidas da competição por altas barreiras à entrada. ${ }^{45}$ Assim, sustenta esta escola clássica que devem ser evitadas excessivas concentrações de poder no mercado, que acabam por gerar disfunções ao fluxo das relações econômicas. Esta questão estaria relacionada mais diretamente com o número de agentes econômicos no mercado. Assim, o modelo de concorrência deveria perseguir a manutenção ou incremento do número de agentes econômicos no mercado, sendo a

44 WILKS, Stephen. Competition Policy - Towards an Economic Constitution. In WALLACE, Helen; POLLACK, Mark A.; YOUNG, Alasdair R. (coord.). Policy-making in the European Union, cit., p. 134.

${ }^{45}$ SALOM ̃̃O FILHO, Calixto. Direito Concorrencial - As condutas, cit., p. 22. 
concorrência buscada como um fim em si mesma. Mantendo-se pulverizada a estrutura, evitam-se as disfunções do mercado.

A Escola de Chicago, por sua vez, surgiu com trabalhos do economista Aaron Director, o qual ainda de forma simplificada expressou sua teoria do preço. Este trabalho haveria de ser desenvolvido posteriormente, nos anos 60 e 70, por Robert Bork e Richard Posner, com a aplicação da teoria marginalista ao estudo antitruste, que visava focalizar o estudo desta modalidade de direito na eficiência produtiva, além de uma contestação mais direta à ilicitude dos acordos verticais e da teoria tradicional dos preços predatórios. Os autores tinham convicção de que eficiências produtivas eram justificadoras da obtenção ou manutenção de posições dominantes. ${ }^{46}$ Bork lança seu paradoxo: ao mesmo tempo em que o antitruste preserva a concorrência, combate-a, de sorte que se trata de uma "política em guerra com si mesma".

Posner pregava a capacidade inerente aos mercados de se autorregularem, na grande maioria das vezes, defendendo ainda que restrições à concorrência seriam menos frequentes do que imaginava a escola intervencionista objeto de suas críticas. A mais pura expressão da escola de Chicago era fundada na ideia de criação de bem-estar social, o que, aos olhos de Bork, implicava o conceito de eficiência econômica, único fim almejado pelas normas de defesa da concorrência. ${ }^{47}$

As ideias da Escola de Chicago influenciaram a aplicação das leis antitrustes durante seu tempo, assim como a Escola de Harvard também o fez alguns anos antes. O duro padrão de aplicação das normas concorrenciais durante os anos 60 flexibilizou-se para um padrão mais permissivo durante o mandato do Presidente Ronald Reagan, nos anos 80, por exemplo. Naturalmente que o sistema legal tripartite norte-americano funcionava como um balanço na medida em que, verificando-se a diminuição da sua aplicação em nível federal, verificava-se rápida compensação no nível de aplicação das leis estaduais e por parte de particulares presentes no sistema judicial norte-americano.

O pensamento acadêmico continuou ainda sua evolução com figuras como Robert Lande, que defendia a ideia de que o propósito principal da lei de concorrência seria o de prevenir firmas de adquirirem e abusarem de seu poder de mercado como forma de impor aos consumidores sobrepreços. Ele ainda criticava as ideias de Bork em atribuir a preocupação do Congresso norte-americano com maiores preços como resultado do poder

${ }^{46}$ SALOMÃO FILHO, Calixto. Direito Concorrencial - As condutas, cit., p. 21.

47 Defendia ainda Bork a ideia de que outorgar-se discricionariedade a juízes no tocante às metas de aplicação da defesa da concorrência poderia criar um caos sistêmico, fato que, diga-se de passagem, pode ser verificado algumas décadas após sua previsão em algumas vertentes decisórias das cortes norte-americanas. 
de mercado a uma preocupação com a eficiência alocativa. Lande defendia ainda que, diferentemente das ideias de Bork, a maior preocupação do Congresso com a adoção do Sherman Act dizia respeito à indesejável transferência de renda de consumidores, aceitando que os objetivos das leis antitrustes, sobretudo, abarcavam a transferência de renda e as eficiências econômicas. Assim, Lande atribuiu ainda outros valores à análise concorrencial, centrando a preocupação desta nova teoria no conceito de eficiência distributiva, tendo mais tarde admitido que atribuir-se tais valores à análise concorrencial dificilmente seria possível sem incorrer em caos político e social, a exemplo do que pregava Bork.

Rápida referência devemos ainda fazer a outros teóricos que contribuíram com suas teorias, de forma a agregar ao objeto da política da concorrência outros valores sociais, como a proteção de pequenos negócios, por Schwartz, e considerações políticas, apregoadas por Pitofsky no sentido de que o poder econômico derrubaria as instituições democráticas e corroeria a liberdade, fato que por si justificava o aumento do intervencionismo estatal através de políticas antitrustes. Da mesma forma, Hovenkamp reconhecia que a história legislativa dos Estados Unidos trazia considerável evidência de preocupação em condenar gigantismos e acumulação de riquezas em razão da manutenção da facilidade de entrada no mercado e viabilidade de pequenos negócios.

Posteriormente desenvolveram-se novas teorias baseadas em métodos econométricos e analíticos mais voltados aos comportamentos de empresas individuais ou setores da economia. Para Calixto Salomão, "[d]esnecessário dizer que a consequência, no plano jurídico, é o deslocamento do controle das estruturas para o controle dos comportamentos". 48

Esta visão pós-Chicago se compunha, principalmente, de três teorias principais: a teoria dos mercados contestáveis, a teoria dos jogos e a teoria dos custos de transação.

A teoria dos mercados contestáveis visou trazer elemento dinâmico de análise para as estruturas de mercado, passando a analisá-las em função da concorrência potencial de agentes econômicos. Assim, mercados seriam contestáveis em função do número de empresas que poderiam nele ingressar, contestando a posição daqueles que lá estivessem. Bastaria a um mercado, portanto, funcionar mais próximo à sua contestabilidade, e não necessariamente sob as premissas de uma concorrência perfeita. ${ }^{49}$

\footnotetext{
${ }^{48}$ SALOMÃO FILHO, Calixto. Direito Concorrencial - As condutas, cit., p. 23.

${ }^{49}$ Mercados perfeitamente contestáveis seriam aqueles em que a entrada é absolutamente livre e a saída não importa relevantes custos para o produtor.
} 
Por sua vez, a teoria dos jogos, semeada pela obra de J. Von Neumann e O. Morgenstern, ${ }^{50}$ e desenvolvida posteriormente por John Nash $^{51}$ e seus seguidores, procura demonstrar que todo comportamento humano estaria motivado por razões exclusivamente individualistas, sendo que a estratégia do jogador seria motivada pela provável resposta ao comportamento dos demais jogadores - Nash Equilibrium. O equilíbrio de Nash se daria, desta forma, diante da melhor estratégia adotada por um jogador, em função da estratégia esperada dos demais jogadores. A combinação de comportamento a ser adotada seria aquele em que nenhum jogador poderia obter melhor resultado adotando outra estratégia, levando em consideração o comportamento esperado dos demais jogadores.

Surge ainda neste momento a nova economia institucional, com uma preocupação mais focada nas instituições em substituição à preocupação essencial dos neoclássicos com os mecanismos microeconômicos que orientam o mercado. A teoria dos custos de transação vem neste sentido introduzir novos conceitos para estudo do mercado e sua configuração. O estudo inicial de Ronald Coase, desenvolvido por Oliver Williamson, define como custos de transação aqueles necessários para realizar uma transação no mercado, ao invés de simplesmente realizá-lo no interior da empresa. Com isso vem a reboque os conceitos de racionalidade limitada, centrada na pequena capacidade do ser humano de resolver problemas transacionais complexos, aumentando as incertezas negociais. Ainda, comportamentos oportunísticos seriam verificados diante da tendência de perseguir fins egoísticos nas operações de mercado em detrimento dos demais agentes econômicos. Assim, a eliminação das incertezas dos mercados incentiva o agente econômico a internalizar suas atividades na empresa. ${ }^{52}$

Verificamos ainda que a teoria dos custos de transação pode implicar mais permissividade com relação ao controle das estruturas, na medida em que eficiências são identificadas na internalização de funções ou verticalização, reduzindo custos de transação.

A teoria institucionalista traz ainda evoluções de relevo para o direito, como a teoria dos comportamentos estratégicos. Sua proposição considera que muitas vezes o agente econômico não age movido por uma racionalidade individual, sobretudo quando é capaz de influenciar a posição jurídica da outra parte. Uma vez que sua atuação seria, portanto, voltada à obtenção de maior lucro nas transações, mesmo que isso envolva a

\footnotetext{
${ }^{50}$ NEUMAnN, J. Von; MORGEnStern, O. The Theory of Games and Economic Behaviour. Princeton University Press, 1944.

${ }^{51}$ NASH, J. The bargaining problem. In KUH, H. Classics in Game Theory. Econometrica, vol. 18, 1950.

52 SAlOMÃO FILHO, Calixto. Direito Concorrencial - As condutas, cit., p. 30: "Na empresa as transações são comandadas pela organização empresarial e não pelo mercado, e a empresa será tanto maior quanto mais interessante for para o empresário substituir as transações de mercado por transações internas."
} 
eliminação da contraparte, cumpriria ao Direito desestimular comportamentos estratégicos e incentivar comportamentos cooperativos. ${ }^{53}$

Reconhecemos, portanto, que todas as teorias descritas influenciaram, cada qual a seu tempo e à sua maneira, a aplicação das leis de defesa de concorrência não somente nos Estados Unidos, ainda hoje colocando desafios institucionais diversos em debate, dentre os quais os limites do objetivo da lei de defesa da concorrência e sua respectiva aplicação. Nessa jurisdição é interessante verificarmos a ideia do pêndulo que gravita sobre a atividade concorrencial, marcada por vezes como política intervencionista que se assemelha ao pensamento de Harvard, outras vezes, como tem sido nos últimos anos, calcada nas ideias fundamentalmente liberalistas enraizadas nos modelos de Chicago e suas evoluções. Referido pêndulo encontra-se atrelado, indubitavelmente, aos dogmas políticos predominantes nos momentos históricos diversos, numa clara alusão à captura por parte da função jurisdicional administrativa. ${ }^{54}$

Em síntese, verifica-se que o embate entre ideias intervencionistas e liberalistas existe de longa data, em especial nos Estados Unidos, contribuindo substancialmente para o debate acerca das responsabilidades dos agentes dominantes, visto que se confunde com os limites do direito que se pretende impor a estes na manutenção da saúde do sistema de concorrência. Contudo, e conforme mencionado anteriormente, os tribunais norteamericanos têm colocado algumas regras um pouco de lado em períodos mais recentes, como a proteção de pequenos negócios e a proteção de concorrentes ao invés da garantia institucional da concorrência. ${ }^{55}$

Devemos lembrar ainda da aplicação cíclica das normas de concorrência nos Estados Unidos, através de congelamento de certos valores e recuperação de outros, de tempos em tempo, sem talvez uma linha lógica para determinados temas de relevância, e que acabam por gerar, por que não dizer, certo caos no reconhecimento de padrões de subsunção do sistema norte-americano concorrencial, conforme previa Bork.

\footnotetext{
53 SALOMÃO FILHO, Calixto. Direito Concorrencial - As condutas, cit., p. 34.

54 Os anos 60 nos Estados Unidos foram marcados por uma aplicação dura das leis de concorrência influenciada, dentre outras razões, pelas ideias disseminadas pela Escola de Harvard. O período subsequente, que se iniciou ao final da década de 70 até o final dos anos 80 , foi marcado por uma atuação mais permissiva das autoridades, muito em razão das ideias de Bork. Os anos 90, por sua vez, trouxeram mais ênfase no controle da transferência de renda, através de uma atuação mais incisiva da lei se comparada ao período antecedente. Vide SULLIVAN, Lawrence A.; GRIMES, Warren S. The Law of Antitrust. An Integrated Handbook, p. 7.

${ }^{55} \mathrm{E}$, diga-se de passagem, que esta é uma das maiores críticas de doutrinadores e mesmo autoridades com relação à política concorrencial europeia.
} 
Na Europa, por sua vez, a visão predominante com a instituição do Tratado de Roma vinha no sentido de fomento a um mercado comum de forma a gerar benefícios a todos os seus integrantes. Tratava-se de uma visão liberal econômica que, à época, encontrou muito ceticismo em razão das teorias socialistas que se fortaleciam. Tornou-se somente uma visão dominante no continente como resultado das revoluções neoliberais da década de 80 e com o programa do mercado comum em 1992, visão esta ainda consolidada pelo colapso do sistema comunista soviético. ${ }^{56} \mathrm{Em}$ uma política capitalista de livre iniciativa, a concorrência efetiva é a dinâmica central da atividade empreendedora, bem como a melhor maneira de fomentar o sistema econômico seria através da obtenção de bem-estar social.

Atualmente, podemos dizer que a política concorrencial europeia baseia-se em cinco pilares de sustentação: proibição de contratos entre agentes econômicos que limitem a concorrência; proibição do abuso de posição dominante por um ou mais agentes econômicos; controle de fusões e aquisições que venham a criar agente econômico com posição dominante; controle de auxílio estatal ou "state aid" por Estados-membros a agentes econômicos ou categorias econômicas; e liberalização de medidas pelos Estadosmembros para favorecerem o segmento de infraestruturas nacionais. ${ }^{57}$

Desta forma, verificamos que na Europa a política concorrencial desempenha função essencial na integração do mercado e da economia, trazendo benefícios diretos e indiretos aos seus administrados. A Comissão Europeia, neste sentido, que possui significativos poderes para aplicação da norma antitruste, tem sido de especial importância, contando com o apoio do Tribunal de Primeira Instância e do Tribunal de Justiça Europeu. Esta política - na Europa há difundida utilização da expressão "política de concorrência, a exemplo do Brasil - tem sido usada não somente para disciplinar empresas, mas também governos, em especial por conta das particularidades do regime europeu de integração do mercado comum. Isso porque o escopo de integração econômica europeia promoveu normativos para acordos e condutas de agentes de mercado, regras para auxílios estatais e políticas de desestatização de setores da economia.

Muitos países da Europa Oriental, por sua vez, inseriram no contexto de aplicação de suas normas concorrenciais políticas de nacionalização, intervenção seletiva, planejamento indicativo, encorajamento de concentrações, de economias de escala, e apoio

\footnotetext{
${ }^{56}$ WILKS, Stephen. Competition Policy - Towards an Economic Constitution, cit., p. 134.

57 Os respectivos princípios estão previstos nos artigos 101, 102 e 107 do Tratado, EC Merger Regulation, editado pela Comunidade Europeia (Official Journal L 24, 29.01.2004), e artigos 31 e 86 do TEC.
} 
à criação de campeões nacionais. E quantas das características elencadas não podem ainda hoje ser reconhecidas até mesmo em países de tradição concorrencial? Após a crise econômica de 2008, muitos dos pontos antes criticados ressurgiram. A própria Comissão Europeia criou suas isenções de bloco para auxílios estatais a bancos, a ser aplicada até o período de 2010.

Sob o prisma político, cabe notar que as decisões do Parlamento Europeu sobre matéria de concorrência levam em consideração votos de Conselheiros de cada Estadomembro, os quais podem ter interesses divergentes. Porém a Comissão Europeia possui relativa independência do Parlamento, gozando de liberdade para editar normativos e desempenhando forte papel no design e execução das políticas concorrenciais, de forma centralizada, portanto.

Há muito se fala de uma desejada convergência na aplicação das normas de defesa da concorrência pelos Estados Unidos e pela Europa. Mais do que isso, contudo, deve-se pensar em convergência de pensamentos globais. Apesar de reconhecermos que ainda hoje a aplicação das normas concorrenciais por muitos países em nada se assemelha a outros tantos, reconhecemos também que há grande consenso nos pilares estruturais para a criação de um sistema concorrencial que venha a ser minimamente eficiente. Alguns países levaram menos tempo para reconhecê-los e aplicá-los, outros ainda possuem grande desafio à frente.

No caso dos Estados Unidos e da Europa, apesar de episódios conflitantes entre a forma de aplicação da lei de concorrência muitas vezes para os mesmos ou similares casos, há de se reconhecer grande convergência nos últimos anos. Ao se estudar a história da formação de um consenso em torno da importância do direito da concorrência, verificamos particularidades que ainda hoje se aplicam a determinada região, bem como podemos projetar uma perspectiva de amadurecimento em razão dos pontos comuns reconhecidos.

Assim, devemos lembrar que a própria União Europeia demorou a ter reconhecido, pela sua comunidade empresarial, a importância das políticas de concorrência no direcionamento dos seus negócios empresariais, sendo que, até os anos 90, a maioria das empresas não tratava tal política com a devida importância, em termos de sua influência na estratégia comercial traçada. Não obstante, atualmente as regras concorrenciais são constante fator de consideração, para não dizer pressão, no desenho das estratégias negociais.

As razões para esta mudança de perspectiva são diversas, a se elencar, por exemplo, o refinamento e a expansão dos regramentos legais, dos próprios instrumentos 
informativos, persecutórios e punitivos, até o ativismo das autoridades, que acaba por aumentar as chances de detecção de infrações, bem como o rigor das penalidades aplicadas, tornando-se menos atrativo e mais arriscado às empresas qualquer exposição. A persecução criminal ainda não é uma possibilidade segundo o diploma europeu, mas alguns Estados-membros que adotam tais medidas contribuem para a mudança de perspectiva. As crescentes multas aplicadas pelas autoridades têm ainda contribuído para uma mudança positiva desta visão.

Pode-se dizer que este comportamento, em razão dos elementos fáticos que se colocam, vai além do previsível segundo os princípios da economia comportamental. $\mathrm{O}$ homem racional que tem para si a busca constante da mais valia, passa a levar em consideração novos elementos para sua atividade estratégica, tal como a probabilidade de detecção de seu comportamento ilícito e a probabilidade de sua condenação administrativa, civil e criminal.

Nas próprias sociedades asiáticas, por exemplo, os princípios concorrenciais ainda hoje encontram grande desconfiança e crítica por parte da comunidade empresarial. Em algumas, a recente história político-econômica socialista impede, ou pelo menos retarda, a adoção de um dos princípios mais puros do capitalismo - a concorrência no seu mérito. Outras vezes, a própria história recente de formação econômica de uma nação, ditada por ideais concentracionistas e cooperativos que fomentam ganhos de escala, segundo ainda uma origem comum ou relacionada, como seria o exemplo da Coreia, trazem significativas barreiras à compreensão da necessidade de gerenciamento unilateral de seus negócios, bem como do tênue limite da cooperação pró e anticompetitiva.

Talvez a dificuldade da definição acerca do escopo das normas de defesa da concorrência, sob a ótica dos países que adotam tal sistema, encontre-se na controvérsia do tema. Grandes empresas ou conglomerados econômicos possuem características muito atrativas, tais como presença de economias de escala, largas possibilidades financeiras, não raramente se caracterizando como exemplos de um poder nacional industrial. Mais importante ainda, sob uma ótica econômica, presumidamente seriam capazes de financiar tecnologia de ponta e de operar como multinacionais poderosas capazes de competir diretamente com outras nações - campeões nacionais.

Ainda que se atinja consenso no escopo de uma política de concorrência, fato relativamente utópico na sua essência, não podemos nos esquecer de que a lei posta encontra-se sempre sujeita a interpretações. O controle externo político-administrativo, presente em diversas jurisdições, muitas vezes é exercido de forma sutil, como nos casos 
em que orçamento necessário para uma eficiente aplicação da legislação são limitados. Nestes casos não haveria de se esperar que haja suficiência no desempenho de suas atividades, e certamente a atividade regulatória das autoridades de defesa da concorrência estará abaixo de seu ponto ótimo.

Devemos considerar, em tempo, a extrema discrepância no nível de desenvolvimento econômico das diferentes nações que aplicam o direito concorrencial. Tal fato implica dinâmicas de mercados específicas, mas que merecem aplicações semelhantes: as premissas de aplicação do direito da concorrência devem ser as mesmas, porém os resultados dificilmente serão semelhantes nestas diferentes circunstâncias.

A própria ausência de um mecanismo de controle da legalidade das decisões tomadas pelas autoridades incumbidas do controle concorrencial merece ponto de destaque. Neste sentido temos visto com acerto o modelo institucional adotado na União Europeia de controle das decisões da Comissão Europeia, desempenhado pelo Tribunal de Primeira Instância e pelo Tribunal de Justiça Europeu. São estes os grandes responsáveis por nortear e lapidar a atuação da Comissão, fato não observado em diversas outras nações, como seria o caso do Brasil.

Uma das críticas que se pode fazer ao sistema norte-americano diante da descentralização do controle da livre concorrência viria no sentido da menor especialidade existente na origem da questão, e que uma vez viciada, gera problemas muitas vezes não corrigíveis ao longo de seu trâmite.

Outro ponto que merece consideração seria o grande abismo existente no nível de desenvolvimento e maturidade das instituições políticas das diferentes nações do globo que adotam sistemas concorrenciais. Por vezes, temos visto que a garantia de um ambiente de proteção à livre concorrência pode atrair questões de natureza diversa, como seria o exemplo de questões trabalhistas ou mesmo ambientais - e que se tornam condicionantes de uma análise antitruste. ${ }^{58}$ Talvez mais relacionado ao controle preventivo, observamos ideais relacionados à transferência de renda, manutenção do pleno emprego, correção ou manutenção de contribuições fiscais, dentre outros elementos, mas que fogem ao tema proposto.

Além dos três grandes momentos de embate teórico econômico, a produção de teorias voltadas ao Law and Economics é cada vez mais rica e coloca importantíssimo pilar

\footnotetext{
${ }^{58}$ Neste sentido podemos citar o exemplo das autoridades de defesa da concorrência da África do Sul, que tem reiteradamente condicionado operações de análise estrutural à manutenção dos níveis de emprego existente pré-operação.
} 
de sustentação para as análises concorrenciais. Não há retorno na trilha que nos leva ao uso cada vez mais intenso da teoria econômica aplicada aos preceitos de livre concorrência.

Ao mesmo tempo, deve-se reconhecer o outro lado que seria o papel cada vez mais relevante do instituto da concorrência no contexto da economia moderna, buscando proporcionar aos consumidores preços mais baixos, melhor qualidade e maior variedade de bens ou serviços, bem como inovação tecnológica. Ainda, pretende-se combater, para consecução destes objetivos, mercados tendenciosamente concentrados, cujos incentivos para condutas acertadas e práticas de fechamento são, via de regra, mais acentuados em vista de suas estruturas dinâmicas.

Pergunta-se, pois, ainda hoje e passados mais de cento e vinte anos da edição do Sherman Act, que valores devem ser levados em consideração para que autoridades de defesa da concorrência façam suas análises. $\mathrm{O}$ conceito econômico de eficiência - aqui se levando em conta as eficiências produtivas, alocativas e dinâmicas - deve respaldar as análises de forma exclusiva e, portanto, os fundamentos das decisões, ou fatores de justiça social, estranhos à ótica econômica, devem ser sopesados pelas autoridades?

É certo que a análise normativa das regras postas sobre a repressão ao abuso de poder de mercado deve servir para responder indagações acerca da eficácia do tipo legal, ou seja, se a norma como colocada traz os incentivos necessários para se coibir a prática do abuso. Neste campo do direito em que se discutem os valores axiológicos da norma, a assimetria de informação e a racionalidade limitada dos agentes econômicos ainda nos parece ocupar posição de destaque no que tange às dificuldades para se mensurar seus verdadeiros efeitos.

Apesar de suas origens seculares, é importante notar que os sistemas concorrenciais têm recentemente tomado corpo e importância, sendo que seus princípios ainda não se encontram enraizados na ideologia empresarial de muitos países, entre os quais, ainda hoje, o Brasil. Trata-se de uma das dificuldades que se coloca para que se complete uma análise normativa neste microssistema.

Ainda se torna inevitável mencionarmos a questão da matéria probatória e padrão de prova utilizado pelas autoridades de defesa da concorrência. Tal discussão deve abarcar temas controversos, como as condenações per se e a teoria dos efeitos desenvolvida pelas autoridades concorrenciais brasileiras. Neste sentido não nos parece existir, nos dias de hoje, proporção entre o padrão de provas utilizado no âmbito da administração pública brasileira, no que tange à matéria de defesa da concorrência, e a atividade do poder judiciário em questões de natureza civil, criminal e comercial. Ainda, questionamo-nos se 
as diversas modalidades de acordo criadas pelas autoridades de defesa da concorrência de tantos países, como a leniência e os acordos de cessação de condutas, contribuiriam com real efeito dissuasório para prática de ilícitos, conforme pretendido pelo legislador.

Aumentar o padrão de prova no âmbito da apreciação administrativa ou judicial, por outro lado, pode reduzir as chances de condenação de um agente inocente, da mesma forma que aumentam as chances de não condenação de um agente culpado. Remetemo-nos à pergunta que Blackstone levantou há mais de duzentos anos, questionando se seria melhor que dez culpados fossem inocentados do que um inocente condenado. ${ }^{59}$ No direito concorrencial costuma-se entender a discussão pelo embate entre erros tipo 1, ou falso positivos, e erros tipo 2, ou falso negativos.

No que tange mais especificamente à experiência brasileira, é correto afirmar, preliminarmente, que talvez esta ainda procure o seu eixo de atuação, oscilando em alguns momentos para vieses mais permissivos e, outros, mais raros, um pouco mais intrusivos. Porém, devemos reconhecer que cada vez mais intensamente as autoridades nacionais têm empregado instrumentos de análise econômica capazes de aumentar a objetividade da análise concorrencial. Assim, o escopo de nossa norma antitruste será abordado de modo mais abrangente adiante, segundo as especificidades de nosso ordenamento jurídico e sua organização, dentre outros fatores.

\subsection{Papel do Direito na Regulação dos Mercados}

Como brevemente relatado, a partir da segunda metade do século XX iniciaram-se processos de privatização em diversos países do continente americano e europeu. A atuação estatal passou a se dar de maneira menos intrusiva, indireta, através da regulação de comportamentos. Surgiram assim agências reguladoras com papel de normatizar setores regulados e fiscalizar o comportamento dos agentes econômicos.

Essa interferência do Estado na organização da economia, que teria como propósito corrigir eventuais falhas de mercado, intensificou-se com a globalização, especialmente em razão da dimensão dos impactos por ela causados na concorrência. As inter-relações que se formam a partir desta quebra de fronteiras causam reflexos dos mais variados em todas as nações que, de alguma forma, interagem no comércio internacional.

O Estado, cujo objetivo é o bem comum, incumbe-se de garantir o adequado

\footnotetext{
${ }^{59}$ Neste sentido vide FRIEDMAN, David D. Law's Order. Princeton, 2000. C. 2.
} 
funcionamento do mercado, o que lhe permite divulgar e utilizar informações sinalizadoras aos agentes, ${ }^{60}$ bem como acelerar o processo de mudanças e adequações institucionais, buscando adaptar normas e leis à realidade mutante da sociedade. Já o mercado, por meio do qual são distribuídos bens e serviços, cumpriria sua função de alocação de recursos escassos - na sociedade, valendo-se do direito, enquanto Estado, notadamente de princípios constitucionais econômicos, para viabilização de suas garantias de acesso e disposição de oportunidades de troca. ${ }^{61}$ Assim, seriam indissociáveis os conceitos de direito e mercado, na medida em que o primeiro instrumentaliza o exercício de políticas, no seu sentido amplo, voltadas à preservação do mercado e à acumulação de capital.

O papel que se atribui ao direito na persecução dos objetivos estatais teria, portanto, natureza bivalente, atendendo à função de viabilizar e justificar as relações que fluem segundo as regras da economia de mercado, bem como instrumentalizar o exercício pelo Estado de políticas voltadas à preservação do mercado e à acumulação de capital. Desta forma, estaria atuando o Estado como agente regulador, segundo sua função legislativa, bem como árbitro, segundo sua função judicante, na solução de avenças surgidas entre as partes contratantes. ${ }^{62}$

Disso podemos inferir que o direito é instrumento apto a promover uma implementação de políticas públicas, as quais devem ser tratadas, para fins de cortes metodológicos, como políticas públicas de preservação do sistema, na medida em que se prestam a estabelecer normas acessórias que garantam eficácia à livre economia de mercado, e políticas públicas de intervenção no sistema, destinadas à intervenção direta do Estado na economia, sob regime de exceção, criando-se condições artificiais que assemelhem as relações econômicas às relações verificadas sob a realidade da livre economia de mercado. Ao que se discuta ainda tratarem, especificamente, as normas de defesa da concorrência de políticas públicas ou garantias institucionais.

\footnotetext{
${ }^{60}$ Vide NORTH, Douglas. Institutions, Institutional Change and Economic Performance. Cambridge: Cambridge University Press, 1990.

61 "O mercado é uma das formas de organização econômica e, consequentemente, de alocação de recursos na sociedade. Através dos mercados bens são distribuídos ou alocados entre os indivíduos. A forma organizacional alternativa a que se faz breve menção seria a alocação de bens por meio da intervenção de autoridade exógena, que no caso tratar-se-ia da atuação do próprio Estado" (FORGIONI, Paula A. A evolução do direito comercial brasileiro: da mercancia ao mercado. São Paulo: Ed. Revista dos Tribunais, 2009. p. 194).

62 “Ao direito cabe conferir expressão formal e vinculativa a esse propósito, transformando-o em leis, normas de execução, dispositivos fiscais, enfim, conformando o conjunto institucional por meio do qual opera a política e se realiza seu plano de ação. (...) A realização das políticas deve dar-se dentro dos parâmetros da legalidade e da constitucionalidade, o que implica que passem a ser reconhecidos pelo direito - e gerar efeitos jurídicos - os atos e também as omissões que constituem cada política pública" (BUCCI, Maria Paula Dallari. O Conceito de Política Pública em Direito. In: BUCCI, Maria Paula Dallari (org.). Políticas Públicas: Reflexões sobre o conceito Jurídico. São Paulo. Saraiva, 2006. p. 37).
} 
Fato irrefutável é que o mercado não existe sem o direito, haja vista que seu desenvolvimento ocorre nos espaços deixados pelas regras jurídicas. Assim, a imagem do mercado baseia-se nos princípios constitucionais que o limitam e formatam. Referimo-nos mais notadamente aos princípios da livre iniciativa, livre concorrência, liberdade de contratar e do direito de propriedade, bem como da defesa do consumidor.

Devemos lembrar que a origem dos mercados reputa-se à Idade Média, especificamente às feiras medievais. $\mathrm{Na}$ época, o mercado resumia-se à reunião de pessoas em torno das trocas, destinado a preencher necessidades relativas à circulação de bens. ${ }^{63}$ Com Adam Smith, altera-se essa perspectiva para fundir-se às ideias de concorrência e liberdade econômica; vale dizer, concebe-se o mercado como arena na qual os agentes trocam e competem livremente. O mercado, concorrência e liberdade, então, passam a constituir os pilares do sistema. A partir da década de 70, autores ligados à Escola de Chicago propõem a concepção de mercado não apenas como centro do sistema econômico, mas também jurídico. O direito também passa a ser analisado sob a ótica da eficiência econômica alocativa, definida abstratamente como maximização do bem-estar. Aos pilares do sistema junta-se, finalmente, o positivismo - segurança e previsibilidade - eis que o desenvolvimento do mercado ocorre justamente nos espaços deixados pelas regras jurídicas. $^{64}$

Disso extrai-se a ideia de que "ausente o sistema normativo, os mercados não prosperam, pois mercado é a norma que o disciplina e constitui". ${ }^{65}$ Vale dizer, o mercado é uma ordem e esta traz em seu bojo a lógica de regularidade e previsibilidade que permitem um cálculo sobre o futuro, o denominado "calculable law" de Max Weber, pressuposto do capitalismo moderno. Esse sistema, porém, depende do Direito ante a impossibilidade de antever, ou seja, de calcular a jogada alheia na ausência de um sistema jurídico racional.

É nesse contexto histórico e atual que se identificam três dimensões do mercado: social, política e jurídica. A primeira enaltece o caráter redistributivo do mercado na medida em que se reserva ao Direito o papel de não apenas preservar o sistema de produção, mas, sobretudo, implementar políticas públicas e, assim, consolidar os objetivos sociais constitucionalmente fixados. No que tange à segunda, diz respeito às escolhas políticas que fixam os objetivos perseguidos pelo sistema, cujos resultados, distributivos,

\footnotetext{
${ }^{63}$ SZTAJN, Rachel. Teoria Jurídica da Empresa: atividade empresária e mercados. São Paulo: Atlas, 2004. p. 22.

${ }^{64}$ FORGIONI, Paula A. A evolução do direito comercial brasileiro: da mercancia ao mercado, cit., p. 203.

${ }^{65}$ IRTI, Natalino. L'ordine giuridico del mercato. 3. ed. Roma: Laterza, 1998. p. 12.
} 
derivam da implementação de políticas públicas, e não da dinâmica de atuação espontânea do mercado. Por derradeiro, tem-se a dimensão jurídica do mercado concebida como o conjunto de regras e princípios que pauta o comportamento dos agentes econômicos e se divide em normas exógenas e normas endógenas.

As normas exógenas nada mais são do que as leis positivadas, cabendo-lhes a função de implementação de políticas públicas. É por meio delas que as relações empresariais são delineadas em perfil diverso daquele que possivelmente assumiria caso o mercado funcionasse livremente, isto é, motivado exclusivamente pela racionalidade econômica dos agentes. Saliente-se, ainda, que essas normas frequentemente funcionam como catalisadoras do fluxo de relações econômicas, seja por meio da diminuição dos custos de transação, seja mediante redução ou até mesmo eliminação das falhas de mercado.

As normas endógenas, por sua vez, referem-se aos usos e costumes que constituem a denominada tipicidade social, isto é, normas que viabilizam a previsibilidade e calculabilidade do comportamento do parceiro social, assim como a capacidade de planejar a própria jogada com maior margem de segurança. Refletem, pois, complexa interação entre texto normativo, atos dos comerciantes e jurisprudência.

Discute-se, neste contexto, a liberdade de iniciativa dos agentes com posição dominante e os limites gerais e abstratos que lhe são impostos. Assim, deve ser reconhecida aos agentes com posição dominante liberdade de atuação na medida em que sua conduta não acarrete danos ao instituto da concorrência. Este prejuízo ora referenciado é posto pelo Direito através das regras de concorrência, caracterizadas como normas exógenas cogentes. Mas seria somente esta a limitação dos agentes com posição dominante?

É inegável que o nicho de atuação dos agentes econômicos com posição dominante diminuiu ao longo das últimas décadas, premido não somente pelo surgimento das novas gerações de direitos, mas ainda por traços provenientes de novos ramos do direito, dentre os quais merece destaque o concorrencial. ${ }^{66}$

É de se constatar, portanto, que a liberdade de iniciativa dos agentes econômicos está longe de se reputar absoluta, devendo respeitar as normas cogentes inseridas no ordenamento. Desta forma, serão contrapostas à praxe de mercado imprescindíveis

\footnotetext{
${ }^{66}$ FORGIONI, Paula A. A evolução do direito comercial brasileiro: da mercancia ao mercado, cit., p. 83.
} 
exigências de salvaguarda dos valores fundamentais reconhecidos e promovidos no ordenamento. Assim, as disposições cogentes apresentam seu papel de soberania.

Temos ainda que a instrumentalização do direito para observância dos objetivos fundamentais do Estado visa assegurar um mínimo existencial necessário para garantia da dignidade humana, incluindo-se ainda, neste mínimo existencial, direito à educação fundamental, direito à saúde básica, saneamento básico, assistência social, tutela da livre concorrência, tutela do meio ambiente, acesso à justiça, direito do consumidor, entre outros tantos.

As relações comerciais pressupõem ainda constante colaboração entre as partes não somente para a contratação, mas também para sua manutenção, cabendo a estes disciplinarem de forma direta os termos da colaboração. Contudo, diante da racionalidade maximizadora e limitada dos agentes, que, conforme visto anteriormente, cria incentivos ao oportunismo, caberia ao Direito regular esta colaboração.

Muito se diz que o Direito Econômico, por exemplo, trata da implementação de políticas públicas pelo Estado nas suas mais diversas formas de manifestação. Segundo leciona Fernando Herren Aguillar, o Direito Econômico é o direito das políticas públicas na economia. É o conjunto de normas e institutos jurídicos que permitem ao Estado exercer influência, orientar, direcionar, estimular, proibir ou reprimir comportamentos dos agentes econômicos num dado país ou conjunto de países. ${ }^{67}$

Do que se infere que políticas públicas são "conjunto[s] de ações que visam compatibilizar a racionalidade privada com a racionalidade coletiva". ${ }^{68}$ Neste sentido vem Ada Pellegrini Grinover, que, ao se referir à conceituação trazida pelo trabalho eminente de Oswaldo Canela Junior, o descreve “irrepreensível”, citando seu entendimento como "o conjunto de atividades do Estado tendentes a seus fins, de acordo com metas a serem atingidas". Tratar-se-ia de conjunto de normas, atos e decisões que visem à realização dos fins primordiais do Estado. ${ }^{69}$

\footnotetext{
${ }^{67}$ AGUILLAR, Fernando Herren. Direito Econômico. Do Direito Nacional ao Supranacional. 1. ed. São Paulo: Atlas, 2006. p. 1.

${ }^{68}$ FARINA, Elizabeth Maria Mercier Querido; AZEVEDO, Paulo Furquim de; SAES, Maria Sylvia Macchione. Competitividade: Mercado, Estado e Organizações. São Paulo: Singular, 1997. p. 151.

${ }^{69}$ GRINOVER, Ada Pellegrini. O controle de políticas públicas pelo Poder Judiciário, cit., p. 113. Por sua vez, Maria Paula Dallari Bucci traz conceituação dotada de aspectos processuais: "Política pública é o programa de ação governamental que resulta de um processo ou conjunto de processos juridicamente regulados - processo eleitoral, processo de planejamento, processo de governo, processo orçamentário, processo legislativo, processo administrativo, processo judicial - visando coordenar os meios à disposição do Estado e as atividades privadas, para a realização de objetivos socialmente relevantes e politicamente determinados” (BUCCI, Maria Paula Dallari. O Conceito de Política Pública em Direito, cit., p. 39).
} 
O Poder Judiciário pode intervir nas questões de política pública, sem que, contudo, viole o princípio da separação dos poderes, de forma a atender aos objetivos fundamentais do Estado, implementando-os ou promovendo sua correção, quando equivocados. A política de concorrência, não obstante, é tratada de um modo difuso pelo judiciário brasileiro, em razão do princípio da inafastabilidade da tutela jurisdicional e diante da natureza predominantemente administrativa das discussões de cunho concorrencial.

Verifica-se ainda que o embate entre políticas públicas é constantemente enfrentado pelo judiciário. Estes embates, via de regra, se não sopesados e sistematizados, podem constituir elevado ônus para os administrados, na medida em que promovam políticas públicas em detrimento de princípios fundamentais de livre concorrência e livre iniciativa, ainda mais se tidos como garantias institucionais, aumentando os custos de transação envolvidos. Diversos seriam os exemplos de escolhas do judiciário diante de questões contrastantes envolvendo diferentes naturezas de políticas públicas. ${ }^{70}$

Destarte, observa-se que as falhas de mercado são inevitáveis, notadamente em virtude das distorções atinentes à orientação racional dos agentes de mercado em suas atividades econômicas. Em face disso, torna-se imprescindível a subordinação desses

\footnotetext{
${ }^{70}$ No primeiro caso (MS No 11.863 - DF 2006/0106365-2) é trazido à baila o embate entre o princípio da livre concorrência e a política industrial governamental de proteção e fomento ao desenvolvimento regional, qual seja, a Zona Franca de Manaus. A decisão do STJ impõe aos fabricantes de pré-forma de resina Pet o dever de adquirir, no mínimo, 50\% de matéria-prima dos produtores nacionais, bem como um tabelamento do preço a ser cobrado pelas indústrias fornecedoras. Entende-se, contudo, que tais imposições violam o art. 170, caput e inciso IV, da CF (princípio da livre concorrência) e o art. 20 , $§ 1^{\circ}$, da Lei n. 8.884/94, além de inviabilizarem a utilização do benefício fiscal previsto no art. $3^{\circ}$ do Decreto-lei n. 288/67. Inegável aduzir-se, adicionalmente, que tal imposição promove aumento dos custos de transação. Em outras palavras, vislumbrase de incentivos para o fomento da industrialização regional em detrimento da liberdade de iniciativa e liberdade de contratação, fato que pode promover ineficiências no mercado. Da mesma forma, no segundo caso em comento (REsp N. 609.047 - SP 2003/0193287-4), o embate entre as diferentes políticas públicas ocorre no tocante à propriedade intelectual e o princípio da livre concorrência. Neste caso, o STJ decidiu que importações paralelas são realizadas à margem do sistema de distribuição seletiva criado pelo fabricante do produto e titular do direito de propriedade industrial. Trata-se da discutida teoria da exaustão, pela qual não pode o titular da marca opor ao adquirente do produto restrições de redistribuição, pois a colocação do produto no mercado esgota o seu direito de propriedade industrial, ainda que a titularidade da marca no Brasil seja diversa da titularidade da marca no exterior. Neste caso existe privilégio dado à política de concorrência em detrimento da proteção da propriedade industrial, o que tende, não obstante, a aumentar o custo da transação na medida em que aumentam-se as incerteza do negócio. Por fim cabe trazer decisão proferida no Recurso Especial N. 802.085 - RJ (2005/0201087-9), cujo embate invoca os princípios da livre concorrência e mecanismos de regulação ex ante supostamente destinados à correção de falhas de mercado. Assim, discute-se o sistema de quotas mensais imposto pela Portaria 72/00 da ANP para aquisição de combustível por parte de agente distribuidor. Além de discussão acerca da competência da ANP para fixação destas quotas, verifica-se limitação do princípio da livre concorrência na medida em que a fixação de quotas mensais altera o livre fluxo mercadológico, até mesmo restringindo o mercado para novos entrantes. Assim, a previsibilidade que se procura vem em detrimento de outros valores, talvez até mesmo das eficiências de mercado.
} 
agentes a alguma forma de controle exercido pelo Estado, para neutralizar, senão eliminar tais falhas, cuja intervenção é feita em prol da preservação dos mercados.

A ideia por detrás da interferência estatal, mediante implementação de políticas públicas, seria regularizar o funcionamento do mercado, próximo a um modelo perfeito. Tais políticas traduzem respostas adequadas a necessidades econômicas, permitindo o cálculo de jogadas, facilitando as contratações e reduzindo assim seus custos.

No âmbito concorrencial, em especial, a intervenção do Estado tem por escopo coibir abusos de poder econômico, propiciando condições de concorrência e, portanto, sobrevivência de outros agentes econômicos. Essas questões, consoante demonstrado, são balizadas pela jurisprudência que realiza a lapidação do Judiciário, sinalizando para o mercado ao fazer uma "seleção natural” das denominadas normas endógenas.

Inevitável verificarmos, assim, que as políticas públicas constituem eficiente mecanismo para a preservação do mercado, aliada à redução de custos de transação nas relações comerciais, ao proporcionar a calculabilidade e confiança aos agentes econômicos em suas relações, conferindo-lhes a capacidade de planejar a própria jogada com maior margem de segurança.

A questão do poder de mercado traz ainda interessante embate teórico entre duas modalidades de política pública que, ulteriormente, podem servir ao mesmo propósito. Para tanto, verifica-se, sob um ponto de vista da economia, que políticas industriais buscam eficiência estática e eficiência dinâmica, e que o aproveitamento de economias de escala e escopo e capacidade de manter atividades de pesquisa e desenvolvimento demandam, via de regra, a presença de grandes corporações. Portanto, políticas industriais, para alcançarem seus fins, devem "amparar setores oligopolizados e promover um processo de concentração onde a pulverização é excessiva". ${ }^{71}$

Contudo, ainda na visão de Farina e Azevedo, se na versão da indústria infante a proteção contra a concorrência internacional resultava em recomendação de política, na versão moderna a discussão se coloca em termos da aceitação de práticas cooperativas entre os agentes decisórios, que implicam redução da concorrência - um comportamento tipicamente não cooperativo e obviamente conflitante com uma política antitruste agressiva e poderosa. $^{72}$

${ }^{71}$ FARINA, Elizabeth Maria Mercier Querido; AZEVEDO, Paulo Furquim de; SAES, Maria Sylvia Macchione. Competitividade: Mercado, Estado e Organizações, cit., p. 123.

${ }^{72}$ Idem, ibidem, p. 123. 
Assim, há os que consideram que teóricos e defensores de uma política industrial seriam adversários da política antitruste. No ponto convergente entre as duas modalidades de política pública estaria o estímulo à obtenção de vantagens competitivas dinâmicas. Não obstante, enquanto a política de concorrência se presta ao papel de manutenção e fomento à livre concorrência, quando não se tratar de monopólio natural, as políticas industriais têm por objetivo a estimulação da criação e desenvolvimento de instituições e organizações que garantam a provisão dos bens públicos e coletivos que interferem na competitividade privada. Assim:

\begin{abstract}
Pode-se afirmar que o maior desafio de uma política industrial é encontrar o equilíbrio entre cooperação e concorrência. Uma forte política de concorrência pode se tornar um ingrediente fundamental para corrigir possíveis distorções da política industrial. Ao promover redes inter-firmas, a política industrial pode, ao mesmo tempo, facilitar a supressão da concorrência de preços, cujas consequências (maléficas ou benéficas) não podem ser definidas no abstrato. ${ }^{73}$
\end{abstract}

Não obstante o aparente embate, considera-se que políticas de concorrência e políticas industriais constituem um conjunto articulado de ações cujo objetivo é estabelecer um ambiente favorável e indutor de busca permanente pela competitividade.

Conclui-se, portanto, que uma vez identificadas falhas de mercado, decorrem distorções na situação concorrencial ótima em razão de orientação racional dos agentes de mercado em suas atividades econômicas. Nestas situações, pressupõe-se a subordinação do comportamento racional destes agentes de mercado a alguma forma de controle exercido pelo Estado, invocando-se sua intervenção em prol da preservação dos mercados. A ideia por detrás desta interferência estatal seria trazer o mercado ao funcionamento mais normal possível, próximo ao modelo de concorrência perfeita. Assim, a eliminação das distorções por meio das mais variadas formas de política pública funcionariam em benefício do próprio mercado.

Em linha com o exposto, temos que o reconhecimento de uma condição especial, e consequentemente de responsabilidades especiais, sobre os agentes com posição dominante, implicam a adoção de políticas públicas concorrenciais de ajuste que levem em consideração maior eficiência do mercado, em termos de alocação de recursos, bem como a correta sinalização dinâmica para inovações tecnológicas de produtos, serviços, meios de produção, entre outros.

${ }_{73}$ FARINA, Elizabeth Maria Mercier Querido; AZEVEDO, Paulo Furquim de; SAES, Maria Sylvia Macchione. Competitividade: Mercado, Estado e Organizações, cit., p. 159. 
Ademais, como veremos oportunamente, os princípios constitucionais tutelados e a instrumentalização das normas de defesa da concorrência transcendem, em nosso entender, a natureza de políticas públicas, tratando de garantias institucionais do sistema e que, como tal, merecem tratamento.

\subsection{Teoria Econômica}

\subsubsection{O papel e Relevância da Teoria Econômica}

A teoria econômica aplicada se preza a um papel tão amplo quanto ao da complexa instrumentalização da análise jurídico-concorrencial. Reconhecemos seu verdadeiro caráter de essencialidade ao se permitir delinear uma teoria acerca do comportamento humano racional, consequentemente antecipando ações mais previsíveis a serem tomadas e permitindo-se ajustes no ordenamento jurídico que direcionem à medida racional esperada. Neste sentido, verificamos na economia comportamental a base para uma "atividade futurologista" encabeçada em alguns campos do direito.

Segundo Rachel Sztajn ${ }^{74}$, a teoria do Direito e Economia, ou Law and Economics, seria, "segundo alguns, uma corrente ou escola de pensamento que busca, para compreender e explicar efeitos de normas jurídicas, apoio em modelos e premissas desenvolvidos por economistas, é, para outros, apenas uma técnica de avaliação da eficácia das normas".

Interessante verificarmos que a autora, nesta passagem, apresenta um conceito da teoria do Direito e Economia centrado na ideia de instrumento para avaliação de eficácia de normas. Ainda neste sentido, Gary Becker assevera que o objetivo mais fundamental da economia não se caracteriza pelo capital ou a própria economia no seu sentido estrito, mas pelas implicações da escolha racional, que se constitui como uma ferramenta essencial para se determinarem os efeitos de dispositivos legais sob análise. ${ }^{75}$

Em tempo, vale citar David Friedman, que entende que a análise econômica do direito compreende três funções intimamente relacionadas, quais sejam, a previsão dos efeitos que as regras postas terão, a explicação de razões às restrições legais e, finalmente, a decisão sobre quais disposições legais devem subsistir.

\footnotetext{
${ }^{74}$ SZTAJN, Rachel. Direito e Economia, cit., p. 221.

75 BECKER, Gary. Nobel Lecture: The Economic Way of Looking at Behavior. Journal of Political Economy. University of Chicago Press, 1993, vol. 101(3), p. 385-409.
} 
Fato é que a economia nos proporciona instrumento sem o qual se torna tarefa árdua a compreensão da racionalidade da atividade dos aplicadores e receptores dos institutos jurídicos tutelados. Isto tanto no âmbito legislativo, no que tange à promulgação das normas legais, quanto no âmbito judicial, na subsunção da norma ao fato. Em ambos os casos se faz necessário o uso das teorias econômicas para que se avaliem os efeitos dissuasórios da norma, aqui considerados os incentivos gerados pela quantidade de sansão e probabilidade de condenação.

Inicialmente aplicada ao direito antitruste a partir da década de 60, percebeu-se a possibilidade da extensão da análise econômica do direito a outros ramos desta ciência, como o direito da responsabilidade civil, direito de propriedade, direito processual, contratos, direito constitucional, direito criminal, entre outros, passando ainda a ser adotada por diversos juízes americanos em sua fundamentação legal. Para o Juiz Richard A. Posner:

\footnotetext{
$\mathrm{O}$ aspecto mais interessante do movimento do Law and Economics [Direito e Economia] tem sido sua aspiração de posicionar o estudo do direito segundo uma base científica, através de uma teoria coerente, uma hipótese precisa deduzida desta teoria e testes empíricos da hipótese. ${ }^{76}$
}

Pelos conceitos trazidos acima e pela possibilidade de aplicação da análise econômica do direito à mais diversa gama de institutos e relações, reconhecemos que a economia é capaz de nos fornecer modelos que criam previsibilidade dos efeitos de determinadas decisões. Assim, a aplicação da teoria econômica ao direito deve ser estimulada a fim de se preverem comportamentos, criando estímulos para se atingir determinado fim, principalmente no que tange à antecipação da atividade legislativa ou mesmo à atividade jurisdicional. Em especial, citamos sua importância na aplicação às relações de concorrência entre agentes econômicos e regulação das falhas de mercado, objeto do presente estudo, bem como à análise da criminalidade comportamental, às teorias de escolha pública, às questões de sustentabilidade visando redução de externalidades negativas, entre tantas outras.

O ponto de partida para se iniciar qualquer análise sobre a relação entre Direito e Economia centra-se na figura do agente racional maximizador. Neste sentido, a dogmática econômica assevera que todo ente racional busca maximizar o seu bem-estar social, na

\footnotetext{
${ }^{76}$ POSNER, Richard A. Essays in Law and Economics. In Michael Faure e Roger Van den Bergh (Eds.). 1989.
} 
busca de seus próprios interesses, para sua satisfação pessoal. Segundo Otávio Yasbek: "Para a teoria econômica neoclássica, os agentes individuais agem sempre de forma racional, ou seja, procurando satisfazer suas necessidades da melhor forma possível a partir do estado de coisas que se lhes apresenta". ${ }^{77}$

Assim, tornam-se previsíveis os comportamentos dos agentes, estabelecidas as premissas ou modelos econômicos, dadas como constantes e inalteráveis. Conforme brevemente exposto, nos parece residir na previsibilidade comportamental, que pode ser aplicada às mais diversas situações, segundo uma análise econômica positivada, o maior legado da teoria do Direito e Economia.

Ao aplicarmos a teoria do agente racional maximizador ao objeto de nosso estudo, podemos reconhecer que os agentes econômicos com poder de mercado, aqui incluídos os monopolistas, comportam-se racionalmente sob a ótica da análise econômica ao buscarem a maximização de seus resultados. Cabe lembrar que esta visão maximizadora leva em consideração o conceito de eficiência, segundo uma visão finalística, pela qual os meios menos dispendiosos devem ser utilizados para se atingir ao fim perseguido.

Assim, agentes econômicos dominantes agem de forma racional, segundo a teoria econômica, ao buscarem a maximização de seus resultados através de precificação monopolística. A busca pela apropriação de renda de terceiros verifica-se na medida em que promove transferência de parcela do bem-estar do consumidor para si, gerando ainda peso morto que se perde nesta relação - “deadweight losses" ${ }^{78}$ Trata-se de contradição clara à Teoria Clássica de Valor, que determina que o preço é lastreado no trabalho incorporado a determinado bem, levando-se em conta todos os custos de produção, porém encontra conformidade na teoria neoclássica que a sucede, introdutória dos conceitos de custo marginal para formação de preços. ${ }^{79}$

Modelos econômicos explicativos dos prejuízos acarretados pelos comportamentos monopolísticos surgiram com a superação da teoria da mão invisível do Estado, de Adam Smith, pela teoria do equilíbrio de mercado. Nas palavras de Otávio Yasbek:

\footnotetext{
${ }^{77}$ YAZBEK, Otavio. Regulação do Mercado Financeiro e de Capitais. 2. ed. São Paulo: Elsevier, 2008. p. 9-10.

${ }^{78}$ Neste sentido, cabe lembrarmos que os agentes econômicos racionais caracterizam-se como "rent seekers", termo da doutrina econômica que se refere ao comportamento dos agentes de tentarem extrair para si parcela de renda gerada por terceiros sobre a qual não tenham contribuído para a geração.

${ }^{79}$ YAZBEK, Otavio. Regulação do Mercado Financeiro e de Capitais, cit., Cap. 1.
} 
Se os fornecedores e os consumidores de bens ou de serviços agem de forma racional e maximizadora, presume-se que em todas as operações econômicas se obtenha o melhor resultado possível. Este é o ponto de equilíbrio ao qual, de acordo com a teoria neoclássica, todos os mercados tendem, e em que convergem a oferta e demanda. ${ }^{80}$

Ainda, diversas objeções surgiram com relação às teorias neoclássicas. Passou-se a reconhecer, conforme já tratado, a existência das denominadas falhas de mercado justificadoras da atividade reguladora do Estado, dentre as quais se insere o poder econômico.

Da mesma forma, poderíamos argumentar, sob a ótica econômica em discussão, que agem de forma racional os agentes dominantes ao introduzirem práticas comerciais diversas potencialmente capazes de dificultar a operação, ou até mesmo excluir a concorrência para determinado produto sob o qual tenham atuação comercial privilegiada, visto implicarem referidas práticas em ulterior maximização de seus resultados, atingidos os objetivos excludentes perseguidos. Ressalvamos, contudo, que tal análise encontrar-seia isenta de quaisquer valores axiológicos ou princípios éticos, bem como a uma análise sistemática finalística do propósito do direito concorrencial.

Devemos assim considerar que alguns embates parecem trazer relação mais áspera à análise econômica do direito. O principal deles reside no fato de que economistas, via de regra, se preocupam com maximização de eficiências, enquanto juristas não se furtam de agregar outros valores à sua atividade interpretativa, valores tais como justiça e equidade. Podemos perceber, via de consequência, um conflito posto entre a subjetividade e a objetividade decorrente de tais ideias.

Neste sentido, se por um lado a economia positiva ${ }^{81}$ olha para fatos passados e mediante projeções tenta predizer como serão os comportamentos dos agentes diante de fenômenos supostamente similares, a economia normativa analisa fenômenos sociais, regras morais e princípios éticos, particularmente quando observa as instituições sociais e normas legais existentes, visando recomendar, quando disso se tratar, alterações para aperfeiçoá-las. Para Rachel Sztajn:

A cooperação parece mais fácil no plano da Economia Positiva visando-se à
eficiência do sistema; quanto a mudanças e ao estudo dos seus efeitos sobre a
distribuição da riqueza e renda, do ângulo da Economia Normativa, as propostas

${ }^{80}$ YAZBEK, Otavio. Regulação do Mercado Financeiro e de Capitais, cit., p. 7.

${ }^{81}$ Friedman defende que a Economia Positiva é a ciência de adotar tentativas de generalizações dos fenômenos econômicos, usada para predizer consequências de mudanças das circunstâncias (SZTAJN, Rachel. Direito e Economia, cit., p. 223). 
dos economistas nem sempre são aceitáveis. Aqui, diferenças metodológicas seriam o foco da disputa. ${ }^{82}$

Neste sentido, conclui a Ilma. jurista que "a racionalidade, central no pensamento econômico, serve ao Direito na medida em que, padrão de comportamento racional do agente, permite, com mais facilidade, prever condutas e construir modelos de interação social". 83

Verificamos que o embate Direito e Economia ainda hoje ativa feroz discussão no âmbito do direito da concorrência, vivenciado pelas Escolas de Harvard e Chicago, a tratar, ulteriormente, de mensurar a profundidade da atividade intervencionista do Estado, contrabalanceando a mão invisível com a teoria de equilíbrio de mercado e das falhas de mercado apontada por Robert Bork.

Como fomento à discussão que se pretende ao longo do presente trabalho, vale mencionar que, na análise da racionalidade das normas de defesa da concorrência, merece destaque o modelo econômico de Cournot que, grosso modo, trata de estratégia não cooperativa de atuação de empresas em mercados oligopolísticos, nos quais atuam os agentes de forma independente, mas levando em consideração o comportamento esperado de outros concorrentes para maximização de seus lucros. ${ }^{84}$

Consequentemente, sob as premissas econômicas do modelo, podemos argumentar que o preço imposto ao consumidor em situações de oligopólio em que haja oferta por empresas dominantes e fringing firms ${ }^{85}$ considera que a empresa dominante tenderá a precificar na sua curva residual de oferta, o que equivale a dizer que os preços nesta condição estrutural de mercado ainda seriam menores do que preços de monopólio puro.

Desta forma, poderíamos vislumbrar de racionalidade, por parte das autoridades de defesa da concorrência, ao imporem algumas responsabilidades especiais aos agentes dominantes. Segundo esta ótica, tais imposições tenderiam a manter a existência ou fomentar a entrada de fringing firms no mercado, o que traria benefícios aos consumidores no médio ou longo prazo.

\footnotetext{
${ }^{82}$ SZTAJN, Rachel. Direito e Economia, cit., p. 224.

${ }^{83}$ Idem, ibidem, p. 224.

${ }^{84}$ Segundo este modelo, "[t]he firms are worse off and the consumers are better off [at the Cournot Equilibrium] than if firms act collusively as a cartel (monopoly). (CARLTON, Dennis W.; PERLOFF, Jeffrey M. Modern Industrial Organization. 3. ed. Addison Wesley Longman, p. 167).

${ }^{85} \mathrm{O}$ conceito de "fringing firms" engloba a "franja competitiva" de um mercado, ou seja, várias pequenas empresas tomadoras de preço.
} 
Portanto, como ponto de partida para uma análise mais aprofundada acerca da economia normativa do direito da concorrência, colocamos alguns debates que clamam maior reflexão e conclusão, a fim de contribuir para a teoria das responsabilidades especiais dos agentes dominantes.

Finalmente, não podemos nos furtar à conclusão de que à economia cumpre a função de sinalizar, de direcionar o direito, orientando o rumo das ações em vista dos incentivos econômicos existentes, levando-se em conta a racionalidade instrumental do indivíduo. Não obstante, ainda que discordem os liberais exaltados, indispensável se faz que valores outros sejam sopesados à economia pura de mercado lastreada na busca da eficiência. Justifica-se, portanto, a intervenção estatal para balanceamento deste direito, através de políticas públicas que visem a, muitas vezes, criar incentivos artificiais no mercado.

Diante das conclusões acima, faz-se instrumental e indispensável a verificação de alguns elementos atinentes à teoria econômica, a fim de se possibilitar o estudo do tema pretendido.

\subsubsection{Falhas de Mercado e Correção do Sistema}

Em um Estado Democrático de Direito, são uníssonos os ensinamentos que apregoam que a intervenção estatal na economia deve se dar em regime de exceção, observadas situações que impedem o mercado de se autorregular, entendendo-se, portanto, seu caráter de ultima ratio. Assim, as teorias normativas da regulação reconhecem que o Estado somente deverá intervir diante de uma falha dos mercados em promoverem uma alocação eficiente de recursos com base no sistema de transações de mercado mediado pelo binômio preço e quantidade. ${ }^{86}$ A esse fenômeno refere-se a doutrina tradicional como falha de mercado.

Dentre as principais falhas de mercado reconhecidas pela doutrina tradicionalista cabe referência às externalidades, às assimetrias de informações, ao poder econômico e aos

\footnotetext{
86 "Segundo as teorias normativas da regulamentação, o Estado deve intervir quando o sistema de transações impessoais de mercado, mediado somente pelos preços, falha em proporcionar uma alocação eficiente de recursos. O mercado perfeitamente competitivo constitui o padrão de referência dessas teorias, operando em um ambiente de racionalidade ilimitada" (FARINA, Elizabeth Maria Mercier Querido; AZEVEDO, Paulo Furquim de; SAES, Maria Sylvia Macchione. Competitividade: Mercado, Estado e Organizações, cit., p. 115).
} 
bens públicos. Assim, inicialmente reconhecemos originar-se o tema em análise, qual seja o abuso do poder econômico, de uma falha de mercado.

No que tange, primeiramente, às externalidades, trata-se de efeitos produzidos pelas partes a terceiros na execução de seus contratos. Estes efeitos podem ser positivos ou negativos, sendo que no caso dos primeiros, agentes econômicos que não deram causa à externalidade se beneficiam involuntariamente; e no caso dos segundos, os efeitos não seriam suportados pelas partes que deram causa, gerando custos para os demais agentes. ${ }^{87}$

As externalidades negativas muitas vezes comprometem o bom funcionamento do mercado. Via de consequência, fornecem justificativa econômica suficiente para que sejam criadas regulamentações específicas, tais como normas de emissão de poluentes, restrições ao uso de terra e proteção ambiental.

Já no tocante ao problema das externalidades positivas, verifica-se que sua implicação é diversa, resultando em subinvestimento na medida em que se verifica a impossibilidade de apropriação privada do retorno dos investimentos realizados. Exemplos seriam as pesquisas de variedades agrícolas ou desenvolvimento de um novo medicamento revolucionário. $\mathrm{O}$ sistema de proteção de propriedade industrial implica fator mitigador dos problemas de apropriação dos resultados gerados, mas que são incapazes de oferecer uma resolução completa da problemática, trazendo ainda outras distorções admitidas pelo Direito. $^{88}$

Com relação à falha de mercado modalizada pelos bens públicos, vale dizer que seriam caracterizados como não rivais e não exclusivos. Em outras palavras, uma vez produzido determinado bem, o número de consumidores não altera o custo de sua produção, ao mesmo tempo em que não é possível excluir consumidores do seu uso. Assim, verifica-se que o aviamento é ignorado pelos agentes econômicos que não são suficientemente incentivados, estimulando comportamentos oportunísticos de carona (freeridding). Um exemplo de bem público seria um programa de erradicação de praga na agricultura em que todos os agricultores sairiam beneficiados.

\footnotetext{
${ }^{87}$ Em tempo, Farina reconhece a existência de externalidades sempre que o cálculo privado diferir do cálculo social da produção ou investimento e podem ser atribuídas à inexistência de mercados organizados e competitivos que gerem preços para os bens em questão, impedindo que seus valores sejam computados como custos ou benefícios privados. Isto é, efeitos da produção ou consumo não se refletem em preços de mercado e, portanto, são externos ao agente tomador de decisão (FARINA, Elizabeth Maria Mercier Querido; AZEVEDO, Paulo Furquim de; SAES, Maria Sylvia Macchione. Competitividade: Mercado, Estado e Organizações, cit., p. 115).

88 A proteção à propriedade intelectual pode conferir ao seu beneficiário poder econômico e, consequentemente, afetar a capacidade dos mercados de prover eficiência alocativa em determinado período de tempo.
} 
A assimetria informacional, por sua vez, tende a impedir que os mercados operem de forma eficiente, principalmente no que tange à eficiência alocativa do mercado considerado. O modelo de concorrência perfeita vê-se prejudicado na medida em que vendedores e compradores não disporiam de informações necessárias e suficientes para lastrearem suas decisões.

Finalmente, o poder econômico, talvez a falha de mercado que, atualmente, mereça maior atenção por partes das autoridades públicas, possui, em nosso entender, duas vertentes de tratamento. A primeira trata de situação de dependência econômica no âmbito de relações privadas e sob um contexto histórico-jurídico da relação entre as partes. Já a segunda perspectiva desta falha de mercado se dá no âmbito das relações institucionais de mercado e leva em conta não somente o histórico relacional das partes, mas toda dinâmica de mercado que implica a determinado agente um poder, quer seja com relação aos seus concorrentes, quer seja com relação aos seus clientes ou fornecedores.

Desta feita, verificamos uma situação de dependência econômica quando um dos contratantes está em posição de impor suas condições ao outro, que deve aceitá-las para sobreviver; assim, um dos contratantes estaria em posição de superioridade com relação ao outro. Estas modalidades de abuso devem se tratadas em vista da hipótese normativa trazida pelo artigo 187 do Código Civil ${ }^{89}$, requerendo, contudo, que a prática da conduta seja desviada de sua função econômica ou ainda frustrada a legítima expectativa do agente.

Caso o abuso seja praticado por empresa em situação de poder de mercado e implique em prejuízo à livre concorrência, em qualquer de suas modalidades estaremos diante de um abuso de poder de mercado a ser coibido pelas autoridades de defesa da concorrência. Assim, reconhece a doutrina tradicionalista situação de poder de mercado quando uma empresa com poder econômico unilateral tem a capacidade de restringir produção e elevar preços acima dos níveis de concorrência perfeita, independentemente da atuação de seus concorrentes ou clientes. Segundo Farina, a teoria econômica mostra que esta não é uma solução Pareto-ótima e, portanto, não é um resultado eficiente. ${ }^{90}$ Isto porque se reconhece que em situações de mercados monopolistas ou oligopolistas, não há garantias de que consumidores serão beneficiados com custos menores e, consequentemente, preços mais em conta, ou ainda com inovações.

\footnotetext{
${ }^{89}$ Art. 187. Também comete ato ilícito o titular de um direito que, ao exercê-lo, excede manifestamente os limites impostos pelo seu fim econômico ou social, pela boa-fé ou pelos bons costumes.

90 FARINA, Elizabeth Maria Mercier Querido; AZEVEDO, Paulo Furquim de; SAES, Maria Sylvia Macchione. Competitividade: Mercado, Estado e Organizações, cit., p. 151.
} 
Assim, segundo a teoria econômica moderna, diante do reconhecimento de uma falha de mercado justificada estaria a intervenção estatal, em alguma das modalidades previstas no ordenamento.

\subsubsection{A Teoria da Regulação}

A regulação é ponto que merece destaque na análise concorrencial das responsabilidades especiais dos agentes econômicos com posição dominante. Em especial, o vasto escopo da regulação e os princípios constitucionais inerentes a este instituto são de especial referência ao presente trabalho, visto que possui a regulação de diversos pontos de convergência com a defesa da concorrência.

Antes de mais nada, vale recordar que, na sua origem, a atuação direta do Estado na economia era vista como uma forma eficiente de tratar as reconhecidas falhas de mercado, tais como assimetria de informações, externalidades, segurança e utilidade pública, desemprego, deficiências de demanda decorrentes de distorções na distribuição de renda, monopólios naturais, entre outras. Inevitavelmente, como se sabe, a expansão do setor público foi incapaz de atingir os objetivos perseguidos. As razões para tanto foram diversas, a citar algumas, falha comunicacional e de coordenação entre as empresas públicas e o governo central e falha de um controle eficiente de custo-benefício. A substituição do ideal de maximização de lucro para a persecução de interesses públicos contribuiu para a ineficiência dos empreendimentos, outra causa relevante da falha apontada.

Diante desta realidade, o Reino Unido parece ser um dos melhores exemplos de desregulamentação, tendo sido considerado um dos pioneiros no processo de privatizações na Europa. ${ }^{91}$ Os benefícios esperados das privatizações seriam as eficiências econômicas originadas, devendo-se esperar, portanto, aumento da quantidade produzida, aumento da qualidade e redução de custos, que resultariam em maiores benefícios alocados aos consumidores.

Na maioria das vezes, o processo de privatização foi acompanhado de um marco regulatório destinado a promover transparência, proteção ao consumidor, garantia de qualidade e, especialmente, correção das falhas de mercado. Os problemas relacionados à

\footnotetext{
${ }^{91}$ No seu caso os principiais motivos para a desregulamentação foram suas restrições financeiras nos setores nacionalizados, falta de uma estrutura de incentivos e eficiência, falta de objetivos transparentes, dentre outros.
} 
transferência de controle dos meios de produção do Estado para particulares são, via de regra, acompanhados de diversos dilemas, como a necessidade de introdução de concorrência no mercado - em razão da existência de barreiras à entrada de novos concorrentes - na ausência da qual abusos tenderiam a ser cometidos. Da mesma forma se deve pregar pela supervisão de antigos monopólios no que tange à qualidade de seus produtos e serviços, além, obviamente, das obrigações de acesso universal, quando pertinentes.

Dentre os conceitos de regulação colocados, devemos citar aquele trazido por Selznick: "sustained and focused control exercised by a public agency over activities that are valued by a community". ${ }^{92}$ Da mesma forma a conceituação trazida por Baldwin e Cave: "regulation involves the promulgation of binding set of rules to be applied by a body devoted to this purposes". 93

Em nosso entender, a regulação compreende um conjunto de regras e instituições responsáveis pelo monitoramento de determinado mercado ou segmento de mercado, que requer mecanismo ativo de controle ex ante direcionado à manutenção da produção contínua e padronizada de produtos e serviços, bem como à introdução e contínuo fomento ao desenvolvimento da livre concorrência.

Diversas seriam, neste sentido, as justificativas para a existência da regulação. Baldwin e Cave, por exemplo, reputam sua importância à disciplina das falhas de mercado:

\footnotetext{
Many of the rationalities for regulating can be described as instances of market failure. Regulation in such cases is argued to be justified because the uncontrolled market place will, for some reason, fail to produce behavior or results in accordance with the public interest. (...) when there is a gap of the Adam's Smith free hand theory, some mechanism of achieving the autoregulation of the market may be needed. ${ }^{94}$
}

Assim, a criação do conceito de regulação veio ancorada na necessidade de controle que foi perdido com o processo de liberalização. Uma vez que os ideais de interesse público se viram substituídos pelos ideais capitalistas de maximização de lucros, reguladores deveriam assumir responsabilidades para garantir que os objetivos da privatização seriam atendidos. Em especial, a proteção do consumidor deveria se dar através de diversos mecanismos, como controle de preços, controle de taxas de retorno,

\footnotetext{
${ }^{92}$ SELZNICK, P. Focusing Organization Research on Regulation. In R. Noll (Ed.), Regulatory Policy and the Social Sciences, Berkeley, University of California Press, p. 363.

93 BALDWIN, Robert; CAVE, Martin; LODGE, Martin. The Oxford Handbook of Regulation. Oxford University Press (Ed.), 2012.

${ }^{94}$ Idem, ibidem.
} 
continuidade da disponibilidade de serviços e promoção da concorrência. Vale verificar que aqui, tal como se verifica no direito da concorrência, há uma ideia de tutela de beneficiários diretos e indiretos.

Neste sentido, talvez a primeira pergunta que se deva fazer seria como a regulação pode afetar a aplicação das normas de defesa de concorrência? Poderíamos iniciar esta exemplificativa digressão com olhar nas barreiras legais impostas pela regulação, as quais poderiam afetar o conceito de substituibilidade pelo lado da oferta, na medida em que produtos que em princípio seriam substituíveis não poderiam ser incluídos no mesmo mercado relevante. Da mesma forma, a utilização da capacidade excedente das redes já instaladas poderia servir como forma de reduzir custos de entrada em determinado mercado, aqui entendido como o compartilhamento de acesso. Ainda, a convergência tecnológica pode implicar modificação na forma pela qual os serviços de determinado setor são ofertados - como pacotes ou "cluster markets". 95

Fato é que a importância da teoria da regulação encontra-se intrinsecamente ligada à aplicação das normas de defesa de concorrência. Como veremos adiante, a busca pela modelação de um mercado que atenda progressivamente aos ditames concorrenciais da livre iniciativa e livre concorrência, segundo ainda os parâmetros de justiça social apregoados pela Constituição Federal, pressupõe uma interação contínua entre a regulação ex ante e a regulação ex post. $\mathrm{O}$ tema adquire ainda especial relevância ao reconhecermos toda influência da teoria da regulação estrangeira no sistema jurídico brasileiro, com a proliferação das agências reguladoras para os mais variados setores econômicos.

Devemos recordar que a atuação do Estado na economia encontra-se regulamentada nos artigos 173 e 174 da Constituição Federal, sendo três suas funções: (i) agente direto da atividade econômica; (ii) agente fiscalizador do exercício da atividade econômica; e (iii) agente normativo da atividade econômica. ${ }^{96}$ Quanto à fiscalização e normatização, devemos verificar a natureza da atividade que será prestada para avaliarmos a extensão dos poderes a ela inerentes. Algumas seriam as teorias utilizadas para se verificar, portanto, casos em que as normas de defesa de concorrência não se aplicariam diante da existência de um ambiente regulatório. ${ }^{97}$

\footnotetext{
95 SALOMÃO FILHO, Calixto. Regulação e Concorrência (estudos e pareceres). São Paulo: Malheiros, 2002. p. 20-23. O conceito de cluster market consiste no agrupamento de produtos ou serviços que, pela simples razão de estarem agrupados, implicam uma maior atratividade para o consumidor.

${ }^{96}$ SALOMÃO FILHO, Calixto. Regulação da Atividade Econômica, cit., p. 135.

${ }^{97}$ Neste sentido viriam as Teorias da Ação Política (State Action Doctrine) e a Teoria do Poder Amplo (Idem, ibidem, p. 136 e ss.).
} 
Contudo, a linha que separa a regulação da defesa da concorrência é muito tênue, em especial no trato das situações de monopólios reconhecidos. Nestes casos, temos que mais intenso deveria ser o escrutínio concorrencial quanto mais brando verificar-se o controle imposto pelas autoridades regulatórias. Esta, por sua vez, deve ter como princípio basilar a introdução ou fomento da livre concorrência em setores nos quais o mercado, por si, é incapaz de fazê-lo. ${ }^{98}$

Em rápida digressão metodológica, podemos citar as duas escolas mais tradicionais que perseguiram uma teoria da regulação: a Escola do Interesse Público e a Escola Neoclássica. Enquanto a primeira procurou justificar a regulação na busca do interesse público, a segunda buscava replicar em laboratório condições perfeitas de concorrência. Ainda no tocante à Escola do Interesse Público, em razão da dificuldade de conceituação do termo - interesse público - para fins da intervenção do Estado na economia, aquela ganhou importância através do seu desenvolvimento jurídico. $\mathrm{Na}$ experiência nacional, mais reconhecida como a Escola do Serviço Público, verificamos a submissão da atividade econômica a um regime próprio de serviços públicos. A noção de serviço público, neste sentido, encontra-se ligada à ideia de prestação de um serviço em regime de direito público. Conforme ilustra Calixto Salomão Filho:

Há aqui outro elemento fundamental para o estudo da teoria da regulação. É a partir da colocação do regime de direito publico no centro da noção de serviço público que se teoriza a mais importante (e mais deletéria) forma de regulação da economia: a concessão de serviço público. ${ }^{99}$

Continua no sentido de ilustrar que seriam duas as formas de regulação segundo o ordenamento jurídico brasileiro: a concessão de serviço público e o exercício do poder de polícia. Contudo, as principais críticas vêm no sentido de que, de um lado, seriam insuficientes para atender às necessidades de sistemas econômicos estruturalmente imperfeitos as concepções claramente liberais e passivas do poder de polícia; e de outro, o regime de concessão de serviços públicos parte de uma imperfeição de fundo quase insolúvel assentada na crença de que seria possível transformar agentes privados em persecutórios do interesse público. ${ }^{100}$

\footnotetext{
${ }^{98}$ Vale ainda citação de Calixto Salomão Filho: "Significam, na verdade, que, progressivamente, mais setores formalmente não regulados devem se submeter a uma disciplina antitruste incisiva que não se limite a sancionar atos, ilícitos, mas passe a impor comportamentos (o que, como se verá, é típico da disciplina regulatória)" (Regulação da Atividade Econômica, cit., p. 16).

99 Idem, ibidem, p. 19.

${ }^{100}$ Idem, ibidem, p. 19-20.
} 
Já a Escola Neoclássica negava fundamentos de interesse público na regulação, sob a crença da previsibilidade dos resultados que lhe permitiria indicar os fins da atividade econômica, servindo a regulação como substituto do mercado. Assim, esta escola defendia a possibilidade de simulação dos mercados nos gráficos de oferta e demanda. Setores sujeitos a monopólios naturais, nos quais a informação seria inadequada, ou em que condições estruturais levariam a uma concorrência excessiva ou predatória, devem ser regulados.

Da mesma forma, para esta teoria a regulação só seria necessária diante da ausência de solução de mercado mais eficaz, origem, portanto, dos movimentos desregulatórios. Interessante notar que, para autores da época, a regulação serviria nada mais nada menos que à proteção da indústria, e não a qualquer motivo de interesse público. Mais tarde Posner desenvolveria, baseado em pressupostos de Stigler, a teoria da captura, segundo a qual os interesses privados acabariam por sobrepor os motivos de interesse público, vez que as agências tenderiam a sujeitar-se à influência dominante dos regulados, sendo capturados pelos seus interesses. ${ }^{101}$

Contudo, a reprodução em laboratório das regras de mercado revelou-se impossível - ou ainda tem se revelado desta forma. E segundo os preceitos teóricos de formação da própria escola, a solução dada viria no sentido da desregulação, fazendo com que o mercado funcione por si só. Tal desregulação deveria se dar, contudo, através de mecanismos de autorregulação que sejam capazes de tentar criar ambiente semelhante à concorrência perfeita - o que foi feito, por exemplo, através da criação de bolsas de negócios com criação de regras internas de autorregulação - porém que igualmente mostrou-se falho, vez que se tentou uma mudança na forma, mas não no conteúdo. ${ }^{102}$

As duas Escolas apresentaram-se, contudo, falhas sob o ponto de vista das teorias que apregoavam. Novas ideias surgiram, neste sentido, para trazer nova modulação à regulação. A primeira trazida seria a da existência de setores não regulamentáveis, em que se deveria dar prestação direta de serviços por parte do Estado. Aqui estariam as atividades econômicas que pressupõem externalidades positivas ou negativas, visto que seria impossível recompensar-se os benefícios ou compensar-se os malefícios. Na visão de

\footnotetext{
${ }^{101}$ Regulação da Atividade Econômica, cit., p. 22-23.

102 Interessante notar crítica trazida por Calixto Salomão Filho na questão exemplificativa da criação do mercado atacadista de energia no Brasil (MAE), que deveria funcionar com uma perfeita bolsa de valores, autorregulada e em concorrência perfeita, mas que não verdade seria um convite e um incentivo à oligopolização dos mercados. Tratou-se de cópia de um modelo inglês que, contudo, era baseado em energia termoelétrica ao invés de hidroelétrica, como seria o caso do Brasil, assim pressupondo-se a impossibilidade de estoque de energia, tornando mais difícil a livre concorrência (Idem, ibidem, p. 24-25).
} 
Calixto Salomão Filho, importa a existência de relevância social na atividade que faz com que ela não possa ser prestada por particulares sem efeitos distributivos perversos, visto que seria inútil tentar mudar sua natureza através de regimes jurídicos específicos: "Não há regime de direito público que consiga mudar, ao menos no que tange às decisões econômicas, a mentalidade individualista dos particulares". ${ }^{103} \mathrm{O}$ setor em questão, seria, portanto, não regulável.

Com relação aos demais setores, deveríamos perseguir mudança no foco da preocupação "da busca de um objetivo predeterminado e pré-jurídico para a garantia efetiva da correção e da lealdade da integração dos vários agentes econômicos no mercado e de sua igualdade material em termos concorrenciais". ${ }^{104}$ Como garantia institucional da correção e equilíbrio da interação econômica dos diversos agentes, a justificativa da regulação passaria a ser a criação de uma igualdade material entre todos os agentes econômicos, para que possam desenvolver suas atividades em iguais condições. Para que se dê uma igualdade material entende Calixto Salomão a necessidade de uma difusão forçada do conhecimento econômico entre os indivíduos, que só poderia ser assegurada através de uma garantia firme de existência de concorrência. ${ }^{105}$

Colocados alguns pressupostos da teoria regulatória moderna, é inegável retornar à análise do binômio concorrência-regulação. Aqui pressupomos a inegável existência de um paralelo na aplicação dos dois institutos, sendo que a orientação do direito concorrencial presta serviço essencial à regulação. Enquanto a intervenção das normas de defesa da concorrência pressupõe-se de certa forma passiva, controlando estruturas quando provocada e reprimindo condutas quando implementadas, a intervenção regulatória pressupõe-se ativa, preocupando-se com a efetiva criação de utilidade pública, através de um sistema de concorrência orientador e vinculante sobre seus administrados.

Inegável ainda reconhecermos que a efetiva competição é um valor fundamental da regulação, devendo o Estado agir no sentido de garantir a existência de concorrência. Calixto Salomão Filho rememora que este seria um pretexto da teoria do direito concorrencial:

Garantindo a instituição (concorrência) e seu efetivo desenrolar através de regras comportamentais e estruturais (que são procedimentais na medida exata em que não impõem um resultado, efeito ou comportamento, mas apenas garantem que o relacionamento entre os concorrentes se dê de forma leal e equânime, sem

\footnotetext{
${ }^{103}$ SALOMÃO FILHO, Calixto. Regulação da Atividade Econômica, cit., p. 28.

${ }^{104}$ Idem, ibidem, p. 30.

${ }^{105}$ Idem, ibidem, p. 30.
} 
prevalência de uns sobre os outros), essa teoria pretende assegurar a possibilidade de os agentes econômicos coordenarem suas relações da forma mais justa e eficiente. ${ }^{106}$

A concorrência passa a ser admitida como um valor institucional a ser protegido. Os valores da concorrência não admitem, em especial, o abuso de poder econômico. Assim, seria tarefa mínima da regulação garantir as condições básicas de concorrência, de forma ativa, o que poderia se dar em duas situações: diante da existência de condições estruturais que impeçam o estabelecimento da livre concorrência - mercados dominados e quando as condições estruturais não impeçam sua criação, mas a tornem instável mercados instáveis. Em razão do tema em questão, privilegiamos a análise do primeiro viés de regulação.

Podemos afirmar que o objetivo clássico da regulação viria no sentido de criação de um ambiente de concorrência em mercados tomados por uma dinâmica que a dificulta, onde estariam presentes fortes barreiras ao seu estabelecimento. A justificativa de sua aplicação estaria no regime constitucional dos serviços públicos. Uma vez transferidos para a iniciativa privada aqueles serviços sem externalidades sociais, deve-se aplicar um regime de regulação institucional de atividades em que há posições dominantes. Neste sentido, o artigo 175 da Constituição Federal permitiria uma intervenção efetiva da concorrência e do amplo acesso aos serviços, sendo possível regular diretamente os contratos de concessão e fiscalizar seu cumprimento, bem como as relações entre concorrentes e consumidores. ${ }^{107}$

Há ainda situações de setores que requerem controle de acesso e permanência por questões de garantia de higidez do sistema ou segurança do mercado. Contudo, tais regras de acesso e permanência tendem a estabelecer condições propícias à formação de posições dominantes, privilegiando muitas vezes empresas sólidas e de grande dimensão. Importante que se estabeleçam regras que evitem a dominação de mercado por agentes econômicos, bem como o abuso dos consumidores. Conflitos aparentes encontrados no binômio regulação-concorrência como, por exemplo, higidez e concorrência, merecem trato profundo em outra ocasião.

\footnotetext{
${ }^{106}$ SALOMÃO FILHO, Calixto. Regulação da Atividade Econômica, cit., p. 34.

${ }^{107}$ Idem, ibidem, p. 46.
} 


\subsubsection{A Função Social Segundo a Teoria da Regulação}

Os princípios e escopo da regulação e sua necessária interação com a defesa da concorrência são outro aspecto que requer aprofundamento teórico. Aqui vale identificar o princípio do acesso necessário, que se relaciona diretamente com a dificuldade de respostas, sob o ponto de vista do direito da concorrência, a questões do problema de acesso para concorrentes e consumidores.

Com relação ao acesso entre concorrentes, veremos adiante que o problema é bastante relacionado ao instrumento de análise concorrencial da recusa de contratação, que trata de ferramenta utilizada diante de um comportamento negativo - a recusa de acesso injustificada. Aqui a doutrina desenvolveu disciplina da infraestrutura essencial, ou ainda "essential facilities", analisada em maior profundidade adiante, e que traz questões sensíveis como garantia não somente do acesso, mas da sua prestação em igualdade absoluta de condições com os próprios serviços, sendo admissíveis certas diferenças desde que razoáveis. E seriam estes critérios de razoabilidade geralmente utilizados pelas autoridades de defesa da concorrência. Estas justificativas vêm no sentido de se admitir vedação ao caronista ou "free-riding", inexistência de poder econômico, falta de espaço disponível, incapacidade financeira, custos de compartilhamento, entre outros.

Admitimos à regulação uma função de criação e fomento à livre concorrência ou estabelecimento de condições necessárias para que esta venha a ocorrer de forma ativa, como condição para operação de um agente econômico, em especial nos casos de desestatização de empresas públicas. ${ }^{108}$ A pergunta que se coloca, portanto, vem no sentido de reconhecer os mesmos poderes que os citados para a atividade regulatória ao direito da concorrência, ou estaria esta atividade regulatória ex post preventa de exigir postura semelhante? Confunde-se com a indagação do presente estudo: qual seria o limite das responsabilidades especiais outorgadas aos agentes econômicos com posição dominante?

Com relação aos consumidores, parece ainda mais delicada a questão. Se a concorrência é meio para que se atinja o fim - prestação de serviços eficientes -, parece inquestionável a possibilidade de trato das questões diretamente relacionadas aos consumidores. Discute-se assim a universalização de acesso aos consumidores. Esta seria, em regra, não lucrativa, uma vez que implica investimentos maiores que as possibilidades

108 O artigo 28 do Regulamento Geral de Interconexão (aprovado pela Resolução 40 da ANATEL, de 23.07.1998) afirma que as redes "devem ser organizadas como vias integradas de livre circulação" e, no inciso III, que o "direito de propriedade sobre as redes é condicionado pelo dever de cumprimento de sua função social". 
de lucro - extensão de uma rede a espaços longínquos e a consumidores sem poder aquisitivo. Restariam aqui duas opções: a extensão da longa manus do Estado, ou a imposição de obrigações condicionadas aos contratos de concessão. Indagamos se haveria área de conflito em que a defesa da concorrência não possuiria alcance.

Calixto Salomão Filho parece negar ao direito concorrencial as funções acima perquiridas. Permitimo-nos, contudo, concluir sobre o tema na forma que segue, segundo extensão de nosso ordenamento jurídico pátrio. Dispensável ainda comentarmos que qualquer reconhecimento das funções acima enunciadas teria natureza subsidiária à regulação, sendo ativados se insuficiente ou falha a atuação do agente regulador.

Como ferramenta de análise à questão que se pretende, merece destaque o princípio constitucional da função social da propriedade, que por muito tempo teve sua aplicação bastante limitada, em especial pela imprecisão e ameaça que sua conceituação parece despertar.

Fábio K. Comparato, no seu clássico artigo "Função social da propriedade dos bens de produção", tratou de elucidar que este princípio atinge mais do que a propriedade na sua acepção estática, incluindo a propriedade dos bens de produção, i.e., exercício de poder de controle empresarial. ${ }^{109}$ Neste sentido, passaria a função social a significar uso da propriedade em benefício de terceiros.

Indo além, Calixto Salomão pondera que a classificação bens de consumo ou bens de produção não esgota a variedade de bens sujeitos ao princípio da função social, lembrando a existência dos bens de acesso, que seriam aqueles cuja utilização dependeria da possibilidade de concorrência em determinado mercado, consistente não somente na sua boa utilização, mas ainda em sua disponibilização a terceiros. ${ }^{110}$

Portanto, reconhece o autor que a função social deveria consistir, ao se tratar de bem de consumo, nas restrições ao uso e, por vezes, à disposição coercitiva do bem; ao se tratar de bem de produção, na ideia de utilização do bem em benefício da comunidade; e finalmente ao se falar em bens de acesso, na obrigatoriedade de compartilhamento dos bens dos quais depende o acesso.

Com relação mais especificamente aos bens de acesso, alternativas trazidas para o compartilhamento vêm no sentido de estipular-se uma copropriedade de bens de acesso, solução que traz alguns problemas na sua implementação em caso de existência de poder

${ }^{109}$ COMPARATO, Fabio Konder. Função social da propriedade dos bens de produção. In Revista de Direito Mercantil Industrial Econômico Financeiro. São Paulo: Ed. Revista dos Tribunais. Ano XXV (Nova Serie). n. 63. julho/setembro de 1986.

${ }^{110}$ SALOMÃ̃ FILHO, Calixto. Regulação da Atividade Econômica, cit., p. 60. 
compensatório - a aquisição do comprador que exerce poder compensatório pode eliminar o empecilho para o exercício do poder monopolista -, bem como coloca-se um elemento facilitador da colusão diante da maior possibilidade de troca de informações sensíveis entre concorrentes.

A segunda alternativa, mais comumente utilizada e com menores riscos concorrenciais, seria a obrigatoriedade de compartilhamento dos bens de acesso. Refere-se tal acesso não somente às redes operadas por terceiro - interconexão -, mas também ao uso de infraestrutura de terceiros. Tal alternativa impõe limitação do direito de fruição inerente à propriedade. Significaria dizer que o preço da ligação à rede, ou interconexão, não poderia ser imposto pelo monopolista. Assim, mais do que se impedir a aferição de lucros exorbitantes por parte do titular do bem, tema de grande sensibilidade dentro da doutrina concorrencial, visaria impedir o fornecimento em condições discriminatórias com suas próprias condições de custo, diante de uma situação de integração vertical, que é mais comumente verificada nestas situações:

\footnotetext{
Assim, o cumprimento do dever de oferecer o acesso só estará plenamente caracterizado quando o titular do bem conseguir suprir os agentes econômicos que dele dependem de forma equivalente à que ocorreria caso existisse um mercado competitivo. Só assim os efeitos nocivos da existência de uma essential facility serão eliminados. ${ }^{111}$
}

A premissa que se coloca é de que a existência de bens cuja utilização é condição indispensável para produção de outro bem ou prestação de um serviço acarreta obrigação especial ao titular do bem - detentor, na sua origem, de poder de mercado com relação ao produto e local - de compartilhá-lo com os demais agentes econômicos, potenciais concorrentes. Implica, portanto, obrigação de contratar com o concorrente, diante de remuneração não discriminatória relativa ao acesso. ${ }^{112}$

Este princípio geral ainda se completa pelo princípio da interconexão, segundo o qual não somente a infraestrutura deve ser compartilhada, mas também a própria rede, inclusive os meios técnicos para transmissão de informações. Importante frisar que tais

\footnotetext{
${ }^{111}$ SALOMÃO FILHO, Calixto. Regulação da Atividade Econômica, cit., p. 63-64.

${ }^{112}$ A LGT, em seu artigo 73, estabelece que qualquer prestador de serviço de interesse coletivo tem o direito de utilizar a infraestrutura de outros prestadores de serviços de interesse público. O mesmo princípio de compartilhamento se verifica na Lei do Petróleo (Lei n. 9.478/97), que em seu artigo 58 faculta a qualquer interessado o uso dos dutos de transporte e dos terminais marítimos existentes ou a serem construídos, mediante remuneração adequada.
} 
princípios não estariam sequer adstritos aos setores com expressa disposição em seus normativos, visto tratar-se de atuação de princípio constitucional. ${ }^{113}$

Devemos ainda reconhecer o dirigismo contratual que se verifica mais intensamente na defesa do consumidor, que trata de verdadeira "fuga do contrato", tendência de busca de proteção em regramentos institucionais estáveis vis a vis as regras contratuais instáveis. O mesmo se verificaria no campo regulatório, em que a posição dominante no mercado requer um aparato regulatório que venha a estabelecer proteção institucional de acesso. A liberdade de atuação do agente econômico não se apresenta absoluta. Isso ainda porque se admite cada vez mais na doutrina moderna que o contrato não somente afeta as partes diretamente envolvidas, mas diversos outros agentes, entre os quais os concorrentes e consumidores, devendo a regulação, portanto, balancear a relação contratual privada com os efeitos públicos do contrato.

Vistos alguns dos princípios mais relevantes para modulação da teoria da regulação, e que, como veremos adiante, merecem aplicação analógica no campo da defesa concorrencial, vale discorrer sobre interessante questão corroborada também por Calixto Salomão Filho: seriam os princípios básicos regulatórios garantias institucionais ou apenas instrumento de política econômica? Caso a resposta seja centrada na segunda alternativa, deveríamos concluir que a aplicação de ambos os instrumentos seria feita em conjunto com outras políticas públicas, como monetária, fiscal, etc.

Se por outro lado focarmos na primeira alternativa, deveríamos reconhecer que tais princípios têm conteúdo mínimo necessário a ser preservado. ${ }^{114}$ Ou seja, colocar a própria existência da concorrência como garantia institucional mínima resulta na afirmação deste instituto como valor mínimo a ser perseguido, garantindo a liberdade de escolha e informação o mais abundante possível para o consumidor. E parece ser exatamente isso que a teoria jus-concorrencial persegue, garantindo proteção institucional e efetivo desenrolar através de regras comportamentais que assegurem uma interação entre os agentes econômicos de forma mais justa. ${ }^{115}$

Por fim, retomamos a indagação colocada acerca da competência dos instrumentos legais antitrustes de fixar responsabilidade de fomento à concorrência ou estabelecimento de condições mínimas para que tal ocorra. Quer nos parecer respondida ao reconhecermos a existência da teoria das infraestruturas essenciais, que não seria mais do

\footnotetext{
${ }^{113}$ SALOMÃO FILHO, Calixto. Regulação da Atividade Econômica, cit., p. 66.

${ }^{114}$ Idem, ibidem, p. 102.

${ }^{115}$ Idem, ibidem, p. 104.
} 
que a imposição de tais obrigações, no caso concreto, a um agente com posição dominante e que controla bens indispensáveis para a difusão do elemento concorrencial. Restaria, portanto, discorrer acerca dos limites desta competência legal.

\subsubsection{Mercado Relevante e sua Análise Dinâmica}

A definição de mercado relevante aplica-se no contexto de análises preventivas ou repressivas levadas a efeito pelas autoridades de defesa da concorrência. Implica apurar o conjunto de produtos ou serviços, em definida área geográfica, que possuam, entre si, elasticidade cruzada de preços positiva, ou, em outras palavras, que se reputem substituíveis entre si, preferencialmente pelo lado da demanda. ${ }^{116}$ Possui relevância essencial na discussão dos abusos de poder econômico unilateral, em especial quando estamos diante de mercados de inovação.

Diante de um pequeno, porém significativo e não transitório aumento de preços ${ }^{117}$ nos produtos ofertados pelas partes envolvidas em determinada operação, caso se observe migração da demanda para qualquer outro produto fora da fronteira inicialmente considerada na análise, restaria inviabilizada a conduta comercial por seu agente econômico, em razão do desvio de suas vendas em uma medida que supere seus supostos ganhos monopolísticos. Assim, pressupõe a análise identificação do conjunto de produtos e respectiva área geográfica de atuação do agente econômico - que impeça alternativas de desvio da demanda, tornando-se factível o aumento de preços a níveis monopolísticos.

Em resumo, da forma como é tratado pela doutrina econômica, o mercado relevante seria o conjunto de produtos de determinada área geográfica para os quais um monopolista hipotético poderia implementar um pequeno porém significativo e não transitório aumento de preços, sem possíveis contestações ao seu poder de mercado.

Sua importância, inegável para a maioria dos juristas e economistas, reside no fato de que propõe uma delimitação do campo operatório de análise dos efeitos decorrentes de determinada operação ou conduta. Assim, segundo a teoria tradicional dos mercados relevantes, para que se construa uma análise concorrencial, deve-se verificar, como

\footnotetext{
${ }^{116}$ Por vezes, considera-se ainda a substituição pelo lado da oferta para definição do campo operatório de análise.

${ }^{117}$ Convencionalmente adotam autoridades de defesa da concorrência, principalmente a americana, patamar de 5\% de aumento. Por sua vez, a Comissão Europeia geralmente utiliza a medida de $10 \%$. Contudo, essas medidas podem variar entre mercados e ao longo do tempo, bem como dependerão de características do produto, observação de aumento de preços passados, taxas de inflação e uma série de outros fatores.
} 
primeira medida, os níveis de concentração do mercado sob análise, sendo as participações de agentes envolvidos e seus respectivos concorrentes mensuradas dentro deste campo operatório.

De vital importância, portanto, no campo da atuação preventiva das autoridades, na medida em que permite análise de níveis de concentrações ex ante e ex post à operação, servindo de forte indício não somente para a justificação de análise mais profunda da operação, mas muitas vezes funcionando de forma a se presumir efeitos deletérios ao mercado, promovendo, na prática, verdadeira inversão de ônus de prova para os agentes econômicos. ${ }^{118}$

Da mesma forma funcionaria para delimitação do campo operatório de análise de condutas investigadas pelas autoridades. Importante notar que a configuração de infração à lei de defesa da concorrência brasileira requer verificação de poder de mercado como requisito apto a gerar efetiva potencialidade de dano, quer seja coordenado, quer seja unilateral.

Assim, pode-se constatar, das lições trazidas, que a definição do mercado relevante não seria um fim em si mesma, mas um meio, instrumento ou ferramenta para se identificar e definir os limites de concorrência entre agentes econômicos e, consequentemente, das pressões competitivas que se exercem sobre tais.

Vale recordar que a primeira vez que se cogitou de uma definição de mercado, segundo a literatura econômica, foi na opinião do Juiz Learned Hand no caso United States vs. Aluminium Co. of America, em que concluiu que uma firma deveria possuir uma parcela significativa do mercado para ser um monopolista, e para se determinar este critério de avaliação se fazia necessário determinar quais produtos estavam inseridos neste mercado. $^{119}$

Ao tratar do tema, o Guia de Análise Horizontal Norte-Americano de 1992, editado conjuntamente pela Comissão Federal de Comércio e pelo Departamento de Justiça norte-americano - "DOJ" - dispõe que este seria um produto ou grupo de produtos tal que um hipotético agente maximizador de lucros que se caracterizasse como único vendedor

\footnotetext{
${ }^{118}$ Não obstante reconheçamos que a análise do mercado relevante e avaliação da sua estrutura estática, mais precisamente das participações de mercado envolvidas, não bastam para o reconhecimento de uma posição dominante, verificamos verdadeira presunção iuris tantum de poder de mercado diante de certos níveis de concentração. Assim reza o próprio dispositivo legal da norma concorrencial brasileira - artigo $36, \S 2^{\circ} \mathrm{da}$ Lei n. 12.529/11.

${ }^{119}$ United States vs. Aluminium Co. of America, nota 49.
} 
atual ou futuro deste produto, portanto monopolista, provavelmente imporia um pequeno, porém significativo aumento de preços não transitório. ${ }^{120}$

O Guia Europeu, editado na forma de "Comunicação da Comissão relativa à definição de mercado relevante para efeitos do direito comunitário da concorrência", dispõe que:

\begin{abstract}
A definição de mercado constitui um instrumento para identificar e definir os limites da concorrência entre as empresas. Permite estabelecer o enquadramento no âmbito do qual a Comissão aplica a política de concorrência. O principal objecto da definição de mercado consiste em identificar de uma forma sistemática os condicionalismos concorrenciais que as empresas em causa têm de enfrentar. O objectivo de definir um mercado tanto em função do seu produto como em função da sua dimensão geográfica é o de identificar os concorrentes efectivos das empresas em causa susceptíveis de restringir o seu comportamento e de impedi-las de actuar independentemente de uma pressão concorrencial efectiva. ${ }^{21}$
\end{abstract}

O guia tem por objeto fornecer orientações quanto à forma como a Comissão aplica os conceitos de mercado geográfico relevante e mercado de produto com o intuito de avaliar os impactos das operações no Mercado Comum. Vale mencionar que a Comissão adota sistemática idêntica na sua atuação repressiva às empresas que se beneficiam de uma posição dominante exclusiva ou coletiva, cabendo a ela investigar e pôr termo a eventuais abusos de posição dominante, que devem ser igualmente definidos em função do mercado relevante. $^{122}$

120 Guia de Análise Horizontal norte-americano de 1992, disponível em: $<$ http://www.ftc.gov/bc/docs/horizmer.shtm>. "The analytic process described in this section ensures that the Agency evaluates the likely competitive impact of a merger within the context of economically meaningful markets--i.e., markets that could be subject to the exercise of market power. Accordingly, for each product or service (hereafter "product") of each merging firm, the Agency seeks to define a market in which firms could effectively exercise market power if they were able to coordinate their actions. (...) Absent price discrimination, the Agency will delineate the product market to be a product or group of products such that a hypothetical profit-maximizing firm that was the only present and future seller of those products ("monopolist") likely would impose at least a "small but significant and non-transitory" increase in price."

${ }^{121}$ Comunicação da Comissão relativa a definição de mercado relevante para efeitos do direito comunitário da concorrência, Jornal Oficial n. C 372 de 09/12/1997 p. 0005 - 0013, disponível em: <http://eurlex.europa.eu/LexUriServ/LexUriServ.do?uri=CELEX:31997Y1209(01):PT:HTML>.

${ }^{122} \mathrm{O}$ Guia Europeu reconhece ainda a suscetibilidade das empresas a condicionalismos concorrenciais de três ordens: a substituibilidade pelo lado da procura, a substituibilidade pelo lado da oferta e a concorrência potencial. Sob a perspectiva europeia econômica, para a definição de um mercado relevante, a substituição pelo lado da procura constitui o elemento de disciplina mais imediato e eficaz, sendo os condicionalismos concorrenciais decorrentes da substituibilidade pelo lado da oferta e concorrência potencial de efeito menos imediato, requerendo, de qualquer forma, análise de fatores adicionais. Em consequência, esses condicionalismos são tomados em consideração na fase de apreciação da análise da concorrência. Dispõe ainda o Guia Europeu, em seu $§ 20$, que a substituibilidade pelo lado da oferta pode ainda ser tomada em consideração na definição dos mercados nos casos em que os seus efeitos são equivalentes aos da substituição do lado da procura em termos de eficácia e efeito imediato. Para tanto, deve-se avaliar se os fornecedores são capazes de transferir suas respectivas produções para os produtos relevantes e comercializá- 
O Guia Brasileiro para Análise Econômica de Atos de Concentração Horizontal, que em muito se baseou no Guia Norte-Americano de 1992, dispõe que:

(a) definição de um mercado relevante é o processo de identificação do conjunto de agentes econômicos, consumidores e produtores, que efetivamente limitam as decisões referentes a preços e quantidades da empresa resultante da operação. Dentro dos limites de um mercado, a reação dos consumidores e produtores a mudanças nos preços relativos - o grau de substituição entre os produtos ou fontes de produtores - é maior do que fora destes limites. ${ }^{123}$

Definidos os mercados relevantes para fins da análise concorrencial, seja esta preventiva ou repressiva, e verificadas as participações de mercado relativas a cada agente econômico, obtemos o ponto de partida para se definir a essencialidade de apuração de outros fatores que incidem sobre a dinâmica concorrencial. Conforme é notório e pacífico na doutrina e jurisprudência mundial, altas participações de mercado não implicam, de forma absoluta e irrefutável, a conclusão acerca da existência de poder de mercado. Assim, para avalição dos prováveis efeitos de concentrações de mercado, sejam efeitos deletérios ou eficiências econômicas, imprescindível verificarmos os fatores que efetivamente exercem pressão competitiva contra determinado produto ou conjunto de produtos ofertados pelos agentes econômicos em questão.

Uma vez definido este campo operatório, segundo uma análise tradicional, produtos se colocariam em um dos dois cenários que se apresentam: estariam inseridos nas fronteiras da definição do mercado relevante ou estariam fora das fronteiras deste mercado predefinido.

Contudo, notória constatação da teoria econômica nos relembra que raramente haveria, no mundo real, sólida fronteira de mercado como se propõe definir. A regra que se verifica, em consonância com a estratégia dos agentes econômicos em diversificar seus produtos para fugirem da concorrência exclusivamente por preços, seria a de produtos heterogêneos, baseados nos mais diversos fatores intrínsecos ao produto, como a qualidade, duração, sabor, utilidade e funcionalidade, ou ainda extrínsecos ao produto, porém inerentes à percepção do consumidor, como a marca do produto, seus serviços

los a curto prazo, sem incorrer em custos ou riscos suplementares significativos. Por outro lado, sempre que a substituibilidade pelo lado da oferta implicar a necessidade de uma adaptação significativa dos ativos, a realização de investimentos adicionais, alterações nas decisões estratégicas ou substanciais atrasos, esta não deverá ser considerada na fase de definição do mercado relevante.

${ }^{123}$ Guia Para Análise Econômica de Atos de Concentração Horizontal; Portaria Conjunta SEAE/SDE n. 50, de $1^{\circ}$ de agosto de 2001, publicada no Diário Oficial da União n. 158-E, de 17/08/01, Seção 1, páginas 12 a 15, disponível em <www.seae.fazenda.gov.br/central_documentos/guias/portconjseae-sde.pdf>. 
acessórios - como atendimento - localização, estratégias de marketing, sua associação com uma imagem vencedora ou de sucesso, dentre outros fatores. Assim, com certa precisão pode-se afirmar que a exceção, a bem da verdade, seria a existência de produtos homogêneos, indiferenciados, cuja única forma de concorrência se daria em preços.

Como elucida David Evans, apesar de a linguagem de definição do mercado parecer sugerir que haveria uma tentativa de identificação de um fator invariável - definido como "o mercado" - na verdade, trata-se de um processo de identificação dos fatores de pressão competitiva relevantes às questões que ora se enfrentam e para avaliar a existência de poder de mercado. ${ }^{124}$ Assim, em linha com o acima exposto, simplesmente localizar as fronteiras do mercado relevante de forma estanque e calcular as respectivas participações dos agentes econômicos envolvidos não se coaduna em método confiável de avaliação da extensão dos fatores de pressão competitiva ou do grau de poder de mercado exercido por determinado agente econômico. Da mesma forma, limitar a análise de fatores de pressão concorrencial às fronteiras de mercado identificadas igualmente pode apresentar-se de maneira insuficiente para uma análise concorrencial apurada e precisa.

Não se trata de negar, em absoluto, a importância de uma definição inicial do mercado e respectiva mensuração da participação dos agentes econômicos envolvidos em determinada discussão, quer no âmbito preventivo, quer no âmbito repressivo, o que tende a trazer diagnóstico geral acerca do mercado, esboçando-se assim sua estrutura estática.

Intensifica-se o debate sobre a procura da "base de sustentação" sob a qual a participação de mercado deverá ser calculada. A crítica trazida por Evans e outros economistas é de que, na grande maioria dos casos, as discussões se focam na questão do mercado relevante ao invés de tratar-se preponderantemente dos efeitos potencialmente nele gerados. ${ }^{125}$

Se por um lado as autoridades de defesa da concorrência norte-americanas já se deram conta do problema e, assim, procuram flexibilizar a aplicação da análise dos mercados relevantes, por outro os tribunais americanos relutam em aceitar estas novas ideias e deixar de lado a aplicação engessada dos conceitos, sobre os quais se firma toda jurisprudência americana do antitruste, principalmente tratando-se o país de perpetuar a tradição do common law.

\footnotetext{
${ }^{124}$ EVANS, David. Lightening Up on Market Definition. In Research Handbook on the Economics of Antitrust Law. New York: Edward Elgar, 2011. p. 5.

${ }^{125}$ Idem, ibidem.
} 
Cresce o movimento de pressão nas autoridades de defesa da concorrência para focarem seus escassos recursos na análise dos efeitos que as práticas comerciais geram no mercado, após uma análise deste mercado que foque em entender o cenário competitivo e os fatores de pressão concorrencial incidentes, mas que não seja firmada sobre tais fronteiras estanques de definição do mercado. Justifica-se o pensamento na medida em que equivocada a definição de mercado, por assunção de falsas ou falhas premissas, comprometida estaria toda análise de efeitos que se sucede. ${ }^{126}$

Aplicando-se o debate ao caso brasileiro, talvez se cogite de eventual problema para adoção desta estratégia que reside na expressa menção feita pela lei de concorrência aos conceitos de mercado relevante. Nos Estados Unidos, por sua vez, não haveria regramento que limitasse o relaxamento dessa definição, uma vez que os estatutos americanos não fazem menção expressa a esta metodologia em seus diplomas legais seculares. $^{127}$

Importante notarmos, segundo análise de casos paradigmáticos testados pelas autoridades de defesa da concorrência brasileira, que estanque metodologia de análise de mercado relevante também tem sido regra nas decisões proferidas, não obstante se inicie movimento no próprio Tribunal do CADE no sentido de sua flexibilização.

Inegável que o conceito de mercado relevante é essencialmente econômico e, portanto, requer modelos econômicos para sua sustentação. Diversos seriam, desta forma, os testes desenvolvidos ao longo dos anos pelos economistas para basear sua aplicação, alguns mais, outros menos contestados. $\mathrm{O}$ de maior notoriedade, inserte na esmagadora maioria dos guias de análise adotados pelas autoridades de proteção à livre concorrência, seria o teste do monopolista hipotético, também conhecido como teste "SSNIP". Como já brevemente tratado, o teste determina que o mercado relevante deve ser definido como o menor grupo de produtos e a menor área geográfica necessários para que suposto

\footnotetext{
126 “The US Courts have embraced economic reasoning in almost every aspect of their approach to antitrust. Market definition - and the related subject of market power - is one of the few remaining areas in which the courts rely on an approach that is not supported by economic science. To align themselves with the modern economic approach to antitrust the courts would have to make but a modest change from their long jurisprudence. They would merely need to abandon their insistence on drawing hard boundaries and making all subsequent analytical steps dependent on where those lines are drawn. They would continue to have market definitions as the first step in the analysis and build their subsequent narratives off of it. They would only have to avoid economically unsupported conclusions drawn from artificial market boundaries" (EVANS, David. Lightening Up on Market Definition, cit., p. 2).

127 'Section 7 of the Clayton Act refers to 'lines of commerce' but it is hard to imagine Congress intended that to require drawing hard boundaries. The Sherman Act is silent on the subject of markets referring only generally to trade or commerce" (Idem, ibidem, p. 2).
} 
monopolista esteja em condições de impor um pequeno porém significativo e não transitório aumento de preços. ${ }^{128}$

O mercado relevante não deve ser um conjunto de produtos que se parecem uns com os outros, mas sim um conjunto de produtos e áreas geográficas que efetivamente exerçam pressão competitiva uns sobre os outros. Deve-se considerar, contudo, que dificuldades comumente encontradas pelos economistas dizem respeito à sua natureza hipotética e obtenção das informações necessárias para colocá-lo em prática. Raramente se observam experimentos naturais em que o monopolista unilateralmente promove aumento de preços para verificar os resultados. Assim, na prática o tipo das informações que são usadas incluem estimativas de parâmetro de sistemas de demanda, características de produtos e preferências do consumidor, movimentações de preços passados, tecnologias e custos, dentre outras.

Constata-se, portanto, que a aplicação do teste do monopolista hipotético invariavelmente requer deduções indiretas via modelos econométricos, estudos de práticas e comportamentos passados, entre outras fontes, sendo as respostas apresentadas com certo grau de imprecisão.

Neste sentido, o Guia Brasileiro destaca diversos testes econômicos à disposição dos economistas para delimitação do mercado relevante, tais como elasticidade cruzada ou o teste da correlação de preços ao longo do tempo. A citar, da mesma forma, os normativos da Comissão Europeia, que trazem em sua nota de definição do mercado relevante uma série de testes quantitativos especificamente concebidos para tal fim, tais como estimativas da elasticidade e elasticidade cruzada da procura, analogia das oscilações dos preços ao longo do tempo, efeito de causalidade entre séries de preços e a semelhança entre os níveis de preços ou sua convergência. ${ }^{129}$

\footnotetext{
${ }^{128}$ Para sua operacionalização, deve-se considerar um conjunto de produtos, inicialmente abarcados pelos bens produzidos e vendidos pelas empresas envolvidas na operação, e sua respectiva área geográfica de exploração comercial, avaliando-se qual seria o resultado final de um pequeno, porém significativo e não transitório aumento dos preços para este universo de produtos e área geográfica inicialmente considerados. Caso o resultado seja redução da receita em virtude da migração da demanda, deve-se acrescer à definição original o substituto mais próximo aos produtos inicialmente considerados, bem como a extensão territorial para onde se verifica a migração da demanda. Deve-se repetir este exercício sucessivamente até que seja identificado um grupo de produtos e um conjunto de localidades para os quais seja economicamente interessante, para um suposto monopolista, impor um pequeno, porém significativo e não transitório aumento de preços.

129 Dentre os testes econométricos utilizados, primeiramente cabe mencionar a análise de elasticidade de preço própria e cruzada. A elasticidade própria da demanda seria a variação em quantidade dada uma variação em preço, enquanto a elasticidade cruzada da demanda pressupõe a variação em quantidade de $y$ dado uma variação em preço de $x$. Trata-se, portanto, de formas de se mensurar a perda de receita quando o preço de um determinado produto aumenta. Se a elasticidade da demanda própria for alta, pressupõe-se mercado elástico, tendendo o mercado relevante a ser mais amplo do que o considerado, uma vez que um
} 
Importante frisar-se que, além dos fatores físicos e comerciais dos produtos, a percepção do consumidor e seu comportamento passado, outros fatores impactantes sobre a substituibilidade devem ser considerados, como as características dos processos produtivos, a evolução dos preços relativos e das quantidades vendidas, o tempo e os custos envolvidos na decisão de consumir e produzir produtos substitutos, dentre outros.

Alguns cuidados, contudo, devem ser observados por economistas ao se aplicarem testes econométricos para definição de mercados relevantes. Primeiramente, requerem cuidados os mercados assimétricos, na medida em que determinada região pode contestar outra, mas o inverso não seria verdadeiro; ou ainda produtos novos que contestam produtos antigos, sem que o inverso seja verdadeiro. Da mesma forma, cuidados são essenciais no caso de cadeias sucessivas de substituição de produtos, nas quais pode haver produtos mais substituíveis do que outros, normalmente no que tange ao escopo geográfico do mercado. $^{130}$

aumento de preços não se verificaria rentável em vista da substituição de produtos pelos consumidores. Por sua vez, caso a elasticidade da demanda própria seja baixa, pressupõe-se mercado inelástico, tendendo o mercado a ser restrito ao considerado, haja vista que os consumidores não encontram produtos substitutos. Ainda, no caso de elasticidade de demandas cruzadas positivas, pressupõem-se produtos substitutos, enquanto elasticidade de demandas cruzadas negativas pressupõem produtos complementares. Da mesma forma, utilizam-se ferramentas para delineação do mercado centradas em análises de séries temporais de preços, através de modelos de correlação, causalidade de Granger e Cointegração. Assim, o modelo de correlação de Stigler \& Sherwin determina que se dois produtos estão no mesmo mercado, o preço de um deles contesta o preço de outro e, portanto, seus preços devem se mover conjuntamente. Em outras palavras, os diferentes produtos estarão mais estreitamente integrados quanto menores os movimentos de seus preços. Da mesma forma, os diferentes locais ou regiões estarão mais estreitamente integrados quando melhores forem o fluxo das mercadorias de um determinado mercado para outro (STIGLER, J.G.; SHERWIN, R.. The extent of the Market, cit.). Por sua vez, o método de análise de preços por causalidade de Granger traz um avanço em relação à correlação, pois leva em consideração não apenas correlações contemporâneas, mas também padrões dinâmicos. Assim, caso a variação no preço de $x$ ajudar a prever os valores de $y$, haveria indicação de que os dois produtos estariam abarcados no mesmo mercado. Finalmente, o método de causalidade de preços por Cointegração, por sua vez, incorpora um possível efeito de longo prazo numa análise de curto prazo, permitindo que se identifiquem possíveis relações de causalidade entre duas variáveis originárias de uma mesma tendência de longo prazo. Outros métodos de estimação de demanda, como o log-linear, o linear, o AIDS, o família logit, dentre outros, estão à disposição dos economistas em seu exercício de definição do campo operatório. O uso de cada modelo depende de disponibilidade de dados, características do produto - homogêneo - e outras hipóteses assumidas na modelagem. Contudo, talvez o método mais utilizado para implementação do teste SSNIP pelos economistas seja o teste da Perda Crítica (Critical Loss) que, para sua implementação, requer somente informações acerca da margem de lucro dos produtos em questão. $\mathrm{O}$ teste de Perda Crítica visa estimar quanto um agente monopolista deveria perder em vendas para tornar um aumento de preços não rentável. Caso as vendas caiam mais que o benchmark da perda crítica, o aumento de preços não se reputaria rentável e, portanto, o mercado relevante deveria ser expandido. Assim, consideram-se dois efeitos: o efeito negativo, relativo às perdas nas vendas, e o efeito positivo, relativo ao aumento de margem. Se os efeitos negativos superarem os positivos, um aumento de preço não seria rentável e, portanto, o mercado deveria ser expandido, pois outros produtos possivelmente o contestam.

${ }^{130}$ Consumidores do supermercado da cidade A decidem dirigir até a cidade B se o preço de A aumentar. Preços de B, portanto, contestam preços de A. Se os consumidores de B, por outro lado, dirigem até a cidade $\mathrm{C}$ (sob aumento do preço de $\mathrm{B}$ ), os preços de $\mathrm{C}$ não apenas contestam $\mathrm{B}$ mas também $\mathrm{A}$, através desta cadeia. 
Também se discutem alguns dos fatores de complicação para definições de mercados relevantes. $\mathrm{O}$ primeiro a que se faz referência diz respeito a produtos situados em mercados intermediários da cadeia, ou seja, produtos que não são vendidos diretamente a consumidores - mercados de atacado. Assim, caso o mercado em análise seja de atacado, resta claro que a consequência de um aumento de preços - por exemplo, em torno de $10 \%$ - no mercado de atacado dependerá, em parte, do comportamento no mercado a jusante mercado de varejo. As duas questões de relevância seriam, neste sentido, o grau do repasse ou "pass-through rate" - à medida que atacadistas são capazes de repassar a integralidade do aumento aos seus clientes -, bem como a reação dos consumidores a qualquer aumento de preços efetivamente repassados. Portanto, a reação final do consumidor será responsável em grande parte pela ação dos varejistas, que por sua vez disciplinará a ação dos atacadistas. ${ }^{131}$

Outro fator de complicação intensamente abordado por doutrinadores, autoridades e tribunais diz respeito à "falácia do celofane". Implica dizer que um monopolista poderia elevar seus preços até o ponto em que consumidores fiquem à beira de substituírem tal produto por outro, ou mesmo se retirarem do mercado, situação em que os lucros do monopolista encontrar-se-iam maximizados. Nesta conjuntura de preços monopolistas no mercado, poderia parecer que existiriam diversos produtos substitutos. Contudo, esta situação aparente não deve se refletir na definição do mercado, ou seja, os produtos aparentemente substitutos não deveriam ser incluídos no teste do monopolista hipotético e, portanto, compor o mercado relevante. ${ }^{132}$

Via de consequência, os cuidados e fatores acima elencados contribuem às críticas acerca de categorias estanques de definição de mercado e consequente flexibilização e reposicionamento da importância de se definir estritamente o mercado relevante. A definição tradicional traz delineação estrita e, diante disso, procede-se toda análise subsequente. Assim, devemos ter claro que o principal papel da definição de mercado seria de ajudar a identificar as pressões competitivas incidentes e avaliar a extensão do poder de mercado de agentes econômicos.

Ao longo dos anos, contudo, os encantos do teste do monopolista hipotético foram se reduzindo para os economistas e autoridades em razão, principalmente, das dificuldades existentes na aplicação dos modelos. Para se implementar o teste do monopolista

${ }^{131}$ GEROSKI, Paul; GRIFFITH, Rachel. Identifying Anti-Trust Markets. In: NEUMANN, M; WEIGAND, J (eds.). International Handbook of Competition. Edward Elgar, 2003. p. 7.

${ }^{132}$ Idem, ibidem, p. 8. 
hipotético faz-se necessária a construção de um conceito de empresa com produtos múltiplos e sua respectiva mensuração de margem de lucro, bem como avaliação da substituibilidade de todos os produtos do agente econômico com relação a todos os produtos não consolidados por aquele agente, o que o torna um modelo de difícil implementação.

Da mesma forma, se critica que, caso haja informação suficiente para aplicação do teste do monopolista hipotético, determinando-se o mercado relevante, haveria dados suficientes para se determinar, com o mesmo modelo econômico, se a concentração em questão seria capaz de resultar em aumento unilateral de preços. Assim, defendem alguns economistas que, caso as autoridades tenham à sua disponibilidade todas as informações para avaliar os efeitos de uma concentração, não deveriam dispender seus esforços na delineação de mercados e avaliação de poder de mercado. Caso as autoridades disponham de informações sobre margens de preço e custo, bem como evidências sobre a diversidade de vendas entre duas firmas em combinação, poderiam determinar, através do mesmo modelo econômico utilizado para o SSNIP teste, os efeitos diretos desta fusão nos preços. $^{133}$

Por conta de todas estas questões, o Guia de 1992 foi revisto em 1997 e, mais recentemente, substituído por um novo Guia de Análise conjunto do FTC e DOJ, publicado em agosto de 2010. O novo Guia de 2010 pretendeu consolidar as principais técnicas analíticas, práticas e política de execução das leis de defesa da concorrência pelas autoridades norte-americanas relativamente a fusões e aquisições envolvendo concorrentes atuais ou potenciais. ${ }^{134}$

\footnotetext{
${ }^{133}$ EVANS, David. Lightening Up on Market Definition, cit.

${ }^{134}$ Ao longo do guia são discutidas ferramentas analíticas para determinação do mercado relevante, no seu aspecto de produto, tomando relevância o monopolista hipotético e respectivos testes econométricos de suporte à determinação do mercado relevante, alguns dos quais já tratados acima. No tocante ao seu aspecto geográfico, analisam-se alguns cuidados que devem ser tomados pelas autoridades neste exercício, como o benchmarking de preços a serem utilizados, a questão de mercados em que há possibilidade de discriminação de preços entre clientes e a arbitragem é limitada, o ponto de vista de localização dos clientes e dos fornecedores na determinação do mercado geográfico, dentre outros. Da mesma forma, se refere o guia aos participantes do mercado, atuais ou potenciais, às participações do mercado, ressaltando que determinadas alterações de condições do mercado podem contribuir para que a atual participação de determinado agente venha a superestimar ou subestimar a significância competitiva daquela empresa no futuro. Assumi ainda que participações de mercados não necessariamente refletem a força competitiva de uma empresa, sendo que as autoridades parecem dar mais importância a participações de mercado estáveis ao longo do tempo. Os índices de mensuração da concentração de mercados persistem no guia, devendo tais índices ser medidos em razão do número de concorrentes significativos, particularmente em casos em que haja grande diferença nas participações de mercado, bem como em mercados em que a medida de receitas é de difícil constatação. $\mathrm{O}$ HHI, ainda utilizado pelas autoridades, sofreu também alteração nos seus percentuais de análise. O guia traz ainda tratamento mais explícito sobre a teoria dos efeitos unilaterais. Neste sentido dispõe o guia que a definição de mercado e a concentração de mercado seriam menos relevantes à teoria dos danos concorrenciais resultantes de efeitos unilaterais. Desta forma, a pergunta que se deve fazer, segundo o guia,
} 
Em linha com a experiência recente norte-americana, Richard Whish reconhece que diversos doutrinadores acreditam que muita ênfase é colocada na definição de mercado relevante sob o sistema de controle europeu, ao menos porque técnicas têm sido desenvolvidas para se permitir prever se determinada concentração levaria a aumento de preços, sem que necessariamente se determine, de maneira formal, o mercado relevante ou o poder de mercado. Não obstante tais opiniões e o mérito que possam ter, reitera o autor que existe, sob a prática atual, importante função emprestada ao mercado relevante e agentes que venham a notificar suas operações, os quais devem, de fato, identificar os mercados afetados no formulário de notificação, tendo os tribunais reiterado a necessidade de definição do mercado no contexto das análises concentracionais. ${ }^{135}$

Em resumo, para fins de avaliação de qualquer novo paradigma de análise de mercados relevantes, deve-se considerar, primordialmente, o custo dos erros decorrentes de definições estanques e imprecisas que desvirtuam toda análise concorrencial subsequente. Esta análise reconhece que, quando pessoas tomam decisões imperfeitas, fundadas em informações imperfeitas, cometem erros, os quais geram custos. ${ }^{136}$

Tal problemática nos quer parecer mais acentuada na presença de mercados de inovação, como em situações em que possa haver tendências a conversões tecnológicas e que o próprio limite dos mercados relevantes é de difícil apuração. Nestes casos as soluções acima apontadas parecem se adaptar melhor à finalidade a que se destinam.

seria se a empresa resultante da operação será capaz de exercer poder de mercado ausentes quaisquer possibilidades de resposta dos seus concorrentes. Vale recordar que as autoridades consideram duas básicas teorias de efeitos competitivos: efeitos coordenados e efeitos unilaterais. Assim, poderia se cogitar de efeitos coordenados na medida em que a concentração resultasse na probabilidade de colusão entre as empresas em consolidação e seus concorrentes, ou mesmo tornar seus comportamentos mais "acomodados". Por sua vez, os efeitos unilaterais surgem se a concentração trouxesse à entidade em consolidação um incentivo unilateral para aumentar preços, consequentemente lesando consumidores finais. Enquanto efeitos unilaterais não podem, via de regra, ser naturalmente diagnosticados através da análise da concentração de mercado, existiriam testes possíveis de se determinar a probabilidade de que venham a ser uma das questões enfrentadas pelas autoridades concorrenciais (Guia de Análise Horizontal Norte Americano de 2010, p. $10)$.

${ }^{135}$ WHISH, Richard. Competition Law. 6. ed. Oxford: Oxford University Press, 2008. p. 850. Neste sentido vale relatar exemplo bem-sucedido de análise flexível do mercado relevante, que pode ser verificada na decisão da autoridade do Reino Unido - Office Of Fair Trade (“OFT”) - no caso da fusão entre a Amazon e a LOVEFILM, únicas provedoras de aluguel de DVDs online. A discussão que se deu foi no sentido de se avaliar se o serviço prestado por estas empresas sofria pressões competitivas de outros canais dos quais os consumidores poderiam obter filmes e outros conteúdos televisivos, como lojas de aluguel de DVDs como a Blockbuster, lojas de venda de DVDs como WHSMith, operadoras de TV a cabo com conteúdo de pay-perview ou pacotes de assinatura, e mesmo conteúdo veiculado em televisões abertas. Apesar de uma análise preliminar do OFT indicar que haveria evidências nos autos demonstrando que a concentração poderia de fato gerar aumento de preços, o OFT considerou as evidências de que o aluguel de DVDs online da Amazon exercia pouca pressão competitiva na LOVEFILM e, de que as duas empresas atuavam como se sofressem pressões competitivas relevantes dos outros canais acima mencionados. Assim, concluiu o OFT que havia pressões competitivas advindas de outros provedores de vídeos e shows televisivos que seriam capazes de impedir um aumento significativo de preços.

${ }^{136}$ EVANS, David. Lightening Up on Market Definition, cit., p. 25. 
Portanto, definições de mercado estanques podem resultar em erros da avaliação dos efeitos concorrenciais porque afetam a informação considerada nos passos subsequentes da análise. Na fase de definição do mercado relevante deve-se decidir se um produto substituto, pelo lado da demanda ou, por vezes da oferta, estaria dentro ou fora das fronteiras do mercado relevante, o que poderia representar a inclusão de um produto que de fato não exerce qualquer pressão competitiva, ou exclusão de um produto que de fato exerce.

$\mathrm{Na}$ visão de alguns economistas, não seria possível se construir um método de definição de fronteiras de mercado estanques capazes de produzir poucos falsos positivos ou falsos negativos pela simples razão de que fronteiras de mercado estanques raramente existem no mundo real. Não obstante, a nova proposição dos economistas parece concordar na razão dos problemas existentes, porém discordar na proposição de uma solução. Assim, uma primeira corrente reconhece a importância dos exercícios de definição de mercados relevantes, na medida em que estes modelos inferem a substituibilidade pelo lado da demanda e oferta, como instrumento de avaliação das pressões competitivas exercidas para possibilitar um termômetro do poder de mercado existente e seus efeitos concorrenciais. $\mathrm{O}$ foco desta análise estaria na avaliação das pressões competitivas existentes.

Para esta corrente de economistas, a definição de mercados relevantes deveria permanecer como passo inicial da análise concorrencial. Contudo, esta análise deveria se dar de forma aberta e expansiva, possibilitando um entendimento mais extensivo das pressões competitivas exercidas. Não deveriam os tribunais, portanto, insistir na fixação de fronteiras de mercado estanques quando os fatos assim não o suportarem. Os maiores problemas com definições de mercados relevantes surgiriam do esforço de identificação de algo que, no mundo real, não existiria. Da mesma forma, os tribunais não deveriam confiar de maneira plena nas participações de mercado verificadas, devendo ser usadas tão somente como uma das fontes de informação para avaliação das pressões competitivas existentes.

De outro lado, insurge-se corrente que defende um foco direto nos efeitos concorrenciais, através da análise dos fatores que exercem pressão competitiva nos agentes econômicos em questão, renegando a análise de mercados relevantes a uma regra secundária. De toda forma, parece ganhar força o clamor por uma equiparação da validade probatória de evidências diretas de efeitos aos tradicionais testes econométricos de delimitação de mercados relevantes e mensuração de poder de mercado. 
Se alguma crítica se pode fazer sobre a renegação dos mercados relevantes a um segundo plano, retirada das lições de David Evans, seria a de que uma análise focada em evidências diretas de efeitos faria com que autoridades deixassem de avaliar alguns detalhes da indústria ou segmento em questão, fato que poderia implicar desconhecimento de informações que pudessem, de alguma forma, questionar a plausibilidade da análise de dados relativa aos efeitos concorrenciais. Assim, a vantagem de se fazer uma análise preliminar do mercado relevante seria a de favorecer um entendimento do segmento em análise, e da dinâmica concorrencial deste mercado, criando-se uma base para avaliação da plausibilidade da análise de efeitos concorrenciais.. ${ }^{137}$

A se considerar a análise de condutas por parte das autoridades de defesa da concorrência, em que pesem opiniões diversas, o procedimento utilizado para construção do mercado relevante impactante da conduta em apreço deve ser o mesmo utilizado para a análise de estruturas, vez que não encontramos elemento que justifique tratamento divergente. $\mathrm{O}$ que podemos dizer, contudo, é que a flexibilidade na adoção destes conceitos para investigações envolvendo abuso de poder de mercado deve ser ainda mais intensa do que no controle das estruturas. Isso porque na maioria das vezes, a análise de condutas se dá posteriormente à geração de efeitos anticoncorrenciais, podendo - e devendo - as autoridades valerem-se de ferramentas econômicas para avaliação e mensuração destes efeitos de forma a justificar-se repreensão administrativa.

\subsubsection{Monopólios, Poder de Mercado e Posição Dominante}

O termo monopolista é muitas vezes utilizado em sentido amplo para se referir a um agente econômico com algum poder de mercado, capaz, portanto, de agir de maneira independente de seus clientes e concorrentes no mercado. Da mesma forma que situações de concorrência perfeita são raras de se verificar na prática, assim também seriam situações de monopólio perfeito.

Quando próximas a este conceito geralmente se devem a regramentos jurídicos e não propriamente a situações relacionadas à dinâmica dos mercados, como em casos de monopólio legal, com a exploração exclusiva do Estado de forma direta na economia, em setores estratégicos reservados, ou concessões públicas para exploração de setores regulados.

137 EVANS, David. Lightening Up on Market Definition, cit., p. 36. 
Da mesma forma, podemos reconhecer no sistema de proteção dos direitos de propriedade industrial monopólio legal temporário, que visa conferir posição de mercado privilegiada a um agente inovador como prêmio à eficiência dinâmica alcançada. Daqui retiramos uma primeira incontestável premissa: posição dominante que resulte de um processo natural calcado na maior eficiência de um agente econômico com relação aos seus concorrentes não justifica, em princípio, tentativa de censura por parte do Estado. Em outras palavras, nenhum monopólio deve ser condenado per se.

Nem mesmo situações de monopólio legal devem ser recepcionadas pelo ordenamento jurídico pátrio de forma a isentarem agentes econômicos envolvidos da aplicação das normas de defesa da concorrência, a qual deve alcançar todas as pessoas físicas ou jurídicas de direito público ou privado, associações de entidades ou pessoas, constituídas de fato ou de direito, ainda que temporariamente, com ou sem personalidade jurídica, mesmo que exerçam atividade sob regime de monopólio legal. ${ }^{138}$ Exemplos diversos ocorrem em outras jurisdições em que setores inteiros, ou situações específicas, são isentos desta análise antitruste, contudo. ${ }^{139}$

Em uma situação de monopólio perfeito, um único vendedor possui um único produto, o qual não encontra substitutos próximos no mercado. Uma empresa em posição dominante tende, desta forma, a adotar comportamento típico de um monopolista, promovendo aumento de preços a níveis supracompetitivos, reduzindo ou estagnando a qualidade do produto - sem investimentos em pesquisa e desenvolvimento - e mesmo impondo aos demais agentes econômicos práticas de mercado que não adotariam em condição estrutural de concorrência.

Para tanto, basta compreender que em situações de concorrência perfeita, diferentes consumidores com variado poder aquisitivo predispõem-se a pagar certo valor por um mesmo produto, valor superior para alguns e inferior para outros, aqui compreendido como reserva de preço. Caso um agente econômico que produza referido produto decida aumentar seus preços, diante de uma situação de concorrência perfeita, esse agente tenderá a perder todas as suas vendas, na medida em que haveria outros produtos semelhantes ofertados por outros agentes econômicos que poderiam cobrir um desvio de demanda. Assim, o modelo de concorrência perfeita mais próximo de nossa realidade é representado por uma demanda levemente inclinada para baixo. $\mathrm{O}$ aumento de preços gera

\footnotetext{
${ }^{138}$ Art. 31 da Lei n. 12.529/11.

139 A própria legislação brasileira traz isenção de notificações de operações, portanto isenção no controle preventivo, aos atos de concentração destinados às licitações promovidas pela administração pública direta e indireta e aos contratos delas decorrentes (Artigo 90, § único da Lei n. 12.529/11).
} 
uma diminuição considerável de sua produção, até um preço $x$ em que suas vendas serão inexistentes. Esse modelo possui uma curva de demanda elástica. Uma empresa atuante no mercado que possua uma curva de demanda elástica para seus produtos não goza de poder de mercado.

Em situação de monopólio, contudo, a curva da demanda possui um grau acentuado - geralmente superior a 45 graus - que confere ao agente de mercado poder para aumentar seus preços, de forma mais ou menos significativa a depender do cenário, sem que haja relevante alteração da quantidade vendida. Nessa situação a curva da demanda é conhecida como inelástica. Assim, a elasticidade cruzada implica o aumento de vendas de um produto em decorrência do aumento do preço de outro produto semelhante e perfeitamente substituível.

Numa situação de concorrência perfeita, a curva da demanda se confunde com a curva do custo de produção. Isso porque em teoria, numa situação de concorrência, o agente de mercado fixa seu preço em conformidade com o seu custo, pois se não há coordenação e os custos são semelhantes, o preço a maior irá acarretar perda substancial de suas vendas $(\mathrm{P}=\mathrm{CP})$. Nessa situação não há perda econômica para o consumidor, que adquire o produto ao seu preço de custo, bem como não há transferência de renda do consumidor para o produtor. Devemos ter em vista que o custo a que nos referimos inclui uma remuneração justa ao produtor, que deve incluir até mesmo gastos com pesquisa e desenvolvimento de seus produtos, gerando ao final o trinômio eficiência alocativa, não transferência de riquezas e eficiência dinâmica.

Contudo, numa situação de monopólio, o agente dominante é capaz de fixar seu preço acima de seus custos. O preço em que esse agente é capaz de maximizar seus ganhos é fixado pelo encontro da curva de sua receita marginal - a receita que recebe decorrente da produção de uma unidade adicional - com seu custo marginal - o custo de produzir uma unidade adicional. Obviamente, se o agente dominante ultrapassar essa quantidade de produção, estará perdendo receita.

O prejuízo causado à sociedade em virtude de uma situação de monopólio é ainda conhecido como "deadweight loss", ou peso morto. Porque menos consumidores adquirem o produto em razão da elevação artificial de seus preços, o resultado é uma alocação ineficiente de recursos e consequente transferência de riquezas do consumidor para o produtor. Da mesma forma, ainda que discorde parte da teoria econômica, temos que um agente dominante não possui incentivos para investir no desenvolvimento de seus 
produtos, haja vista a comodidade com a situação e a maximização de suas receitas segundo o modelo monopolista.

Situação mais comumente encontrada no mercado, contudo, seria a presença de alguns vendedores, geralmente três a cinco, a que podemos chamar de oligopólio. Oligopolistas, via de regra, possuem algum grau de poder de mercado, sendo capazes de aumentar suas receitas através de medidas disciplinares de preços. A grande dificuldade encontrada por autoridades antitrustes, contudo, concerne à forma pela qual oligopolistas o fazem. Acordos para fixação de preços, quantidades, alocação de território, acerto de ofertas públicas ou fixação de outras variáveis concorrenciais entre oligopolistas são repudiados e geralmente considerados infrações per se em diversas jurisdições, ou seja, seus efeitos restritivos à livre concorrência não requerem sequer comprovação, visto que seriam presumidos. ${ }^{140}$

Reconhecidamente ao longo das últimas décadas, cartéis têm sido ponto de destaque dentre as preocupações das autoridades mundiais de concorrência. Diversas seriam as razões para tanto, que passam pelo alto grau de reprovabilidade destes acordos para eliminação da concorrência, pelos seus relevantes efeitos deletérios ao mercado, até mesmo pelo menor grau de complexidade da atividade punitiva do Estado, que via de regra se vale de instrumentos persecutórios eficientes para comprovação da existência destes ilícitos.

Contudo, em certos mercados não há acordo, ou, por dizer, encontro consciente de vontades entre concorrentes visando à maximização de resultados dos entes cooperantes. O próprio mercado traz, contudo, estrutura que incentiva comportamentos racionais paralelos entre concorrentes. Tais comportamentos paralelos, geralmente, não são puníveis prima facie com medidas repressivas, pois não passam de comportamentos racionais praticados de maneira independente pelos agentes econômicos em interação.

Caso se consiga demonstrar que o comportamento não é economicamente racional e que existe um elemento adicional sugerindo a ausência de decisões independentes e unilaterais, segundo a doutrina do paralelismo plus adotada pela jurisprudência de diversos países, poder-se-ia caracterizar uma infração concorrencial. Aqui, ao contrário do que se pode verificar em cartéis, onde se evidenciam acordos formais ou informais, comportamentos colusivos tácitos pressupõem, simplesmente, atitude econômico-racional

\footnotetext{
140 A regra per se, de origem norte-americana, contudo, não possui amparo legal e, portanto, tampouco deveria merecer amparo doutrinário e jurisprudencial, no Brasil. A discussão sobre o tema é, contudo, intensa e controversa.
} 
de empresas em busca do objetivo maior inerente à moderna organização industrial capitalista: o lucro.

A ideia do comportamento colusivo tácito é explicada por modelos econômicos diversos, mas encontra seu ponto fundamental de sustentação na Teoria dos Jogos e no Equilíbrio de Nash. Dessa forma, em estruturas oligopolistas, empresas consideram as práticas empresariais de seus concorrentes, especialmente no que tange a preço e produção, para fixação de sua própria política empresarial. Assim, empresas reconhecem, baseadas em estudos empíricos, sua estratégia dominante, ou, em outras palavras, a melhor estratégia de preços ou produção em vista da estratégia de seus competidores. ${ }^{141}$ Por certo, para que ocorram, diversos fatores devem ser reconhecidos na estrutura dinâmica do mercado, como a transparência de informações, a previsibilidade de ação dos agentes interagidos no jogo e a aferição de padrões de comportamentos do setor em situações passadas ou análogas.

Assim, retornando ao conceito em exploração no presente tópico, implicaria o poder de mercado na capacidade de um agente de elevar preços substancialmente e não transitoriamente sem que isso lhe acarrete diminuição nas suas vendas capazes de anular o ganho obtido com o incremento no preço. Ou simplificando, trata-se do poder de aumentar os preços, ou reduzir oferta, sem que haja relevante alteração na demanda de seus produtos.

\footnotetext{
${ }^{141}$ Comportamentos colusivos tácitos são caracterizados, portanto, por ações independentes de um agente, ainda que consciente da estratégia de seus competidores. A empresa adota uma estratégica lógica em busca de maior lucratividade. Exemplos de comportamentos colusivos tácitos verificam-se no dia a dia das empresas participantes de mercados oligopolistas. O curto período de tempo entre os anúncios de reajuste e o semelhante nível percentual de aumento anunciado, tendo-se em vista um mercado oligopolista, pode sugerir reconhecimento das estratégias dominantes das empresas concorrentes no mercado. Não se pode perder de vista que referidas empresas agem dentro da legalidade do sistema concorrencial brasileiro ao pautarem suas decisões de forma independente, ainda que levem em conta, para referida decisão, a "provável" estratégia de seus concorrentes. Quisessem as autoridades concorrenciais proceder à investigação do nível de preços praticado aos consumidores, entrariam em seara delicada e de difícil comprovação econômica e justificação legal, pois arbitrar-se o conceito de lucro excessivo é poder ainda não exercido pelas autoridades concorrenciais brasileiras. Quisessem, por outro lado, investigar coordenação expressa ou cartel, evidências acerca de comportamento acertado não independente das empresas deveria ser trazido à baila. Assim, diante das limitações legais e do tênue liame existente entre a proteção da defesa concorrencial e os direitos constitucionais à propriedade e à exploração de atividade comercial, evidencia-se a inexistência de controle repressivo direcionado à coordenação tácita entre concorrentes quando da verificação de prejuízos ao sistema concorrencial. A alternativa que se tem verificado plausível e intensamente estimulada, principalmente na Comunidade Europeia, é o controle preventivo de fusões tendentes a criar estruturas oligopolistas facilitadoras de coordenação ou cujos incentivos ao arrefecimento da concorrência possam ser verificados. Assim, remédios estruturais ou comportamentais poderiam ser impostos como condição de aprovação de atos de concentração, não somente pelo perigo do exercício do poder unilateral de mercado, mas também pela possibilidade de facilitação da coordenação entre concorrentes.
} 
Dentre os diversos conceitos doutrinariamente admitidos, entende-se aqui por poder de mercado "a habilidade do vendedor de elevar e sustentar um aumento de preço sem perder muitas vendas que o faça desistir de seu comportamento". ${ }^{142}$

Da mesma forma, é também entendido no Velho Continente como:

uma posição de poder econômico de que goza determinada empresa e que lhe permite evitar uma concorrência efetiva em determinado mercado ao dar-lhe o poder de ter uma conduta, em larga medida, independente dos seus concorrentes, dos seus clientes e mesmo dos consumidores. ${ }^{143}$

Finalmente, e ainda no intuito de apresentar as acepções da expressão mais usualmente defendidas, cabe remissão à doutrina nacional reconhecida:

[a] posição dominante implica sujeição (seja dos concorrentes, seja de agentes econômicos atuantes em outros mercados, seja dos consumidores) àquele que o detém. Ao revés, implica independência, absoluta liberdade de agir sem considerar a existência ou o comportamento de outros sujeitos. ${ }^{144}$

Em geral, reconhece a doutrina tradicionalista situação de poder de mercado quando uma empresa tem a capacidade, unilateralmente, de restringir produção e elevar preços acima dos níveis de concorrência, independentemente da atuação de seus concorrentes ou clientes. Esta situação, contudo, não representa uma solução Pareto-ótima e, portanto, não traz resultado eficiente. Isso porque se reconhece que, em situações de mercados monopolistas ou oligopolistas, não há garantias de que consumidores serão beneficiados com custos menores e, consequentemente, preços mais em conta.

A Portaria Conjunta SEAE/SDE n. 50, de $1^{\circ}$ de agosto de 2001, que editou o Guia Para Análise Econômica e Atos de Concentração Horizontal, traz definição e considerações para que se dê o exercício de um poder de mercado. Tal exercício:

consiste no ato de uma empresa unilateralmente, ou de um grupo de empresas coordenadamente, aumentar os preços (ou reduzir quantidades), diminuir a qualidade ou a variedade dos produtos ou serviços, ou ainda, reduzir o ritmo de inovações com relação aos níveis que vigorariam sob condições de concorrência

142 “(...) [market Power is] the seller's ability to raise and sustain a price increase without losing so many sales that it must rescind the increase" (SULLIVAN, Lawrence A.; GRIMES, Warren S. The Law of Antitrust. An Integrated Handbook, cit., p. 22).

${ }^{143}$ Comunicado da Comissão. Orientação sobre as prioridades da Comissão na aplicação do artigo 82 do Tratado CE a comportamentos de exclusão abusivos por parte de empresas em posição dominante (OJ [2009] C 45/7).

${ }^{144}$ FORGIONI, Paula A. Os Fundamentos do Antitruste, cit., p. 317. 
irrestrita, por um período razoável de tempo, com a finalidade de aumentar seus lucros.

Ainda segundo o guia, uma vez definido o mercado relevante, pressupõe-se que uma empresa controla uma parcela substancial desse mercado quando for capaz de, ao restringir as quantidades que oferta, provocar variações nos preços vigentes por um período razoável de tempo. Neste sentido pondera o guia que:

O controle de uma parcela substancial de mercado é uma condição necessária, mas não suficiente, para que a nova empresa formada exerça o poder de mercado de que desfruta. Adicionalmente, é necessário que existam, no mercado, elementos que tornem lucrativa a restrição das quantidades ofertadas. Se não for verificada essa condição, a adoção de tais condutas não será economicamente atrativa e a empresa, ainda que possa desviar suas condutas de seus níveis competitivos, decidirá não fazê-lo.

Alta participação de mercado não necessariamente refletirá poder de mercado. Uma análise da participação de mercado de um vendedor é o ponto inicial para uma análise de poder de mercado, mas diversos outros fatores devem ser considerados para se concluir acerca da existência desse poder. Ao extremo, podemos considerar que altas participações de mercado - a se discutirem tais níveis, que variam de jurisdição a jurisdição - trazem presunção iuris tantum da existência de poder de mercado, indispensável, portanto, que para a reversão da presunção verificada demonstre existência de fatores de pressão competitiva na estrutura dinâmica do mercado.

O Tribunal de Justiça Europeu tem decidido, desde AKZO v Commission ${ }^{145}$, que uma participação de mercado de $50 \%$ poderia ser considerada bastante elevada para que, na ausência de circunstâncias excepcionais indicando o contrário, um agente econômico viesse a ser presumido dominante, e portanto carregue o ônus de reversão de tal presunção. Não obstante, a Comissão não trouxe em seu documento intitulado "Orientação sobre as prioridades da Comissão na aplicação do artigo 82 do Tratado CE a comportamentos de exclusão abusivos por parte de empresas em posição dominante"146 a fixação do referido percentual para fins de presunção da posição dominante. Considera o documento, por outro lado, que a experiência da Comissão sugere, em participações inferiores a $40 \%$ no mercado relevante, pouca probabilidade de existência de posição dominante, podendo contudo

\footnotetext{
${ }^{145}$ Case C-62/86 [1991] ECRI_3359, [1993] 5 CMLR 215.
}

146 OJ 2009/C 45/02. 
existir casos específicos em que os concorrentes não tenham capacidade de pressionar de forma eficaz a conduta da empresa dominante. ${ }^{147}$

Tratou o referido guia, contudo, de apoiar-se na jurisprudência Europeia, a fim de prever que a posição dominante não é, por si só, ilegal e uma empresa nessa situação teria o direito de concorrer no mérito, observada contudo "uma especial responsabilidade de não permitir que a sua conduta obste a uma concorrência efectiva e não falseada no mercado interno". 148

Outra discussão surgida na Europa se refere a situações de superdominância, muito próximas a situações de monopólio, em que abusos se tornam mais prováveis de acontecer. A ideia, mais explorada adiante, viria no sentido de que as obrigações impostas a agentes dominantes se tornariam mais onerosas dependendo das circunstâncias especiais do caso.

Nos Estados Unidos, não obstante os tribunais tenham elaborado diversas definições de poder de mercado, ao longo dos anos tem sido ao menos reconhecida a importância do poder que o vendedor teria sobre os preços praticados, restando esse conceito muito atrelado à elasticidade da demanda. Não obstante esta permaneça no centro do tratamento dispensado pela Suprema Corte ao poder de mercado, os esforços para sua definição permanecem um trabalho em evolução. ${ }^{149}$

No que tange à legislação brasileira, vale mencionar que a Lei n. 8.884/94, que vigorou até o dia 28 de maio de 2012 , previa em seu artigo $20, \S 3^{\circ}$, que a posição dominante seria presumida quando a empresa ou grupo de empresas controlasse ao menos $20 \%$ de um mercado relevante, podendo esse percentual ser alterado pelo CADE para setores específicos da economia. A nova lei, por sua vez, alterou alguns parâmetros para estabelecer, em seu artigo $36, \S 2^{\circ}$, que a posição dominante se presume sempre que uma empresa ou grupo de empresas for capaz de alterar unilateral ou coordenadamente as condições de mercado ou quando controlar $20 \%$ ou mais do mercado relevante, podendo este percentual ser alterado pelo CADE para setores específicos da economia. Os efeitos da referida alteração serão discutidos adiante.

Fatores de pressão ou constrição competitiva, portanto, instrumentos de análise aptos a reconhecer efetivo poder de mercado a um agente econômico, seriam aqueles tendentes a reduzir os lucros esperados que tal agente poderia auferir por tomar alguma

\footnotetext{
${ }^{147}$ OJ 2009/C 45/02, § 14.

${ }^{148}$ OJ 2009/C 45/02, § 1 .

${ }^{149}$ SULLIVAN, Lawrence A.; GRIMES, Warren S. The Law of Antitrust. An Integrated Handbook, cit., p. $22-26$.
} 
medida que possa prejudicar consumidores. ${ }^{150}$ Assim, caso uma empresa $A$ venha a aumentar o preço de seus produtos $x$, é possível que venha a auferir menor lucro como resultado da diminuição de suas vendas, por diversas razões. Essas razões seriam os fatores de pressão a que fazemos referência.

As Orientações sobre a aplicação do artigo 82 do Tratado $C E$ sugerem que a análise acerca da existência de posição dominante deverá levar em consideração a estrutura concorrencial do mercado e, nomeadamente, os fatores de pressão resultantes dos fornecimentos de concorrentes atuais e da sua posição no mercado; os fatores de pressão resultantes de um risco crível de uma futura expansão dos atuais concorrentes ou de entrada de concorrentes potenciais, e finalmente os fatores de pressão resultantes da capacidade de negociação dos clientes da empresa.

Alguns desses fatores poderiam ser descritos pela opção do consumidor, diante de tal hipotético aumento de preços, em desviar sua demanda para produtos alternativos, adquirir produtos de outros agentes econômicos que eventualmente viessem a adaptar sua linha de produção ou mesmo de adquirir produtos de outros agentes que venham a entrar no mercado em decorrência das oportunidades criadas. Entre tais fatores temos, primeiramente, a existência de produtos reputados substituíveis pelo consumidor. Assim, diante de um aumento significativo e não transitório de preços, o consumidor poderia optar por adquirir menor quantidade do produto ou mesmo passar a adquirir outros produtos. No caso, por exemplo, de um aumento de preços da marca de refrigerantes Coca-Cola, o consumidor poderia optar por adquirir outra marca que, segundo sua percepção, possua características semelhantes, como Pepsi. Poderia ainda optar por adquirir outros tipos de bebidas, como os sucos de caixinha, ou mesmo aumentar seu consumo de água gaseificada. $^{151}$

\footnotetext{
${ }^{150}$ EVANS, David. Lightening Up on Market Definition, cit.

${ }^{151}$ Modelos econométricos como a elasticidade própria da demanda serviriam para determinar o quanto a demanda restaria alterada em termos de quantidade com um aumento de preço de $1 \%$. Quanto maior a elasticidade deste preço, maior seria a predisposição do consumidor em reduzir seu consumo diante de um aumento de preço, pelas diversas razões apontadas acima. Ainda poderiam se utilizar modelos de elasticidade cruzada de preços que, de forma semelhante, visam mensurar a alteração da demanda do produto $x$, em termos de quantidade, diante de um aumento de preço de $1 \%$ de outro produto $y$. Diante de uma elasticidade cruzada de preços positivo, concluir-se-ia que os produtos seriam substitutos. Caso, contudo, tal elasticidade de preços restasse negativa, os produtos deveriam ser reputados complementares. Devemos ainda verificar, diante de uma estratégia de majoração de preço do produto $x$ pelo seu agente econômico, se seus concorrentes: (i) tenderiam a aumentar suas respectivas produções - de produtos em tese substituíveis - a fim de capturar oportunidades de renda adicional que o mercado lhes oferece; (ii) tenderiam a aumentar seus preços para acompanhar o aumento de preço do produto $x$ - assumindo um paralelismo consciente isento de qualquer tentativa concertada - ou ainda (iii) tenderiam a reposicionar seus produtos como resultado do aumento - no sentido de mudar sua estratégia comercial para criação de diferente percepção no consumidor. Da mesma forma, caso o preço de um produto $x$ sofra majoração, oportunidades de mercado surgem para
} 
Em tempo, é de se notar que eventuais estratégias de agentes econômicos para majoração de preços de determinados produtos poderia ainda impactar produtos complementares que viessem a ofertar ao mercado. Um exemplo seriam as impressoras e seus respectivos cartuchos - um eventual aumento nos preços dos cartuchos pode impactar na quantidade de impressoras vendidas ao mercado. Aqui assumimos que o consumidor considera o pacote de produtos na sua opção consciente de aquisição.

Efeitos de rede indiretos, na medida em que o número de usuários de um determinado produto pode aumentar o valor de outro produto, devem ainda ser identificados em certas situações e mercados, em especial nos mercados envolvendo tecnologia. A existência destes efeitos foi reconhecida, por exemplo, no caso Microsoft decidido pela Comissão Europeia. ${ }^{152} \mathrm{O}$ mesmo se poderia dizer sobre os mercado multiplataformas, na medida em que estes dependeriam da interconexão entre diferentes grupos de consumidores independentes. ${ }^{153}$ Tais temas são tratados de forma mais detida adiante.

Ainda, para verificação de que determinada empresa de fato possui poder de mercado, deve-se avaliar quão independente são os agentes econômicos com relação ao líder do mercado, quão forte seriam seus incentivos para adquirir participação de mercado dos seus concorrentes e se teriam possibilidades de fazê-lo. Desenvolvimentos recentes sugerem o uso de modelos estruturais mais ricos e consideração de evidências que sugiram um resultado de equilíbrio. ${ }^{154}$

Poder de compra é também um dos fatores de pressão competitiva no mercado, ou ainda seu efeito reflexo, conhecido como poder compensatório. O poder de compra seria nada mais do que o poder de mercado exercido no mercado a montante. Assim, um comprador teria poder de compra, ou poder de monopsônio, quando fosse capaz de exercer

\footnotetext{
aqueles agentes econômicos que sejam capazes de adaptar suas linhas de produção para ofertar produtos que venham a ser reputados pelos consumidores como produtos substituíveis ao produto $x$. Os fatores que apresentariam estímulos aos agentes econômicos para efetivamente investirem na adaptação de suas linhas de produção seriam, em termos econômicos, principalmente, a existência de custos irrecuperáveis, ou ainda outros tipos de barreiras à entrada que pudessem ser verificadas no mercado em questão, como economias de escala e escopo, direitos de propriedade intelectual ou barreiras regulatórias. O mesmo se poderia dizer acerca de nova entrada de um agente econômico.

152 Case COMP/C-3/37.792 - Microsoft: "Existem alguns obstáculos à entrada no mercado dos sistemas operativos de servidores de grupos de trabalho. Em especial, quanto mais fácil é encontrar técnicos especializados em administrar um determinado sistema operativo, mais os clientes tendem a comprar esse sistema operativo de servidores de grupos de trabalho. Por outro lado, porém, quanto mais popular for um sistema operativo de servidores de grupos de trabalho entre os clientes, mais fácil se torna para os técnicos adquirirem (e desejarem adquirir) especialização relativa a esse produto. Este mecanismo pode ser formalizado de uma perspectiva económica em termos de efeitos de rede."

${ }^{153}$ EVANS, David. Lightening Up on Market Definition, cit.

${ }^{154}$ Idem, ibidem, p. 10.
} 
pressão competitiva nos seus fornecedores. Não se pretende aqui discutir os malefícios que podem ser perpetuados pelo exercício deste poder de compra, capaz de reduzir o bem-estar social direto ou indireto do consumidor, ou mesmo o positivo balanceamento que poderia gerar no combate ao poder de mercado eventualmente exercido por seus fornecedores. Pretende-se, tão somente, reconhecer a devida importância à tese do poder de compra e do poder compensatório como fatores de exercício de pressão concorrencial muitas vezes eficiente.

Similarmente, entrantes em potencial são, por vezes, considerados no âmbito da definição dos mercados relevantes, outras vezes considerados como fatores de pressão competitiva. Assim, agentes rivais não necessariamente precisam estar presentes no mercado para exercerem efeito no grau de concorrência. A ameaça crível de entrada, em determinadas circunstâncias, pode disciplinar o comportamento de agentes econômicos que possam exercer poder de monopólio. Contudo, as autoridades ponderam que a possibilidade de entrada no mercado relevante deve aliviar preocupações sobre efeitos anticompetitivos somente se tal entrada seja capaz de deter ou compensar quaisquer efeitos deletérios, de forma que a operação não prejudique consumidores.

Uma situação de indiferença e independência de determinada empresa ou grupo com relação aos demais agentes do mercado pode ainda surgir da sua maior disponibilidade de recursos ("deep pocket"). Aqui pressupomos a facilidade de captação ou disponibilização de recursos significativos que permita a uma empresa não somente impor seu poder econômico em determinado mercado, mas ainda atuar em diversos mercados com o propósito de impulsionar atividades ou produtos paralelos ou complementares. Também merece destaque eventual capacidade ociosa do agente econômico, que lhe pode proporcionar rápida resposta a um aumento na demanda, disciplinando a entrada de novos agentes econômicos. Por fim, caberia citar o nível de verticalização de uma empresa ou grupo econômico, as vantagens tecnológicas que podem colocar um agente em posição de independência, o grau de crescimento do setor econômico envolvido e a sazonalidade de elevadas participações de mercado, fatores a se considerar na avaliação da dinâmica do mercado e dos fatores de constrição concorrencial. ${ }^{155}$

O Guia para análise econômica de atos de concentração horizontal dispõe ainda sobre as variáveis que afetam a probabilidade de exercício de poder de mercado, quais sejam as importações, a entrada, a efetividade da rivalidade, e outros fatores que favorecem

${ }^{155}$ FORGIONI, Paula A. Os Fundamentos do Antitruste, cit., p. 342-345. 
a coordenação de decisões. Vai ainda mais além, dispondo que as autoridades deverão deduzir a inexistência de probabilidade do exercício unilateral do poder de mercado quando as importações forem um remédio efetivo contra este exercício, quando a entrada for "provável, tempestiva e suficiente"; ou ainda quando a rivalidade entre as empresas existentes no mercado for efetiva.

Por outro lado, sugere o guia que, em cenário de elevada concentração de mercado e ausentes tais condições listadas, deverá se concluir pela existência de probabilidade de exercício de poder de mercado unilateral, ou coordenado, caso existam ainda no mercado outros fatores que favoreçam a coordenação de decisões.

As considerações acima se fazem de vital importância ao tema na medida em que a avaliação da probabilidade de poder de mercado por parte de agente econômico é tarefa inicial e indispensável para avaliação dos efeitos de determinada conduta. Verificados determinados parâmetros, opera-se ainda uma presunção deste poder.

O correto entendimento de todos os elementos necessários para a análise detida da condição de posição dominante de um agente econômico, portanto, servirá de roteiro para que empresas presumidamente detentoras de participação de mercado ensejadora da presunção legal possam refutá-la, demonstrando que os elementos presentes na dinâmica concorrencial do mercado não lhe permitem o imputado exercício abusivo. Sem prova de, ou refutada a presunção, não se cogita da aplicação da responsabilidade especial a este agente e não se colaciona a procedimentos investigativos elemento essencial da condição da ação, segundo a teoria do abuso de poder de mercado.

\subsection{Temas Relevantes da Nova Economia}

A disciplina do poder de mercado dos agentes econômicos e dos limites da sua atuação dentro da legalidade das normas concorrenciais merece profunda reflexão, dadas as complexidades envolvidas, as quais propomos trazer a debate na presente tese. Vale, contudo, adicionar, a esta implexa análise, temas contemporâneos que muitas vezes são capazes de alterar parâmetros da análise, ou no mínimo requerem instrumentos adicionais de avaliação.

Neste sentido, vale frisar que a nova economia a que se disciplinam as relações comerciais entre agentes econômicos nas mais diversas partes do globo tem sido intensamente marcada por quatro principais fatores: mudanças tecnológicas, globalização, 
poder dos mercados e mutação cada vez mais rápida das atividades econômicas. ${ }^{156}$ Isto tudo:

vai conduzir a uma maior importância de bens e serviços baseados no conhecimento, com custos fixos elevados e custos marginais reduzidos, por vezes insignificantes. As consequências para o direito da concorrência são significativas. Alguns mercados tendem para estruturas monopolistas por uma força aparentemente irresistível, apesar de não terem qualquer semelhança com os monopólios naturais herdados dos séculos XIX e XX. ${ }^{157}$

Assim, constatamos que mercados que envolvem inovação tecnológica acentuada têm merecido cada vez mais atenção por parte das autoridades de defesa da concorrência, bem como das suas respectivas autoridades regulatórias. A própria teoria econômica tem se ocupado, também, em refletir acerca dos temas envolvidos nestes mercados.

\subsubsection{Externalidades de Rede e Efeitos Lock-in}

Dentre os temas de relevância, devemos tratar da análise de efeitos externos de rede, ou "network externalities", que implicam que efeitos positivos à qualidade do produto resultam diretamente do número de participantes na rede. Em outras palavras, quanto mais ampla a rede de usuários e, portanto, a conexão entre estes usuários, maior será o valor desta rede e de seu produto.

Neste sentido, Katz e Shapiro ${ }^{158}$ distinguem dois tipos de externalidades: redes de comunicação e redes virtuais. As primeiras se caracterizam pela presença dos efeitos de rede propriamente ditos, enquanto as segundas - identificadas como o paradigma softwarehardware - dariam lugar a um "positive-feedback effect", análogo aos efeitos de rede. Assim, o paradigma software-hardware seria um problema típico de bens complementares, que implicam que ao adquirir um computador o utilizador terá de ponderar qual será a escolha de outros utilizadores informáticos, pois, quanto maior o número de compradores de um determinado sistema informático, maior será a variedade e quantidade de programas para utilização neste sistema. Assim, reconhece-se que o sucesso de um nível da cadeia gera benefícios recíprocos entre seus produtos complementares, alimentando desta forma

\footnotetext{
${ }^{156}$ SUMMERS, Lawrence H. Competition Policy in the New Economy. Antitrust Law Journal, vol. 69, n. 1, 2001. p. 353.

${ }^{157}$ MOURA E SILVA, Miguel . O Abuso de Posição Dominante na Nova Economia, cit., p. 18.

158 Vide KATZ, Michael L.; SHAPIRO, Carl. Network Externalities, Competition and Compatibility.
} American Economy Review, vol. 75, n. 3, p. 424. 1985. 
um círculo vicioso. Ainda, identificam efeitos externos a assistência técnica para bens duradouros, assimilados na categoria do paradigma software-hardware.

Questão de relevância seria avaliarmos ainda se os efeitos de rede constituem uma falha de mercado, a ser tratada sob tal prisma. Neste sentido, Liebowits e Margolis entendem que efeitos de rede não se traduzem necessariamente na existência de externalidades enquanto falhas de mercado. Verificam que os principais problemas na análise são, por um lado, a definição dos efeitos de rede como efeitos externos ou externalidades no sentido de falhas de mercado e, por outro, a correção dos pressupostos de que partem Katz e Shapiro quanto à analogia entre redes físicas e virtuais. ${ }^{159}$

Devemos notar, contudo, que perante um efeito externo positivo, os mecanismos normais de mercado não permitiriam um volume ótimo desta atividade, uma vez que os responsáveis por ela não interiorizam os benefícios resultantes, os quais irão favorecer outros agentes. Na medida em que a afetação de recursos pode ser melhorada, justifica-se intervenção tendente a encorajar aumento no nível de atividade que gera efeitos positivos.

Em muitos casos, o aumento do número de utilizadores da rede virtual gera efeitos de redução de custos, permitindo economias de escala. Neste sentido vem a crítica de Liebowitz, de que não se tratariam de efeitos indiretos de rede, mas sim de situações normais de mercado, com a realização de economias de escalas. A dificuldade estaria em estabelecer-se um nexo causal diante de eventual queda de preços provocada por aumento no número de utilizadores; seria este o resultado de efeitos positivos externos ou de economias de escala?

Shapiro defende que a concorrência nestes mercados deve ser vista como uma concorrência entre bens complementares, existindo três fatores de diferenciação com relação a produtos individuais: (i) papel das expectativas com relação ao futuro sucesso do sistema; (ii) problemas de coordenação entre os produtores de bens complementares e com os próprios consumidores; e (iii) compatibilidade.

Assim, um primeiro problema constatado seria que a opção dos fabricantes e consumidores por um sistema tenderia a direcionar o mercado, fato que implicaria controle por uma empresa desse mercado e consequente poder de monopólio ou dominância desta empresa - no presente caso se cogitam da harmonização de sistemas verificados em diversos mercados relevantes, criando-se padrões. Aqui caberia uma verificação acerca de eventuais meios ilícitos que possam ter sido utilizados para provocar a inclinação do

159 LIEBOWITS, Stan J.; MARGOLIS, Stephen. Network Externality: An Uncommon Tragedy. J. Econ. Persp., vol. 8, n. 2, p. 133-135, 1994. 
mercado. Por sua vez, se desenvolvido por diversas empresas, possivelmente serão verificados problemas de colaboração entre concorrentes para adoção de padrões com compartilhamento de lucros - sistema ótimo - ou adaptação dos produtos de uma empresa para a outra - o que poderia ser barrado por direitos de propriedade intelectual -

utilizando-se eventualmente de engenharia reversa para fins de compatibilidade e interoperabilidade.

Um segundo problema verificado seriam efeitos de lock-in ou path dependency. Aqui nos referimos à escolha inicial do consumidor por um primeiro sistema e que o torna dependente daquele em razão dos altos custos de troca, ficando preso a um sistema por vezes menos eficiente.

\subsubsection{Direitos de Propriedade Intelectual}

Outras discussões verificadas nos mercados de inovações geralmente tangenciam questões inerentes aos direitos de propriedade intelectual. Vale recordar que as normas de propriedade intelectual possuem como principal objetivo a busca por um equilíbrio adequado entre o grau de proteção necessário para incentivar inovações socialmente úteis, por um lado, e a garantia da disseminação e utilização ótima dessas inovações. Para tanto, salvaguardas a certa margem de concorrência geralmente são aceitas, devendo ainda o direito da concorrência desempenhar papel de controle quanto à necessidade de se manter um mercado competitivo em matéria de inovação. O grau de interação necessária entre os dois reguladores é muito maior do que geralmente eles próprios reconhecem.

Direitos de propriedade intelectual permitem ao seu titular impedir que terceiros produzam, utilizem ou coloquem no mercado produtos que incorporem o objeto protegido. Não existe, contudo, uma correspondência necessária ou conclusiva entre a concessão de um direito de propriedade intelectual e monopólio econômico ou posição dominante, situação que requer análise da dinâmica concorrencial em questão.

A própria concorrência poderia ter impacto negativo na inovação ao permitir concorrentes de se apropriarem livremente da inovação sem incorrerem nos respectivos custos; é o conhecido problema do caronista ou free-ridding. Assim, os direitos de propriedade intelectual poderiam ser considerados um mecanismo de correção deste tipo reconhecido de falha de mercado. Na opinião de Miguel Moura “[o] conflito entre propriedade intelectual e direito da concorrência poderia, por conseguinte, ser limitado aos 
casos em que "os objetivos dinâmicos do direito intelectual colidem com as finalidades estáticas do direito da concorrência em matéria de afectação de recursos". ${ }^{160}$ Assim, reconhece-se necessário trade-off entre as acepções estática e dinâmica da eficiência econômica.

Os Tribunais norte-americanos parecem demonstrar mais afinco em introduzir preocupações regulatórias a propósito da razoabilidade da recompensa obtida pelo titular desse direito. Aqui estaria uma das diferenças entre o tratamento dado pelo direito de concorrência aos direitos de propriedade tradicionais e intelectuais. Para os primeiros, há ideia geral de que os tribunais não devem determinar a razoabilidade de preços. ${ }^{161} \mathrm{~A}$ possibilidade de auferir lucro de monopólio é um incentivo que não pode ser anulado, pois tendo sido incitado a concorrer, o concorrente bem-sucedido não deve ser prejudicado quando atinge o sucesso. Conflito mitigado segundo um entendimento dinâmico da natureza da concorrência.

O direito concorrencial pode ser incitado a corrigir falhas regulatórias ou deficiência no sistema de propriedade intelectual que impeçam efetiva apropriação dos resultados de uma inovação. Schumpeter defende que a inovação tecnológica é estimulada pela existência de grandes empresas - o que pressupõe uma estrutura de mercado oligopolista ou mesmo monopólio - e desincentivada pela concorrência devido à alegada capacidade das grandes empresas de melhor suportarem os custos e riscos da atividade de investigação e desenvolvimento. Na sequência, a análise de Schumpeter e seus seguidores acerca dos incentivos para a inovação é devota às ideias dos direitos de propriedade intelectual. Monopolistas teriam incentivos a não permitirem aos seus concorrentes se beneficiarem de sua inovação sem suportar custos de pesquisa e desenvolvimento, muitas vezes através da adoção de práticas monopolísticas. ${ }^{162}$

\footnotetext{
${ }^{160} \mathrm{Em}$ tempo, o direito concorrencial poderia impor preço igual a custo marginal de forma a reproduzir condições de mercado numa estrutura de concorrência perfeita em casos em que o custo marginal de transmissão de informações tecnológicas ao licenciado fosse igual a 0 . Contudo, o entendimento por detrás dos direitos de propriedade intelectual o considera como instrumento de apropriação de lucros supranormais (visão estática) justificáveis como recompensa à atividade de inovação - premissa essencial da teoria da recompensa. Há autores que defendem o lucro de monopólio, como Demaret e Bowman (BOWMAN, Ward. Tying Arrangements; Patent and Antitrust Law - A Legal and Economic appraisal. Chicago: University of Chicago Press, 1973; DEMARET, Paul. Patents, Territorial Restriction, and ECC Law. Weinheim: Verlag Chemie, 1978. v. 2). Assim, em princípio, na linha de entendimento de Miguel Moura, todas as práticas tendentes a assegurar a maximização dos lucros no mercado coberto pelo direito exclusivo, como, por exemplo, a imposição de royalties discriminatórios ou a subordinação das licenças a outros produtos ou serviços, estariam igualmente abrangidas pela proteção conferida pelos direitos de propriedade intelectual. (MOURA E SILVA, Miguel. O Abuso de Posição Dominante na Nova Economia, cit., p. 460).

${ }^{161}$ U.S. v. Aluminium Co. of America et al. (Alcoa).

${ }^{162}$ SCHUMPETER, Joseph A. Capitalism, Socialism and Democracy. 5. ed. Londres: Routledge, 1976. p. 102.
} 
Já Kennet Arrow defende que quanto mais concentrada a indústria, menor o incentivo para sua inovação, pois um monopolista que aufere lucros supranormais tem menos a ganhar com uma inovação que vai reduzir as suas receitas do que uma empresa situada num mercado competitivo no qual não dispõe de poder sobre o preço. As críticas verificadas às teorias de Kenneth incluiriam menção à estrutura de mercado que não afeta a apropriação dos quase rents que resultam da introdução da inovação, o que somente aconteceria se o sistema de proteção aos direitos de propriedade intelectual fosse perfeito; e não consideração se uma empresa de menor porte seria tão eficiente no seu esforço de inovação quanto uma de médio porte. ${ }^{163}$

A existência de alguma concorrência aumentaria o estímulo à inovação. Neste sentido, duopólios seriam melhores que situações de monopólios. Porém, as análises levadas a efeito seriam inconclusivas acerca da estrutura de mercado e seus estímulos à inovação.

Circunstâncias especiais surgem ainda em casos de recusa de fornecimento envolvendo direitos de propriedade intelectual. Tais debates têm merecido o palco principal de artigos acadêmicos, congressos e tribunais, sendo fervorosas as defesas dos diversos posicionamentos. Nestes casos, vem à tona o dever de equilibrar o incentivo para inovar, protegido pelo direito de propriedade intelectual, através da efetiva promoção da concorrência no mercado.

A maneira pela qual esta tenha sido tratada no âmbito do direito europeu, em linha com outras jurisdições, é que não seria a posse, mas o abuso, da propriedade intelectual, que atrai a aplicação da norma. Se o direito é exercido de forma a prosseguir uma finalidade manifestamente contrária aos objetivos do artigo 102, não estaria mais sendo exercido de acordo com a sua função essencial e o direito comunitário deveria prevalecer sobre qualquer uso da propriedade intelectual. ${ }^{164}$

\subsubsection{Convergência Tecnológica}

Um tema que também merece destaque seria convergência tecnológica. $\mathrm{O}$ desenvolvimento tecnológico de produtos e sistemas tem permitido, cada vez mais e de

\footnotetext{
${ }^{163}$ SCHERER, Ross. Industrial Market Structure and Economic Performance. 3. ed. Boston: Houghton Mifflin, 1990. p. 630.

${ }^{164}$ MCMAHON, Kathryn. Interoperability: Indispensability and Special Responsibility in High Technology Markets. In High Technology Markets. Tulane Journal of Technology \& Intellectual Property. Vol. 9, 2007. p. 6-7. Cópia eletrônica disponível em: <http://ssrn.com/abstract=1523146>.
} 
forma mais intensa, a integração de usuários destes produtos e sistemas, com economias de escopo crescentes. Estas mudanças geram, assim, alteração da estrutura dinâmica dos mercados, tornando obsoletas certas tecnologias ou produtos, criando outros, e muitas vezes integrando produtos existentes.

O desenvolvimento da telefonia celular, por exemplo, pode ser reputada como uma quebra de parâmetros que afetou profundamente a dinâmica dos mercados de telecomunicações. Onde antes se colocavam intensas barreiras à entrada de novos concorrentes, na medida em que a duplicação das redes de telecomunicação não era considerada economicamente viável, na esteira da teoria das utilidades essenciais, passouse a contar com novos concorrentes para um serviço substituível sob o ponto de vista da demanda do consumidor, e que passaram a ingressar no mercado com nova tecnologia que dispensava investimentos com custos irrecuperáveis acentuados. A regulação passa a desenvolver papel fundamental de introdução e fomento à concorrência no mercado, uma vez alterados os parâmetros de mercado relevante e, consequentemente, das pressões competitivas exercidas até o desenvolvimento daquela nova tecnologia.

Outro exemplo que podemos trazer à baila seria a disseminação das redes de assinatura de programação televisiva a cabo e que passaram a contar com a concorrência da tecnologia DTH via satélite, serviços igualmente reputados substituíveis pelo consumidor, apesar de fundados em tecnologias diversas.

Discuta-se ainda a abertura e integração dos mercados de telefonia, provimento de internet e assinatura de programação televisiva. Assim, permitir-se que empresas de telefonia concorram com provedores de internet, que concorrem ainda com provedores de programação televisiva, tende a fomentar a concorrência e permitir a absorção de economias de escala e escopo.

Faz-se inevitável, portanto, que autoridades concorrenciais mantenham-se sempre alinhadas e cooperativas, de forma ativa, às autoridades regulatórias, promovendo discussão constante acerca dos mecanismos que podem ser utilizados para que se permita a introdução de maior concorrência em determinado setor. Igualmente, autoridades de defesa da concorrência devem estar sempre antenadas à existência de novas tecnologias e o papel por elas desempenhado na alteração das estruturas dinâmicas dos mercados, quer seja segundo um contexto de análise preventiva, quer seja no contexto de uma análise repressiva. 


\section{CAPÍTULO 3 NOVO SISTEMA JUS-CONCORRENCIAL BRASILEIRO}

\subsection{Garantias Constitucionais Jus-Concorrenciais do Estado e dos Administrados}

Em conformidade com o direito democrático, o Estado deve estar a serviço de políticas econômicas constitucionalmente adotadas visando a implementação de direitos fundamentais, conforme se depreende da leitura sistematizada dos artigos $1^{\circ}, 3^{\circ}, 5^{\circ}, 6^{\circ} \mathrm{e}$ 170, da Constituição Federal ("CF").

Em face disso, o Estado atua no domínio econômico de forma direta, por meio de sociedades estatais sob regime de monopólio legal, conforme disciplina do artigo 177 da $\mathrm{CF},{ }^{165}$ e quando necessário aos imperativos de segurança nacional ou relevante interesse coletivo. Esta atuação deve se dar em regime de exceção, contudo, sendo a regra da livre iniciativa disciplinada pelo próprio Estado na qualidade de agente normativo e regulador da atividade econômica, exercendo as funções de fiscalização, incentivo e planejamento, conforme disposto no artigo 174 da CF. Esta intervenção indireta pode se dar através da normatização ou da regulação da economia, ${ }^{166}$ também denominadas intervenção por indução e intervenção por direção. ${ }^{167}$

$\mathrm{Na}$ forma indireta de atuação estatal, a normatização apresenta-se como a produção de normas, pelo devido processo legal, de transformação da economia, com o objetivo de instrumentalizar a realização das políticas públicas adotadas pela Constituição Federal. A regulação, por sua vez, é a que se coaduna com os princípios da subsidiariedade e eficiência, norteadores do Direito Econômico, e pode ocorrer por meio de fiscalização Estado polícia, como as sanções aplicadas pelo Conselho Administrativo de Defesa Econômica ("CADE") -, incentivo - bancos de desenvolvimento que fomentam investimentos em áreas da economia - e planejamento do Estado no domínio econômico -

\footnotetext{
${ }^{165}$ Segundo o artigo 177 da CF, constituem monopólio da União: (i) a pesquisa e a lavra das jazidas de petróleo e gás natural e outros hidrocarbonetos fluidos; (ii) a refinação do petróleo nacional ou estrangeiro; (iii) a importação e exportação dos produtos e derivados básicos resultantes das atividades citadas em "i" e "ii"; (iv) o transporte marítimo do petróleo bruto de origem nacional ou de derivados básicos de petróleo produzidos no País, bem assim o transporte, por meio de conduto, de petróleo bruto, seus derivados e gás natural de qualquer origem; (v) a pesquisa, a lavra, o enriquecimento, o reprocessamento, a industrialização e o comércio de minérios e minerais nucleares e seus derivados, com exceção dos radioisótopos cuja produção, comercialização e utilização poderão ser autorizadas sob regime de permissão.

${ }^{166}$ FONSECA, João Bosco Leopoldino da. Direito Econômico. 5. ed. Rio de Janeiro: Forense, 2007. p. 272.

${ }^{167}$ GRAU, Eros Roberto. A ordem econômica na Constituição de 1988. 3. ed. São Paulo: Malheiros, 2012. p. 163.
} 
conforme se depreende, em especial, dos artigos 165 e 166 da CF, incluindo o plano plurianual, diretrizes orçamentárias e orçamentos anuais.

Com relação à forma direta de atuação estatal, trata-se de uma situação excepcional, eis que por força dos princípios da livre iniciativa e da propriedade privada, previstos na Carta Constitucional, as atividades de produção de bens e serviços para o mercado devem ser desenvolvidas, prioritariamente, pelos particulares. Assim, a exploração dessas atividades típicas do setor privado é, por vezes, realizada por intermédio de empresas estatais. Devem, contudo, restringir-se às hipóteses de interesse geral previstas na Constituição Federal, em caráter de subsidiariedade, e desde que o mercado não esteja apto a fazê-lo de forma mais adequada.

No entanto, impõe-se advertir que essa aptidão da empresa privada não pode ser inferida da simples existência de particulares operando no setor produtivo ou com possibilidade de nele operar. Ainda que a iniciativa privada esteja presente em determinado mercado, o Estado poderá dele participar desde que, sem a sua participação, sejam desatendidos os imperativos de segurança nacional e o relevante interesse coletivo ${ }^{168}$.

Por essa razão, a problemática acerca dos limites dessa modalidade de intervenção estatal na economia centra-se, em verdade, na definição das situações fáticas que se enquadram nesses dois pressupostos constitucionais, mormente porque ambos apresentam conteúdos indeterminados. Daí, não se afigura possível indicar, a priori, todos os casos que podem ser compreendidos nos conceitos de imperativo da segurança nacional e relevante interesse coletivo, pois tal pretensão encontra limite na natural barreira da linguagem. ${ }^{169}$

Todavia, o legislador infraconstitucional não é totalmente livre para definir o conteúdo desses pressupostos. A legitimação do Estado empresário para atuar na defesa do relevante interesse coletivo está diretamente associada à necessidade de sua intervenção para corrigir as falhas do mercado. ${ }^{170}$ Eventuais situações de crise internacional que possam colocar em risco o desempenho econômico geral da nação, como aponta a recente

\footnotetext{
${ }^{168}$ RIBEIRO, Marcia Carla Pereira. Sociedade de economia mista e empresa privada. Curitiba: Juruá, 1999. p. 115.

${ }^{169}$ Reza a Constituição Federal, no seu artigo 173, que à lei cabe definir as situações que se enquadram nos pressupostos antes referidos. Diante da manifesta impossibilidade de o legislador exaurir todas as hipóteses que demandam a intervenção direta do Estado no mercado, essa legislação não poderá ir além de dispor sobre os critérios gerais para a identificação dos casuísmos passíveis de serem incluídos nos conceitos. O artigo 173, caput, não dispõe sobre a natureza da lei genérica que deve delinear os conceitos de imperativo de segurança nacional e relevante interesse coletivo. Porém, impõe-se a adoção de lei complementar, pois é desta natureza a legislação que delimitará as áreas de atuação das Empresas Públicas e Sociedades de Economia Mista (CF, art. 37, $\mathrm{XIX).}$

${ }^{170}$ CHIRILlO, Eduardo J. Rodríguez. Privatización de la Empresa Pública y Post Privatización: Analysis Jurídico. Buenos Aires: Abeledo-Perrot, 1995. p. 75-76.
} 
crise que se iniciou no mercado de operações financeiras nos Estados Unidos, também poderiam servir, em nosso entender, de justificativa para convocação do Estado a atuar de forma direta na economia, com base no relevante interesse coletivo.

De qualquer modo, é preciso salientar, a atividade de mercado haverá de ser explorada pelo Estado em regime de competição com a iniciativa privada, vedada, assim, a instituição de monopólios estatais, além daqueles constitucionalmente previstos. ${ }^{171} \mathrm{E}$ essa exigência deflui não somente do princípio da livre concorrência, como também da liberdade econômica assegurada a particulares.

No entanto, é evidente a possibilidade de o Estado atuar sem concorrentes, quando, por exemplo, utiliza-se de uma de suas empresas para suprir a ausência de oferta de determinado produto ou serviço pela iniciativa privada. $\mathrm{O}$ que não se pode admitir, na verdade, é que o ente estatal reserve para si a exploração de determinada atividade fora dos parâmetros de reserva constitucional discutidos, impedindo, por via de norma infraconstitucional, a instalação da concorrência nesse setor. ${ }^{172}$

Sob outra perspectiva, podemos ainda estabelecer o nexo entre o Poder Público e o princípio da livre concorrência sob três diferentes ângulos. O primeiro relativo à ação reguladora do Estado que, por meio de mecanismos legislativos - Leis n. 4.771/65, 8.078/90 e 12.529/11 -, intervém para corrigir os desvios praticados pelos agentes econômicos no mercado. O segundo correspondente à ação estatal, a qual busca alcançar, pela via empresarial, o mesmo objetivo. E por fim a perspectiva concernente ao dever que tem o Estado de respeitar o princípio da livre concorrência na sua própria atuação como empresário.

Nos dois primeiros casos o ente estatal age para assegurar o cumprimento da norma constitucional, ao passo que, no último, atua sob o influxo dela. Por conseguinte, pode-se afirmar que, de certo modo, o princípio da livre concorrência se apresenta também como um condicionamento à atuação empresarial do Estado na esfera econômica de mercado, decorrendo daí a impossibilidade de serem o imperativo da segurança nacional e o relevante interesse coletivo atendidos, via de regra, mediante a instituição de empresas estatais que operem em regime de monopólio legal.

Em rápida, porém fundamental retrospectiva histórica, que enseja os fundamentos da atuação estatal, deve-se recordar as teorias liberais que objetivaram o enfraquecimento

${ }^{171}$ COMPARATO, Fábio Konder. Direito público: estudos e pareceres. São Paulo: Editora Saraiva, 1996. p. 146.

${ }^{172}$ Em sentido contrário, admitindo a possibilidade de instituição de monopólios estatais por via de lei, vide GRAU, Eros Roberto. A ordem econômica na Constituição de 1988, cit. 
do Estado e a restrição de sua atuação no campo das liberdades individuais. Tratava-se do período da primeira geração de direitos fundamentais, ou, ainda nas palavras de Ada Pellegrini Grinover: "das liberdades ditas negativas, em que o Estado só tinha o dever de abster-se, para que o cidadão fosse livre de fruir de sua liberdade". ${ }^{173}$

A transição deste estado de liberdade para um estado infringido de preocupações sociais, num segundo momento, promovera uma alteração substancial na concepção do Estado e de suas finalidades:

\begin{abstract}
Nesse quadro, o Estado existe para atender ao bem comum, e consequentemente, satisfazer direitos fundamentais e, em última análise, garantir a igualdade material entre os componentes do corpo social. Surge a segunda geração de direitos fundamentais - a dos direitos econômico-sociais -, complementar à dos direitos de liberdade. ${ }^{174}$
\end{abstract}

Finalmente, levantam-se os direitos de terceira geração, ainda concebidos no curso de um processo indefinido de extensão e ampliação dos direitos inicialmente postulados como individuais. Dentre outros direitos de terceira geração, mencionam-se o direito ao meio ambiente equilibrado, o direito à biodiversidade e o direito ao desenvolvimento. ${ }^{175}$

Desta forma, para que pudesse o Estado atingir os objetivos fundamentais a que se propõe, consagrados segundo a norma fundamental, houve a necessidade de sua organização para incidência sobre a realidade social, transformando-se o estado liberal em estado democrático de direito.

Das considerações teóricas até então traçadas, repise-se que o Direito é indispensável ao mercado, cujo perfil é desenhado especialmente pelos princípios constitucionais. E nesse panorama, "os princípios constitucionais são a forma que primeiramente moldará o mercado", ${ }^{176}$ em cuja perspectiva se destacam os classicamente ligados ao funcionamento deste, a saber: livre iniciativa, livre concorrência, liberdade de contratar, direito de propriedade e proteção do consumidor. Neste sentido reza o artigo 170 da $\mathrm{CF}$ ao dispor que a ordem econômica é fundada na valorização do trabalho humano e na livre iniciativa, tendo por finalidade assegurar a todos existência digna segundo os ditames de justiça social, e observados os princípios da soberania nacional, propriedade privada,

\footnotetext{
${ }^{173}$ GRINOVER, Ada Pellegrini. O controle de políticas públicas pelo Poder Judiciário, p. 110.

${ }^{174}$ Idem, ibidem, p. 110.

${ }^{175}$ BUCCI, Maria Paula Dallari. O Conceito de Política Pública em Direito, cit., p. 3.

${ }^{176}$ FORGIONI, Paula A. A evolução do direito comercial brasileiro: da mercancia ao mercado, cit., p. 204.
} 
função social da propriedade, livre concorrência, defesa do consumidor, defesa do meio ambiente, redução das desigualdades regionais e sociais, busca do pleno emprego e tratamento favorecido para as empresas de pequeno porte.

\subsubsection{Princípios Constitucionais Concorrenciais Consagrados}

Vale breve menção aos princípios mais consagrados na análise antitruste antes de promoção de um debate sobre suas respectivas formas de interação, não somente entre si mesmos, mas ainda em consideração aos demais princípios elencados no rol do artigo 170 da CF.

Neste sentido, o princípio da livre iniciativa historicamente corporificou o ideal de libertação dos laços das corporações medievais para proporcionar mais espaço ao sistema de mercado que à época começava a se impor. A liberdade de iniciativa traduzia nada mais que o aumento do espaço de atuação privada em face de privilégios concedidos a determinados agentes econômicos. A lógica atual do princípio traz, portanto, arraigado esse cunho histórico, concebendo-se atualmente como garantia aos agentes econômicos de ingresso e permanência no mercado. Vale dizer, assegura-se o acesso às oportunidades de troca, firmando-se para tanto contratos. ${ }^{177}$

Já o princípio da livre concorrência garante a disputa de trocas propriamente ditas, com a respectiva competitividade, sem que para isso sejam subtraídas as oportunidades dos agentes econômicos por terceiros. Resulta dizer que os efeitos ao agente econômico incluem o dever de diminuir o preço e aumentar a qualidade por um lado, com consequente aumento de seu proveito econômico decorrente de provável conquista de mercado e aumento de lucros.

No que se refere ao princípio da liberdade de contratar, constitui garantia da disposição de oportunidades de troca. Assim, tutela-se a disputa pela celebração de um contrato, ao se assumir um princípio derivado do princípio da livre iniciativa. O funcionamento do sistema pressupõe que deva ser possível contratar os agentes econômicos. Nas palavras de Terence Daintith e Gunther Teubner,: "O princípio legal da

\footnotetext{
${ }^{177}$ FORGIONI, Paula A. A evolução do direito comercial brasileiro: da mercancia ao mercado, cit., p.
} 206. 
liberdade contratual e a elaboração de regras do contrato empresarial são pré-requisitos para o desenvolvimento das complexas transações econômicas de mercado". ${ }^{178}$

Por sua vez, como pondera Paula Forgioni acerca do direito de propriedade, além de constituir vetor instrumental da ordem econômica, é direito individual a ser exercido dentro dos ditames da função social. Em sendo objeto das trocas sob a ótica do mercado, constitui um incentivo para maior eficiência da atividade com reflexo em todo sistema, posto que lícita a apropriação por parte do empresário dos resultados do empreendimento. Relevante a limitação apontada para fins de direcionamento da utilização da propriedade, conforme aprofundamento adiante.

Por fim, destaca-se o princípio da proteção do consumidor que assegura a manutenção de possibilidades de troca entre os agentes econômicos. Esse ramo assentou-se com base na premissa de que o consumidor precisava de proteção especial, não podendo subjugar-se ao regramento aplicável aos mercadores em geral. Em especial, a observação acerca da hipossuficiência de uma das partes na relação contratual motivou a criação de um regime especial de regras aplicáveis. E essa proteção significa incrementar o fluxo de relações econômicas que, outrossim, atua em prol do interesse geral do comércio. Portanto, hoje se reconhece o direito da concorrência como atuante de forma mediata nas relações de consumo. Frise-se que "sem consumo não há mercado, pois não há sentido para a produção". ${ }^{179}$

Conforme se depreende da análise acima, o rol de princípios estabelecidos pelo artigo 170 da CF e que deve reger a ordem econômica nacional é relativamente vasto, e a exata medida de sua aplicação incerta: "[a] exata medida em que princípios como 'livre iniciativa' e 'justiça social' bem como 'propriedade privada' e 'função social da propriedade' devem conviver é deixada ao trabalho interpretativo do aplicador do Direito". 180

\footnotetext{
${ }^{178}$ DAINTITH, Terence; TEUBNER, Gunther. Sociological jurisprudence and legal economics: risks and rewards, p. 3. In FORGIONI, Paula A. A evolução do direito comercial brasileiro: da mercancia ao mercado, cit., p. 211.

${ }^{179}$ FORGIONI, Paula A. A evolução do direito comercial brasileiro: da mercancia ao mercado, cit., p. 221.

${ }^{180}$ Idem, ibidem.
} 


\subsubsection{Demais Princípios Constitucionais Aplicáveis}

Assim, traçados os princípios mais consagrados na análise concorrencial, quais sejam a livre iniciativa, livre concorrência, liberdade de contratar, propriedade privada e defesa [mediata] do consumidor, passemos a examinar os demais princípios elencados pela Constituição Federal, de forma agrupada: (i) valorização do trabalho humano com a redução das desigualdades regionais e sociais e busca do pleno emprego; (ii) a defesa do meio ambiente; (iii) tratamento favorecido para as empresas de pequeno porte; e (iv) justiça social com a função social da propriedade.

No que tange primeiramente à valorização do trabalho humano com a redução das desigualdades regionais e sociais e busca do pleno emprego, devemos reconhecer, antes de tudo, o intenso regramento trazido por nossa Norma Fundamental, na forma de direitos e garantias individuais do cidadão. Assim, estabelece o artigo $5^{\circ}$ que "é livre o exercício de qualquer trabalho, ofício ou profissão, atendidas as qualificações profissionais que a lei estabelecer". Da mesma forma, vale mencionar que o artigo $7^{\circ}$ da CF traz ainda, no capítulo dos direitos sociais, previsão acerca dos direitos dos trabalhadores urbanos e rurais.

Interessante notar que a revogada Lei de Concorrência brasileira, Lei n. 8.884/94, trazia em seu artigo 58, que tratava do Compromisso de Desempenho para os interessados em aprovações de atos de concentrações, no tocante à definição dos compromissos de desempenho, que seria levado em consideração o grau de exposição do setor à competição internacional e as alterações no nível de emprego, dentre outras circunstâncias relevantes. Tais referências lastreadas no nível de emprego, contudo, foram excluídas do novo diploma legal editado em 2012.

Aqui reconhecemos, não obstante tratar-se de princípio relativo à ordem econômica consagrado constitucionalmente, que esta tratou de elencar os direitos sociais dos trabalhadores no próprio artigo $7^{\circ}$, os quais indubitavelmente promovem a valorização do trabalho humano e a busca do pleno emprego.

Devemos, contudo, na aplicação do direito concorrencial, cuidar para que o princípio em comento não receba tratamento distorcido por parte das autoridades e do próprio poder judiciário, a exemplo do que se verifica em outros sistemas. Assim, cabe esclarecer que a proteção pretendida pelo legislador abrange a garantia do livre exercício do trabalho, não se devendo permitir quaisquer restrições a tais direitos sem que haja a devida compensação. Por outro lado, questões como manutenção de níveis de emprego, 
especialmente decorrentes de concentrações verificadas no mercado, podem confrontar diretamente com a persecução de níveis de eficiência esperados e justificadores do próprio objetivo concentracionista, não devendo receber consideração na avaliação de sua legitimidade competitiva.

No que tange à redução das desigualdades regionais e sociais, vale dizer que se o direito da concorrência reconhecer, em si, viés redistributivo, estaria atendido, ao menos em parte, o princípio em comento. Na nossa visão, o regramento do exercício do abuso de poder econômico promove, indiretamente, a prevenção ou redução de transferência de renda indesejável do consumidor para os agentes com poder de mercado, reconhecido pelos economistas como peso morto ou "deadweight losses". Assim, não há de se negar o caráter redistributivo que veste a aplicação do direito concorrencial, deixando-se claro que tal objetivo é alcançado de forma indireta, mediata.

Ir além do quanto acima exposto, contudo, na aplicação do direito concorrencial, mais precisamente na disciplina do abuso de poder econômico, reconhecendo o escopo de aplicação direta deste princípio no balanceamento dos fatores em jogo, seria dar trato à questão fora dos existentes e eficientes fóruns de debate apropriados para o tema. Não há justificativa para se tratar, assim, deste tema no âmbito das normas de defesa da concorrência.

A defesa do meio ambiente, enquanto direito de terceira geração e princípio constitucional geral regulador da atividade econômica, também possui foro próprio de debate, não guardando qualquer semelhança ou trazendo qualquer instrumento analítico que corrobore para uma análise concorrencial mais apurada, e não merecendo, portanto, consideração na análise das questões de exercício de poder econômico.

Já com relação ao princípio de tratamento favorecido para as empresas de pequeno porte, poder-se-ia inicialmente levantar questionamento acerca da utilização das normas de defesa da concorrência para promoção das pequenas estruturas econômicas, como verificado nos capítulos anteriores. A se relembrar, tal ênfase foi reconhecida por diversas vezes pelos tribunais norte-americanos na aplicação do antitruste, tendo merecido profundo debate acadêmico até se atingir uma postura de relativo consenso acerca desta insensatez.

E o mesmo deveríamos concluir com relação ao ordenamento pátrio e seu viés concorrencial. Não se verifica sensato qualquer argumento no sentido de se promover ou favorecer empresas de pequeno porte na aplicação da lei concorrencial, além de protegêlas, assim como a quaisquer outros agentes atuantes no mercado, do exercício abusivo de 
poder econômico praticado por detentores deste. E nem parece ser este o viés trazido pela Constituição Federal, ao dispor adiante, em seu artigo 179, aplicação de um tratamento jurídico diferenciado que venha a promover simplificação, redução ou eliminação de suas obrigações administrativas, tributárias, previdenciárias e creditícias.

Mais precisamente com relação ao tratamento constitucional emprestado ao exercício do abuso de poder econômico, notamos o artigo $173, \S 4^{\circ}$, dispondo que "[a] lei reprimirá o abuso do poder econômico que vise à dominação dos mercados, à eliminação da concorrência e ao aumento arbitrário dos lucros". Desta feita, vale notar que, em contrapartida a diplomas constitucionais anteriores, os conceitos de atos de abuso de poder econômico tendentes à "dominação do mercado" e à "eliminação da concorrência" passaram a ser identificados como as locuções centrais dos dois pilares da lei concorrencial brasileira: o controle das condutas e o controle das estruturas. ${ }^{181}$

Segundo Calixto Salomão Filho, é importante ainda notar que "a concentração do dispositivo constitucional na figura do abuso de poder econômico não implica que essa figura seja a única ilícita para a ordem concorrencial", amparando-se neste dispositivo, por exemplo, a regulamentação da concorrência desleal. ${ }^{182}$

Interessante notar, a título de impropriedade praticada pelo legislador constituinte de 1988, que o $\S 4^{\circ}$ encontra-se inserido no âmbito do artigo 173, o qual dispõe sobre a "exploração direta de atividade econômica pelo Estado". O mesmo se diga com relação ao $\S 5^{\circ}$ do artigo 173 que prevê a normatização da responsabilidade individual da pessoa jurídica e seus dirigentes, pelos atos praticados contra a ordem econômica e financeira e contra a economia popular.

Assim, pode-se reconhecer talvez a maior preocupação daquele constituinte em disciplinar situações de abuso praticadas pelo próprio Estado na exploração da atividade econômica. Fato, contudo, é que se encontra assentado o entendimento de que as normas de defesa da concorrência editadas com fundamento no $\S 4^{\circ}$ aplicam-se a toda forma de atuação, de qualquer agente econômico, seja público ou privado, na ordem econômica nacional.

Finalmente, vale mais profunda reflexão o tema acerca da justiça social e função social da propriedade, que será devidamente tratado a seguir.

\footnotetext{
${ }^{181}$ SALOMÃO FILHO, Calixto. Direito Concorrencial - As condutas, cit., p. 108.

${ }^{182}$ Idem, ibidem, p. 107.
} 


\subsection{A Concorrência como Garantia Institucional}

Conforme brevemente discorrido nos capítulos anteriores, para se compreender a extensão do conceito de abuso de poder econômico trazido por nossa norma fundamental, devemos entender a defesa da concorrência como garantia institucional. ${ }^{183}$ Da mesma forma, ilustra Calixto Salomão tratar-se a ordem econômica de norma afirmativa, que demanda a atuação do Estado no sentido de garantir a correta atuação do mercado. Daí caracterizarem-se os direitos de ordem econômica, segundo a doutrina, de direitos fundamentais de segunda geração, direcionados à coletividade.

O mesmo pensamento havia sido aplicado pelo autor à teoria da regulação, colocando-se a indagação se seriam os princípios básicos regulatórios garantias institucionais ou apenas instrumento de política econômica. Naquela ocasião em que abordamos a teoria da regulação restou caracterizado que, caso se tratasse de um instrumento de política econômica, sua aplicação deveria se dar em conjunto com outras políticas públicas. Porém, caso se tratasse de uma garantia institucional, deveríamos reconhecer que tais princípios têm conteúdo mínimo necessário a ser preservado.

Assim, tratar a concorrência de garantia institucional mínima resulta na afirmação deste instituto como valor mínimo a ser perseguido, garantindo a liberdade de escolha e disseminação da informação. E parece ser exatamente isso que a teoria jus-concorrencial persegue, garantindo proteção institucional e regras comportamentais que assegurem uma interação mais justa entre os agentes econômicos. Nas palavras de Calixto Salomão:

Na verdade, a expressão 'abuso de poder econômico' é dotada de muito maior riqueza interpretativa. Sua descoberta, no entanto, só é possível concentrando as atenções sobre a defesa da concorrência como garantia institucional. ${ }^{184}$

Como garantia institucional da correção e equilíbrio da interação econômica dos diversos agentes, a justificativa da regulação passaria a ser a criação de uma igualdade material entre todos os agentes econômicos, para que possam desenvolver suas atividades em iguais condições. Para que se dê uma igualdade material haveria necessidade de uma difusão forçada do conhecimento econômico entre os indivíduos, que só poderia ser assegurada através de uma garantia firme de existência de concorrência. ${ }^{185}$

\footnotetext{
${ }^{183}$ SALOMÃO FILHO, Calixto. Direito Concorrencial - As condutas, cit., p. 108.

${ }^{184}$ Idem, ibidem.

${ }^{185}$ Idem, ibidem, p. 30.
} 
E o mesmo devemos concluir a respeito das normas de defesa da concorrência. Assim, nos quer parecer que a concorrência representaria um fim em si mesmo, muito mais do que um instrumento para se alcançar algo. Ao admiti-la como instrumento, abrimos a possibilidade de atingimento do fim colimado por outros meios, ou instrumentos, que eventualmente poderiam até mesmo prescindir da concorrência. Por outro lado, ao admitila como fim em si mesma, pressupomos os benefícios decorrentes do seu atingimento, já discutidos acima.

A concorrência visaria, portanto, não somente a manutenção, mas ainda a promoção de um ambiente concorrencial que atenda aos princípios legais da ordem econômica estabelecida, regulando-se, de forma a prevenir, o exercício do abuso de poder econômico.

Assim, como garantia institucional que deve ser reconhecida ao direito da concorrência, justifica-se a repressão a qualquer forma de abuso do poder econômico que possa feri-la, sendo os efeitos das condutas os objetivos visados pelo ato abusivo. A existência deste objetivo só poderia ser admitida, contudo, diante da possibilidade de produção dos efeitos elencados.

A própria inclusão do regramento do abuso de poder econômico no campo dos poderes e deveres da atuação estatal na ordem econômica poderia apresentar um duplo objetivo: equiparar os deveres do detentor de poder econômico aos deveres do agente estatal, o que deixaria transparecer a existência de um direito-função; ao mesmo tempo em que disciplina a intervenção do Estado para proteção dessa importante garantia institucional, transparecendo o poder-dever do Estado de atuar segundo esta garantia. ${ }^{186}$

Assim, ao tratar as normas de defesa da concorrência como garantia institucional posta pelo ordenamento jurídico, indagamos se o artigo $173, \S 4^{\circ}$, da Constituição Federal atribuiria ao poder econômico um cunho social, uma função pública, da mesma forma que atribui ao Estado um poder-dever de preservação do sistema. Da mesma forma discutimos a função dos agentes econômicos, em especial aqueles agentes com poder econômico, ou mais precisamente poder de mercado, para que se determine se haveria desvio de função na sua atuação.

Interessante, neste sentido, notar o pensamento de Paula Forgioni, que coloca como explicação plausível para separação entre a concorrência lícita e predatória a

\footnotetext{
${ }^{186}$ SALOMÃO FILHO, Calixto. Direito Concorrencial - As condutas, cit., p. 109-110.
} 
aplicação do princípio geral previsto em nosso ordenamento regrando situações de abuso de direito: ${ }^{187}$

\begin{abstract}
No caso do abuso do poder econômico, o direito de que se abusa é a liberdade econômica, liberdade de iniciativa, liberdade de concorrência etc. (ou seja, todos os direitos que assistem ao agente econômico no Estado liberal.) (...) No momento em que há abuso do poder econômico, há abuso do direito à liberdade econômica, liberdade de iniciativa, liberdade de concorrência etc. O sujeito passa a fazer uso anormal, reprovável, ilegítimo, imoral desses seus direitos, ou seja, excedente manifestamente os limites impostos pelo seu fim econômico ou social, pela boa-fé ou pelos bons costumes, nos termos do art. 187 , já mencionado. ${ }^{188}$
\end{abstract}

Importante ainda as lições do nobre jurista Modesto Carvalhosa ao descrever uma situação de abuso de direito, que "ocorre quando alguém, no exercício ou no uso de seus direitos subjetivos, desvirtua, sem um motivo legítimo ou com inobservância do princípio de boa-fé, a finalidade econômica ou social do instituto jurídico de que deriva seu direito". 189

As críticas que se poderiam fazer a tal acepção incluiriam o fato de não se tratar o poder econômico de um direito, mas sim de situação fática, ao máximo derivando de uma liberdade econômica, seu caráter privatista, que ficaria aquém do papel do antitruste. Sugere assim, citando Vicente Ráo, considerar a repressão ao abuso de direito como um princípio que embasa o ordenamento jurídico, não se limitando à proteção dos direito e interesses privados. ${ }^{190}$

Vale aqui recordar, para os efeitos de breve analogia a que se pretende com relação ao abuso de poder de controle, também de caráter privatista, que este gênero de abuso engloba duas espécies de abuso: (i) o desvio de poder ${ }^{191}$ e (ii) o excesso de poder. ${ }^{192}$

\footnotetext{
${ }^{187}$ Art. 187. Também comete ato ilícito o titular de um direito que, ao exercê-lo, excede manifestamente os limites impostos pelo seu fim econômico ou social, pela boa-fé ou pelos bons costumes.

${ }^{188}$ FORGIONI, Paula A. Os Fundamentos do Antitruste, cit., p. 323.

189 CARVAlhOSA, Modesto. Comentários à Lei de Sociedades Anônimas. 4. ed. São Paulo: Saraiva, 2008. v. 2. p. 508.

${ }^{190}$ FORGIONI, Paula A. Os Fundamentos do Antitruste, cit., p. 326-327.

191 Segundo Comparato e Salomão, por desvio de poder subentende-se uma via direta que deixou de ser seguida, para se atingir um alvo ou se chegar a um resultado. Consiste, portanto, num afastamento não da forma, mas do espírito da lei, representando ato típico de fraus legis (COMPARATO, Fabio K.; SALOMÃO, Calixto. O Poder de Controle na Sociedade Anônima. 5. ed. Rio de Janeiro: Forense, 2008. p. 364). Ainda segundo Modesto Carvalhosa, desvio de poder ocorre "quando o agente, embora observando as formalidades e não cometendo violação alguma expressa em lei, exerce o seu poder com uma finalidade diversa daquela para a qual lhe foi conferida essa prerrogativa" (Comentários à Lei de Sociedades Anônimas, cit., p. 508).

${ }_{192}$ Ainda segundo Comparato e Salomão, ocorre quando o agente, embora perseguindo os fins consagrados pelo ordenamento, interfere de modo mais que necessário na esfera jurídica alheia (COMPARATO, Fabio K.; SALOMÃ̃, Calixto. O Poder de Controle na Sociedade Anônima, cit., p. 364). Vide ainda, no tocante ao excesso de poder, art. 620 do Código de Processo Civil; art. 23, §ú do Código Penal e art. 188 do Código Civil. Segundo Modesto Carvalhosa, excesso de poder se verifica "quando o agente não exerce com
} 
Para o instituto do abuso de poder de controle, reconhecemos as seguintes finalidades ou objetivos legitimadores: (i) finalidade intraempresarial: satisfação dos interesses de todos os participantes na empresa (acionistas, titulares de outros valores mobiliários, empregados, administradores); e (ii) a finalidade extraempresarial: satisfação dos interesses da comunidade local, regional ou nacional no qual se insere a empresa. ${ }^{193}$ Vale verificar, neste sentido, que a harmonização dos interesses internos e externos da empresa se faz naturalmente, segundo a prevalência do segundo sobre o primeiro. ${ }^{194}$

Da mesma forma, as teorias institucionalistas, em clara contraposição às contratualistas consagradas, observaram em Rathenau a semente que trouxe embasamento à atuação mais incisiva do Estado, através de sua teoria da "empresa em si”, pela qual se entendia que a empresa teria funções próprias e dever de cumpri-las independentemente do interesse de seus acionistas. Desenvolve-se a partir daí uma teoria com vistas a subordinar os interesses das empresas ao interesse público predominante, diante de seu novo caráter institucional, subjugando-se a autonomia da vontade ao referido interesse público.

Rathenau sustentava que os empresários detêm o poder de controle não para servir aos capitalistas - sócios ou acionistas -, mas sim para servir segundo os interesses públicos representados pela empresa, como organização que transcende a sociedade comercial. ${ }^{195}$

$\mathrm{O}$ ordenamento jurídico brasileiro parece assumir o caráter institucionalista da norma, conforme se depreende dos artigos 116 e 117 da Lei das Sociedades Anônimas:

Art. 116, § ú. O acionista controlador deve usar o poder com o fim de fazer a companhia realizar o seu objeto e cumprir sua função social, e tem deveres e responsabilidades para com os demais acionistas da empresa, os que nela

moderação a prerrogativa que lhe é legalmente atribuída, fazendo-o contrariamente ao interesse de terceiros e com o objetivo de causar-lhe danos, seja cerceando-lhes o exercício de seus direitos, seja visando a alcançar, com o abuso, enriquecimento ilícito ou vantagem sem justa causa" (CARVALHOSA, Modesto. Comentários à Lei de Sociedades Anônimas, cit., p. 508).

${ }^{193}$ COMPARATO, Fabio K.; SAlOMÃO, Calixto. O Poder de Controle na Sociedade Anônima, cit., p. 364-365.

194 Por exemplo, exemplificam Comparato e Salomão: "O direito ao lucro ou à expansão da empresa não é garantido contra os interesses da comunidade local, regional e nacional em que ela se insere; interesses estes não só de ordem econômica (independência tecnológica ou economia cambial, por exemplo), como também de ordem social em sentido amplo (proteção do meio ambiente, dos interesses dos consumidores, ou do patrimônio cultural) (O Poder de Controle na Sociedade Anônima, cit., p. 365).

195 RATHENAU, W. Eine geschaeftliche Betrachtung. Tradução italiana La Realtà della Società per Azioni, p. 912 e ss. Vale ainda mencionar a Lei Germânica de 37, que em seu art. 70 previa o dever dos membros do Vorstand de dirigir os negócios sociais segundo o "bem do estabelecimento" (Wohl des Betriebs) e dos seus empregados, assim como no interesse comum da nação e do Reich. Esta foi a fonte do art. 116, $\S 7^{\circ}$, do Decreto-Lei n. 2.627. Contudo, a reforma legal de 1965 na Alemanha não repetiu a fórmula, uma vez marcada pelo espírito nazista, limitando-se a declarar que a Vorstand deveria dirigir a sociedade sob sua responsabilidade (COMPARATO, Fabio K.; SALOMÃO, Calixto. O Poder de Controle na Sociedade Anônima, cit., p. 366). 
trabalham e para com a comunidade em que atua, cujos direitos e interesses deve lealmente respeitar e atender.

Art. 117, § $1^{\circ}$ : São modalidades de exercício abusivo de poder: (a) orientar a companhia para fim estranho ao objeto social ou lesivo ao interesse nacional, ou levá-la a favorecer outra sociedade, brasileira ou estrangeira, em prejuízo da participação dos acionistas minoritários nos lucros ou no acervo da companhia, ou da economia nacional;

Com base nas teorias acima exibidas, destinadas à verificação do uso do poder de controle por parte dos acionistas em conformidade com a função social da propriedade, reconhecendo-se desvio de função quando da orientação de empresa para fim estranho ao interesse nacional ou em prejuízo à economia popular, poderíamos traçar um paralelo para o reconhecimento do nível de institucionalização do direito da concorrência para o ordenamento jurídico brasileiro. Ainda que críticas se possam fazer com relação ao caráter privatista do tratamento acima, objetivo maior deve ser reconhecido pelos acionistas, e ulteriormente pela própria empresa, na consecução de seus objetivos sociais.

Importante ainda, para que se apure o desvio, debruçarmos acerca de qual seria a função econômica dos agentes com posição dominante. Neste sentido, inegável que o novo Estado contemporâneo cumpre uma função relevante de redistribuição de renda, vez que o particular ou o mercado jamais o fariam, e a qual pode se dar de diversas maneiras. Assim, não seria tal caráter somente amparado pelo direito tributário, cabendo ainda à regulação o papel da redistribuição. Isso porque o objetivo redistributivo é também uma forma de dar eficiência ao Estado. Segundo Calixto Salomão:

\footnotetext{
Ela pode ser direta, como ocorre, por exemplo, quando a regulação exige dos grandes produtores ou monopolistas que estendam seus serviços a consumidores (ou candidatos a consumidores) que a eles não tem acesso. É o que se tem, ultimamente, chamado de universalização de serviços. ${ }^{196}$
}

A consequência legal da cobrança de preços não compatíveis com o mercado concorrencial no caso de bens essenciais implica a ilicitude da conduta, independentemente da análise da situação específica de preço e custo do agente no caso concreto, visto que sua justificativa é encontrada na disciplina do desvio de função. A razão para tanto estaria no fato de se interpretar o desvio da função como algo a ser medido em relação ao agente com poder econômico, segundo um critério, portanto, eminentemente subjetivo. Importante que se defina a função do agente econômico detentor de poder de mercado:

\footnotetext{
${ }^{196}$ SALOMÃO FILHO, Calixto. Regulação da Atividade Econômica, cit.
} 
Entende-se que a conduta do detentor do poder econômico no mercado é lícita na exata medida em que ele cumpre regularmente a sua função num sistema concorrencial. Ora, essa função é o fornecimento de bens a preços competitivos e seu desvio, a cobrança de preços supra competitivos. ${ }^{197}$

Segundo Calixto Salomão, esta regra, que já seria válida para o sistema econômico em geral, ganha particular reforço tratando-se de essential facility, pois aqui haveria um dever específico de não impedir o acesso dos concorrentes a esse bem, sendo que o não cumprimento deste dever caracterizaria desvio de função e, na essência, o abuso:

\footnotetext{
É preciso portanto entender a existência da concorrência como um valor em si, inadmitindo o poder econômico e exigindo que ganhos de escala sejam repartidos com o consumidor (admitindo-se, portanto, a eficiência só no sentido distributivo, e não alocativo), ao mesmo tempo em que não se permite que o processo de interação econômica leve à exclusão social (exigindo-se, portanto, que compromissos de desempenho incluam regras estritas de garantia de emprego, i.e., cumprido com rigor o disposto no art. $58 \S 1$, da lei concorrencial). ${ }^{198}$
}

Portanto, como garantia institucional que deve ser, as normas de defesa da concorrência implicam fim sem si mesmas, qual seja o de garantir que abusos de poder de mercado não sejam cometidos, ou sejam remediados, através dos instrumentos jurídicos pertinentes. De forma análoga, ao que verificamos nas diversas teorias de abuso de poder de controle, condutas praticadas por agentes econômicos com alguma forma de desvio ou excesso, levando-se em conta sua função econômica ditada pelo ordenamento, podem configurar ilícito reprimível sob a égide da Lei n. 12.529/11. Resta apurarmos quais os limites desta função.

\subsection{A Função Social na Atividade Empresarial}

A aplicação da teoria da função social no campo do direito econômico tem se dado de forma bastante tímida e concentrada em algumas vertentes de análise. Trata-se de tema ainda polêmico, como nunca deixou de ser a própria discussão aplicada à propriedade privada ordinária. Estender-se o conceito de propriedade privada para a propriedade dos bens de produção, sob o prisma de atuação do Direito Econômico, aplicando-lhe a teoria da função social, não deixaria, portanto, de tratar de tema igualmente polêmico e controverso.

\footnotetext{
${ }^{197}$ SALOMÃO FILHO, Calixto. Regulação da Atividade Econômica, cit.

${ }^{198}$ Idem, ibidem.
} 
Antes de mergulharmos na discussão, vale recordar o célebre artigo discorrendo sobre a função social da propriedade dos bens de produção de Fabio Konder Comparato, ${ }^{199}$ reconhecendo que em determinado momento histórico a vida passara a ser orientada para a atividade de produção e distribuição de bens ou prestação de serviços em massa, conjugada a um consumo padronizado. Neste cenário, a distinção jurídica de importância entre os bens evoluiu para uma discussão sobre a importância dos bens de produção ${ }^{200}$ e consumo.

Ao invocar a análise funcional do direito, o autor ressalta que "tanto os bens, quanto as relações jurídicas ou os negócios jurídicos, podem ter várias funções ou utilidades na vida social". ${ }^{201}$ Assim, reconhecendo o vínculo entre a propriedade privada e a proteção do indivíduo e da família contra as necessidades materiais, no sentido de provimento de sua subsistência, tendo passado para uma garantia de reparação de danos em tempos mais modernos, conclui que a "eficiência da propriedade, como técnica de realização dos interesses individuais e familiares, sempre esteve ligada à estrutura da relação real (...)". Por consequência, elucida ainda que "[n]a medida em que esse caráter absoluto pode ser conferido a outros direitos, eles passam a servir para o exercício da mesma função atribuída à propriedade".

Introduz, portanto, o conceito dos bens de produção que viriam a substituir a função da propriedade privada, em especial no que tange à realização dos interesses dos indivíduos, reconhecendo, contudo, a organização empresarial por detrás da persecução destes interesses, passando a propriedade de bens de produção a ser compreendida como poder de controle.

Notemos que, como reconheceu Comparato, a função social da propriedade não serve ao propósito de impor restrições ao uso e gozo dos bens em questão, mas sim à finalidade de vincular ao objeto da propriedade destino determinado:

\footnotetext{
Quando se fala em função social da propriedade não se indicam as restrições ao uso e gozo dos bens próprios. Estas últimas são limites negativos aos direitos do proprietário. Mas a noção de função, no sentido em que é empregado o termo nesta matéria, significa um poder, mais especificamente, o poder de dar ao objeto da propriedade destino determinado, de vinculá-lo a certo objetivo. O adjetivo social mostra que esse objetivo corresponde ao interesse coletivo e não ao interesse próprio do dominus; o que não significa que não possa haver

${ }^{199}$ COMPARATO, Fabio Konder. Função Social da Propriedade dos Bens de Produção, cit.

${ }^{200}$ Por bens de produção Comparato entende compreender os móveis e imóveis; não somente a terra, mas também o dinheiro, sob a forma de moeda ou crédito; os bens destinados ao mercado ou mercadorias, enquanto englobadas no fundo de comércio. Neste sentido, a classificação dos bens se baseia na destinação que lhes é dada (Idem, ibidem, p. 72).

${ }^{201}$ Idem, ibidem, p. 73.
} 
harmonização entre um e outro. Mas de qualquer modo, se se está diante de um interesse coletivo, essa função social da propriedade corresponde a um poderdever do proprietário, sancionável pela ordem jurídica. ${ }^{202}$

Ainda mais importante, verifica-se dos ensinamentos acima refletidos que tal objetivo estaria ligado à ideia de "social", de "interesse coletivo", e não necessariamente ao interesse do detentor do bem, aqui entendido a empresa ou seu controlador. Assim, trataria a função social da propriedade de um poder-dever do proprietário, estando, via de consequência, sujeita a sanções por parte do Estado. Neste sentido reconhece ainda que:

[E]m se tratando de bens de produção, o poder-dever do proprietário de dar à coisa uma destinação compatível com o interesse da coletividade transmuda-se, quando tais bens são incorporados a uma exploração empresarial, em poderdever do titular do controle de dirigir a empresa para a realização dos interesses coletivos.

Resta evidente o caráter coletivo que deve ser reconhecido à utilização dos bens de produção por parte das organizações empresariais e, em última escala, por parte de seus controladores.

Inegável reconhecermos que a construção do princípio da autonomia da vontade no âmbito das relações privadas deve se dar nos espaços deixados pelas normas de ordem pública. O interesse coletivo, mensurável e objetivado, portanto, constitui-se como um destes feixes limitadores da atuação empresarial privada.

No que tange ao seu universo sancionatório, após discorrer sobre sanções atreladas ao abuso da propriedade ordinária, que reconhece tratar de situações de acumulação particular de terras agricultáveis para fins de especulação, ou retenção de terras públicas do mesmo tipo sem utilização compatível com os interesses da coletividade, o artigo em comento traça analogia aos casos de abuso da propriedade de bens de produção, reconhecendo a ausência de remédios adequados apresentados pelo ordenamento jurídico para endereçar a questão. ${ }^{203}$

Reconhece ainda Comparato, ao final, que a destinação social dos bens de produção não deveria estar submetida ao princípio da autonomia individual, tampouco ao poder discricionário da Administração Pública, devendo o abuso da não utilização de bens de produção ou de sua má utilização ser sancionado de forma mais adequada: no caso de propriedade privada, pela expropriação não condicionada ao pagamento de indenização

\footnotetext{
${ }^{202}$ COMPARATO, Fabio Konder. Função Social da Propriedade dos Bens de Produção, cit., p. 76.

${ }^{203}$ Idem, ibidem, p. 77.
} 
integral ou mesmo sem indenização; e pela propriedade pública por meio de algum remédio judicial de efeito mandamental.

Fundamental identificarmos, no âmbito do nosso ordenamento jurídico, as expressões trazidas relativas à função social da propriedade, em especial sua aplicação sobre os bens de produção e mesmo sobre os contratos, visto que, como reconhecido por Asquini, uma empresa nada mais seria do que feixes de contratos. ${ }^{204}$

Conforme já mencionado acima, a norma fundamental do sistema jurídico brasileiro traz, em seu artigo 170, III, previsão acerca da função social da propriedade como princípio basilar da ordem econômica. Da mesma forma, o princípio em referência é repetido no inciso I do artigo 173 ao tratar da aplicação da função social da propriedade nos regimes de exploração da atividade econômica por empresa pública, sociedade de economia mista e suas subsidiárias. Antes, contudo, a Constituição Federal traz a função social como um direito e garantia individual dos cidadãos, ao qualificar o direito de propriedade, de forma que esta deverá atender a sua função social, dispondo ainda sobre o procedimento para desapropriação.

Em se tratando de legislação infraconstitucional, vale breve menção ao reconhecimento da função social pelo Código Civil brasileiro, que em seu artigo 186 a discute no tocante à propriedade rural. Interessante, para fins comparativo-analíticos, verificar que o dispositivo em referência entende cumprida a função social desta modalidade de propriedade, uma vez atingidos os seguintes requisitos: (i) aproveitamento racional e adequado; (ii) utilização adequada dos recursos naturais disponíveis e preservação do meio ambiente; (iii) observância das disposições que regulam as relações de trabalho; e (iv) exploração que favoreça o bem-estar dos proprietários e dos trabalhadores.

Verificamos aqui, portanto, que a observação da função social estaria amparada, de forma agrupada, em três prismas de análise centrais: (i) utilização adequada de um bem e de seus recursos, (ii) maximização do lucro - que seria o resultado lógico do bem-estar do proprietário, e (iii) respeito às normas dos trabalhadores - entendemos que o próprio respeito a esta norma representaria o bem-estar dos trabalhadores.

Em tempo, ainda nos referirmos à função social do contrato, que vem de forma a impor limites na liberdade das partes de contratar, em atendimento ao artigo 421 do Código Civil. Esta ideia viria ligada ao conceito de dependência econômica e sua repressão

${ }^{204}$ Vide ASQUINI, Alberto. Perfis da Empresa. Trad. port. de Fábio K. Comparato. Revista de Direito Mercantil 104 (1996). 
deveria se dar não somente no âmbito do direito da concorrência, mas ainda da teoria contratual. A situação de dependência econômica ocorre quando um dos contratantes é capaz de impor suas condições ao outro, que não possui alternativa senão aceitá-las, para fins de sua sobrevivência. No campo do direito contratual as situações de abuso podem se subsumir às hipóteses dos artigos do Código Civil previstos acima sempre que o exercício da faculdade assegurada pela cláusula desviar-se de seu fim econômico.

Em se tratando de bens de produção e da necessária condução dos negócios empresariais na sua forma organizada, devemos ainda procurar reconhecer a aplicabilidade da função social segundo os ditames da Lei das Sociedades Anônimas. Neste sentido o artigo 116 da Lei n. 6.404/76 prevê o poder-dever do acionista controlador para usar seu poder de controle com o fim de fazer a companhia realizar o seu objeto e cumprir sua função social. O dispositivo ainda deixa bastante claro que o acionista controlador tem deveres e responsabilidades para com os demais acionistas da empresa, os que nela trabalham e para com a comunidade em que atua. Claríssimo, portanto, o caráter institucional da norma e a vinculação que se deve fazer entre função social e, sobretudo, os interesses da comunidade em que atua.

Similarmente, o artigo 177 da mesma norma prevê responsabilização do acionista controlador pelos danos causados por atos praticados com abuso de poder, listando como modalidades de exercício abusivo de poder a orientação da companhia para fim estranho ao objeto social ou lesivo ao interesse nacional, ou ainda em prejuízo da economia nacional. Aqui verificamos forte a ideia, novamente, da proteção da economia nacional, com o consumidor ocupando papel de destaque na tutela jurídica.

Reconhecemos ainda o dever de observância da função social na atividade empresarial consoante artigo 154 da Lei das Sociedades Anônimas, colocando sob a responsabilidade do administrador as atribuições estatutárias para alcançar os fins segundo os interesses da companhia, observadas as exigências do bem público e da função social da empresa, sob pena de desvio de poder.

Finalmente, a Lei n. 12.529/11, que trouxe nova disciplina às normas de defesa da concorrência, referiu-se ainda de maneira muito tímida ao caráter da função social da propriedade no âmbito da regulação da concorrência ex post, em sistemática reprodução aos princípios constitucionais positivados:

Art. $1^{\circ}$ Esta Lei estrutura o Sistema Brasileiro de Defesa da Concorrência SBDC e dispõe sobre a prevenção e a repressão às infrações contra a ordem econômica, orientada pelos ditames constitucionais de liberdade de iniciativa, 
livre concorrência, função social da propriedade, defesa dos consumidores e repressão ao abuso do poder econômico.

Ainda que se discuta a aplicabilidade do princípio da função social dos meios de produção ao instituto da defesa da concorrência pátrio, notamos desde já sua expressão com relação a condutas abusivas de agentes econômicos, a qual tem se dado de maneira pontual, sem maior sistematização proposta. Em especial, verifica-se atrelada ao dever de acesso que incumbe aos detentores de posição dominante decorrentes de monopólios naturais, ou ainda decorrentes de razões estruturais que não permitem autorregulação ou resposta por parte do próprio mercado. A teoria dos "essential facilities", bastante discutida adiante, representaria, atualmente, esta vertente de aplicação da função social à análise antitruste.

Portanto, de fundamental importância ao tema o reconhecimento, ou extensão, promovido por Calixto Salomão Filho, ao trabalho de Comparato, no que tange à variedade de bens que podem estar sujeitos à aplicação do princípio da função social. Neste sentido, além dos bens de consumo e bens de produção, existiriam ainda os bens de cuja utilização depende a possibilidade de concorrer em determinado mercado, os chamados bens de acesso necessário. A função social nesta seara não somente consistiria na boa utilização destes bens, mas ainda da sua disponibilização a terceiros. ${ }^{205}$

Assim, ao responder à sua própria indagação acerca da sustentabilidade do princípio da função social do monopolista de bens essenciais diante do ordenamento jurídico brasileiro, afirma Calixto Salomão que tal assunção seria mais do que compatível, encontrando-se na própria gênese da lei concorrencial brasileira. Reconhece, desta forma, que dos dispositivos previstos na lei sobre abusos de preços é que se poderia vislumbrar a imposição de deveres aos monopolistas, e seria desta imposição de deveres que poderia ser inferida a existência de uma função. ${ }^{206}$

Se por um lado o abuso de preços caracteriza-se sempre que exista prática de preços excessivos ou aumento de preços de forma injustificada por parte do agente com posição dominante, por outro seria intuitivo o dever de praticar preços competitivos. E estes deveres seriam até mesmo mais extensos do que o decorrente da teoria das infraestruturas essenciais, uma vez que atingiria as relações diretas com os consumidores.

Fato é que se coloca embate teórico de extrema sensibilidade acerca da funçãodever de um monopolista. Não podemos olvidar que, conforme coloca o próprio Código

${ }^{205}$ SALOMÃO FILHO, Calixto. Direito Concorrencial - As condutas, cit., p. 114.

${ }^{206}$ Idem, ibidem, p. 117. 
Civil, restaria atingida a função social dos meios da propriedade privada - no tocante à propriedade rural -, uma vez atingido o bem-estar dos proprietários e dos trabalhadores. Da mesma forma, outras questões como a justa recompensa ao agente inovador devem ser consideradas, como forma de criação de um sistema de incentivos que não mine o próprio objetivo da concorrência.

Discutida em capítulos anteriores a origem dos dispositivos de preços excessivos do ordenamento jurídico brasileiro, temos afirmado que seu controle direto não merece tutela do direito concorrencial, ao qual caberia utilizar de outros meios de fomento à concorrência para geração de benefícios aos consumidores, com produtos melhores e mais baratos.

Portanto, nos quer parecer perigoso ao próprio objetivo do direito concorrencial utilizar a função social para justificação de controle direto de preços excessivos ou aumentos injustificados por parte do agente dominante. Para tanto, se discutiria a justa remuneração do agente dominante, papel que não deve caber às autoridades de defesa da concorrência. O próprio dever de praticar preços competitivos deve levar em conta a referida justa remuneração do agente econômico dominante, em especial do inovador.

Com relação, contudo, aos bens de acesso, aqui sim teríamos clara a função-dever do agente com posição dominante. O que implica dizer que este agente econômico possui, ao menos e em determinadas situações, dever de fomento da livre concorrência. Oportuna, consequentemente, a análise acerca da forma de manifestação da função social dos meios de produção e dos bens essenciais com relação às condutas de abuso de poder de mercado objeto do presente estudo, o que se pretende adiante.

Devemos considerar a completude do conceito de 'acesso' acima discorrida. Como visto, os bens de acesso visam permitir a possibilidade de concorrência nos mercados, consistindo não somente na boa utilização desses bens, mas ainda na sua disponibilização a terceiros, muito em linha com a amplitude conceitual a ser alcançada pelo conceito de inovação.

Assim sendo, se preocupa a função social com o efetivo acesso de produtos ou serviços aos consumidores, devendo justificar sua tutela. Qualquer impedimento ou dificuldade, portanto, promovidos por agentes econômicos em posição dominante, capazes de afetar o acesso destes produtos ou serviços, acabaria por infringir o princípio da função social aplicada ao direito da concorrência. 


\subsection{As Normas de Defesa da Concorrência Brasileira}

\subsubsection{A Antiga Lei n. 8.884/94 e sua Evolução}

A Lei n. 8.884, de 11 de junho de 1994, considerada pela doutrina como a primeira lei de defesa da concorrência brasileira verdadeiramente aplicada de forma sistemática em nosso ordenamento, representou o início de um sistema jurídico preocupado com a educação, a prevenção e a repressão aos abusos de poder de mercado e acordos anticompetitivos. Conforme anteriormente discutido, a partir de mudanças verificadas no cenário econômico brasileiro segundo uma postura mais liberal adotada por governos empossados no início dos anos 90, permitiu-se a configuração de um ambiente propício ao controle concorrencial que se pretendia implementar desde a década de 30 .

Neste novo cenário, verificamos o aparelhamento de uma autarquia federal, o Conselho Administrativo de Defesa Econômica (CADE) bem como de Secretarias vinculadas ao Ministério da Justiça e Ministério da Fazenda - Secretaria de Direito Econômico (SDE) e Secretaria de Acompanhamento Econômico (SEAE) respectivamente, que teriam funções próprias, porém muitas vezes concorrentes, visando a execução de três básicas funções: a educação dos administrados, através de uma pretendida eficiente advocatícia da concorrência; o controle preventivo de atos de concentração que pudessem de qualquer forma limitar ou prejudicar a livre concorrência ou ainda resultar na dominação de mercados relevantes de bens ou serviços; e por fim o controle repressivo de infrações contra a ordem econômica, tudo segundo os preceitos constitucionais basilares de garantia da liberdade de iniciativa, da livre concorrência, da função social da propriedade, da defesa dos consumidores e da repressão ao abuso de poder econômico.

Ao longo dos mais de vinte anos de sua aplicação, é inegável o amadurecimento alcançado pelo sistema de controle concorrencial implementado pelo Brasil. Foram pontuais e acertados, ao longo deste período, os ajustes, que permitiram às autoridades adequar a sua atuação aos problemas por ela endereçados, sempre levando em conta a insuficiência de recursos empregados pelo Governo Federal no Sistema Brasileiro de Defesa da Concorrência. Assim, se fazia necessária uma escolha, de forma que se empregassem os escassos recursos nas questões que tivessem maior potencial de prejuízo aos ditames constitucionais pregados. 
De uma atuação desfocada e centrada na análise de atos de concentração irrelevantes para o sistema num primeiro momento, alterou-se a interpretação acerca do filtro para submissões, permitindo-se maior ênfase ao combate às infrações concorrenciais, com foco na repressão aos acordos colusivos praticados entre agentes econômicos. Para tanto, desenvolveram-se instrumentos jurídicos de importância inquestionável para a defesa da concorrência, como a previsão legal especial para buscas e apreensões, os acordos de leniência e mesmo os compromissos de cessação de prática anticompetitivas.

Some-se a isso a persecução criminal já prevista desde 1990, com a edição da Lei n. 8.137, que regulamentava os crimes contra a ordem tributária, econômica e contra as relações de consumo. Não obstante sua previsão de longa data, mais recentemente é que os instrumentos criminais começaram a ser utilizados, segundo uma atuação mais alinhada entre as autoridades de defesa da concorrência e o Ministério Público. Como se sabe, a possibilidade de penas criminais é fator dissuasório considerado para a grande maioria da doutrina.

Não obstante todos os avanços reconhecidos, até mesmo por outras autoridades de peso no mundo, reformas estruturais se faziam indispensáveis. Reformas menores no conteúdo da própria lei, que sempre fora, desde seu nascimento, alinhada com os preceitos legais de jurisdições tradicionais no tema, porém mais profundas com relação à própria organização e funcionamento do Sistema, na definição de competências, na eficiência dos procedimentos internos, na qualificação dos profissionais, no inter-relacionamento com demais autoridades concorrências estrangeiras, autoridades regulatórias nacionais e com o próprio poder judiciário, dentre outras tantas questões. Faltava ainda uma disseminação da cultura da concorrência, visto que a advocacia da concorrência nunca se deu de forma eficiente no país, ainda hoje.

Não obstante os desafios, reconhecemos que as normas de defesa da concorrência possuem tipologia aberta, talvez como nenhuma outra natureza de norma no Brasil. Se por um lado cria dificuldades à previsibilidade e segurança jurídica, por outro permite adaptação mais rápida por parte das autoridades a mudanças e práticas comerciais verificadas ao longo do tempo, contanto que haja preparo neste sentido.

Em função da reformulação necessária, a Lei n. 8.884/94 foi revogada pela Lei n. 12.529, em 30 de novembro de 2011, a qual viria a prestar enorme serviço no sentido do reconhecimento da importância do Sistema Brasileiro de Defesa da Concorrência, não somente pelo próprio poder público, mas principalmente pela comunidade empresarial brasileira. 


\subsubsection{O Novo Diploma Legal e seus Ajustes de Rumo}

A nova lei de concorrência promoveu completa reestruturação do sistema, com a criação do novo Conselho Administrativo de Defesa Econômica. O antigo sistema composto pela Secretaria de Acompanhamento Econômico, Secretaria de Direito Econômico e pelo CADE, que dividia funções de instrução, investigação e julgamento, foi reformulado. O novo CADE absorveu o Departamento de Proteção e Defesa Econômica, departamento da SDE com atuação voltada para a defesa da concorrência, bem como as funções instrutórias antes a cargo da SEAE, deixando sob a jurisdição desta apenas as atividades de advocacia da concorrência, unificando, desta forma, funções antes compartilhadas entre os três órgãos. ${ }^{207}$

Em razão dessas alterações, o CADE passou a ser composto pelo Tribunal Administrativo de Defesa Econômica, competente para proferir decisões administrativas terminativas; pela Superintendência-Geral, competente para instrução e até mesmo decisão de atos de concentração de menor complexidade, bem como de investigações de condutas; e pelo Departamento de Estudos Econômicos, com funções de elaboração de pareceres econômicos. A Procuradoria Federal e o Ministério Público, com atuação atrelada ao CADE, continuam a desempenhar seus respectivos relevantes papéis junto ao Sistema.

Ainda que não se trate do propósito do presente trabalho, vale, para fins de percepção da importância reconhecida à nova instituição, breve referência à adoção de um sistema de notificação prévia, que requer análise a priori e respectiva decisão por parte do CADE acerca das operações notificadas anteriormente à implementação e conclusão do negócio. Assim, as partes ficam obrigadas a submeter operações que atinjam os critérios de notificação trazidos pela nova lei ao $\mathrm{CADE}^{208}$ e aguardar a decisão final por parte da

\footnotetext{
207 A advocacia da concorrência, em nosso entender, deverá continuar a se dar de forma ineficiente e insuficiente. Em especial agora que fora retirada da competência do SBDC, ausente ainda qualquer previsão na lei de interação entre SEAE e SBDC sobre este importante instrumento de política e de difusão de conhecimento.

${ }^{208}$ A Lei n. 12.529/2011 altera os critérios para submissão obrigatória das operações. Assim, requer-se a submissão de atos de concentração em que uma das partes, ou seu respectivo grupo econômico, tenham registrado faturamento bruto ou volume de negócios, no ano anterior ao da operação, pelo menos $\mathrm{R} \$ 750$ milhões no Brasil, cumulativamente ao registro, por pelo menos outra empresa ou grupo econômico envolvido na operação, no ano anterior ao da operação, de faturamento bruto ou volume de negócios mínimo de R 75 milhões no Brasil. A nova lei extingue ainda o critério de participação de mercado anteriormente vigente, segundo o qual se fazia obrigatória a notificação de operações que implicassem participação igual ou superior a $20 \%$ de um mercado relevante. Com a adoção da notificação prévia, o CADE terá um prazo de 240 dias para analisar o caso e proferir sua decisão, prazo este prorrogável por mais 90 dias a pedido do CADE, ou 60 dias a pedido das partes, desde que devidamente fundamentada a necessidade de dilação. Neste período, as partes estarão proibidas de adotar quaisquer medidas para implementação da operação.
} 
autoridade para consumar o negócio, a exemplo do que ocorre na maioria das jurisdições que possuem controle de fusões e aquisições. ${ }^{209}$

No que importa mais ao objeto do presente estudo, as alterações promovidas no controle repressivo das condutas anticoncorrenciais foram pontuais, algumas das quais trazem relevante alteração dos parâmetros até então estabelecidos.

A conjugação de uma teoria de efeitos com o rol exemplificativo de condutas foi mantida no artigo 36 do novo diploma concorrencial, tendo havido, contudo, rearranjo do rol exemplificativo de forma a agregar as condutas colusivas sob o inciso I deste artigo, inclusive no que tange ao dispositivo que trata de acertos em licitações. Da mesma foram excluídas as condutas exemplificativas anteriormente referidas nos itens XVII abandonar, fazer abandonar ou destruir lavouras ou plantações, sem justa causa comprovada; XIX - importar quaisquer bens abaixo do custo no país exportador, que não seja signatário dos códigos Antidumping e de subsídios do GATT; XX - interromper ou reduzir em grande escala a produção, sem justa causa comprovada; e finalmente XXIV impor preços excessivos, ou aumentar sem justa causa o preço de bem ou serviço, sendo que neste último quesito foi excluído o parágrafo único que trazia os fatores a serem considerados para avaliação de preços excessivos.

Por outro lado, foi incluído no rol exemplificativo da lei o exercício ou exploração abusiva de direitos de propriedade industrial, intelectual, tecnologia ou marca, o que reputa a importância crescente e interconexão muitas vezes verificadas entre o direito concorrencial e o direito de propriedade intelectual.

\subsubsection{A Presunção de Poder de Mercado sob o Novo Diploma}

De relevante consideração seria a alteração promovida no critério de presunção de posição dominante da nova lei. Conforme brevemente verificado, a nova lei determina, em seu artigo $36, \S 2^{\circ}$, que a posição dominante se presume "sempre que uma empresa ou grupo de empresas for capaz de alterar unilateral ou coordenadamente as condições de

\footnotetext{
209 A nova lei tentou ainda resolver um dos problemas fundamentais do sistema anterior, qual seja a insuficiência de recursos humanos para as atividades das autoridades, prevendo a criação de duzentos novos cargos de gestores, visando maior adequação do contingente às novas demandas de atuação do SBDC. Contudo, tais cargos dependem ainda de composições políticas, devendo ser criados de forma progressiva ao longo dos próximos anos.
} 
mercado ou quando controlar $20 \%$ ou mais do mercado relevante, podendo este percentual ser alterado pelo CADE para setores específicos da economia".

Um primeiro ponto a se tratar consiste na situação de posição dominante coletiva. Neste sentido, nos parece ter o legislador estendido a aplicação da presunção de posição dominante a tais situações, na medida em que introduz conceito de alteração coordenada das condições de mercado. Ainda que ausente referida alteração, nos parece igualmente possível a adoção dos novos critérios estabelecidos para condutas envolvendo dominância coletiva.

O ponto de principal reflexão, contudo, refere-se à aparente transformação de um conceito consagrado de posição dominante, qual seja a possibilidade de alteração unilateral ou coordenadamente das condições de mercado por empresa ou grupo de empresas, em presunção de posição dominante.

Ora, se uma empresa ou grupo de empresas é, de fato, capaz de alterar unilateral ou coordenadamente as condições de mercado, esta empresa ou grupo de empresas possui, efetivamente, posição dominante. Não há, portanto, de se falar em presunção sob este conceito e, consequentemente, meios de prova admitidos para reversão da presunção em questão. Há uma antecipação, portanto, da análise, que não caberia à presunção, tratandose de erro técnico do legislador.

Resolve-se o dilema reconhecendo, portanto, para fins de presunção e consequente inversão do ônus da prova, tão somente o critério da participação de $20 \%$ como apropriado para tanto, a exemplo do que fazia a legislação anterior.

\subsubsection{O Novo Regramento de Penas Previsto}

Outra alteração que se verificou trata das penalidades aplicáveis, tendo havido desmedido retrocesso nas normas de defesa da concorrência, na contramão ainda da tendência do próprio SBDC e demais jurisdições no enrijecimento de aplicação das penalidades às condutas anticoncorrenciais. Assim, a nova legislação traz redução da previsão legal da pena anteriormente de $1 \%$ a $30 \%$ do valor do faturamento bruto, excluídos os impostos, para $0,1 \%$ a $20 \%$ do valor do faturamento bruto da empresa, grupo ou conglomerado obtido no ramo de atividade empresarial em que ocorreu a infração, não devendo ser inferior à vantagem auferida quando possível sua estimação. 
Embora a diminuição do patamar mínimo para aplicação da penalidade represente maior flexibilidade para que o CADE possa aplicar multas de caráter educativo em condutas consideradas de baixa gravidade, a redução do patamar máximo poderia representar enfraquecimento no combate a condutas de maior potencial ofensivo, sinalizando maior complacência em relação ao abuso do poder econômico, na contramão da tendência observada nas demais jurisdições, e colocando em risco a disseminação e efetividade da política de combate a cartéis do SBDC. Também tem gerado discussões a base de cálculo prevista para aplicação das penas, qual seja o ramo de atividade empresarial, e a possibilidade que se coloca de aplicação de pena com base no faturamento bruto do grupo ou conglomerado.

Em casos de pessoas jurídicas que não exerçam atividade empresarial, portanto não se fazendo possível a utilização do critério do valor do faturamento bruto para fins de multa, trouxe a nova lei previsão de aplicação de multa que pode variar de $\mathrm{R} \$ 50.000,00$ (cinquenta mil reais) e $\mathrm{R} \$ 2.000 .000 .000,00$ (dois bilhões de reais).

Da mesma forma, a nova lei trouxe sutil esclarecimento e redução no percentual de multa para responsabilização dos administradores, direta ou indiretamente, pela infração cometida, ao sujeitá-la à comprovação de culpa ou dolo, podendo ainda variar de $1 \%$ (um por cento) a $20 \%$ (vinte por cento) daquela aplicada à empresa ou demais pessoas jurídicas condenadas.

Outra importante alteração trazida pela nova lei diz respeito à penalização, na esfera criminal, das pessoas físicas envolvidas na infração. A pena prevista no artigo $4^{\circ}$ da Lei n. 8.137/90 passará a ser de 2 a 5 anos de reclusão e, cumulativamente, multa, alterando-se seu caráter alternativo. Neste sentido verifica-se endurecimento das penas aplicáveis, na medida em que a alteração levada a efeito impossibilita hipóteses de suspensão condicional do processo ou transação penal, requerendo a aplicação de penas de reclusão dentro dos parâmetros estipulados.

Ainda que se reconheça que no geral as alterações promovidas pela nova norma de defesa da concorrência sejam positivas, há diversos pontos de preocupação que merecem atenção e correção por parte do SBDC, a fim de que se atinjam os objetivos colimados. 


\section{CAPÍTULO 4 \\ A TEORIA DO ABUSO DE POSIÇÃO DOMINANTE COMO ELEMENTO DE AMPARO ÀS RESPONSABILIDADES ESPECIAIS}

\subsection{O Abuso de Posição Dominante}

Como veremos adiante, a teoria das responsabilidades especiais não se propõe à identificação da concorrência no mérito decorrente da conduta de agentes com posição dominante, não servindo ao propósito de isolá-la daquela concorrência predatória ou abusiva eventualmente praticada. Por esta razão, justamente, é que devemos nos socorrer de uma análise detalhada da teoria do abuso de posição dominante, segundo os parâmetros utilizados pelas diversas autoridades para identificação destas situações.

Igualmente, veremos que ainda carece o sistema jus-concorrencial brasileiro de efetiva sistematização de preceitos para aplicação de uma teoria do abuso de posição dominante. Esta realidade cria a necessidade de revisitação do tema de forma a encaixá-lo no ordenamento jurídico brasileiro, complementando e permitindo a aplicação efetiva da teoria das responsabilidades especiais. Sem a primeira parte deste trabalho não haveria como se aplicar a tese das responsabilidades especiais, reiteremos.

Neste exercício inicialmente complementar, notamos que a lei concorrencial brasileira, a exemplo de jurisdições de tradição jus-concorrencial, não censura posição dominante obtida com base em maior eficiência de agente econômico em relação a seus competidores. $^{210}$ Consequentemente, não há de se falar em qualquer forma per se de censura que decorre exclusivamente de uma posição de dominância no mercado. Assim, a situação fática estática de poder de mercado não é passível de punição por si só.

Neste sentido, nosso ordenamento requer a prática ou exercício de uma conduta que possa ser considerada abusiva para que se verifique a pretensão punitiva por parte do Estado. Não há, assim, definição acerca do que seria o abuso de posição dominante, mas tão somente um tipo aberto de condutas que, na medida em que sejam capazes de gerar os efeitos previstos no artigo 36 da Lei n. 12.529/11, poderiam ser considerados como abuso de posição dominante.

\footnotetext{
${ }^{210} \mathrm{O} \S 1^{\circ}$ da Lei $\mathrm{n} .12 .529 / 11$ expressamente dispõe que "[a] conquista de mercado resultante de processo natural fundado na maior eficiência de agente econômico em relação a seus competidores não caracteriza o ilícito previsto no inciso II do caput deste artigo".
} 
Para que haja a possibilidade de produção de um efeito deletério à garantia institucional mínima da livre concorrência é necessário que, ao agente econômico, seja reconhecida posição dominante, o que vai muito além da verificação de sua participação de mercado estática. Caso contrário não se reconhece o requisito legal para caracterização do ilícito, visto que na ausência de posição dominante suas condutas não serão capazes de produzir efeitos sobre consumidores e sobre o mercado de forma geral.

Assim, identificamos dois tipos de condutas que podem levar à dominação de mercados, no seu sentido de limitação da concorrência. Aqui teríamos condutas unilaterais e condutas colusivas. As duas modalidades sempre avaliadas segundo a máxima racional individualista do agente econômico: "ou se coloca o concorrente fora do jogo (ex-ludere), passando a dominar sozinho o mercado; ou se joga com o concorrente (co-ludere), dominando em conjunto o mercado". 211

Com relação à segunda modalidade, condutas colusivas, temos que esta pode se dar de diversas formas, de maneira formal ou informal, através de acordos entre concorrentes ou associações entre empresas visando alocação de clientes ou territórios, acerto de condições comerciais, acerto de participação em licitações, compromissos de não concorrência, boicotes a fornecedores, entre outras condutas verificáveis.

Contudo, é nas condutas unilaterais, objeto do presente estudo, que verificamos maior controvérsia das práticas mercadológicas e seus efeitos. Os prejuízos ou limitações à livre concorrência devem ser analisados na perspectiva dinâmica de interação dos agentes econômicos envolvidos nas relações de mercado. Abusos de posição dominante tendem a extrair ganhos superiores aos padrões de mercados competitivamente eficientes, seja através de práticas que visem a excluir, dificultar e impor barreiras aos seus concorrentes efetivos ou potenciais, seja em decorrência de práticas que venham a explorar posição dominante em detrimento de clientes ou fornecedores. Aqui, portanto, reconhecemos as duas faces do abuso de poder de mercado: práticas excludentes de mercado e práticas exploratórias de mercado.

Naquilo que vem a ser o conceito de abuso, não definido pelo nosso ordenamento jurídico, devemos traçar breve paralelo interdisciplinar a fim de extrairmos elementos que possam ser utilizados na análise antitruste. Recordemos o conceito de abuso de direito elucidado pelo Ilmo. jurista Modesto Carvalhosa, para quem "ocorre quando alguém, no exercício ou no uso de seus direitos subjetivos, desvirtua, sem um motivo legítimo ou com

${ }^{211}$ SALOMÃO FILHO, Calixto. Direito Concorrencial - As condutas, cit., p. 125. 
inobservância do princípio de boa-fé, a finalidade econômica ou social do instituto jurídico de que deriva seu direito". ${ }^{212}$ Da mesma forma, esclarece Paula Forgioni que o abuso de poder econômico seria o "uso 'anormal', 'reprovável', 'ilegítimo', 'imoral' desses seus direitos [liberdade econômica, liberdade de iniciativa, liberdade de concorrência etc.], ou seja, 'excedente manifestamente os limites impostos pelo seu fim econômico ou social, pela boa-fé ou pelos bons costumes' (...)". ${ }^{213}$

Portanto, o abuso de posição dominante pode consistir no exercício de uma ampla margem de apreciação pela empresa dominante, em virtude da especial posição que ocupa, e consequentemente da especial responsabilidade que se lhe aplica, de forma a obter vantagens que, na presença de contestabilidade de mercado, ou seja, grau de concorrência apreciável, não poderia alcançar. Estas vantagens podem resultar de abusos de exploração, bem como da preservação ou reforço dessa posição dominante pelo recurso a meios aptos a excluir a concorrência sem justificação objetiva.

O exercício de poder de mercado só dá lugar à responsabilidade pela conduta subsequentemente à aquisição de tal posição dominante. Só pode ser sujeito de responsabilidade especial inerente ao conceito de posição dominante aquele que tem o dever de se comportar de forma especial. Tal pensamento seria válido diante de real entendimento e convergência no sentido da existência desta responsabilidade especial, a qual discutiremos adiante.

De forma geral, para se analisar os efeitos de uma prática de mercado requer-se, primeiramente, delimitação do mercado relevante afetado pela conduta em análise, a avaliação das posições estáticas de participação e análise de sua dinâmica concorrencial, para ulterior avaliação acerca da efetiva posição dominante exercida pelo agente econômico. Uma vez concluída a análise acerca destes instrumentos processuais, visto que a definição de mercado relevante não é fim em si mesma, devem-se avaliar os efeitos potenciais e reais que a conduta pode acarretar na estrutura concorrencial do mercado. Vale recordar que, como pretendemos sugerir anteriormente, a análise do mercado relevante

\footnotetext{
${ }^{212}$ CARVALHOSA, Modesto. Comentários à Lei de Sociedades Anônimas, cit., p. 508.

${ }^{213}$ FORGIONI, Paula A. Os Fundamentos do Antitruste, cit., p. 323. Vale ainda citar, sob o prisma do Direito Europeu, que no caso Hoffmann-La Roche v Commission, o Tribunal de Justiça Europeu trouxe a seguinte definição, reiteradamente usada nas decisões europeias para definir abuso: "An objective concept relating to the behavior of an undertaking in a dominant position which is such as to influence the structure of a market where, as a result of the very presence of the undertaking in question the degree of competition is weakened and which, through recourse to methods different from those which condition normal competition in products or services on the basis of the transaction of commercial operators, has the effect of hindering the maintenance of the degree of competition still existing in the market or the growth of that competition." (Case 85/76 [1979] ECR 461, [1979] 3 CMLR 211).
} 
afetado deve se dar de forma flexível, valorando evidências diretas de efeitos sem predeterminação de fronteiras estanques. Por fim, requer o protocolo a avaliação de eventuais justificativas econômicas objetivas para a prática analisada, a qual funcionaria com efeito próximo ao verificado nos excludentes de ilicitude aplicados no processo penal.

Reconhece-se ainda tangenciamento do tema não inserte no espectro de análise jus-concorrencial a questão da dependência econômica, que possui natureza privatista. Não obstante, cabe a menção em virtude dos elementos utilizados para sua avaliação, que trazem conceitos que podem ser aproveitados na análise dos direitos difusos e coletivos levada a efeito pelos sistemas de defesa da concorrencial.

Assim, verifica-se situação de dependência econômica quando um dos contratantes encontra-se apto a impor suas condições ao outro, que deve aceitá-las para sobreviver. Um dos contratantes estaria, portanto, em posição de superioridade com relação ao outro contratante. Estas modalidades de abuso devem ser tratadas em vista da hipótese normativa trazida pelo artigo 187 do Código Civil, requerendo, contudo, que a prática da conduta seja desviada de sua função econômica ou ainda frustrada a legítima expectativa do agente.

Casos de dependência econômica tratados sob a égide privatista, com base no dispositivo do Código Civil descrito, podem prescindir, segundo nosso entendimento, da configuração de posição dominante no mercado. Tratar-se-ia, portanto, de relação de dependência econômica entre partes contratantes, estabelecida por força de uma relação jurídica acordada. Caso, contudo, este fator de dependência econômica de clientes ou fornecedores se estabeleça de forma semelhante sobre todos os agentes que interagem em determinado mercado, configurada, portanto, uma posição dominante, estaríamos diante de um abuso de posição dominante eventualmente censurável sob o prisma concorrencial.

Devemos ainda analisar casos de dominância coletiva, tipificação possível em nosso ordenamento jurídico. Não somente bastaria avaliarmos a participação de mercado relativamente aos agentes oligopolistas em questão, o que se faz de forma semelhante a situações de monopolistas, mas acima de tudo deveríamos avaliar se o bloco em questão funciona efetivamente como tal, inexistindo concorrência nas suas relações internas, verificando-se, a bem da verdade, comportamento paralelo intencional. 


\subsubsection{Exploração do Estado de Dependência Econômica}

Merece breve consideração a teoria da exploração da dependência econômica por agentes que possuem poder de mercado com relação a seus clientes sem, contudo, possuírem posição dominante no mercado, visto que sujeitos a pressões competitivas de seus concorrentes.

Conforme ilustra Paula Forgioni, práticas neste sentido podem ser verificadas com certa frequência em grandes mercados varejistas, como supermercados. ${ }^{214} \mathrm{O}$ poder de compra conquistado por estas grandes redes, muito em razão do processo concentracionista vivenciado, principalmente, na última década no Brasil, permitiu certo descolamento destas grandes redes da equiparação de forças que possuía com seus fornecedores, gerando questões diversas como estrangulamento de suas margens de lucro, sem que contudo haja repasse efetivo para os consumidores, e gerando ainda certo aniquilamento dos sistemas de distribuição tradicionais. As marcas próprias introduzidas pelas grandes redes varejistas passaram ainda a permitir exercício mais eficiente de pressão competitiva com relação aos fornecedores das marcas tradicionais.

Ausente o requisito da posição dominante, seriam reduzidas as possibilidades de chancela ilegítima da prática pelas autoridades de defesa da concorrência. Não obstante as dificuldades de promoção dos devidos remédios no âmbito do SBDC, entendemos que haveria a possibilidade de reparação de danos relevantes causados a fornecedores segundo a teoria contratual, com base nos dispositivos do Código Civil. ${ }^{215}$

Tais abusos possuem ainda maior poder de lesividade quando decorrentes da alteração de um "status quo", uma relação de longa data predeterminada e que tenha gerado certo grau de dependência do fornecedor com relação ao seu distribuidor ou rede de varejo. Este parece ser mais o foco de aplicação jurisprudencial inclusive na Europa, que possui conjunto razoável de casos onde a conduta de uma empresa é censurada devido a sua alegada natureza abusiva em face do relacionamento com a entidade objeto do comportamento. $^{216}$

Verificamos, por exemplo, que no caso BP, o Tribunal de Justiça considerou objetivamente justificada a discriminação de clientes atuais se comparados àqueles antigos

\footnotetext{
${ }^{214}$ FORGIONI, Paula A. Os Fundamentos do Antitruste, cit., p. 389 e ss.

${ }^{215}$ Código Civil, "Art. 186. Aquele que, por ação ou omissão voluntária, negligência ou imprudência, violar direito e causar dano a outrem, ainda que exclusivamente moral, comete ato ilícito."

216 MOURA E SILVA, Miguel. O Abuso de Posição Dominante na Nova Economia. Teses de Doutoramento, cit., p. 435 e ss.
} 
que rescindiram seus contratos antes de uma situação de escassez generalizada. Este caso traria "experimentalismos" por parte da Comissão nos deveres de conduta para com os antigos distribuidores de uma empresa que integra um mercado concentrado, mas que não seria dominante em termos individuais. Parece assim haver aplicação de uma definição de mercado estrita - intramarca -, que levaria à conclusão de uma política da defesa da concorrência focada no bem-estar do consumidor e não na proteção dos agentes econômicos de menor dimensão - teoria do parceiro obrigatório.

Introdução da figura do abuso se deu na França, com a Odonance de 86, tendo sido inclusive inserida no ordenamento Português (Decreto Lei 371/92). ${ }^{217}$ Da mesma forma na Alemanha, tendo sido já decidido neste país que o abuso de poder relativo no mercado pode, em algumas circunstâncias, ser tão nocivo ao mercado quanto a discriminação exercida por empresa em posição dominante. ${ }^{218}$

Podemos nos perguntar ainda o que teria a proibição do abuso de dependência econômica a ver com a defesa da concorrência e de que modo tal interdição contribuiria para o bem-estar social dos consumidores ou para o progresso econômico ou inovação. A lógica da dependência econômica faria assim sentido apenas no âmbito da proibição do abuso de posição dominante. Conforme bem frisou Miguel Moura, em última análise o problema trata de uma questão de "oportunismo, de protecção de investimentos, em especial quando estes implicam custos irreversíveis, de resolução de problemas de free riding e um conjunto de outros problemas que a perspectiva económica da análise dos custos de transacção tem vindo a esclarecer". ${ }^{219}$

Interessante, contudo, lançarmos a semente de uma tese de abuso de posição dominante coletiva, ao se verificar paralelismo nas ações das grandes redes que criam dificuldades ao funcionamento dos fornecedores quando promovem, de forma disseminada no mercado, estreitamento de suas margens. Ainda que tal estreitamento, por si só, não deva representar infração concorrencial, ao invocarmos um suposto dever de repasse das eficiências obtidas na negociação entre os agentes econômicos para consumidores finais

\footnotetext{
${ }^{217}$ Conselho Português parece ter utilizado definição teleológica para interpretar a norma, aproximando-a às regras de concorrência tradicionais (só poderia haver abuso caso a conduta tivesse por objeto ou efeito a restrição da concorrência). O alcance dado às normas de dependência econômica pelo Conselho da Concorrência vem no sentido de estabelecerem um conjunto de regras que enquadrem essas modificações ou mesmo a cessação de relações, atendendo as repercussões que tais condutas poderão ter na concorrência, designadamente através da eliminação de agentes econômicos sem qualquer justificativa objetiva (Idem, ibidem, p. 438).

${ }^{218}$ FORGIONI, Paula A. Os Fundamentos do Antitruste, cit., p. 390.

${ }^{219}$ MOURA E SILVA, Miguel. O Abuso de Posição Dominante na Nova Economia. Teses de Doutoramento, cit., p. 443.
} 
dos produtos estaríamos dificultando a colação de justificativas objetivas à prática de um ato lesivo à operação dos fornecedores.

\subsection{Espécies de Infrações e Respectivas Qualificações}

\subsubsection{Efeitos Lesivos das Condutas Unilaterais}

Como previsto em nosso ordenamento, a análise das condutas de abuso de posição dominante se dá em função da possibilidade de geração de efeitos ao mercado. Não basta que um abuso seja praticado por aqueles que não exerçam efetiva posição dominante, cujas condutas não são capazes de gerar efeitos, ainda que potencialmente.

Da mesma forma, devemos consignar que a verificação de posição dominante individual ou coletiva não bastaria para a configuração do abuso de poder econômico na medida em que pode haver justificativas econômicas objetivas, ou mesmo eficiências compensatórias geradas decorrentes da conduta. Fato é que, diante de posição dominante reconhecida e ausência de eficiências ou justificativas econômicas objetivas, a conduta do agente pode gerar efeitos deletérios à garantia de concorrência nos mercados.

Neste sentido reconhece a legislação brasileira caracterização de infração da ordem econômica a todos os atos manifestados, que tenham por objeto ou possam produzir, ainda que tais efeitos não sejam alcançados: (i) limitação, falseamento ou prejuízo à livre concorrência ou à livre iniciativa; (ii) dominação de mercado relevante de bens ou serviços; (iii) aumento arbitrário de lucros; e (iv) exercício de forma abusiva da sua posição dominante.

Interessante notar que a legislação pátria caracteriza o abuso com base na mera intenção do agente econômico em produzir tais efeitos - "atos que tenham por objeto" -, os quais, contudo, não precisam ser alcançados. Não obstante, requer o caput do artigo que os atos sejam, de alguma forma, efetivamente manifestados.

O que nos leva a duas reflexões relevantes. A primeira, de que não basta que haja qualquer intenção por parte do agente econômico em produzir os efeitos listados se não houver sua efetiva manifestação, de alguma forma, no mercado. A mera intenção não externalizada não é punível, a exemplo do que verificamos no direito penal. ${ }^{220}$

\footnotetext{
${ }^{220}$ Neste sentido, vide, por exemplo, o artigo 31 do Código Penal: Art. 31. O ajuste, a determinação ou instigação e o auxílio, salvo disposição expressa em contrário, não são puníveis, se o crime não chega, pelo menos, a ser tentado.
} 
Devemos reconhecer ainda, com base na análise de nosso ordenamento jurídico, que haveria duas modalidades de ilícito: ilícitos por objeto e ilícitos por efeito. No tocante aos ilícitos por efeito muito se discute a sua potencialidade, faltando critérios críveis e padronização dos elementos probatórios para demonstração da referida potencialidade. Já com relação aos ilícitos por objeto, fazemos referência adiante da recente decisão tratando de imposição de preços ou margens mínimas de revenda, reputadas condutas ilícitas por objeto, tendo decidido o CADE que esta imposição de preços mínimos teria a capacidade e o propósito de restringir a concorrência e, somente em casos excepcionais, dependentes de análise caso a caso, poderiam ser consideradas cláusulas auxiliares à outra conduta racional e, consequentemente, lícita. ${ }^{221}$

Já com relação propriamente aos efeitos disciplinados pela norma concorrencial, vale analisá-los com maior cuidado e de forma aplicada às condutas unilaterais. Assim, devemos reconhecer que enquanto o inciso I visa predominantemente a regular situações de práticas colusivas, os incisos II e IV visam a endereçar, predominantemente, condutas unilaterais.

Assim, vale nos atermos ao escrutínio do que viria a ser dominação de mercado relevante de bens ou serviços, visto que também o inciso IV traz como efeito o próprio tema do capítulo - exercício de forma abusiva de posição dominante. Nos posicionamos no sentido de que efeitos da dominação de mercado devem ser entendidos como aqueles tendentes à exclusão da concorrência em um mercado relevante, decorrente de qualquer forma de imposição de custo adicional de produção e distribuição ou imposição, direta ou indireta, de qualquer dificuldade para o seu funcionamento, tendente a gerar exclusão. ${ }^{222}$ Inegável que qualquer dominação pressupõe exclusões, e neste sentido deve ser interpretado o dispositivo.

Por sua vez, o inciso III, como já mencionado anteriormente, traz normativo cuja origem se encontra nos preceitos de combate aos crimes contra a economia popular com origem na estrutura extremamente concentrada do mercado brasileiro desde os primórdios de nossa colonização. Se por um lado pode auxiliar o dispositivo na definição dos deveres dos monopolistas - de não praticar lucros abusivos -, por outro não há como se inferir, de forma sistemática, objetividade econômica tampouco jurídica acerca do que poderia vir a

\footnotetext{
${ }^{221}$ Vide item 6.10 para mais informações sobre a decisão.

${ }^{222}$ Calixto Salomão entende, da análise constitucional aplicada às normas de defesa da concorrência, que há necessidade de a dominação ser atingida por ato abusivo. Assim, se o abuso objetiva a dominação, deve-se entender por dominação dos mercados qualquer limitação efetiva ou potencial da concorrência, qualquer que seja seu grau (Direito Concorrencial - As condutas, cit., p. 121).
} 
ser um lucro abusivo. Esta seria a razão pela qual as práticas exploratórias têm merecido menor atenção por parte de autoridades concorrenciais de todo o mundo, exceto quando conjugadas a outras práticas excludentes, estas sim foco mais direto da tutela jusconcorrencial.

\subsubsection{Espécies de Condutas Exploratórias e Tratamento Emprestado}

A mais intuitiva forma de exercício de poder de mercado para maximização de lucros do agente econômico é a atuação direta nos próprios preços ou nas quantidades produzidas. Somem-se a isso imposições de outras condições comerciais de transação abusivas, as quais acabam por acarretar indesejada transferência de renda dentro da cadeia de produção ou escoamento, e ulteriormente do consumidor. Neste sentido, por práticas abusivas de exploração poderíamos citar, a título ilustrativo, preços excessivos, redução de margens, fixação de preço de revenda, royalties excessivos, dentre outros.

A dificuldade para as autoridades concorrenciais reside no limite a ser observado na regulação ex post, que deve prescindir de qualquer forma de controle direto de preços. Assim, proibições de preços excessivos são raramente aplicadas pelas autoridades.

O que se deve controlar são as condições de entrada, de forma a se mitigar eventuais barreiras que sejam colocadas pelo agente incumbente monopolista, ou mesmo atuando-se através da advocacia da concorrência no caso de barreiras legais que possam ser atenuadas pelo Estado. Nos casos de monopólios naturais, talvez a mais provável saída seja a regulação, até que um dia se veja alterado o cenário por conta, principalmente, de inovações tecnológicas, mas sempre se buscando a introdução e fomento à livre concorrência.

Práticas monopolistas sugerem a aferição de lucros supracompetitivos e ulterior transferência de renda de concorrentes e do consumidor para monopolistas. Estes não possuem incentivos para inovação ou para aumento de sua eficiência e redução de custos, visto que não estaria exposto à concorrência. Há os que defendam, contudo, maiores incentivos à inovação e eficiência em razão da própria estrutura monopolística verificada, uma vez perseguido o racional maximizador de lucros. Para esta corrente, monopolistas encontram-se constantemente sobre o incentivo da inovação e busca por eficiência. Ao que verificamos que tal percepção parece ser mais verdadeira em mercados envolvendo alta tecnologia, ou mercados de inovação propriamente ditos. 
Em rápida reflexão, a interessante questão que se poderia colocar em debate vem no sentido de cobrar-se do agente monopolista o investimento em inovação ou aumento de sua eficiência, ao extremo quando se cogita para determinadas situações de um dever de fomento à livre concorrência, segundo uma responsabilidade especial que possa carregar tal agente econômico.

Contudo, a resposta a esta indagação nos quer parecer bastante sedimentada, no sentido da impossibilidade de tal cobrança de forma direta pelas autoridades. Ao próprio mercado e sua mão invisível caberia tal disciplina, cumprindo o Estado o papel de garantidor do livre funcionamento destes mercados.

Não obstante as considerações acima, cabe verificar que a repressão às práticas exploratórias encontra embasamento no diploma legal brasileiro, no inciso III do artigo 36 da Lei n. 12.529/11, implicando o aumento arbitrário de lucros.

Podemos dizer que o próprio efeito tipificado no inciso III não requer tutela direta por parte das autoridades, uma vez que todos os demais incisos do artigo 36 - limitar, falsear ou de qualquer forma prejudicar a livre concorrência ou a livre iniciativa; dominar mercado relevante de bens ou serviços; ou exercer de forma abusiva posição dominante tem a potencialidade, ou ainda mais, o objetivo, de gerar o efeito de aumento arbitrário de lucros. Mas, como discutido anteriormente, tal dispositivo remonta a razões históricas cuja intenção era capitular abusos dos direitos do consumidor, e não indireto via limitação da concorrência. Daí por que não merece igual atenção por parte das autoridades.

A bem da verdade, temos verificado a pouca incidência de casos analisados com base nestas categorias de abuso, pelas diversas razões já expostas. Na maioria destes casos em que a discussão acerca destes abusos se coloca, ela tende a vir conjugada com outras modalidades de abuso por exclusão, em especial com questões relativas à discriminação de preços ou condições comerciais. ${ }^{223}$ Não obstante o foco do presente estudo centre-se na

\footnotetext{
${ }^{223}$ Neste sentido orientou recentemente a Comissão Europeia, na divulgação da Comunicação da Comissão Orientação sobre as prioridades da Comissão na aplicação do artigo 82 do Tratado CE a comportamentos de exclusão abusivos por parte de empresas em posição dominante (OJ [2009] C 45/7): "O presente documento apresenta as prioridades que irão orientar a ação da Comissão na aplicação do artigo 82. aos comportamentos de exclusão por parte de empresas em posição dominante. O objectivo é, juntamente com as decisões de execução específicas da Comissão, tornar mais claro e previsível o quadro geral utilizado pela Comissão na análise e decisão quanto à abertura de processos relativamente a diferentes formas de comportamentos de exclusão e ajudar as empresas a avaliarem melhor se um determinado comportamento pode dar azo a uma intervenção por parte da Comissão ao abrigo do artigo 82. . (...) No contexto do objectivo de formulação de orientações relativamente às suas prioridades na aplicação da lei, a Comissão limitar-se-á, na presente fase, a abordar os comportamentos de exclusão e, em especial, determinados tipos de comportamentos de exclusão que, de acordo com a sua experiência, parecem ser mais comuns."
} 
análise dos abusos por exclusão em detrimento dos abusos por exploração, algumas considerações tecidas pela Comissão Europeia sobre o assunto merecem reparo.

Primeiramente, merece menção o caso United Brands, ${ }^{224}$ em que a integração vertical permitia que a UB recebesse carregamentos de banana sendo os preços estabelecidos para os diferentes distribuidores nacionais em função de cada país, por conta de diferente elasticidade de procura entre os diferentes mercados regionais. A discriminação de preços nos diversos países levava ainda em conta a proibição de arbitragem, na medida em que os distribuidores deveriam amadurecer as bananas, não conseguindo, assim, exportá-las para os demais países. Entre a Irlanda e Dinamarca, por exemplo, havia variação de $138 \%$ no preço. A Comissão considerou, portanto, que os preços cobrados na Alemanha, Dinamarca e Benelux eram excessivos em face do valor econômico do produto fornecido. A comparação com a lucratividade dos preços praticados na Irlanda trazia indícios de preços excessivos em outras localidades.

O Critério elencado pelo Tribunal exigia análise dupla: em primeiro lugar a relação entre custo e preço deveria revelar uma desproporção excessiva; depois deveria considerar-se se o preço era excessivo ou não, olhando-se o próprio produto ou através de uma análise comparativa com produtos concorrentes. Na Europa, ainda se permitia olhar os preços praticados nos diversos Estados-Membros como medida comparativa de eventual desproporcionalidade. Ao que percebemos, os ideais de fortalecimento do mercado interno europeu justificariam a análise, facilitando até mesmo os padrões de avaliação da conduta.

Em outro caso julgado pela Comissão Europeia, que envolvia sociedades gestoras de direitos de autor, vislumbravam-se tabelas de taxa de reprodução mecanográfica da SACEM sensivelmente superiores às tabelas que vigoravam em outros Estados-Membros, com base em pesquisas feitas pela Comissão Europeia. ${ }^{225}$ As justificativas objetivas apresentadas incluíam a existência de duas taxas cobradas na França, o que não ocorria nos demais países da União, e desenvolvimento de certo laxismo na cobrança por parte de outros Estados-Membros. O Tribunal de Justiça, neste caso, fez uma análise da organização da sociedade para chegar à conclusão de sua ineficiência, o que seria possível no caso de empresas detentoras de direitos especiais e exclusivos.

Até o caso Microsoft de 2008, a Comissão pareceria ter abandonado qualquer tentativa de proibição de preços excessivos, conforme se verá adiante. A Comissão parece,

\footnotetext{
${ }^{224}$ Acórdão do Tribunal de Justiça de 14.2.1978, Proc. 27/76, United Brands c. Comissão, Colect. 1978.

${ }^{225}$ Acórdão do Tribunal de Justiça de 13.7.1989, Procs. apensos 110/88, 241/88 e 242/88, Lucazeau e o. c. SACEM, Colect. 1989.
} 
assim, ter por regra a reserva de sua discricionariedade para não aplicação do Tratado quando perceptível que preços excessivos atrairão nova entrada. Contudo, nunca se isentou de exercer pontualmente pressões no sentido da redução de preços em caso de elevado impacto na opinião pública, como ocorrido em Visa International. ${ }^{226}$

No caso Microsoft, ${ }^{227}$ que envolvia royalties considerados excessivos, dentre outras condutas, a Comissão qualificou como requisito para que uma remuneração pudesse ser considerada razoável que a mesma fosse justificada mediante a comprovação da possibilidade de concorrência viável com o sistema operativo da Microsoft para servidores, e que constituísse uma compensação adequada pelo valor da tecnologia transferido. Assim, a Microsoft não poderia se valer do fato de ter se tornado sua tecnologia incontornável, resultando em seu domínio enquanto padrão de fato, para auferir remuneração abusiva.

Nesta linha, conforme mais bem explorado adiante, a discussão parece merecer ainda mais destaque quando envolve direitos de propriedade intelectual e criação de padrões, com o necessário licenciamento de tecnologias para que concorrentes possam, efetivamente, fazer parte do processo competitivo estabelecido por referidos padrões.

Em resumo, e como será verificado indiretamente ao longo do presente trabalho, pode-se dizer que os casos que têm sido trazidos por autoridades de defesa da concorrência e que desafiam preços reputados excessivos, via de regra, são acompanhados por outras modalidades de abuso que explicitam uma teoria excludente.

Ressalva se faça somente no tocante à aplicação da regra do mercado comum da política europeia, que traz incentivos não verificados em outras jurisdições, legitimando maior repressão direta de preços excessivos decorrentes de práticas capazes de ameaçar esta vertente de proteção do Tratado.

\subsubsection{Espécies de Condutas Excludentes e Tratamento Emprestado}

Comportamentos de exclusão implicam práticas comportamentais voltadas imediatamente às garantias institucionais de concorrência, de forma a preveni-las, limitálas ou expurgá-las, atingindo de forma mediata o próprio consumidor que se vê alijado de suas opções consumeristas. Aqui vale citar a venda casada, exclusividade negocial, recusa

\footnotetext{
${ }^{226}$ A decisão de 2002 obrigava a Visa International a reduzir progressivamente as comissões interbancárias multilaterais europeias supletivas para uma taxa máxima de 0,7\% até 2007. Decisão da Comissão Europeia, de 24.7.2002, COMP/29.373, Visa International - Comissão Interbancária Multilateral, J.O. L 318, de 22.11.2002, p. 17.

${ }^{227}$ Vide capítulo 7.2.2.
} 
de contratação, discriminação, preços predatórios, marketing predatório ou excessivo, aumento de capacidade produtiva, exploração de patente, recusa de contratação, estreitamento ou redução de margem, bem como quaisquer outras formas de aumento de custo de rivais, criação de dificuldades às suas operações ou fechamento de mercado à concorrência. Não somente devemos considerar aqui efeitos diretos à concorrência já existente, mas também à concorrência potencial.

Desta forma, a cada modalidade de prática abusiva vislumbramos um padrão restritivo maior ou menor para a operação do agente dominante. A análise das responsabilidades especiais baseadas nas condutas excludentes é o foco do presente estudo. Para tanto elencamos cinco modalidades de abuso de posição dominante a serem endereçadas, de forma a avaliarmos o tratamento que tem sido dado pela doutrina e jurisprudência, comparativamente nas três jurisdições que propomos estudar. As modalidades tratadas abaixo são recusa de contratação, venda casada, preços predatórios, desconto de fidelidade e exclusividade.

A escolha das espécies de conduta baseou-se naquelas práticas que são atualmente consideradas como as mais polêmicas e, ao mesmo tempo, as de maior incidência e riqueza de decisões sob o prisma das condutas unilaterais.

\subsubsection{Recusa de Contratação}

Recusas de contratação podem se dar segundo as mais variadas circunstâncias, caracterizando ou não infração à ordem econômica. Podem ser analisadas sob a luz de situações de relação comercial preexistentes ou em situações de promoção de novo produto ou serviço, por empresas que detenham parcela de mercado de maior ou menor relevância, prejudicando indiretamente clientes ou consumidores ou ainda promovendo incentivos ou desincentivos a inovações tecnológicas. Os efeitos decorrentes das condutas negativas de prestação positiva - deixar de fornecer produto ou prestar serviço - devem assim ser analisados sob o contexto que se apresentam a fim de avaliarmos os casos de reais abusos de posição dominante.

O desenvolvimento de uma teoria própria acerca do que se constituiria como infraestrutura essencial não duplicável ao desenvolvimento ou operação no mercado vem no sentido de trazer maior objetivação daquela que seria a responsabilidade especial reconhecida a um agente dominante nesta modalidade de abuso. 
Destarte, a recusa de contratação pode configurar abuso de posição dominante na medida em que determinado agente econômico recuse-se a fornecer, interrompa o fornecimento ou recuse-se a outorgar licença para exploração de um bem quando a parte interessada possuir, de alguma maneira, relação de dependência econômica perante o agente monopolista. Reconhecemos que tais condutas são mais comumente verificadas em mercados de monopólios naturais ou mercados em que a situação de dominância possui razões estruturais, como aqueles envolvendo redes de duplicação inviável.

Trata-se de espécie de abuso que talvez traga a maior resistência intuitiva ao seu conceito e efeito, visto que sua aplicação pode implicar restrição aos princípios da liberdade de iniciativa e da autonomia de vontade das partes. Contudo, cabe lembrar que uma recusa em contratar pode, por outro lado, ferir outro princípio constitucional que merece igual valoração: o princípio da livre concorrência. Negar-se acesso a uma infraestrutura essencial, à prestação de um serviço ou à manufatura ou venda de um produto pode ferir a livre concorrência sob a perspectiva de um novo entrante no mercado.

Na nova Lei n. 12.529/11, a conduta vem tipificada no seu artigo 37, inciso XI: "recusar a venda de bens ou a prestação de serviços, dentro das condições de pagamento normais aos usos e costumes comerciais."

Vale analisar as situações típicas em que se coloca o tema. Primeiramente, nos parece menos controverso concluir acerca da responsabilidade especial incidente sobre um agente econômico que se tornou monopolista como resultado de um processo de desestatização e que detenha acesso exclusivo a determinado bem de produção. Aqui parece mais clara a utilidade pública desempenhada por aquela empresa previamente, qualificação que não deve desaparecer com o processo de privatização. Assim, as responsabilidades especiais fundadas na função social da propriedade destes bens de acesso, que antes eram reconhecidas ao Estado, devem permanecer com o agente privado.

Intuitivamente esta responsabilidade especial deveria ser regrada de forma preventiva, na própria regulação que deve anteceder o processo de desestatização, devendo constituir-se como cláusula de compromisso no processo licitatório. Sob a ótica da regulação, tais responsabilidades especiais seriam os compromissos de interconexão e os compromissos de acesso universal.

Contudo, ainda que por alguma razão não sejam as considerações acima tratadas de forma preventiva em regulação, não escapa ao direito concorrencial o dever de agir no caso concreto para correção da falha de mercado verificada, determinando assim remédio 
comportamental ou mesmo estrutural. A imposição do dever de contratar de forma não discriminatória seria um exemplo desta primeira modalidade.

No que tange a relações contratuais diversas, fora do contexto, portanto, da desestatização de bens públicos, demonstrar-se o intuito excludente de uma recusa de contratação inicial é sempre mais complexo do que demonstrá-lo diante de uma situação de interrupção abrupta injustificável de uma relação contratual preestabelecida. Aqui, vale dizer, tratamos menos da limitação dos princípios da liberdade de iniciativa e da autonomia da vontade e mais do princípio da força obrigatória dos contratos. O ponto central no caso de recusa de nova relação contratual, portanto, é demonstrar que o comportamento se insere dentro de um planejamento empresarial destinado a eliminar a concorrência.

Para análise da configuração de abuso, as justificativas econômicas utilizadas pelo agente dominante devem prevalecer sobre seus efeitos anticoncorrenciais, como, por exemplo, a exclusão ou aumento dos custos de operação do agente dependente quando da interrupção de fornecimento de matéria-prima. Já no caso de fornecimento ou acesso a novos clientes, a matéria é ainda mais controversa, sendo certo que as hipóteses de aplicação da teoria do abuso devem ser ainda mais limitadas que as primeiras, apenas quando a matéria-prima seja indispensável para a nova empresa operar em um mercado à jusante.

Neste contexto surge também a teoria das infraestruturas essenciais, conhecida como "essential facilities", que segundo Richard Whish pondera:

\footnotetext{
T] he idea is that there are some facilities that firms must have access to if they are able to compete in a downstream market. (...) The term essential facility is particularly apt where an undertaking seeks access to a physical infrastructure such as a port, airport, railway network or a pipeline. ${ }^{228}$
}

Bem como visto acima, as discussões acerca das infraestruturas essenciais e potenciais recusas abusivas à contratação podem surgir no contexto de acordos entre concorrentes, no plano de sua formação - uma das questões a se analisar seria se as empresas não poderiam ter desenvolvido o ativo em concorrência - e no plano de seu funcionamento - uma das perguntas seria quais empresas fariam parte do acordo e quais estariam de fora, sendo o acesso limitado aos membros. Pode ainda surgir no contexto das análises de concentrações, em que medidas podem ser impostas para se corrigir o problema. E por fim, podem se dar no âmbito das condutas unilaterais, onde uma ou mais

${ }^{228}$ WHISH, Richard. Competition Law, cit., p. 691. 
empresas deteriam, por exemplo, posição dominante em mercados a montante e poderiam usar da recusa ou imposição de condições não isonômicas para diminuição do grau de concorrência no mercado a jusante.

Recusas de fornecimento de licenças de propriedade intelectual ou informações relativas à interoperabilidade de produtos a terceiros podem configurar recusa de contratação por parte do agente dominante. Ainda, preços abusivos ou imposição de "estreitamento de margens" no fornecimento para empresa operante em mercado a jusante podem configurar espécie de recusa de contratação construtiva, segundo a doutrina moderna.

Assim, há situações em que quebras ou denúncias contratuais surgem em vista de tornar-se ineficiente para empresas dominantes o fornecimento de matéria às empresas economicamente dependentes. Ao extremarmos, citemos o exemplo de empresa cuja receita marginal para determinado produto se torne inferior ao seu custo marginal de produção, em função de alterações estratégicas comerciais da empresa.

Portanto, justificativas econômicas suscitadas pelos agentes dominantes, a exemplo do quanto acima citado, devem ser levadas em consideração pelas autoridades concorrenciais na análise de condutas supostamente ilícitas. Algumas destas justificativas econômicas reiteradamente utilizadas e que, via de regra, corroboram com a licitude desta prática, seriam a duvidosa capacidade de pagamento do consumidor, sua eventual insuficiência de estoque, ou mesmo interrupção inesperada e momentânea de produção por fatores externos ao seu controle. Tais justificativas funcionariam como um fator de limitação às responsabilidades especiais que atingem os agentes econômicos.

Assim, no que tange a esta modalidade de conduta, a questão que se coloca visa a criticar, e consequentemente apurar, os limites de atuação da autoridade concorrencial em vista do embate ineficiência produtiva e alocativa do agente dominante versus dependência econômica de outros agentes econômicos.

\subsubsection{Venda Casada}

A conduta praticada por empresa dominante visando obtenção de vantagem em mercados relacionados pode ser considerada abusiva aos olhos do direito concorrencial. Ao lado da prática de preços predatórios, talvez seja esta uma das modalidades mais controversas do direito da concorrência. Envolve dois ou mais mercados, sendo que a 
conexão pode resultar da sua articulação vertical ou da complementariedade entre dois produtos ou serviços. A conduta de uma empresa dominante de condicionar a aquisição de um produto "subordinante" à de outro produto "subordinado" pode assumir várias formas.

A subordinação ou tying, que se configuraria, segundo as Orientações da Comissão sobre Restrições Verticais: “(...) quando o fornecedor condiciona a venda de um produto à compra de outro produto distinto por parte do fornecedor ou de alguém por ele nomeado", pressupõe que o consumidor possa ainda adquirir o produto subordinado sem adquirir necessariamente o subordinante. ${ }^{229}$

Por sua vez, práticas de bundling, ou pacote de vendas, podem ser classificadas como bundling puro, em que o fornecedor limita-se a vender os dois produtos em pacote, sem disponibilizá-los de forma separada; ou ainda bundling misto, em que ambos os produtos são disponibilizados de forma separada, mas são também vendidos em pacote a um preço inferior à soma de seus respectivos preços individualizados. Assim, enquanto no primeiro haveria elemento de coação, no segundo haveria incentivo econômico à aquisição conjunta. $^{230}$

Trabalhos de Adams e Yellen demonstram que uma estratégia de bundling pode ser justificada mesmo na ausência de reduções de custos ou de complementariedade do consumo. ${ }^{231}$ Já Nalebuff indicava um conjunto de efeitos anticompetitivos decorrentes das práticas de mixed bundling: criação de obstáculos artificiais à entrada, aumento dos custos dos concorrentes, redução dos lucros dos concorrentes, vantagens através de ganhos de eficiência, extensão do poder de mercado, proteção de posição dominante no mercado principal, compromissos para dissuadir novas entradas no mercado, ocultação do preço, tornando mais difícil a escolha dos consumidores.

Há preocupação dúplice em jogo, que implicaria a tutela da livre escolha do consumidor de um lado e na tutela da garantia institucional da concorrência e da prevenção à criação de dificuldades ou encerramento de oportunidades à operação dos agentes de mercado. Enquanto a primeira preocupação encontra-se objetivada no Código de Defesa do Consumidor, que prevê sanções para as práticas de venda casada, ${ }^{232}$ o intuito de dominação

\footnotetext{
${ }^{229}$ Comunicação da Comissão (O.J. [2000] C 291/1).

${ }^{230}$ Neste sentido define ainda a doutrina estrangeira que se transcreve: "the seller conditionally or absolutely denies a product or service (the tying product) unless the buyer also purchases another product or service (the tied product)" (SULLIVAN, Lawrence A.; GRIMES, Warren S. The Law of Antitrust. An Integrated Handbook, cit., p. 387).

${ }^{231}$ ADAMS, William James; YELLEN, Janet L. Commodity Bundling and the Burden of the Monopoly, Q.J. of Econ., vol. 90, n. 3, 1976, p. 475.

${ }^{232}$ NALEBUFF, Barry J. Bundling, Tying, and Portfolio Effects. Department of Trade and Industry Economics Paper n. 1, 2003.
} 
de mercado encontrado na segunda preocupação mencionada reputa-se como o elemento de jurisdição das normas de defesa da concorrência.

Questão bastante controversa que se coloca, e por vezes central, vem no sentido de avaliarmos se os produtos objeto do bundling ou tying constituiriam produtos separados ou único produto. Ainda, no bundling é mais forte a tese de que possam existir eficiências ou benefícios econômicos aos consumidores como resultado da integração.

Tais situações de "tying" e "bundling" são tratadas no Brasil de forma agregada como venda casada, que vem tipificada no artigo 37, inciso XVIII da Lei de Defesa da Concorrência: "subordinar a venda de um bem à aquisição de outro ou à utilização de um serviço, ou subordinar a prestação de um serviço à utilização de outro ou à aquisição de um bem."

O questionamento que se traz aqui vem no sentido de identificarmos as situações em que venda conjunta de dois produtos ou serviços deve ser considerada justificada ou abusiva, no último caso, portanto, tendente à dominação de mercado. $\mathrm{O}$ exemplo de venda de sapatos ilustra bem o conceito, na medida em que aqueles consumidores que necessitarem adquirir um único sapato, ao invés do par, deverão arcar com os custos resultantes de venda em separado. Isso porque a venda de um par de sapatos é natural e esperada diante do padrão de consumo do homem médio. ${ }^{233}$

Assim, devemos avaliar dois elementos ao propósito de identificação de uma prática de venda casada: se haveria a presença de um elemento de coerção na aquisição por parte do consumidor, e se haveria o intuito de dominação de mercado - aqui entendido como o planejamento empresarial com vistas à dominação de mercado. Esse planejamento poderia ser objetivado com a criação de substanciais barreiras à entrada de novos agentes e ausência de justificativa econômica plausível para o comportamento. ${ }^{234}$

$\mathrm{Na}$ maioria das vezes estamos diante da análise de produtos acessórios ou complementares. Caso não haja um mercado em separado para tais produtos, não haveria de se falar em coerção, não existindo abuso.

\footnotetext{
${ }^{233}$ Calixto Salomão Filho conceitua que "venda casada não é só aquela em que é obrigatória a compra dos dois produtos em conjunto. Ela também existe quando o preço cobrado pelo produto vendido separadamente é exorbitante, isto é, não corresponde nem aproximadamente ao acréscimo de custo causado ao vendedor pela separação dos produtos. Neste caso a correção não é jurídica, mas sim econômica. O consumidor sente-se constrangido a comprar os produtos em conjunto para evitar o prejuízo decorrente da compra separada do produto que lhe interessa. Não seria assim se o preço cobrado pelo produto em separado for igual aos custos da separação, hipótese em que não haveria qualquer coerção econômica, sentindo-se o consumidor absolutamente livre para adquirir os produtos em separado ou em conjunto, segundo sua utilidade" (Direito Concorrencial - As condutas, cit., p. 225-226).

${ }^{234}$ Idem, ibidem, p. 227.
} 
A lógica racional do agente dominante é a de estender, por via da venda casada, o seu poder de mercado para um produto verticalmente integrado ou com alguma relação com o produto principal, sob o qual não detenha poder de mercado, de forma a possibilitar a imposição de preços monopolísticos aos seus consumidores finais, uma vez atingido seu objetivo de dominação no segundo mercado. Não obstante, frequentes são as circunstâncias em que a venda casada pode trazer benefícios a tais consumidores. ${ }^{235}$

Novamente se coloca o debate acerca da responsabilidade especial imposta aos agentes dominantes, desta vez levando-se em conta o embate entre as eficiências distributivas imediatas reconhecidas na conduta sob comento versus possíveis efeitos anticoncorrenciais gerados no médio ou longo prazo pelos incentivos artificiais criados na relação de consumo. Qual seria, neste sentido, a importância que se deveria dar aos modelos econômicos capazes de simular os efeitos de determinada prática no futuro, na constância e inalterabilidade de suas premissas?

\subsubsection{Preços Predatórios}

O conceito de preço predatório está centrado na ideia de redução temporária de preço final imposto ao consumidor, por parte de um agente dominante, abaixo de certa medida de custo, ocasionando efetiva e imediata perda econômica na prática comercial levada a efeito, com o intuito de excluir do mercado um ou mais concorrentes de forma que o agente dominante possa vir a praticar preços monopolísticos, alcançado o sucesso de sua estratégia excludente.

Neste sentido, o preço predatório não possui racionalidade econômica imediata, na medida em que a estratégia acarreta perdas imediatas para o agente que o pratica. Os neoclássicos pregavam que, não obstante possam se verificar comportamentos estratégicos na predação, esses casos seriam tão marginais que não seria conveniente persegui-los. Some-se a isso a complexidade da produção de provas e os efeitos negativos dos erros de

\footnotetext{
${ }^{235}$ Como exemplo, podemos citar um dos casos mais emblemáticos, recentemente decidido pelas autoridades concorrenciais dos Estados Unidos e da Europa que, vale mencionar, divergiram sobre a aplicação do direito. Tratava-se de inclusão, pela Microsoft, do aplicativo do Media Player no seu software Windows. Segundo argumentos da Microsoft, o programa era disponibilizado a título gratuito ao consumidor, que por conta do benefício gerado deixava de adquirir programa concorrente, que passou a perder participação de mercado. Se por um lado existem argumentos de que o sucesso da estratégia da Microsoft poderia excluir do mercado seu(s) concorrente(s) e, via de consequência, possibilitar a precificação a níveis monopolísticos, segundo a ótica racional maximizadora, por outro lado fora levantado o argumento de que as autoridades de defesa da concorrência estariam impedindo repasse de benefícios imediatos aos consumidores em razão de um exercício de futurologia calcado em modelos econômicos, que sabemos não são, como previstos, constantes e inalterados. Para mais detalhes sobre o caso, vide capítulo VII adiante para mais detalhes sobre o caso.
} 
avaliação sobre as estratégias predatórias - falsos positivos. ${ }^{236}$ Assim, diante da geração de benefícios econômicos imediatos ao consumidor final, ao impor responsabilidades especiais aos agentes dominantes, estariam as autoridades concorrenciais impedindo repasse de benefícios imediatos. ${ }^{237}$

O ceticismo sobre a teoria da predação se baseia em grande escala na análise dinâmica da estratégia, em que a recuperação das perdas incorridas num primeiro momento deveria se dar com ganhos resultantes da imposição de preços monopolísticos num segundo. Novas teorias têm sido adotadas pela doutrina e pela jurisprudência no sentido de flexibilizar este requisito de recuperação dos custos incorridos para a predação, uma vez que nem sempre o comportamento racional fundado na expectativa de recuperação das perdas seria precursor da estratégia predatória. A citar, uma estratégia voltada à construção de uma reputação de predador para a concorrência potencial, mais bem explorada adiante, viria neste sentido.

Conforme já mencionado, o controle daquilo que poderia ser considerado preço predatório é dos temas mais controversos dentro do direito concorrencial. Miguel Moura, em sua obra, comenta: "[p]aradoxalmente, o grande debate doutrinal das últimas três décadas tem sido centrado na questão de saber até que ponto não será a repressão de tais práticas a quimera do antitruste." 238

Com relação à aplicação da teoria da predação, vale mencionar controvérsia que se estende até os dias de hoje no sentido de se determinar qual a melhor medida de custo de produção para se comparar ao preço de venda do produto ou serviço, a fim de se caracterizar venda abaixo do custo e, via de consequência, abuso de posição dominante por predação.

Areeda e Turner propuseram, em 1975, ${ }^{239}$ que, se o preço se situasse abaixo do custo marginal, poderíamos assumir se tratar de predação, haja vista que a empresa não teria qualquer razão comercial legítima para levar a efeito uma política comercial que lhe impusesse prejuízo imediato, fato que poderia ser evitado abstendo-se de produzir a

\footnotetext{
${ }^{236}$ Falsos negativos ocorreriam diante da crença de que não haveria predação, quando de fato esta ocorresse, e falsos positivos seriam situações em que se acredita na estratégia predatória, porém esta não se verifica.

${ }^{237}$ Neste sentido viria Bork, que considerava a prática de preços predatórios como uma vaga preocupação teórica. A racionalidade desta prática, na sua visão, seria improvável e, portanto, tentativas de proibi-la iriam dissuadir a concorrência da empresa dominante e prejudicar consumidores.

${ }^{238}$ MOURA E SILVA, Miguel. O Abuso de Posição Dominante na Nova Economia, cit., p. 204.

239 AREEDA, Phillip; e TURNER, Donald F. Predatory Pricing and Related Practices under Section 2 of the Sherman Act. Harvard Law Review, Vol. 88, n. 4, 1975, p. 697-733.
} 
quantidade em questão. ${ }^{240}$ Contudo, como reconhecido pelos autores, a medida de custo marginal é de difícil constatação, razão pela qual propõem, alternativamente, a utilização de custo variável médio.

Em seu artigo, Areeda e Turner consideram como um dos pressupostos o sacrifício dos lucros e natureza temporária dos preços e das perdas:

\begin{abstract}
(...) predation in any meaningful sense cannot exist unless there is a temporary sacrifice of net revenues in the expectation of greater future gains. Indeed, the classically-feared case of predation has been the deliberate sacrifice of present revenues for the purposes of driving rivals out of the market and then recouping the losses through higher profits earned in the absence of competition. ${ }^{241}$
\end{abstract}

Segundo Areeda e Turner, a adoção de preço situado imediatamente acima do preço concorrencial, de forma que este seja reduzido ao ponto de desestimular nova entrada ou expansão, não é censurável. Portanto, preços cobrindo somente o custo médio total do monopolista implicariam apenas que agentes menos eficientes deveriam ser excluídos.

Richard Posner sugere uma resposta direta dos consumidores à prática eventualmente levada a efeito de preço predatório; porém, reconhece a utopia de sua sugestão. Ao contrário da Escola de Chicago, acredita que não se pode excluir a possibilidade de predação por conta de sua alegada irracionalidade e sugere manutenção de regra proibitiva da prática. ${ }^{242}$

Ainda, discorda de Areeda e Turner acerca da permissibilidade de preço acima do custo variável médio, propondo que, caso o preço se situe acima do custo marginal - ou custo variável médio - mas abaixo do custo médio total, a análise acerca da predação dependeria das justificativas objetivas e razões para a redução de preços, admitindo que a empresa poderia ter razões legítimas para agir desta forma, suportando o custo marginal e lhe permitindo recuperar parte dos custos fixos. Da mesma forma, preços situados acima do custo médio total nunca seriam considerados predatórios. Assim, alarga o critério criado

\footnotetext{
${ }^{240}$ Isso porque, segundo os modelos econométricos, uma empresa em concorrência perfeita maximiza seu lucro quando preço é igual ao custo marginal - custo de se produção de uma unidade adicional. Assim, nesta situação de custo marginal igual a preço teria sido vendido o último produto possível com lucro. A partir daí todo produto a mais produzido geraria resultado negativo, visto que curva de preço é decrescente em relação à quantidade, e a curva de custo marginal crescente.

${ }^{241}$ Segundo ainda Miguel Moura: "Aqui se encontra a base do critério da recuperação das perdas, cuja prova deve ser feita por quem alega a existência de uma infracção ao artigo $2^{\circ}$ do Sherman Act, enquanto tal prova é a dispensada na jurisprudência comunitária" (MOURA E SILVA, Miguel. O Abuso de Posição Dominante na Nova Economia, cit., p. 210).

${ }^{242}$ POSNER, Richard. Antitrust Law. 2. ed. Chicago e Londres: The University of Chicago Press, 2001.
} 
por Areeda e Turner para estender à regra proibitiva preços situados entre custos variáveis médios e custo médio total. ${ }^{243}$ Segundo a linha adotada por Posner, só deveriam ser considerados ilícitos os comportamentos suscetíveis de eliminar concorrentes tão eficientes quanto a empresa dominante.

As preocupações acerca de uma teoria sólida sobre práticas de preços predatórios trazem o receio de que uma regra restritiva limitaria a concorrência por parte das empresas monopolistas. Deve-se levar em conta ainda o fato de consumidores se beneficiarem, mesmo que temporariamente, das reduções de preços.

Em resumo, a teoria econômica tem asseverado, em suas expressões mais modernas e de forma complementar, que preços predatórios estariam condicionados a um nível inferior ao custo marginal, ou ainda custo variável médio em razão das dificuldades de encontrar o custo marginal. Da mesma forma, preços acima do custo médio total restariam legitimados, ainda que lesem concorrentes menos eficientes. Práticas de preços situadas entre custo médio total e custos variáveis médios poderiam representar um problema à concorrência na medida em que prejudiquem concorrentes tão eficientes, devendo-se avaliar a intenção predatória do agente.

Legitimação excluída por Areeda e Turner viria com relação ao argumento de que prática de preços inferiores a qualquer nível de custos poderia ser justificada quando implementada em resposta à redução de preços por um concorrente que igualmente o faz abaixo de seu custo. $\mathrm{O}$ ato do concorrente seria lícito e constituiria concorrência no mérito, sendo que o concorrente teria razões legítimas para a prática de preços promocionais - que poderia, por exemplo, ser mais vantajosa que investimento em publicidade. ${ }^{244}$

Outros ainda propuseram critérios de análise levando em conta outros fatores. Assim, Scherer e Williamson propuseram um critério alternativo conhecido como "output increase rule", que implicava no fato de a empresa dominante aumentar produção substancialmente durante o período de um ano ou um ano e meio, sendo considerada tal conduta predatória. Já Baumol propôs qualificar preço predatório segundo um critério verificável a posteriori - haveria preço predatório caso a prática levasse à saída de um concorrente, sendo posteriormente aumentado pelo monopolista. ${ }^{245}$

Finalmente, Bolton, Brodley e Riordan empregam critério finalístico para conceituar preço predatório, propondo que sejam demonstrados os seguintes requisitos a

\footnotetext{
${ }^{243}$ POSNER, Richard. Antitrust Law, cit.

${ }^{244}$ MOURA E SILVA, Miguel. O Abuso de Posição Dominante na Nova Economia, cit., p. 212.

${ }^{245}$ Idem, ibidem.
} 
fim de se caracterizar a prática de preços predatórios: (i) comportamento verificado em mercado cuja estrutura facilita o sucesso da estratégia predatória (caracterizado por elevados obstáculos à entrada, poder de mercado e assimetria substancial entre os concorrentes, por exemplo); (ii) estratégia predatória condizente com a teoria, corroborada por fatos; e (iii) provável recuperação das perdas. Ainda, com relação ao último teste, propõem certa flexibilização do critério: a depender da suficiência de elementos que comprovem a recuperação de perdas, sendo esta elevada, admitir-se-á menor exigência quanto à prova de uma estratégia viável, podendo ser esta presumida a partir dos elementos de prova da recuperação; caso, contudo, a teoria da estratégia reste fortemente demonstrada, a exigência com relação à prova da recuperação de custos deveria ser menos exigente. Caso sejam ultrapassados os três elementos de análise, o preço abaixo de certa medida de custo passaria a ser analisado, propondo para tanto o custo evitável médio em lugar dos custos variáveis médios, sendo a licitude estabelecida para preços acima do custo incremental médio de longo prazo em substituição ao custo médio total. ${ }^{246}$

Inegável reconhecer-se que a prática de preços predatórios em situações que mereçam reprovação jurídica é rara, sendo a pergunta que se faz se esses tipos de práticas devem realmente ser proibidos, ainda que a conduta implique comportamento economicamente irracional, por serem socialmente reprováveis. Neste sentido, importante mencionar o pensamento de Posner, que reconhece certa medida de irracionalidade na mente humana e sugere que isso seja levado em conta. A pergunta, portanto, passa a ser como se postular regra que leve em conta e evite erros tipo 1 e 2 . Da mesma forma, reconhece-se a centralidade de um critério relacionado a medidas de custos.

No tocante à configuração do abuso de posição dominante por prática de preços predatórios, a doutrina tem disciplinado que os seguintes requisitos devem ser observados: (i) o comportamento ocorre em mercado cuja estrutura facilita o sucesso da estratégia predatória, portanto presentes condições de elevadas barreiras à entrada, elevada participação de mercado e assimetria de participação com relação aos concorrentes, por exemplo; e (ii) prova da estratégia predatória. Já com relação ao elemento de comprovação de provável recuperação de perdas, verificamos acentuada divergência na doutrina e jurisprudência acerca da imprescindibilidade deste elemento. Isso porque a recuperação pode se fazer de diversas formas, não necessariamente econômicas, como a criação de uma reputação de "crazy firm", ou seja, a louca empresa que está disposta a arriscar seus lucros

\footnotetext{
${ }^{246}$ MOURA E SILVA, Miguel. O Abuso de Posição Dominante na Nova Economia, cit., p. 227 e ss.
} 
e sua sobrevivência para proteção de seu mercado. Também esta recuperação pode se dar em outros mercados, na medida em que uma reputação construída para um de seus mercados de atuação pode prevenir entrada em outros que a empresa atue.

No que tange à prova da estratégia, deve-se levar em consideração qualquer material que revele a existência de um planejamento empresarial direcionado à eliminação da concorrência, podendo ainda haver presunção desta estratégia com base em dados objetivos que indiquem sua existência. Aqui, não obstante a teoria dos comportamentos estratégicos fornecer excelente instrumento, o padrão mais genérico para tal verificação viria no sentido do bom senso negocial, que prega pela exclusão de qualquer conduta empresarial que vise ao prejuízo. ${ }^{247}$

Adaptando-se a teoria aos requisitos do ordenamento jurídico brasileiro, além da necessidade de avaliação de preço abaixo das medidas de custo discutidas, faz-se necessário demonstrar, em linha com a condição acima apresentada, que a estratégia traria a real possibilidade de eliminação do concorrente do mercado.

Da mesma forma, se faz necessário dividir a análise em dois cenários: a exclusão de concorrentes já estabelecidos e as barreiras impostas para entrada de novo concorrente. Assim, ao passo que já tratamos da primeira hipótese acima, caberia elucidar que não seria conveniente comparação de preços e custos para novos entrantes. Interessante nesta segunda situação seria a aplicação de um critério semelhante proposto por Scherer e Williamson, que trata da quantidade ofertada ao mercado. Ou seja, diante de nova entrada, o agente monopolista poderia aumentar sua quantidade ofertada ao mercado, reduzindo consequentemente o preço de seu produto, predando o novo concorrente. ${ }^{248}$

${ }^{247}$ SALOMÃO FILHO, Calixto. Direito Concorrencial - As condutas, cit., p. 177 e ss. Aqui seria ainda importante, para verificação do bom senso negocial, comparar-se a estratégia levada a efeito pelo empresário com aquela que lhe seria conveniente negocialmente. Segundo Calixto, ainda: "[o] bom senso negocial, que também evidencia, a contrario sensu, a lealdade da conduta, é determinado por um método eminentemente comparativo. É preciso comparar a conduta praticada com aquela que seria efetivamente conveniente para o empresário."

${ }^{248}$ Interessante notar algumas teorias que podem fundamentar estratégias predatórias. Primeiramente, a teoria do "deep pocket" é bastante utilizada no sentido de que uma empresa ou grupo econômico com intuito predatório deverão ter maior recurso financeiro do que seus concorrentes-alvo. Esta teoria seria questionada pela nova fundamentação de que não importa uma comparação entre os recursos das empresas envolvida, mas sim o impacto da campanha predatória na relação entre a vítima e seus investidores. Aqui, contudo, a teoria de predação dos mercados financeiros - "financial market predation theory" - defenderia a possibilidade de o próprio predador tirar proveito das imperfeições dos mercados financeiros, fazendo com que o apoio financeiro seja retirado à vítima devido ao mau desempenho resultante do baixo preço e consequente diminuição do volume de negócios. Outras teorias ainda consideradas, para fins de abrangente compreensão do tema, recorrem a mecanismos de comunicação informal. Neste sentido a estratégia predatória visando efeitos de reputação: racionalidade da prática advém da criação de uma reputação no sentido de que a empresa dominante irá sempre responder a qualquer ameaça de entrada com reduções substanciais de preços. Ainda a teoria da comunicação dos custos, em que a empresa dominante pode reduzir o preço para transmitir ao novo concorrente que dispõe de uma estrutura de custos muito mais eficiente, 
Com relação especificamente aos temas mais ligados à nova economia, podemos vislumbrar de predação tecnológica. Aqui podemos citar a predação por inovação, que seria a introdução de inovações tecnológicas com o objetivo de eliminação da concorrência. Também a predação pela incompatibilidade de sistemas, que será discutida adiante em mais detalhes. ${ }^{249}$

\subsubsection{Descontos de Fidelidade}

Outro tema disseminador de grande intranquilidade para a comunidade empresarial são os descontos de fidelidade, pelo que se pretende, ao longo do presente trabalho, analisar sistematicamente as censuras que têm sido aplicadas pelas autoridades concorrenciais diante de descontos promovidos por agentes econômicos segundo suas políticas comerciais.

Descontos de fidelidade são benefícios comerciais diretos ou indiretos ofertados pelas empresas com o propósito de fomentar consumo de seus produtos ou serviços em detrimento de seus concorrentes, segundo fatores que margeiam sua eficiência. De forma mais técnica, podemos ainda dizer, conforme definido pela Comissão Europeia no caso Hoffmann-La Roche v Commission, ${ }^{250}$ que tratam de descontos condicionados à escolha do cliente para obtenção de toda, ou da maior parte, de suas necessidades, do agente em posição dominante, independentemente de sua quantidade adquirida ser grande ou pequena. Os descontos de fidelidade funcionariam de forma semelhante a contratos de compra exclusiva quando seus incentivos forem significativos.

Contudo, não obstante orientação dos tribunais europeus de que tais descontos devam ser tratados sob uma perspectiva de ilícito per se, faz-se necessário, em especial aos olhos do ordenamento jurídico brasileiro, que como sabemos, não admite regras per se de condenação, análise acerca dos efeitos deste desconto no mercado, ainda que

levando à saída prematura deste. Para que seja crível é necessária a ocorrência de algum evento - anúncio de nova tecnóloga, por exemplo. Devemos citar ainda a estratégia predatória de atuação em mercado de ensaio, onde a redução de preços pelo predador tem a finalidade de impedir que o novo concorrente - em fase de ensaio de entrada - obtenha informações corretas sobre as reais condições do mercado, em particular quanto ao comportamento da procura. Neste sentido vide MOURA E SILVA, Miguel. O Abuso de Posição Dominante na Nova Economia, p. 233 e ss; SALOMÃO FILHO, Calixto. Direito Concorrencial - As condutas, cit., p. 180 e ss.

${ }^{249}$ Vide SALOMÃO FILHO, Calixto. Direito Concorrencial - As condutas, cit., p. 185 e ss.

${ }^{250}$ [1979] ECR 461, [1979] 3 CMLR 211, para 89. 
potencialmente. ${ }^{251}$ Assim, inicialmente discutimos se deveriam ser punidos descontos que ficassem acima das medidas de custo consideradas para casos de preços predatórios.

Ainda que verifiquemos que o preço final praticado, após consideração dos descontos, situa-se acima do custo variável médio do agente monopolista, cálculo de difícil e impreciso resultado em razão das diversas variáveis que incorrem, pode haver questões outras a serem consideradas pelo consumidor e que poderiam guiá-lo a uma situação de exclusão da concorrência. Isso porque devemos reconhecer que nem sempre o comportamento racional deve ser esperado não somente por parte dos agentes econômicos, mas principalmente por parte dos consumidores, para quem os problemas de assimetria de informação são ainda mais relevantes, e os apelos emocionais ainda mais reconhecidos, com mais pesar em determinados mercados.

Portanto, ainda que possamos verificar, o que será feito adiante, que na maioria das análises levadas a efeito pelas autoridades o que se considera seriam critérios objetivos de custo para avaliação dos efeitos anticoncorrenciais, até onde esta análise objetiva deve ser considerada em detrimento de outras variáveis? Deveriam incentivos sinalizados ao consumidor reputarem-se como critério para avaliação dos efeitos da conduta, visto que podem de fato apresentar efeito de perpetuação da exclusividade?

Neste sentido dispõe Richard Whish:

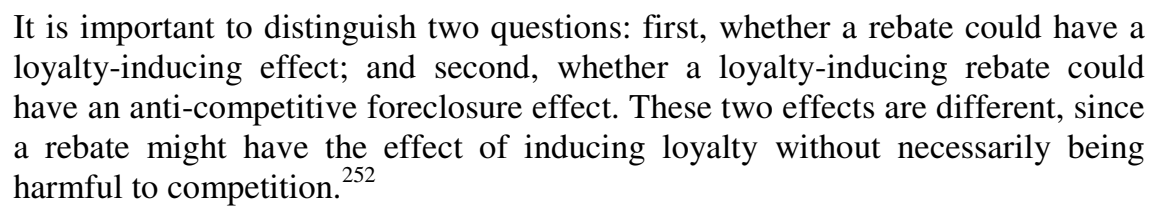

Portanto, pretendemos avaliar, sob a ótica do sistema jus-concorrencial pátrio, o limite para a atuação de agentes econômicos com posição dominante no que tange às práticas de descontos de fidelidade, verificando-se em quais circunstâncias trariam efeitos deletérios à garantia institucional da concorrência.

Inicialmente, temos que os descontos de fidelidade podem ser divididos em (i) descontos sobre cestas ou pacotes de produtos; (ii) descontos condicionais sobre produtos únicos; e (iii) descontos incondicionais sobre produto único - que podem ser seletivos ou não.

${ }^{251}$ Admite-se recente julgado que trata da condenação de ilícitos por objeto, que com as devidas particularidades reconhecidas, se aproxima um pouco da perspectiva per se. Vide capítulo 6.10 para mais detalhes.

${ }^{252}$ WHISH, Richard. Competition Law, cit., p. 723. 
Interessante a visão do "Discussion Paper" europeu de como se deve dar a análise relacionada a critérios objetivos de custos. Circunstâncias em que concorrentes igualmente eficientes seriam capazes de ofertar todos os produtos da cesta ou somente um dos produtos da cesta suscitam discussão de como se fazer a análise de predação - se com relação ao custo de toda a cesta ou se com relação ao custo do produto competitivo da cesta. $^{253}$

O racional dos descontos de fidelidade em situações reconhecidamente predatórias por certo se confunde com o racional da própria prática de preços predatórios, em que se pretende a oneração da concorrência a patamares excludentes de sua atuação no mercado. A partir daí poderia cogitar, o agora monopolista, revogação dos descontos e precificação a níveis monopolísticos para que haja recuperação das perdas incorridas.

Por certo que o sucesso da estratégia dependerá da contestabilidade do mercado. Se após o aumento de preços por parte do monopolista forem criadas oportunidades de mercado tais que atraiam novos entrantes, ausentes barreiras à entrada, a possibilidade de sucesso da estratégia reduz-se. Assim, relevante se faz a análise da dinâmica concorrencial dos mercados em questão e da probabilidade de nova entrada. Poderíamos até mesmo cogitar tratar-se de barreira à entrada a reputação predatória do agente monopolista que, ameaçado, reintroduz os descontos espantando a entrada.

Não se pode, contudo, deixar de reconhecer que, na linha da teoria dos preços predatórios, descontos de fidelidade geram benefícios diretos no curto prazo ao consumidor, o que traz à tona novamente preocupação com os erros tipo 2 e as formas de mitigação destes problemas verificados.

\subsubsection{Exclusividade}

A exclusividade imposta por agente econômico com posição dominante aos seus clientes implica necessariamente a prevenção de contratação dos serviços ou aquisição de produtos de seu concorrente, criando verdadeira reserva de mercado. Trata-se de uma das mais graves limitações que podem ser impostas, confrontando de forma direta o princípio da livre iniciativa. Seria ainda mais séria por objetivar limitação geral e abstrata no mercado, impedindo a contratação com qualquer outra empresa que deseje fazê-lo.

\footnotetext{
${ }^{253}$ DG Comp Discussion Paper on the Application of Article 82 of the Treaty.
} 
Podemos olhar as práticas de exclusividade sob diversos prismas. No tocante a sua vertente upstream, a exclusividade visa impedir o acesso de concorrentes da empresa dominante às fontes de insumo, matérias-primas, equipamentos e tecnologia, dentre outros meios de produção. Já na sua vertente downstream, a exclusividade visa impedir acesso, principalmente, aos canais de distribuição do produto. Em ambos os casos criam-se dificuldades para a atuação ou entrada de concorrentes no mercado.

As eficiências são de vital importância ao tema, na medida em que cláusulas de exclusividade são capazes de reduzir ou eliminar muitas fontes de incerteza do empresário e possibilitar a redução de custos sem que haja concentração econômica. Isso se daria principalmente com a eliminação do free-riding. A penetração em determinada rede de distribuição, que requer para seu estabelecimento e funcionamento relevantes investimentos, seria um exemplo de free-riding que as cláusulas de exclusividade podem limitar, a fim de que não se ressaltem desestímulos a este investimento.

Assim, se faz bastante claro que a teoria das ilicitudes no campo das cláusulas de exclusividade é bastante centrada na ideia de eficiências geradas. Contudo, devem ser consideradas na exata medida em que sejam, ao mesmo tempo, incapazes de promover dominação do mercado, ou seja, exclusão da concorrência. ${ }^{254}$

Portanto, poderíamos considerar alguns dos efeitos concorrenciais das cláusulas de exclusividade, em especial a potencial dominação dos mercados, tornando-se as cláusulas de exclusividade importante barreira à entrada de novos concorrentes. Tais cláusulas podem representar uma séria ameaça aos concorrentes, em especial aos pequenos concorrentes e aos potenciais entrantes no mercado, que terão poucas alternativas para suprir.

Entre os requisitos que devem ser analisados para configuração de uma prática ilícita de exclusividade, ou ainda negociação compulsória, estaria o requisito da coerção, sendo que exclusividade deve ser imposta pelo agente com posição dominante. Da mesma forma deve-se avaliar o objetivo anticoncorrencial de dominação do mercado, o qual ficaria caracterizado diante dos seus requisitos estruturais. Por fim, devem-se avaliar as justificativas econômicas da prática, provando-se as eficiências resultantes destas práticas.

Em estudo publicado por Krattenmaker e Salop, ${ }^{255}$ quatro seriam as hipóteses de exclusão de concorrentes pelos aumentos de custos: (i) criação de estrangulamentos ou

\footnotetext{
${ }^{254}$ SALOMÃO FILHO, Calixto. Direito Concorrencial - As condutas, cit., p. 251 e ss.

${ }^{255}$ KRATTENMAKER, Thomas G.; e SALOP, Steven C. Anticompetitive Exclusion: Raising Rivals' Costs to Achieve Power Over Price. Yale Law Journal 209, 1986.
} 
bottlenecks, mediante a contratação com fornecedores mais eficientes, deixando os menos eficientes para os concorrentes; (ii) exclusão efetiva em que a empresa adquire o controle da maior parte do fornecimento a montante, diminuindo a quantidade disponível aos concorrentes; (iii) cartel ringmaster, organização de cartel de fornecedores contra os seus concorrentes; e (iv) aumento da probabilidade de colusão entre os fornecedores não vinculados, levando-os a aumentar os preços praticados a seus concorrentes. Entre os pressupostos trazidos pelos autores, tem-se que:

\begin{abstract}
A viabilidade de uma estratégia de incremento dos custos dos concorrentes supõe que os mercados em causa devem ser caracterizados por elevados obstáculos à entrada. Quanto ao mercado excluído, esta condição é indispensável para que a conduta da empresa em causa possa ter um impacto suficiente na estrutura da oferta que leve ao aumento dos custos dos restantes produtores; caso a entrada fosse fácil, entrariam no mercado novos fornecedores para responder ao aumento temporário de preços resultante da cativação de parte da oferta. ${ }^{256}$
\end{abstract}

A empresa dominante que persegue a estratégia de exclusão deverá aumentar os seus preços, uma vez que os preços dos concorrentes também aumentam, não podendo verificar-se elevação na produção, vez que anularia os efeitos. Assim, o aumento do poder de mercado estaria nos lucros supranormais. Outro problema apontado por Bork e Posner vem no sentido da necessidade de se levar os fornecedores a aderirem à estratégia de exclusão, apontando que a irracionalidade da conduta residiria na necessidade de dissipação dos lucros supranormais sob a forma de compensação dos fornecedores. Crítica ao modelo seria, portanto, a não consideração dos custos adicionais da empresa dominante com a adesão dos fornecedores. Ainda é pressuposto que os concorrentes não possam contrariar a iniciativa da empresa dominante. ${ }^{257}$

Com base no modelo acima existiria, portanto, uma presunção de lesividade e, consequentemente, ilicitude, contra a empresa dominante no uso de cláusulas de exclusividade. Justificativas objetivas, contudo, seriam possíveis.

\title{
4.3. Guias de Análise de Abuso de Poder
}

É indiscutível a importância dos chamados "instrumentos de soft-law", caracterizados pelas comunicações e guias de análise expedidas pela Comissão Europeia,

${ }^{256}$ MOURA E SILVA, Miguel. O Abuso de Posição Dominante na Nova Economia. Teses de Doutoramento, cit., p. 163.

${ }^{257}$ Idem, ibidem, p. 164. 
pelo Departamento de Justiça dos Estados Unidos e pela Comissão Federal de Comércio dos Estados Unidos. Ao externar as áreas de maior preocupação e foco na aplicação das normas concorrenciais, as autoridades trazem maior segurança jurídica aos administrados na escolha de suas políticas comerciais, ao mesmo tempo em que promove maior compliance resultante de uma sinalização da prática promovida pelas autoridades.

O Brasil, historicamente, pouco tem se preocupado com a expedição destes guias de análise, fato que parece continuar após a promulgação da nova lei. As resoluções e portarias trazidas até então, salvo raras exceções, se preocupam mais em regular procedimentos do que propriamente trazer foco à política concorrencial a ser perseguida pela autarquia. Maior insegurança jurídica, portanto, é verificada no país, ausentes quaisquer sinalizações por parte das autoridades, ainda mais se considerada a falta de um padrão decisório institucional em que possam confiar os administrados.

Em razão da importância reconhecida ao direito concorrencial, pretendemos abordar as orientações de alguns destes guias nesta seção, naquilo que possam contribuir ao entendimento de algumas das modalidades da teoria do abuso de posição dominante.

Primeiramente, ilustramos as disposições encontradas na Comunicação da Comissão que traz orientação sobre as prioridades na aplicação do artigo 102 do Tratado CE a comportamentos de exclusão abusivos. ${ }^{258}$ Vale notar que, antes de sua edição, a Comissão iniciou, em 2005, reflexão sobre a política inerente ao artigo 102 e a forma pela qual deveria aplicá-la, inserida em consulta pública sobre o tema aos administrados. ${ }^{259}$

Tal comunicação não possui natureza de norma legal, mas traz tão somente explicações sobre as prioridades a serem perseguidas pela Comissão na aplicação do artigo. Torna, assim, mais claro e previsível o quadro geral utilizado pela Comissão na análise e decisão quanto à abertura de processos relativamente a diferentes formas de comportamentos de exclusão, ajudando as empresas a avaliarem melhor se seus comportamentos, baseados em suas respectivas políticas econômicas, podem dar azo a uma intervenção por parte da Comissão.

Como apontado por Richard Whish:

The Discussion Paper led to feverish debate as to the proper application of Article 102, in which a broad spectrum of views was expressed, ranging from a staunch defense of the status quo, on the one hand, to demands, on the other, for a radical reorientation of the law of Article 102 that would leave dominants firms

\footnotetext{
${ }^{258}$ Comunicação da Comissão (OJ [2009] C 45/7).

${ }^{259}$ DG Comp Discussion Paper on the Application of Article 82 of the Treaty.
} 
substantially freer from the risk of surveillance by competition authorities and hostile litigation in domestic courts. ${ }^{260}$

Parece, contudo, ter se alcançado senso comum de que o artigo 102 não deveria ser utilizado para a proteção de concorrentes, mas sim da concorrência; que uma empresa dominante se sobrepondo aos seus concorrentes como resultado de sua maior eficiência não deveria ser conduta considerada abusiva; que, apesar da análise econômica bastante complexa, não se trataria de uma área do ordenamento que mereça tratamento formalístico per se; e que uma conduta deveria ser considerada abusivamente excludente quando demonstrado que tal conduta traria, ou teria potencial de trazer, sério efeito anticoncorrencial no mercado. ${ }^{261}$

A Comunicação da Comissão, que na opinião de alguns autores trouxe tratamento mais leniente do que sugeriria o Discussion Paper, começa reconhecendo que a posição dominante não é, por si só, ilegal, e uma empresa nessa situação tem o direito de concorrer no mercado com base nos seus méritos. No entanto, a empresa em causa tem uma especial responsabilidade de não permitir que a sua conduta obste a uma concorrência efetiva e não falseada no mercado interno. ${ }^{262}$

Novamente reconhece a Comissão que o mais importante é a proteção do verdadeiro processo de concorrência, e não a mera proteção dos concorrentes, e que isso poderá significar que os concorrentes que tenham um desempenho inferior para os consumidores em termos de preço, gama da oferta, qualidade e inovação poderão realmente desaparecer do mercado. ${ }^{263}$

Ao contrário do ordenamento brasileiro, a Comissão considera que participações inferiores a $40 \%$ no mercado relevante trazem pouca probabilidade de existência de posição dominante, podendo existir casos específicos a serem considerados. Ainda, quanto mais elevada a participação e quanto mais longo for o período de tempo da conduta, maior será a probabilidade de existência de posição dominante. Deverá haver, contudo, análise da dinâmica concorrencial para a conclusão sobre o tema.

A aplicação do artigo 102 requer que a Comissão, com base em provas sólidas e convincentes, demonstre a probabilidade de que o comportamento alegadamente abusivo deverá conduzir a um fechamento anticoncorrencial do mercado, devendo levar em conta, para tanto, os seguintes fatores: posição dominante da empresa, condições do mercado

${ }^{260}$ WHISH, Richard. Competition Law. 7. ed., p. 175.

${ }^{261}$ Idem, ibidem.

${ }^{262}$ Comunicação da Comissão (OJ [2009] C 45/7), parág. $1^{\circ}$.

${ }^{263}$ Comunicação da Comissão (OJ [2009] C 45/7), parág. $6^{\circ}$. 
relevante (dinâmica), posição dos concorrentes da empresa dominante, posição dos clientes e fornecedores dos meios de produção e amplitude do abuso. Podem se valer de provas indiretas dos efeitos, como variação das participações de mercado da empresa dominante e seus concorrentes, quando provas diretas da estratégia excludente.

A Comissão normalmente deverá intervir a fim de evitar fechamento do mercado para concorrentes considerados tão eficientes quanto o agente dominante. Contudo, em determinadas circunstâncias, um concorrente menos eficiente poderá igualmente exercer uma pressão que deverá ser tida em consideração quando se avalia se determinado comportamento baseado no preço pode levar ao fechamento do mercado. Nestes casos a Comissão deverá adotar perspectiva dinâmica desta pressão visto que, na ausência de prática abusiva, tal concorrente poderá beneficiar-se de vantagens relacionadas com a procura, designadamente efeitos de rede e de aprendizagem, que terão tendência a melhorar a sua eficiência.

Se a informação sugerir claramente que um concorrente de igual eficiência consegue efetivamente concorrer com as práticas de preços da empresa em posição dominante, não será provável que estas tenham um impacto negativo na concorrência.

Devemos ainda considerar que uma empresa em posição dominante pode trazer sua defesa de comportamento objetivamente necessário e ganhos de eficiência que compensem quaisquer efeitos anticoncorrenciais. Nestes casos, segundo a Comunicação, a Comissão irá avaliar se o comportamento é indispensável e proporcional ao objetivo pretendido pela empresa.

Já nos Estados Unidos, o guia publicado pelo Departamento de Justiça em $2008^{264}$ acabou sendo retirado no ano seguinte pela mesma autoridade, sem que outro houvesse tomado seu lugar. As razões para tal retirada baseiam-se no liberalismo supostamente exacerbado do documento.

Previa que o propósito da Seção 2 do Sherman Act seria o de prevenir condutas que prejudicassem o processo competitivo, ao mesmo tempo em que não deveria haver qualquer desencorajamento de concorrência agressiva, seja esta de monopolistas ou de outros concorrentes. Interessante notar os princípios básicos explicitados pelo DOJ no documento em questão, que teriam emergido das decisões dos tribunais e comentários:

\footnotetext{
${ }^{264}$ Competition and Monopoly: Single Firm Conduct under Section 2 of the Sherman Act - Department of Justice (2008) (available at: http://www.justice.gov/atr/public/reports/236681.pdf)
} 
1. Single-firm conduct comes within the scope of section 2 only if the firm possesses, or is likely to achieve, monopoly power.

2. Section 2 does not prohibit the mere possession or exercise of monopoly power.

3. Acquiring or maintaining monopoly power through conduct harming the competitive process should be condemned.

4. Section 2 protects the competitive process but not individual competitors.

5. Distinguishing beneficial competitive conduct from harmful exclusionary or predatory conduct often is difficult.

6. Section 2 standards should prevent conduct that harms the competitive process, but should avoid overly broad prohibitions that suppress legitimate competition.

7. Section 2 standards should be understandable and clear to businesspeople and judges and must account for the possibility of error and administrative costs in their application.

Interessante ainda mencionar o reconhecimento do guia acerca do grande debate existente no mundo antitruste sobre a aplicação da Seção 2. Enquanto acadêmicos do mundo jurídico e economistas revelam que muitas práticas unilaterais presumidamente violadoras do dispositivo podem criar eficiência e benefícios aos consumidores, desenvolve-se mais simpatia para a tese do potencial prejuízo resultante de restrições excessivas unilaterais, particularmente relacionadas aos prejuízos à inovação, mais importante fonte de crescimento econômico. O debate coloca, portanto, diversas perspectivas, desde a criação de regras per se para as condutas típicas da Seção 2 até redução das penas previstas e até mesmo sua revogação.

O documento ainda debate os conceitos de poder de mercado e poder de monopólio, diferenciando-se segundo o entendimento da Suprema Corte. Enquanto o primeiro implica a capacidade de aumentar preços acima do que seria cobrado em um mercado competitivo, o segundo é reconhecido como o poder de controlar preços ou excluir a concorrência. A diferença encontra-se no grau de concentração verificado e consequente capacidade de restringir a contestabilidade do mercado. Importante notar que, no tocante aos níveis de participação em que se reconhece maior probabilidade de poder de monopólio, há reconhecimento de que percentuais menores do que 50\% seriam inadequados para tal reconhecimento. Diversos são ainda os citados mecanismos para mensuração de poder de monopólio, tais como evidências diretas de altos lucros, margens de preço-custo e elasticidade da demanda.

Em termos dos testes a serem aplicados para práticas excludentes, enquanto alguns sugerem único teste aplicado para as mais diversas práticas, outros clamam por testes específicos ou zonas de conforto - "safe harbors" - para determinadas categorias de 
conduta. Os testes gerais mencionados no documento incluem o teste do balanceamento dos efeitos, teste do sacrifício dos lucros, teste da irracionalidade econômica, teste do competidor igualmente eficiente e teste da desproporcionalidade.

O resultado dos debates deixou clara a impressão generalizada de que nenhum deles funcionaria perfeitamente em todas as situações; todos possuem suas virtudes assim como suas falhas. Diferentes tipos de condutas, portanto, mereceriam, segundo o DOJ, diferentes testes, que dependeriam, dentre outros fatores, do escopo do prejuízo resultante da prática, os custos relativos dos falsos positivos, falsos negativos e da aplicação da norma; a facilidade de sua aplicação e outras preocupações administrativas.

\subsection{Introdução às Formas de Defesa Garantidas aos Agentes Dominantes}

Verificada a posição dominante e modelado um abuso por parte de um agente econômico, com perdas reais ou potenciais à livre concorrência e ao bem-estar do consumidor, haverá situações em que tais práticas poderão ser justificadas em razão da sua essencialidade ou geração de eficiências econômicas.

Neste sentido, agentes econômicos dominantes deverão ter sempre à sua disposição, visto que prerrogativa, a oportunidade de justificar de forma objetiva sua conduta, ainda que o façam, como veremos adiante, como resultado de um processo de presunção de efeitos deletérios decorrente da responsabilidade especial que lhe cabe. Para tanto, impõe-se a análise justificadora através de dois passos: (i) a determinação do abuso prima facie; e (ii) a justificação objetiva da conduta ou o balanceamento dos efeitos anticompetitivos com seus efeitos pró-competitivos.

Assim, a defesa dos agentes econômicos com base em justificativas objetivas e geração de eficiências parece ser uma ponderação das autoridades diante da necessidade de moderação na aplicação do artigo 102 para reduzir o risco de resultados não razoáveis ou contraproducentes que venham a conflitar com os objetivos do artigo.

Conforme brevemente verificado na seção anterior, o Comunicado da Comissão dispõe que uma empresa em posição dominante pode trazer sua defesa de comportamento objetivamente necessário e ganhos de eficiência que compensam quaisquer efeitos anticoncorrenciais.

Continua o Comunicado esclarecendo que o comportamento de exclusão pode, por exemplo, ser considerado objetivamente necessário por razões de saúde ou segurança 
relacionadas à natureza do produto em questão. No entanto, a prova de que tal comportamento é objetivamente necessário deverá levar em consideração que compete normalmente às autoridades públicas definir e aplicar as normas de saúde e de segurança. ${ }^{265} \mathrm{O}$ termo utilizado é encontrado em diversas decisões e julgados, ao lado do requisito da proporcionalidade para que haja o reconhecimento da defesa em questão. ${ }^{266}$

A Comissão ainda considera que uma empresa em posição dominante poderia justificar seu comportamento com base em ganhos de eficiência que sejam suficientes para tornar pouco provável um prejuízo para os consumidores, cabendo a ela demonstrar o preenchimento de algumas condições cumulativas. Primeiramente, deve demonstrar que os ganhos de eficiência concretizaram-se, ou é provável que se concretizem, em consequência do comportamento. Segundo, podem levar em conta, por exemplo, melhorias técnicas na qualidade dos bens ou a redução do custo de produção ou distribuição. Terceiro, o comportamento é indispensável para a concretização dos ganhos de eficiência, não podem existir alternativas menos anticompetitivas que permitam produzir os mesmos ganhos de eficiência. Quarto, os prováveis ganhos de eficiência gerados pelo comportamento devem compensar os efeitos negativos sobre a concorrência e bem-estar dos consumidores. E por fim, o comportamento não pode eliminar a concorrência efetiva, através da supressão de todas ou parte das fontes atuais ou potenciais de concorrência. Neste tocante ainda, quando não existir concorrência residual, tampouco ameaça provável de entrada, a proteção da rivalidade e do processo de concorrência sobrepõe-se a possíveis ganhos de eficiência.

Da mesma forma, a defesa das justificativas objetivas pró-competitivas é reconhecida no exercício de aplicação da Seção 2 do Sherman Act, uma vez demonstrado pelo autor da ação, a quem cabe o ônus probatório, que uma determinada conduta prejudica o processo competitivo. Caso tenha sucesso em demonstrar tal justificativa, há novamente inversão de tal ônus para que o autor demonstre a natureza anticompetitiva segundo este padrão.

Já no Brasil a defesa das justificativas objetivas, bem como das eficiências geradas que superam eventuais ou reais efeitos deletérios no mercado também são aceitos, conforme verificaremos mais adiante.

\footnotetext{
${ }^{265}$ Comunicação da Comissão (OJ [2009] C 45/7), parág. 29.

${ }^{266}$ WHISH, Richard. Competition Law. 7. ed., p. 211.
} 


\title{
CAPÍTULO 5 \\ TRATAMENTO COMPARADO DO ABUSO DE POSIÇÃO \\ DOMINANTE: ESTADOS UNIDOS
}

\subsection{Tratamento Normativo Norte-Americano}

\begin{abstract}
Section 2: "Every person who shall monopolize, or attempt to monopolize, or combine or conspire with any other person or persons, to monopolize any part of the trade or commerce among the several States, or with foreign nations, shall be deemed guilty of a felony, [and, on conviction thereof, shall be punished by fine not exceeding $\$ 100,000,000$ if a corporation, or, if any other person, $\$ 1,000,000$, or by imprisonment not exceeding 10 years, or by both said punishments, in the discretion of the court]. ${ }^{267}$
\end{abstract}

A seção 2 do Sherman Act define como prática criminosa a monopolização, tentativa de monopolização, ou ainda a combinação ou conspiração para monopolização de parte do comércio entre estados ou com nações estrangeira. Assim, o entendimento atual das cortes norte-americanas, a exemplo de outras jurisdições, requer a verificação de dois elementos para a caracterização da conduta: a existência de uma situação de posição dominante e a verificação de uma conduta ou de sua intenção.

Neste sentido, o teste articulado em $\operatorname{Alcoa}^{268}$ requer, para a caracterização da monopolização, prova de aquisição ou manutenção premeditada de posição monopolista. Já em United Shoe Machine, ${ }^{269}$ o Juiz Wyzanski elaborou três testes para configuração da monopolização ilegal: (i) o teste clássico de determinar-se se o agente econômico adquiriu monopólio através de conduta que viola, de forma independente, as proibições da Seção 1; (ii) o teste de exclusão, em que se verifica se o agente adquiriu monopólio através de uma conduta excludente ou predatória, objetivamente ou que gerasse tais efeitos; e (iii) o teste prima facie, em que se permitia refutar-se prima facie a conduta ilegal de monopolização em casos que os agentes econômicos empenhassem conduta benigna - como por exemplo sua capacidade superior - para aquisição de monopólio. Por fim, vale mencionar que em Griffith $^{270}$ a Suprema Corte entendeu que o poder de excluir competidores violava a Seção 2 do Sherman Act se combinado com o propósito ou intenção de exercer aquele poder.

\footnotetext{
${ }^{267} \mathrm{O}$ texto original do Sherman Act não previa as penalidades para eventual infração, cuja redação foi incluída posteriormente.

268148 F.2d 416 (2d Cir. 1945).

269110 F.Supp. 296, 342-43 (D.Mass. 1953), aff'd per curiam, 347 U.S. 521, 74 S.Ct. 699, 98 L.Ed. 910 (1954).

270334 U.S. 100, 107, 68 S.Ct 941, 92 L.Ed. 1236 (1948).
} 
Aqui, evidências diretas de intenção da prática poderiam auxiliar a avaliação da eventual infração. $^{271}$

Casos mais recentes envolvendo a Seção 2, contudo, segundo o teste desenvolvido em Otter Trail Power Co. v. United States ${ }^{272}$ e Aspen Skiinf Co. v. Aspen Highlands Skiing Corp., ${ }^{273}$ requerem que o júri determine se o agente econômico praticou conduta excludente ou de outra forma proibitiva considerando: (i) a intenção do monopolista; (ii) o efeito da conduta do agente no representante, nos consumidores e no próprio agente praticante da conduta; e (iii) se o agente teria justificativas negociais baseadas em eficiência para sua conduta. ${ }^{274}$

De vital relevância para a presente tese, no contexto dos testes desenvolvidos pelos tribunais norte-americanos, cabe a observação trazida por Sullivan e Grimes:

\begin{abstract}
Harmful, exclusionary strategies sufficient to violate the conduct test must be distinguished from beneficial or benign competitive methods that will be tolerated even from a monopolist. It is a beginning to say that 'competition on the merits' is protected. The phrase is descriptive, but to vague and susceptible to subjective interpretation to provide a clear rule for distinguishing conduct that should be proscribed under Section 2. A wide variety of marketplace conduct has been challenged under Section 2. Examples include: predatory (below cost) and discriminatory pricing; predatory or excessive advertising, brand introduction, or capacity increases; design manipulation; patent exploitation; foreclosing restraints of numerous kinds; and refusals to deal, price squeeze and leveraging power from one market to another. In evaluating any conduct challenged as unreasonable exclusionary context is crucial. The inquire always involve the rule of reason. Possible harms and benefits must both be identical and gauged. The basic guides are purpose and effect. Given the structural setting and its performance implications, why did the defendant selected this strategy or collection of strategies? What is the likely effect? Will the strategy improve the defendant's product or service, protect or enhance its goodwill, reduce or stabilize its costs? Will the strategy constrain competitors by differentially increasing their costs or foreclosing them from needed resources or outlets? Is adverse impact upon competitors the only or a major factor making the strategy a profit-maximizing for the defendant? If the strategy both harms competitors and gives the defendant additional benefits, could those benefits have been attained in a less restrictive way? ? $^{275}$
\end{abstract}

Já com relação à modalidade de tentativa de monopolização, esta requer uma intenção específica de monopolizar uma conduta predatória ou anticompetitiva e, por fim, uma perigosa probabilidade de sucesso. Por sua vez, uma combinação ou conspiração para

${ }^{271}$ SULLIVAN, Lawrence A.; GRIMES, Warren S. The Law of Antitrust. An Integrated Handbook, cit., p. 102.

272410 U.S. 366, 93 S.Ct. 1022, 35 L.Ed.2d 359 (1973).

273472 U.S. 585, 105 S.Ct. 2847, 86 L.Ed.2d 467 (1985).

${ }^{274}$ SULLIVAN, Lawrence A.; GRIMES, Warren S. The Law of Antitrust. An Integrated Handbook, cit., p. 103.

${ }^{275}$ Idem, ibidem, p. 105. 
monopolização requer a prova de uma ação concertada, deliberadamente direcionada com a intenção específica de obtenção de monopólio, bem como a prática de ao menos um ato evidente de manutenção da conspiração. ${ }^{276}$

Com relação ainda à prática de combinação ou conspiração, cumpre inicialmente reconhecer que podem atingir os mesmos efeitos de um monopólio, pois agindo de forma combinada agentes que não possuem poder de mercado podem alcançá-lo. Tratar-se-ia de instituto semelhante ao reconhecido no Brasil como infração por dominância coletiva. E por muitas vezes se assemelharia aos efeitos de um cartel, podendo criar alguma confusão no tocante à tipificação da conduta.

Vale mencionar que por monopolista não devemos entender unicamente que um agente econômico possua uma posição dominante, mas ainda situações de (i) empresas exercendo posição dominante em cooperação com outras, (ii) empresas competindo com rivais em um mercado primário mas exercendo posição dominante em mercados secundários de peças ou serviços, ou (iii) empresas exercendo posição dominante sobre preços ou quantidade através de uma marca forte ou exploração de assimetria informacional por parte do comprador. ${ }^{277}$

Um ponto adicional a se considerar diz respeito à quantificação do efeito alcançado, na medida em que a norma demanda que a conduta seja adotada em qualquer parte do comércio entre os estados federativos dos Estados Unidos ou com nações estrangeiras. Haveria uma quantificação mínima de efeito? Como os tribunais americanos construíram esta questão?

Os tipos legais trazidos pelo Sherman Act são abertos, comparativamente ao que se verifica no Brasil. Assim, resta a função de se estabelecerem parâmetros para a aplicação dos dispositivos, papel que foi desempenhado ao longo do século pelos tribunais norte-americanos. Torna-se necessário, para melhor entendimento da questão, que se conheçam as premissas básicas de funcionamento do sistema norte-americano de combate às infrações.

Vale breve histórico acerca dos diferentes, porém relacionados diplomas legais norte-americanos, para melhor entendimento do funcionamento de seu sistema. O primeiro deles, Sherman Act, entrou em vigor em 1890, tendo sido idealizado com o propósito de regular a atividade de monopolização ou tentativa de monopolização de mercado, bem

\footnotetext{
${ }^{276}$ SULLIVAN, Lawrence A.; GRIMES, Warren S. The Law of Antitrust. An Integrated Handbook, cit., p. $132-136$.

${ }_{277}$ Idem, ibidem, p. 75.
} 
como expurgar do sistema todos os acordos, combinações e conspirações que restringissem o livre comércio. O diploma previa não somente a aplicação de pesadas penas administrativas, mas também condenações criminais para pessoas físicas envolvidas.

Por sua vez, o Clayton Act foi instituído em 1914, alterado ainda em 1950 com o propósito de instituir o controle de concentrações, e visava proibir fusões e aquisições que pudessem vir a restringir a livre concorrência. Proibia ainda outras práticas comerciais, podendo fomentar a concorrência sob certas circunstâncias, tratando-se de um estatuto puramente civil, sem previsões criminais.

No mesmo ano se instituiu o Federal Trade Commission Act, que proibia métodos injustos de competição no comércio interestadual e criou o Federal Trade Commission, ${ }^{278}$ ou Comissão Federal de Comércio. Tratava-se, da mesma forma, de um estatuto puramente civil, sem previsões criminais.

A Comissão Federal de Comércio é composta por cinco Comissários, sendo um presidente, todos indicados pelo Presidente dos Estados Unidos e ratificado pelo Senado Federal, sendo no máximo três Comissários do mesmo partido. Possui ainda competência exclusiva para aplicação do Federal Trade Commission Act. Vale notar que a tipologia aberta da norma permite o alcance das condutas tratadas pelo Sherman Act, indo além destas, contudo.

\subsection{Organização do Sistema Legal Norte-Americano}

O sistema norte-americano de combate às condutas reputadas ilegítimas sob o ponto de vista de livre concorrência é predominantemente judicializado desde sua origem. Em paralelo ao normativo federal, os estados federativos norte-americanos e municípios possuem competência legislativa para editarem norma sobre a tutela do direito da concorrência. Assim, não são raros os estados que levam adiante, em tribunais estaduais, processos contra empresas e cidadãos por infringirem preceitos da norma de concorrência.

Há, reconhecidamente, uma multiplicidade de atores no sistema norte-americano: os órgãos federais, os órgãos estaduais e partes privadas, todos com competência específica relacionada à tutela da concorrência. As duas agências norte-americanas encarregadas da

\footnotetext{
${ }^{278}$ A Comissão Federal de Comércio foi criada como uma reação do Congresso Norte-Americano ao anúncio da regra da razão pelos tribunais. A intenção era de criação de uma agência especializada que pudesse aconselhar melhor os agentes econômicos na linha das práticas proibidas e permissivas, permitindo ainda o controle da política antitruste pelo Congresso.
} 
tutela da concorrência, a Divisão Antitruste do Departamento de Justiça (DOJ) e a Comissão Federal de Comércio (FTC) possuem competência concorrente no que tange à maioria dos diplomas federais. Os estados, governos locais ${ }^{279}$ e partes privadas podem, por sua vez, trazer ações tanto no âmbito federal, quanto estadual ou municipal, caso haja legislação neste sentido.

A Divisão Antitruste do Departamento de Justiça, chefiada pelo Procurador Geral Assistente, possui jurisdição para aplicação do Sherman Act e Clayton Act, sendo o único órgão, contudo, com competência para promoção de ações criminais. Também possui competência para intervir em assuntos regulatórios perante agências federais quando houver questões concorrenciais. No caso de ações promovidas por partes privadas, a Divisão Antitruste geralmente submete amicus curiae. Também atua conjuntamente com a Comissão Federal de Comércio na revisão de casos e na elaboração de guias relacionados a diversos tópicos que afetem a concorrência. ${ }^{280}$

Já a Comissão Federal de Comércio possui competência exclusiva para aplicação deste diploma legal, bem como do Robinson-Patman Act. Possui ainda competência concorrente para aplicação do Clayton Act.

Em investigações cíveis, as agências federais possuem poderes para interrogar e receber documentos de empresas e indivíduos investigados, conhecidos, respectivamente, como subpoenas e discovery. No caso de abertura de investigações exclusivamente cíveis, não há possibilidade de utilização do tribunal do júri, que somente pode ser utilizado, concomitantemente com subpoenas, quando há investigações criminais. Tal natureza de investigação é amplamente utilizada no caso de infrações horizontais per se, como fixação de preços ou alocação de mercados. A exemplo do Brasil, reconhece-se a garantia contra autoincriminação; contudo, o mesmo não se aplica a pessoas jurídicas. As agências podem ainda promover medidas cautelares perante os tribunais. ${ }^{281}$

Existe ainda a possibilidade de se trazer uma representação administrativa perante a Comissão Federal de Comércio, amparada em violações ao Federal Trade Commission

\footnotetext{
${ }^{279}$ Com relação à aplicação das leis antitrustes por municipalidades, vale mencionar que esta se verifica limitada ao pequeno número de promotores que empregam especialistas antitruste na sua divisão de consumidor, como, por exemplo, Los Angeles, Nova Iorque e San Diego.

${ }^{280}$ Entre os guias produzidos em cooperação encontram-se o Guia de Operações Internacionais, Guias de Propriedade Intelectual, Guias do Setor de Saúde, Guia de Colaborações entre Concorrentes, Guia de Joint Ventures.

${ }^{281}$ As competências para medidas cautelares promovidas pela Divisão Antitruste amparam-se na Seção 4 do Sherman Act e na Seção 15 do Clayton Act. Com relação à Comissão Federal de Comércio, ampara-se na Seção 13 do Ato da Comissão. Tais medidas englobam pedidos preliminares, permanentes e cautelares de danos. São mais utilizadas nos casos de submissões prévias de operações.
} 
Act ou ao Clayton Act, sendo que o remédio possível seria uma ordem de cessação no formato de medida liminar - cease and desist order -, mas que não gera possibilidade de ressarcimento de danos ou penalidades criminais. Este expediente, portanto, somente é utilizado ausente a verificação de violação direta às disposições do Sherman Act. Estes casos são geralmente trazidos para um juiz administrativo com possibilidade de recurso à própria Comissão, onde os próprios Comissários formam um tribunal de apelação. As decisões emanadas são vinculantes perante a Comissão Federal, mas os representados podem ainda apelar ao Tribunal de Apelação em questões exclusivamente legais.

As iniciativas investigatórias abertas com base em normas antitrustes pelo FTC e pelo DOJ frequentemente terminam com acordos, os chamados consent resolutions ou consent decrees. As razões para tanto incluem a incerteza com relação ao resultado e tempo do litígio, a possibilidade de pagamento do dano triplicado no caso de condenação trebble damages - e o resultante ônus de prova que recai sobre aqueles que desejem ingressar com ações para ressarcimento de danos resultante das práticas contestadas. Tais acordos podem incluir condições comportamentais ou estruturais.

Com relação à provocação do sistema pelos estados, o Procurador Geral Estadual possui competência para ingressar com ação sobre legislação federal antitruste e legislação estadual antitruste, tanto nos tribunais estaduais quanto nos tribunais federais. Neste caso, a ação pode ser trazida em benefício do Estado como vítima da conduta ou como protetor do interesse público: tratar-se-iam de ações parens patriae para obtenção de compensação ou medidas liminares para as partes ou indivíduos prejudicados.

Independentemente de todo aparato público existente para a persecução de infrações às normas de concorrência nos Estados Unidos, cabe observar a importância da aplicação dos dispositivos por partes privadas. Neste sentido, as seções 4 e 16 do Clayton Act trazem a base para atuação dos agentes privados no âmbito das normas concorrenciais. $^{282}$

Assim, diversos seriam os incentivos para atuação dos agentes privados em temas de livre concorrência. Não somente encontram-se os agentes privados aptos a trazerem ações perante o sistema judiciário e obterem decisões liminares no caso de ameaça de perdas ou danos efetivos ocasionados pela ação de terceiros, mas ainda encontram-se legitimados a trazerem ações de ressarcimento dos danos causados, garantindo-lhes a

282 "Section 4: Any person injured in his business or property by an antitrust violation can bring suit to recover threefold damages (...)"; "Section 16: Any person, firm, corporation, or association shall be entitled to sue for and have injunctive relief against threatened loss or damage due to such violation (...)" 
restituição do triplo do dano ocasionado. Em breve recapitulação histórica vale notar que os danos triplicados foram instituídos pela Seção 7 do Sherman Act e posteriormente estendidas para a Seção 4 do Clayton Act.

Em 1914 direitos adicionais foram concedidos aos litigantes privados, como a possibilidade de utilizarem as decisões favoráveis dos tribunais como evidência prima facie de uma violação em ações de ressarcimento de danos privados, a suspensão da prescrição durante a pendência da decisão em ações promovidas pelo governo e a possibilidade de ações com pedidos liminares. ${ }^{283}$ A possibilidade de ações de classe, ou class actions, também representa um remédio de especial interesse para a proteção de direitos difusos, na medida em que permite a reunião de diversos consumidores lesados por práticas anticompetitivas. ${ }^{284}$

É muito claro, portanto, que os incentivos ao sistema de ações privadas no âmbito do direito concorrencial nos Estados Unidos se amparam em dois fatores primordiais: dissuasão das práticas e compensação dos danos ocasionados.

Se por um lado a aplicação da lei pelo agente público possui algumas vantagens eficientes, como a motivação decorrente do real interesse público ao invés de motivação pecuniária, bem como maior experiência e ferramentas para lidarem com ações antitrustes, por outro lado podem incorrer em algumas desvantagens, como a seletividade das ações por parte do poder público, na medida em que os agentes públicos tendem a focar em ações com maiores chances de sucesso, e que por vezes não seriam ações com maiores prejuízos aos consumidores. Da mesma forma, restrições orçamentárias podem fortalecer a seletividade das ações. Por fim, a limitação do expertise para todas as áreas em questão, sendo que os agentes privados poderiam identificar mais facilmente uma violação concorrencial na sua área de expertise. Assim, reconhece-se a importância da atividade privada nas ações antitruste como complemento à tutela estatal.

Apesar da existência de certas limitações para a atividade privada, os tribunais norte-americanos sedimentaram precedentes que foram permeando o acesso ao judiciário, mitigando questões relacionadas à caracterização e mensuração dos danos, facilitando o

\footnotetext{
${ }^{283}$ A Seção 5(i) do Clayton Act prevê que a prescrição se interrompe durante a pendência de decisão em procedimentos cíveis ou criminais para aplicação da lei antitruste, aplicando-se ainda a procedimentos administrativos promovidos pelo FTC.

${ }^{284}$ As ações de classe são reguladas pela regra 23 do Federal Rules of Civil Procedure, que prevê os requisitos para sua aplicação: "Prerequisites. One or more members of a class may sue or be sued as representative parties on behalf of all members only if: (1) the class is so numerous that joinder of all members is impracticable; (2) there are questions of law or fact common to the class; (3) the claims or defenses of the representative parties are typical of the claims or defenses of the class; and (4) the representative parties will fairly and adequately protect the interests of the class."
} 
encerramento de casos complexos e assegurando ressarcimento de danos. ${ }^{285}$ Vale ainda mencionar que os réus de uma ação antitruste podem ser considerados responsáveis solidários por danos concorrenciais decorrente de ações privadas.

Tem-se, com isso, o quadro-resumo da jurisdição dos diversos atores norteamericanos no sistema antitruste daquele país:

\begin{tabular}{|c|c|c|}
\hline Atores & Legislação com Jurisdição & Natureza da Ação \\
\hline DOJ & $\begin{array}{l}\text { Sherman Act } \\
\text { Clayton Act }\end{array}$ & Civil e Criminal (per se). \\
\hline FTC & $\begin{array}{l}\text { FTC Act } \\
\text { Clayton Act } \\
\text { Robinson-Patman Act }\end{array}$ & $\begin{array}{l}\text { Civil somente, mas pode referenciar } \\
\text { assuntos para o DOJ, que possui } \\
\text { competência criminal. }\end{array}$ \\
\hline $\begin{array}{l}\text { Estados (às vezes } \\
\text { Município) }\end{array}$ & $\begin{array}{l}\text { Sherman Act } \\
\text { Clayton Act } \\
\text { State Legislation }\end{array}$ & Civil (Tribunais Estaduais ou Federais). \\
\hline Partes Privadas & $\begin{array}{l}\text { Sherman Act } \\
\text { Clayton Act } \\
\text { Legislação Estadual }\end{array}$ & Civil (Tribunais Estaduais ou Federais). \\
\hline
\end{tabular}

285 Remédios para os danos usualmente incluem, quando custos administrativos decorrentes da sua distribuição verifiquem-se proibitivos, a possibilidade de sua distribuição por vias alternativas como a emissão de cupons de descontos ou exigência de preços reduzidos por determinado período de tempo. Com relação à prova do dano, os autores devem demonstrar que a violação do réu causou um dano ao negócio ou propriedade do autor e deve estabelecer uma base para uma estimativa razoável do montante a compensar o dano. Medidas de danos envolveriam a determinação do peso morto ao consumidor - consumer deadweight losses - estimativa da sobretaxa cobrada, custos envolvidos na ação e eventuais eficiências promovidas pela conduta em questão. 


\subsection{Construção Jurisprudencial e Doutrinária Norte-Americana}

\subsubsection{Formação e Aplicação Inicial da Seção 2 do Sherman Act}

Monopólios sempre foram temas de grande preocupação nos Estados Unidos, berço das teorias modernas de censura aos abusos cometidos por agentes monopolistas. Recorde-se, neste sentido, a proposta apresentada pelo Senador Sherman ao final do século XIX, com o objetivo de reprimir os abusos que estavam sendo cometidos por grandes trustes contra agentes econômicos dependentes e consumidores, a qual se consubstanciou em diploma de grande relevância para a economia norte-americana, disseminando-se ainda para todo o mundo. Ousamos dizer que o pioneirismo do diploma, que nas décadas seguintes provocou profundo debate jurídico e econômico sobre sua racionalidade e limites, desempenhou grande papel na moldura da economia norte-americana.

Nos capítulos que antecedem o presente trouxemos o contexto da origem do Sherman Act, primeiro diploma de relevo a regrar normas de comportamento entre agentes econômicos no seu processo de interação competitiva. Caberá neste capítulo brevemente discorrermos, após análise da norma em si, sobre a evolução de sua aplicação ao longo dos anos, antes de adentrarmos ao tratamento das condutas elencadas à análise.

Para tanto, temos que nos primórdios de aplicação das regras estipuladas pelo Sherman Act, os tribunais não se preocuparam com a avaliação da existência efetiva de qualquer grau de poder de mercado, mas sim com as próprias condutas que estavam sendo praticadas pelos agentes econômicos, segundo uma intepretação literal do texto legal. Um dos primeiros casos norte-americanos, Northern Securities Co. v. United States, ${ }^{286}$ envolvia a formação de uma empresa holding para controlar as maiores linhas de trem concorrentes, tendo o arranjo sido reprimido pela Suprema Corte norte-americana que entendeu que uma empresa formada para controlar linhas de trens concorrentes violava as normas do estatuto em questão. Apesar de a opinião majoritária dos juízes não ter apontado uma regra clara de análise para avaliação acerca da ilegalidade dos monopólios, ela implicava que consolidações levando a um poder de mercado substancial deveriam ser consideradas ilícitas. $^{287}$

\footnotetext{
${ }^{286} 193$ U.S. 197, 24 S. Ct. 436, 48 L.Ed. 679 (1904).

${ }^{287}$ SULLIVAN, Lawrence A.; GRIMES, Warren S. The Law of Antitrust. An Integrated Handbook, cit., p. 81.
} 
Outros casos julgados posteriormente seguiram a mesma linha, como Standard Oil Co. v. United States, ${ }^{288}$ que resultou na segregação do poderoso trust Standard Oil formado por John D. Rockfeller, e United States v. American Tobacco Co. ${ }^{289}$ que censurou uma série de condutas predatórias com o intuito de excluir concorrentes do mercado, ambas as decisões mais formalísticas, focando nas condutas praticadas, sem empregarem maior atenção à questão da análise de poder de mercado.

Foi somente em United States vs. Alcoa ${ }^{290}$ que, pela primeira vez, se falou de forma mais estruturada em definição e avaliação do poder econômico dentro daquele mercado predefinido, expresso em voto do Juiz Hand. Tais critérios passaram a ser utilizados em quase todos os casos subsequentes, com melhoramentos graduais ao longo dos anos, porém sem alteração de sua essência.

Os tribunais norte-americanos desempenharam papel decisivo, em casos posteriores, ao interpretar que participações de mercado constituem somente parte da análise, devendo-se tomar em conta outros tantos fatores, como barreiras à entrada, dentro das quais economias de escala, propriedade de recursos escassos e direitos de propriedade intelectual, além da integração vertical, gastos com marketing e outros diversos fatores de pressão concorrencial.

Algumas decisões merecem menção, além da já citada no caso envolvendo a Standard Oil, em que o tribunal ressaltou que o crescimento do conglomerado não era resultado de métodos normais de desenvolvimento industrial. Vale menção ao caso United States v. Griffith, ${ }^{291}$ onde se discutiu a intenção de uso do poder para excluir concorrentes. Já em United States v. Grinnell Corp., ${ }^{292}$ o tribunal pela primeira vez contrastou o conceito de "obtenção ou manutenção premeditada de poder econômico" com crescimento ou desenvolvimento resultante de um produto superior, perspicácia negocial ou acontecimento histórico. Posteriormente, em United States v. United Shoe Machine, ${ }^{293}$ o teste elaborado pelo Hiz Wyazanski trazia o questionamento: teria o réu se engajado em conduta excludente que restringia oportunidades competitivas, distorcia o processo competitivo e cujos resultados fortaleciam o poder de mercado, ou estaria, simples e agressivamente exercendo pressão competitiva no seu mérito?

\footnotetext{
288221 U.S. 1, 31 S.Ct. 502, 55 L.Ed. 619 (1911).

289221 U.S. 106, 31 S.Ct. 632, 55 L.Ed. 663 (1911).

290148 F 2d 416 (2d Cir.1945).

291334 U.S. 100, 107, 68 S. Ct. 941, 92 L.Ed. 1236 (1948).

292384 U.S. 563, 570-71, 86 S.Ct. 1698, 16 L.Ed.2d 778 (1966).

293347 U.S. 521, 74 S.Ct. 699, 98 L.Ed.910 (1954).
} 
Assim, teria se pacificado o entendimento acerca da legalidade de posse de poder de mercado por um agente econômico. Para se estabelecer uma monopolização ilegal, um agente econômico deveria ter demonstrado uma obtenção ou manutenção premeditada de uma condição monopolista. Da mesma forma, não se faria suficiente prova da intenção, demandando ainda prova de uma conduta prejudicial. Deve-se considerar ainda, de forma equiparada, abusos decorrentes de posição dominante do lado do comprador, o chamado poder de monopsônio, contanto que tal abuso fosse capaz de afetar a alocação eficiente de recursos através da redução da quantidade de produtos ou serviços.

Os tribunais norte-americanos acabaram, enfim, por optar pela aplicação do teste de exclusão, que deveria pautar o rumo de suas análises. Neste sentido, o teste deve considerar se o agente econômico engajou-se em conduta excludente ou reprovável considerando-se: (i) a intenção do monopolista; (ii) o efeito da conduta do monopolista no reclamante, nos consumidores, e em si mesmo; (iii) se o monopolista teria justificativas comerciais lastreadas em critérios de eficiência para sua conduta. Assim, os seguintes critérios devem se reunir para que se justifique ação contra a conduta em revisão: (i) resultados danosos à concorrência; (ii) concorrência por parte do monopolista não sofreria constrições; e (iii) intenção anticompetitiva.

Geralmente, ações com base na seção 2 do Sherman Act trazem, conjuntamente, alegações de monopolização e de tentativa de monopolização, uma vez que o segundo critério traz ônus probatório menor. Em termos gerais, os requisitos geralmente exigidos para a configuração do ilícito concorrencial requer: (i) a realização de uma prática predatória ou anticompetitiva; (ii) a intenção de monopolizar; ${ }^{294}$ e (iii) perigosa probabilidade de alcançar poder econômico. ${ }^{295}$

Por sua vez, uma combinação ou conspiração para monopolização requer: (i) prova de uma ação concertada, deliberadamente direcionada com a intenção específica de obtenção de monopólio, e (ii) a prática de ao menos um ato evidente de manutenção da conspiração. $^{296}$ Aqui não haveria a necessidade de demonstrar-se poder econômico ou perigosa probabilidade de alcance desta situação. Por conta do maior padrão probatório

\footnotetext{
${ }^{294} \mathrm{O}$ gênesis deste requisito para demonstração da ilicitude da conduta reside na opinião formulada pelo Juiz Holmes, no caso Swift \& Co v US (196 U.S. 375, 25 S.Ct. 276, 49 L.Ed. 518 (1905): "[T]here must be a showing of dangerous probability even if an intent is proved. Internal documents may constitute valuable evidences, but are not absolute to prove intent. A showing of an unambiguously anticompetitive conduct may obviate the need for any intent proving requirement, since such intent it is implicit on the conduct."

${ }^{295}$ SULLIVAN, Lawrence A.; GRIMES, Warren S.. The Law of Antitrust. An Integrated Handbook, cit., p. 132 e ss.

${ }^{296}$ Idem, ibidem, p. 136 e ss.
} 
exigido desta modalidade de abuso, em especial da dificuldade de obtenção de prova da ação concertada, há pouquíssimos casos trazidos e decididos sobre esta tipificação.

Outro debate de vital importância ao tema reside nas diferentes regras de aplicação das leis antitrustes nos Estados Unidos, desenvolvidas ao longo dos anos: a perspectiva per se e a perspectiva da regra da razão. Enquanto colusões horizontais passaram, com a maturidade das discussões, a se desenrolarem sobre a regra per se, as condutas de exclusão decorrentes de abusos de posição dominante têm sido tratadas sob a perspectiva da regra da razão e seus guias básicos seriam o propósito e a intenção, conforme se verifica adiante.

A regra da razão requer uma avaliação da natureza, propósito e efeitos das condutas. Sempre quando houver uma rápida avaliação que sugira a ausência de um prejuízo à concorrência no contexto da conduta ou que os benefícios resultantes possam de alguma forma superar eventuais efeitos anticoncorrenciais, a regra da razão deveria ser aplicada. Assim, sob a aplicação da regra da razão deve-se promover efetivo balanceamento dos efeitos pró e anticompetitivos resultantes de uma determinada prática, isto é, dos efeitos deletérios e das eficiências resultantes da prática para o ambiente concorrencial e para o consumidor. Ainda, deve-se perguntar se os benefícios decorrentes da conduta poderiam ser alcançados por outras formas menos danosas à livre concorrência, casos em que deveria a prática ser reprovada.

A regra per se tem sido aplicada a certos casos em que se verificou, após sucessiva aplicação da regra da razão, que invariavelmente chegavam a resultados incontroversos, reconhecendo os efeitos lesivos à livre concorrência resultantes de sua prática. Nestes casos, passou-se a dispensar a prova de efeitos deletérios à livre concorrência visto que tais efeitos passaram a ser presumidos sob a regra per se. Condutas geralmente consideradas sob a regra per se incluem fixação de preços horizontais, divisão de territórios ou clientes, acordos entre concorrentes para redução de produção, boicotes, entre outros.

O desenvolvimento da regra per se iniciou-se nos casos Joint-Traffic ${ }^{297} \mathrm{e}$ Standard Oil ${ }^{298}$. Contudo, o caso Socony-Vacuum Oil Co. ${ }^{299}$ consolidou a perspectiva da regra per se. Tratava-se de fixação de preços em violação à Seção 1 do Sherman Act,

\footnotetext{
${ }^{297} 171$ U.S. 505, 568, 18 S.Ct 25, 43 L.Ed. 259 (1898).

298221 U.S. 1, 65, 31 S.Ct. 502, 55 L.Ed. 619 (1911).

299310 U.S. 150, 60 S.Ct. 811, 84 L.Ed. 1129 (1940).
} 
independentemente de possuírem os conspiradores poder de mercado para afetarem preços ou efetivamente alterarem os preços no mercado.

Vale ainda mencionar que na década de 70, com a decisão em Professional Engineers $^{300}$ e subsequentemente com diversos casos que se seguiram, a Suprema Corte norte-americana sugeriu um approach intermediário às duas regras então em curso: a análise da regra da razão truncada ou abreviada ("truncated rule of reason"). A regra da razão abreviada implica rápida análise da conduta sem que se tenha que provar todos os elementos da conduta, ao contrário do que se deve esperar do procedimento verificado na regra da razão. Assim, presumem-se os efeitos aparentemente lesivos de uma determinada conduta, porém se permite ao agente praticante da conduta demonstrar sua justificativa econômica pró-competitiva, caso em que se deverá promover uma análise sob a regra da razão. Caso, contudo, não sejam demonstradas as justificativas, a conduta presumidamente lesiva é declarada ilegal.

Sob as diferentes perspectivas das regras da razão, da regra per se e, mais recentemente, da regra da razão abreviada, discorremos acerca da formação jurisprudencial da aplicação do direito antitruste nos Estados Unidos, desde seus primórdios, ainda que de forma resumida e focada na evolução dada ao tratamento dos abusos de poder de mercado.

\subsubsection{Recusa de Contratação}

O tema das censuras à eventual recusa de contratação sempre demandou alta complexidade analítica por parte das autoridades de defesa da concorrência, ao ponto de suscitar o desenvolvimento de teoria de extrema importância para a atividade antitruste global.

A origem da teoria das infraestruturas essenciais, ou "essential facilities doctrine", começou a tomar forma nos Estados Unidos no início do século XX, com o caso Terminal Railroad Association of St. Louis. ${ }^{301}$ A Associação em questão tratava de conglomerado que detinha diversas instalações e terminais ferroviários na área de St. Louis, nas duas margens do Rio Mississipi, possuindo ainda a única ponte ferroviária da cidade e linhas interligando aquela ponte às ferrovias principais. Durante vários anos, a única alternativa era oferecida pela Wiggins Ferry Company, proprietária de vários quilômetros de margem oposta à St. Louis. Em 1890, contudo, foi construída uma segunda ponte, conhecida como

\footnotetext{
300435 U.S. 679, 98 S.Ct 1355, 55 L.Ed.2d 637 (1978).
}

301224 US 383 (1912). 
Merchant's Bridge, mais tarde adquirida pela Terminal Railroad Associations. Por sua vez, a Rock Island Railroad Co., após alguns anos, adquiriu a Wiggins Ferry Co., passando posteriormente a integrar também a Terminal Railroad Associations, que concentrou sob seu controle as três alternativas para travessia do Rio Mississipi. Com base nos artigos $1^{\circ} \mathrm{e}$ $2^{\circ}$ do Sherman Act, após reclamações de companhias ferroviárias que não integravam a associação e alegavam serem vítimas de condições discriminatórias, o DOJ ordenou a dissolução do conglomerado.

A situação topográfica e geográfica da região impedia a construção de novas travessias ferroviárias. Encontrava-se aqui, portanto, um dos aspectos nucleares para a teoria que viria a ser desenvolvida, acerca da essencialidade das infraestruturas, em que se considerava que o ativo em questão seria essencial não somente para quem o controla, mas também para os concorrentes. Em razão do exposto, foi determinada a cisão da Terminal Railroad Association em três empresas distintas, cada qual com a posse de uma ponte. Também foi determinada a abertura do capital da Terminal Railroad Association a qualquer empresa ferroviária, bem como a abertura e utilização dos terminais a empresas que não optassem pelo ingresso no capital social da empresa, impondo-se assim verdadeira obrigação de acesso.

O caso Associated Press, ${ }^{302}$ por sua vez, envolvia cooperação horizontal. A Associated Press era uma associação de jornais que contava com mais de 1.200 membros disseminados por todo o país e atuando como uma agência de notícias que distribuía aos seus membros notícias recolhidas por seus próprios jornalistas, dos seus membros de associações estrangeiras com quem tinha relação contratual. Nos seus estatutos, contudo, havia cláusula que previa o direito de veto pelos seus membros a novos associados, bem como os impedia de vender notícias para terceiros. ${ }^{303}$

A Suprema Corte entendeu que a limitação gerava desvantagem concorrencial aos não membros, apesar de existirem outras fontes e de alguns jornais concorrentes terem conseguido operar sem acesso às notícias fornecidas pela Associated Press. Assim, as medidas corretivas implicavam a proibição de veto por concorrentes de um candidato a associado, devendo ser aberta para todos os jornais de maneira indiscriminada, porém

\footnotetext{
302326 U.S. 1 (1945).

303 "The joint effect of these By-Laws is to block all newspaper non-member from any opportunity to buy news from AP or any of its publisher members. Admission to membership in AP thereby becomes a pre requisite to obtaining AP news or buying news from any one of its more than twelve hundred publishers. The erection of obstacles to the acquisition of membership consequently can make it difficult, if not impossible for non-members to get any of the news furnished by AP or any of the individual members of this combination of American newspaper publishers." (326 U.S. 1 (1945)).
} 
reconhecendo o direito da associação de não aceitar novos membros desde que a justificativa se fundasse em razões diversas à existência de uma relação de concorrência com um membro atual.

Contudo, tal acórdão não reconhece uma lógica e sistematização na aplicação da teoria das infraestruturas essenciais, conforme explica Miguel Moura: ${ }^{304}$

\begin{abstract}
Em primeiro lugar, e como era claro para alguns juízes, a decisão não impôs à AP o dever de acolher todo e qualquer candidato. Em causa estava apenas o fundamento e o procedimento da exclusão de candidatos, o qual permitia dessa forma o afastamento de concorrentes dos membros actuais, colocando aqueles numa situação concorrencialmente menos vantajosa. É também clara a preocupação com os efeitos em alguns segmentos de mercado, como os jornais da manhã. Com efeito, o acórdão limita-se a exigir que a AP permita a adesão de novos jornais que concorram com os actuais membros. Em segundo lugar, este caso não se reporta ao exercício unilateral do poder de exclusão, pelo que dificilmente se pode radicar aqui um dever de conceder acesso que possa ser imposto na ausência de comportamentos colusivos, isto é no contexto de um acordo entre empresas concorrentes. (...)
\end{abstract}

Seguiu-se ao acórdão Associated Press o caso Otter Tail, ${ }^{305}$ que tratava de empresa geradora de eletricidade e controladora de todas as linhas de transmissão de eletricidade de alta tensão, bem como das linhas de distribuição, para 465 cidades dos Estados Unidos, em três estados diferentes. Esta última atividade era desenvolvida com base em concessões por períodos que variavam entre 10 e 20 anos. Quando a concessão da distribuição de eletricidade encerrou-se, diversas comunidades decidiram adquirir eletricidade de outros produtores. Contudo, a Otter Tail recusou-se a vender eletricidade ao nível atacadista, não permitindo a utilização de suas linhas de alta tensão para transmissão de eletricidade adquirida de outras empresas geradoras.

A Suprema Corte decidiu que a rede de distribuição de eletricidade constituía monopólio natural e que, aos municípios que quisessem adquirir eletricidade de outras fontes geradoras, seria essencial não somente o contrato com uma empresa geradora de energia, mas ainda acesso às redes de transmissão de alta tensão controladas pela Otter Tail. O dever de acesso através da interconexão entre os dois elementos era uma saída possível, via regulador, mas que não se deu. Assim a questão a ser arbitrada pela Suprema Corte passava por decidir se a sujeição a um regime regulatório isentava uma empresa dos seus deveres concorrenciais refletidos pela legislação antitruste.

\footnotetext{
${ }^{304}$ MOURA E SILVA, Miguel. O Abuso de Posição Dominante na Nova Economia, cit., p. 336.

305410 U.S. 366 (1973).
} 
A Suprema Corte ratificou a decisão do juízo de primeira instância de que a intenção inerente à conduta, qual seja a própria recusa, era fortemente caracterizada como monopolista, não existindo explicações técnicas para justificar a recusa de acesso. Teria, portanto, como única finalidade, impedir que as municipalidades viessem a contestar a posição monopolista daquela empresa na distribuição de eletricidade.

A Suprema Corte norte-americana reconheceu, contudo, a existência de um limite à obrigação de acesso, no sentido de permitir ao incumbente a cobrança de taxas razoáveis para o acesso, bem como ao elucidar que tal dever somente deveria verificar-se na medida em que não prejudicasse a capacidade do incumbente de servir outros clientes. Decidiu, contudo, no sentido de excetuar desta limitação a possibilidade de o monopolista contornála estendendo o seu monopólio a um patamar do mercado onde não existiria controle de preços. $^{306}$

Em certa medida, fica evidente da análise do caso a existência de falhas regulatórias que devem ser complementadas pela análise antitruste. Ao que pese tal afirmação, devemos reconhecer que a atuação das regras de concorrências pode não ser suficiente em razão das especificidades existentes nos mais diversos mercados. A imposição de acesso pode viabilizar o aparecimento de novos concorrentes. Contudo, verifica-se uma natural dificuldade no balanceamento das obrigações de acesso com o equilíbrio financeiro das empresas que realizam vultosos investimentos. Assim, a intervenção deveria competir, em primeiro lugar, aos reguladores, atuando a defesa da concorrência de forma subsidiária e complementar. Por outro lado nada indica que os consumidores obterão qualquer ganho neste processo, ao menos que exista previsão regulatória de repasse das eficiências obtidas ao consumidor.

Em Aspen Skiing, ${ }^{307}$ esta empresa explorava três das quatro maiores estâncias de esqui em Aspen. Em 1979, contudo, foi processada por sua concorrente, a Highlands, detentora da outra pista, por monopolização do mercado de serviços de pistas de esquis em Aspen, em violação ao artigo $2^{\circ}$ do Sherman Act. Durante vários anos as empresas tinham colaborado na comercialização de um bilhete conjunto para seis dias, o qual dava acesso a todas as estâncias por elas exploradas. A Aspen Skiing passou a ofertar, em dado momento, um bilhete limitado às suas estâncias, em concorrência com o bilhete conjunto, porém as vendas do último continuaram superiores. As receitas dos bilhetes eram repartidas em

\footnotetext{
306 Assim, cobrança de um dos inputs a preços monopolistas será imputada ao consumidor e lucro supranormal surgirá a nível não controlado - custos de interconexão em alta tensão.

307472 U.S. 585 (1985).
} 
função de um sistema de amostragem dos utilizadores em cada estância. Na temporada de 77 a 78, a Aspen Skiing obrigou a Highlands a aceitar uma proposta de rateio fixa, significativamente inferior à correspondente aos dados históricos com base no uso dos bilhetes, e pôs fim à comercialização conjunta após recusa da Highlands em aceitar.

Esta ainda tentou o lançamento de um produto alternativo, o Adventure Park, que consistia em bilhete de três dias para suas estâncias e três para outra estância de Aspen, tendo sido este pacote recusado pela Aspen Skiing, que passou a aceitá-los somente após a inclusão de ordens de pagamento ou cheques de viagem. Assim, a tentativa de criar um sucessor ao pacote pela Highlands falhou, e sua quota de mercado caiu rapidamente. ${ }^{308}$

A Highlands sagrou-se vitoriosa na disputa perante o Tribunal do Circuito, o Tribunal Distrital e, finalmente, perante a Suprema Corte norte-americana, tendo evitado decidir o caso com menção expressa à teoria das infraestruturas essenciais. As discussões centraram-se, assim, na existência ou não de justificativa objetiva para a recusa. A Suprema Corte ainda ponderou que mesmo a decisão de uma empresa com poder de mercado em introduzir uma alteração importante pode não ser anticoncorrencial se existir uma justificativa objetiva para tanto. A Suprema Corte ainda invocou o critério de sacrifício dos lucros - profit-sacrifice test - atribuindo a este conceito o elemento de ponderação da racionalidade econômica da recusa no âmbito da metodologia da regra da razão aplicada aos efeitos do artigo $2^{\circ}$ do Sherman Act.

Até agora verificamos que os casos acima referenciados foram resolvidos sem recurso à teoria mais elaborada acerca das infraestruturas essenciais. O expoente da aplicação desta teoria deu-se no caso MCI vs. AT\&T, de 1983. O Sétimo Circuito decidiu que a $A T \& T$ havia violado o artigo $2^{\circ}$ do Sherman Act ao recusar a interligação da MCI com a sua rede nacional de telefonia vocal, sendo que essa interconexão era essencial para que a MCI pudesse concorrer com a AT\&T no serviço de longa distância:

\footnotetext{
A monopolist's refusal to deal under these circumstances is governed by the socalled essential facilities doctrine, such a refusal may be unlawful because a monopolist's control of an essential facility (sometimes called a "bottleneck") can extend monopoly power from one stage of production to another, and from one market into another. Thus, the antitrust laws have imposed on firms controlling an essential facility the obligation to make the facility available on nondiscriminatory terms. ${ }^{309}$
}

\footnotetext{
${ }^{308}$ Sua participação de mercado caiu de $20,5 \%$ em $76-77$ para $11 \%$ em $80-81$.

309708 F2d 1081 (7th Cir 1983).
} 
O acórdão trouxe ainda quatro requisitos para a aplicação da teoria das infraestruturas essenciais, os quais têm sido seguidos por tribunais e agências ao redor do mundo até os dias atuais, por vezes com algumas adaptações. Verifica-se, assim, infração ao artigo $2^{\circ}$ do Sherman Act, a recusa de acesso à infraestrutura essencial caso: (i) esta infraestrutura seja controlada por um monopolista; (ii) um concorrente seja incapaz de construir uma infraestrutura da mesma natureza por incapacidade prática ou razoável; (iii) o acesso seja recusado a um concorrente; e finalmente (iv) que o acesso à infraestrutura seja exequível.

No caso Chicago Bulls, ${ }^{310}$ dois consórcios disputavam a compra da equipe de basquete do Chicago Bulls. Uma das partes, Fisherman, tinha um acordo para a compra, mas apenas caso conseguisse obter a locação de um estádio. A outra parte interessada, Wirtz, controlava o estádio em que jogava o próprio time do Chicago Bulls, tendo se recusado a locar a estrutura para Fisherman. Assim, o Tribunal considerou que o fato de poder-se construir um novo estádio não era pertinente para afastar a teoria das infraestruturas essenciais uma vez que implicava a necessidade de o concorrente potencial entrar em dois níveis do setor - equipe e estádio. O Tribunal considerou que o estádio não era duplicável sem um gasto que seria desarrazoado em razão do tamanho da operação. Interessante notar que, anos mais tarde, foi construído na cidade de Chicago outro estádio.

Discutiu-se acima ainda que o conceito de infraestrutura essencial é amplo, podendo abranger, além de estádios e pontes, informações. O que é essencial para a teoria é que o objeto da recusa seja algo cujo acesso seja indispensável para o desenvolvimento da atividade a jusante e sem o qual a concorrência a este nível é eliminada.

No entanto, pode haver justificativas objetivas legítimas para a recusa, como a necessidade de investimentos para acesso por parte do monopolista ou ainda falta de capacidade para o acesso sem que isso venha a afetar seus negócios. Da mesma forma, haveria defesa dos interesses comerciais da empresa monopolista, caso o acesso implique modificação da organização ou lese as relações comerciais com seus clientes. ${ }^{311}$

Outro caso de relevo para a teoria das infraestruturas essenciais é Olympia Equipment Licensing v. Western Union Tel. Co. Aqui, Western Union até 1970 exigia de seus subscritores o aluguel de seus terminais de telex, os quais eram adquiridos da Teletype Corporation. Contudo, em 1968, a Comissão Federal de Comunicações abriu o mercado de equipamentos terminais de telefone, inclusive de equipamentos terminais de telex. Decidiu

\footnotetext{
310807 F2d 520 (7th Cir 1986).

${ }^{311}$ MOURA E SILVA, Miguel. O Abuso de Posição Dominante na Nova Economia, cit., p. 351.
} 
assim anunciar que também abriria o mercado de terminais de telex para a concorrência, separando seus preços de serviços e equipamentos. Também permitiu o cancelamento do serviço de aluguel e liberou a aquisição ou aluguel de seus equipamentos. Ainda promoveu uma lista de fornecedores de equipamentos a ser disponibilizada aos compradores dos serviços de telex que desejassem adquirir terminais. Contudo, a Western Union decidiu, após criar e encorajar a concorrência, cessar seu auxílio aos novos entrantes, pois sentiu que não poderia liquidar seus ativos tão rapidamente quanto havia imaginado. Em interessante passagem o acórdão firma o entendimento:

\begin{abstract}
Some cases hold, however, that a firm which controls a facility essential to its competitors may be guilty of monopolization if it refuses to allow them access to the facility. We accept the authority of these cases absolutely. They are well illustrated by Otter Tail Power Co. v. United States, 410 U.S. 366, 93 S.Ct. 1022, 35 L.Ed.2d 359 (1973), where a wholesale supplier of electricity refused to supply electric power to a power system that competed with it in the retail electrical power market and had no other source of supply. It might seem that if a monopolist's refusal to sell his products or services to a competitor can thus be actionable under antitrust law, it must mean that monopolists sometimes do have a duty to help their competitors and that the cases which deny this proposition are wrong. But the monopolistic-refusal-to-deal cases qualify rather than refute the no-duty-to-help-competitors cases. If a competitor is also a customer his relationship to the monopolist is not only a competitive one. The monopoly supplier who retaliates against customers who have the temerity to compete with him, by cutting such customers off, is severing a collateral relationship in order to discourage competition. ${ }^{312}$
\end{abstract}

Restou claro, portanto, que o caso tratava de ausência do dever de auxílio diante de uma situação de concorrência. O presente caso poderia ser interpretado como um caso de infraestrutura essencial caso a Western Union tivesse se negado a fornecer um serviço de telex a um cliente que tivesse adquirido seu terminal diretamente de outra empresa, como a própria Olympia. Assim, não se verifica no presente caso a característica essencial dos casos de recusa de venda, qual seja, a discriminação dos agentes monopolistas contra um cliente por conta de sua decisão de competir com seu fornecedor.

Cabe ainda notar que a teoria das infraestruturas essenciais, que se desenvolveu nos Estados Unidos a partir dos casos acima tratados, nunca chegou a ser expressamente endossada pela Suprema Corte norte-americana.

Areeda propôs estabelecer alguns limites ao seu alcance, de forma a mitigar os efeitos dissuasores da inovação e do investimento. Assim, propunha o reconhecimento de que não havia um direito geral de partilhar ativos, ou seja, o dever de concessão de acesso

312797 F.2d 370 (7. Circuito, 1986). 
teria caráter excepcional. Em segundo lugar, o qualificativo de essencial deveria ser aplicado de forma restritiva - infraestrutura somente seria essencial se simultaneamente fundamental para a competitividade do concorrente e determinante para a concorrência no mercado. O terceiro impingia obrigação de ponderar prováveis consequências da imposição do dever de acesso - somente se este acesso viesse a melhorar a concorrência no mercado secundário, em termos de desempenho. $\mathrm{O}$ quarto limite seria uma justificativa objetiva legítima para a recusa. Em quinto lugar, teríamos a existência de um elemento de censurabilidade na recusa. E por fim, nenhum tribunal deveria impor dever de contratar que não pudesse explicar ou supervisionar de forma adequada e razoável. ${ }^{313}$

Com todas as críticas levadas a efeito acerca das decisões de recusa de contratação, são os Tribunais Federais de segunda instância norte-americanos que passaram a limitar o alcance da teoria. Esta mudança coincide ainda com a grande reforma do setor de telecomunicações, uma vez aprovado o Telecommunications Act de 1996, que impôs deveres positivos especiais de apoio dos monopólios locais aos concorrentes, os quais não existiam nas leis antitrustes, visando estimular o desenvolvimento de um mercado concorrencial de telecomunicações. Assim, previa-se uma concatenação dos regimes de concorrência com o regime regulatório.

A título de reflexão, vale notar que os deveres especiais de fomento à introdução da concorrência, geralmente via acesso não discriminatório, instituídos em ambientes regulatórios de transição de regimes monopolistas legais para regimes de concorrência, se assemelham aos propósitos, e muitas vezes à forma, verificados na teoria das infraestruturas essenciais.

No caso Trinko, ${ }^{314}$ a Verizon, operadora local historicamente dominante em Nova Iorque, pediu às autoridades regulatórias acesso aos serviços de longa distância, sujeitando-se assim ao regime de acesso ao lacete local. Em 1999 alguns concorrentes queixaram-se de demoras e entraves de acesso ao lacete local de propriedade da Verizon. Em 2000 os reguladores estaduais e federais conseguiram obter um conjunto de compromissos por parte da Verizon, pondo fim aos atrasos. A Trinko, escritório de ações coletivas (class actions), tinha se tornado cliente da AT\&T e apresentou uma ação coletiva contra a Verizon, pedindo sua condenação ao abrigo do artigo $2^{\circ}$ do Sherman Act, alegando

\footnotetext{
${ }^{313}$ AREEDA, P. Essential Facilities. In MOURA E SILVA, Miguel. O Abuso de Posição Dominante na Nova Economia, cit., p. 389.

${ }^{314}$ Verizon Commc'ns Inc. v. Law Offices of Curtis V. Trinko, LLp, 540 U.S. 398, 408 (2004).
} 
que a empresa incumbente não tinha concedido acesso aos concorrentes em condições adequadas e dando como único exemplo o caso resolvido pelos reguladores em 2000.

A decisão dizia, entre outras coisas, que a teoria das infraestruturas essenciais, fosse esta admissível ou não, não seria necessária quando existisse uma imposição legal de acesso, a exemplo do verificado no Telecommunications Act de 1996.

Em seu voto, o Juiz Scalia defendia o papel dos monopólios enquanto motores da concorrência, haja vista que empresas visam consolidarem-se como monopolistas. Apenas quando o fazem por meios ilícitos é que o direito antitruste é chamado a intervir e, assim mesmo, não contra os preços de monopólio, mas sim contra os recursos a tais meios para atingir um fim em si mesmo, não censurável, se alcançado o mérito concorrencial. O Juiz Scalia via ainda na obrigação de acesso não um meio de se viabilizar a concorrência, mas sim um risco de colusão em face do monopólio. Também se discutia o papel subsidiário das leis de concorrência quando já existe regulação sobre o acesso; neste caso as normas de concorrência pouco teriam a contribuir, em razão da rápida e precisa resposta dos reguladores. Assim, a Suprema Corte negou-se a estabelecer que haveria um dever de negociação por parte do monopolista.

A tendência por uma perspectiva mais liberal da recusa de contratação aplicada pela Suprema Corte e também pelos tribunais norte-americanos pode ser ainda verificada no Guia de Aplicação da Seção 2 do Sherman Act, de 2008, repelido pelo Departamento de Justiça:

\begin{abstract}
The general right of a firm freely to determine with whom it will and will not deal was first established by the Supreme Court nearly nine decades ago. In its 1919 Colgate decision, the Supreme Court observed that "[i]n the absence of any purpose to create or maintain a monopoly, the [Sherman Act] does not restrict the long recognized right of [a] trader or manufacturer engaged in an entirely private business, freely to exercise his own independent discretion as to parties with whom he will deal." The Court reaffirmed that principle eighty-five years later in Verizon Communications Inc. v. Law Offices of Curtis V. Trinko, LLP, where, citing Colgate, the Court affirmed dismissal of an action alleging that non-compliance with state and federal regulations mandating the sale of services to rivals violated section 2.6 In Trinko, the Court noted that, "as a general matter," the antitrust laws impose no duty upon a firm to deal with rivals. ${ }^{315}$
\end{abstract}

A exemplo do que se observou após o acórdão sobre preços predatórios relativo ao caso Brooke Group, as decisões posteriores dos Tribunais Federais norte-americanos confirmam a tendência de tornar ainda mais excepcional o alcance da obrigação de

\footnotetext{
${ }^{315}$ Competition and Monopoly: Single Firm Conduct under Section 2 of the Sherman Act, p. 120.
} 
contratar, relegando tais hipóteses para alguns casos onde já existisse uma relação comercial preexistente. Em outras palavras, parece que o alcance do dever de contratar fica assim reduzido à cessação de uma relação de fornecimento. ${ }^{316}$

Novamente, vale menção ao repelido Guia de Aplicação da Seção 2 do Sherman Act de 2008:

\begin{abstract}
After reviewing and considering the case law and commentary, as well as the panelists' views, the Department believes that there is a significant risk of longrun harm to consumers from antitrust intervention against unilateral, unconditional refusals to deal with rivals, particularly considering the effect of economy wide disincentives and remedial difficulties.

(...)

The Department thus concludes that antitrust liability for unilateral, unconditional refusals to deal with competitors should not play a meaningful part in section 2 enforcement.
\end{abstract}

\title{
5.3.3. Venda Casada
}

Modalidade de abuso relativamente comum no meio empresarial, a subordinação da venda de um produto sobre o qual o agente econômico detenha posição dominante a um segundo produto para o qual tal agente pretenda estender tal poder de mercado possui, muitas vezes, o potencial de encerrar ou limitar oportunidades de negócios para a concorrência em geral. Diante de tal situação, cabe às autoridades concorrenciais utilizar das ferramentas disponíveis para avaliação da potencialidade lesiva destas práticas.

A venda casada nos Estados Unidos, ou "tying", tecnicamente pode ser contestada judicialmente com base em quatro dispositivos legais: (i) Seção 1 do Sherman Act - que proíbe contratos restritivos ao comércio; (ii) Seção 2 do Sherman Act - que reputa ilegal a "monopolização"; (iii) Seção 3 do Clayton Act - que proíbe arranjos de exclusividade que possam reduzir substancialmente a concorrência; e (iv) Seção 5 do FTC Act - que proíbe métodos injustos de concorrência.

No tocante aos casos decididos pelos Tribunais norte-americanos referentes às práticas de venda casada, vale incialmente menção ao caso Motion Picture Patents ${ }^{317}$, ligado à ideia de extensão abusiva da patente (patent misuse). Verificamos neste caso que o titular de uma patente sobre um projetor vendia o produto sob a condição de utilização de filmes protegidos por patentes já expiradas. A Suprema Corte rejeitou a alegação de

\footnotetext{
${ }^{316}$ MOURA E SILVA, Miguel. O Abuso de Posição Dominante na Nova Economia, cit., p. 398.

${ }^{317}$ Motion Picture Patents Co. v. Universal Film Manufacturing Co., 243 U.S. 502 (1917).
} 
infração de patente sob o argumento de tratar-se de tentativa ilícita de extensão da proteção patentária para os filmes projetados. Considerou assim que o direito de uso exclusivo, assim como o direito de venda exclusiva, estaria limitado à invenção em si, e que a legislação não permite ao detentor daquela patente estender o escopo de seu monopólio através da limitação dos materiais necessários para sua operação, mas que não seriam parte da invenção patenteada, ou mesmo de enviar tais artigos para canais de venda sujeitos às condições de uso ou pagamento de royalties.

Já no caso International Salt ${ }^{318}$, esta empresa atuava como fabricante de máquinas patenteadas utilizadas para injetar sal em conservas de carne. O titular da patente estava subordinando a locação das máquinas à aquisição, com exclusividade, de pastilhas de sal para usar com as máquinas. Vale notar que a International Salt era ainda a maior produtora de sal para usos industriais nos EUA. A Suprema Corte declarou que as cláusulas do contrato constituíam restrições de comércios infringentes ao artigo $1^{\circ}$ do Sherman Act, equiparando-se ainda sua prática à fixação de preços, o que impingia um caráter de ilicitude per se da conduta.

Críticas à decisão da Suprema Corte não tardaram, no sentido de que não necessariamente havia poder de mercado resultante da patente na medida em que outros fabricantes de máquinas de injetar sal existiam no mercado. Da mesma forma, não se debruça a análise na mensuração da quota de mercado alegadamente excluída pela cláusula, não tendo havido delimitação do mercado do produto subordinado, tampouco dos agentes atuantes neste mercado. Críticas foram ainda trazidas por Posner e Bork, apontando a ausência de fundamentos de racionalidade econômica que permitissem concluir pela existência de risco real para a concorrência. ${ }^{319}$

Além da questão talvez mais polêmica da decisão, qual seja o tratamento per se emprestado à análise antitruste nos casos de venda casada, os autores em referência argumentavam que não haveria racionalidade econômica na alegação de que haveria risco real para a concorrência visto que a prática de subordinação não seria apta a promover a extensão do poder de mercado, ou sua projeção para outro mercado. Fundamentam sua visão sob um princípio de análise segundo o qual em cada mercado existe um lucro de monopólio único, que pode ser repartido ou completamente absorvido por um único monopolista, mas não pode ser aumentado através da conexão com outro mercado. Assim,

\footnotetext{
${ }^{318}$ International Salt Co. v. U.S., 332 I.S. 392 (1947).

${ }^{319}$ Neste sentido vide BORK. The Antitrust Paradox: a policy at war with itself. New York: Basic Books, 1978. p. 365; e POSNER, R. Antitrust Law, cit., p. 173.
} 
se o monopolista não consegue aumentar seu lucro de monopólio mediante subordinação, qual seria então a finalidade da prática? A resposta de Chicago viria no sentido de que não existiria uma finalidade óbvia, o que para os seus apoiadores se traduz numa redução da produção ou numa diminuição do bem-estar total, então a prática só pode ser eficiente, caso contrário nenhuma empresa a empregaria.

Para Ward Bowman, a subordinação passa a apresentar uma justificativa não necessariamente anticoncorrencial, no sentido de considerar as práticas em questão como um sistema de medição do uso do produto subordinante que permite, mediante um ajustamento de preços, aumentar o acesso diminuindo o custo deste produto, em troca de um preço mais elevado pelo produto subordinado. Exemplo tradicional seria a redução do preço da impressora, garantindo maior acesso ao produto. ${ }^{320}$

Questões inerentes aos descontos multiprodutos ou mixed bundling foram ainda abordadas pelos tribunais norte-americanos, com as práticas de block booking. Implicavam a contratação de uma série de filmes predeterminados por parte dos distribuidores de filmes junto às salas de cinemas, estendendo-se posteriormente aos canais de televisão. Assim, no caso Lowe's Inc., ${ }^{321}$ a Suprema Corte entendeu que haveria violação ao artigo 1 do Sherman Act quando distribuidores individuais de filmes para exibição em televisões, protegidos por direitos autorais, praticaram block booking, condicionando a licença ou venda do direito de exibição de um ou mais filmes à aceitação, por cada estação, de um pacote de filmes contendo um ou mais filmes de menor qualidade ou indesejados, ainda que houvesse ausência de qualquer combinação ou conspiração entre os distribuidores ou qualquer monopolização ou tentativa de monopolização. ${ }^{322}$

O tratamento severo das condutas de venda casada nos anos que se seguiram começou a mudar com a decisão da Suprema Corte em 1977 sobre a prática de extensão de termos favoráveis de crédito por parte da U.S. Steel, para um construtor de casas sob a condição que este se utilizasse das casas pré-fabricadas daquela empresa. ${ }^{323}$ A Suprema Corte decidiu ao final que o construtor falhou na prova de que a U.S. Steel tinha alguma vantagem não compartilhada pelos seus concorrentes no mercado de crédito.

\footnotetext{
${ }^{320}$ Ward Bowman. Tying Arrangements.

${ }^{321}$ United States v. Lowe's Inc. - 371 U.S. 38 (1962).

${ }^{322}$ Algumas decisões que envolvem questões de descontos multiprodutos foram tratadas abaixo no capítulo que versa sobre descontos de fidelidade.

${ }^{323}$ U.S. Steel Corp. v. Fortner Enters., Inc., 429 U.S. 610, 622 (1977).
} 
No caso Jefferson Perish Hospital District, ${ }^{324}$ por sua vez, a Suprema Corte norteamericana foi instada a decidir situação em que o Dr. Edwin Hyde, médico anestesista, solicitou sua admissão ao quadro de médicos habilitados a prestarem serviços no hospital demandado, sendo seu pedido indeferido pela administração devido à existência de um contrato entre o hospital e uma sociedade de médicos anestesistas que exigia que todos os serviços de anestesia do hospital fossem prestados por médicos daquela sociedade. A subordinação foi julgada como infrativa ao artigo $1^{\circ}$ do Sherman Act, optando os juízes por manter, por maioria, a restrição per se, porém adotando metodologia de análise de práticas de subordinação consistente em versão abreviada do rule of reason, que passou a ser conhecida como trunkated rule of reason, ${ }^{325}$ visto que a análise da venda casada exigia verificação do poder de mercado e dos possíveis efeitos anticoncorrenciais verificados.

O acórdão ainda qualificava os tipos de subordinação, ressaltando que quando houver a possibilidade de aquisição de produtos de forma separada, a subordinação não imporia restrição não razoável, e discorrendo que tais vendas em pacotes podem corresponder a uma forma de concorrência mais eficiente, caso os consumidores prefiram a aquisição conjunta. A Suprema Corte menciona ainda que o reprimível seria o elemento de coação existente, e introduz, por fim, o conceito de poder de mercado como elemento que permite ao agente implantar a conduta de subordinação, o que não faria em mercado competitivo. Vale menção a trecho do voto do Juiz Stevens:

\begin{abstract}
Thus, the law draws a distinction between the exploitation of market power by merely enhancing the price of the tying product, on the one hand, and by attempting to impose restraints on competition in the market for a tied product, on the other. When the seller's power is just used to maximize its return in the tying market, where presumably its product enjoys some justifiable advantage over its competitors, the competitive ideal of the Sherman Act is not necessarily compromised. But if the power is used to impair competition on the merits in another market, a potentially inferior product may be insulated from competitive pressures. $^{326}$
\end{abstract}

Com isso a Suprema corte introduziu uma questão prévia na aplicação da proibição per se: a análise dos mercados em causa e o poder de mercado do autor da prática, bem como eventuais consequências no mercado do produto subordinado. Ainda, outros requisitos surgiram no voto vencido do Juiz O'Connor: (i) existência de poder de mercado por parte do vendedor no mercado do produto subordinante; (ii) ameaça

\footnotetext{
${ }^{324}$ Jefferson Parish Hospital District No. 2v Hyde, 466 US 2 (1984).

${ }^{325}$ Vide item 5.1.3.1., p. 174.

${ }^{326}$ Jefferson Parish Hospital District No. 2v Hyde, 466 US 2 (1984), considerando 13.
} 
substancial de o autor da prática vir a adquirir poder de mercado no produto subordinado; e (iii) existência de dois produtos distintos. Com relação ao terceiro requisito, a pergunta que se deveria fazer, segundo o Juiz O'Connor, seria se haveria procura distinta do produto subordinado sem o produto subordinante. Caso existisse, entendia o juiz que seria o caso de se analisarem eventuais defesas da eficiência quanto aos benefícios da integração. Preenchidos assim os requisitos, passariam as autoridades para o próximo passo, que seria analisar os efeitos anti e pró-competitivos da prática.

A decisão em Jefferson Parish foi ainda encarregada de estabelecer limiar de 30\% das vendas no mercado do produto subordinado como valor mínimo de exclusão para que uma alegação de subordinação possa ter sucesso.

Contudo, o princípio enunciado em International Salt e aparentemente apoiado pela maioria no acórdão Jefferson Parish, o qual preconizava que uma patente conferia poder de mercado, ou "responsabilidade especial", para exercício de coação sobre compradores, foi abandonado por recente decisão da Suprema Corte americana no caso Illinois Tools Works Inc et al. V Independent Ink, Inc. ${ }^{327}$ Neste caso, a Suprema Corte reiterou a necessidade de análise do mercado para identificação dos potenciais efeitos anticompetitivos inerentes à conduta da subordinação.

Mais recentemente em 2001, o Tribunal Distrital norte-americano decidiu, no caso Microsoft, que a venda casada contratual e tecnológica do seu navegador de internet no seu sistema operacional não necessariamente constituía venda casada ilegal sob a Seção 1 do Sherman Act. O tribunal ainda decidiu que uma análise sob a regra da razão deveria prevalecer, devendo os reclamantes provarem que os benefícios da prática são menores do que os prejuízos verificados no mercado do produto subordinado. ${ }^{328}$

As decisões acima elencadas não parecem promover guia explícito dos parâmetros que devem ser utilizados para se distinguir as práticas legais das ilegais. Tentativamente, contudo, podemos reconhecer que: (i) requer-se uma análise sobre a regra da razão, balanceando-se efeitos pró e anticompetitivos; (ii) deve-se verificar a existência de dois produtos ou serviços separados; (iii) deve haver o condicionamento de aquisição de um produto a um segundo produto, sendo que quando houver a possibilidade de aquisição de produtos de forma separada, a subordinação não imporia restrição não razoável reprimível seria o elemento de coação existente; (iv) deve-se verificar poder de mercado

\footnotetext{
${ }^{327}$ Illinois Tool Works Inc. et al v. Independent Ink., 547 US 28 (2006).
}

${ }^{328} 253$ F.3d 34, 84 (D.C. Cir. 2001). 
como elemento que permite ao agente implantar a conduta de subordinação; e (v) deve-se verificar ainda substancial volume de comércio no produto subordinado.

\subsubsection{Preços Predatórios}

Historicamente, o tratamento dos preços predatórios sempre foi marcado por dois aspectos: (i) dificuldade de se delinear de forma clara e correta que práticas deveriam constituir a ofensa e (ii) medo exagerado de que grandes empresas estariam inclinadas às práticas de preços predatórios. Por esta razão, antes das decisões da Suprema Corte mencionadas abaixo os reclamantes obtinham sucesso na maioria dos casos litigados.

Neste sentido foi a decisão no caso Utah Pie \& Co. v. Continental Banking Co., ainda que no contexto do Robinson-Patman Act. A Continental, concorrente da Utah Pie, vendia tortas de maçã à USD 2,85 a dúzia, que seria menos do que seus custos diretos e indiretos. Via de consequência, a Utah Pie teve de reduzir os preços das suas tortas de maçã congeladas para USD 2,75 a dúzia, preço que a Continental se recusou a praticar. A Suprema Corte decidiu que a Continental havia praticado preços predatórios em razão da conclusão do júri de que um concorrente que é forçado a reduzir seu preço para um valor historicamente baixo em mercado de preços em declínio irá sentir ao longo do tempo dificuldades financeiras e terá uma força concorrencial menos eficiente. ${ }^{329}$

Dois acórdãos da Suprema Corte marcaram a discussão acadêmica acerca de preços predatórios. No primeiro deles, Matsushita, ${ }^{330}$ sete empresas japonesas produziam equipamentos eletrônicos e foram acusadas de colusão em dois mercados, ao longo de duas décadas: no mercado japonês, através de fixação de preços, e no mercado norte-americano, através da prática de preços predatórios com o objetivo de excluir os concorrentes americanos.

Os princípios trazidos pelo acórdão proferido pela Suprema Corte para avaliação da configuração de um abuso requeriam: (i) que o autor da prática tivesse uma expectativa razoável de alcançar o monopólio, o que, no caso em questão, parecia improvável, em vista de supostamente tratar-se de cartel e não de uma única empresa; (ii) que o autor da prática mantivesse sua posição alcançada, em razão das barreiras à entrada e impossibilidade de expansão dos concorrentes remanescentes; e finalmente (iii) que o predador previsse que

\footnotetext{
329386 U.S. 685 (1967).

${ }^{330}$ Matsushita Elec. Indus. Co. v. Zenith Radio Corp., 475 U.S. 574, 106 S.Ct. 1348, 89 L.Ed.2d 538 (1986).
} 
tais condições lhe permitiriam exercer poder de mercado durante prazo suficiente para recuperar os custos de seu investimento.

A Suprema Corte entendeu que os autores apresentaram uma teoria predatória plausível, no sentido de que as empresas japonesas já teriam cartelizado o mercado japonês, mantendo preços supracompetitivos naquele mercado. Possuindo maiores custos fixos e capacidade ociosa substancial, os japoneses precisavam de um mercado amplo para colocarem seus produtos, sendo os Estados Unidos uma alternativa. Contudo, precisavam tomar algumas medidas no sentido de evitar desvios na colusão que poderiam impactar nos altos preços praticados no Japão. Assim estabeleceram um piso nos preços predatórios, a fim de limitarem suas perdas ao necessário para precificarem abaixo dos preços norteamericanos, e limitando o número de distribuidores norte-americanos por produtor japonês. Com suas perdas limitadas, parecia possível o atingimento de um equilíbrio, com altos preços no Japão e perdas mínimas nos Estados Unidos, não se verificando necessário o requisito da recuperação adstrita ao mercado norte-americano. Apesar da teoria plausível, a Suprema Corte, mais sensível à teoria de Chicago sobre o tema, conclui sua análise em favor das empresas japonesas, por maioria de votos.

O caso Brooke Group, ${ }^{331}$ por sua vez, envolvia a indústria do tabaco americana, considerada superconcentrada. No início dos anos 80, uma das concorrentes havia perdido significativa participação de mercado. Para não quebrar, criou uma marca genérica e passou a precificar com $30 \%$ de desconto com relação às demais marcas, alcançando, em nove anos, participação de mercado em torno de $15 \%$, frente aos $2 \%$ que possuía no início de sua estratégia. Brown \& Williamson, empresa que detinha pouco mais de $11 \%$ do mercado e maior prejudicada com a perda de seus consumidores, criou estratégia semelhante, iniciando guerra de preços no atacado, sem alterações no varejo.

Concorrente da Brown \& Williamson, a Liggett promoveu ação contra a prática predatória daquela no Tribunal Distrital, tendo havido condenação pelo júri popular. Não obstante, o juízo anulou a condenação, o que foi confirmado pela Suprema Corte. O acórdão da Suprema Corte estabeleceu dois requisitos para configuração de preços predatórios: (i) o preço deveria situar-se abaixo de uma medida adequada dos custos do concorrente; e (ii) a autora deveria demonstrar que o concorrente tem uma probabilidade razoável ou perigosa de recuperar o investimento em preços abaixo do custo.

\footnotetext{
${ }^{331}$ Brooke Group Ltd. v. Brown \& Williamson Tobacco Corp., 509 U.S. 209, 113 S.Ct. 2578, 125 L.Ed.2d 168 (1993).
} 
Edlin, $^{332}$ em crítica ao acórdão Brooke Group, considera que o princípio enunciado deve se limitar a casos de oligopólio ao abrigo do Robson Patman Act, não se aplicando a casos de monopolização onde, para o autor, mesmo preços acima do custo podem ser predatórios devido aos seus efeitos negativos ao bem-estar dos consumidores. $\mathrm{O}$ autor mostrava-se preocupado com a forma como as regras tendem a impedir o próprio fenômeno da persecução de preços predatórios.

Edlin propõe ainda a impossibilidade de redução de preços por parte da empresa dominante quando da entrada de novo concorrente com preços mais baixos, ou mesmo a introdução de melhoramentos significativos, até que o novo concorrente tenha período razoável para recuperar custos de entrada e se tornar viável, ou até que sua quota cresça ao ponto da outra empresa deixar de ser dominante. Interessante teoria para centrar a discussão nos incentivos necessários ao jogo da concorrência, para que produza o máximo de benefícios ao consumidor.

Após o caso Brooke Group, os tribunais norte-americanos tentativamente se debruçaram sobre o desafio de definição de uma medida apropriada de custo. $\mathrm{O}$ caso $A M R$ Corp., decidido pelo $10^{\circ}$ Circuito, fomentou muito debate, sem contudo se alcançar consenso sobre o tema. ${ }^{333}$ Neste caso houve arquivamento sumário em favor de uma companhia de aviação estabelecida que alegadamente promoveu um esquema de corte de preço e oferta de capacidade adicional predatória com o intuito de excluir uma nova entrante. O Circuito ao final determinou que a administração pública não demonstrou a precificação abaixo de certa medida de custo.

Vale mencionar que o tribunal declinou em estabelecer uma medida definitiva de custos para todos os casos, observando que custo médio variável seria um padrão comumente aceitável para custos marginais em casos de preços predatórios. Foi além ao afirmar que qualquer parâmetro que venha a ser utilizado para medir custos marginais deve ser preciso e confiável em razão das circunstâncias específicas do caso.

O Guia de Aplicação da Seção 2 do Sherman Act, não obstante tenha sido afastado pelo DOJ por seu suposto liberalismo exacerbado, traz bom resumo da visão dos tribunais acerca da prática de preços predatórios e seu combate. Neste sentido afirma a importância de sua condenação em circunstâncias apropriadas uma vez que pode prejudicar a concorrência, ressaltando a importância de desenvolver-se regra clara,

\footnotetext{
${ }^{332}$ EDLIN, Aaron S. Stopping. Above-Cost Predatory Pricing, Yale L. J, vol. 111. No. 4, 2002, p. 946.

333 335 F.3d 1109, 1115 (10th Cir. 2003).
} 
objetiva, efetiva e administrável que permitam às empresas prever se seus respectivos cortes de preços poderão resultar em responsabilidade antitruste.

Continua com o reconhecimento de que somente processos envolvendo preços abaixo de medida de custo médio evitável ou abaixo de certa medida de custo, combinado com uma perigosa probabilidade de recuperação, deveriam restar sujeitos à responsabilidade decorrente da lei. Defesas baseadas nas eficiências, quando suportadas por evidências, deveriam também ser consideradas e, em casos nos quais medidas preventivas são apropriadas, deveriam se tomar os devidos cuidados para garantia de que os remédios impostos beneficiem, ao final, os consumidores.

\subsubsection{Descontos de Fidelidade e Multiprodutos}

Verificamos poucas decisões de tribunais norte-americanos analisando descontos de fidelidade ou multiprodutos, nenhuma delas, contudo, da Suprema Corte.

Um dos primeiros casos trazidos à decisão do $3^{\circ}$ Circuito envolvia práticas de descontos por parte da Eli Lilly \& Co. em prejuízo da SmithKline Corp. A última, tendo licenciado um produto conhecido como cephalosporins de uma empresa estrangeira para venda a hospitais sem fins lucrativos, começou a sofrer concorrência predatória da primeira. A Elli Lilly, neste sentido, que já possuía quatro tipos de cephalosporins, licenciou a mesma droga e a chamou de Kefzol, e passou a modificar seu esquema de descontos - antes baseado no volume adquirido das quatro drogas, reduzindo o desconto em aproximadamente 3\% e adicionando um bônus de 3\% desde que os hospitais adquirissem as quantidades mínimas específicas de três cephalosporins específicos - dois em que ela possuía posição dominante e o Kefzol.

O tribunal verificou que para que a SmithKline Corp alcançasse o preço praticado pela Elli Lilly, deveria aplicar um desconto de cerca de $20 \%$, o que tornaria sua comercialização não lucrativa. Assim, a prática seria capaz de excluir até mesmo se a SmithKline Corp. fosse uma concorrente tão eficiente quanto a Elli Lilly, tendo o tribunal condenado a última por infração à Seção 2 do Sherman Act.

Alguns anos após, a Ortho Diagnostics trouxe um caso contra a Abbott Laboratories, Inc., por prática de descontos em uma licitação para produtos destinados a centros de doação de sangue. Por conta de possuir os cincos diferentes tipos de produtos tubos de ensaio - objeto da licitação, a Abbott ofereceu um pacote com descontos 
significativos caso o Conselho da Comunidade dos Centros de Bancos de Sangue adquirissem os cinco tipos de produto. A Ortho Diagnostics alegou que os descontos criavam um incentivo significativo para que todos os tubos de ensaio fossem adquiridos da Abbott.

O tribunal afirmou que estaríamos diante de prática ilícita se com o desconto conjunto o monopolista vendesse abaixo do custo médio variável ou, alternativamente, se o concorrente é pelo menos tão eficiente quanto o monopolista, porém não pode continuar a produzir sem perdas devido ao baixo preço praticado na sequência do desconto. Em razão da Ortho Diagnostics não ter alegado que não poderia produzir e comercializar o produto com lucro como resultado dos descontos ofertados pela Abbott, o tribunal não encontrou violação à Seção 2 do Sherman Act.

Já no caso Virgin Atlantic Airways v. British Airways Plc., ${ }^{334}$ esta empresa havia entrado em acordos de incentivos com várias agências de turismo e clientes corporativos com diversas metas para rotas ou grupos regionais de rotas, e determinando pagamentos de incentivos cada vez que as metas fossem atingidas. A Virgin alegava que um cliente da BA que adquirisse rotas em que a empresa detivesse monopólio teria um incentivo para adquirir rotas em que a Virgin competia, ainda que a Virgin ofertasse um preço para tais rotas inferior aos da BA.

O tribunal replicou a conclusão alcançada no caso Ortho Diagnostics de que o produto competitivo deveria ser vendido abaixo do custo médio variável após o desconto dos produtos monopolistas ser reduzido do produto competitivo. Em razão, contudo, das provas insuficientes neste sentido trazidas pela Virgin não houve condenação da BA.

$\mathrm{O}$ caso LePage $e^{335}$, contudo, representa uma mudança de rumo no tocante à condenação das práticas de descontos de fidelidade. O caso se refere a um fornecedor de materiais de escritório que começou a fabricação de fita adesiva transparente no início dos anos 80, atuando como segunda marca, tratando de um produto mais barato do que a marca líder da 3M. Assim, passou a fornecer fita aos grandes grupos atacadistas para a venda com suas respectivas marcas próprias, fazendo-a atingir participação de cerca de $88 \%$ no segmento de marca branca em 1992, porém representativa de pequena parcela se considerado o mercado como um todo.

A 3M, com propósito deliberado, segundo evidências colhidas, de afastar a ameaça concorrencial à sua posição dominante, entrou no segmento de marcas brancas no

\footnotetext{
${ }^{334} 69$ F.Supp. 2d 571 (S.D.N.Y 1999), aff'd, 257 F.3d 256 (2d Cir. 2001).

${ }^{335}$ LePage's Inc v. 3M, 324 F3d 141 ( $3^{\text {rd }}$ Cir. 2003).
} 
início da década de 90, lançando a Highland. Na segunda metade da década a 3M lançou um programa de descontos junto a grandes atacadistas, tanto do comércio especializado como grandes distribuidores, os quais eram concedidos em função de compras realizadas com relação a toda gama de seus produtos, celebrando ainda acordos de compras exclusivas, o que reduziu drasticamente as vendas da LePage no segmento da marca branca.

O Terceiro Circuito norte-americano decidiu, em grau de recurso, confirmar o provimento à ação, fixando indenização de cerca de USD 22,8 milhões, sujeitos ainda a danos triplicados. Essencialmente, o Terceiro Circuito reprimiu a conduta da 3M por ter estabelecido descontos por objetivos em que, caso não fossem atingidos com relação a uma gama de produtos da empresa, levariam à perda da totalidade do desconto dobre todos os outros produtos. Ainda, a dimensão dos descontos foi algo considerado pelos juízes, visto que tais descontos poderiam chegar, para grandes atacadistas, a cerca de metade do valor anual de vendas da LePage a essas empresas. Vale ainda mencionar que foram encontradas evidências da estratégia excludente da 3M, além desta empresa deter significativa participação de mercado nos produtos em questão, em especial seu poder de portfólio. A análise proferida pelo Circuito foi muito semelhante à análise proferida pela Comissão Europeia no acórdão Hoffmann-La Roche.

No que tange à metodologia de análise empregada, alegava a 3M que os seus descontos nunca implicaram vendas abaixo do custo médio variável, defendendo a aplicação de metodologia de preços predatórios.

Tal metodologia viria a ser empregada no caso Cascade Health, ${ }^{336}$ pelo Nono Circuito. A prática sob análise consistia na realização, pela PeaceHealth, de condições diferenciadas junto a empresas de seguros de saúde, oferecendo preços mais favoráveis caso estes a nomeassem prestadora preferencial para determinado território. Vale mencionar que a PeaceHealth detinha $75 \%$ do mercado de serviços primários e secundários, e 90\% dos terciários, de planos de seguros de saúde. Cascade, por sua vez, não prestava serviços terciários.

Os descontos promovidos pela PeaceHealth chegavam a $40 \%$ nos cuidados terciários. Assim, o tribunal de primeira instância concluiu pela verificação da infração, condenando a PeaceHealth a uma indenização de USD 16 milhões, após a triplicação dos danos. O Nono Circuito, que apreciou o recurso, mostrou-se preocupado com as críticas à

\footnotetext{
${ }^{336}$ Cascade Health v. PeaceHealth, 479 F.3d 726 ( $9^{\text {th }}$ Cir. 2007).
} 
LePage e, considerando as ubiquidades das práticas de bundling e ganhos de eficiência ao consumidor, não se justificava critério tão limitador da liberdade de concorrer pelo preço, mesmo no caso de empresa com séria probabilidade de alcançar poder de mercado. Discutia-se, portanto, qual metodologia deveria ser empregada nos casos de mixed bundling, tendo entendido o Tribunal que tais descontos só devem ser proibidos na medida em que sejam suscetíveis de excluir concorrentes igualmente eficientes.

Assim, o Nono Circuito retomou a proposta da Comissão de Modernização do Direito Antitruste instituindo um critério de três partes: (i) a venda do produto concorrencial terá de ocorrer abaixo do seu custo incremental; (ii) será necessário demonstrar que existe uma possibilidade efetiva de recuperação de perdas a curto prazo; e por fim, (iii) deve-se ainda averiguar qual o efeito negativo, atual ou provável, na concorrência. No que tange ao primeiro requisito restava ainda definir-se seu critério de aplicação, sendo afinal aceito novamente o critério proposto pela Comissão de Modernização: "o valor total do desconto dado pelo réu na combinação será alocado ao produto competitivo. Se o preço resultante do(s) produto(s) competitivo(s) estiver abaixo do custo incremental do réu de produzi-los, então a conclusão a que se deve chegar é que o desconto multiproduto será excludente para o propósito do artigo 2". 337

Não há sinalização por parte da Suprema Corte no tocante ao correto parâmetro a ser aplicado para abusos de posição dominante decorrentes de descontos de fidelidade. Há decisões de certa forma conflitantes nas cortes federais. Enquanto o $3^{\circ}$ Circuito, em sua decisão em 2003 no caso LePage's, não se utilizou de um teste objetivo baseado em custos para determinação da infração - o que de certa forma se aproxima ao padrão europeu outros casos, antes e depois de LePage's, em especial PeaceHealth, têm se utilizado de um padrão baseado em custo, apesar de nem sempre terem sido utilizados as mesmas medidas de custos.

\subsubsection{Exclusividade}

Historicamente, precedentes da Suprema Corte relacionados à exclusividade focam na questão essencial do fechamento da concorrência em parte substancial da linha de comércio afetada pela conduta. Não obstante, os tribunais inferiores avaliam a legalidade de práticas de exclusividade através do exame de diversos outros fatores, como:

\footnotetext{
${ }^{337}$ MOURA E SILVA, Miguel. O Abuso de Posição Dominante na Nova Economia, cit., p. 285.
} 
(i) a natureza do produto e relação entre as partes do arranjo; (ii) o percentual de fechamento do mercado para a concorrência como resultado do arranjo; (iii) a sua duração.

O primeiro caso decidido pela Suprema Corte considerava um contrato proibindo um dos revendedores da Standard Fashion de carregar outros padrões de vestuário. ${ }^{338}$ Quando desrespeitada a cláusula, a Standard Fashion pleiteou danos do revendedor por infração contratual. O Tribunal arquivou a ação sob o argumento de que o contrato violava o Clayton Act. Ao verificar que a Standard Fashion possuía uma participação de aproximadamente $40 \%$ dos revendedores padrão nos Estados Unidos, o Tribunal decidiu que os arranjos de exclusividade em muitas das cidades implicavam monopólio.

Já em 1949, na decisão Standardo Oil Co. of California v. United States, a Suprema Corte manteve decisão que proibia a Standard Oil de executar dispositivos contratuais que obrigavam estações de gasolina em sete estados de adquirirem somente gasolina daquela empresa. Naquela ocasião a Suprema Corte reconheceu que apesar da possibilidade de vantagens econômicas tanto para o comprador quando para o vendedor, e consequentemente indiretamente para os consumidores, tais justificativas seriam irrelevantes em razão de (i) ausência de intenção por parte do Congresso de que os tribunais medissem em cada caso o requisito final do interesse público; e (ii) que os tribunais seriam mal equipados para a tarefa de balanceamento de efeitos pró e anticompetitivos. O percentual de fechamento de mercado representava $16 \%$ dos pontos de vendas de gasolina em sete estados, concluindo a Suprema Corte pela violação ao Clayton Act.

Outro caso decidido pela Suprema Corte logo após Standard Oil foi a recusa de venda por parte de um jornal de vender espaço publicitário a empresas que, da mesma forma, compravam publicidade de uma estação de rádio. Parecia haver, neste sentido, tentativa por parte do jornal de se tornar o fornecedor exclusivo de publicidade na região. A Corte entendeu que a Seção 2 do Sherman Act proibia o jornal de tentar recuperar seu monopólio através da exclusão da estação de rádio, concluindo, portanto, que havia violação ao dispositivo quando houvesse utilização do monopólio para destruição de ameaça de concorrência. ${ }^{339}$

Já em 1961 a Suprema Corte reconheceu a validade de um contrato em que a Nashville Coal concordou em vender toda a demanda de carvão para operação da Tampa

\footnotetext{
${ }^{338}$ Standard Fashion Co. v. Magrane-Houston Co., 258 U.S. 346, 357 (1922).

${ }^{339}$ Lorain Journal Co. v. United States, 342 U.S. 143 (1951).
} 
Electric em algumas de suas plantas de energia. ${ }^{340}$ Neste sentido, quando a fornecedora se recusou ao cumprimento do contrato, foi processada pela Tampa Electric, tendo ainda alegado em sua defesa que o Clayton Act proibia contratos de exclusividade, os quais por sua vez exigiam ao longo de vinte anos entrega de mais de USD 128 milhões em carvão, cerca de $1 \%$ do mercado relevante.

A Suprema Corte foi além da metodologia empregada em Standard Station para afirmar que a legalidade do acordo dependeria da análise de diversos fatores. Assim, determinou na decisão em comento a necessidade de balanceamento dos prováveis efeitos do contrato na efetiva concorrência em uma região relevante, considerando-se (i) a força relativa das partes, (ii) o volume proporcional de comércio envolvido em relação ao volume total de comércio na região relevante e (iii) o provável efeito imediato e futuro que aquela participação de mercado poderia ter na efetiva concorrência.

Aplicando a metodologia em referência, a Suprema Corte concluiu que o contrato garantia uma fonte de fornecimento estável para a Tampa Electric e permitia à Nashville Coal a redução de despesas de vendas.

Logo após o tratamento mais leniente verificado no caso acima, a Suprema Corte condenou a Brown Shoe, sob a Seção 5 do FTC Act, em decorrência dos seus arranjos de exclusividade com aproximadamente $1 \%$ dos revendedores varejistas dos Estados Unidos. $^{341}$ A Corte verificou que os arranjos exigiam dos varejistas de calçados que limitassem substancialmente seu comércio com os concorrentes da Brown Shoe, entendendo que o programa de exclusividade em questão obviamente conflitava com a política central da Seção 1 do Sherman Act e da Seção 2 do Clayton Act no sentido de que tais contratos retiravam a liberdade dos compradores de aquisição em um mercado aberto.

Sem decisões da Suprema Corte desde Brown Shoe, ${ }^{342}$ os tribunais federais foram responsáveis por desenvolver um pouco mais a metodologia de análise de casos de exclusividade. Assim, reconheceram a métrica utilizada em Tampa Electric - que abandonou o foco limitado empregado em Standard Stations, considerando a variedade de fatores trazida naquela decisão. Assim, o foco aparentemente permaneceu na questão da probabilidade exclusão de rivais do mercado, levando em conta o volume de comércio envolvido e percentual de fechamento, e passando ainda os tribunais a considerarem o

\footnotetext{
${ }^{340}$ Tampa Elec. Co. v. Nashville Coal Co., 365 U.S. 320, 329 (1961).

${ }^{341}$ FTC v. Brown Shoe Co., 384 U.S. 316, 321 (1966).

${ }^{342}$ Vale recordar que Jefferson Parish (466 U.S. 2, 30 n. 51, 1984) trouxe elementos de arranjos de exclusividade, reconhecido por alguns juízes da Corte, apesar de se tratar de caso tipificado sob a modalidade de venda casada.
} 
período do arranjo e justificativas pró-competitivas ao avaliarem a legalidade das práticas, tais como uma estável fonte de fornecimento e preços, ${ }^{343}$ ou ainda a promoção mais vigorosa da marca e prevenção dos caronistas nos esforços de vendas do produto. ${ }^{344}$

${ }^{343}$ Barry Wright Corp. v. ITT Grinnell Corp., 724.

${ }^{344}$ Roland Mach. Co. v. Dresser Indus., Inc., 749 F.2 d 380, 395 (7th Cir. 1984) (Posner, J.). 


\section{CAPÍTULO 6 \\ TRATAMENTO COMPARADO DO ABUSO DE POSIÇÃO \\ DOMINANTE: UNIÃO EUROPEIA}

\subsection{Tratamento Normativo Europeu}

Inicialmente, vale recordar a política concorrencial levada a efeito pela União Europeia, que se baseia em cinco pilares tradicionais, notadamente a proibição dos contratos entre agentes econômicos que limitem a concorrência, a proibição do abuso de posição dominante por um ou mais agentes econômicos, o controle de fusões e aquisições que venha a criar agente econômico com posição dominante; o controle de auxílio estatal por Estados-membros a agentes econômicos ou categorias econômicas e, finalmente, a liberalização de medidas pelos Estados-membros para favorecerem o segmento de infraestruturas nacionais.

Vale ainda recordar que a União Europeia teve sua primeira lei concorrencial supranacional com a edição do Tratado de Roma em 1957, nos seus artigos 85 e 86 . Esse diploma foi posteriormente reformado pelo Tratado de Maastricht em 1994, e mais recentemente pelo Tratado de Lisboa em dezembro de 2007. ${ }^{345}$

Assim, o Tratado Sobre o Funcionamento da União Europeia ("TFUE") dispõe, na sua Parte III (Políticas e Ações Internas da União), Título VII (As Regras Comuns Relativas à Concorrência, à Fiscalidade e à Aproximação das Legislações), Capítulo 1 (As Regras de Concorrência), Seção 1 (As Regras Aplicáveis às Empresas), dispositivos legais que visam regular atividades das empresas no que tange aos seus efeitos diretos na concorrência e indiretos nos consumidores, conforme se depreende da análise dos artigos $101^{346}$ a 109 . Os artigos 107 a 109 tratam ainda de regramento aos auxílios concedidos pelos estados.

\footnotetext{
${ }^{345}$ Com a Edição do Tratado de Roma, a denominação estabelecida à época foi Comunidade Econômica Europeia. Esta denominação foi alterada em 1992 com o Tratado de Maastricht, passando a Comunidade Europeia, e mais recentemente com a entrada em vigor do Tratado de Lisboa, assinado em 13 de dezembro de 2007 e em vigor desde $1^{\circ}$ de dezembro de 2009, passando a União Europeia. Em 30 de março de 2010 foi publicada a versão consolidada do Tratado da União Europeia e do Tratado sobre o Funcionamento da União Europeia.

${ }^{346}$ Artigo 101 (ex-artigo 81 do TCE). 1. São incompatíveis com o mercado interno e proibidos todos os acordos entre empresas, todas as decisões de associações de empresas e todas as práticas concertadas que sejam susceptíveis de afectar o comércio entre os Estados-Membros e que tenham por objectivo ou efeito impedir, restringir ou falsear a concorrência no mercado interno, designadamente as que consistam em: a)
} 
Em especial vale notar o artigo 3(b) do TFUE, que dispõe acerca da competência exclusiva da União Europeia sobre o estabelecimento das regras de concorrência necessárias ao funcionamento do mercado interno.

No que tange especificamente ao escopo do presente estudo, temos o artigo 102 do TFU que trata do abuso de posição dominante:

\begin{abstract}
Artigo 102 (ex-artigo 82 do TCE): É incompatível com o mercado interno e proibido, na medida em que tal seja susceptível de afectar o comércio entre os Estados-Membros, o facto de uma ou mais empresas explorarem de forma abusiva uma posição dominante no mercado interno ou numa parte substancial deste.

Estas práticas abusivas podem, nomeadamente, consistir em:

a) Impor, de forma directa ou indirecta, preços de compra ou de venda ou outras condições de transacção não equitativas;

b) Limitar a produção, a distribuição ou o desenvolvimento técnico em prejuízo dos consumidores;

c) Aplicar, relativamente a parceiros comerciais, condições desiguais no caso de prestações equivalentes colocando-os, por esse facto, em desvantagem na concorrência;

d) Subordinar a celebração de contratos à aceitação, por parte dos outros contraentes, de prestações suplementares que, pela sua natureza ou de acordo com os usos comerciais, não têm ligação com o objecto desses contratos.
\end{abstract}

À sombra do dispositivo, alguns elementos merecem destaque. Primeiramente, o reconhecimento de que a exploração abusiva de uma posição dominante pode se dar não exclusivamente por parte de uma única empresa dominante, mas por mais de uma empresa. Trata-se do conceito da dominância coletiva - ainda que uma única empresa não tenha a possibilidade de exercer posição dominante, ao disciplinar sua conduta com outros agentes estes passam a exercer um poder de mercado de forma conjunta.

Da mesma forma, o artigo traz o conceito de susceptibilidade de efeito, o que leva ao entendimento, similarmente ao que se reconhece no Brasil, de que a mera possibilidade

Fixar, de forma directa ou indirecta, os preços de compra ou de venda, ou quaisquer outras condições de transacção; b) Limitar ou controlar a produção, a distribuição, o desenvolvimento técnico ou os investimentos; c) Repartir os mercados ou as fontes de abastecimento; d) Aplicar, relativamente a parceiros comerciais, condições desiguais no caso de prestações equivalentes colocando-os, por esse facto, em desvantagem na concorrência; e) Subordinar a celebração de contratos à aceitação, por parte dos outros contraentes, de prestações suplementares que, pela sua natureza ou de acordo com os usos comerciais, não têm ligação com o objecto desses contratos. 2. São nulos os acordos ou decisões proibidos pelo presente artigo. 3. As disposições no n. 1 podem, todavia, ser declaradas inaplicáveis: a qualquer acordo, ou categoria de acordos, entre empresas, a qualquer decisão, ou categoria de decisões, de associações de empresas, e a qualquer prática concertada, ou categoria de práticas concertadas, que contribuam para melhorar a produção ou a distribuição dos produtos ou para promover o progresso técnico ou económico, contanto que aos utilizadores se reserve uma parte equitativa do lucro daí resultante, e que: a) Não imponham às empresas em causa quaisquer restrições que não sejam indispensáveis à consecução desses objectivos; b) Nem deem a essas empresas a possibilidade de eliminar a concorrência relativamente a uma parte substancial dos produtos em causa. 
de afetação da concorrência pode ensejar disciplinamento por parte das autoridades, não sendo necessária a verificação efetiva de um dano.

Outro elemento que merece reparo trata-se da necessidade de a conduta ser suscetível de afetação no mercado interno ou numa parte substancial deste. Devemos recordar que um dos objetivos primordiais do Tratado é o estabelecimento e bom funcionamento do mercado único [interno] europeu, em especial preocupando-se com a eliminação dos obstáculos para a livre circulação de produtos e serviços. Por esta razão, em especial, as normas de defesa de concorrência europeias, apesar de encontrarem seus pilares e assemelharem-se a diplomas de outras jurisdições, neste quesito assumem feição particular. Mas não se deve olvidar que tais nações possuem ainda seus próprios sistemas de proteção à livre concorrência, que devem ser utilizados quando não haja afetação do comércio entre Estados-Membros, sempre segundo as orientações da legislação comunitária.

No que tange às condutas expressamente reguladas pelos dispositivos acima, primeiramente se faz relevante notarmos que, por óbvio, o rol trazido é não exaustivo, abarcando todo tipo de conduta suscetível de afetar o comércio entre Estados-Membros. Especificamente com relação ao rol trazido, temos restrições elencadas à imposição de condições comerciais não equitativas, à limitação à atuação de concorrentes no mercado, à discriminação nas condições comerciais impostas a parceiros comerciais e, por fim, à venda casada; todos elementos de tradicional preocupação por parte de autoridades concorrenciais.

\subsection{Organização do Sistema Concorrencial Europeu}

As instituições europeias de alguma forma relacionadas à defesa da concorrência incluem o Conselho da União Europeia - ou ainda Conselho de Ministros - que, apesar de não sistematicamente envolvido na política concorrencial, às vezes atuas sob os poderes do Tratado para editar normas, como a regulação das fusões ("ECMR"), delegando ainda poderes à Comissão Europeia para funções relacionadas, como o poder de outorgar exceções de bloco.

A Comissão Europeia, por sua vez, seria o coração da política concorrencial europeia, responsável por investigações e punições de infrações, condução de investigações setoriais, definição das exceções de bloco, avaliação de notificações de 
operações e de auxílio estatal, desenvolvimento de políticas e legislações concorrencial e cooperação com autoridades da concorrência estrangeiras. Um dos Comissários da União Europeia se torna o Comissário para Concorrência. DG COMP seria o Diretório da Comissão especificamente responsável pela política concorrencial, possuindo ainda um Diretor Geral e três Diretores Gerais Adjuntos e um Economista Chefe, sendo dividido ainda em nove unidades administrativas.

Recursos contra as ações ou decisões envolvendo política concorrencial por parte da Comissão são inicialmente trazidos perante o Tribunal de Primeira Instância, incluindo recursos trazidos pelos Estados-Membros. Por sua vez, o Tribunal de Justiça Europeu recebe recursos das decisões proferidas pelo Tribunal de Primeira Instância. Contudo, tais recursos devem versar exclusivamente sobre "pontos legais", sendo vedado ao tribunal adentrar em questões fáticas nos casos em recurso. Também recebe referências dos Estados Membros para se manifestar sobre pontos legais. O Tribunal de Justiça é ainda auxiliado por um Procurador Geral - Advocate General, selecionado de um painel de oito, que apresenta uma opinião não vinculativa.

Há ainda os Comitês Consultivos sobre Práticas Restritivas e Posição Dominante, bem como sobre Concentrações, além das autoridades nacionais pertencentes a cada Estado-Membro, o Parlamento Europeu e seu comitê especial - Comitê de Assuntos Econômicos e Monetários ("ECOSOC"), que são consultados em assuntos de política concorrencial e podem se tornar influentes, por exemplo, com relação ao processo legislativo ou persuadindo a Comissão a não tomar ações com relação a assuntos em particular.

Importante frisar que os Estados-Membros possuem atualmente sistemas concorrenciais modelados, em maior ou menor grau, nos artigos 101 e 102 do TFUE. Contudo, a legislação comunitária possui prioridade sobre legislações nacionais, ou seja, em caso de conflito de normas, a legislação comunitária deve ser aplicada. Da mesma forma, sobre o regime da Regulação da Modernização, ${ }^{347}$ a Comissão possui competência concorrente para aplicação dos artigos 101 e 102 com autoridades nacionais e com tribunais nacionais, os quais podem aplicar ainda sua legislação doméstica. Contudo, de acordo com a regulação em referência, as autoridades ou tribunais nacionais devem ainda aplicar os artigos 101 e 102 quando pertinentes diante da possibilidade de afetação do comércio entre Estados-Membros.

\footnotetext{
${ }^{347}$ Regulação da Comissão Europeia n. 1/2003.
} 
Interessante ainda notarmos que há exigência de convergência com relação aos acordos ilegais previstos no artigo 81, de forma que não pode haver tratamento mais leniente das autoridades nacionais em relação ao entendimento da legislação comunitária. Contudo, não se verifica a necessidade de convergência com relação às condutas unilaterais regradas pelo artigo 102 do TFUE. Ainda, a Regulação 1/2003 permite que autoridades nacionais possam ainda aplicar legislações nacionais que protejam interesses outros além da proteção da livre concorrência, desde que tais legislações sejam compatíveis com os princípios gerais e demais dispositivos da legislação comunitária.

Portanto, verificamos que a atuação da Comissão Europeia, responsável direta pela instrução, investigação, determinação de cessação ou correção da infração e punição de empresas envolvidas, atua de maneira interna corporis, emanando suas próprias decisões, diferentemente do que geralmente se verifica no sistema norte-americano, mas semelhante ao que se verifica no sistema brasileiro.

Contudo, há intenso escrutínio de suas decisões pelo Tribunal de Primeira Instância, em pontos legais e fáticos, não sendo raras as anulações de decisões por erros procedimentais ou interpretativos, revendo-se o próprio mérito das decisões por vezes, ou ainda sua parcial correção, muitas vezes corrigindo-se a dosimetria das penas aplicadas. E ainda, nos pontos legais, existe escrutínio severo por parte do Tribunal de Justiça Europeu. Tal mecanismo revisor, sem qualquer sombra de dúvida, tem sido responsável pela modelagem da atuação da Comissão Europeia nos casos que decide trazer adiante, pelo respeito ao devido processo legal, aos direitos humanos fundamentais, e ao arcabouço jurisprudencial que determinam a correta interpretação dos dispositivos da legislação comunitária ou mesmo das legislações nacionais.

\subsection{Construção Jurisprudencial e Doutrinária Europeia}

\subsubsection{Formação e Aplicação Inicial do Artigo 82}

Segundo o Ilmo. jurista Miguel Moura Silva, em tese de doutoramento que trata do abuso de posição dominante na nova economia, a aplicação do artigo 82 pela Comissão Europeia ficou inicialmente renegada a segundo plano. Muito se discutiu, ao longo do período inicial de operação do Tratado, se o artigo 82 deveria ser utilizado somente diante 
de um prejuízo direto ao consumidor, ou se deveria aplicar-se diante de uma situação de prejuízo indireto, tendo prevalecido o segundo posicionamento. ${ }^{348}$

Discussão de relevância na Europa e que vem ao encontro de nossas conclusões seria o regime especial a que estariam sujeitas empresas dominantes, prevenindo-as de se utilizarem de recursos por vezes tão generalizados, como desconto de fidelidade, devido à susceptibilidade que teriam de prejudicar seus concorrentes no mercado.

Recentemente, debates acerca da modernização do artigo 102 roubaram a cena na Europa. Miguel Moura, em manifesta crítica à política de concorrência norte-americana, indaga quais seriam as implicações da revisão do artigo 82:

Será este um mero exercício para neutralizar a aplicação das regras de concorrência a condutas unilaterais, a exemplo dos desenvolvimentos no ordenamento dos Estados Unidos, por vezes contraditórios, mas nos últimos anos coerentemente no sentido de retirar qualquer alcance útil a velha proibição da monopolização e da tentativa da monopolização? ${ }^{349}$

A discussão, segundo Miguel, envolve ainda:

[U]ma filosofia de relação entre o Estado e o mercado, regida por um direito casuístico e certo, mas assente em princípios gerais e abstratos e não na mão invisível da regulação administrativa, e sujeito ao mais intenso escrutínio judicial e acadêmico. Este faz convergir economistas e juristas num intenso debate de ideias que, incidindo numa temática muito técnica, implicam escolhas sobre que sociedade queremos e que modelo de organização econômica e respectivo enquadramento jurídico mais se adéqua a esta visão. (...) [S]ão muitas as vozes que defendem que sigamos os Estados Unidos e tornemos impossível a prova destas práticas [preços predatórios], por receio de uma mão cheio de condenações dissuadir as empresas dominantes a actuar na União de beneficiar os consumidores baixando os seus preços, ainda que tal possa eliminar concorrentes, desde que estes sejam "menos eficientes". 350

O Comunicado da Comissão Europeia com orientação sobre as prioridades na aplicação do artigo 82 do Tratado CE a comportamentos abusivos de exclusão por parte de empresas em posição dominante dispõe, logo em seu primeiro parágrafo, que:

\footnotetext{
${ }^{348}$ MOURA E SILVA, Miguel. O Abuso de Posição Dominante na Nova Economia, cit., p. 15: "Debatiase então se apenas podiam ser subsumidos ao conceito de abuso de posição dominante aqueles comportamentos que prejudicassem de forma directa o consumidor ou se aquela proibição também abarcava práticas que, ao entravar a concorrência e criar obstáculos à liberdade de mercado dos concorrentes, causassem um dano para o processo concorrencial e só indirectamente ao consumidor. Joliet, no seu clássico estudo comparativo com o regime da monopolização, instituído nos Estados Unidos, foi um ardente defensor da interpretação mais restritiva. Mestmäcker, apoiado pelo Memorando de 1965 da Comissão, foi o mentor da interpretação aparentemente mais ousada, por permitir ate a proibição da aquisição de um concorrente por uma empresa dominante."

${ }^{349}$ Idem, ibidem, p. 16.

${ }^{350}$ Idem, ibidem, p. 18.
} 
$\mathrm{O}$ artigo $82^{\circ}$ do Tratado que institui a Comunidade Europeia ("artigo 82") proíbe o abuso de posição dominante. De acordo com a jurisprudência, a posição dominante não é, por si só, ilegal e uma empresa nessa situação tem o direito de concorrer no mercado com base nos seus méritos. No entanto, a empresa em causa tem uma especial responsabilidade de não permitir que a sua conduta obste a uma concorrência efectiva e não falseada no mercado interno. $\mathrm{O}$ artigo 82 . $^{\circ}$ é a base jurídica de um dos elementos essenciais da política de concorrência e a sua eficaz aplicação ajuda ao bom funcionamento do mercado em benefício das empresas e dos consumidores. No contexto do objectivo mais global da realização de um mercado interno integrado, este facto reveste-se de especial importância. ${ }^{351}$

Conforme pudemos constatar, verificou-se intenso debate acerca do rumo que se planejava para o processamento dos abusos de posição dominante na Europa. Porém, antes disso, elementos mais essenciais dos dispositivos em questão merecem destaque, como a instrumentalização jus-concorrencial à disposição da Comissão Europeia, que consiste em combinação de objetivos, conceitos gerais e definições e, mais especificamente, textos legais. E conceitos gerais identificados pelos Tribunais necessitam complementação com testes mais específicos.

Como visto acima, temos como um dos objetivos centrais do TFUE impedir a distorção no mercado interno. Assim, qual o propósito que a proteção da concorrência deveria servir? Deveria esta proteção se dar no interesse de consumidores, uma vez que o artigo 101 prevê a inaplicabilidade dos dispositivos proibitivos do Tratado quando contribuírem "para melhorar a produção ou a distribuição dos produtos ou para promover o progresso técnico ou económico, contanto que aos utilizadores se reserve uma parte equitativa do lucro daí resultante (...)". Os benefícios resultantes devem ao menos compensar os consumidores pelos impactos negativos da prática restritiva. Apesar de o artigo 102 não contar com dispositivo semelhante, o Tribunal de Justiça Europeu tem reiterado que servem ao mesmo propositivo. ${ }^{352}$

Em linhas gerais, o Tribunal de Justiça Europeu tem articulado, em suas decisões, conforme se elucida adiante, dois conceitos guiando a identificação de abusos excludentes de posição dominante: (i) a noção de que empresas dominantes possuem uma "responsabilidade especial" de não distorção da concorrência; e (ii) uma descrição ou definição básica de abusos excludentes de posição dominante de mercado. Crítica reiterada vem no sentido de que estes conceitos são muito vagos e indeterminados para funcionarem

\footnotetext{
${ }^{351}$ Comunicação da Comissão - Orientação sobre as prioridades da Comissão na aplicação do artigo $82^{\circ}$ do Tratado CE a comportamentos de exclusão abusivos por parte de empresas em posição dominante (2009/C $45 / 02$ ), parágrafo $1^{\circ}$.

${ }^{352}$ Acórdão do Tribunal de Justiça de 21.2.1973, Proc. 6/72, Europemballage Corporation e Continental Can Company Inc. c. Comissão das Comunidades Europeias, Colect. 1973.
} 
como um teste substantivo administrável para distinguir condutas pró e anticoncorrenciais de empresas com posição dominante.

Os conceitos gerais trazidos pela Comissão Europeia e tribunais europeus estabelecem os objetivos finais perseguidos pelo artigo 102 do Tratado, quais sejam a noção de responsabilidade especial e definições básicas acerca das condutas excludentes. Contudo, não especificam quais os meios concretos que devem ser utilizados para identificar conduta excludente sob a égide do artigo 102. Para melhor compreender-se a distinção entre práticas legitimas e ilegítimas por parte de agentes dominantes, faz-se necessário olhar em mais detalhes os precedentes relacionados às categorias específicas de condutas. Daí verificam-se critérios específicos concretos desenvolvidos pelo Tribunal de Justiça Europeu para as mais diferentes modalidades. Adicionalmente, os tribunais têm permitido aos agentes com poder de mercado maior ponderação acerca das justificativas objetivas legitimadoras de suas condutas.

No que tange ao conceito de posição dominante, temos que uma primeira definição na Europa surge com o Memorando sobre a Concentração do Mercado Comum, de $1^{\circ}$ de dezembro de 1965, um estudo promovido pela Comissão Europeia com a colaboração de um grupo de sábios, sobre a aplicação das regras do Tratado a concentrações, algo que não foi levado a efeito intencionalmente pela Comissão:

[I]l y a position dominante sur um marche donné lorsqu'une ou plusieurs entreprises peuvent agir de façon essentielle sur les décisions d'autres agentes économiques au moyen d'une stratégie indépendante de sorte qu'une concurrence práticable et suffisamment efficace ne peu apparaitre et se maintenir sul le marché.

[I]l a exploitation abusie d'une position dominante lorsque le détenteur de cette position utilize les possibilites qui em découlent por obtenir des avantajes qu'il n'obtiendrait pas em cas de concurrence práticable et suffisamment efficace. (ponto 4)

Bien que l'article 86 ne vise pas une position dominante sur um marché déterminé, mais une position dominante tout court, il est geénéralement admis qu'une enterprise ocupe em tout cas une position dominante au sens de l'article 86 quand ele domine um marché. La dominaton du marché ne peut pas être uniquement définie à partir de 1 apart dum arché que détient une enterprise ou d'autres éléments quantitatifs d'une structure du marché donnée. C'est emé premier lieu um pouvoir économique, c'est-à-dire la faculté d'exercer sur le fonctionnement du marché une influence notable et em príncipe prévisible pour l'entrerise dominante. Cette faculté économique d'une entreprise dominante influe sur le comportement et sur les décisions économiques d'autres entreprise, qu'elle soit utilisée ou non dans un sens donné. Une entreprise qui peut évincer, quando ele le désire, les autres entreprises concorrentes dum arché peut déjà disposer d'une position dominante et déterminer d'une façon décisive le 
comportement des autres entreprises même si as propre part dum arché est encore relativement faible. (ponto 22). ${ }^{353}$

Segundo as leis de defesa da concorrência europeias, um importante e central aspecto seria a distinção entre abusos de posição dominante de exclusão e comportamento legítimo de mercado. Inegável que os tipos e conceitos são muito abertos no que tange às normas concorrenciais em geral, o que traz percepção de certa insegurança jurídica. Como já discutido, de outra forma não poderia ser, visto que a velocidade evolutiva das relações comerciais traz desafio às normas postas, não podendo se ver as autoridades atadas a normas que não lhes suportam a repressão de novas modalidades de abusos cometidos. Tal se verifica, reconheçamos, a expensas da segurança jurídica nas relações empresariais. De forma a se mitigar tal percepção, desempenha papel essencial neste contexto a economia, na tentativa de trazer a segurança jurídica que as normas postas aparentemente falham em fazer. $^{354}$

A aplicação do artigo 102 a práticas de agentes dominantes que possam excluir concorrentes do mercado requer um balanceamento cuidadoso de interesses. Neste sentido, apesar da existência de poder econômico que permite aos agentes dominantes prejudicarem a efetiva concorrência no mercado relevante, estas empresas devem, sem sombra de dúvida, ser capazes de competir, de forma legítima, em seus respectivos mercados de atuação. Assim, se ao conceito de abuso é dada interpretação muito restrita, os agentes dominantes podem usar seu poder para prejudicar o processo competitivo; se por outro lado for interpretado de forma muito ampla, pode arrefecer o processo competitivo uma vez que tais agentes dominantes podem ser impedidos de competir efetivamente. ${ }^{355}$

Os efeitos econômicos de práticas específicas no mercado também podem ser de difícil previsão ou constatação. Existe, assim, tênue linha separando comportamentos pró e anticompetitivos por parte dos agentes com poder de mercado. Uma mesma conduta pode apresentar efeitos diferentes sob circunstâncias diferentes, ou mesmo condutas diferentes podem apresentar efeitos similares. Ainda, condutas sempre tendem a apresentar efeitos pró-competitivos e anticompetitivos em um mesmo caso, a se considerar, especialmente, seus efeitos no curto e longo prazo. ${ }^{356}$

\footnotetext{
${ }^{353}$ MOURA E SILVA, Miguel. O Abuso de Posição Dominante na Nova Economia, cit., p. 43.

354 ØSTERUD, Eric. Identifying Exclusionary Abuses by Dominant Undertakings under EU Competition Law: The Spectrum of Tests, cit., p. 2.

${ }^{355}$ Idem, ibidem, p. 2.

${ }^{356}$ Idem, ibidem, p. 3.
} 
No contexto europeu, a definição de abusos de exclusão, ponto de maior interesse ao presente trabalho, inicialmente se deu em Hoffmann-La Roche em 1979, com a necessidade de prover mais clareza aos termos do artigo 102. Porém, o conceito precisa ser amplo o suficiente para capturar uma extensa gama de condutas, tornando-se assim muito vago, o que requer especificação adicional:

\begin{abstract}
A noção de exploração abusiva é uma noção objectiva que abrange os comportamentos de uma empresa em posição dominante susceptíveis de influenciar a estrutura de um mercado no qual, precisamente na sequência da presença da empresa em questão, o grau de concorrência já está enfraquecido e que têm como consequência impedir, através de meios diferentes daqueles que regem uma competição normal de produtos ou serviços com base em prestações dos operadores económicos, a manutenção do grau de concorrência ainda existente no mercado ou o desenvolvimento desta concorrência. ${ }^{357}$
\end{abstract}

Assim, o elemento utilizado para a verificação de uma prática abusiva seria a forma do comportamento de um agente, que deveria ser "diferente daqueles que regem uma competição normal de produtos ou serviços". Cria-se a distinção entre comportamento normal e anormal, porém ausente um critério para tal definição. Segundo o precedente, uma forma particular comumente utilizada no mercado escaparia à aplicação do artigo 102. Os problemas que decorrem desta interpretação é que determinadas práticas, comuns a alguns mercados, e que portanto não ensejariam sua ilegitimidade, poderiam ser incomuns em outros mercados, caracterizando o abuso. As incertezas decorrentes deste critério, portanto, são relevantes.

Já no caso Michelin, decidido em 1983, nos quer parecer que a questão essencial está centrada no desempenho da empresa dominante:

\begin{abstract}
Article 86 covers practices which are likely to affect the structure of a market where, as a direct result of the presence of the undertaking in question, competition has already been weakened and which, through recourse to methods different from those governing normal competition in products or services based on traders' performance, have the effect of hindering the maintenance or development of the level of competition still existing on the market. ${ }^{358}$
\end{abstract}

Da mesma forma no acórdão Akzo, o fundamento centra-se em "métodos outros que não aqueles os quais venham dentro do escopo da concorrência com base em

\footnotetext{
357 Acórdão do Tribunal de Justiça de 13.2. 1979, Processo 85/76, Hoffmann-La Roche \& Co. AG c. Comissão das Comunidades Europeias, parágrafo 91.

${ }^{358}$ Acórdão do Tribunal de 9.11.1983, Processo 322/81, N.V. Nederlandsche Banden-Industrie-Michelin c. Comissão das Comunidades Europeias.
} 
qualidade" 359 . A corte sustentou ainda que um agente dominante não deveria ter recursos outros que não os objetivos de concorrência no seu mérito.

Aqui parece estar estabelecido, portanto, que a ideia principal seria que agentes com posição dominante estão autorizados a competir através de seu desempenho ou mérito. A dificuldade viria no sentido de estabelecer-se o que seria uma concorrência baseada no seu mérito, e quais os testes aptos a demonstrar tal valor.

O segundo elemento da definição, por sua vez, seriam os efeitos das condutas, ou impacto na estrutura do mercado. Haveria assim um escopo de proteção da concorrência residual do mercado em razão da fragilidade de sua estrutura decorrente da presença de uma empresa dominante? Neste sentido, a limitação ou criação de dificuldades à manutenção do grau de concorrência que resta, ou mesmo a limitação ou criação de dificuldades ao crescimento desta concorrência parecem ser suficientes para se estabelecer efeitos anticoncorrenciais no mercado.

Eficiências, por sua vez, não parecem ser parte do conceito geral de abuso, não tendo desempenhado papel essencial na sua caracterização. Assim, os elementos essenciais levados em consideração seriam a forma da conduta e a estrutura do mercado. Ainda assim, os termos parecem vagos para se diferenciar a conduta legítima daquela tida como abusiva. Necessário, portanto, a análise caso a caso para se determinar, por exemplo, o que seriam condutas amparadas no seu mérito, ainda que reconheçamos a dificuldade de um conceito genérico e abstrato que vise abarcar as mais variadas modalidades de abuso, caindo no risco de uma conceituação vaga demais.

O segundo elemento também é problemático na medida em que não traz os requisitos para se determinar em que ocasião é abusivo. Não se sabe se uma prática conclusivamente tem o efeito de restringir a concorrência ou em que ocasiões precisa-se investigar um pouco mais a fundo. Conforme se verá adiante, as decisões dos tribunais europeus muitas vezes contêm conclusões contrastantes que geram insegurança jurídica com relação aos testes que devem ser aplicados. Nos Estados Unidos reconhecemos que o problema é ainda mais profundo, a considerar-se o sistema de aplicação legal existente.

Assim, conclusivamente, a definição básica de abuso de exclusão não é satisfatória, sendo muito vaga e sem regras claras que determinem se uma prática cai na seara do ilícito ou não, e os precedentes que poderiam trazer maiores esclarecimentos se apresentam contraditórios. Contudo, tais precedentes servem ao propósito de reconhecer

${ }^{359}$ Acórdão do Tribunal (Quinta Secção) de 3.07.1991, Processo C-62/86, AKZO Chemie BV c. Comissão das Comunidades Europeias. 
que a conduta de uma empresa dominante pode ser abusiva em razão da presença de um objetivo ou propósito de exclusão da concorrência. ${ }^{360}$

Não parece, contudo, haver um único teste aplicável para todos os tipos de conduta, no exercício de analisar-se se tal conduta implica comportamento de mercado legítimo ou abuso de exclusão por parte de agentes com posição dominante. Assim, os tribunais europeus têm desenvolvido específicos testes operacionais para categorias individuais de condutas abusivas.

O grau de dominância pode ainda influenciar na probabilidade de reconhecimento de um abuso de poder mercado. Apesar de estabelecerem as mais diversas jurisdições pontos de partida para presunção de poder de mercado, na medida em que se aprofundam tais constatações aumenta-se a probabilidade de efeitos deletérios ao mercado.

Uma postulação para identificação de abusos de exclusão deveria distinguir entre concorrência eficiente ou legítima de condutas anticompetitivas de agentes em posição dominante. A dificuldade reside em desenvolver procedimentos que levem em conta os corretos resultados econômicos e ao mesmo tempo traga clareza e previsibilidade jurídica.

O conceito de abuso não deveria ser aplicado de forma a prevenir agentes com poder de mercado de competirem de forma vigorosa e efetiva, mesmo que concorrentes sejam prejudicados. Aplicação extensiva do critério pode levar à condenação de práticas pro-competitivas e de aumento de eficiência, gerando os erros de tipo 1 ou falsos positivos.

Seria até mesmo irrealista assumir-se que não haveria erros resultantes da aplicação do conceito de abuso, até mesmo pelo nível de conhecimento que se tem acerca dos efeitos das condutas unilaterais, havendo posições divergentes acerca da habilidade dos mercados de se autocorrigirem, a probabilidade de criação de efeitos anticoncorrenciais de diversas práticas e de como se devem balancear efeitos pró e anticompetitivos. Outro problema se relaciona com a assimetria informacional que as autoridades têm com relação à conduta e à estrutura do mercado. Isso torna difícil se prever com maior grau de certeza os efeitos econômicos de uma conduta específica no mercado.

Neste sentido, defendem autores que regras claras e simples podem ser mais prováveis de aumentarem a segurança jurídica do que padrões complexos. Uma regra simples e clara, em que a aplicação da lei é determinada por um ou um conjunto limitado de fatos predefinidos, pode aumentar a segurança jurídica, uma vez que limita a discrição

360 ØSTERUD, Eirik. Identifying Exclusionary Abuses by Dominant Undertakings under EU Competition Law, cit., p. 45. 
na sua aplicação. Também diminuem os custos relacionados ao monitoramento do cumprimento da lei e o custo de sua exequibilidade. ${ }^{361}$

A primeira decisão proferida pela Comissão Europeia acerca da política que deveria se seguir com relação ao artigo 102 veio somente em 1971. Contudo, ainda antes de tratar da aplicação deste artigo em sua função controladora da legalidade das decisões da Comissão, o Tribunal de Justiça Europeu passou a colacionar um conjunto de princípios essenciais para a sistematização da proibição do abuso de posição dominante.

Assim, num dos primeiros acórdãos de relevância decididos pelo Tribunal de Justiça, caso Consten/Gunding ${ }^{362}$ firmou-se discussão acerca da aplicação dos artigos 101 a acordos verticais. Da decisão do Tribunal se extrai importante corolário no sentido de que o âmbito de aplicação do artigo 101 seria mais extenso do que a proibição do artigo 102, sendo que decisões intraempresariais apenas seriam proibidas se caracterizassem alguma espécie de abuso de posição dominante.

Subsequentemente, no caso Park Davis $^{363}$, o Tribunal estabeleceu que o exercício de um direito exclusivo de propriedade intelectual não seria suficiente, por si só, para preencher os requisitos da proibição de um abuso de posição dominante. Tais requisitos, trazidos no acórdão, implicariam que:

o fato proibido exige, por isso, a verificação de três elementos: a existência de uma posição dominante, a sua exploração abusiva e a possibilidade de o comércio entre estados membros poder ser afetada.

Tais princípios trazidos por ocasião do acórdão Park Davis seriam mais bem elucidados em Sirene c. Ede. ${ }^{364}$ Além de confirmar aqueles princípios, o Tribunal de Justiça acrescentou uma expressão de vital importância para a aplicação do artigo 102, a noção de justificativa objetiva. Assim, “a expressão ‘justificação objetiva’ pode indicar um

361 ØSTERUD, Eirik. Identifying Exclusionary Abuses by Dominant Undertakings under EU Competition Law, cit., p. 15-16.

362 Acórdão do Tribunal de 13.7.1966, Processos 56 e 58-64, Établissements Consten S.à.R.L. e outros c. Comissão da Comunidade Económica Europeia. O caso tratava de um distribuidor - Consten - que recebeu proteção territorial absoluta contra importações paralelas.

363 Park Davis v. Probel, Acórdão do Tribunal de Justiça de 29.2.1968. Park Davis detinha patentes em vários Estados-Membros quanto ao medicamento "cloranfenicol”, sendo que à época não era possível obter tais direitos na Itália, visto que concorrentes comercializavam medicamentos com mesmo princípio ativo. A Probel e Centrafarm começaram a adquirir os produtos da Park Davis na Itália e revendê-los na Holanda, onde aquela possuía patentes e o preço do medicamento era mais alto. Assim questionava-se a possibilidade de importações paralelas no mercado comum.

${ }^{364}$ Sirene c. Eda, Acórdão do Tribunal de Justiça de 18.2.1971. O caso tratava de uma empresa americana que cedeu seus direitos relativos a uma marca de creme cosmético para outras empresas na Itália e Alemanha. Assim, quando a empresa italiana exerceu seus direitos para impedir comercialização na Itália de cremes com aquela marca, viu-se questionada por importadores. 
maior grau de exigência na justificação de diferenciais de preços e no exercício de direitos de propriedade intelectual quanto a produtos protegidos por marcas e não patentes". 365

Por sua vez, em Deutsche Grammophon ${ }^{366}$ o Tribunal anunciou, pela primeira vez, o princípio do esgotamento dos direitos de propriedade intelectual, ainda conhecido como o princípio da exaustão. Também por obra deste acórdão, se apresentou ensaio de uma primeira definição de posição dominante, a qual implicaria a "possibilidade de constituir obstáculo a uma concorrência efectiva numa parte importante do mercado a tomar em consideração, tendo designadamente em conta a existência eventual de produtores distribuindo produtos similares e a sua posição no mercado". ${ }^{367}$ Reconhecia-se assim a importância da consideração do tema segundo a caracterização de um mercado relevante, onde seriam identificadas as pressões competitivas a que a empresa estaria sujeita e seriam avaliadas as possibilidades de um agente econômico dominante atravancar a concorrência efetiva em razão da insuficiência destes fatores de pressão competitiva.

Importantes para análise do tema as conclusões do Advogado-Geral Roemer no caso, que desenvolve as linhas essenciais do que seria caracterizado como posição dominante em casos subsequentes, destacando-se a conexão estabelecida com o conceito econômico de poder de mercado, ao entender posição dominante como conferindo a "possibilidade de determinar preços ou de controlar a produção e a distribuição numa parte substancial do mercado comum”. Neste sentido, deveria ainda ser examinado se a empresa disporia de uma margem de independência que lhe permitisse agir sem ter em conta os seus concorrentes, os seus clientes e fornecedores. ${ }^{368}$

O caso Continental Can traria a primeira grande discussão sobre a aplicação do artigo 82. O Tribunal de Justiça, em revisão à decisão da Comissão Europeia a qual considerou que a posição dominante da Continental Can em parte substancial do Mercado Comum caracterizaria abuso ao adquirir um concorrente holandês, relevou a importância da definição do mercado relevante, essencial para mensuração dos fatores de pressão e posição dominante. ${ }^{369}$ Assim, cobrou o Tribunal posicionamento acerca de justificativa

365 MOURA E SILVA, Miguel. O Abuso de Posição Dominante na Nova Economia. Teses de Doutoramento, cit., p. 49.

366 Deutsche Grammophon c. Metro. Acórdão do Tribunal de Justiça de 8.6.1971. O caso implicava importação, pela Metro, para a Alemanha, de discos editados na França pela Polydor, subsidiária da Deutsche Grammophon. Esta, quando tomou conhecimento da prática, invocou o direito que protege os fabricantes de suportes de som, algo semelhante a um direito de autor.

${ }^{367}$ Idem acima, considerando 17.

${ }^{368}$ MOURA E SILVA, Miguel. O Abuso de Posição Dominante na Nova Economia. Teses de Doutoramento, cit., p. 50.

${ }^{369}$ Acórdão do Tribunal de Justiça de 21.2.1973, Proc. 6/72, Europenballage Corporation e Continental Can Company Inc. c Comissão das Comunidades Europeias. Colect 1973, p. 109. 
para a segmentação do mercado e das particularidades que os esperavam. Por fím, teceu comentários acerca da necessária ponderação da concorrência potencial para a análise de posição dominante. ${ }^{370}$

No que tange à definição de posição dominante, a Comissão define como dominantes:

\begin{abstract}
empresas que têm uma possibilidade de adoptar comportamentos independentes que lhes permite agir sem ter, nomeadamente, em conta os concorrentes, os clientes ou os fornecedores; tal que sucede quando, devido a sua quota de mercado, ou desta em combinação, nomeadamente, com a posse de conhecimentos técnicos, de matérias-primas ou de capitais, elas dispõem da possibilidade de determinar os preços ou de controlar a produção ou a distribuição para uma parte significativa dos produtos em causa; que esta possibilidade não deve necessariamente resultar de um domínio absoluto que permite a essas empresas eliminar completamente a vontade dos seus parceiros económicos, bastando que ela seja suficientemente forte no seu conjunto para lhes garantir uma independência global de comportamento, mesmo quando existam diferenças de intensidade na sua influencia sobre diferentes mercados. ${ }^{371}$
\end{abstract}

Assim, a análise em questão se faria levando em conta não somente a identificação da participação de mercado das empresas envolvidas, mas ainda a identificação de um conjunto de fatores de pressão concorrencial das atividades da empresa.

O Tribunal de Justiça reconheceu ainda que o artigo 102 se aplica a práticas que prejudicam a concorrência efetiva no mercado, e não somente às práticas que diretamente exploram consumidores, reconhecendo a aplicabilidade do artigo para práticas excludentes ou anticompetitivas que, indiretamente, podem afetar consumidores, através do prejuízo causado à estrutura de concorrência. Abusos exploratórios, por sua vez, resultam em efeito direto de perda de bem-estar do consumidor.

No acórdão Hoffmann-La Roche, o Tribunal traz ainda maiores esclarecimentos acerca de definições mais complexas de mercados relevantes. Aqui, os elementos mais considerados foram: (i) a ratio entre quota de mercado da Roche e demais concorrentes, (ii) vantagens tecnológicas e comerciais, (iii) ausência de concorrência potencial, e (iv) capacidade instalada. ${ }^{372}$

\footnotetext{
370 Outros acórdãos de importância para discussão acerca da definição de mercado, que se sucederam à Continental Can, foram United Brands, Hoffmann-La Roche, Michelin e Hugin que, sobretudo, vêm esclarecer a metodologia de definição do mercado relevante.

${ }^{371}$ Decisão da Comissão Europeia, de 9.12.1971, Continental Can Company, J.O. L 7, de 8.1.1972, p. 35.

372 Acórdão do Tribunal de Justiça de 13.2.1979, Processo 85/76, Hoffmann-La Roche \& Co. AG c. Comissão das Comunidades Europeias, parágrafo 48.
} 
United Brand traz também definição do conceito de posição dominante, repetindo basicamente o conceito trazido por Continental Can: ${ }^{373}$

Referida posição dominante diz respeito a uma situação de poder econômico detida por uma empresa, que lhe da o poder de impedir a manutenção de uma concorrência efectiva no mercado em questão, ao possibilitar-lhe a adoção de comportamentos independentes, numa medida apreciável, relativamente aos seus concorrentes, aos seus clientes e, por fim, relativamente aos consumidores.

Diante de breve histórico acerca do conceito de posição dominante que foi sendo construído pela Comissão Europeia e Tribunais ao longo dos anos, vale recordar que o artigo 102 não traz definição de abuso, mas sim proibição de cláusula geral seguida de tipologia exemplificativa. Adicionalmente aos principais dispositivos atinentes ao controle da concorrência, artigos 101 e 102, deve-se notar ainda que a Comissão recorre igualmente a um critério teleológico, influenciado pelo artigo 66 do Tratado CECA, que dispõe que “[e]xiste exploração abusiva quando o comportamento contraria os objetivos fixados pelo Tratado".

E no contexto da normativa europeia, pode-se perguntar qual o propósito da sua norma de concorrência? Assegurar e manter uma situação de concorrência ou evitar os "abusos" cometidos em detrimento do instituto da concorrencial? O Advogado Geral Poermer defendeu que o artigo 102 não proíbe a formação de posição dominante, mas tão somente seu abuso ou exploração abusiva. O Tribunal de Justiça adotou a tese da Comissão, em Continental Can, considerando que o reforço por parte de uma empresa em posição dominante dessa mesma posição constitui um abuso se o grau de dominância atingido for tal que a consequência seja substituição reduzida, apenas substituindo no mercado empresas cujo comportamento é dependente daquela". 374

O desafio levantado implica a decisão de se procurar um conceito de exploração abusiva socorrendo-se de valores que devem informar a conduta competitiva; ou, alternativamente, encontrar um conceito a partir dos exemplos fornecidos nas diversas alíneas do artigo $102 .{ }^{375}$

Hoffmann-La Roche trouxe ainda conceito de abuso, um tanto quanto problemático, visto que não levava em consideração a maior eficiência obtida:

\footnotetext{
${ }^{373}$ Acórdão do Tribunal de Justiça de 14.2.1978, Proc 27/76, United Brands c. Comissão, Colect. 1978, p. 77. ${ }^{374}$ MOURA E SILVA, Miguel. O Abuso de Posição Dominante na Nova Economia. Teses de Doutoramento, cit., p. 67.

${ }^{375}$ Idem, ibidem, p. 69.
} 
De acordo com a jurisprudência constante do Tribunal de Justiça das Comunidades, "o conceito de abuso é um conceito objectivo que se reporta ao comportamento de uma empresa em posição dominante que de tal natureza influencia a estrutura do mercado quando, em resultado da própria presença da empresa em questão, o grau de concorrência é enfraquecido e que, pelo recurso a meios diferentes daqueles em que assenta a concorrência normal em produtos ou serviços na base das transações entre operadores comerciais, tem por efeito impedir a manutenção do grau de concorrência ainda existente no mercado ou o desenvolvimento dessa concorrência. ${ }^{376}$

O Tribunal de Justiça reconheceu, contudo, no caso United Brands a admissibilidade de uma empresa em posição dominante adoptar comportamentos tendentes à defesa de seus interesses comerciais:

189. Embora seja certo, como refere a recorrente, que a existência de uma posição dominante não pode privar a empresa que se encontre nessa posição do direito de preservar os seus próprios interesses comerciais quando sejam atacados e que é necessário permitir, em medida razoável, o exercício das acções que considere apropriadas para a protecção dos referidos interesses, tais comportamentos não podem ser admitidos quando tenham precisamente por objectivo reforçar essa posição dominante e abusar dela.

190. Mesmo sendo de aceitar a possibilidade de um contra-ataque, ele deve ser proporcional a ameaça, tendo em conta o poder econômico respectivo das empresas em causa. ${ }^{377}$

Do acórdão em questão podemos verificar três requisitos para a compatibilidade de uma reação de defesa de interesses comerciais: (i) as medidas devem ser necessárias para a proteção de interesses legítimos, não podendo consistir no reforço e abuso de posição dominante; (ii) as medidas adotadas devem ser aptas à defesa desses direitos; (iii) a reação da empresa dominante deve ser proporcional à ameaça, tendo em consideração a desproporção inerente à posição que ela ocupa no mercado e a independência de comportamento de que goza em face dos seus concorrentes, clientes, fornecedores e consumidores. Trata-se de uma caraterização em construção acerca do conceito de justificativa objetiva, que passa pela racionalidade da decisão tomada, segundo a teoria econômica.

O artigo 102 ainda condena o fato de uma ou mais empresas abusarem de sua posição dominante, de forma coletiva. A primeira pergunta, neste sentido, seria acerca da fronteira existente, portanto, entre os artigos 101 e 102. Alguns ordenamentos criaram controle de oligopólios ou monopólio parcial para lidar com comportamentos paralelos, a

\footnotetext{
376 Acórdão do Tribunal de Justiça de 13.2.1979, Proc. 85/76, Hoffmann-La Roche \& Co. AG c Comissão das Comunidades Europeias, Colect. 1979-I, p. 217.

377 Acórdão do Tribunal de 14 de fevereiro de 1978, Processo 27/76, United Brands Company e United Brands Continental BV contra Comissão das Comunidades Europeias.
} 
exemplo do Reino Unido. ${ }^{378}$ Outros, como os Estados Unidos, tentaram estender a aplicação do artigo $5^{\circ}$ do $F T C$ Act sob o argumento de que não se fazia necessária a prova da existência do acordo ou conspiração como exigido pela Seção 1 do Sherman Act, bastando simplesmente o paralelismo e a análise da estrutura de mercado propícia à colusão tácita, além da prova dos efeitos, extensão que foi negada pelos tribunais norteamericanos. ${ }^{379}$ Outros ainda estenderam o conceito legal de posição dominante, como a Alemanha. $^{380}$

Contudo, houve certa relutância do Tribunal em aceitar a tese da dominância coletiva, posição que começou a se inverter com o caso dos vidros planos na Itália, quando a Comissão aplicou o artigo 102 simultaneamente com o artigo 101, com o argumento de que as partes teriam não somente participado de cartel, mas ainda abusado de posição dominante coletiva, visto que se apresentavam no mercado como única entidade, no que mereceu apoio por parte do Tribunal:

\begin{abstract}
O Tribunal realça que os próprios termos do primeiro parágrafo do artigo 86. preveem que 'uma ou mais empresas' possam explorar de forma abusiva uma posição dominante. A jurisprudência constante, como, aliás, admitem todas as partes, é no sentido de que, no contexto do artigo 85. do Tratado, o conceito de acordo ou de prática concertada entre empresas não se refere a acordos ou práticas concertadas entre empresas que pertençam a um mesmo grupo se formam uma unidade económica (v. por exemplo, o acórdão do Tribunal de Justiça de 31 de Outubro de 1974, Centrafarm, já referido, n. 41). Daqui resulta que, quando o artigo 85. se refere a acordos ou práticas concertadas entre 'empresas', visa relações entre duas ou mais entidades económicas capazes de entrar em concorrência umas com as outras. ${ }^{381}$
\end{abstract}

No que tange à utilização do conceito de dominância coletiva na análise de concentrações, vale dizer que o primeiro caso bem-sucedido de oposição na Europa se deu com o caso Gencor. ${ }^{382}$ Os fatores de correlação considerados foram a consciência da interdependência e o interesse recíproco no alinhamento ou elos jurídicos-estruturais. Tal

\footnotetext{
${ }^{378}$ Vide RODGER, Barry J. Oligopolistic Market Failure: Collective Dominance Versus Complex Monopoly. E.C.L.R., vol. 16, no. 1, 1995, p. 21.

379 E.I. du Pont De Nemours \& Co. v. FTC, 729 F2d 128 (2d Cir. 1984).

380 A legislação alemã estabeleceu presunção iuris tantum para verificação de dominância, que considera como individualmente dominantes empresas detentoras de ao menos um terço de um mercado relevante, sendo tal posição também reconhecida coletivamente a duas ou três empresas caso suas quotas agregadas atinjam 50\% do mercado, ou no caso de quatro ou cinco empresas, ao menos dois terços do mercado.

381 Acórdão do Tribunal de Primeira Instância (Primeira Secção) de 10.03.1992, Procs. Apensos T- 68, T-77 e T-78/89, Società Italiana Vetro SpA e o. v. Comissão das Comunidades Europeias, Colect. 1992, p. II 1403, parágrafo 357. Apesar de no mérito anulada pelo Tribunal de Primeira Instância, o conceito de abuso de posição dominante coletiva mereceu apoio por parte deste órgão.

${ }^{382}$ Acórdão do Tribunal de Primeira Instância (Quinta Secção Alargada) de 25.3.1999 no Proc. T-102/96, Gencor c. Comissão, Colect. 1999, p. II-753. A operação visava estabelecer um controle conjunto pela Gencor e Lonrho dos interesses no setor de platinoides (minerais).
} 
caso reforçou a criação de verdadeiro controle preventivo na formação de estruturas oligopolistas susceptíveis de prejuízo à livre concorrência no mercado comum. ${ }^{383}$

Nova tentativa por parte da Comissão se deu no caso Airtours. Contrariamente aos outros casos, os nexos entre as empresas eram essencialmente resultantes da estrutura de mercado pós-concentração, que facilitava comportamentos colusivos. A Comissão, reconhecendo o limite do conceito de criação ou reforço de posição dominante a casos onde o resultado da concentração fosse um oligopólio que induzisse a um equilíbrio de cooperação entre os remanescentes, procurou sustentar sua aplicação a casos em que cada um destes passaria a ter incentivos para exercício de maior grau de poder de mercado, mediante, no caso concreto, a redução da capacidade hoteleira disponível, independentemente da reação dos concorrentes remanescentes.

A decisão foi anulada pelo Tribunal de Primeira Instância, que concluiu pela ausência de evidências de uma posição dominante coletiva. Tal acórdão estabeleceu um elenco de três requisitos cumulativos para a verificação da existência de dominância coletiva: (i) transparência do mercado - a simples consciência de interdependência não basta, devendo haver a possibilidade de verificação do comportamento da concorrência remanescente; (ii) interesse comum - a mera percepção de interesse comum não se faz suficiente, devendo haver um "incitamento ao não afastamento da linha de conduta comum no mercado"; e (iii) estabilidade da colusão - que dependeria da dificuldade que os clientes ou outros concorrentes possam proporcionar ao equilíbrio colusivo.

O fracasso da Comissão gerou uma transição de um modelo baseado na "criação ou reforço de posição dominante" para um modelo ancorado na "redução substancial da concorrência", critério seguido nos Estados Unidos, fundamentando no artigo 7 do Clayton Act, e que proíbe aquisições que possam resultar em redução substancial da concorrência ou tendam a criar um monopólio. ${ }^{384}$

O primeiro processo de condenação por abuso de posição dominante coletiva na União Europeia veio no caso Compagnie Maritime Belge, que envolvia comportamentos adotados por membros de uma conferência marítima contra um novo concorrente. ${ }^{385} \mathrm{O}$

\footnotetext{
${ }^{383}$ Decisão da Comissão Europeia de 22.9.1999, IV/M. 1524, Proc. IV/M.1524, de 22.9.1999, J.O. L 93, de 13.4.2000, p. 1.

384 MOURA E SILVA, Miguel. O Abuso de Posição Dominante na Nova Economia. Teses de Doutoramento, cit., p. 126.

385 Acórdão do Tribunal de Primeira Instância (Terceira Secção Alargada) de 8.10.1996, Proc. Apensos T24/93, T-25/93, T-26/93, T-28/93, Compagnie Maritime Belge Transports SA c Comissão, Colect. 1996, p. II 1201. A Cewal era uma conferência marítima que agrupava empresas de transporte marítimo com serviços de transporte regular entre os portos do Zaire e Angola e dos portos no mar do Norte. Com a entrada de um novo concorrente para prestar serviços nas mesmas linhas, as empresas da Cewal adotaram uma série de condutas
} 
Tribunal de Justiça Europeu firmou entendimento de que a definição de posição dominante coletiva passaria por determinar se as empresas em questão constituiriam, em conjunto, uma entidade coletiva em relação aos seus concorrentes, parceiros comerciais e consumidores, sem que houvesse, necessariamente, um acordo, mas através de uma ação coletiva, dependente da estrutura do mercado em questão. Ainda, os requisitos elencados no caso Airtours viriam a ser aplicados pelo Tribunal de Primeira Instância em sua revisão do caso.

Em crítica à posição adotada pelos tribunais europeus, Miguel Moura inflama algumas questões resultantes:

\begin{abstract}
Este acórdão suscita assim diversas perplexidades: pode o artigo 82 ser utilizado para combater uma prática de colusão tácita a qual, por definição, não preenche os requisitos da noção de acordo e/ou prática concertada? E como se identifica a posição dominante coletiva? A partir do próprio abuso? Será abusivo o facto de todas as empresas em alegada posição dominante colectiva praticarem o mesmo preço ou só haverá abuso caso, por exemplo, esse preço seja fixado a um nível excessivo?

Estamos em crer que a aplicação analógica invertida dos critérios desenvolvidos em sede de controle prévio de concentrações é uma metodologia errada, perigosa e, em última análise incompatível com a estrutura do artigo 82. e sua articulação com o artigo 81.

(...) No campo do controle de condutas, é absurdo pretender que possa existir abuso por mera possibilidade de colusão. Os requisitos em sede de artigo 82 foram, por isso, sempre mais exigentes, obrigando a que as empresas em causa se comportassem como se de uma mesma entidade se tratasse. ${ }^{386}$
\end{abstract}

\title{
6.3.2. Recusa de Contratação
}

Talvez configure a presente conduta em espécie motivo das maiores divergências em termos de política concorrencial entre aos dois grandes sistemas jus-concorrenciais existentes no globo: a Europa e os Estados Unidos. Reconhecem desta forma alguns juristas, como Miguel Moura:

\begin{abstract}
Aqui encontramos outro tipo de considerações, inerentes à tradição jurídica de cada sistema. Assim, na União Europeia o objetivo central das normas sobre abuso de posição dominante é regular o comportamento destas empresas, obrigando-as a comportarem-se como se estivessem sujeitas a uma concorrência eficaz. Já nos Estados Unidos, o escopo da disciplina dos delitos de monopolização e tentativa de monopolização prende-se com a prevenção e
\end{abstract}

reputadas infrativas pela Comissão Europeia com base no artigo 82 do Tratado, dentre as quais a prática dos navios de combate, reserva de mercado com os portos em questão para os membros da Cewal e acordos de fidelidade com os carregadores, com a produção inclusive de uma lista negra dos "infiéis".

386 MOURA E SILVA, Miguel. O Abuso de Posição Dominante na Nova Economia. Teses de Doutoramento, cit., p. 141-142. 
repressão deste tipo de estruturas, condenando a aquisição de um monopólio ou práticas tendentes a essa obtenção, quando essa conduta seja de considerar ilícita. $^{387}$

O artigo 102, em sua alínea $b$, caracteriza o abuso de posição dominante tendente a limitar a produção, a distribuição ou o desenvolvimento técnico em prejuízo dos consumidores. Mediante a recusa de venda ou prestação de serviço uma empresa dominante pode limitar tais fatores, seja de forma direta, recusando o acesso de seus clientes; seja de forma indireta, mediante a recusa com uma empresa que a ela concorra, à jusante ou à montante.

Assim, em Commercial Solvents, a Comissão Europeia condenou a ICI e a CSC por abuso de posição dominante, obrigando-as a fornecerem à Zoja e aplicando-lhes multa de 200.000 unidades de conta. ${ }^{388}$ Foram definidos dois mercados, um constituído pela matéria-prima e outro do produto derivado - mercado secundário. Neste sentido, a condenação se deu por abuso de posição dominante no mercado de matéria-prima ao configurar-se recusa no fornecimento à cliente habitual, porém que concorria com os fornecedores da matéria-prima no mercado derivado. $O$ Tribunal não aceitou que a alteração de padrões de fornecimento pudesse se legitimar pela entrada em concorrência com o seu antigo cliente.

Já no caso British Petroleum, ${ }^{389}$ o Tribunal legitimou a recusa de fornecimento para antigo cliente com base na prioridade atribuída a clientes habituais num período de escassez de combustíveis.

Em United Brands, ${ }^{390}$ a recusa de continuidade no abastecimento de bananas Chiquitas para a Olesen, principal amadurecedor-distribuidor dinamarquês, foi questionada pela Comissão, em razão deste ter iniciado a comercialização e promoção de bananas provenientes de outro produtor. Neste caso, o Tribunal sedimentou o dever de não interromper uma relação comercial duradoura com um cliente que não motivou quebra contratual. Assim, o tribunal admite a defesa dos interesses comerciais de uma empresa dominante, desde que o objetivo dos comportamentos alegadamente defensivos não consista no reforço e abuso dessa posição, e o meio escolhido para responder seja

387 MOURA E SILVA, Miguel. O Abuso de Posição Dominante na Nova Economia. Teses de Doutoramento, cit., p. 302.

${ }^{388}$ Decisão da Comissão Europeia, de 14.12.1972, Zoja/CSC - ICI (Commercial Solvents), J.O. L 299, de 31.12.1972, p. 51.

389 Decisão da Comissão Europeia em 19.4.1977, BP c. Comissão Europeia, IV/28.841, J.O. L.117/1, de 09.5.1977.

390 Acórdão do Tribunal de 14 de Fevereiro de 1978, Processo 27/76, United Brands Company e United Brands Continentaal BV contra Comissão das Comunidades Europeias. 
proporcional à ameaça, tendo em conta o poder econômico respectivo das empresas em causa. $^{391}$

No caso envolvendo a $C B E M,{ }^{392}$ que desenvolvia atividades de televendas, esta empresa contratou, em 1982, serviços de marketing da cadeia televisiva RTL dirigido ao público do Benelux. Após ter concluído um acordo exclusivo com a entidade que geraria os espaços publicitários da RTL - a IPB - onde seria usado seu número de telefone, a CBEM verificou mudança na política da IPB, que passaria a proibir anúncios de televendas com números para televendas de terceiros, exigindo que os seus números de televendas passassem a prestar os serviços diretamente. O Tribunal reconheceu poder de mercado da RTL em anúncios para a região do Benelux, bem como reconheceu que a imposição de uma condição aos anunciantes que eliminava qualquer concorrência na realização de televendas aos serviços da própria IPB era abusivo. Não havia justificativa objetiva fundamentada para tanto.

Nos casos acima, circunstâncias comuns eram as recusas que interromperam relação comercial preexistente. Somente em 1998 o Tribunal de Justiça finalmente analisou uma prática de recusa de concessão de licenças de direito de propriedade intelectual, no sentido de que a recusa não implicava o fornecimento de um bem ou prestação de um serviço, mas sim a autorização para a prática de um ato que, se não feito, poderia implicar violação das regras do Tratado.

Assim, temos o caso Volvo vs Veng, ${ }^{393}$ em que a Volvo, fabricante sueca de automóveis, processou a Veng por violar seus direitos sobre desenho industrial relativos a peças de substituição para automóveis. A Veng passou a importar e comercializar as peças no Reino Unido sem consentimento da Volvo, uma vez que esta se recusou a licenciar à Veng, mesmo mediante contrapartida de royalties oferecida. O Tribunal considerou que o exercício do direito correspondia ao benefício do direito exclusivo que a Volvo possuía, que lhe permitia impedir a produção e venda de produtos protegidos por terceiros ausente sua autorização, o que não poderia, portanto, ser visto como uma prática abusiva de eliminação de concorrência. A recusa da licença, não foi, portanto, considerada abusiva, uma vez que o Tribunal considerou que a imposição ao titular de um direito exclusivo da

\footnotetext{
${ }^{391}$ Idem, conforme se infere dos parágrafos 182, 183 e 190.

392 Acórdão do Tribunal (Quinta Secção) de 3 de Outubro de 1985. Processo 311/84. SA Centre belge d'études de marché - télémarketing (CBEM) v. SA Compagnie luxembourgeoise de télédiffusion (CLT) e SA Information publicité Benelux (IPB). Pedido de decisão prejudicial: Tribunal de commerce de Bruxelles Bélgica.

${ }^{393}$ Acórdão do Tribunal de Justiça de 21.06.1998, Proc 238/87, AB Volvo c. Erik Veng (UK) Ltd., Colect. 1998 , p. 6211.
} 
obrigação de conceder uma licença, ainda que mediante remuneração, tratava de atingir o objeto específico do direito em causa.

Contudo, o Tribunal forneceu três exemplos de práticas resultantes do exercício de direitos exclusivos que poderiam ser consideradas abusivas aos olhos do Tratado: (i) recusa arbitrária por parte de uma empresa com posição dominante em fornecer peças sobressalentes a reparadores independentes; (ii) a prática de preços excessivos em relação às peças sobressalentes; e (iii) decisão de deixar de produzir peças para determinados modelos de automóveis enquanto número significativo de modelos continuava a circular.

Outro caso que merece referência diz respeito à Maxicar c. Renault. Consorzio, associação de fabricantes e comerciantes de peças de substituição para automóveis, e Maxicare, um dos membros da associação, ingressaram com ação requerendo a nulidade dos pedidos de proteção de desenho industrial arquivados pela Renault, relativos a peças sobressalentes, impedindo sua fabricação, comercialização, importação e exportação. Pediam ainda reconhecimento de que a produção e comercialização de peças sobressalentes que não fossem de origem não constituiria concorrência desleal. O Tribunal italiano, ainda que reconhecendo o direito à proteção das peças como desenhos industriais, entendeu que o exercício dos direitos exclusivos resultantes desta proteção poderiam ser contrários ao Tratado, visto que o titular já obteve remuneração pelo direito exclusivo sobre o conjunto da carroceria.

Esta situação criava duas oportunidades para o ressarcimento das montadoras, no que tange à recuperação de seu custo de inovação - na concorrência para venda de veículos automotivos e na concorrência para a venda de painéis de carroceria. O Advogado Geral situa a problemática, a fim de se evitarem conflitos, no exercício abusivo do direito em concreto; porém a mera obtenção do direito não seria abusiva, faltando um elemento adicional de conduta. A Comissão, no acórdão do Tribunal de Justiça, subscreve a tese do abuso, questionando-se ainda se não haveria dever de licenciar produtores independentes para a produção das peças sobressalentes. O Tribunal seguiu a mesma argumentação do caso Volvo, apenas divergindo que o questionamento neste caso seria a própria obtenção do direito, o que o Tribunal não reconheceu como abusivo. ${ }^{394}$

\footnotetext{
394 “(...) encontramos aqui a convergência do princípio da jurisprudência sobre o conflito entre os direitos de propriedade intelectual de raiz nacional e o direito comunitário sobre as restrições à livre circulação de mercadorias e livre prestação de serviços, por um lado, com o direito da concorrência, por outro, e, em especial, a clarificação que o exercício daqueles direitos não esta imune à aplicação do artigo 82, ao ponto de este poder punir como abusiva a recusa em conceder uma licença, ainda que em condições muito excepcionais, em que é claro o dano para o consumidor" (MOURA E SILVA, Miguel. O Abuso de Posição Dominante na Nova Economia. Teses de Doutoramento, cit., p. 318).
} 
Ainda, verificamos que o Tribunal não ofereceu resposta satisfatória na questão da diferença dos preços entre as peças de origem e fabricadas por independentes, invocando o caso Park Davis, no sentido de que o titular de um modelo ornamental depositado pode legitimamente aspirar a uma remuneração das despesas que efetuou para desenvolver o modelo protegido. 395

Outro caso de relevância para a análise do tema em terras europeias é o caso Magill. ${ }^{396}$ Tratou de recusa de fornecimento de listas de programação semanal, por parte das cadeias de televisão existentes no Reino Unido e República da Irlanda. Tais cadeias possuíam listas semanais de programação próprias e protegiam tais listas como obras literárias pelo direito de autor. Magill queria criar um guia geral que incluísse a programação semanal de todos os canais captados na Irlanda. As estações invocaram a proteção intelectual para obterem dos tribunais a suspensão da publicação.

Diante da situação de recusa, Magill entrou com reclamação perante a Comissão, que considerou o comportamento das estações um abuso de posição dominante, ordenando a concessão de licenças em termos não discriminatórios a quem as solicitasse, contra remuneração. A decisão foi confirmada nas duas instâncias superiores.

No caso concreto, o comportamento censurado consistia na recusa de concessão de uma licença para a reprodução de objeto protegido por legislação nacional de direito de autor, integrando bens complementares num produto cuja novidade era a agregação de conteúdos protegidos. As emissoras estavam, assim, privando os consumidores de benefícios de um guia geral com periodicidade semanal. A decisão pelos Tribunais demonstra ainda a sua repugnância pela extensão do direito de autor a obras que não apresentavam um caráter secreto, invocado ou sequer relacionado com a investigação. Assim, o esforço necessário para elaboração das listas tinha sua contrapartida na emissão dos programas, e utilizar-se do direito de autor para garantir o mercado de divulgação destas listas não correspondia aos objetivos do direito de autor. O Tribunal de Justiça consagra, portanto, o princípio segundo o qual o exercício do direito exclusivo pelo titular pode, em circunstâncias excepcionais, dar lugar a um comportamento abusivo. ${ }^{397}$

\footnotetext{
395 Acórdão do Tribunal de 29 de fevereiro de 1968. Processo 24-67. Parke, Davis and Co. c. Probel, Reese, Beintema-Interpharm e Centrafarm.

${ }^{396}$ Acórdão do Tribunal de 6 de abril de 1995. Processos apensos C-241/91 P e C-242/91 P. Radio Telefis Eireann (RTE) e Independent Television Publications Ltd (ITP) contra Comissão das Comunidades Europeias.

397 Acórdão do Tribunal de 6 de abril de 1995. Processos apensos C-241/91 P e C-242/91 P. Radio Telefis Eireann (RTE) e Independent Television Publications Ltd (ITP) contra Comissão das Comunidades Europeias, considerando 50.
} 
Interessante notar que o Tribunal de Justiça, a exemplo da Suprema Corte norteamericana, vinha evitando sistematicamente o recurso ao conceito de infraestrutura essencial nas análises de recusa de fornecimento ou prestação enquanto abuso de posição dominante, por diversas razões.

A primeira referência explícita à teoria das infraestruturas essenciais no continente europeu se deu no caso Sea Containers. ${ }^{398}$ Discutia-se o acesso de um novo operador ao porto Britânico de Holyhead, porto explorado pela Stena, empresa dividida em duas sociedades, o operador portuário e a empresa de navegação, sendo o porto sua propriedade. Este porto era o único porto entre as ilhas da Grã-Bretanha e Irlanda, apto a prestar serviços de ferry de pessoas e veículos. Assim, verificou-se que a Stena possuía posição dominante e seu abuso consistia na demora em autorizar a Sea Containers, empresa concorrente que pretendia desenvolver um novo serviço, o ferry rápido, a operar no seu porto. Um dos argumentos para o atraso era a impossibilidade de utilização intensiva do posto.

Porém, previstas as obras de expansão, estas estavam sempre sendo adiadas, tendo a empresa de navegação da Stena obtido licença para operar o mesmo serviço em 93, antes que a Sea Containers obtivesse sua autorização. Em vista deste cenário, a Comissão considerou abusiva a conduta da Stena, segundo os princípios da doutrina das infraestruturas essenciais.

Vale situar as decisões que seguem no contexto histórico vivenciado pela União Europeia à época, quando da revisão do Tratado para implementação dos ditames do mercado único. Percebeu-se que setores específicos, como energia, transporte e telecomunicações, permaneciam imunes à pressão da concorrência e integração das atividades econômicas. Este fato parece ter influenciado de forma significativa a postura aparentemente intervencionista da Comissão para pressionar Estados-Membros na liberalização dos setores. A ideia dos autores do Tratado era permitir a existência de empresas em posição dominante, dotadas de direitos especiais ou exclusivos, mas impondo-lhes ônus de serem sujeitos de deveres especiais de conduta que as levasse a atuar como se submetidas à disciplina do mercado via concorrência. ${ }^{399}$

\footnotetext{
398 Decisão da Comissão Europeia de 21.12.1993 (94/19/CE), IV/34.031, Sea Containers c. Stena Sealink, J.O.L. 15, de 18.1.1994.

${ }^{399}$ MOURA E SILVA, Miguel. O Abuso de Posição Dominante na Nova Economia. Teses de Doutoramento, cit., p. 344 e ss. Em tempo, ao se questionar se o recurso utilizado pelas autoridades concorrenciais para caracterização dos efeitos anticompetitivos envolvendo infraestruturas essenciais traria uma nova modalidade de abuso, com requisitos específicos por comparação com o abuso geral, Miguel Moura expressa sua conclusão negativa: “A expressão 'infraestrutura essencial' é uma fórmula que traduz a
} 
Em Ladbroke, ${ }^{400}$ a sociedade belga dedicava-se à aceitação de apostas de corridas de cavalos que ocorriam no exterior. Com alteração da lei, em que se permitiu a abertura das casas no período da tarde, a Ladbroke pretendeu obter uma licença do agrupamento de empresas que organizava corridas de cavalos na França para os direitos de transmissão televisivas na Bélgica, a fim de exibir as imagens nas suas agências e atrair mais clientes. Recebeu, contudo, resposta negativa do lado francês.

O Tribunal de Primeira Instância analisou a recusa em termos de seu efeito hipotético no mercado onde atuava a denunciante - aceitação de apostas na Bélgica relativamente a corridas de cavalos no estrangeiro -, concluindo que o abuso restaria configurado somente se dissesse respeito a um produto ou serviço essencial para o exercício da atividade em causa. Em não se caracterizando a transmissão televisiva como indispensável à atividade de aceitação de apostas, não estaria configurado o abuso.

Em European Night Services, ${ }^{401}$ um conjunto de empresas ferroviárias de diversos estados membros, celebrou acordo que constituía uma empresa comum chamada ENS, a qual passou a denominar-se, posteriormente, Eurostar. A empresa fora constituída para prestação de serviços de transporte ferroviário de passageiros através do túnel do Canal da Mancha. Pelo acordo, a ENS adquiria material que permitiria circulação nas diferentes redes ferroviárias e no trajeto do túnel, enquanto outras empresas comprometiam-se a prestar serviços à ENS como tração ferroviária, limpeza no interior dos comboios e manutenção e reparação do equipamento e serviços de passageiros. Apesar de problemas concorrenciais verificados, a Comissão considerou o balanço econômico positivo e concedeu isenção ao acordo, sob a condição de que as partes prestassem serviços indispensáveis correspondentes aos por elas prestados à ENS, incluindo disponibilização de tração e dos canais horários nas respectivas redes e no Canal da Mancha, a qualquer novo concorrente. A decisão foi anulada pelo Tribunal de Primeira Instância, que criticou a

existência de poder de monopólio, de um poder de controlo do acesso ao mercado, de domínio do ponto de estrangulamento, dos 'bottle-neck of businesss' de que falava um dos mais ilustres responsáveis pela política antitruste dos Estados Unidos, do período tardio do New Deal. Mas bastará esse epíteto para considerarmos imediatamente preenchidos todos ou sequer parte dos elementos do tipo de ilícito abuso de posição dominante? Mais uma vez, a nossa resposta é negativa. O Conceito de infraestrutura essencial recolhe em si uma referência conjunta a dois elementos: um subjetivo e o outro objectivo. O primeiro é a posição de especial poder de que se encontra investida a empresa dominante; o segundo a possibilidade de eliminação da concorrência pela recusa de acesso. Ou seja, o seu sentido tem uma dimensão expressiva mas que não substitui os conceitos subjacentes ao abuso de posição dominante, como consagrado no artigo 82.(...)"

400 Acórdão do Tribunal de Primeira Instância (Segunda Secção Alargada) de 12.6.1997, Proc. T-504/93, Tiercé Ladbroke v. Comissão.

401 Acórdão do Tribunal de Primeira Instância (Segunda Secção) de 15 de Setembro de 1998, Processos apensos T-374/94, T-375/94, T-384/94 e T-388/94, European Night Services Ltd (ENS), Eurostar (UK) Ltd, e outros v. Comissão das Comunidades Europeias. 
definição de mercado relevante adotada pela Comissão e a análise das reais possibilidades de concorrência em mercado ainda em fase de liberalização. Considerou ainda que um produto ou serviço só pode ser considerado essencial se não existir qualquer alternativa real ou potencial, referindo-se à essencialidade das locomotivas:

\begin{abstract}
Quanto a este aspecto, o Tribunal faz notar que resulta da jurisprudência relativa à aplicação do artigo 86. do Tratado que um produto ou serviço só pode considerar-se essencial ou indispensável se não existir qualquer alternativa real ou potencial (acórdão do Tribunal de Justiça de 6 de Abril de 1995, RTE e ITP/Comissão, C-241/91 P e C-242/91 P, Colect., p. I-743, n.os 53 e 54, e acórdão do Tribunal de Primeira Instância de 12 de Junho de 1997, Tiercé Ladbroke/Comissão, T-504/93, Colect., p. II-923, n._ 131).

Em consequência, quando, como no presente caso, se está perante um acordo de criação de uma empresa comum abrangido pelo artigo 85, n.1, do Tratado, o Tribunal entende que as empresas-mãe e/ou a empresa comum assim criada só podem ser consideradas como estando na posse de infraestruturas, de produtos ou serviços 'indispensáveis' ou 'essenciais' para o acesso ao mercado relevante se essas infraestruturas, produtos ou serviços não forem 'alternativos entre si' e se, pelas suas características particulares, designadamente o custo proibitivo da sua reprodução e/ou do tempo razoável requerido para esse efeito, não existirem alternativas viáveis para os potenciais concorrentes da empresa comum, que ficariam, por isso, excluídos do mercado. ${ }^{402}$
\end{abstract}

Cabe ainda referência ao caso Oscar Bronneer, ${ }^{403}$ que apesar de anterior ao caso ENS, já trazia referência à aplicação da teoria das infraestruturas essenciais. Mediaprint, um grupo editorial austríaco que edita dois jornais de grande circulação, representando uma parte de mercado de $46,8 \%$ em tiragem e $42 \%$ em receitas publicitárias, com grande difusão, bem como $71 \%$ de todos os leitores de jornais diários e 53,3\% de todas as pessoas maiores de 14 anos que vivem em economia familiar. Possuía uma filial especializada na distribuição, com escala nacional, que entregava os seus jornais nas primeiras horas da manhã.

Oscar Bronner, por sua vez, editava, produzia e distribuía jornal diário de pequena circulação, representando 3,6\% em termos de tiragem e 6\% em termos receitas publicitárias. Bronner interpôs uma ação perante a autoridade concorrencial austríaca por abuso de posição dominante, com base na lei austríaca, pretendendo obter da Mediaprint a integração do seu jornal no sistema de distribuição domiciliária, com contrapartida razoável. Dois argumentos da tese defendida por Bronner eram a ausência de uma

\footnotetext{
402 Acórdão do Tribunal de Primeira Instância (Segunda Secção) de 15 de Setembro de 1998, Processos apensos T-374/94, T-375/94, T-384/94 e T-388/94, European Night Services Ltd (ENS), Eurostar (UK) Ltd, e outros v. Comissão das Comunidades Europeias, considerandos 208 e 209.

${ }^{403}$ Acórdão do Tribunal de Justiça (Sexta Secção) de 26.11.1998, Proc. C-7/97, Oscar Bronner c Mediaprint, Colect. 1998, p. I 7791.
} 
alternativa equivalente, uma vez que a distribuição era somente feita ao final da manhã, e a impossibilidade racional de organização de seu próprio sistema de distribuição. Invocou teoria das infraestruturas essenciais para a Mediaprint, estando ela obrigada a dar acesso ao seu sistema de distribuição. Alegava ainda prática discriminatória na medida em que a Mediaprint havia incorporado, à sua distribuição, jornal diário econômico que não era antes editado pelo grupo.

A Mediaprint alegou em defesa a dimensão de seus investimentos administrativos e financeiros para criação de um sistema de distribuição domiciliar e ausência de capacidade para abrir aquele sistema ao conjunto de editores de jornais diários austríacos. Ainda alegou circunstâncias excepcionais para imposição de obrigação de contratar e assentiu não implicar sua recusa a eliminação de toda a concorrência no mercado a jusante; e que havia justificativas objetivas para a recusa, baseadas na possibilidade de uma medida vir a afetar o bom funcionamento de seu sistema ou se tornar impossível por conta da falta de capacidade.

O advogado Jacobs, em sua opinião, expressou-se no sentido de que existe um direito geralmente reconhecido de escolher os parceiros contratuais e dispor livremente de sua propriedade. Desta forma, continua que qualquer ingerência das regras de concorrência na liberdade de contratar de uma empresa dominante deve ponderar considerações dinâmicas como a redução de incentivos ex ante para empresas dominantes na criação de infraestruturas. Por fim, deveríamos perguntar se existe ou não concorrência a jusante.

O Tribunal analisou a questão da proporcionalidade de investimento levado a efeito pelo agente dominante e o pedido da representante, caso contrário poderia restar o petitório desproporcional. O Tribunal redefiniu o mercado no que tange a outros modais de distribuição, reconhecendo a posição dominante da Mediaprint no mercado nacional.

Ainda, partindo do acórdão Magill, o Tribunal reinterpretou-o, quebrando a questão da indispensabilidade em duas: a indispensabilidade do bem ou serviço recusado para que possa ser desenvolvida a atividade no mercado secundário; e que tal recusa impeça o lançamento de um produto novo para o qual exista uma procura potencial. Da mesma forma, deveria se considerar se tal recusa não teria uma justificação, e por fim, que a recusa seja apta a excluir qualquer concorrência de quem requer o serviço no mercado secundário. ${ }^{404}$ Deixa assim claro que não basta que a recusa conduza à exclusão de toda a concorrência e que não exista justificativa objetiva, mas deve ainda ser indispensável para

\footnotetext{
${ }^{404}$ Acórdão do Tribunal de Justiça (Sexta Secção) de 26.11.1998, Proc. C-7/97, Oscar Bronner c Mediaprint, Colect. 1998, p. I 7791, considerando 40.
} 
o exercício da atividade, devendo inexistir qualquer substituto real ou potencial. ${ }^{405}$ É neste item que o Tribunal foca para demonstrar que não assiste razão a Oscar Bronner. Assim, a distribuição domiciliar não seria indispensável para o exercício da atividade de edição de jornais, visto que existiriam outros meios de distribuição, concluindo que indispensável não é o mesmo que desejável ou vantajoso.

Vislumbra de oferta autônoma de "distribuição" no mercado, tendo, contudo, optado a Mediaprint a integrar-se verticalmente. Questiona ainda o Tribunal se o ativo indispensável é passível de reprodução ou parcial substituição? Segundo o Tribunal, não haveria obstáculos técnicos, regulamentares ou mesmo econômicos que tornem impossível a organização de um sistema de distribuição em escala nacional, sendo a duplicação possível.

Por fim, cabe menção ao caso IMS, ${ }^{406}$ que envolvia empresas dedicadas à atividade de acompanhamento de vendas na indústria farmacêutica, fornecendo às empresas farmacêuticas dados relativos às vendas de medicamentos efetuadas pelas farmácias, bem como quanto às receitas emitidas pelos médicos. A IMS era líder mundial no fornecimento de informações à indústria farmacêutica e de cuidados de saúde. A NDC, por sua vez, prestava serviços de base de dados com especialização no setor farmacêutico, tendo ingressado no mercado alemão através de aquisição de uma empresa fundada em 1999 por um antigo funcionário da IMS.

A IMS desenvolveu a chamada estrutura de 1860 módulos, que tratava de segmentação do território da Alemanha em 1860 zonas geográficas, utilizadas para apresentar informações segmentadas de vendas de medicamento. A IMS se recusou a conceder licença à NDC para utilização de suas estruturas de 1860 módulos, tendo o Tribunal Alemão impedido o uso, por terceiros, da estrutura 1860, além da 1847 e 3000, também desenvolvidas pela IMS, por entender que infringia seu direito de autor.

Em vista dos fatos, concluiu a Comissão Europeia que o caso traria condições excepcionais $^{407}$ na linha utilizada pelo Tribunal de Justiça em Magill interpretado

\footnotetext{
405 Acórdão do Tribunal de Justiça (Sexta Secção) de 26.11.1998, Proc. C-7/97, Oscar Bronner c Mediaprint, Colect. 1998, p. I 7791, considerando 41.

${ }^{406}$ Decisão da Comissão Europeia de 3.7.2001, IV/38.044 - NDC Health/IMS Health: Interim measures.

407 Especificamente com relação ao alegado efeito da decisão nos direitos de propriedade intelectual, a Comissão se manifestou: "211. The Commission fully recognizes the essential role played by intellectual property rights in promoting innovation and competition. Nevertheless, as IMS admits and as the Court established in the Magill judgment (paragraph 50), read in conjunction with the Ladbroke and Bronner cases, Community law can apply to the exercise of that right in 'exceptional circumstances'. Such exceptional circumstances exist in this case. A dominant company has negotiated over a long period with its customer industry, who are now dependent on it, so as to produce a structure which it subsequently claims is its intellectual property, and refuses to license this structure to competitors so that no competing products based
} 
conjuntamente com Landbroke e Bronner. Assim, teria a IMS criado, em colaboração com empresas farmacêuticas, uma estrutura que se tornou, de fato, padrão para a apresentação de serviços de dados regionais. Ainda, concluiu que da leitura de Landbroke não havia efetivamente a necessidade de que a recusa no fornecimento impedisse o surgimento de um novo produto para que se caracterizasse abusiva. Contudo, restava claro que a recusa de acesso à estrutura 1860 provavelmente eliminaria toda concorrência no mercado a jusante, não encontrando justificativa objetiva para a recusa no licenciamento por parte da IMS. ${ }^{408}$ Ordenou a Comissão, com isso, que a IMS licenciasse a estrutura 1860 em termos não discriminatórios à NDC e à AzyX.

O Tribunal de Justiça começou a analisar a essencialidade da estrutura de 1860 módulos e seus efeitos no mercado. Verificou assim que a IMS desenvolveu, juntamente com as empresas farmacêuticas, um padrão para prestação das informações sem, contudo, garantir disponibilidade para outros potenciais concorrentes, gerando um efeito lock-in de dependência. Assim, pela criação do padrão, nenhuma outra estrutura de apresentação de dados seria capaz de concorrer, pois os custos da mudança do lado das indústrias farmacêuticas seriam proibitivos. Sublime-se ainda que o grau de inovação era muito reduzido e não havia originalidade, em vista da arbitrariedade da escolha operada. $\mathrm{O}$ Tribunal de Justiça concluiu, assim, que estes seriam fatores pertinentes para aferir a essencialidade do acesso à referida estrutura de 1860.

Em sede de questões prejudiciais sobre a interpretação do artigo $82 \mathrm{CE}^{409} \mathrm{o}$ Tribunal de Justiça considerou que, como resultado do caso Bronner, para determinação da indispensabilidade de um produto ou serviço ao exercício da atividade de uma empresa num determinado mercado, há que se averiguar se existem produtos ou serviços que constituam soluções alternativas, mesmo que sejam menos vantajosas, e se existem obstáculos técnicos, regulamentares ou econômicos susceptíveis de tornar impossível, ou pelo menos de difícil razoabilidade a criação de produtos ou serviços alternativos. Assim, para admitir-se a existência de obstáculos de natureza econômica, deve-se, pelo menos, provar-se que a criação desses produtos ou serviços não é economicamente rentável para

on this structure can be produced. These circumstances, which give rise to an abuse of Article 82 , are extremely specific. Under these circumstances, exclusive use of the 1860 brick structure and its derivatives by IMS is a means of monopolizing the market for regional data services in Germany."

${ }^{408}$ Decisão da Comissão Europeia de 3.7.2001, IV/38.044 - NDC Health/IMS Health: Interim measures, considerando 180-181.

409 Acórdão do Tribunal de Justiça (Quinta Secção), de 29.04. 2004, Processo C-418/01, IMS Health GmbH 6c Co. OHG e NDC Health GmbH \& Co. KG. 
uma produção a uma escala comparável à da empresa que controla o produto ou o serviço existente. $^{410}$

Neste sentido, reforça o Tribunal de Justiça mais adiante que, para a recusa de uma empresa titular de um direito de autor, da permissão de acesso a um produto ou serviço indispensável para exercício de determinada atividade, possa ser qualificada como abusiva, basta que estejam preenchidas três condições cumulativas: (i) que essa recusa obste a aparição de um novo produto para o qual exista uma potencial procura por parte dos consumidores; (ii) que ela careça de justificação objetiva; e (iii) que seja susceptível de excluir toda a concorrência no mercado derivado. ${ }^{411}$

Havia, no caso, discussão acerca da existência de dois mercados e, portanto, não seria o ativo em causa objeto de transação. Contudo, asseverou o Tribunal, bastava que um mercado potencial ou hipotético fosse identificado, o que seria verificado pela procura por parte daqueles para quem o acesso a esse serviço ou ativo seria indispensável ao exercício da atividade em questão. ${ }^{412}$

Cabe ainda breve menção a dois casos envolvendo discussões sobre infraestrutura essencial em Portugal, Canal RTP Portugal e Infobolsa, ${ }^{413}$ que tratavam de casos de recusa de venda como abuso de posição dominante enquanto vigorava, em Portugal, o artigo 4 do Decreto-Lei n. 370/93. ${ }^{414}$ Tal dispositivo impunha obrigação geral de contratação/venda no

${ }^{410}$ Acórdão do Tribunal de Justiça (Quinta Secção), de 29.04. 2004, Processo C-418/01, IMS Health GmbH 6c Co. OHG e NDC Health GmbH \& Co. KG, considerando 28.

${ }_{411}$ Acórdão do Tribunal de Justiça (Quinta Secção), de 29.04. 2004, Processo C-418/01, IMS Health GmbH 6c Co. OHG e NDC Health GmbH \& Co. KG, considerando 38.

${ }^{412}$ Idem, considerando 44.

${ }^{413} \mathrm{O}$ caso Infobolsa envolvia a Bolsa de Valores de Lisboa, que fornecia, mediante remuneração, aos seus vendors de informação (Bloomberg, Reuters e outras), conjunto de dados gerados pelo sistema de negociação ao qual só tinham acesso seus associados (informações sobre a melhor e a pior transação por título). Após modificações do sistema de informática, passou a ter condições de transmitir as cinco melhores/piores transações, informação sobre profundidade do mercado. Em 97 a Bolsa lançou um produto próprio de informação bolsista que concorria com os vendors (importante a natureza de complementariedade dos produtos, além de concorrência, pois empresas assinavam ao menos 2 serviços). O novo sistema foi disponibilizado no Infobolsa, mas não imediatamente aos vendors. Reuters apresentou queixa contra a Bolsa por recusa em disponibilizar informações sobre profundidade do mercado e discriminação com relação ao serviço Infobolsa. A Bolsa de Lisboa alegou como defesa não ter negado acesso e invocou dificuldades técnicas para o fornecimento. Um acordo em 2000 modificou o quadro do litígio, que acabou arquivado pelo Conselho de Concorrência. A questão que se colocava era saber se existiria ou não um dever de facultar acesso em condições de igualdade às informações sobre a profundidade do mercado. Ao contrário do que ocorria no caso Magill, a Bolsa não teria qualquer direito exclusivo legal sobre a informação, uma vez que não havia proteção de propriedade intelectual. Assim, não parece existir um esforço de inovação que mereça proteção, ainda mais que qualquer direito imposto de acesso não seria capaz de prejudicar a produção e difusão das informações aos associados da Bolsa, não retirando o incentivo à inovação. O Conselho perdeu grande oportunidade de discutir a aplicação das regras em comento.

414 O Decreto-Lei n. 380/93, de 15 de novembro, visou, essencialmente, permitir ao Governo acompanhar a evolução das estruturas acionistas das empresas a reprivatizar, nas diferentes fases sucessivas das operações de reprivatização, tendo em vista o reforço da capacidade empresarial daquelas, de forma compatível com as orientações assumidas na condução do processo de reprivatizações. Essa necessidade de acompanhamento da 
direito português, independentemente de tratar-se de bens ou serviços essenciais e do resultado de prejuízo para o mercado, ou mesmo de poder de mercado.

A reforma legislativa de 2003, com a edição do Decreto n. 18/03, trouxe novidade no sistema jurídico português, segmentando as proibições de abuso de posição dominante por recusa de contratação em duas modalidades: uma primeira modalidade de recusa de venda de bens ou serviços no mercado, seja ela inicial ou subsequente, direta ou indireta, a um concorrente ou a um cliente e relativa a produtos tangíveis ou intangíveis, preenchidos os demais requisitos, lastreada na alínea $f$ do n. 1 do artigo 4; e um tipo especial, qualificando como abuso de posição dominante à recusa inicial de bens ou serviços a um concorrente que não são oferecidos no mercado, desde que preenchidos os restantes elementos do tipo, lastreado no artigo 6,3, $b$ do diploma em referência.

Já no novo diploma que revogou a Lei n. 18/2003 - Lei n. 19/2012, de 8 de maio de 2012 - houve previsão expressa, como modalidade de exploração abusiva, unilateral ou coletiva, a recusa ao acesso a infraestruturas essenciais, prevendo ainda justificativas objetivas para a recusa. ${ }^{415}$

\subsubsection{Venda Casada}

A conduta praticada por empresa dominante visando obtenção de vantagem em mercado conexo é expressamente consagrada como abusiva pela alínea $d$ do parágrafo $2^{\circ}$ do artigo 102. Para sua caracterização, se faz necessário que os produtos sejam distintos, que se verifique poder de mercado ao nível do produto subordinante - trazendo ainda elemento de coação - e que haja produção de efeitos anticoncorrenciais.

Um dos casos de maior relevância na Europa tratando do tema é conhecido como Eurofix-Bauco c. Hilti. ${ }^{416}$ A Hilti fabricava pistolas de pregos e consumíveis, detendo 55\% do mercado de pistolas de prego, $70 \%$ do mercado de fitas cartucho compatíveis com a

evolução das estruturas acionistas resultou, fundamentalmente, da realização de operações de reprivatização que não se esgotam numa única fase, mas se prolongam por estágios sucessivos. O Decreto foi revogado em 10 de março de 2004.

415 "Artigo 11. Abuso de posição dominante. 1. É proibida a exploração abusiva, por uma ou mais empresas, de uma posição dominante no mercado nacional ou numa parte substancial deste. 2. Pode ser considerado abusivo, nomeadamente: (...) (e) Recusar o acesso a uma rede ou a outras infraestruturas essenciais por si controladas, contra remuneração adequada, a qualquer outra empresa, desde que, sem esse acesso, esta não consiga, por razões de facto ou legais, operar como concorrente da empresa em posição dominante no mercado a montante ou a jusante, a menos que esta última demonstre que, por motivos operacionais ou outros, tal acesso é impossível em condições de razoabilidade."

${ }^{416}$ Acórdão do Tribunal de Primeira Instância (Segunda Secção) de 12 de dezembro de 1991. Processo T30/89. Hilti AG contra Comissão das Comunidades Europeias. 
pistola e entre $70 \%$ e $80 \%$ do mercado de pregos compatíveis com a pistola. A Hilti foi condenada por abuso de posição dominante por, entre outras práticas, subordinar a venda de pregos com suas pistolas com fitas de cartucho, diminuindo a concorrência ao nível de pregos compatíveis. A Hilti alegou em seu recurso tratar-se de único produto e, portanto, mercado relevante, assim como alegou a existência de justificativas objetivas para a subordinação. O Tribunal rejeitou as alegações, por inferir, em razão de diversas questões de fato trazidas, que haveria três mercados específicos, declarando ainda que o mercado dos produtos em causa seria dos pregos destinados às pistolas de pregos que fabricavam. ${ }^{417}$ Com relação às justificativas objetivas, o Tribunal entendeu que uma empresa em posição dominante, dispondo do direito de acautelar os seus interesses comerciais, não podia, pelas razões de segurança, impedir unilateralmente os clientes de adquirir pregos de fabricantes concorrentes. $^{418}$

Outro caso acerca do tema na Europa veio a ser Tetra Pak II. ${ }^{419}$ O grupo Tetra Pak era especializado em equipamentos utilizados para o acondicionamento em embalagens de cartão de produtos alimentares líquidos ou semilíquidos, desenvolvendo suas atividades nos setores de acondicionamento asséptico e não asséptico. Tais atividades consistiam em produzir embalagens de cartão e máquinas de enchimento. No sector asséptico, a Tetra Pak produzia o sistema chamado 'Tetra Brik', destinado ao acondicionamento de leite UHT, sendo seu único concorrente a empresa PKL, com um sistema comparável. A detenção de uma técnica de enchimento asséptico é a chave do acesso tanto ao mercado das máquinas, como ao das embalagens de cartão assépticas. Em contrapartida, o acondicionamento não asséptico necessita de um equipamento menos sofisticado.

À data da infração, a Tetra Pak detinha entre $90 \%$ e $95 \%$ do mercado de equipamentos para enchimento em embalagens de cartão no segmento asséptico, com apenas um concorrente. No mercado de equipamentos para enchimento em embalagens de cartão no segmento não asséptico, havia uma estrutura oligopolista, em que a Tetra Pak detinha entre 50 e 55\%, Elopak com $27 \%$ e a $P K l$ com $11 \%$ e outros pequenos produtores. No segmento de embalagens de cartão havia três outras empresas com $11 \%$.

\footnotetext{
417 Acórdão do Tribunal de Primeira Instância (Segunda Secção) de 12 de dezembro de 1991. Processo T30/89. Hilti AG contra Comissão das Comunidades Europeias, considerando 66.

${ }^{418}$ Idem, considerandos 118 e 119.

419 Acórdão do Tribunal (Quinta Secção) de 14 de novembro de 1996. Processo C-333/94 P. Tetra Pak International SA contra Comissão das Comunidades Europeias.
} 
O principal concorrente no mercado de equipamentos para enchimento em embalagens de cartão no segmento não asséptico era a Elopak, que não estava tão presente no mercado asséptico. A Comissão concluiu pela existência de quatro mercados relevantes: mercado de máquinas de enchimento asséptico; mercado de embalagens de cartão asséptico; mercado de máquinas de enchimento não asséptico; e mercado de embalagens de cartão não asséptico. As condutas verificadas por parte da Tetra Pak implicavam subordinação da venda de embalagens de cartões à aquisição de máquinas de enchimento, o que conseguiu através de cláusulas contratuais diversas, que tinham um efeito de criação de dependência do cliente em relação àquele fornecedor, bem como práticas de preços discriminatórios entre utilizadores situados em Estados-membros diferentes e predatórias em face dos concorrentes da Tetra Pak.

Assim, foi a empresa condenada por subordinar as vendas das suas máquinas às vendas de cartões para tais máquinas. Segundo a Comissão, a renda assegurada com as vendas a preços mais elevados nos cartões permitiam venda das máquinas abaixo do preço de custo. A Comissão considerou que a conduta da Tetra Pak integrava uma estratégia global destinada a criar uma relação de dependência econômica por parte dos clientes. A alínea $d$ do artigo 82 requer prova das partes quando excluem da proibição os casos em que a natureza ou os usos comerciais justifiquem a integração das vendas.

\subsubsection{Preços Predatórios}

Reforcemos com vigor que, ao lado das recusas de fornecimento, práticas de preços predatórios certamente encontram-se entre os temas mais controversos no direito concorrencial, em especial pelo seu caráter benéfico ao consumidor no curto prazo e pela difusão de teorias acerca da medida de custo que caracterizaria tal prática, bem como a natural dificuldade de avaliação dos custos da empresa sob investigação. Miguel Moura, em sua obra, comenta que: "[p]aradoxalmente, o grande debate doutrinal das últimas três décadas tem sido centrado na questão de saber até que ponto não será a repressão de tais práticas a quimera do antitruste". 420

O artigo 102 do TFUE proíbe, na alínea $a$ do segundo parágrafo, práticas abusivas que possam consistir na imposição, de forma direta ou indireta, de preços de compra ou de

420 MOURA E SILVA, Miguel. O Abuso de Posição Dominante na Nova Economia. Teses de Doutoramento, cit., p. 207. 
venda ou outras condições de transação não equitativas. ${ }^{421}$ Assim, conforme discorrem diversos autores, a aplicação deste dispositivo para as práticas de preços predatórios nunca mereceu dúvidas particulares ou contestações; não obstante, somente em 1980 surgiram os primeiros casos de preços predatórios na Europa.

Em 1985, a Comissão Europeia decidiu o primeiro deles, que dizia respeito à conduta praticada pela ECS/Akzo. ${ }^{422}$ A filial da Akzo, localizada no Reino Unido, produzia peróxido orgânico, produto que possui duas aplicações principais: indústria de plásticos e compostos para a indústria moageira, como agentes branqueadores de farinhas. No mercado de compostos para indústria moageira, havia três grandes produtores - Akzo, ECS e Diaflex. Por sua vez, a estrutura de procura era relativamente concentrada - RHM, Spillers e Allied Mills, com 85\% do mercado, seguidos dos grandes independentes, com $10 \%$ do mercado, e pequenos moageiros, com 5\%. RHM era abastecida pela Akzo e Diaflex; Allied abastecida pela Akzo; Spillers pela Akzo e Diaflex; os grandes independentes eram abastecidos pela $E C S$, na proporção de 2/3, e o restante pela Akzo. Quando a ECS começou a comercializar peróxido orgânico para o mercado de plásticos, a Akzo respondeu ameaçando eliminar a ECS do mercado de compostos para indústria moageira a menos que esta renunciasse ao mercado de plásticos.

A ECS conseguiu dos tribunais britânicos medida cautelar que impedia a Akzo de reduzir seus preços com o objetivo de eliminá-la do mercado, porém após 1982, quando a transação que pôs termo ao litígio se encerrou, a ECS se queixou à Comissão de suposto abuso de posição dominante por parte da Akzo. Durante as investigações foram encontrados memorandos internos da Akzo com detalhes de um plano para disciplinar e, se necessário, eliminar a ECS em retaliação pela sua entrada. Além da redução da participação de mercado da ECS durante o período da conduta, de $35 \%$ a $30 \%$, com respectivo aumento da $A k z o$ de $50 \%$ para $55 \%$, a Comissão verificou ainda diversas práticas anticoncorrenciais. $^{423}$

\footnotetext{
421 "Uma vez que a letra do Tratado invoca o conceito de preços (ou outras condições de compra ou venda) não equitativos, tal indicia, por um lado, que deve existir um elemento qualificativo que torne o preço em questão contrário aos fins do artigo 82 e, mais geralmente, aos fins do Tratado. Por outro lado, nenhum critério é estabelecido quanto à metodologia de determinação do caracter não equitativo de um preço. E, como vimos, existe um amplo espaço de debate sobre a questão de qual a metodologia correcta e como ela pode ser aplicada judicialmente" (Idem, ibidem, p. 239).

${ }_{422}$ Decisão da Comissão Europeia, de 14.12.1985, IV/30.698 - ECS/AKZO Chemie, J.O. L. 374, de 31.12.1985, p. 1.

${ }^{423}$ Decisão da Comissão Europeia, de 14.12.1985, IV/30.698 - ECS/AKZO Chemie, J.O. L. 374, de 31.12.1985, considerando 82. "The behaviour of Akzo has to be considered as a whole, but the particular aspects in which the circumstances of the present case its pricing conduct is abusive under Article 86 are as follows: (i) making direct threats to ECS in two meetings in late 1979; (ii) from about the end of 1980
} 
Com base nisso, a Comissão condenou a Akzo em EUR 10 milhões, ordenando a interrupção de sua conduta, proibindo-a ainda de fazer ofertas ou fixar preços e outras condições de venda que tivessem por efeito a discriminação de preços entre os clientes da ECS e os seus clientes. Neste sentido, a Akzo estaria limitada a praticar preços diferenciados para repercutir, de forma razoável e objetiva, diferenças de custos de produção e de entrega, podendo tomar em consideração o volume de compras anual, a importância da encomenda e outros fatores de natureza comercial.

No seu trabalho de controle da decisão da Comissão, o Tribunal de Justiça enunciou ainda que:

\begin{abstract}
[p]reços inferiores à media dos custos variáveis (quer dizer, dos custos que variam em função das quantidades produzidas) de que uma empresa dominante se serve para tentar eliminar um concorrente devem ser considerados abusivos. Uma empresa dominante não tem, efectivamente, nenhum outro interesse em praticar tais preços, que não seja o de eliminar os seus concorrentes para poder, a seguir, aumentar os preços utilizando a situação de monopólio, uma vez que cada venda implica para ela uma perda, ou seja, a totalidade dos custos fixos (quer dizer, dos que permanecem constantes, qualquer que seja a quantidade produzida), e uma parte, pelo menos, dos custos variáveis atribuíveis a unidade produzida. Por outro lado, preços inferiores à media dos custos totais, incluindo os custos fixos e os variáveis, mas superiores à media dos custos variáveis, devem considerar-se abusivos, quando são fixados no quadro de um plano que tem como finalidade eliminar um concorrente. Estes preços podem, de facto, afastar empresas do mercado que podem ser tão eficazes como a empresa dominante mas que, pela sua menor capacidade financeira, são incapazes de resistir à concorrência que lhes é movida. ${ }^{424}$
\end{abstract}

Acolheu o Tribunal de Justiça, desta forma, critério misto de análise de custos proposto por Posner, porém atribuiu à intenção um papel complementar que amplia substancialmente o âmbito da proibição. Pode-se reconhecer, desta forma, fundamento

onwards, systematically offering and/or supplying flour additives to Provincial Merchants, Allied Mills and the customers of ECS in the large independent sector at unreasonably low prices intended to damage ECS's viability by either taking the customer's business or forcing ECS itself to supply at uneconomic prices in order to keep the business; (iii) making the above quotations selectively to ECS customers while maintaining substantially (up to $60 \%$ ) higher prices to the similarly-placed customers it already supplied itself; (iv) offering potassium bromate and vitamin mix (the latter a product which it did not normally supply) at bait prices to ECS's customers so as to secure the whole of their business in flour additives; (v) as part of the plan to damage ECS by keeping prices generally at an uneconomic level, which it could survive because of its superior financial resources, maintaining below cost prices to Spillers and RHM over a prolonged period of time; (vi) pursuing an exclusionary commercial policy in respect of RHM and Spillers by obtaining from the customer precise details of quotes from other producers and then offering a price just below the competing quotation so as to obtain the business, coupled (in the case of Spillers) with an exclusive supply obligation which kept out other suppliers; (vii) implementing the above tactics with the long-term purpose of damaging and/or securing the withdrawal of ECS as a competitor in the broader organic peroxides market as a whole." Verificar:

$<$ http://eurlex.europa.eu/smartapi/cgi/sga_doc?smartapi!celexplus!prod!CELEXnumdoc\&lg=en\&numdoc=385D0609>. ${ }^{424}$ Decisão da Comissão Europeia, de 14.12.1985, IV/30.698 - ECS/AKZO Chemie, J.O. L. 374, de 31.12.1985, considerandos 71 e 72. 
para a decisão em dois grandes princípios: o do concorrente igualmente eficiente, em que a conduta será apta a excluir um concorrente tão eficiente quanto a empresa dominante, ainda que o preço seja superior aos custos variáveis médios, porém inferior ao custo total. Por outro lado, há o reconhecimento da teoria do poder financeiro como uma das justificações para a racionalidade de tal prática.

Alguns anos mais tarde a Comissão decidiu o caso Tetra Pak II, já tratado acima em seu viés de conduta de subordinação ou venda casada. ${ }^{425}$ Recorde-se, para tanto, que as condutas praticadas pela Tetra Pak implicavam subordinação da venda de embalagens de cartões à aquisição de máquinas de enchimento, bem como práticas de preços discriminatórios entre utilizadores situados em Estados-Membros diferentes e predatórias em face dos concorrentes da Tetra Pak. Em especial, os preços cobrados de clientes na Itália para venda ou aluguel das máquinas eram tão díspares se comparados aos preços nos demais Estados-Membros, que a possibilidade de que estas máquinas estavam sendo vendidas ou alugadas com perdas nestes casos eram relativamente altas.

A Comissão condenou a Tetra Pak por ter abusado de sua posição dominante nos mercados assépticos, decisão confirmada pelo Tribunal de Primeira Instância Europeu, que rejeitou o argumento da empresa de que deveria a Comissão, com base no caso Akzo, demonstrar a intenção predatória, bem como em linha com o acórdão Brooke Group, dos Estados Unidos, deveria demonstrar que a empresa poderia razoavelmente esperar recuperar as perdas incorridas na sua conduta predatória. Da mesma forma se manifestou o Tribunal de Justiça:

\footnotetext{
44 - Convém acrescentar que, nas circunstâncias do presente caso, não seria oportuno exigir também, a titulo de prova adicional, que se demonstrasse que a Tetra Pak tinha uma possibilidade real de recuperar as suas perdas. Com efeito, uma prática de preços predatórios deve poder ser penalizada quando exista o risco de eliminação dos concorrentes. Ora, esse risco foi verificado no caso presente pelo Tribunal de Primeira Instancia nos $n^{\circ}$ s 151 e 191 do acordão impugnado. $\mathrm{O}$ objectivo pretendido, que é de preservar uma concorrência não falseada, não permitir aguardar que uma estratégia dessa natureza leve à eliminação efectiva dos concorrentes. ${ }^{426}$
}

\footnotetext{
${ }^{425}$ Acórdão do Tribunal de Justiça (Quinta Secção) de 14.11.1996, Proc-C333/94 P, Tetra Pak International c. Comissão, Colect. 2005, p. I 4609.

${ }^{426}$ Acórdão do Tribunal de Justiça (Quinta Secção) de 14.11.1996, Proc-C333/94 P, Tetra Pak International c. Comissão, Colect. 2005, p. I 4609.
} 
Por sua vez, o caso Compagnie Maritime Belge envolveu preços predatórios por parte de entidade dominante constituída pelos membros da conferência marítima Cewal. ${ }^{427}$ A Cewal recorreu à prática dos chamados navios de combate, nas ligações com o Zaire, entre 1988 e 1989, tendo por objetivo eliminar empresas que não integrassem aquela conferência. Verificou-se que havia informações prestadas pelo secretariado da conferência aos seus membros quanto às datas das próximas partidas da empresa independente, assim como natureza da carga, e, quando possível, a identidade dos carregadores. Aqueles que fizessem movimentação de cargas com as concorrentes eram colocados em uma lista negra. De dois em dois meses reunia-se um Special Fighting Committee, que designava os navios e respectivas companhias que apresentariam tarifas de combate, de forma que tais navios deveriam partir na mesma data ou em datas próximas do concorrente. As tarifas de combate eram fixadas em função do preço da empresa concorrente e as perdas suportadas por todos os membros, numa parceria predatória. A Cewal argumentava que a estratégia implicava registrar ganhos menores, porém não prejuízos, o que foi rebatido pela Comissão.

Neste segundo caso, o Tribunal de Justiça estabeleceu critérios com base em custos de produção da empresa em causa. Da mesma forma, o carácter multilateral e intencional demonstra a natureza abusiva de um comportamento que consiste em estabelecer um preço excepcional concertado com o objetivo de eliminar um concorrente. $^{428}$

Em sua decisão, a Comissão não procura sequer demonstrar tarifas abaixo de qualquer medida de custo, mas simplesmente fundamentar a prática na designação comum dos navios de combate, na fixação em comum de uma tarifa especial inferior aos preços de tabela e, por fim, na redução dos lucros decorrentes daquela prática. No considerando 82

\footnotetext{
${ }^{427}$ Acórdão do Tribunal (Quinta Secção) de 16 de Março de 2000, Processos apensos C-395/96 P e C-396/96 P, Compagnie Maritime Belge Transports SA (C-395/96 P), Compagnie Maritime Belge SA (C-395/96 P) e Dafra-Lines A/S (C-396/96 P) c. Comissão das Comunidades Europeias.

${ }_{428}$ Decisão da Comissão Europeia de 23.12.1992, IV/32.448 e IV/32.450, Cewal, Cowac and Ukwal; eIV/32.448 e IV/32.450: Cewal, considerandos 80 e ss: "A este respeito, deve-se distinguir uma decisão concertada de várias empresas, reunidas neste caso numa conferência marítima, que consiste em fixar, no âmbito de um plano, um preço especial com vista a eliminar um concorrente, do caso anteriormente examinado pela Comissão e pelo Tribunal de Justiça relativo a preços abusivamente baixos estabelecidos por uma única empresa actuando unilateralmente, onde havia que distinguir preços predatórios de uma concorrência agressiva (37). Não pode admitir-se este tipo de comportamento por parte das empresas em posição dominante colectiva, como os membros da Cewal. De facto, o Tribunal declarou que o recurso por parte das empresas a comportamentos que impliquem meios que não sejam os que regem uma concorrência normal baseada no mérito (38). É este o caso dos navios de combate, tanto mais que, sendo a Cewal uma conferência marítima, os seus membros devem respeitar a tabela comum. Consequentemente, os membros da Cewal abusaram da posição dominante conjunta para eliminar a concorrência do seu principal concorrente através da utilização de navios de combate."
} 
aponta a questão do desequilíbrio invocado entre o poder financeiro do novo concorrente e dos membros da conferência, ao mesmo tempo em que traz vaga alegação de subsídio cruzada com tarifas regulares. ${ }^{429}$ Vale mencionar que o Tribunal desconsiderou o fato de o concorrente ter visto sua quota crescer, o que poderia indicar que o resultado não fora atingido.

A Cewal, por sua vez, defendeu ainda no Tribunal de Justiça seus direitos de proteger seus interesses comerciais, até mesmo para uma entidade dominante, reduzindo seletivamente os preços, desde que estes não se situassem a um nível definido abusivo pelo acórdão Akzo. O Tribunal enquadra a conduta na tese do acórdão Continental Can, evitando-se alargar a tese de preços predatórios acima do custo médio total. Para tanto evoca Tetra Pak II, afirmando que "o âmbito de aplicação material da responsabilidade particular que impende sobre uma empresa em posição dominante deve ser apreciado tendo em conta as circunstâncias específicas de cada caso, que demonstrem um enfraquecimento da concorrência". 430

O Tribunal parece ainda reconhecer que as especiais circunstâncias deste caso justificariam a qualificação da prática dos navios de combate como abusiva, pois os membros da conferência beneficiavam-se do poder de manipulação das tarifas com o objetivo declarado de eliminar o único concorrente. ${ }^{431}$

Importante descrever a posição do Advogado Geral, que admite que desde que o preço não seja inferior aos custos, uma empresa dominante poderia prosseguir com reduções de preços na condição de que as mesmas não sejam discriminatórias, fundamentando-se assim nos benefícios ainda que temporários para os consumidores e no

\footnotetext{
${ }^{429}$ Idem, considerando 82: "A Cewal alegou que os seus membros não teriam tido prejuízos com os preços de combate; teriam apenas registado ganhos inferiores do que se houvessem aplicado os 'preços normais'. A este respeito, deve assinalar-se que, embora estas alegações se afigurem contraditórias relativamente às declarações dos membros da conferência que constam das actas das reuniões do 'Fighting Committee', o facto de subsidiar o custo dos 'preços de combate' com os 'preços normais' da conferência obtidos nas outras viagens em que a conferência não recorre a navios de combate constitui, por si só, no caso em apreço, uma conduta abusiva destruidora da concorrência; esta conduta abusiva poderá afastar do mercado uma empresa que é provavelmente tão eficaz como a conferência dominante mas que, devido à sua menor capacidade financeira, é incapaz de resistir à concorrência que lhe é feita de um modo concertado e abusivo por parte de um grupo poderoso de armadores reunidos numa conferência marítima. A serem verdadeiras, as afirmações da Cewal demonstrariam apenas que, devido à existência da conferência, os preços de frete 'normais' estão largamente acima dos custos suportados pelos seus membros, o que, por seu lado, indica a existência de uma fraca concorrência no mercado.'

${ }^{430}$ Acórdão do Tribunal de Justiça (Quinta Secção) de 14.11.1996, Proc-C333/94 P, Tetra Pak International c. Comissão, considerando 114.

431 MOURA E SILVA, Miguel. O Abuso de Posição Dominante na Nova Economia. Teses de Doutoramento, cit., p. 250.
} 
fato de tais reduções não serem aptas a excluir concorrentes tão ou mais eficientes que as empresas dominantes. ${ }^{432}$

Por fim, dos quatro grandes casos envolvendo preços predatórios na Europa cabe menção ao caso France Telecom. ${ }^{433}$ A Wanadoo Interactive, filial do Grupo France Telecom, atuava no mercado francês de banda larga. Neste caso a Comissão considerou que a Wanadoo praticou, no mercado atacadista de acesso à internet de alta velocidade (banda larga), preços que não permitiam à empresa cobrir seus custos variados até agosto de 2001, tampouco seus custos totais a partir desta data, considerando-se assim que havia estratégia de apropriação do mercado de acesso à internet de alta velocidade, numa fase importante do seu desenvolvimento.

Duas foram as questões relevantes discutidas no âmbito do acórdão do Tribunal: a metodologia para determinação dos custos da Wanadoo e as justificativas invocadas no que tange ao abuso. A Wanadoo alegava que havia necessidade de acompanhamento dos preços dos seus concorrentes. O Tribunal não rejeitou a tese, mas esclareceu que o "fato de uma empresa em posição dominante acompanhar os preços dos concorrentes não é em si mesmo abusivo ou condenável, porém acrescenta que a redução para enfrentar a concorrência poderá ser abusiva dependente da intenção subjacente". ${ }^{434}$

Isso não parece ensejar que se admite uma justificação mesmo nos casos abrangidos pela Akzo. Segundo Miguel Moura:

\footnotetext{
(...) preços abaixo do custo médio variável são sempre considerados abusivos, presumindo-se judicialmente que eles não correspondem a qualquer natureza objectiva, uma vez que a empresa poderia reduzir as perdas abstendo-se de produzir; quando o preço se situa entre aquele limiar e o custo médio total, como vimos, a defesa é firmada pela existência de uma intenção de eliminar a concorrência (...). ${ }^{435}$
}

Houve também negativa da "defesa da eficiência". A Wanadoo argumentava que os baixos preços praticados tinham a virtualidade de gerar um conjunto de ganhos de eficiência que, em seu entender, deveriam ser ponderados. Alegava assim que o custo variável de alguns produtos diminuía com a quantidade produzida, dependendo do volume

\footnotetext{
432 MOURA E SILVA, Miguel. O Abuso de Posição Dominante na Nova Economia. Teses de Doutoramento, cit., p. 251.

433 Acórdão do Tribunal de Justiça (Quinta Secção) de 30.1.2007, Proc-T340/03. France Telecom c Comissão, Colect. 1998, p. I.

434 Acórdão do Tribunal de Justiça (Quinta Secção) de 30.1.2007, Proc-T340/03. France Telecom c Comissão, Colect. 1998, p. I.

435 MOURA E SILVA, Miguel. O Abuso de Posição Dominante na Nova Economia. Teses de Doutoramento, cit., p. 252.
} 
da demanda, enquanto um alto volume de produção poderia ensejar experiência e, consequentemente, redução nos custos de futura produção. Aos olhos da Comissão, contudo, este argumento traçava o objetivo racional da conduta, que seria o de reservar à empresa as economias de escala do mercado e atrasar a chegada de seus concorrentes ao mesmo nível de produção que permitira economias de escala. ${ }^{436}$

Houve, portanto, negativa da admissibilidade da defesa da concorrência. Assim, quando tais ganhos de eficiência são consequências diretas do próprio comportamento abusivo, os mesmos não poderão ser levados em consideração.

O Relatório dos Serviços do DG Comp. ${ }^{437}$ sugere adaptação dos critérios aos moldes atuais, socorrendo-se do modelo de Bolton, Broadley e Riordan. Ainda, fica clara a ausência do critério de recuperação de perdas. ${ }^{438}$

\subsubsection{Descontos de Fidelidade}

O regime de controle dos descontos de fidelidade pela Comissão Europeia começou a ser delineado com o caso do Cartel do Açúcar, que implicava acordos diversos entre os principais produtores de açúcar para manutenção da repartição dos mercados nacionais, impedindo importações. ${ }^{439}$ Havia quotas mínimas e máximas estipuladas, sendo que, fora disso os participantes do acordo não tinham garantia de escoamento de produção, auxílio à exportação e deveriam vender a terceiros países, ainda se aplicando preços de intervenção. O problema surgiu na Alemanha com a SZV, que detinha quota de mais de $90 \%$ do mercado, e passou a aplicar um desconto de fidelidade de 0,30 marcos por $100 \mathrm{~kg}$, conforme definido no final do ano, caso o cliente adquirisse a totalidade dos abastecimentos junto aos membros da SZV.

A Comissão Europeia, inicialmente, considerou a prática como discriminação injustificável, na medida em que "a atribuição de um desconto (remise), que não depende da quantidade adquirida mas apenas da condição que as necessidades anuais sejam

\footnotetext{
${ }^{436}$ Decisão da Comissão de 16 de julho de 2003 referente ao procedimento sobre o Artigo 82 do Tratado (COMP/38.233 - Wanadoo Interactive), considerandos 306 e 307.

${ }^{437}$ DG Competition Discussion Paper on the Application of Article 82 of the Treaty to Exclusionary Abuses. Brussels, 2005.

${ }^{438}$ MOURA E SILVA, Miguel. O Abuso de Posição Dominante na Nova Economia. Teses de Doutoramento, cit., p. 254.

${ }_{439}$ Decisão da Comissão Europeia de 2.1.1973, IV/26.918 - Indústria Europeia do Açúcar, J.O L 140, de 26.5.1973.
} 
cobertas exclusivamente pela SZV, constitui um prejuízo injustificado para os compradores que adquiram, além do açúcar da SZV, açúcar de outras origens". ${ }^{40}$

Três aspectos se sobressaem na decisão da Comissão: (i) os descontos eram atribuídos com o principal objetivo de eliminar ou mitigar incentivos criados pelas variações de preços decorrentes da importação de açúcar proveniente da França; (ii) a vantagem conferida era na verdade uma ameaça de retirada de um benefício caso não fossem acatadas as condições impostas pela empresa dominante; e (iii) embrionário fundamento para a imputação de um efeito de exclusão, sem grande necessidade de concretização fática, pela importância que o volume dos produtos adquiridos à entidade dominante tinha no volume de vendas dos distribuidores - mesmo uma reduzida taxa de desconto tinha como resultado anulação do efeito do diferencial relevante de preços na França.

Concluiu a Comissão que quando um desconto desta natureza é concedido por uma empresa em posição dominante para limitar ainda mais as oportunidades de importação e reforçar essa posição dominante, o mesmo configura um abuso. O Acórdão do Tribunal traz ainda consideração equivocada ao afirmar que um desconto que seja função das quantidades adquiridas ao longo de um determinado período não infringiria o art. $102 .{ }^{441}$

O caso Hoffmann-La Roche explicita estratégia baseada na criação de vínculos de compra exclusiva com os seus principais clientes, sendo que o principal atrativo que lhes era oferecido para aderirem a tal proposta era um sistema de atribuição anual, e em alguns casos semestral, de um desconto entre $1 \%$ e $5 \%$, aos clientes que tivessem obtido a totalidade ou a maior parte dos seus abastecimentos de vitaminas junto à Roche, englobando os diferentes grupos de vitaminas. ${ }^{442}$

No entender da Comissão, a conduta representava um abuso de posição dominante na medida em que tais práticas falseavam a concorrência ao eliminar a liberdade de escolha dos clientes, impedindo-os de comprar vitaminas dos concorrentes da Roche, bem como na medida em que promovia sistema de descontos intrinsecamente discriminatório, uma vez que dois clientes que adquirissem a mesma quantidade poderiam ter preços diferentes por conta da não exclusividade ou desconto. O Tribunal condenou, dessa forma, as obrigações

\footnotetext{
440 MOURA E SILVA, Miguel. O Abuso de Posição Dominante na Nova Economia. Teses de Doutoramento, cit., p. 169.

${ }^{441}$ Idem, ibidem, p. 172.

442 Acórdão do Tribunal de Justiça de 13.2.1979, Proc. 85/76, Hoffmann-La Roche \& Co. AG c Comissão das Comunidades Europeias, Colect. 1979-I, p. 217.
} 
de compra exclusiva, por não se basearem em prestação econômica que justifique tal encargo ou vantagem, destinando-se a retirar ou restringir a possibilidade de escolha do comprador com relação às fontes de abastecimento, impedindo a entrada dos outros produtores no mercado. Assim, os descontos estariam reforçando uma posição dominante mediante uma concorrência não baseada em prestações e, consequentemente, falseada.

A prática foi assim condenada, residindo o problema justamente na existência de efeito indutor do aumento de compras em todas as categorias de descontos. Devido à ausência, nos descontos de quantidade, de um elemento que premie a exclusividade, como sucedia no sistema da Roche, o Tribunal faz uma distinção tipológica baseada na forma, e não no efeito. ${ }^{443}$

Já no caso Michelin, discutia-se a política comercial do grupo francês no mercado holandês de pneus novos de substituição para caminhões e carros. Michelin havia desenvolvido nova tecnologia - pneus radiais -, e após o término da patente ainda detinha posição dominante, sendo que seus cinco principais concorrentes não ultrapassavam de $4 \%$ a $8 \%$ do mercado. Os descontos possuíam um componente fixo, sobre a forma de um desconto na fatura, anunciado no início do ano, variando de $15 \%$ a $30 \%$, e um componente variável, um bônus anual, baseado no cumprimento de objetivos de venda. Tal componente utilizava como comparativo as vendas do ano anterior, as quais deveriam ser superadas entre $1 \%$ e $5 \%$. Havia ainda adiantamentos mensais dos descontos a clientes. Vale notar que concorrentes da Michelin também aplicavam descontos significativos. ${ }^{444}$

Este sistema de descontos tinha por objetivo levar os distribuidores a adquirirem mais pneus daquela marca, em detrimento da concorrência, objetivo natural a qualquer sistema de descontos. O problema verificado foi o desconto variado em que o distribuidor teria de ultrapassar os valores de vendas do ano passado, o que criava uma pressão para o incremento de vendas no ano seguinte.

O conceito de abuso de posição dominante enunciado pelo Tribunal corresponde à definição usada no caso Hoffmann-La Roche, sublinhando a importância de uma empresa dominante não influenciar, mediante o emprego de meios diferentes daqueles que são ditados por uma concorrência normal, a estrutura do mercado onde o grau de concorrência

443 MOURA E SILVA, Miguel. O Abuso de Posição Dominante na Nova Economia. Teses de Doutoramento, cit., p. 177. Crítica de Miguel Moura a esta passagem: “A acusação, segundo a qual o Tribunal de Justiça e posteriormente o Tribunal de Primeira Instância se atêm a uma visão que valora os comportamentos da empresa dominante independentemente do seu efeito e aplicam uma categorização abstrata, encontra aqui um dos seus alvos preferidos."

${ }^{444}$ Acórdão do Tribunal de Primeira Instância (Terceira Secção) de 30.09.2003, Proc. T-203/01, Michelin c. Comissão, Colect. P. II 4071. 
já se encontra enfraquecido devido à presença da empresa dominante. Sublinhe-se que, neste mesmo acórdão, o Tribunal tinha afirmado que a qualificação de uma empresa como dominante tinha por consequência a sujeição desta a uma responsabilidade especial de não atentar pelo seu comportamento contra uma concorrência efetiva e não falseada no mercado comum. ${ }^{445}$

Segue o Tribunal de Justiça a fixar que, no exercício de avaliação do abuso de uma posição dominante decorrente da adoção de um sistema de descontos será necessário considerar todas as circunstâncias, em especial o critério e as regras para a outorga dos descontos, e investigar se, ao fornecer vantagem não amparada em qualquer serviço econômico que o justifique, o desconto tenda a remover ou restringir a liberdade do comprador em escolher sua fonte de fornecimento, de barrar o acesso ao mercado, de aplicar condições desiguais a transações equivalentes com outros parceiros comerciais ou de reforçar uma posição dominante por distorção da concorrência". ${ }^{446}$

O Tribunal estabelece assim um critério finalista, em que o objetivo prosseguido pela proibição do abuso de posição dominante se converte em critério identificador da natureza lícita ou ilícita da conduta em causa - verificar o conjunto das circunstâncias e, nomeadamente, os critérios e modalidades de atribuição para produzir o efeito ilícito reconhecido. Assim, a tese central da Comissão se assentava na convergência entre a estrutura do desconto e o contexto da sua concretização para estabelecer uma situação objetiva de pressão sobre os revendedores, incentivando-os a aumentar as vendas de pneus Michelin. ${ }^{447}$

A Michelin contestava o resultado de condenação desta prática alegando que isso corresponderia a impedir uma empresa dominante de procurar continuar o seu crescimento mediante a concessão de incentivos aos seus distribuidores, os quais teriam como contrapartida a possibilidade de um melhor planejamento da produção. Contudo, o Tribunal reforçou posicionamento de que o sistema de descontos restringia a possibilidade de os revendedores exercerem livre escolha de fornecedores e contribuía para dificultar o acesso de concorrentes ao mercado.

\footnotetext{
445 Acórdão do Tribunal de Primeira Instância (Terceira Secção) de 30.09.2003, Proc. T-203/01, Michelin c. Comissão, Colect. P. II 4071, considerando 57.

${ }^{446}$ Acórdão do Tribunal de Primeira Instância (Terceira Secção) de 30.09.2003, Proc. T-203/01, Michelin c. Comissão, Colect. P. II 4071, considerando 73.

447 O Tribunal ainda reforça elementos do caso: (i) diferenças de quotas entre Michelin e concorrentes faziam com que estes não estivessem em condições de disputar vendas marginais junto aos distribuidores Michelin, (ii) falta de transparência no sistema de descontos, colocando os distribuidores numa situação de insegurança.
} 
Outro caso que discutia o tema em questão foi Irish Sugar, ${ }^{448}$ empresa que detinha 90\% da produção de açúcar de beterraba na Irlanda e Irlanda no Norte. Entre as várias práticas trazidas ao conhecimento da Comissão Europeia, a Irish Sugar era acusada de um sistema de descontos seletivos aos clientes situados na fronteira com a Irlanda do Norte, onde enfrentava a concorrência britânica. A empresa dominante, por sua vez, alegava tratar de resposta legítima à ameaça das importações, apresentando assim os descontos uma finalidade defensiva.

Reforçou o Tribunal de Justiça a jurisprudência europeia sobre o tema, no sentido de que os descontos de fidelidade concedidos por empresa em posição dominante constituem abuso do Tratado quando têm como objetivo impedir, através da concessão de vantagens financeiras, que os seus clientes se abasteçam junto de produtores concorrentes, devendo apreciar-se o conjunto de circunstâncias, em especial os critérios e modalidades de concessão dos descontos, bem como examinar se tendem, por meio de uma vantagem que não seja baseada em nenhuma prestação econômica que a justifique, a retirar ao comprador ou a restringir a possibilidade de escolha deste das suas fontes de abastecimento, a fechar o acesso do mercado aos concorrentes, a aplicar a parceiros comerciais condições desiguais para prestações equivalentes ou a reforçar a posição dominante através de uma concorrência falseada. ${ }^{449}$

O Tribunal afirmou ainda que uma posição dominante não priva qualquer empresa nessa situação do direito de preservar os seus próprios interesses comerciais quando estes são ameaçados. Contudo, para que tal defesa seja considerada legítima, ela deve se assentar em critérios de eficácia econômica e apresentar um interesse para os consumidores. No caso em tela, como a concessão de descontos fronteiriços tinha por finalidade fidelizar os compradores expostos às ofertas dos concorrentes, sem benefícios ao conjunto dos clientes da empresa dominante, a evicção de um concorrente devido a essa prática ilustraria o seu carácter abusivo. $^{450}$

Em Virgin/British Airways, o caso implicava um sistema de descontos aplicados às agências de viagens estabelecidas no Reino Unido, pelo qual a British Airways lhes atribuía direito a pagamentos de comissão e outros incentivos sobre as respectivas vendas

\footnotetext{
${ }^{448}$ Acórdão do Tribunal de Primeira Instância (Terceira Secção) de 7.10.1999, Proc. T-228/97, Irish Sugar c. Comissão, Colect. 1999, p. II 2969.

${ }^{449}$ Acórdão do Tribunal de Primeira Instância (Terceira Secção) de 7.10.1999, Proc. T-228/97, Irish Sugar c. Comissão, Colect. 1999, p. II 2969, considerando 197.

${ }^{450}$ Idem, considerandos 189-191.
} 
de bilhetes para os seus voos, excluindo por consequência seus concorrentes do mercado de transporte aéreo no Reino Unido. ${ }^{451}$

Vale notar que a British Airways era uma compradora de serviços das agências de viagem, para quem pagavam comissão por bilhetes vendidos, sendo que os descontos neste caso se referiam ao nível de comissão paga. Da mesma forma, notava-se que o nível de comissão aumentava toda vez que uma nova meta de venda era atingida, sendo que a comissão seria então paga sobre todos os bilhetes vendidos, e não somente sobre as vendas incrementais acima daquela meta. Portanto, o efeito de fidelização decorrente de tal política era reconhecidamente forte. A Comissão entendeu ainda que a mecânica dos descontos gerava uma situação de discriminação entre os agentes de viagem.

O Tribunal de Justiça, negando provimento ao recurso da British Airways, reforçou que, antes de mais nada, dever-se-ia verificar se os descontos poderiam ter efeitos excludentes, ou seja, se seriam capazes, por um lado, de restringir ou mesmo suprimir o acesso ao mercado dos concorrentes da empresa em posição dominante, e por outro, se haveria a possibilidade de os co-contratantes desta empresa escolherem entre várias fontes de abastecimento ou vários parceiros comerciais. Subsequentemente, dever-se-ia averiguar se existiria uma justificação econômica objetiva para os descontos concedidos. ${ }^{452}$

O caso, também levado aos tribunais norte-americanos, resultou em diferente conclusão. Ao utilizar-se de precedentes que requeriam análise dos preços de vendas do produto competitivo vs. custo médio variável após o desconto dos produtos sujeito a monopólio, não havia, na opinião do tribunal, provas suficientes para uma condenação.

Diante dos casos ora referidos, cabe breve sistematização da jurisprudência europeia, devendo-se levar em conta as modalidades de descontos que se apresentam. Assim, temos que os descontos podem ser de quantidade e de fidelidade, no último caso quando os descontos estejam condicionados à aquisição em exclusivo junto à empresa dominante, bem como atrelados a objetivos específicos de venda. A compatibilidade destes descontos com o artigo 102 dependerá da apreciação conjunta de todos os fatores relevantes, dividida em dois passos. Primeiramente, será necessário aferir-se se os descontos controvertidos são ou não, por si, susceptíveis de promover exclusão de concorrentes ou limitação da liberdade de escolha dos compradores. Em segundo lugar, em

\footnotetext{
451 Acórdão do Tribunal de Justiça (Terceira Secção) de 15 de março de 2007, Processo C-95/04 P, British Airways plc contra Comissão das Comunidades Europeias.

452 Acórdão do Tribunal de Justiça (Terceira Secção) de 15 de março de 2007, Processo C-95/04 P, British Airways plc contra Comissão das Comunidades Europeias, considerandos 68-69.
} 
sendo a conclusão ao primeiro passo afirmativa, será necessário verificar se é objetivamente justificável ou não.

Nesta toada, um primeiro aspecto a levarmos em consideração seria a irrenunciabilidade, por parte do cliente, à parte substancial das suas compras junto às empresas dominantes, como primeiro nível de compreensão dos efeitos de exclusão inerentes à própria existência do poder de mercado. Não obstante, não há condenação por posição dominante per se, devendo-se indagar se as práticas controvertidas deverão ou não agravar substancialmente esse resultado natural do domínio do mercado. Assim, devemos perseguir a determinação do grau de entrave colocado à entrada ou expansão por parte de concorrentes atuais ou potenciais.

Relevante se faz análise acerca do Relatório DG Comp, ${ }^{453}$ que assevera que o limiar do desconto não deve ser colocado acima da quantidade normalmente comprada da empresa dominante. Somente quando se situar acima deste valor é que poderá desviar vendas dos concorrentes. Assim, seria legítimo que uma empresa premiasse a fidelidade dos seus clientes, desde que o faça para premiar a continuação da fidelidade, e não o aumento da fidelidade, dentro dos meios de concorrência normal para uma empresa dominante.

\subsubsection{Exclusividade}

Os aspectos restritivos verificados nas práticas de imposição de obrigações de compra exclusiva encontram-se na eliminação de oportunidades de venda aos concorrentes da empresa dominante ou criação de dificuldades para o escoamento de seus produtos, mediante o controle que se estabelece das fontes de matéria-prima e dos canais de escoamento ou distribuição. A teoria do incremento dos custos de concorrentes - raising rival costs ou RRC - veio a dar um enquadramento econômico mais robusto e sofisticado a tais preocupações.

O Guia de Restrições Verticais Europeu trata do tema no seu aspecto downstream, de distribuições exclusivas, que se verificam quando o fornecedor concorda em vender os seus produtos apenas a um distribuidor para revenda num determinado território.

\footnotetext{
${ }^{453}$ DG Competition Discussion Paper on the Application of Article 82 of the Treaty to Exclusionary Abuses.
} 
Simultaneamente, o distribuidor é limitado no tocante às suas vendas ativas naqueles territórios atribuídos em exclusividade. ${ }^{454}$

O caso Hoffmann-La Roche, recorde-se, implicava práticas de compras exclusivas combinadas com descontos de fidelidade, diante de um sistema de cláusula de nação mais favorecidas, com descontos aplicados sobre o total das vendas, e com relação a todo portfólio de vitaminas. Desta forma, se um cliente se abastecesse com qualquer concorrente da Roche, este perderia todo o desconto sobre todas as compras de vitaminas da empresa. Concluiu a Comissão que as práticas de exclusividade e desconto de fidelidade constituíam abuso de posição dominante na medida em que falseavam a concorrência ao eliminar a liberdade de escolha dos clientes. O desconto era a contrapartida da exclusividade. Da mesma forma, o sistema de descontos era intrinsecamente discriminatório, uma vez que estava ligado diretamente à conduta de cada produtor na contratação de concorrentes da Roche, independentemente do volume adquirido. ${ }^{455}$

No que tange à discussão acerca do padrão probatório inerente a esta modalidade de conduta, vale citar o caso BPB Industries, em que o Tribunal de Justiça decidiu que um contrato de compra exclusiva não deve ser considerado infração ao artigo 101, não se coadunando em uma infração por objeto, mas os efeitos decorrentes devem ser analisados sob o contexto específico. ${ }^{456}$

Já no caso Delimitis, invocou-se a incompatibilidade do contrato de compra mínima com o artigo 101:

\begin{abstract}
Devemos aqui recordar que a aplicação do artigo 81, no. 3 é, legitimamente, visto pela Comissão Europeia como, em princípio, de excluir relativamente a restrições impostas em acordos verticais por uma empresa em posição dominante. Trata-se, com efeito, de retirar todas as ilações de interpretação dada pelo Tribunal de Justiça à natureza complementar das duas normas do Tratado sobre a concorrência aplicáveis a empresas. Sendo uma das condições do balanço econômico a não eliminação da concorrência quanto a uma parte substancial dos produtos em causa, a actuação da empresa dominante presta-se a, por via das cláusulas de compra exclusiva ou da obtenção de garantias equivalentes mediante a concessão de descontos de fidelização, entravar a concorrência remanescente (...). ${ }^{457}$
\end{abstract}

\footnotetext{
${ }^{454}$ Comunicação da Comissão (O.J. [2000] C 291/1).

455 Acórdão do Tribunal de Justiça de 13.2.1979, Processo 85/76, Hoffmann-La Roche \& Co. AG c. Comissão das Comunidades Europeias.

${ }^{456}$ Acórdão do Tribunal de Primeira Instância (Segunda Secção) de $1^{\circ}$ de abril de 1993. BPB Industries Plc e British Gypsum Ltd contra Comissão das Comunidades Europeias.

${ }^{457}$ MOURA E SILVA, Miguel. O Abuso de Posição Dominante na Nova Economia, cit., p. 158.
} 
Vale ainda citar intervenção da Comissão em caso envolvendo fornecedor de matéria-prima com posição dominante que se recusava a fornecer para determinado cliente exceto em condições que fechariam o mercado para seus concorrentes, persuadindo a IMC and Angus a fechar contratos de fornecimento com duração de dois anos renováveis. Da mesma forma, no caso Soda-ash, a Comissão multou a Solvay em EUR 20 milhões e a ICI em EUR 10 milhões por exigirem de seus clientes contratos com período indeterminado com compromisso de fidelidade e descontos destinados a excluir concorrentes do mercado. A Comissão ainda determinou a rescisão de contrato de exclusividade firmado entre a ACNielsen para a obtenção de dados relacionados a determinados produtos de consumo, bem como exigiu que o Aeroporto de Frankfurt abandonasse contratos de longa duração com empresas aéreas para a prestação de serviços de pista. ${ }^{458}$

A Coca-Cola também entrou em acordo com a Comissão com relação aos seus contratos de compra exclusiva com seus clientes em 2004, se comprometendo a abrir mão da exclusividade exigida, e também se comprometendo a não exigir que seus clientes adquirissem porcentagem mínima de suas necessidades da Coca-Cola. ${ }^{459}$

Ainda, no caso De Beers, a Comissão considerou que contratos de exclusividade de longa duração para fornecimento de diamantes brutos, firmado com a Alrosa, poderiam restringir a concorrência, visto que Alrosa e De Beers eram concorrentes no mercado relevante. A preocupação da Comissão era de que os contratos de fornecimento poderiam guiar a De Beers a uma situação de distribuição exclusiva. A De Beers ofereceu compromissos para um acordo, que foram aceitos pela Comissão, mas posteriormente anulados pelo Tribunal de Primeira Instância. ${ }^{460}$

Sob a modalidade em questão, o caso Van Den Bergh Foods, em que a Comissão concluiu pelo abuso por parte da empresa quando esta passou a fornecer para seus atacadistas, a título gratuito, refrigeradores, sob a condição de que deveriam servir, exclusivamente, para o armazenamento dos sorvetes de sua marca. A Comissão entendeu que a Van den Bergh alcançou uma situação de exclusividade com seus atacadistas em razão do fato de que estes dificilmente, como de fato se verificou, manteriam um segundo refrigerador em suas lojas, recorrendo a compras, de forma exclusiva, da empresa dominante. $^{461}$

\footnotetext{
${ }^{458}$ WHISH, Richard. Competition Law, cit., p. 676.

${ }^{459}$ Decisão da Comissão Europeia de 22.06.2005

${ }^{460}$ Decisão da Comissão Europeia de 22.02.2006, Case COMP/B-2/38.381.

461 Acórdão do Tribunal de Primeira Instância (Quinta Secção) de 23 de outubro de 2003. Processo T-65/98. Van den Bergh Foods Ltd contra Comissão das Comunidades Europeias.
} 


\subsection{Tratamento da Doutrina Relativamente às Responsabilidades Especiais}

Pretendemos, com o presente trabalho, fomentar uma discussão mais focada nos efeitos gerados à dinâmica competitiva dos agentes com posição dominante que carregam consigo o ônus de uma responsabilidade especial de perpetuação de concorrência efetiva e não falseada no mercado. A doutrina e a jurisprudência internacionais pouco discutem sobre o tema. No seu próprio berço de nascimento, tais discussões se furtam ao pretendido aprofundamento, limitando-se a reconhecer sua existência. Antes, portanto, de adentrarmos à discussão, recordemos algumas das considerações trazidas pelos tribunais europeus ao longo dos anos até o reconhecimento das responsabilidades especiais.

Em 1979, o caso Hoffmann-La Roche, que tratava de abuso de exclusão por parte de uma empresa em posição dominante, reconheceu a capacidade de influência da estrutura de mercado no qual "o grau de concorrência já está enfraquecido", tendo por consequência impedir conduta "através de meios diferentes daqueles que regem uma competição normal de produtos ou serviços". ${ }^{462}$ Criou-se, assim, distinção entre um comportamento normal e anormal, porém ausente um critério para tal definição, sendo que determinadas práticas comuns a um mercado escapariam à tipificação.

Na sequência, Michelin, decidido em 1983, centrou-se no desempenho da empresa dominante, restando caracterizado um abuso diante de práticas que provavelmente afetam a estrutura do mercado cuja concorrência encontre-se enfraquecida por conta do agente econômico em posição dominante e que atue "através do recurso a métodos diferentes daqueles disciplinando a concorrência normal em produtos e serviços baseados em razão do desempenho do comerciante". ${ }^{463}$

Já no caso Akzo, o fundamento centrava-se em "métodos outros que não aqueles os quais venham dentro do escopo da concorrência com base em qualidade". ${ }^{464}$ O Tribunal sustentou ainda que um agente dominante não deveria ter outros recursos que não os objetivos de concorrência no seu mérito. Aqui parece estar estabelecido, portanto, que a ideia principal seria que agentes com posição dominante estão permitidos de competir através de seu desempenho ou mérito, deixando em aberto, contudo, a dificuldade de se medir o que seria uma concorrência no seu mérito.

\footnotetext{
${ }^{462}$ Acórdão do Tribunal de Justiça de 13.2.1979, Processo 85/76, Hoffmann-La Roche \& Co. AG c. Comissão das Comunidades Europeias, parágrafo 91.

463 Acórdão do Tribunal de 9.11.1983, Processo 322/81, N.V. Nederlandsche Banden-Industrie-Michelin c. Comissão das Comunidades Europeias.

${ }^{464}$ Acórdão do Tribunal (Quinta Secção) de 3.07.1991, Processo C-62/86, AKZO Chemie BV c. Comissão das Comunidades Europeias.
} 
Do que podemos extrair que as definições básicas de abuso de exclusão não eram satisfatórias à análise, apresentando-se muito vagas e sem regras claras que determinassem se elencada prática cairia na seara de uma conduta ilícita ou não. ${ }^{465}$

$\mathrm{Na}$ esteira do construtivismo lógico de sua teoria, o Tribunal de Justiça Europeu, em determinado momento, assentiu que empresas dominantes possuíam uma responsabilidade especial de não distorção da concorrência, passando a tratar tal natureza de responsabilidade de critério geral utilizado para diferenciar práticas pró e anticompetitivas. ${ }^{466} \mathrm{O}$ conceito foi introduzido pelo Tribunal de Justiça no caso Michelin:

\begin{abstract}
[a] finding that an undertaking has a dominant position is not in itself a recrimination but simply means that, irrespective of the reasons for which it has such a dominant position, the undertaking concerned has a special responsibility not to allow its conduct to impair genuine undistorted competition on the Common Market. ${ }^{467}$
\end{abstract}

O pensamento segue a lógica de que a posição dominante em si não é reprimida, mas sim o abuso desta posição. Assim, agentes econômicos que exercitem tal posição dominante possuiriam responsabilidade especial de não distorção do processo competitivo se comparados aos agentes econômicos que não se encontram nesta posição de dominância no mercado. Isso implica que condutas que são legítimas por agentes sem posição dominante, quando desempenhadas por aqueles que possuem tal dominância, podem ser contrárias à inteligência da lei.

Em passagens posteriores, como no caso da BPB Industries, o Tribunal de Primeira Instância explicou que pagamentos promocionais em troca de compromissos de compra exclusiva em condições de concorrência normal no mercado podem se dar no

465 ØSTERUD, Eirik. Identifying Exclusionary Abuses by Dominant Undertakings under EU Competition Law, cit., p. 45.

${ }^{466}$ A origem do conceito da responsabilidade especial teria sido a ideologia ordoliberal desenvolvida pela Escola de Freiburg de pensamento econômico e legal, entre 1930 e 1950. Neste sentido, Gormsen sugere que a noção provavelmente desenvolvida da teoria ordoliberal que exigia que agentes com posição dominante agissem como se confrontados com completa concorrência, ou seja, ausente o poder de mercado de agentes econômicos particulares (L. Lovdahl Gormsen. Article 82 EC: Where Are We Coming from and Where Are We Going to?, The Competition Law Review 2, $\mathrm{n}^{\circ} 2$ (206):10); in ØSTERUD, Eirik. Identifying Exclusionary Abuses by Dominant Undertakings under EU Competition Law, p. 33-34). Rousseva ainda reconhece a origem do conceito segundo a noção da teoria ordoliberal em que: "the one who has power has no right to be free, and the one who wants to be free should have no power" (ROUSSEVA, E. Modernizing by Eriadicating: How the Commission's New Approach to Article 81 EC Dispenses with the Need to Apply Article 82 EC to Vertical Restraints. Common Market Law Review 42, n. 3 (2005): 592; in ØSTERUD, Eirik. Identifying Exclusionary Abuses by Dominant Undertakings under EU Competition Law, cit., p. 33-34).

${ }^{467}$ Acórdão do Tribunal de 9.11.1983, Processo 322/81, N.V. Nederlandsche Banden-Industrie-Michelin c. Comissão das Comunidades Europeias. 
interesse das partes, e portanto não deveriam ser reputados ilegais. Contudo, tal conclusão não deveria ser a mesma se praticada em mercados nos quais, precisamente por conta da posição de domínio de um dos operadores econômicos, a concorrência já seria restrita, uma vez que o agente dominante possuiria responsabilidade especial. ${ }^{468}$

Da mesma forma em Van Der Bergh Foods, que tratava de oferta de fornecimento de freezers para varejistas condicionados ao seu uso exclusivo para os sorvetes da empresa dominante. O Tribunal decidiu que, independentemente da forma pela qual atingiu posição dominante, o agente econômico teria responsabilidade especial de não permitir que sua conduta viesse a impedir concorrência genuína e não distorcida no mercado:

The concept of special responsibility of dominant undertakings thus indicates that the Courts will consider the protection of residual competition to be of prime importance when applying Article 102 TFUE to exclusionary conduct by dominant firms. ${ }^{469}$

A concorrência residual existente no mercado aparece como ponto de destaque para atuação dos tribunais, de forma a prevenir que os agentes dominantes de alguma forma a limitem ou a encerrem, com fundamento, para tanto, na responsabilidade especial que possuem.

Esta responsabilidade especial não deve ainda restar limitada ao mercado em que a posição dominante se encontra, devendo se estender aos demais em que possa exercer sua influência, como em mercados verticalmente integrados e nos horizontalmente relacionados.

Subsequentemente, em Compagnie Maritime Belge, o Tribunal de Justiça Europeu sugeriu que uma responsabilidade especial de não restringir a concorrência pode ser ainda mais forte na medida em que os agentes dominantes se aproximam de uma situação de monopólio:

[t]he actual scope of the dominant firm's special responsibility must be considered in relation to the degree of dominance held by that firm and to the special characteristics of the market which may affect the competitive situation. $^{470}$

\footnotetext{
${ }^{468}$ Acórdão do Tribunal de Primeira Instância (Segunda Secção) de $1^{\circ}$ de abril de 1993. BPB Industries Plc e British Gypsum Ltd contra Comissão das Comunidades Europeias.

${ }^{469}$ Acórdão do Tribunal de Primeira Instância de 23 de outubro de 2003. Processo T-65/98.

470 Acórdão do Tribunal (Quinta Secção) de 14 de novembro de 1996. Processo C-333/94 P. Tetra Pak International SA contra Comissão das Comunidades Europeias.
} 
No caso Intel, a Comissão Europeia remeteu para a mesma responsabilidade especial de não impedir a concorrência efetiva e não falseada no mercado. Já em Microsoft, o Tribunal de Primeira Instância considerou que uma empresa dominante detinha especial responsabilidade, independentemente das causas dessa posição dominante, de não permitir que seu comportamento prejudicasse a concorrência não falseada no mercado interno, e que a Microsoft não teria considerado de forma suficiente tal elemento. Além disso, o Tribunal considerou que o interesse público na manutenção de uma concorrência efetiva no mercado permitiria a interferência com direitos exclusivos do titular do direito de propriedade intelectual e, por fim, não teria havido justificativa objetiva. ${ }^{471}$

Uma das maiores preocupações apontadas pelos tribunais europeus no caso Microsoft foi, sem sombra de dúvida, a questão da interoperabilidade:

\begin{abstract}
One of the central issues before the Court of First Instance in the appeal against the European Commission's 2004 decision in Microsoft 1 is the question of interoperability‘. Interoperability ' generally arises in high technology markets where software producers may be dependent on interface information concerning the operation of other software (e.g. platform operating systems) in order to produce products (applications) which are compatible. The failure of a dominant undertaking to supply this information may, in some circumstances, be considered an abuse under Article 82 of the EC Treaty ${ }^{472}$.
\end{abstract}

Neste sentido a Diretiva do Conselho ${ }^{473}$ dispõe sobre a proteção legal de programas de computadores. Além de requerer que os Estados Membros da União Europeia introduzam regras de proteção de direitos autorais para programas de software e, portanto, que não sejam infringidos tais direitos, principalmente por licenciados que observem, estudem e testem o funcionamento do programa, ele traz também o direito de acesso às informações de interoperabilidade através do processo de engenharia reversa desde que necessário para obter informações de interoperabilidade com outros programas de computadores.

O problema, contudo, é mais latente quando esta engenharia reversa não é possível técnica ou economicamente, em especial em mercados de inovação rápida e constante, e o pedido de acesso a estas informações é negado pelo detentor do direito de PI. Daí surgem os maiores problemas.

\footnotetext{
${ }^{471}$ MCMAHON, Kathryn. Interoperability: Indispensability and Special Responsibility in High Technology Markets, cit.

${ }^{472}$ Idem, p. 2.

${ }^{473}$ Diretiva do Conselho n. 91/250/EEC.
} 
Assim, o conceito de responsabilidade especial que tem sido aplicado pelos tribunais europeus sinaliza para uma atenção especial às condutas comerciais praticadas por agentes em posição dominante, na medida em que parece sugerir a existência de atitude suspeita destes. No que não nos parece equivocado, na medida em que quanto maior o poder de mercado verificado por um agente econômico, maior seria a probabilidade de produção de efeitos deletérios ao instituto da concorrência em decorrência de tentativa de manutenção ou aumento deste efetivo poder de mercado.

Outra discussão igualmente surgida na Europa e que merece endereçamento refere-se a situações de superdominância de agentes econômicos quase monopolistas, em que abusos se tornam mais prováveis de acontecerem. A ideia viria no sentido de que obrigações impostas a agentes dominantes se tornariam mais onerosas dependendo das circunstâncias especiais do caso. Por exemplo, em Tetra Pak, a participação de mercado que a empresa detinha em equipamentos para enchimento em embalagens de cartão no segmento asséptico situava-se entre $90 \%$ e $95 \%$, tendo sido a empresa condenada por abuso ainda que sua conduta não tenha se dado no mercado em que era dominante, bem como não era destinada a beneficiar sua posição naquele mercado. ${ }^{474}$

Em Compagnie Maritime Belge, ${ }^{475}$ a participação da conferência estava acima de $90 \%$, enquanto no caso $I M S^{476}$, em que foi ordenada a outorgar licença de seus direitos autorais a terceiros no mercado de forma não discriminatória, a empresa era quase monopolista. Ainda neste sentido veio a Comissão Europeia em Deutsche Post AG afirmar que "[t]he actual scope of the dominant firm's special responsibility must be considered in relation to the degree of dominance held by that firm and to the special characteristics of the Market which may affect the competitive situation". 477

Finalmente no tocante à discussão da superdominância temos o caso Microsoft, em que a empresa possuía participação de mercado acima de 90\%. O Comissário disse em discurso, após confirmação da decisão pelo Tribunal de Primeira Instância, que o tribunal estava enviando claro sinal de que empresas superdominantes não podem abusar de sua

\footnotetext{
474 Acórdão do Tribunal (Quinta Secção) de 14 de novembro de 1996. Processo C-333/94 P. Tetra Pak International SA contra Comissão das Comunidades Europeias.

${ }^{475}$ Acórdão do Tribunal (Quinta Secção) de 16 de março de 2000. Processos apensos C-395/96 P e C-396/96 P, Compagnie Maritime Belge Transports SA (C-395/96 P), Compagnie Maritime Belge SA (C-395/96 P) e Dafra-Lines A/S (C-396/96 P) c. Comissão das Comunidades Europeias.

${ }^{476}$ Decisão da Comissão Europeia de 3.7.2001, IV/38.044 - NDC Health/IMS Health: Interim measures.

${ }^{477}$ Decisão da Comissão Europeia de 25.7.2001, IV/ 36.915 - Deutsche Post AG - Intercepção de correio transfronteiriço.
} 
posição de mercado para prejudicar consumidores e reduzir inovação através da exclusão da concorrência em mercados relacionados. ${ }^{478}$

Semeada a origem do conceito, com base na evolução jurisprudencial europeia da teoria dos abusos de posição dominante, passaremos, mais adiante, ao aprofundamento de seus efeitos nos agentes econômico detentores de poder de mercado.

${ }^{478}$ Vide SPEECH/07/539, 17 de setembro de 2007. 


\section{CAPÍTULO 7 \\ TRATAMENTO NORMATIVO, DOUTRINÁRIO E JURISPRUDENCIAL BRASILEIRO}

\subsection{Introdução}

Investigações e condenações envolvendo as diversas modalidades de abusos de posição dominante ainda possuem pouca representatividade se comparadas ao número total de investigações promovidas pelas autoridades de defesa da concorrência brasileiras. Ainda mais, poucas foram as decisões que podemos reputar esclarecedoras da intepretação dos tipos legais de abusos de posição dominante trazidos pela Lei n. 12.529/11 e diplomas antecessores.

Em um primeiro momento - até 1994 - o baixo nível de atividade das autoridades concorrenciais deveu-se principalmente à existência de controle interministerial de preços que intimidava e dispensava qualquer tentativa de regulação ex post, conforme anteriormente verificado. Esse cenário começa a mudar com a nova Assembleia Constituinte de 1988, sistematicamente reconhecedora de uma economia de mercado fundamentada na livre concorrência e livre iniciativa, bem como com a abertura de fato da economia brasileira e com a efetiva adoção de novo diploma regulador da defesa da concorrência no país, instituído em 1994.

Ainda, nos referimos à evolução na aplicação da própria Lei n. 8.884/94 em capítulos anteriores. Para tanto é imperativo reconhecermos que qualquer autoridade de defesa de concorrência ou sistema de proteção à livre concorrência, a exemplo de qualquer sistema institucional, possui diversas fases de maturação, tendo o caso brasileiro passado por três momentos principais. Um período embrionário, de 1962 a 1994, em que muito se discutiu a própria racionalidade da implementação do sistema, tendo havido tentativas relativamente frustradas de aplicação de dispositivos relativos à livre concorrência.

Um segundo período seguiu de 1994 a 2012, para modelagem e ajuste de engrenagem após a definição do cenário político e econômico do Brasil mais voltado a uma economia de mercado capitalista. Nesta fase verificamos uma efetiva implementação do sistema legal de proteção da livre concorrência e livre iniciativa, mais focado, contudo, na atividade educativa das autoridades, na implementação de um sistema de controle prévio eficiente e com foco nas condutas colusivas locais e internacionais. 
Por fim, um novo e atual momento, com a edição de legislação que digeriu toda a experiência do modelo brasileiro e suas interações com outras jurisdições mais maduras, e que inaugura uma nova fase do antitruste no Brasil a partir de 2012, com a edição da nova lei. É neste cenário que pretendemos modular, através da experiência reconhecida até os dias de hoje decorrente da atuação das autoridades de defesa da concorrência, os abusos de posição dominante.

Para tanto, faz-se necessário dissecarmos os dispositivos legais pertinentes à luz daquilo que ousamos chamar, a exemplo de Calixto Salomão Filho, de garantias institucionais de livre concorrência e livre iniciativa. Da mesma forma, imprescindível tentarmos sistematizar a organização das autoridades brasileiras, seja no seu âmbito administrativo, seja no judiciário, e seus pontos de intersecção, naquilo que essencialmente diga respeito à persecução dos abusos de posição dominante.

\subsection{Tratamento Normativo Brasileiro}

Conforme ditame previsto no artigo primeiro da Lei n. 12.529/11, o novo normativo, aprovado no Congresso Brasileiro e sancionado pela Presidente em 30 de novembro de 2011, com vigência determinada a partir de 29 de maio de 2012, reconhece formalmente a estruturação do Sistema Brasileiro de Defesa da Concorrência com aplicação destinada à prevenção e repressão das infrações contra a ordem econômica, sob os auspícios dos ditames constitucionais de liberdade de iniciativa, livre concorrência, função social da propriedade, defesa dos consumidores e repressão ao abuso do poder econômico.

Inicialmente, cabe ressaltar que o bem jurídico tutelado pela nova lei é, conforme previsto no parágrafo único do artigo $1^{\circ}$, a coletividade. Portanto, cabe ao SBDC o controle dos direitos individuais homogêneos, direitos fundamentais de segunda geração, reconhecendo-se ainda atribuição, ao poder econômico, de um cunho social, uma função pública, e cabendo ainda ao Estado um poder-dever de preservação do sistema, conforme discutido em capítulo anterior.

A lei brasileira adota um sistema de extraterritorialidade baseada em efeitos. Neste sentido dispõe o artigo $2^{\circ}$ ao prever que sua aplicação às práticas cometidas no todo ou em parte no território nacional, ou que nele produzam ou possam produzir efeitos. Assim, o sistema brasileiro atrai jurisdição de práticas cometidas por empresas fora do 
território nacional, mas que neste possa, de alguma forma, gerar efeitos. Esta doutrina encontra-se em linha com outras jurisdições, sendo comumente referida como "effects doctrine".

Têm sido abundantes as tentativas, por parte das autoridades brasileiras, com alguma jurisprudência já firmada, ${ }^{479}$ de reprimir condutas colusivas que tenham sido praticadas, no todo ou em parte, no exterior, em especial aquelas que implicam cartéis internacionais condenados em outras jurisdições. A se observar a evolução dos diversos casos investigados localmente e o eventual reconhecimento e aplicação da teoria pelos tribunais ao longo dos próximos anos.

O mesmo não deveria ser diferente com relação a empresas com posição dominante localizadas no exterior e que venham, de alguma forma, a abusar desta posição dominante no território nacional ou nele produzindo efeitos, na sua interação com os demais agentes econômicos atuantes, quer sejam concorrentes, quer sejam dela dependentes para suas atividades comerciais. A título exemplificativo, poderíamos vislumbrar, ao considerarmos questões mais contemporâneas como a detenção de patentes essenciais para um determinado serviço ou para atuação segundo um padrão tecnológico acordado, eventual recusa de contratação da empresa detentora desta patente essencial com empresas nacionais que dela dependam para atuação no mercado, ainda que aquela empresa não esteja situada no Brasil. Direitos intangíveis como os direitos de propriedade intelectual são, talvez, mais representativos das dificuldades e das circunstâncias que podemos verificar, e que permitem um efeito independentemente de atuação local por um agente com posição dominante ou monopolista.

Em outras circunstâncias pode haver incidência de normas complementares que visam tratar condutas igualmente lesivas à livre concorrência de forma especial, segundo um contexto global, como seria o exemplo de preços predatórios praticados por exportadores para o mercado brasileiro. Para tais condutas há ferramentas de análise mais apropriadas, fundadas na defesa comercial instituída por normas próprias e que visam verificar se um determinado exportador tem praticado preço inferior ao preço no seu mercado de origem ou equivalente - dumping. ${ }^{480}$ Não obstante, cabe reparar que a lei

\footnotetext{
479 Processo Administrativo n. 08012.004599/1999. Representadas F. Hoffmann - La Roche Ltd., Basf Aktiengesellschaft e Aventis Animal Nutrition. Tendo sido o processo arquivado após a condenação e efetivo recolhimento das multas aplicadas pelo $\mathrm{CADE}$, que somavam $\mathrm{R} \$ 16,7$ milhões, não foram identificados recursos contra a decisão.

${ }^{480}$ Lei n. 9.019, de 30 de março de 1995 e legislação reguladora pertinente.
} 
concorrencial pode, como de fato fazia, prever a subsidiariedade de seu diploma para tratar das questões, ainda que lhe possam faltar elementos cognitivos aptos a avaliar a conduta. ${ }^{481}$

Já no tocante ao seu segundo aspecto de relevo, vale reconhecer que a lei traz responsabilidade objetiva da empresa na prática de atos lesivos à livre concorrência e livre iniciativa, cabendo somente comprovação da relação de causalidade entre o ato praticado e o dano cometido para que haja a responsabilização administrativa. Contudo, cabe lembrar ainda que a lei concorrencial não exige a efetivação do dano, punindo a potencialidade lesiva da prática.

Não obstante tal previsão, o dispositivo merece ser tratado com intensa parcimônia por parte das autoridades brasileiras, visto que qualquer conduta praticada fora dos limites do território brasileiro seria capaz de potencialmente afetar o mercado nacional, a se considerar a importância geopolítica e econômica do país nos dias atuais e a relevância das importações, em especial de produtos manufaturados de alto valor agregado.

Ainda que determinado produto ou serviço não seja efetivamente ofertado ao mercado, ao extremo poderíamos verificar argumento no sentido de que as baixas barreiras à entrada, hipoteticamente verificadas, sugeririam escopo geográfico global e, consequentemente, a potencialidade de efeito decorrente da possível entrada a qualquer tempo deste produto. Ou mesmo, quando da real existência de importações ao mercado, porém em patamares insuficientes para discipliná-lo localmente, em que medida esta atuação de importados deveria ser efetivamente considerada capaz de afetar o mercado nacional.

Ainda mais cautela deve ser aplicada pelas autoridades ao considerarmos supostas divisões territoriais para não atuação, ao pretender decolar a tese da potencialidade lesiva pela não atuação, visto que diversas podem ser as justificativas utilizadas por agentes econômicos para não aventurarem-se em determinado mercado. Aqui deve haver prova direta e conclusiva, legitimamente produzida e capaz de demonstrar efetivo acerto entre agentes econômicos, apta a desqualificar justificativas econômicas para a não atuação.

Tais exemplos têm merecido intenso debate e críticas no tocante à atuação das autoridades com relação à persecução de cartéis internacionais, parte de um programa de internacionalização da repressão às condutas anticompetitivas do Brasil.

\footnotetext{
${ }^{481}$ Neste sentido o inciso XIX do artigo 21 da Lei n. 8.884/94 expressamente discorria acerca da modalidade de conduta que implicava importar quaisquer bens abaixo do custo no país exportador, que não seja signatário dos códigos Antidumping e de subsídios do GATT. Este dispositivo não foi replicado na nova legislação concorrencial.
} 
Este debate acerca de efeitos de condutas no Brasil parece ainda confundir, de certa forma, a repressão às condutas colusivas com condutas unilaterais, questão mitigada na atuação das autoridades norte-americanas e europeias, visto que a Seção 1 e 2 do Sherman Act e os artigos 101 e 102 do Tratado da União Europeia, como visto anteriormente, disciplinam as duas modalidades de abuso de maneira segmentada.

No Brasil, contudo, há miscigenação de alguns conceitos e critérios. Assim, o artigo 36 da lei brasileira caracteriza como infração da ordem econômica, independentemente de culpa, todos aqueles atos, sob qualquer forma manifestados, que tenham por objeto ou possam produzir os seguintes efeitos, ainda que não sejam alcançados: (i) limitar, falsear ou de qualquer forma prejudicar a livre concorrência ou a livre iniciativa; (ii) dominar mercado relevante de bens ou serviços; (iii) aumentar arbitrariamente os lucros; e (iv) exercer de forma abusiva posição dominante. O mesmo dispositivo visa, portanto, regulamentar a repressão às condutas colusivas que são capazes de gerar efeitos imediatos de falseamento da livre concorrência ou livre iniciativa. Mas não se pode negar que tenham como efeito mediato - ainda que tenham como racionalidade um aumento arbitrário de lucro.

Uma imprecisão técnica repetida pelo legislador ao longo dos diplomas concorrenciais seria a tentativa de modular como abusivas condutas que possam resultar em aumentos arbitrários de lucros. Neste sentido, vale recordar o histórico legislativo brasileiro que visava, inicialmente, uma proteção direta e imediata ao consumidor, mas que ao longo dos anos resguardou-se a um efeito mediato perseguido, não tendo recebido acerto completo na legislação em questão. ${ }^{482}$ Ressalta-se, portanto, que o efeito em questão - aumento arbitrário de lucro - deve sempre ser interpretado como resultado indireto de todos os demais efeitos vislumbrados pelo legislador, não merecendo aplicação direta e autônoma por parte das autoridades de defesa da concorrência. Os riscos de erros tipo 1 ou falsos-positivos são relativamente grandes em exercício jurisdicional amparado neste dispositivo.

Portanto, com relação ao efeito da limitação, falseamento ou prejuízo à livre concorrência ou a livre iniciativa, nos quer parecer que seu intuito centra-se nas categorias de práticas colusivas entre concorrentes, aqueles que individualmente não possuiriam posição de mercado, mas que ao acordarem conduta não visam gerar exclusão, e sim

\footnotetext{
${ }^{482}$ Vide discussão no capítulo 2.1.2., p. 27, referente ao tema. Neste sentido vale recordar que a nova lei brasileira excluiu do rol exemplificativo de condutas o inciso XXIV do artigo 21, que tratava da imposição de preços excessivos ou aumento sem justa causa do preço de bem ou serviço.
} 
prejuízo direto ao consumidor, visto que alteram o resultado natural do processo competitivo de forma artificial. Assim, traz embasamento às modalidades de práticas colusivas. Novamente aqui podemos verificar que as práticas colusivas são igualmente aptas a gerar os efeitos de aumento arbitrário de lucros.

Já no tocante à dominação do mercado relevante de bens ou serviços e o exercício abusivo de posição dominante, temos aqui o núcleo da repressão aos abusos decorrentes de condutas unilaterais. A exemplo dos Estados Unidos, que reprimem a "monopolização", reconhece-se ao diploma brasileiro a mesma racionalidade no sentido de reprimir uma conduta unilateral cuja intenção seja a dominação de um mercado relevante através de práticas abusivas, requerendo-se, para tanto, prova de aquisição ou manutenção premeditada de posição monopolista. Serviria, portanto, a um motivo maior, qual seja, a prevenção e repressão de estruturas monopolísticas.

É certo que, via de regra, não se vislumbra de possibilidade de dominação de mercado sem que, para tanto, se exclua a concorrência, o que poderia se dar através de práticas unilaterais excludentes ou de práticas unilaterais que venham a erguer barreiras à entrada das mais diversas naturezas, capazes de manter concorrentes em potencial fora dos mercados, uma vez ao menos presumida a posição dominante. Portanto, entendemos que haveria ausência de diferenciação entre os dois efeitos trazidos pela norma. Poderíamos ainda vislumbrar de dominação de mercado através da aquisição ou consolidação de controle societário ou dos meios de produção - sujeitos ao controle de atos de concentração previsto pelo artigo 88 do novo diploma.

Via de consequência, a dominação de mercado relevante de bens ou serviços, a exemplo do aumento arbitrário de lucros, deve ser tratada, a rigor técnico, como provável resultado de um bem-sucedido exercício abusivo de posição dominante lato sensu. Dessa forma, a correta leitura que se deve fazer seria que, em matéria de repressão ao abuso de posição dominante, deveremos analisar as condutas que implicam verdadeiro exercício abusivo de posição dominante, tendentes a promover - ainda que tais efeitos não sejam efetivamente alcançados, mas haja probabilidade além da dúvida razoável de serem alcançados - dominação de um mercado, através da exclusão de concorrentes ou do levantamento de barreiras à entrada capazes de manter a concorrência em potencial à sua margem. O próprio $\S 4^{\circ}$ do artigo 173 da Constituição Federal desata o nó promovido pela legislação, ao prever que a lei reprimirá o abuso do poder econômico que vise à dominação dos mercados, à eliminação da concorrência, bem como ao aumento arbitrário dos lucros, 
ainda que o último não deva, em nossa opinião, ser objeto de tratamento imediato por parte do direito concorrencial.

Na sequência, traz a legislação brasileira, naquilo que poderia tecnicamente se omitir, porém não o faz como efetiva medida de política concorrencial e com vistas a trazer um pouco mais de segurança jurídica ao tipo legal aberto da norma, rol exemplificativo de condutas que tenderiam a promover os efeitos elencados no caput e acima analisados. Referido rol poderia ser agrupado em dois grandes módulos, sendo o primeiro deles práticas colusivas consistentes em acordar, combinar, manipular ou ajustar com concorrente, sob qualquer forma, preços de bens ou serviços ofertados individualmente; produção ou comercialização de quantidade restrita ou limitada de bens ou prestação restrita ou limitada de serviços; divisão de mercado atual ou potencial de bens ou serviços; e finalmente preços, condições, vantagens ou abstenção em licitação pública. Ainda neste grupo incluímos as práticas consistentes em promover, obter ou influenciar a adoção de conduta comercial uniforme ou concertada entre concorrentes, mais verificadas no âmbito de atuação de associações comerciais e de classe.

O segundo grande grupo diz respeito às práticas excludentes, consistentes em limitar ou impedir o acesso de novas empresas ao mercado; criar dificuldades à constituição, ao funcionamento ou ao desenvolvimento de empresa concorrente ou fornecedor, adquirente ou financiador de bens ou serviços; impedir o acesso de concorrente às fontes de insumo, matérias-primas, equipamentos ou tecnologia, bem como aos canais de distribuição; exigir ou conceder exclusividade para divulgação de publicidade nos meios de comunicação de massa; utilizar meios enganosos para provocar a oscilação de preços de terceiros; regular mercados de bens ou serviços, estabelecendo acordos para limitar ou controlar a pesquisa e o desenvolvimento tecnológico, a produção de bens ou prestação de serviços, ou para dificultar investimentos destinados à produção de bens ou serviços ou à sua distribuição; impor, no comércio de bens ou serviços, a distribuidores, varejistas e representantes preços de revenda, descontos, condições de pagamento, quantidades mínimas ou máximas, margem de lucro ou quaisquer outras condições de comercialização relativas a negócios destes com terceiros; discriminar adquirentes ou fornecedores de bens ou serviços por meio da fixação diferenciada de preços, ou de condições operacionais de venda ou prestação de serviços; recusar a venda de bens ou a prestação de serviços, dentro das condições de pagamento normais aos usos e costumes comerciais; dificultar ou romper a continuidade ou desenvolvimento de relações comerciais de prazo indeterminado em razão de recusa da outra parte em submeter-se a 
cláusulas e condições comerciais injustificáveis ou anticoncorrenciais; destruir, inutilizar ou açambarcar matérias-primas, produtos intermediários ou acabados, assim como destruir, inutilizar ou dificultar a operação de equipamentos destinados a produzi-los, distribuí-los ou transportá-los; açambarcar ou impedir a exploração de direitos de propriedade industrial ou intelectual ou de tecnologia; vender mercadoria ou prestar serviços injustificadamente abaixo do preço de custo; reter bens de produção ou de consumo, exceto para garantir a cobertura dos custos de produção; cessar parcial ou totalmente as atividades da empresa sem justa causa comprovada; subordinar a venda de um bem à aquisição de outro ou à utilização de um serviço, ou subordinar a prestação de um serviço à utilização de outro ou à aquisição de um bem; e exercer ou explorar abusivamente direitos de propriedade industrial, intelectual, tecnologia ou marca.

Como mencionado, o rol acima, ainda que exemplificativo, visa trazer maior segurança jurídica acerca das práticas que, uma vez conduzidas por agentes em posição dominante, podem gerar efeitos deletérios à garantia institucional da livre concorrência e, portanto, devem ser sopesadas por tais empresas anteriormente à sua implementação.

Vale ressaltar, como ponto fundamental e já tratado, que a conquista de mercado resultante de processo natural fundado na maior eficiência de agente econômico em relação a seus competidores não caracteriza qualquer ilícito decorrente da lei de concorrência.

Por sua vez, no tocante à presunção de posição dominante, a nova lei veio a alterar, em nosso entender de forma equivocada, o critério a ser considerado pelas autoridades, trazendo maior possibilidade de confusão na sua interpretação. Ao passo que a lei anterior dispunha simplesmente que a presunção de uma posição dominante no mercado se daria quando a empresa ou grupo de empresas controlasse $20 \%$ de um mercado relevante - percentual este que poderia ser alterado pelo CADE para setores específicos da economia -, a nova lei acrescenta ao critério de presunção um segundo, verificado sempre que uma empresa ou grupo de empresas seja capaz de alterar unilateral ou coordenadamente as condições de mercado.

Como já indicado, o ponto em questão refere-se à aparente transformação de um conceito consagrado de efetiva verificação de posição dominante, qual seja a possibilidade de alteração unilateral ou coordenadamente das condições de mercado por empresa ou grupo de empresas, em uma presunção. Ora, se uma empresa ou grupo de empresas é, de fato, capaz de alterar unilateral ou coordenadamente condições de mercado, esta empresa ou grupo de empresas possui, efetivamente, posição dominante. Não há, portanto, que se 
falar em presunção sob este conceito e, consequentemente, meios de prova admitidos para reversão da presunção em questão.

Verifica-se, portanto, antecipação da análise de mérito da questão, e não um critério de presunção que admitiria prova em contrário, tratando-se de erro técnico do legislador. Em outras palavras, ao se reconhecer que uma empresa ou grupo de empresas é efetivamente capaz de alterar unilateral ou coordenadamente as condições de mercado, estaremos diante de uma efetiva posição dominante, e não uma presunção de poder de mercado. Ao que vale reconhecer que o único critério de presunção iures tantum de posição dominante, que consequentemente admite prova em contrário, continua sendo o critério de participação de $20 \%$ de um mercado relevante.

A presunção de poder de mercado se faz importante no tocante à segurança jurídica que se coloca aos administrados, trazendo parâmetros para abertura de investigações e promovendo verdadeira inversão do ônus de prova para se demonstrar a ausência desta posição dominante. Na falta da correta delimitação de um mercado relevante consistente, amparado em precedentes e estudos econômicos existentes, e da efetiva verificação de uma participação de mercado acima destes critérios, caberia às autoridades a prova da posição dominante.

Notamos ainda que o percentual trazido pela lei brasileira é relativamente baixo e conservador se comparado com outras legislações que trazem critérios de presunção firmados em participação de mercado, como na Europa, que assume a improbabilidade de poder de mercado quando a participação situar-se abaixo de $40 \%{ }^{483}$ Sugere-se assim que tal critério seja oportunamente revisto pelas autoridades, de forma que não se coloquem ônus desnecessários aos administrados.

Com relação aos sujeitos objeto da lei concorrencial brasileira, devemos reconhecer que, em princípio, não caberiam exclusões ou isenções a quaisquer que fossem e em quaisquer situações, reconhecida a sua aplicação pelo artigo 31 às pessoas físicas ou jurídicas de direito público ou privado, associações de entidades ou pessoas, que sejam constituídas de fato ou de direito, ainda que temporariamente, com ou sem personalidade jurídica, mesmo que exerçam atividade sob regime de monopólio legal. Não obstante, devemos reconhecer que a lei visa regular as atividades destas pessoas ou associações, em especial de caráter público ou misto, enquanto atuantes diretamente na economia, como

${ }^{483}$ Vide capítulo 3.4., p. 128. 
proposição autorizada constitucionalmente de política pública de intervenção direta do Estado na economia, sob regime de exceção.

Por outro lado, poderíamos argumentar que a atuação estatal segundo o conceito de políticas públicas de preservação do sistema, manifestado na sua atividade de regulador da economia lato sensu, não estaria sujeita à tutela direta da lei de defesa da concorrência. Contudo, devemos lembrar que todas as normas estão sujeitas ao controle de constitucionalidade em razão de tratarem os princípios concorrenciais de garantia institucional. Neste sentido cabe citar Paula Forgioni:

\begin{abstract}
Para tanto, há de se ter em mente que a Lei 8.884 , de 1994 , está voltada à disciplina de condutas de agentes econômicos no mercado, não incidindo sobre a implementação de políticas públicas. Isso significa que a administração Pública, ao desempenhar suas funções (=deveres/poderes), não está sujeita ao mesmo tratamento que as normas antitruste dedicam aos agentes econômicos que atuam no campo da atividade econômica em sentido estrito. Repita-se: a Administração está sujeita às limitações da Lei Antitruste apenas na exploração, pelas entidades que a conformam como Administração Indireta, de atividade econômica em sentido estrito. $^{484}$
\end{abstract}

O texto legal não traz qualquer isenção ou imunidade com relação a outros diplomas legais que expurguem a aplicação das normas de concorrência. Diversos autores reconhecem, contudo, tal imunidade para diplomas específicos, como seria o caso da Lei Ferrari (Lei n. 6.729/79), que veio a regulamentar a concessão comercial entre produtores e distribuidores de veículos automotores de via terrestre. Contudo, nosso posicionamento vem no sentido de que, para que haja imunidade legal à lei de defesa da concorrência, esta deveria ser trazida por legislação ordinária que disponha sobre o tema de forma expressa. Em sua ausência, estaríamos diante de critérios de solução de conflito de normas existentes em nosso ordenamento, os quais podem levar à exegese de que determinado diploma, por ser norma posterior ou mais específica, por exemplo, não deveria ser sobreposto pela lei de defesa da concorrência. Em que pesem tais argumentos, ao se reconhecer às normas de defesa da concorrência uma garantia institucional, devem-se balancear de forma adequada tais critérios.

Cabe ainda tratar de importante aspecto trazido pela lei de defesa da concorrência no tocante à responsabilidade pessoal dos administradores e responsabilidade solidária do grupo econômico pela prática de infrações à ordem econômica. Em seu artigo 32, a Lei n. 12.529/11 estabelece que as diversas formas de infração da ordem econômica implicam a

${ }^{484}$ FORGIONI Paula A. Os Fundamentos do Antitruste, cit., p. 158. 
responsabilidade da empresa e a responsabilidade individual de seus dirigentes ou administradores, solidariamente. Continua o normativo, em seus artigos 33 e 34, ao dispor que serão solidariamente responsáveis as empresas ou entidades integrantes de grupo econômico, de fato ou de direito, quando pelo menos uma delas praticar infração à ordem econômica, podendo a personalidade jurídica do responsável ser desconsiderada quando houver, da parte deste, abuso de direito, excesso de poder, infração da lei, fato ou ato ilícito ou violação dos estatutos ou contrato social. ${ }^{485}$

Tais conceitos, se interpretados conjuntamente com o artigo 37 da lei, que dispõe sobre as penalidades aplicáveis em caso de infração concorrencial, as quais podem representar parcela do faturamento bruto da empresa ou do grupo ou conglomerado a que pertence, traz dispositivo que deve ser balanceado com parcimônia pelas autoridades de defesa da concorrência. A consolidação pela legislação brasileira do dever de fiscalização do grupo econômico pelas práticas das suas subsidiárias é tendência verificada há muitos anos na Europa, apesar de rara a verificação de sua aplicação no território nacional.

Finalmente, no que tange à regulação infralegal das normas concorrenciais no Brasil, vale verificar a inexistência de guias gerais para aplicação dos dispositivos legais atinentes aos abusos de posição dominante e passos necessários à avaliação destas modalidades de conduta, à exceção do guia sobre preços predatórios e outros não relativos à matéria. ${ }^{486}$ Algumas decisões, contudo, trazem precedentes neste tocante ${ }^{487}$ firmando etapas para avaliação geral e determinação da existência de infrações concorrenciais, que passariam por: (i) identificação da natureza da conduta e definição de seu enquadramento legal; (ii) verificação da existência de evidências suficientes das condutas nos autos; (iii) delimitação do mercado relevante; (iv) estimativas das participações no mercado relevante; (v) análise das condições concorrenciais efetivas e potenciais no mercado relevante; (vi) avaliação dos danos anticoncorrenciais da conduta sobre este mercado; (vii) exame de possíveis ganhos de eficiência econômica e outros benefícios gerados pela condutas; (viii) avaliação final dos efeitos anticompetitivos e das eficiências econômicas da conduta.

\footnotetext{
${ }^{485}$ Parágrafo único do artigo 34 ainda dispõe que a desconsideração também será efetivada quando houver falência, estado de insolvência, encerramento ou inatividade da pessoa jurídica provocados por má administração.

${ }^{486}$ Guia para Análise Econômica da Prática de Preços Predatórios e Guia para Análise Econômica de Atos de Concentração Horizontal (Portaria Conjunta SEAE/SDE n. 50, de $1^{\circ}$ de agosto de 2001, publicada no Diário Oficial da União n. 158-E, de 17/08/01, Seção 1, páginas 12 a 15, disponível em: $<w w w . s e a e . f a z e n d a . g o v . b r / c e n t r a l \_d o c u m e n t o s / g u i a s / p o r t c o n j s e a e-s d e . p d f>$ ).

${ }^{487}$ Vide, por exemplo, o Processo Administrativo n. 08000.021977/1997-14. Representada: Cecil Langone Laminação e Metais Ltda.
} 


\subsection{Organização do Sistema Jus-Concorrencial Brasileiro}

O novo Sistema Brasileiro de Defesa da Concorrência visa implementar estrutura mais enxuta e eficiente comparativamente à Lei n. 8.884/94, em que diversos órgãos possuíam competências concorrentes, verificando-se usualmente rediscussões ineficientes de questões pouco relevantes. Visou-se com as mudanças adotadas trazer celeridade à instrução, investigação e julgamento dos atos de concentração, que demandavam respostas mais rápidas em prol da dinâmica exigida pelos negócios empresariais, bem como de condutas lesivas à livre concorrência, que exigiam análise mais estruturada e aplicação de padrões de provas condizentes com a redução de riscos de falsos positivos.

Assim, passou o SBDC, como já brevemente mencionado, a ser formado pelo Conselho Administrativo de Defesa Econômica, autarquia federal vinculada ao Ministério da Justiça com jurisdição em todo o território nacional, com sede e foro no Distrito Federal, e pela Secretaria de Acompanhamento Econômico, vinculada ao Ministério da Fazenda.

Cabe aqui tecermos breves considerações sobre a extensão da "vinculação" existente entre o CADE e o Ministério da Justiça, que não se admite possa extrapolar qualquer entendimento que vá além da mera conexão para fins orçamentários. Neste sentido, o CADE deverá submeter anualmente ao Ministério da Justiça sua proposta de orçamento, bem como planejamento plurianual das suas receitas e despesas para os cinco exercícios subsequentes, com fins de inclusão na lei orçamentária anual. ${ }^{488}$

A lei prevê ainda que constituem receitas próprias do CADE a taxa processual referente à submissão de atos de concentração, recolhida ao Tesouro Nacional; a retribuição por serviços de qualquer natureza prestados a terceiros; as dotações consignadas no Orçamento Geral da União, créditos especiais, créditos adicionais, transferências e repasses que lhe forem conferidos; recursos provenientes de convênios, acordos ou contratos celebrados com entidades ou organismos nacionais e internacionais; doações, legados, subvenções e outros recursos que lhe forem destinados; valores apurados na venda ou aluguel de bens móveis e imóveis de sua propriedade; o produto da venda de publicações, material técnico, dados e informações; valores apurados em aplicações no mercado financeiro das suas receitas e quaisquer outras receitas afetas às suas atividades. Note-se, contudo, que as multas aplicadas pelo CADE, inscritas ou não em dívida ativa,

${ }^{488}$ Vide artigo 29 da Lei n. 12.529/11. Para questões orçamentárias, vide ainda artigos 22; 28, III; e 123 da Lei n. 12.529/11. 
serão destinadas ao Fundo de Defesa de Direitos Difusos, não constituindo qualquer natureza de receita do órgão, em linha com as melhores práticas adotadas por autoridades administrativas sancionadoras. ${ }^{489}$

Não há, portanto, qualquer possibilidade de recurso das decisões emanadas pelo Tribunal do CADE ao Ministro da Justiça ou qualquer outro órgão da Administração Pública. Diante de julgamento de mérito das questões levadas ao CADE, suas decisões são finais e irrevogáveis, salvo as hipóteses de recurso previstos na própria lei, não cabendo revisão no âmbito do Poder Executivo. ${ }^{490}$ No caso de atos de concentração, sua decisão poderá ser revista pelo Tribunal, de ofício ou mediante provocação da SuperintendênciaGeral, se a decisão for baseada em informações falsas ou enganosas prestadas pelo interessado, se ocorrer o descumprimento de quaisquer das obrigações assumidas ou não forem alcançados os benefícios visados. ${ }^{491} \mathrm{~A}$ mesma hipótese não se vislumbra nas decisões de condutas, sendo que qualquer rediscussão deve implicar, necessariamente, em ação própria perante o poder judiciário.

Assim, a nova lei de concorrência promove completa reestruturação do Sistema, passando o CADE a ser composto pelo Tribunal Administrativo de Defesa Econômica, competente para proferir decisões administrativas terminativas; pela SuperintendênciaGeral, competente para instrução e, muitas vezes, decisão de atos de concentrações, bem como de investigações de condutas; e pelo Departamento de Estudos Econômicos, com funções de elaboração de pareceres econômicos. A Procuradoria Federal e o Ministério Público, com atuação atrelada ao CADE, continuam a desempenhar seus respectivos - e relevantes - papéis junto ao Sistema.

Com relação ao mandato dos conselheiros, escolhidos dentre cidadãos com mais de trinta anos de idade, de notório saber jurídico ou econômico e reputação ilibada, nomeados pelo Presidente da República, depois de aprovados pelo Senado Federal, acertadamente estabeleceu-se critério para mandatos alternados, de forma com que se limitem as possibilidades de interrupção das atividades do Conselho por ausência de quórum mínimo.

A possibilidade de ingresso em juízo para os prejudicados por infrações decorrentes da lei é prevista no artigo 47, ou pelos legitimados referidos no art. 82 da Lei n. 8.078/90, para em defesa de seus interesses individuais ou individuais homogêneos obter

\footnotetext{
${ }^{489}$ Artigo 28 da Lei n. 12.529/11.

${ }^{490}$ Artigo $61, \S 3^{\circ}$ da Lei n. 12.529/11.

${ }^{491}$ O primeiro caso de rediscussão das condições de aprovação de um Ato de Concentração pelo Tribunal do CADE foi o Ato de Concentração n. 08012.001015/2004-08.
} 
a cessação de práticas que constituam infração da ordem econômica, bem como o recebimento de indenização por perdas e danos sofridos, independentemente do inquérito ou processo administrativo, que não será suspenso em virtude do ajuizamento de ação.

Ainda, prescrevem em cinco anos as ações punitivas da administração pública federal, direta e indireta, objetivando apurar infrações da ordem econômica, contados da data da prática do ilícito ou, no caso de infração permanente ou continuada, do dia em que tiver cessado a prática do ilícito, ou em três anos, no caso de procedimento administrativo pendente de julgamento ou despacho, paralisado por este período. Quando o fato objeto da ação punitiva da administração também constituir crime, a prescrição reger-se-á pelo prazo previsto na lei penal, que no caso de condutas colusivas é de doze anos.

Interessante notar, no tocante a esta questão, recente alteração promovida pela Lei n. 12.529/11, que alterou o artigo $4^{\circ}$ da Lei n. 8.137/90, a fim de adequá-lo ao padrão internacional utilizado que apregoa repressão criminal tão somente de condutas colusivas e não de condutas unilaterais reputadas abusivas. Assim, revogou a nova lei concorrencial a previsão de persecução criminal às práticas de abuso de posição dominante mediante cessação parcial ou total das atividades da empresa; impedimento à constituição, funcionamento ou desenvolvimento de empresa concorrente; discriminação de preços de bens ou prestação de serviços por ajustes ou acordos de grupo econômico; açambarcamento, sonegação, destruição ou inutilização de bens de produção ou de consumo; venda de mercadoria abaixo do preço de custo com o fim de impedir a concorrência; dentre outras. O efeito desta alteração legal veio no sentido de reconhecer-se a prescrição quinquenal para esta modalidade de abuso, contados da data da prática do ilícito ou, no caso de infração permanente ou continuada, contados do dia em que tiver cessada a prática do ilícito.

A decisão do Plenário do Tribunal, cominando multa ou impondo obrigação de fazer ou não fazer, constitui título executivo extrajudicial, sendo que a execução que tenha por objeto exclusivamente a cobrança de multa pecuniária será feita de acordo com o procedimento para cobrança judicial da Dívida Ativa da Fazenda Pública. ${ }^{492}$ A execução que tenha por objeto ainda o cumprimento de obrigação de fazer ou não fazer, poderá ter concedida tutela específica da obrigação, ou providências que assegurem o resultado prático equivalente ao do adimplemento.

${ }^{492}$ Lei n. 6.830, de 22 de setembro de 1980. 
A execução será feita por todos os meios admitidos, inclusive mediante intervenção na empresa, quando necessária, e será promovida na Justiça Federal do Distrito Federal ou da sede ou domicílio do executado, à escolha do CADE. Em princípio, o oferecimento de embargos ou ajuizamento de qualquer outra ação para desconstituição do título executivo poderá suspender a execução mediante garantia do juízo. Finalmente, cabe verificar que, como dispõe a lei, o processo de execução em juízo das decisões do CADE terá preferência sobre as demais espécies de ação, exceto habeas corpus e mandado de segurança. Existe ainda possibilidade de intervenção na empresa quando necessária para permitir-se a execução específica. ${ }^{493}$

Diante da análise de fundo que se coloca acima, passemos a expor os casos investigados pelas autoridades de defesa da concorrência no Brasil, dentro das diversas modalidades a que se destina o presente estudo.

\subsection{Construção Jurisprudencial e Doutrinária Brasileira}

\subsubsection{Recusa de Contratação}

Como acima discutido, a lei antitruste brasileira traz previsão de diversas condutas que implicam alguma forma de limitação da livre concorrência, como a recusa de contratação. Especificamente relacionado a esta modalidade de infração podemos verificar o inciso XI da lei: "recusar a venda de bens ou a prestação de serviços, dentro das condições de pagamento normais aos usos e costumes comerciais". Da mesma forma, o inciso XII prevê a possibilidade de um agente econômico "dificultar ou romper a continuidade ou desenvolvimento de relações comerciais de prazo indeterminado em razão de recusa da outra parte em submeter-se a cláusulas e condições comerciais injustificáveis ou anticoncorrenciais". Entre os dispositivos verifica-se uma situação originária no primeiro caso, em que não há relação comercial preestabelecida, e uma situação de manutenção de relação comercial no segundo cenário.

Contudo, outros dispositivos podem levar ao reconhecimento de uma racionalidade de conduta de recusa na contratação, de forma indireta, como propõem os incisos III, IV e V do artigo 36, os quais modulam, respectivamente, a limitação ou impedimento de acesso de novas empresas ao mercado; a criação de dificuldades à

${ }^{493}$ Vide artigos 93 a 111 da Lei n. 12.529/11. 
constituição, ao funcionamento ou ao desenvolvimento de empresa concorrente ou de fornecedor, adquirente ou financiador de bens ou serviços; e o impedimento de acesso de concorrente às fontes de insumo, matérias-primas, equipamentos ou tecnologia, bem como aos canais de distribuição. Assim, para que reste configurada uma recusa, não se faz necessário que haja efetiva e expressa negativa por parte do agente econômico em posição dominante, pois muitas vezes esta vem disfarçada de condutas que geram dificuldades à concorrente dependente de um agente dominante.

Introduzida a tipificação desta modalidade de abuso, vale breve análise dos casos discutidos perante o SBDC a fim de tentativamente modularmos o parâmetro que tem sido utilizado pelas autoridades para constatação de abusos de posição dominante. Assim, em 2003 o CADE viria a decidir processo administrativo que envolvia acusações de que a Matec, uma filial da Ericsson, havia ilegalmente se recusado à venda de peças e componentes para o Sistema Telefônico Ericsson MD 110. ${ }^{494}$ Empresas independentes que ofereciam contratos de manutenção de sistemas telefônicos alegaram que estariam impedidas de competir efetivamente no mercado MD 110 visto que não possuíam acesso às peças de reposição. Em decisão proferida em 2003 o CADE definiu dois mercados relevantes: serviços de manutenção para o sistema telefônico MD 110 e peças de reposição de sistema. No primeiro destes mercados, a Matec detinha mais de $90 \%$ de participação à época da violação; no último, era monopolista. O CADE constatou que a Matec havia ilegalmente eliminado a concorrência no mercado de serviços de manutenção de sistemas, pois as empresas concorrentes não podiam operar sem acesso às peças de reposição. A eliminação reduziu os benefícios do consumidor, uma vez que os compradores do sistema telefônico afetados estavam "presos" ao sistema telefônico MD 110 em razão dos altos custos de troca de sistema. A concorrência no ponto de venda para sistemas telefônicos não era adequada para evitar uma falha de mercado. Ainda, as regras de concorrência pública impossibilitavam o governo, um grande cliente do MD 110, de escolher outra oferta que não a mais baixa, sem considerar os custos de serviços pós-compra. A Matec foi assim condenada por infração à ordem econômica, sendo-lhe aplicada multa de $\mathrm{R} \$ 620.000,00$.

Além do caso acima relatado, o CADE ainda condenou a Microsoft em caso de recusa de contratação no âmbito de investigação detalhada adiante, tendo absolvido a empresa em outros casos envolvendo propriedade intelectual. Da mesma forma, diversas foram as investigações de recusas de contratação arquivadas pelas autoridades por

\footnotetext{
${ }^{494}$ Processo Administrativo N. 08012.000172/1998-42, representante Power-Tech Teleinformática, Ltda.,
} representada Matec. 
insuficiência probatória. ${ }^{495}$ Outros tantos foram os casos envolvendo recusa de venda arquivados em razão da verificação de prescrição e que, portanto, não permitem maiores aferições acerca dos padrões que devem ser utilizados em tais modalidades de abuso. ${ }^{496}$

Merece destaque, dentre os casos arquivados pelas autoridades brasileiras, processo administrativo contra a Petrobras versando sobre suposta recusa ou limitação de acesso à rede de transporte de gás natural, em detrimento de carregadoras concorrentes. ${ }^{497}$ A $T G B$, operadora do Gasoduto Bolívia-Brasil (GASBOL), que tinha como sócia majoritária a Petrobras Gás S.A., controlada pela Petrobras, estaria recusando ou limitando o acesso das empresas British Gás do Brasil Ltda. e Energia do Brasil Ltda. ao GASBOL. Havia ainda indícios de sobrerrequisição de gás natural à $T B G$ pela Petrobras nas estações de entrega compartilhadas com a British Gás, e sobrenominação pela Petrobras nas estações de gás não compartilhadas, por meio de requisição de volumes superiores aos retirados, tudo com o intuito de favorecer a Petrobras e prejudicar o desenvolvimento de carregadores de gás concorrente.

Por sua vez, a Petrobras alegava que teria sido a principal financiadora do gasoduto, pagando adiantado pelos serviços de transporte de gás de forma a garantir a escala mínima necessária ao investimento. Assim, a regulação de livre acesso à infraestrutura de transporte protegeria o carregador-investidor contra eventuais tentativas

495 Assim, ainda sob a vigência da Lei n. 8.158/91, foi instaurado o Processo Administrativo n. 08000.014821/1995-33, contra a Fosfertil Fertilizantes Fosfatados S/A, Takenata S/A Indústria e Comércio, Solorrico S/A Indústria e Comércio, e IAP S/A, para apuração de eventual conduta concertada e recusa de venda. A suposta recusa à empresa Prodap Ltda. teria se dado em função da cessação da produção do MAP/ração pela Fosfértil S/A. Não foram, contudo, encontrados indícios de conduta no sentido de retirar um concorrente do mercado, tendo o CADE afirmado que deixar de produzir um produto, por si só, não importa em violação da ordem econômica. O entendimento da autoridade concorrencial vinha amparado no fato de que a Fosfértil deixou de produzir o Fertipec M-23 por decisão interna, e que não significou dano para o mercado em função de sua pequena participação, representando cerca de $1,5 \%$ do mercado, bem como da existência de outros fornecedores do mesmo produto, além de produtos substitutos que ocuparam a maior parte da demanda no mercado relevante analisado. Também no âmbito da Averiguação Preliminar n. 08012.011463/2007-54, a Santa Casa, único hospital de Arcos, Minas Gerais, recusou-se a credenciar o plano Prontomed. Neste caso, a SDE e o CADE entenderam que a recusa da representada, movida por motivos de divergência de preços de contratação, não configurava limitação à livre concorrência, determinando o arquivamento do processo. Em tempo, na Averiguação Preliminar n. 08700.004336/2007-41, originado por meio de denúncia do TRT/SP, a empresa ThyssenKrupp Elevadores S.A. foi acusada de recusar fornecimento de peças de manutenção de elevadores e softwares de programação para empresas independentes. A SDE somente analisou o mercado de peças de reposição, tendo concluído que havia substitutos, sem perda qualitativa, para tanto. A decisão do CADE seguiu, portanto, o entendimento da SDE, quanto às peças de reposição, porém analisou também a recusa de fornecimento do software. A questão recaia na compreensão acerca da finalidade do programa, se o mesmo serviria para verificar autenticidade das peças - caso não fossem autênticas, haveria isenção da responsabilidade da TKE em seu manejo - ou se seria, de fato, forma de impedir a concorrência de empresas independentes, pelo efeito lock-in nos consumidores. Houve determinação do retorno dos autos à SDE para maiores investigações quanto à problemática do software e arquivamento quanto às peças de reposição.

${ }_{496}$ Processos Administrativos n. 08012.007205/1998-58, 08012.003607/1998-10 e 08000.000075/1996-17.

${ }^{497}$ Processo Administrativo 08012.002692/2002-73. Representadas: Petrobrás e Gasbol. 
oportunistas de acesso por terceiros interessados no transporte do gás natural que não teriam incorrido nos pesados investimentos e nos riscos significativos relativos ao empreendimento, razão pela qual a Resolução n. 27/2005 da ANP autorizava que a abertura fosse feita após seis anos do início das operações.

Segundo a $T G B$, a Enersil teria solicitado acesso à infraestrutura na modalidade não firme, pela qual não arcaria com os riscos do empreendimento, enquanto a Petrobras contratava na modalidade ship or pay. Já com relação à British Gás, esta teria solicitado acesso sob a modalidade de contrato firme, porém de curto prazo, enquanto que a Petrobras oferecia contratos de longa duração. Consequentemente, seria economicamente irracional por parte da $T B G$ deixar de priorizar a Petrobras para atender empresas que lhe oferecessem contratos de curta duração ou não firmes, quando do excesso de demanda do gás. Na visão da Representada, seriam a British Gás e Enersil free riders nos investimentos promovidos pela Petrobras.

As negativas de acesso ocorreram em 2000, quando ainda não havia regramento sobre os requisitos mínimos de acesso e, consequentemente, parâmetros para uma justificativa de recusa ou para negociação de tarifas entre as partes. Assim, reconheceu o CADE que, se por um lado, a questão da capacidade disponível era primordial para análise do tema, podendo ser ou não justificativa razoável para a recusa, por outro lado era reconhecidamente relevante a necessidade de o proprietário original da infraestrutura recuperar os investimentos por ele aportados. E no caso em concreto reconheceu o CADE que a recusa seria justificada em razão da necessidade de recuperação dos pesados investimentos aportados pela Petrobras na construção do GASBOL, visto que o enorme investimento levado a efeito jamais poderia ter sido recuperado em um curto período de dois ou três anos. ${ }^{498}$

Com relação aos casos de recusa de contratação envolvendo propriedade intelectual, cujo exercício teria o condão de restringir a livre concorrência, vale observar que a grande maioria restou arquivada pelo CADE em razão, igualmente, da ausência de evidências comprovatórias dos abusos. Alguns dos quais passamos a expor pela relevância de temas atrelados à nova economia, a que pretendemos dar destaque.

Caso de destaque para fins da presente análise refere-se às alegadas condutas praticadas pela Monsanto, que fora acusada, em 1998, de condicionar a venda de sementes

\footnotetext{
498 A exemplo de outros casos, não parece ter havido aqui uma análise apurada acerca da quantidade contratada e da capacidade produtiva da Petrobras, a fim de se avaliar se se tratava de reserva de mercado e elevação de barreiras à entrada.
} 
transgênicas de soja à venda de seus herbicidas, bem como de impedir acesso de seus concorrentes de herbicidas às suas sementes transgênicas, com o intuito de eliminação da concorrência para herbicidas. ${ }^{499}$ A Representante do caso alegava que a Monsanto recusava-se a disponibilizar suas sementes para os testes de seus concorrentes. O caso foi arquivado com base na ausência de evidências de venda casada e com base no legítimo interesse da Monsanto em não suprir as sementes, uma vez que tais sementes não teriam ainda sido lançadas no mercado.

O caso em referência, adicionalmente ao caso Microsoft, consubstanciou-se em um dos primeiros em que se discutiam eventuais violações ao direito da concorrência no contexto de proteções alegadamente excessivas de direitos de propriedade intelectual, seguidos ainda por outros. Casos em que se discutiu ainda licenciamento de tecnologias para utilização em padrões tecnológicos também foram objeto de escrutínio pelas autoridades brasileiras. Neste tocante recordemos, segundo os dispositivos da norma antitruste brasileira, que a própria criação de um padrão tecnológico pode ensejar obrigatoriedade de notificação prévia às autoridades, a fim de se avaliar eventuais efeitos deletérios à livre concorrência, tendo o CADE recebido algumas notificações neste sentido. $^{500}$

Neste sentido, em 2009 o CADE decidiu representação trazida pela Gradiente e pela $C C E$ contra a Philips, ${ }^{501}$ bem como representação trazida pela Videolar também contra a Philips. ${ }^{502}$ Os dois casos aparentemente tiveram instrução superficial em razão da ausência de evidências apresentadas pelas Representantes.

O primeiro envolvia reclamação de que a Philips estaria abusando de sua posição dominante no mercado de fornecimento de tecnologia de produção de aparelhos para discos digitais de vídeo (DVDs), em razão de supostas tentativas de influenciar sua posição no mercado a jusante de aparelhos de DVD via exclusão de seus concorrentes. Conforme argumentado pelos Representantes, a tecnologia de leitura e reprodução de DVD incluía

\footnotetext{
${ }^{499}$ Averiguação Preliminar n. 08012.008659/1998-08.

${ }^{500}$ A Sony, Philips, Panasonic, Hitashi, Samsung e Ciberlink notificaram, em 2009, Ato de Concentração informando sobre a formação de pool de patente e aquisição de participação em empresa futuramente responsável pela negociação global de licenças das patentes essenciais para a produção de produtos com tecnologia Blue-Ray, aprovado incondicionalmente (Ato de Concentração n. 08012.008810/2009-23). Da mesma forma, a Sony, Philips e Pioneer submeteram operação ao SBDC envolvendo aquisição da empresa One-Red LLC, que viria a oferecer serviços de gerenciamento de programas de licenciamento de patentes, tendo sido da mesma forma aprovado pelas autoridades (Ato de Concentração n. 08012.000734/2011-22). A nova lei de defesa da concorrência traz ainda o conceito de "contratos associativos", sob o qual devem se inserir, em princípio, a formação dos referidos padrões tecnológicos.

${ }^{501}$ Averiguação Preliminar n. 08012.001315/2007-21. Representada: Koninklijke Philips Eletronics, N.V. ("Philips") e Philips do Brasil Ltda. ("Philips Brasil").

${ }^{502}$ Averiguação Preliminar n. 08012.005181/2006-37. Representada: Philips do Brasil Ltda.
} 
trinta e nove invenções, dezoito das quais protegidas por patentes registradas perante o INPI. As empresas detentoras dos direitos de propriedade industrial estavam organizadas em dois diferentes pools - pool 3C e pool 6C - os quais licenciavam diferentes, porém complementares tecnologias. Assim, fazia-se necessária a obtenção de licenciamento das patentes dos dois grupos para produção e comercialização legítima de aparelhos de DVDs no território brasileiro. ${ }^{503}$

A Philips, parte do pool 3C, era encarregada de representar o referido pool na negociação de acordos de licenciamento das tecnologias detidas por aquelas empresas no Brasil. Assim, as condutas estavam associadas com a maneira pela qual os direitos de propriedade intelectual estavam sendo exercidos pelas empresas representadas, envolvendo: (i) ameaças a clientes, fornecedores, distribuidores e revendedores de aparelhos DVD de cobranças de taxas de royalties devidas; (ii) inclusão no pool de patente, de tecnologias não detidas pelas Representadas, e que não seriam indispensáveis para produção de aparelhos DVD; (iii) cobrança abusiva de preços para licenciamento de suas respectivas tecnologias, que implicariam ainda (iv) recusa de negociação de infraestrutura essencial; (v) cobrança duplicada de royalties e (vi) discriminação entre produtores de aparelhos de DVD.

O mercado relevante definido pelas autoridades envolvia o mercado global de produção e comercialização de hardware para leitura e reprodução de DVDs. Na sua essência, os Representantes alegavam que os royalties cobrados pela detentora de patentes essenciais eram abusivos, implicando estreitamento das margens de lucro de seus rivais ao ponto de impedirem efetivo desafio do poder de mercado dos agentes dominantes. Tal fato seria ainda verificado em decorrência da cobrança duplicada de royalties e discriminação de preços entre os diferentes concorrentes e condutas visando proteção ilegal de direitos de

503 No início dos anos 90, duas unidades de disco óptico de alta capacidade estavam em desenvolvimento: o Compact Disc MultiMedia (MMCD), da Philips e Sony, e o Disk Super Density (SD), da Toshiba, TimeWarner, Matsushita Electric, Hitachi, Mitsubishi, Pioneer, Thomson e JVC. Prevendo a recorrência de problemas ocorridos na década de 80 com VHS e Betamax VCR, as empresas decidiram unir os dois sistemas. Assim, em 1996, Panasonic, Toshiba, Mitsubishi, AOL, JVC, Hitachi, Thomson, Philips, Sony e Pioneer se reuniram e formaram o "Consórcio DVD", com o objetivo de desenvolver técnicas para a fabricação de equipamentos capazes de ler discos ópticos e converter informações em imagens acompanhadas de áudio. Sendo assim, o formato MMCD foi abandonado pela Phillips e Sony, que adotaram o formato da Toshiba com duas modificações em sua tecnologia. A primeira modificação relacionada com a capacidade de mudanças de faixas, uma tecnologia desenvolvida pela Philips / Sony. A segunda foi a adoção de EFMPlus sistema da Philips, que apresentou alta resistência à temperatura, apesar de a capacidade ser um pouco menor em relação ao sistema SD. Essa tecnologia deu origem ao DVD. Em 1997, o Consórcio DVD se tornou o DVD Fórum, aberto a todas as empresas. Havia dois acordos horizontais que caracterizavam os grupos de patentes: o Grupo 3C e 6C, que certificavam e licenciavam diferentes patentes, essenciais para DVD. Em 1998, o Grupo 3C foi formado pela Philips, Sony e Pioneer, para o licenciamento do conjunto de patentes relacionadas com a sua própria tecnologia em DVD. Em 1999, Toshiba, Panasonic, Mitsubishi, AOL, JVC e Hitachi, formaram o Grupo 6C. 
propriedade intelectual, que não seriam essenciais e tampouco seguiriam os padrões legais de concessão da proteção.

O relatório não vinculante emitido pela SDE, responsável pela investigação, concluiu pela ausência de evidências de infrações à ordem econômica, sugerindo o arquivamento do caso. A mesma linha foi seguida pelo Ministério Público e pela Procuradoria Especializada do CADE. Em princípio, os Representantes teriam provado que as empresas sob escrutínio detinham posição dominante no mercado a montante com relação à tecnologia de produção de DVDs, e que haveria condições estruturais para prática de condutas anticompetitivas verticais visando estender sua participação ao mercado a jusante de produção e comercialização de DVDs. Contudo, de acordo com a SDE, o Ministério Público e a Procuradoria Especializada, não estavam presentes nos autos elementos suficientes para concluir que as condutas sob investigação teriam o efeito de prejudicar a livre concorrência.

Desta forma, o CADE considerou que, com relação às ameaças feitas pelas Representadas, restou verificado que as correspondências enviadas somente informavam que a comercialização de aparelhos DVD sem a demonstração de pagamento de royalties pelos produtores poderia implicar medidas judiciais não somente contra os produtores, mas ainda contra revendedores. Decidiu ainda o CADE, sobre a questão da inclusão no pool de patentes de tecnologias que não seriam detidas pelas Representadas ou indispensáveis ao padrão, que os Representantes teriam falhado em identificar quais patentes estariam sujeitas a tais alegações. Adicionalmente, o CADE se referiu ao Departamento de Justiça norte-americano que teria verificado em mais detalhes a legalidade dos contratos de licenciamento no contexto de investigações similares levadas a efeito nos Estados Unidos, concluindo que todas as patentes incluídas no pool seriam essenciais. Por fim, referiu-se o CADE à existência de um valor fixo e independente das patentes negociadas que limitaria o escopo da intervenção antitruste. ${ }^{504}$

Com relação aos alegados preços abusivos para licenciamento de tecnologia que implicariam ainda recusa de contratação de infraestrutura essencial, as informações disponibilizadas nos autos davam conta de que os royalties teriam sido fixados em torno de USD 3,50 por produto vendido, além de um pagamento antecipado de USD 10.0000,00, sendo, portanto, informação insuficiente para se verificar se haveria algum abuso

\footnotetext{
${ }^{504}$ Segue referência específica trazida pelo Conselheiro no qual o direito de fixar os preços a serem cobrados é atribuído aos titulares de propriedade industrial, sendo assim protegidos e em conformidade com a legislação, com exceção nos casos de necessidades. O Conselheiro prossegue concluindo que neste caso não haveria nenhuma recusa vinda das partes representadas.
} 
praticado. ${ }^{505}$ Já com relação à alegação de cobrança duplicada de royalties, o Conselheiro Relator do caso argumentou novamente pela ausência de elementos suficientes para sua conclusão, restando a dúvida acerca do momento do pagamento, uma vez que os Representantes afirmaram que seriam pagos em dois momentos: pelos fornecedores de componentes e pelas empresas que comercializavam o produto final. ${ }^{506} \mathrm{E}$ finalmente, sobre a questão da discriminação entre produtores de DVD, uma vez que o registro de patentes era somente promovido pelas Representadas em alguns países do Mercosul, discriminando, portanto, produtores de aparelhos e desbalanceando a concorrência para as empresas nacionais vis a vis empresas localizadas em outros países do Mercosul, o CADE manifestou-se no sentido de tal questão não possuir natureza concorrencial, dispensando e determinando o arquivamento de todas as acusações.

No segundo caso em questão, trazido pela Videolar, as alegações vinham no sentido de estar a Philips abusando de sua posição dominante no mercado de tecnologia através da eliminação de formatos de mídia concorrentes no Brasil com vistas a estender sua posição dominante no mercado de tecnologia, bem como através da cobrança de royalties excessivos para licenciamento de patentes essenciais para produção de mídia digital. ${ }^{507}$ As condutas em questão teriam ocorrido no mercado de produção de mídia ótica ou armazenamento regravável, especificamente CD-R e DVD-R. A investigação promovida pela SDE culminou em sua opinião de ausência de evidências contra a Representada, sugerindo o arquivamento do caso, no que foi seguido pela Procuradoria e pelo Ministério Público.

No que tange à primeira alegação, a Videolar acusou a Philips de fomentar importação não licenciada de mídia ótica e armazenamento regravável como estratégia para exclusão de mídias magnéticas concorrentes, em especial VHS. A representação focava na omissão da Philips na adoção de medidas cabíveis contra a importação de produtos não licenciados, que deveria ser interpretada como abuso de posição dominante

\footnotetext{
${ }^{505}$ Os precedentes do CADE seguem a linha no sentido de que preços excessivos cobrados como resultado de lucros decorrentes da posição dominante legalmente alcançada não caracterizam violação antitruste.

506 Além disso, o Conselheiro argumentou que, ainda que os royalties tivessem sido cobrados em duplicidade, isso seria um exercício regular dos direitos de propriedade intelectual das partes representadas.

${ }^{507}$ Em 1979, a Philips e outras empresas uniram esforços com P\&D de uma nova tecnologia de mídia de áudio, mais rápida e com maior capacidade de armazenamento, em substituição à tecnologia magnética. Assim, criaram um grupo de trabalho formado por técnicos de diversas empresas para estabelecer um único padrão tecnológico, que ficou conhecido como Compact Disk (CD). Após o lançamento do primeiro CD, em 1982, a Toshiba, Time-Warner, Matsushita Eletric, Hitachi, Mitsubishi, Pioneer, Thomson e JVC formaram um consórcio para desenvolver outras mídias óticas, tais como CD-R e DVD-R. Como resultado do consórcio, um grupo de patentes foi criado para desenvolver tais produtos e a Philips se tornou o gerente do grupo de patentes no Brasil.
} 
tendente a eliminar mídias alternativas. O CADE concluiu que o desempenho e resultado do mercado de VHS não se relacionavam a qualquer conduta cometida pela Philips, mas simplesmente aos resultados da superioridade tecnológica das mídias óticas em relação às magnéticas, representado por melhor qualidade de reprodução, armazenagem e durabilidade; um exemplo típico da destruição criativa de Schumpeter. ${ }^{508}$ Adicionalmente, o CADE esclareceu que a Philips teria prerrogativa para exercer seus direitos de propriedade intelectual.

Já com relação às alegações de royalties abusivas, a Representante afirmou que os preços cobrados no Brasil eram significativamente superiores aos valores cobrados no exterior, e que seria possível adquirir CD-R e DCD-R de empresas no exterior com ou sem o pagamento de royalties, para serem entregues no Brasil. A Posição do CADE com relação a tais alegações veio no sentido de rechaçar a existência de evidências de estratégias de exclusão de concorrentes ou de condutas ilícitas que pudessem, de alguma forma, refutar a legitimidade de preços cobrados, não restando caracterizada qualquer infração da ordem econômica. ${ }^{509}$ Foi ainda verificado que a Representada cobrava uma taxa fixa global para o licenciamento de suas patentes e que, ao considerar os corretos valores dos contratos de licenciamento, o Representante estaria, de fato, pagando menos que o padrão global, em razão dos descontos promovidos pela Philips para recompensar empresas em dia com suas obrigações contratuais. Da mesma forma, com relação ao pleito de que seria possível adquirir produtos não licenciados no exterior, seria irrelevante se tal possibilidade de fato existisse, em razão do fato de que todas as empresas comercializando produtos CD-R e DVD-R no Brasil estariam sujeitas a pagamento de royalties sob pena de prática ilícita sujeita a penalidades.

\footnotetext{
${ }^{508}$ Voto de Conselheiro Paulo Furquim de Azevedo, p. 365.

509 Voto de Conselheiro Paulo Furquim de Azevedo, p. 366 dos registros: "[O] preço ou o seu aumento excessivo não pode ser considerado uma prática ilegal prejudicando a livre concorrência, por si só, que pode ser considerada como tal apenas na medida em que resulta de uma prática ilegal ou capaz de causar efeitos anticoncorrenciais (como a eliminação da concorrência). A interpretação do CADE quanto à conduta em exame converge com a doutrina relacionada à distinção de dois tipos diferentes de preços excessivos: (i) os preços meramente excessivos ou de exploração, resultantes do poder de mercado. Nesses casos, a empresa dominante cobra preços elevados aos seus consumidores finais, sem concorrência; (ii) os preços abusivos que são excludentes, implementado com a finalidade de excluir os concorrentes do mercado (e realizados por empresas verticalmente integradas). Nesse sentido, as autoridades devem exercer um papel e contestar preços excessivos, que são abusivos, com o objetivo de promover as condições de trabalho necessárias para o mercado, corrigindo suas possíveis falhas, sendo impedido porém de substituir os mecanismos de mercado ou assumir o papel do agente privado no processo de tomada de decisões, entre as quais a formação dos preços. Em outras palavras, deve ocorrer no processo de concorrência garantindo a disputa por mercados para ser legal, e o possível poder de mercado resultante de tal disputa para ser legítimo."
} 
Por fim, cabe breve menção à averiguação preliminar instaurada contra a Alcoa ${ }^{510}$ grande produtora de aço no país, de restringir a oferta de estruturas de alumínio de portas de janelas por meio de requisições de registro de desenhos industriais, patentes e modelos de utilidades, seguido de ações judiciais contra as supostas infratoras ao direito protegido. A Alcoa foi ainda acusada de divulgar ao mercado direitos de propriedade intelectual sobre estruturas de alumínio que não teriam sido objeto de proteção pela empresa.

Decidiu o CADE, em 2010, pela ausência de infração uma vez que o registro dos desenhos industriais foi devidamente submetido ao INPI, o que sugeriria a ausência de comportamento oportunístico em razão de possíveis brechas no procedimento de concessão dos direitos de propriedade intelectual. Da mesma forma, argumentou o CADE que a divulgação ao mercado dizia respeito efetivamente às marcas registradas pela Alcoa.

Caso de grande interesse e que segue em discussão no SBDC refere-se à proteção de desenhos industriais por grandes montadoras presentes no Brasil, que alegadamente passaram a exercer seus direitos perante produtores independentes de peças. ${ }^{511}$

O caso, que recebeu parecer opinativo da Secretaria de Direito Econômico no sentido de seu arquivamento, por tratar de exercício regular de um direito de propriedade industrial, foi analisado pelo CADE em 2010, o qual determinou a remessa dos autos de volta à SDE para nova instrução. Na ocasião, o CADE verificou indícios de que as montadoras estariam abusando de seu poder econômico por meio do uso indiscriminado de direitos de proteção de propriedade industrial. O caso vem sendo discutido desde 2007, quando a Associação Nacional dos Fabricantes de Autopeças (ANFAPE) alegou que as montadoras começaram a promover registros de desenho industrial de cerca de onze itens específicos dos automóveis, como para-choques, retrovisores, lanternas, capôs e outros componentes, perante o INPI. Assim, com base no registro dos desenhos industriais mais vendidas no mercado, as montadoras entraram na justiça a fim de impedirem os produtores independentes de comercializar produtos que infringissem os desenhos industriais registrados no mercado de reposição, na maioria das vezes conseguindo a apreensão de tais produtos. $^{512}$

\footnotetext{
${ }^{510}$ Averiguação Preliminar n. 08012.005727/2006-50. Representada Alcoa Alumínio SA.

${ }^{511}$ Processo Administrativo n. 08012.002673/2007-51. Representadas: Ford Motor do Brasil SA, Fiat Automóveis SA e Volkswagen do Brasil SA.

${ }^{512}$ Vale ressaltar que as decisões judiciais relacionadas ao assunto confirmaram os registros de desenho industriais das montadoras em questão, determinando medidas de buscas e apreensão dos produtos e impedindo as empresas visadas de continuarem a produzir autopeças sujeitas à proteção de desenhos industriais.
} 
Em 2008, a SDE concluiu pelo arquivamento da investigação, com base nos argumentos de que a proteção garantida aos desenhos industriais das montadoras estava em linha com a legislação de Proteção Intelectual pertinente e, portanto, validamente registrado. A SDE ainda concluiu naquela ocasião que tais restrições não promoviam o fechamento do mercado de autopeças uma vez que tais empresas poderiam desenvolver suas próprias alternativas e autopeças similares sem copiar os desenhos industriais protegidos. A SDE ainda reconheceu que a proteção dada por direitos de propriedade intelectual seria um trade-off pelo qual se outorga uma exclusividade de exploração para inovadores em troca de incentivos à própria inovação. A SDE determinou ainda o envio de cópia da investigação ao Conselho de Combate à Pirataria para a adoção de providências contra a cópia de design de autopeças.

Apesar do parecer pelo arquivamento exarado pela SDE e pela Procuradoria, o CADE concluiu, em dezembro de 2010, que a investigação e instrução deveriam ser reabertas, promovendo a conversão da averiguação preliminar em processo administrativo. Na ocasião, o conselheiro Carlos Ragazzo, relator do processo, entendeu que: (i) os direitos de propriedade intelectual garantem às montadoras monopólio no mercado de reposição; (ii) havia, claramente, efeitos de travamento dos consumidores ou lock-in effects reconhecidos nos mercados afetados; (iii) a concorrência no mercado primário não pareceria ser suficiente para assegurar a concorrência no mercado de reposição; (iv) o uso efetivo de direitos de propriedade intelectual sobre as autopeças para mercados de reposição estaria possivelmente resultando em prejuízos para os consumidores; e (v) não pareciam haver justificativas objetivas plausíveis por parte das montadoras acerca de suas condutas.

Segundo o Conselheiro-Relator, as montadoras promoveram o registro intelectual das peças sob alegação de que precisariam garantir investimentos em inovação e desenvolvimento tecnológico, sendo que estes investimentos, em princípio, já receberiam tal remuneração no mercado primário - venda de veículos -, e não no secundário reposição de peças. Assim, frisou o Conselheiro que o registro das autopeças é lícito, mas o problema estaria no abuso do direito de propriedade intelectual, visto que o fato de as montadoras atuarem contra a venda de autopeças pelas independentes pode levar a aumentos nos preços para os consumidores. ${ }^{513} \mathrm{O}$ caso se encontra, desde então, em instrução na atual Superintendência Geral.

513 O CADE e a SDE passaram sete anos analisando acusações de preços abusivos de autopeças contra montadoras. Ao todo, foram abertos sete processos. Todos arquivados por falta de provas de que os preços 
Importante que se reconheça que o caso em questão, apesar de aparentemente ainda distante de uma decisão, parece trazer sinalização por parte das autoridades no sentido de que proteções aos direitos de propriedade intelectual não devem ser consideradas de maneira absoluta e, portanto, blindadas à ação das autoridades de defesa da concorrência. Existirão circunstâncias nas quais uma proteção excessiva poderá promover perdas aos consumidores e o adequado balanceamento de proteção à propriedade intelectual será tarefa relevante das autoridades de defesa da concorrência, evitando-se prejuízo ao processo inovativo.

\subsubsection{Venda Casada}

A Lei n. 12.529/11 traz prevista, em seu inciso XVIII, conduta sujeita à caracterização de abuso de posição dominante que implica subordinar a venda de um bem à aquisição de outro ou à utilização de um serviço, ou subordinar a prestação de um serviço à utilização de outro ou à aquisição de um bem. Trata-se do consagrado conceito de venda casa. Como já visto anteriormente, ocorre quando um agente subordina a venda de um bem ou serviço, entendido como produto ou serviço principal ou subordinante, à venda de outro produto ou serviço, entendido como produto ou serviço subordinado ou vinculado. ${ }^{514}$

Sobre o tema vale recordar talvez o primeiro caso de relevo, ainda sob a vigência da Lei n. 8.158/91. A empresa Repro - Materiais e Equipamentos de Xerografia Ltda. trouxe, em 1991, denúncia de infração da ordem econômica contra a Xerox do Brasil Ltda., em que alegava a existência de cláusulas contratuais de subordinação da prestação de serviços de assistência técnica a máquinas locadas ou vendidas à aquisição de materiais de consumo da marca Xerox, a serem utilizados naqueles serviços. ${ }^{515}$ Da mesma forma, alegava coação da Xerox ao enviar comunicados a clientes com o intuito de pressioná-los a adquirir material de consumo da marca Xerox. A empresa, por sua vez, se defendia especialmente com os argumentos de que os atos praticados objetivariam somente a

eram excessivos. A diferença, agora, é que a SDE não está apenas analisando preços excessivos ou fora do padrão de mercado, mas sim, se as montadoras se utilizaram de ações na Justiça baseadas na proteção de direitos de propriedade intelectual para barrar concorrentes no mercado de reposição de peças para veículos.

${ }^{514}$ Diferentemente do que verificamos em outras jurisdições, em que se discute o "tying" - subordinação que pressupõe que o consumidor possa ainda adquirir o produto subordinado sem adquirir necessariamente o subordinante - e o "bundling" - puro quando o fornecedor não disponibiliza os produtos de forma separada ou misto quando os produtos são disponibilizados de forma separada, mas são também vendidos em pacote a um preço inferior à soma de seus respectivos preços individualizados, no Brasil os precedentes e discussões parecem interpretar o conceito de forma mais genérica, considerando tanto o elemento de coação como o incentivo econômico à aquisição conjunta.

515 Processo Administrativo 23/91. Representada: Xerox do Brasil Ltda. 
proteção de sua propriedade, marca, conceito, reputação e qualidade dos seus produtos; que a manutenção das máquinas integrava o negócio jurídico da locação, não se constituindo negócio jurídico distinto que viesse a possibilitar a venda casada; e que o contrato reconhecia o direito do locatário de adquirir materiais de consumo de terceiros.

Concluiu o CADE, à época, que a Xerox detinha posição dominante nos mercados de locação e prestação de serviços de assistência técnica, atingindo $91 \%$ e $74 \%$ de participação de mercado, respectivamente. Da mesma forma, concluiu que a cláusula imposta aos clientes da Xerox os inibia de suprirem-se de material de consumo fabricado por terceiros, o que excluía qualquer dúvida acerca da inibição da concorrência e criação de dificuldades ao funcionamento e desenvolvimento de terceiros nestes mercados. Verificou-se, ainda, que o teor das correspondências enviadas ainda deixava clara a negativa de assistência técnica no caso de aquisição de material de consumo de terceiros. Afirmou o conselheiro relator do caso que "não pode a Xerox erguer barreiras artificiais para eliminar do mercado suas concorrentes, criando dificuldades para a utilização dos produtos por elas fabricados ou fornecidos, sem qualquer prova técnica. Não se lhe nega, contudo, o direito de impugnar os produtos comprovadamente danosos a seus equipamentos". ${ }^{516}$ A Xerox foi condenada, em 1993, ao pagamento de multa no valor de Cr\$25.000.000.000,00.

Diversas foram ainda as investigações trazidas ao CADE por partes interessadas ou lesadas, mas que culminaram em arquivamento. Em um deles, decidido em 2002, investigou o CADE alegação de venda casada decorrente da análise do Ato de Concentração envolvendo acordo comercial firmado entre Goodyear e $S K F$, que se comprometeram a oferecer, em conjunto, produtos e serviços para uso industrial, que passariam a ser comercializados com a marca "Power Solution Kit". Enquanto a Goodyear passaria a fornecer correias transmissoras de potência para máquinas industriais, mangueiras industriais de PVC, borrachas e polias industriais, a $S K F$ forneceria rolamentos, vedações, ferramentas, lubrificantes, equipamentos de monitoramento de máquinas e serviços para manutenção industrial. ${ }^{517}$ As empresas passariam ainda a atuar conjuntamente no marketing, logística, treinamento, vendas e rede de distribuidores.

Segundo foi alegado por terceiros interessados no caso, a operação resultaria em venda casada na medida em que poderia representar a adoção de vendas de produtos em

\footnotetext{
${ }^{516}$ Voto do Conselheiro Relator Marcelo Monteiro Soares.

517 Ato de Concentração n. 08012.006225/2001-31. Requerentes: Goodyear do Brasil Ltda. e SKF do Brasil Ltda.
} 
conjunto aos distribuidores, transferindo, desta forma, poder de mercado de uma das requerentes para a outra, além do fechamento dos canais de distribuição, também alegado. As partes, contudo, informaram que embora as correias e rolamentos constituíssem bens complementares, elas não deteriam condições para exercício abusivo de poder mercado, visto que a ausência de características permitindo a diferenciação dos produtos rolamentos e correias - tornava o preço variável chave para a competitividade das empresas no mercado, influindo de forma relevante na decisão do consumidor. O CADE, verificando a ausência de quaisquer indícios de venda casada ou de determinação de vendas dos produtos de forma conjunta nos contratos, reconheceu como facultado ao consumidor a aquisição dos produtos de forma separada, restando descaracterizada a qualificação do abuso de posição dominante.

Já em 2005 o CADE arquivou representação formulada pela Rodobens em desfavor de Mercedes-Benz do Brasil Ltda. e DaimlerChrysler Administradora de Consórcios Ltda., por supostas práticas de preços predatórios, bancagem e venda casada no mercado de administração de consórcios de veículos comerciais, com o objetivo de exclusão dos concorrentes e dominação do mercado. ${ }^{518}$ A Rodobens imputava às representadas conduta de pagamento de comissões de vendas exorbitantes para concessionários e de prêmios para os funcionários das concessionárias pela venda de quotas dos consórcios por elas administrados, de forma que fosse dada preferência à venda de quotas da DaimlerChrysler em detrimento das quotas das demais administradoras de consórcios. Da mesma forma, imputava às representadas o pagamento ao consorciado contemplado por lance ou sorteio, de um bônus destinado ao pagamento dos custos de licenciamento do veículo, bem como a dispensa de avalista para que o consorciado contemplado recebesse o veículo, práticas incomuns neste mercado. Alegava assim a representante que tais práticas implicariam gastos superiores ao custo médio variável da DaimlerChrysler, o que levava a vultosos prejuízos as empresas que têm como única fonte de renda a taxa de administração dos consórcios.

Com relação à alegação de que a DaimlerChrysler estaria utilizando seu poder como montadora para pressionar as concessionárias a vender as cotas de consórcio da administradora por ela controladas - venda casada -, o CADE entendeu que tal relação montadora-concessionária seria disciplinada pela Lei Ferrari, sendo que a quantidade de veículos a serem entregues à concessionária seria cláusula contratual, sendo improvável

518 Processo Administrativo n. 08012.003578/00-18. Representadas: Mercedes-Benz do Brasil S/A e DaimlerChrysler Administradora de Consórcios S/C Ltda. 
que as representadas pudessem subordinar a entrega de veículos à venda de cotas de consórcio. Interessante notar que a própria representada informou que as práticas adotadas cessaram após a medida preventiva decretada pela SDE, determinando a imediata suspensão das práticas de bancagem ou similares. Contudo, o CADE resolver arquivar o caso sem aplicação de punições às Representadas.

Em 2006, o CADE decidiu arquivar investigação trazida pela Conservel contra empresas de elevadores pelas práticas de limitação ou impedimento de acesso a novas empresas no mercado, criação de dificuldades ao funcionamento de empresa concorrente, impedimento de acesso de concorrentes aos equipamentos ou tecnologia e subordinação de venda de um bem à utilização de um serviço, no mercado de prestação de serviços de manutenção de elevadores no Estado da Bahia, mais precisamente na cidade de Salvador. ${ }^{519}$ No que tange à alegação de venda casada, reconheceu o Conselheiro que o mercado seria competitivo e não existiria dominação por qualquer empresa, pois parcela substancial deste era representado por empresas não fabricantes de equipamentos e parte do volume instalado de elevadores se encontraria na carteira de serviços de empresas concorrentes, além de existirem produtores de peças independentes. A tecnologia de fabricação de peças também foi considerada madura e amplamente disponível, sendo ainda o mercado caracterizado pela ausência de restrição legal ou regulação específica que impedia a entrada de novas empresas, por baixo investimento inicial e reduzido tempo de entrada. Assim, concluiu o Conselheiro Relator, no que foi seguido pelos demais Conselheiros, que não haveria dificuldades para que as empresas adquirissem peças para reposição, dadas as características técnicas e componentes similares, o que conferia caráter de substituibilidade a estas peças. Ainda, concluiu que não haveria efeito lock in, o qual se verificaria quando a aquisição de determinando equipamento implicasse a obrigação de incorrer nos custos de manutenção do mesmo por parte da mesma empresa. Verificou-se ainda que o consumidor de determinado elevador não se obrigava a contratar a manutenção com o fabricante. Concluiu, portanto, diante da inexistência de poder de mercado naquele âmbito geográfico, a impossibilidade de se configurar a venda casada.

Em 2007, conforme já acima mencionado, o CADE arquivou investigação aberta contra a Monsanto sobre diversas práticas, uma das quais a suposta prática de venda casada

\footnotetext{
519 Processo Administrativo n. 08012.009373/98-23. Representados: Conservadora de Elevadores Ltda. Conservel, Elevadores Atlas S/A, Elevadores Kone S.A., Elevadores Otis Ltda., Elevadores Sür S.A., Indústria Villares S.A., e Schindler Elevadores do Brasil S.A.
} 
entre sementes de soja geneticamente modificadas e herbicidas à base de glifosato. ${ }^{520}$ Concluiu o Conselheiro Relator que, à época dos fatos, embora um dos produtos já estivesse sendo comercializado no mercado - glifosato round up -, o comércio das sementes de soja transgênica ainda não estava autorizado, o que tornava inviável a tese de venda casada. Ainda que fosse possível a contratação com terceiros da venda de sementes condicionada à compra do glifosato, sob condição suspensiva, não foram trazidos aos autos evidências conclusivas de que a venda casada tenha de fato ocorrido.

Em 2008 o CADE arquivou averiguação preliminar para investigar suposta venda casada praticada por fabricantes de notebooks que estariam tolhendo a liberdade de escolha de seus clientes, os quais somente poderiam adquiri-los acompanhados de sistema operacional da Microsoft. Segundo o Representante, concedendo à empresa Microsoft privilégios, dificultar-se-ia o ingresso e o desenvolvimento de empresas produtoras de sistemas operacionais concorrentes. Em especial, a SDE constatou que alguns modelos sem o sistema Windows figuravam entre os mais vendidos e/ou populares e que havia demanda maior por equipamentos com o sistema Windows, o que justificaria ser corriqueiro encontrar notebooks com o sistema instalado. ${ }^{521}$

Também em 2008 o CADE arquivou processo administrativo que investigava a imposição de preços excessivos, exigência de condições comerciais injustificáveis, venda casada e uso de informação privilegiada por parte da Companhia Siderúrgica Nacional, monopolista no mercado de produção nacional de folhas de flanders, matéria-prima para produção de latas de aço. ${ }^{522}$ Especificamente com relação à venda casada, alegava-se a subordinação do comércio da folha de flanders com seu respectivo transporte. A Representada, por sua vez, justificava que, devido à limitação física de acesso de caminhões à usina siderúrgica, relevante ainda em razão de segurança, a empresa teria cadastrado diversas transportadoras que cumpririam certos requisitos, de modo que os clientes estariam livres para escolher a que lhes fosse mais conveniente. Com base neste argumento, concluiu o CADE que, ainda que a empresa possa ter imposto regras às transportadoras cadastradas, o que seria esperado, verificava-se que a $C S N$ teria feito o possível para manter a concorrência no mercado de transporte de sua mercadoria. Ainda, segundo o parecer do Conselheiro Relator, esta conclusão teria sido reforçada pela

\footnotetext{
${ }^{520}$ Processo Administrativo n. 08012.008659/1998-09. Representada: Monsanto do Brasil Ltda.

521 Averiguação Preliminar n. 08012.001115/2007-79. Representadas: Hewlett Packard IBM Brasil Indústria, Máquinas e Serviços Ltda., Itautec Philco S.A.; Microsoft Informática Ltda.; Sony do Brasil Ltda.; Toshiba Corporation.

${ }^{522}$ Processo Administrativo n. 08012.008340/2002-21. Representada: Companhia Siderúrgica Nacional.
} 
informação de algumas empresas de que não existiriam problemas em relação ao frete, e que não existiria ainda diferença significativa entre os valores praticados pelos transportadores autorizados pela $C S N$ e os demais no mercado. Foi determinado, assim, com relação à acusação de venda casada, e também às demais condutas imputadas, o arquivamento do processo.

Em 2009 o CADE também arquivou representação contra a Unimed Bauru que incluía, entre as condutas, a prática de venda casada, consistente na venda de medicamentos a preço de custo de forma exclusiva aos usuários do plano de saúde da cooperativa. $^{523}$ Para fins da análise da potencialidade dos efeitos lesivos à livre concorrência, o CADE verificou que, à época da denúncia, a Unimed possuía cerca de $0,5 \%$ de participação no mercado relevante em questão, parcela que não seria suficiente para possibilitar o exercício de poder de mercado por parte da Unimed. Portanto, diante da ausência de poder de mercado no produto condicionante, não haveria como sustentar a prática de infração concorrencial por venda casada, visto que não se poderia falar em alavancagem de poder de mercado de um produto ou serviço para o outro.

Por fim, em 2010 o CADE arquivou representação em que a ASCOFERJ alegava que os laboratórios representados estariam abusando de seu poder econômico por meio de cadeia restritiva, monopolística e indutiva, ao fornecerem cupons promocionais para aquisição de medicamentos a preço de fábrica para pacientes após consulta médica. ${ }^{524} \mathrm{~A}$ SDE, em sua investigação, não constatou a prática de venda casada, uma vez que não teria havido condicionamento de um bem à aquisição de outro e nem sequer teria havido a obrigatoriedade da aquisição de medicamentos em determinado estabelecimento, não se verificando quaisquer imposições. Tal conclusão foi corroborada pelo CADE, que determinou o arquivamento do caso. Afirmou em seu voto, o Conselheiro Relator, que a alegada venda casada se referia não a uma combinação de medicamentos, mas à definição de que o desconto estaria atrelado à aquisição de um medicamento em determinada farmácia; ou seja, o laboratório estaria vendendo medicamento com desconto casado à aquisição em uma rede específica de farmácias. Contudo, não se observava, segundo o Conselheiro, qualquer obrigatoriedade de aquisição do medicamento àquela rede de farmácias, a qual não possuía qualquer poder de mercado.

\footnotetext{
${ }^{523}$ Averiguação Preliminar n. 08012.004118/2002-50. Representada: Unimed Bauru.

524 Averiguação Preliminar n. 08012.002500/2000-67. Representados: Indústrias Químicas e Rede de Drogarias Pacheco, Merck S.A., Laboratório Sanofi-Synthelabo e Laboratórios Bayer S.A.
} 
Dos casos acima examinados, testados pelas autoridades brasileiras com relação às praticas de venda casada, podemos inferir uma ausência de sistematização dos elementos que têm sido reiteradamente investigados para se concluir acerca da ilegitimidade da conduta. Contudo, percebemos que tais elementos parecem transitar ao redor da necessidade de verificação de poder de mercado com relação ao produto subordinante, capaz de configurar alavancagem para um produto ou serviço em outro mercado, bem como no elemento de coação, sendo ainda analisada pelo CADE a existência de incentivos econômicos para a aquisição conjunta.

\subsubsection{Preço Predatório}

A comercialização ou prestação de serviços abaixo de certa modalidade de custo, sem qualquer justificativa objetiva, pode caracterizar abuso de posição dominante prevista no inciso XV do artigo 36 da Lei n. 12.529/11: "vender mercadoria ou prestar serviços injustificadamente abaixo do preço de custo".

Modalidade de abuso que por vezes se confunde às práticas de preços predatórios seriam condutas resultantes em estreitamento de margens, fundamentadas sob o inciso IV da lei: "criar dificuldades à constituição, ao funcionamento ou ao desenvolvimento de empresa concorrente ou de fornecedor, adquirente ou financiador de bens ou serviços". Cabe inferir que o racional econômico desta prática pode, igualmente, implicar a exclusão de concorrente quando de fornecimento de matéria-prima essencial por agente verticalmente integrado e, ao mesmo tempo, concorrente direto no mercado a jusante. Interessante ainda notar que não se trata de preço abaixo do custo, mas prática de preços diferenciados que reduzem a margem da operação a níveis impraticáveis. Elementos fáticos adicionais aos verificados nas práticas de preços predatórios devem ser considerados para tanto como, por exemplo, a essencialidade da matéria-prima ou sua indisponibilidade alternativa, bem como custos impeditivos de sua alteração.

De volta à modalidade tratada de preço predatório, importante a referência ao Guia para Análise Econômica da Prática de Preços Predatórios, ${ }^{525}$ o qual dispõe que a prática de preços abaixo do custo não é, por si, conduta anticompetitiva, sendo necessário demonstrar-se que o agente predador tem poder para eliminar ou disciplinar concorrentes, incorrendo em prejuízos para, posteriormente, elevar os preços e recuperar o que foi

${ }_{525}$ Portaria n. 70, de 12 de dezembro de 2002, publicada no Diário Oficial da União n. 241, de 13/12/2002, Seção 1, págs. 138 a 139. 
perdido. ${ }^{526}$ Assim, para caracterizar preço predatório seriam necessários a verificação de: (i) poder de mercado; (ii) existência de barreiras à entrada; (iii) recuperação de perdas; (iv) possibilidade de expansão de rápida da oferta; e (v) capacidade de financiar a conduta.

Com relação à delimitação de mercado relevante e verificação da existência de poder de mercado, bem como da existência de barreiras à entrada, não há novidades. Vale frisar, contudo, o entendimento das autoridades brasileiras com relação à necessidade de capacidade produtiva da empresa predadora para atender à nova demanda que surge em decorrência da redução do preço. Da mesma forma, com relação à capacidade de financiamento, a plausibilidade da estratégia está necessariamente a ela relacionada, devendo-se investigar a capacidade que a empresa predadora possui de se autofinanciar ou ainda financiar-se via terceiros.

Verificadas as variáveis acima e a existência de condições necessárias para a recuperação das perdas incorridas pelo acusado, deverão ser analisados os fatores referentes ao exercício da predação. Neste sentido, elemento fundamental na determinação de condutas predatórias seria a obtenção de provas da ocorrência injustificada de vendas a preços abaixo de certa modalidade de custo, tendo-se estabelecido algo próximo a um consenso entre os economistas neste tocante, devendo considerar-se o custo variável médio e custo médio total como tais medidas. Assim, podem ser observadas três hipóteses: (i) preço igual ou superior ao custo médio total de produção; (ii) preço entre o custo médio total e o custo variável médio; e (iii) preço inferior ao custo médio variável. A primeira situação levaria a um porto seguro, resultando em arquivamento da investigação. A terceira, por outro lado, presumiria a prática predatória. Por fim, a segunda situação traria suspeita de prática predatória, devendo-se analisar a verificação de contrações repentinas de demandas ou mesmo variação de demandas sazonais, que funcionariam como justificativa para a não configuração do ilícito.

Não há notícia de condenação, no Brasil, de práticas de preços predatórios por parte das autoridades de defesa da concorrência. Não obstante, vale brevemente avaliarmos os diversos casos que trataram do tema e justificativas para arquivamento destas

\footnotetext{
${ }^{526}$ Segundo o Guia, "a venda de mercadoria abaixo do preço de custo não constitui uma infração. Esta venda tem que produzir o efeito, ou ter como objeto, prejudicar a livre concorrência. Assim sendo, para a constatação de uma estratégia de preços predatórios é necessário provar, além da venda abaixo do custo, que as condições necessárias para que essa estratégia seja lucrativa (ou seja, que no longo prazo a concorrência irá se reduzir e com isto a firma predadora terá poder de mercado) estejam presentes, a saber: participação de mercado significativa da firma predadora, elevadas barreiras à entrada, capacidade produtiva para atender o incremento da demanda no curto prazo e capacidade de financiamento devido às perdas incorridas nessa estratégia".
} 
investigações, a fim de delinearmos o tratamento emprestado pela jurisprudência administrativa pátria. ${ }^{527}$

Vale inicialmente referência a caso acima mencionado, decidido pelo CADE em 2005, tratando de representação formulada pela Rodobens em desfavor de Mercedes-Benz e DaimlerChrysler contra supostas práticas de pagamento ao consorciado contemplado por lance ou sorteio de bônus destinado à quitação de custos de licenciamento do veículo, bem como dispensa de avalista para recebimento do veículo. ${ }^{528}$ Tais práticas implicavam gastos superiores ao custo médio variável da DaimlerChrysler, levando a vultosos prejuízos as empresas que tinham como única fonte de renda a taxa de administração dos consórcios.

No que tange aos preços predatórios da investigação, o CADE afirmou que a análise não deveria se resumir à avaliação dos custos médios variáveis, mas que a caracterização desse ilícito implicaria ainda a conduta de uma empresa com poder econômico que venha a oferecer condições para clientes de seus concorrentes que não são necessariamente estendidas aos seus clientes, com objetivo de excluí-los do mercado, recuperando, posteriormente, o custo dessa ação com aumento de preços. Para que esta condição possa ser plausível, discorre o Conselheiro Relator do caso, seria necessário que:

(i) o preço predatório leva à redução do valor presente dos lucros futuros da empresa entrante abaixo dos seus custos fixos de entrada, de tal forma que ela

\footnotetext{
${ }^{527}$ Vale referência ao voto do Conselheiro Prado na Averiguação Preliminar n. 08012.007897/2005-98: "26 No Brasil, a grande maioria das denúnicas de preço predatório são arquivadas sem sequer haver necessidade de análises mais profundas no sentido de analisar preços e custos. Isso porque, de modo geral, constata-se que as empresas alegadamente infratoras não detêm poder de mercado, que os mercados analisados possuem rivalidade efetiva e/ou que não há barreiras à entrada significativa. Com efeito, o CADE tem considerado que todos esses fatores retiram a racionalidade ou impossibilitam a adoção de uma política de preços predatórios com vistas a eliminar concorrentes. É o caso, por exemplo, dos processos n. 08012.000668/1998-06 (Representante: SINPROFAR; Representado: SESI), 08012.003578/200-18 (Representante: Rodobens Administração e Promoções Ltda; Representados: Mercedez-Benz do Brasil SA e DaimlerChrysler Administradora de Consórcios Ltda.), 08012.006358/1997-42 (Representante: Becton Dickinson; Representada: Labnew Indústria e Comércio), 08012.006722/1999-45 Representante: Antonio J.S. Ferreira; Representada: Shell Brasil SA), 08012.009943/2005-93 (Representante: Konet Elevadores Ltda; Representada: ThyssenKrupp Elevadores SA), 08000.004490/1997-11 (Representada: ThyssenKrupp Elevadores SA), 08000.004490/1997-11 (Representante: Rogério Santos Muniz; Representada: Companhia União de Refinadores de Açúcar e Café); 08000.004615/1997-87 (Representante: Konus Icesa SA.; Representada: aalborg Brasil Indústria e Comércio Ltda.); 08000.013472/1995-51 (Representante: Organização Hoteleira Fonte Colina Verde Ltda; Representado SENAC); 08012.000202/1999-92 (Representante: Auto Posto Beira alta; Representado: Alto Posto de Serviços SS Diadema); 08012.000219/2005-02 (Representante: Ministério Público do Ceará; Representada Drogaria São Paulo SA); 08012.003521/2004-23 (Representante: General Electric Company - Divisão Sistemas Médicos; Representados: Hospital do Coração de Londrina Ltda. e Allbio Importadora Ltda.); 08012.007111/2003-71 (Representante: Verma Engenharia Ltda.; Representado: Elevadores Otis Ltda.) e 08012.009373/1998-23 (Representante: Conservadora de Elevadores Ltda- Conservel; Representados: Elevadores Otis Ltda. e outros)."

528 Processo Administrativo n. 08012.003578/00-18. Representadas: Mercedes-Benz do Brasil S/A e DaimlerChrysler Administradora de Consórcios S/C Ltda.
} 
não possa sobreviver no longo prazo; (ii) mesmo depois do aumento do preço não haja incentivos para a entrada de novas empresas. Isto é, haja barreiras à entrada que permita a imposição de preços de monopólio; (iii) que as empresas concorrentes, vítimas desta queda do preço, não tenham certeza que o preço é predatório e/ou não tenham condições financeiras de permanecer no mercado por um tempo o suficiente longo. Isto é, as concorrentes podem, portanto, chegar à conclusão que não há espaço para elas no mercado sob condições normais de competição ou não é economicamente viável, obter recursos para financiar o custo de esperar o fim da prática de preços predatórios. ${ }^{529}$

Segundo o Conselheiro relator, que determinou o arquivamento da investigação, tais condições não eram encontradas no mercado de administração de consórcios de veículos automotores, e uma possível tentativa de praticar preço predatório seria imediatamente frustrada pelas outras concorrentes.

O CADE ainda arquivou investigação contra a Varig em 2008, em que se investigava redução dos preços de passagens aéreas de voos que partiam de Roraima em até $83 \%$, o que poderia caracterizar preço abusivo anterior ou criação de dificuldades à entrada da empresa $G o l .{ }^{530}$ A Representada sustentou a legalidade de sua atuação, já que os preços praticados anteriormente estavam dentro das bandas tarifárias estabelecidas pelo antigo DAC e que a redução posterior à entrada da Gol, autorizada pelo DAC, foi exatamente para adequar o padrão tarifário aos preços praticados pela entrante. A SEAE considerou que as características do mercado de aviação civil comercial eram propícias à prática de descontos promocionais, recomendando o arquivamento do caso. O Plenário do CADE manteve o arquivamento do processo.

Também em 2008 o CADE arquivou denúncia de prática de preços predatórios no mercado de comercialização de medicamentos contra a Unimed Jau. ${ }^{531}$ A Representada estaria se aproveitando de isenções fiscais concedidas às sociedades cooperativas para revender medicamentos abaixo do preço de custo, inclusive para terceiros não cooperados. Deixando de lado a questão da prescrição intercorrente, o Conselheiro Relator corroborou com o entendimento da SEAE de que, em razão de existirem baixas barreiras à entrada, seria impossível à Unimed auferir lucros extraordinários que compensassem os supostos prejuízos. Tal característica dispensaria a análise dos demais aspectos previstos no Guia para Análise Econômica de Preços Predatórios, determinando o CADE o arquivamento do caso.

529 Processo Administrativo n. 08012.003578/00-18. Representadas: Mercedes-Benz do Brasil S/A e DaimlerChrysler Administradora de Consórcios S/C Ltda.

530 Averiguação Preliminar n. 08012.008717/2005-95. Representada: Varig

${ }^{531}$ Averiguação Preliminar n. 08012.005106/2001-61. Representada: Unimed Jau. 
Ainda em 2008 o CADE determinou o arquivamento de caso envolvendo a Petrobras, em que a Refinaria de Petróleos de Manguinhos S/A e a Refinaria de Petróleo Ipiranga alegavam que a prática de preços predatórios em determinados derivados criava dificuldades artificiais à entrada de rivais no âmbito do refino e estipulava discriminação de preços de petróleo por meio de preços de transferência. ${ }^{532}$ Com relação aos preços predatórios, alegavam as Representadas que a Petrobras estaria fixando o preço de alguns derivados de petróleo - em especial da gasolina, óleo diesel e GLP - em patamares inferiores ao custo da matéria-prima, conduta que inviabilizaria a concorrência no segmento de refino de petróleo. Tais margens negativas dos três produtos não seria percebida, visto que a Petrobras manipulava os valores de transferência interna de petróleo. Da mesma forma, alegava-se que os preços nacionais estariam abaixo do aceitável no que tange à importação de diesel e de GLP, uma vez que o Brasil seria importador líquido destes derivados e o preço de venda interno estaria abaixo dos custos de internalização dos produtos. Segundo ainda as denúncias, as práticas de preços abaixo dos custos ocorriam em razão da possibilidade da Petrobras impor subsídios cruzados, que teriam duplo efeito negativo, visto que estes subsídios auxiliavam a recuperação do prejuízo da Petrobras e criavam dificuldades aos entrantes no refino.

A SDE concluiu que a Averiguação Preliminar deveria ser arquivada, por entender que não havia indícios de predação nem de prática de subsídio cruzado por parte da Petrobras. Na sua revisão acerca do recurso de ofício, o Conselheiro Relator, por sua vez, entendeu que havia evidências nos autos das condutas denunciadas, votando pelo conhecimento do recurso e pela remessa dos autos à SDE para instauração de processo administrativo. O Conselheiro desconsiderou as conclusões da SDE acerca das margens positivas da Petrobras, visto que foram obtidas considerando-se uma agregação de produtos (cesta de derivados) e outra geográfica (com todas as refinarias do Sistema Petrobras).

Considerou assim que tal cenário possuía elevado potencial de mascarar uma possível existência de prática de condutas infrativas. Ainda, constatou neste cenário uma margem líquida negativa para os anos de 1996 e 1997, explicada pela retração da capacidade de investimento das refinarias (realização das refinarias não teria acompanhado proporcionalmente a evolução do custo da matéria-prima). Por outro lado, indagou o Conselheiro: "Todavia, outro é o cenário quando uma empresa - monopolista de um

\footnotetext{
532 Averiguação Preliminar n. 08012.007897/2005-98. Representada: Petróleo Brasileiro SA - Petrobras.
} 
insumo essencial - tem de forma obscura e reiterada - utilizado de mecanismos, de forma voluntária, para baixar o preço dos derivados que são produzidos pelas empresas privadas." Desta forma, assumiu o Conselheiro como possível que uma empresa como a Petrobras possa ter mecanismos de transferência do custo da matéria-prima da exploração para o refino, e que a diante de estrutura verticalizada a Petrobras teria sim a possibilidade de utilizar dados contábeis para mascarar possíveis prejuízos, tendo sido ainda juntado aos autos diversas manifestações que contradiziam a existência de margens positivas no refino pela Petrobras.

Contudo, a maioria do Conselho votou pelo não conhecimento do recurso, e consequentemente pelo seu arquivamento, com base no voto divergente que afirmava tratar-se o mercado relevante do insumo essencial petróleo, e fazendo-se desnecessária a discussão dos reais efeitos dos preços dos insumos no mercado a jusante. Na visão do Conselheiro relator do voto divergente, o petróleo inseria-se em mercado relevante internacional, com importação aberta. Assim, não seria possível caracterizar aumento do custo do rival diante de um mercado internacional, faltando ainda prova de tratamento diferenciado pela Petrobras com relação às empresas de seu grupo econômico.

Em representação promovida pela Cecil Langone contra a Termomecânica São Paulo S.A. em 1997, que viria a ser julgada pelo CADE somente em 2010, a qual se referia à prática de preços predatórios na venda do produto barras de latão por meio de subsídios cruzados com o produto tubo de latão, houve, da mesma forma, determinação de arquivamento do caso. ${ }^{533}$ Vale notar que, antes de adentrar à analise do caso em concreto, o Conselheiro Relator definiu como preço predatório "a prática deliberada de preços abaixo do custo variável médio, visando eliminar concorrentes para, em momento posterior, poder praticar preços e lucros mais próximos do nível monopolista". Ainda, mencionou o Conselheiro Relator que a análise da prática requer avaliação detalhada das condições efetivas de custos e do comportamento dos preços ao longo do tempo, a fim de se afastar a hipótese de práticas sazonais normais ou de políticas comerciais da empresa. Ainda, deveria ser analisado o comportamento estratégico, avaliando-se as condições objetivas de ganhos posteriores potencialmente extraordinários, suficientemente elevados e capazes de compensar as perdas da venda abaixo do custo. ${ }^{534}$ Tal conduta deveria ainda ser tratada sob

\footnotetext{
${ }^{533}$ Averiguação Preliminar n. 08000.021977/1997-14. Representada: Termomecânica São Paulo S.A.

${ }^{534}$ Voto do Conselheiro Relator; considerando 35.
} 
a luz da regra da razão, observando as etapas de análise de possíveis condutas infrativas. ${ }^{535}$ Assim, o principal pressuposto a ser considerado, segundo o Conselheiro Relator, seria verificar-se a preexistência de posição dominante no mercado relevante, fato que seria condição necessária mas não suficiente para caracterização do ilícito.

No caso concreto, segundo foi alegado, a Representada teria reduzido cada vez mais seus preços não obstante o aumento do custo da matéria-prima ter se elevado em $28 \%$ e consistir em mais de $80 \%$ dos custos totais do produto. Ainda, constatou-se que, por cerca de quatro meses, a Representada teria vendido abaixo do preço de custo em até $5,23 \%$ para o produto "barras de latão" e teria elevado seu preço final para o produto "tubos de cobre e latão" em até 118,23\%, mercado em que as empresas Cecil Langone e Termomecânica não seriam concorrentes.

Assim, seguindo o Guia para Análise Econômica da Pratica de Preços Predatórios, o Conselheiro Relator avaliou a inexistência de barreiras à entrada no mercado relevante, o que levava à conclusão da inviabilidade da predação na medida em que, após a exclusão, qualquer aumento de preços atrairia nova entrada no mercado. Também, com relação à capacidade ociosa, apesar de ter indicado a Representada que operava com $25 \%$ de capacidade ociosa, o que se verificou nos anos seguintes ao da alegada predação foi uma ligeira queda na produção da Representada e aumento da produção da Representante e demais empresas atuantes no mercado. Não havia, portanto, expansão da oferta por parte da Representada em detrimento dos concorrentes, o que tornaria a prática economicamente pouco racional.

No que se diferenciava do padrão de práticas de preços predatórios investigados, o presente caso implicava que o fator recuperação estaria na própria prática de subsídio cruzado, fato que deveria ter relativizado a importância dada a alguns fatores encontrados na Portaria 70/2002. Neste sentido, segundo o Conselheiro Relator, comparando-se a evolução dos custos da matéria-prima - latão - com os dois principais produtos - barras de latão e tubo de latão -, o primeiro com preço abaixo dos custos e o segundo com preços muito acima dos custos, "nota-se que esses dois produtos finais têm um comportamento semelhante, ou seja, os preços praticados apresentam a mesma tendência". Além disso,

\footnotetext{
${ }^{535}$ Conforme informado anteriormente, a Portaria SEAE 70/2002 prevê as etapas de análise de possíveis condutas anticompetitivas, as quais passam por: (i) identificação da natureza da conduta e definição do seu enquadramento legal; (ii) verificação da existência de evidências suficientes das condutas nos autos; (iii) delimitação do mercado relevante; (iv) estimativa das participações no mercado relevante; (v) análise das condições concorrenciais, efetivas e potenciais, no mercado relevante; (vi) avaliação dos danos anticoncorrenciais da conduta sobre este mercado; (vii) exame dos possíveis ganhos de eficiência econômica e outros benefícios gerados pela conduta; (viii) avaliação final dos efeitos anticompetitivos e das eficiências econômicas da conduta.
} 
lembrou o Conselheiro Relator que a prática de preços abaixo do custo ocorreu poucas vezes dentro do período analisado, não se podendo afirmar que a empresa Termomecânica teria articulado estratégia de monopolização do mercado.

Recorde-se ainda que, para o mercado de tubos de cobre e de latão, haveria a disciplina de concorrentes e dos produtos importados. Decidiu o CADE, portanto, arquivar a averiguação preliminar em questão.

Ainda em 2010, o CADE arquivou processo contra a Textil J. Serrano, acusada de prática de venda casada e de preços predatórios no mercado nacional de tecido $100 \%$ polipropileno para revestimento de móveis estofados, apesar de parecer pela condenação por parte da SDE e do Ministério Público. ${ }^{536}$

Interessante notar os cinco requisitos trazidos pelo Conselheiro Relator apontados para verificação de uma prática de venda casa. Em primeiro lugar, deve-se verificar os incentivos econômicos para que uma prática predatória se revele minimamente racional, que se refletem na presença de poder de mercado. Neste sentido, o entendimento do Conselheiro vem no sentido de que embora se admita a possibilidade de comportamentos irracionais, é pouco provável a conduta ausente a existência de poder de mercado, em vista da magnitude de custos envolvidos na prática vis-a-vis os ganhos esperados. O segundo requisito diz respeito à existência de barreiras à entrada, na ausência da qual perderia a prática todo seu potencial anticompetitivo, visto que excluída a concorrência e restabelecidos os preços monopolísticos, haveria entrada de agentes neste mercado reduzindo os níveis de preços a valores competitivos. Já a terceira característica requer que as vendas futuras sejam rentáveis o suficiente para permitir à firma predadora a recuperação do prejuízo. Um quarto requisito seria a possibilidade de que a empresa investigada tenha capacidade ociosa suficiente para capturar a demanda desviada, ou possibilidade de rápida expansão, a custos compatíveis com a rentabilidade esperada.

O Conselheiro coloca que, na ausência de qualquer dos quatro elementos acima, deveria a investigação de preço predatório ser arquivada. Contudo, aponta questão de relevância ao se referir à possibilidade de que fatores como sinalização ou reputação tenham efeito dissuasório sobre potenciais entrantes. Assim, coloca que:

Na ausência de barreiras estruturais ou institucionais ou de capacidade ociosa para enfrentar o aumento da demanda, uma empresa pode lograr o afastamento de novos competidores por meio da adoção reiterada de estratégias predatórias não lucrativas sob uma perspectiva estática, mas que tem o condão de

\footnotetext{
${ }^{536}$ Processo Administrativo n. 08012.007104/2002-98. Representado: Textil J. Serrano Ltda.
} 
desestimular - por meio de ameaça de guerra de preços, por exemplo - o ingresso de rivais. ${ }^{537}$

Assim, cria uma quinta condição a ser verificada que implicaria o poder econômico do agente, que não se confundiria com a posição dominante ou poder de mercado, e implicaria a capacidade do agente de financiar a conduta, quantas vezes e pelo tempo que for necessário.

No caso em referência, segundo o Conselheiro Relator, estavam ausentes a segunda e a terceira condições necessárias para configuração do ilícito. Além disso, criticou o Conselheiro a definição de mercado de relevante sem, contudo, decidir a questão, visto que irrelevante para a solução do caso.

Procedeu ainda a uma revisão da análise de custo proferida pela SDE, que verificou as vendas de um tecido específico conhecido como "canoas", estimou seu custo de produção, comparando-o aos preços médios de venda aos cem maiores clientes da $J$. Serrano entre 2000 e 2004. A conclusão da SDE veio no sentido de que 18,59\% daquelas vendas foram feitas a preços inferiores ao custo variável médio em 2000; 35,96\% em 2001; 43,61\% em 2002; 50,78\% em 2003; e 56,23\% em 2004; e ainda, considerando-se os dados agregados - média de todas as vendas para todos os clientes, ano a ano -, apenas em 2002 e 2004 o preço médio foi inferior ao custo variável médio. Neste sentido, o Conselheiro Relator questionou a utilização do tecido "canoas" como a base do estudo visto que dois tecidos fabricados a partir de um mesmo fio (1800 denier) podem ter densidades diferentes e, consequentemente, preços diferentes. Da mesma forma, questionou o aumento entre $27 \%$ e $40,6 \%$ no custo estimado de PP promovido pela SDE em razão de suposto subfaturamento, o que não ficou comprovado pela Secretaria da Receita Federal, devendo com isso tal aumento ser excluído do cálculo do custo variável médio.

\subsubsection{Descontos de Fidelidade}

Não há tratamento exemplificativo específico emprestado pela legislação brasileira para a conduta de descontos aplicados a clientes decorrente de sua fidelidade a produto ou marca. Neste sentido, a fidelização para acesso aos descontos incentiva uma situação de exclusividade de fato ou algo muito próximo a isso, capaz de produzir efeitos de fechamento de mercado, elevação de custos das marcas rivais e criação de dificuldades

\footnotetext{
${ }^{537}$ Voto Conselheiro Relator, parágrafo 12.
} 
para operação estes concorrentes. Podem ser, consequentemente, tipificadas sob alguns incisos da Lei n. 12.529/11, como o III: "limitar ou impedir o acesso de novas empresas ao mercado"; IV: "criar dificuldades à constituição, ao funcionamento ou ao desenvolvimento de empresa concorrente ou de fornecedor, adquirente ou financiador de bens ou serviços"; e V: "impedir o acesso de concorrente às fontes de insumo, matérias-primas, equipamentos ou tecnologia, bem como aos canais de distribuição".

Casos de grande relevância julgados pelo SBDC referem-se ao gigante brasileiro de cervejas, a Companhia de Bebidas das Américas (AmBev), envolvida em três grandes casos: seu programa de fidelidade "Tô Contigo!"; a introdução no mercado de garrafa retornável com a inscrição "AmBev", com capacidade para $630 \mathrm{ml}$; e a introdução no mercado da garrafa retornável de um litro - "Litrão". O primeiro deles trata-se do caso referência acerca do tema dos descontos de fidelidade julgado no Brasil, sendo que os demais foram tipificados sobre modalidades outras de limitação e criação de dificuldades para operação de concorrentes, que merecem brevíssima referência.

Com relação ao programa de fidelidade "Tô Contigo!", 538 o processo foi aberto em 2004 depois de denúncia da concorrente Schincariol contra os programas de fidelização de pontos de vendas "Tô Contigo" e "Festeja". A Schincariol acusava a AmBev de oferecer a bares, mercearias e supermercados, acordos de exclusividade, descontos e bonificações para que os pontos de venda comercializassem as bebidas da empresa, prejudicando, assim, a venda de marcas concorrentes. Segundo a Schincariol, os programas da AmBev reduziram a participação de mercado das cervejas Nova Schin e Kaiser em 20\% cada, elevando a participação das marcas da AmBev em 8,5\%, tendo a Antarctica aumentado sua participação em 56,37\%.

Segundo o relatório da SDE, responsável pela instrução do processo, os programas de fidelização poderiam prejudicar a concorrência, fechar mercados e elevar os custos das marcas rivais. Assim, afirmava a Secretaria que havia fortes indícios de que os programas prejudicavam a concorrência, "dificultando o acesso de novas cervejarias ao mercado e criando dificuldade ao funcionamento dos concorrentes já estabelecidos por meio da exclusividade dos pontos de vendas". 539

A SDE fez várias inspeções e até uma pesquisa elaborada pelo Ibope com pontos de vendas para levantar irregularidades. Para o órgão, haveria a imposição de exclusividade aos vendedores que entrassem no programa ou a limitação na

\footnotetext{
${ }_{538}^{538}$ Processo Administrativo n. 08012.003805/2004-10.

539 Idem.
} 
comercialização de marcas concorrentes. Em troca, os vendedores poderiam comprar as cervejas AmBev por preços mais baixos. De acordo com o relatório, a empresa chegava a fiscalizar os freezers dos pontos de venda para checar se não havia marcas concorrentes. Ainda segundo a Secretaria, o programa "Festeja" determinava que os pontos de venda reduzissem o preço das cervejas da AmBev em pelo menos R 0,11 durante a semana e R\$ 0,21 nos finais de semana, impondo aos vendedores margens de lucros menores. A Secretaria, bem como a SEAE e a procuradoria do CADE recomendaram ao Conselho a condenação da AmBev. A multa poderia chegar a 30\% do faturamento da companhia.

Em sua defesa, a AmBev alegou que os programas de fidelização eram legais e que beneficiavam o consumidor e o ponto de venda: "primeiro, porque poderia adquirir produtos com desconto, e, ao segundo, por receber material publicitário específico que lhe permitiria alavancar suas vendas", ${ }^{540}$ afirmou a empresa. Segundo a AmBev, não houve nenhum tipo de sanção aos pontos de vendas que aderiram aos programas e continuaram vendendo outras marcas. A empresa admitiu, porém, que, na primeira fase do programa "Tô Contigo", se algum ponto de venda comercializasse outras marcas, era desligado do programa porque não mais se enquadrava no perfil.

Apesar de sua defesa, em julho de 2009, a AmBev foi condenada por exigir exclusividade dos seus produtos em pontos de venda e inibir a venda de outras marcas. $\mathrm{O}$ CADE entendeu que isso prejudicou as outras marcas de cerveja e o consumidor, condenando-a ao pagamento de multa recorde no Brasil, à época, em torno de $\mathrm{R} \$ 352.6$ milhões, por prejudicar a concorrência no mercado de cerveja. O valor correspondia a $2 \%$ do faturamento bruto da empresa no ano de 2003, anterior à instauração do processo.

Nos outros casos envolvendo a $A m B e v$, não diretamente implicando descontos de fidelidade mas outros meios tipificados de limitação e criação de dificuldades para operação de concorrentes, temos, no primeiro deles, discussão acerca da introdução de novo tamanho de garrafa retornável no mercado, de $630 \mathrm{ml}$, com o logotipo da marca AmBev. A representação foi trazida perante o SBDC por um conjunto de cervejarias e associações - Cervejaria Kaiser (do Grupo Heineken), Cervejaria Imperial, Associação dos Fabricantes de Refrigerantes do Brasil (Afrebras) e Associação Brasileira de Bebidas (Abrabe), tendo sido alegado que a garrafa de $630 \mathrm{ml}$ comercializada no Rio de Janeiro (Skol) e no Rio Grande do Sul (Bohemia) estava fora do padrão de $600 \mathrm{ml}$, o que impedia a reutilização do vasilhame por outras empresas. ${ }^{541}$

\footnotetext{
${ }^{540}$ Processo Administrativo n. 08012.003805/2004-10.

${ }^{541}$ Processo Administrativo n. 08700.001238/2010-57. Representada: Companhia de Bebidas das Américas.
} 
A ação destaca que as garrafas de $630 \mathrm{ml}$ colocavam em risco o sistema de compartilhamento de vasilhames retornáveis vigente no Brasil há muitos anos. Este sistema alegadamente fomenta a livre concorrência, ao permitir que consumidores e varejistas possam escolher livremente entre as marcas de cerveja, já que podem trocar seus vasilhames por quaisquer outros sem qualquer custo adicional.

Neste sentido, trouxeram as representantes argumentos no sentido de que a introdução da nova garrafa pela $A m B e v$ aumentaria artificialmente os custos de suas concorrentes, na medida em que agora seria necessário fazer uma separação entre as garrafas de $630 \mathrm{ml}$ e as comuns, não somente nos pontos de vendas, mas ainda nas linhas de produção. Isso porque não seria permitido a utilização de garrafas de $630 \mathrm{ml}$ da AmBev por seus concorrentes, ao passo que a Ambev poderia continuar se utilizando das garrafas comuns. O custo de estocagem e troca das garrafas recairia, portanto, sobre os concorrentes.

A AmBev alegava, em especial, que as garrafas de $630 \mathrm{ml}$ seriam uma inovação empresarial e proporcionariam ganho de bem-estar ao consumidor, inibindo a pirataria; que os vasilhames de cerveja não seriam infraestruturas essenciais e que a introdução da garrafa não aumentaria os custos de seus rivais ou representaria uma criação de dificuldades artificiais para a sobrevivência deles. A SDE instaurou processo administrativo e acatou pedido de medida preventiva postulado, determinando o recolhimento das garrafas de $630 \mathrm{ml}$ no prazo de 10 dias e a cessação de sua utilização. Após recurso voluntário apresentado pela $A m B e v$, que foi acatado parcialmente pelo CADE, determinou-se a restrição do uso das garrafas de $630 \mathrm{ml}$ às marcas e regiões até então afetadas e a criação de um sistema de trocas.

Em novembro de 2010, a AmBev assinou um acordo com o Conselho Administrativo de Defesa Econômica se comprometendo a interromper a venda das garrafas de $630 \mathrm{ml}$ da marca Skol no Rio de Janeiro em 270 dias, e da marca Bohemia no Rio Grande do Sul em 60 dias. O descumprimento do termo poderia gerar multas diárias, além da reabertura do processo administrativo.

Finalmente, após o acordo firmado entre $A m B e v$ e CADE com relação às garrafas de 630 ml, iniciou-se em 2009 investigação, fomentada por representação apresentada pela Kaiser e Abrabe - Associação Brasileira de Bebidas - contra o lançamento do chamado litrão da AmBev. As concorrentes afirmavam ainda que a empresa havia marcado o vidro 
da garrafa litrão com sua marca, o que seria ilegal em vista da prática de utilização de cascos uniformes. ${ }^{542}$

O Ministério Público Federal opinou, neste sentido, pela condenação da empresa, por entender que a marcação aumentaria os custos das demais cervejarias e dos pontos de vendas, que teriam que armazenar e organizar a devolução das garrafas. Mesmo entendimento trouxe a SDE, tendo, contudo, entendido o CADE que a venda de uma garrafa diferente daquela tradicionalmente compartilhada entre as cervejarias não prejudicava a concorrência, mesmo com a marca da AmBev no vasilhame, motivo pelo qual decidiu pelo arquivamento do processo em maio de 2012.

Vale destacar alguns dos pontos trazidos pelas representantes, bem como argumentos apresentados pelo CADE. Neste sentido, as representantes afirmavam que a AmBev praticava conduta ilegal introduzindo embalagem retornável diferenciada de 1 litro com marca $A m B e v$ impressa, que impedia o intercâmbio de uso de cascos, e que tal prática seria prejudicial à entrada de novos concorrentes. Afirmavam tratar-se de tentativa de atingir os efeitos do antigo programa "Tô Contigo" com a introdução da nova garrafa. Da mesma forma, as representadas requereram a aplicação de medida preventiva contra a AmBev, para que esta se abstivesse de usar garrafas não passíveis de uso de outras cervejarias e para retirada de tais garrafas de circulação. O CADE, contudo, entendeu que não demonstrou a conduta possuir o efeito de gerar danos anticompetitivos, ou efeitos prócompetitivos. Afirmava ainda que a racionalidade da conduta não era exclusiva ou preponderantemente explicada pela sua potencialidade de causar danos aos rivais, e sim por negociação legítima, sendo que uma intervenção nesse caso teria maior risco de desincentivar a concorrência do que fomentá-la.

Indagamos, diante das duas decisões acima mencionadas, cujos fatos possuíam diversas semelhanças, se o erro tipo 1 reconhecido pelo CADE para afastar uma postura mais intrusiva na segunda investigação da mesma forma não se aplicava para o caso anterior, e se de fato havia elementos que justificassem a diferenciação de tratamento emprestada pelo mesmo Conselheiro.

Ainda no que tange a práticas de abuso de posição dominante envolvendo descontos de fidelidade, podemos mencionar processo administrativo instaurado para apurar condutas da BR Distribuidora no Distrito Federal ao conceder benefícios,

\footnotetext{
${ }^{542}$ Processo Administrativo n. 08012.006439/2009-65. Representada: Companhia de Bebidas das Américas.
} 
supostamente lesivos à concorrência, para postos de combustíveis da Rede Gasol. ${ }^{543} \mathrm{O}$ tratamento diferenciado foi observado nos contratos firmados entre 1995 a 2005.

No tocante à conduta investigada, quando o terreno do posto de combustível fosse de propriedade da BR Distribuidora, costumava-se estabelecer contratos de comissão mercantil em que a BR Distribuidora pagava comissão decorrente da venda de combustíveis pelos postos quem com ela mantivessem contrato de exclusividade. Os contratos de comissão mercantil firmados entre a BR Distribuidora e a Rede Gasol eram diferenciados na medida em que esta recebia duas comissões, uma no patamar de $100 \%$ em virtude da execução do contrato e outra de $75 \%$ se a Rede Gasol vendesse maior volume de combustíveis nos postos de propriedade da BR Distribuidora do que nos postos de sua propriedade que ostentavam a bandeira BR Distribuidora, ou de $25 \%$ a título de incentivo quando as vendas de combustíveis fossem maiores nos postos de sua propriedade se comparadas às vendas realizadas nos postos de propriedade da BR Distribuidora. Essa dinâmica comercial foi observada somente nos contratos entre a BR Distribuidora e a Rede Gasol. Os demais postos de combustíveis somente recebiam as comissões mercantis decorrentes da execução normal do contrato.

Some-se a isso o tratamento diferenciado estabelecido por meio dos contratos de aluguéis dos postos de propriedade da BR Distribuidora. A Rede Gasol, por exemplo, pagava aluguéis consideravelmente menores que seus concorrentes. Em alguns casos, postos com localização e área semelhantes aos postos da Rede Gasol pagavam cerca de R \$ 10 mil a mais do que a Rede Gasol. Outro tratamento diferenciado encontrava-se no fato de que a Rede Gasol era isenta de pagamento do IPTU nos postos que possuía contrato de locação com a BR Distribuidora, diferentemente do que ocorria com os demais postos concorrentes, que por estipulação contratual eram obrigados a pagar o IPTU. Por fim, em relação aos contratos de promessa de compra e venda, a BR Distribuidora não estipulava à Rede Gasol volume mínimo de vendas. Por outro lado, para seus demais clientes, a BR Distribuidora estipulava volume mínimo de venda de combustíveis e impunha, nesses casos, multa ou até mesmo rescisão contratual caso o posto não cumprisse a meta estabelecida.

Outros casos de menor relevo passaram pelo SBDC durante o período, tendo sido arquivados por diversas razões, e pouco teriam a contribuir para o presente estudo. ${ }^{544}$

\footnotetext{
${ }^{543}$ Processo Administrativo n. 08012.005799/2003-54.

544 Processo Administrativo n. 08700.003456/2003-05. Representada: Fademac SA. As alegações trazidas informavam que a representada teria aumentado os preços de comercialização de seus produtos - piso
} 


\subsubsection{Exclusividade}

Com relação à exclusividade, não há dispositivo na lei de concorrência que trate especificamente da questão. O tema, contudo, traz em si elemento de fechamento do mercado à livre concorrência através de cláusulas que incentivam, em razão da posição dominante do fornecedor e dependência de seus clientes, a concentração de compras em um único fornecedor. Não obstante, alguns incisos da lei, de tipologia mais aberta, podem embasar a subsunção do fato à norma, como os incisos III: "limitar ou impedir o acesso de novas empresas ao mercado"; IV: "criar dificuldades à constituição, ao funcionamento ou ao desenvolvimento de empresa concorrente ou de fornecedor, adquirente ou financiador de bens ou serviços"; e V: "impedir o acesso de concorrente às fontes de insumo, matériasprimas, equipamentos ou tecnologia, bem como aos canais de distribuição".

Da mesma forma, vale mencionar a tipologia específica trazida pela lei no tocante à exclusividade para publicidade de mídia: "VI - exigir ou conceder exclusividade para divulgação de publicidade nos meios de comunicação de massa". No tocante ao inciso em questão, vale mencionar que em 2000 o CADE condenou as empresas Folha da Manhã S/A e $O$ Estado de São Paulo por práticas contratuais de exigência de exclusividade para veiculação de propaganda publicitária em troca de preço - bonificação - usando de meios fraudulentos para desviar clientela de outrem em proveito próprio, ainda sob a égide da Lei n. $4.137 / 62$, que trazia dispositivo semelhante. ${ }^{545}$

Com relação ao segmento de saúde, mais de uma centena de procedimentos administrativos foram abertos pelo SBDC ao longo da última década contra cooperativas médicas por abuso de posição dominante. Tais cooperativas, na grande maioria das vezes as Unimeds, se beneficiavam de sua posição dominante no seu mercado regional para exigirem exclusividade na prestação de serviços médicos de cooperados. A condenação das cooperativas tem sido uma constante, bem como a determinação para alteração das cláusulas contratuais. Neste sentido foi editada a Súmula n. 07 do CADE: "[c]onstitui infração contra a ordem econômica a prática, sob qualquer forma manifestada, de impedir ou criar dificuldades a que médicos cooperados prestem serviços fora do âmbito da cooperativa, caso esta detenha posição dominante".

vinílico paviflex - devido à redução dos descontos anteriormente concedidos. Tal redução teria se dado em razão de as representantes, sem qualquer contrato de exclusividade, terem resolvido adquirir produtos de mais de um vendedor. $\mathrm{O}$ caso foi arquivado em razão do reconhecimento da prescrição.

${ }^{545}$ Processo Administrativo 08000.000128/1995-98. Representada: S.A. O Estado de São Paulo; e Processo Administrativo 08000.16153/95-89. Representada: Empresa Folha da Manhã S/A. 
Caso já acima referido em virtude de outras condutas tratadas, decidido pelo CADE em 2002 - Messer Griesshem do Brasil Ltda. vs. White Martins -, alegava práticas intrinsecamente relacionadas de suposto comprometimento das fontes de matéria-prima necessárias à produção de gás carbônico, criação de dificuldades ao funcionamento de concorrentes e açambarcamento de matérias-primas. ${ }^{546}$

Para o CADE não restou dúvida de que o primeiro aditamento contratual levado a efeito pela White Martins visava manutenção do controle sobre a oferta de insumos, em especial ao confessar a Representada que a exclusividade sobre os excedentes encontravase acima das quantidades máximas que sua fábrica teria capacidade de produzir, sendo pouco convincente a argumentação de que a absorção dos excedentes estaria ligada aos planos de expansão da empresa. A White Martins, portanto, dispersava no ar o excesso adquirido que não utilizava, com a única e evidente finalidade de afetar e impedir acesso de seus concorrentes à matéria-prima em questão. Concluiu assim o CADE, em 2002, por unanimidade, pelo abuso praticado pela White Martins, condenando-a ao pagamento de multa no valor de $\mathrm{R} \$ 24$ milhões.

Em caso de exclusividade também envolvendo uma Unimed, o Laboratório São Paulo alegava que a Unimed de Ribeirão Preto/SP utilizava-se de exigência de cláusulas de exclusividade para laboratórios prestadores de serviços complementares. ${ }^{547}$ Assim, o mercado relevante envolvia prestação de quaisquer tipos de serviços laboratoriais, no âmbito geográfico da cidade de Ribeirão Preto. Segundo o Conselheiro Relator, "a confirmação de que a Representada utilizava-se da cláusula de exclusividade como o meio mais eficaz de manter a sua posição dominante no mercado, e não apenas como meio de proteger seus cooperados, (...) são, pois, suficientes para concluir que a Representada infringiu os incisos IV, V, VI do artigo 21 c/c o art. 20, incisos I, II e IV da Lei 8.884/94".

Segundo o CADE, o argumento trazido pela Representada de que os contratos regiam-se pelo princípio da liberdade contratual e que não haveria infração não deveriam prosperar, em razão da necessária proteção de interesses difusos como do consumidor, da livre iniciativa e da livre concorrência, e que devem contribuir para o equilíbrio contratual. O CADE decidiu, em setembro de 2001, por unanimidade, condenar a Representada, aplicando multa no valor de $\mathrm{R} \$ 63.846,00$ e outras cominações.

\footnotetext{
${ }^{546}$ Processo Administrativo n. 08000.022579/1997-05. Representada: S.A. White Martins e White Martins Gases Industriais Ltda.

${ }^{547}$ Processo Administrativo n. 08012.006459/1998-31. Representado: Unimed de Ribeirão Preto SA.
} 
Em tempo, caso de destaque no SBDC tratou de investigação acerca da existência de cláusulas de exclusividade na relação entre Visa e VisaNet, relação esta que tornava a VisaNet única credenciadora de estabelecimentos comerciais para aceitação de cartões Visa como meio de pagamento no Brasil e, consequentemente, reduzia a competição no setor de cartões. ${ }^{548}$ Tendo em vista os estatutos da Visa International e a classe de associação da VisaNet ao Grupo Visa, a SDE entendeu existirem cláusulas que tornavam a VisaNet credenciadora única, inviabilizando a existência de credenciadores multibandeira no Brasil. O trâmite do processo foi suspenso em razão da execução de termo de compromisso de cessação celebrado entre as representadas e o CADE em 2002.

O termo firmado estabelecia que a Visa: (i) apresentaria ao CADE requisitos éticos e operacionais a serem preenchidos por interessados no credenciamento da bandeira, devendo os mesmos serem objetivos e não discriminatórios; (ii) publicaria anúncio comunicando a abertura de processo de seleção de novos credenciadores de estabelecimentos comerciais para aceitação de cartões Visa; (iii) disponibilizaria os requisitos éticos, termos comerciais para concessão de uma licença de credenciamento; (iv) iniciaria negociações com candidatos que se mostrassem interessados na concessão de uma licença de credenciamento; (v) concederia licenças de credenciamento aos candidatos que se enquadrassem nos requisitos técnicos e operacionais e que chegassem a acordo quanto aos termos comerciais; (vi) não conferiria status de exclusividade a qualquer credenciador para a realização de afiliação de estabelecimentos para aceitação dos cartões Visa e para credenciamento de transações Visa originárias destes estabelecimentos.

Vale ainda referência a casos trazidos pelas autoridades sobre o tema das cláusulas de exclusividade de atuação geográfica, ou ainda conhecidas como cláusulas de raio, envolvendo shopping centers na cidade de São Paulo. Neste sentido, em 2004 o CADE entendeu, por maioria de votos, que o Shopping Center Iguatemi, na cidade de São Paulo, violou o artigo 20, incisos I, II e IV c/c art. 21 incisos IV e V da Lei n. 8.884/94, ao proibir seus lojistas de se instalarem em quaisquer outros shoppings da cidade, deixando claro que infrações a esta cláusula de exclusividade por parte dos lojistas implicaria rescisão contratual. ${ }^{549}$

O mercado relevante fixado foi de shopping centers de alto padrão nas regiões da Zona Oeste, norte da Zona Sul e oeste da Zona Central da Cidade de São Paulo, restando o

\footnotetext{
${ }^{548}$ Processo Administrativo n. 08000.0022500/96-66. Representada: Visa do Brasil.

${ }^{549}$ PA 08012.009991/1998-82. Representadas: Condomínio Shopping Center Iguatemi e Shopping Centers Reunidos do Brasil Ltda.
} 
poder de mercado inferido a partir do caráter diferenciado do Shopping Center Iguatemi, de sua capacidade de impor preço de locação superior aos demais e de sua parcela de participação no mercado relevante. O Shopping Iguatemi, à época, detinha participação de $30,9 \%$ nas rendas provenientes de aluguel de lojas em shoppings no mercado geográfico relevante e uma participação de $29 \%$ na renda de vendas em shoppings.

O Shopping Iguatemi procurou justificar a cláusula de exclusividade como forma de proteção dos investimentos do empreendimento contra uma popularização das lojas instaladas pelos demais shoppings da cidade de São Paulo, o que afetaria "o conceito de shopping único e diferenciado". Contudo, o CADE concluiu que o Shopping Iguatemi detinha poder de mercado suficiente para limitar a concorrência entre shoppings por meio de dispositivos de exclusividade, reputando a conduta efetivamente ilícita, imputando a prática de infração à ordem econômica e aplicando multa de $1 \%$ de seu faturamento bruto, bem como determinando a imediata cessação da conduta infrativa, retirando-se a cláusula de exclusividade dos contratos que a continham.

A este caso se seguiram diversos outros sobre circunstâncias similares. No início de 2005, o CADE julgou caso de exclusividade similar contra o Shopping Center Norte $(S C N)$, também localizado na cidade de São Paulo, porém em diferente mercado geográfico. O SCN, que detinha participação de 69,9\% no valor do aluguel de lojas e uma participação de $71,6 \%$ no faturamento das lojas em seu mercado relevante geográfico, proibiu seus lojistas de operarem outros pontos de vendas em um raio de mil metros do $S C N .^{550} \mathrm{O}$ CADE considerou esta condição como indevidamente restritiva, multando o Shopping Center Norte em $1 \%$ de seu faturamento bruto. O CADE ainda afirmou que cláusulas de raio não são lícitos per se, mas sua validade estaria verificada quando adstrita a razoavelmente prevenir comportamentos oportunistas e garantir o retorno do investimento sem impor limites não razoáveis à concorrência no mercado relevante.

Caso mais recente de investigação de cláusulas de raio envolveu diversos empreendimentos imobiliários. ${ }^{551}$ Durante o curso deste processo, os representados Administradora PMV S.A., Participações Morro Vermelho S.A. e Condomínio Shopping Jardim Sul firmaram termo de compromisso de cessação com o CADE, no qual se comprometeram a não utilizar em seus contratos de locação cláusulas de raio que

\footnotetext{
${ }^{550}$ Processo Administrativo n. 08012.002841/2001-13. Representado: Center Norte S/A.

551 Processo Administrativo n. 08012.012081/2007-48. Representados: Multiplan Empreendimentos Imobiliários S.A., Saphyr Administradora de Centros Comerciais S.A., Plaza Shopping Administradora Ltda., Condomínio do Shopping Center Morumbi, Condomínio Comercial Villa-Lobos, Condomínio Comercial Shopping Pátio Higienópolis, Administradora PMV S.A., Participações Morro Vermelho S.A. e Condomínio Shopping Jardim Sul.
} 
impusessem aos lojistas restrições territoriais, bem como a excluir as cláusulas referentes a essa restrição dos contratos já existentes. ${ }^{552}$

Em 2008 o CADE condenou também a empresa Celular CRT SA por práticas restritivas à livre concorrência conduzidas nos canais de distribuição para venda de celulares no Estado do Rio Grande do Sul. Segundo foi denunciado à época, a $C R T$ estaria celebrando contratos de exclusividade com grandes empresas da região - pontos de varejo - com tradição no Estado, dificultando o acesso de concorrentes aos canais de vendas de telefones celulares, e elevando os custos dos rivais visto que tais concorrentes precisaram investir na criação de seus próprios canais de distribuição. Segundo afirmou a denunciante Telet S.A., os contratos de exclusividade teriam atingido percentual aproximado de $70 \%$ das vendas efetuadas no mercado do Rio Grande do Sul, sendo ainda maior em algumas cidades do Estado. Durante a investigação, restou incontroversa a existência de contratos de exclusividade, residindo o debate na quantificação do impacto que estas cláusulas tiveram.

Após discussões sobre os índices de segurança para cláusulas de exclusividade, em especial com relação a casos norte-americanos e europeus, o Conselheiro Relator considerou que a conduta de adorar contratos de exclusividade em parte substancial do mercado gerou efeitos negativos, em especial porque as vendas indiretas representavam parte substancial da distribuição no segmento a jusante, significando mais de $80 \%$ das vendas do mercado. Da mesma forma, a Celular CRT era a antiga monopolista no mercado a montante. Diante destes fatos, o CADE concluiu pela existência de efeitos negativos da conduta em razão da dificuldade criada para atuação da concorrência, condenando a representada em multa de $1 \%$ de seu faturamento. ${ }^{553}$

A SDE instaurou em 1998 investigação contra as supostas práticas abusivas da Souza Cruz de firmar contratos de exclusividade com pontos de venda de cigarros. A investigação se originou de reclamação por parte da Philip Morris às autoridades, que alegaram que as práticas da Souza Cruz causavam danos concorrenciais, uma vez que a empresa teria celebrado contratos para que os pontos de vendas não comercializassem produtos de seus concorrentes, bloqueando acesso a parcela relevante dos canais de distribuição do mercado.

A Souza Cruz, por sua vez, alegou tratar-se de disputa privada, e que os contratos da Philip Morris teriam cláusulas semelhantes aos contratos da Souza Cruz, exigindo

\footnotetext{
${ }^{552}$ Requerimento n. 08700.003933/2009-10.

${ }^{553}$ Processo Administrativo n. 53500.000502/2001. Representada: Celular CRT SA.
} 
exclusividade. Após, contudo, o parecer da SDE sugerindo a condenação da Souza Cruz, a empresa firmou acordo com o CADE.

A SDE firmou sua convicção com base em diversos argumentos legais e econômicos. Primeiramente, a SDE notou que havia mais de340 mil pontos de vendas no Brasil e, em razão do baixo valor agregado do produto, a presença em uma parcela significativa destes pontos de vendas representaria uma vantagem competitiva ao incumbente, em especial por representarem os pontos de vendas mais de $90 \%$ das vendas de cigarros. Assim, eficientes canais de distribuição são essenciais para a competitividade do segmento de cigarros e podem caracterizar barreira à entrada no segmento.

Considerando que a Souza Cruz vendia seus produtos em mais de 220.000 pontos de vendas, representando cerca de $65 \%$ deste total, as autoridades concluíram que os contratos de exclusividade teriam efeitos de fechamento do mercado.

Assim, os termos do TCC firmado entre a Souza Cruz e o CADE determinaram a cessação das práticas investigadas e assim, restando a Souza Cruz impedida de impor cláusulas de exclusividade nos seus contratos com pontos de vendas, tendo ainda que alterar as existentes. A Souza Cruz ainda teve de alterar seus contratos de propaganda para inserir cláusula expressamente proibitiva de vendas exclusivas, bem como informar todos os pontos de vendas desta ausência de exclusividade.

Importante frisar que as restrições acima se referiram somente às cláusulas de exclusividade de vendas, mas naquele momento não havia qualquer referência às cláusulas de exclusividade de propaganda.

Consequentemente, em 2005, no contexto e período de cumprimento do TCC, o CADE impôs multa à Souza Cruz por violação ao TCC, em razão de ter a Souza Cruz inserido cláusula de exclusividade sobre exposição de produtos e propaganda no contrato firmado com os pontos de vendas, tendo sido aberta investigação contra a empresa e contra a Philip Morris por tais práticas. ${ }^{554}$

A Procuradoria Geral do CADE considerou que as cláusulas de exclusividade de propaganda estariam cobertas pelo TCC, representando assim quebra de compromisso firmado. Porém, determinou que tais práticas fossem investigadas de maneira mais profunda. O Ministério Público corroborou com a opinião da Procuradoria Geral do CADE de aplicação de multa por violação do TCC.

\footnotetext{
${ }^{554}$ Processo Administrativo n. 08012.003921/2005-10.
} 
O CADE, contudo, voltou atrás na multa imposta pela violação do TCC, principalmente por ter tido acesso anteriormente aos contratos e tê-los aprovados, e em razão de alguns deles se referirem a licitações públicas submetidas à aprovação governamental. A segurança jurídica e boa-fé da empresa que submeteu as minutas dos contratos para aprovação do CADE foram determinantes neste sentido.

Contudo, as investigações sobre as práticas da Souza Cruz e da Philip Morris continuaram. Esta alegava que a empresa não possuía, àquela época, poder de mercado, requisito indispensável à condenação, visto deter menos de $20 \%$ do mercado. Alegava ainda que a prática teria sido implementada pela líder de mercado - Souza Cruz - e que seria seguida por outras empresas atuantes no mercado, como defesa estratégica.

Neste sentido, alegava a Philip Morris que cláusulas de exclusividade que dissessem respeito à exposição de produtos e propaganda, adotadas por concorrentes sem poder de mercado, não deveriam afetar de forma adversa o mercado. Tais práticas somente seriam prejudiciais se e quando adotadas pela própria Souza Cruz, líder do mercado.

A Souza Cruz, por sua vez, alegava que o mercado de cigarros era caracterizado pela fidelidade da marca, e que cláusulas de exclusividade não seriam capazes de prejudicar a concorrência, uma vez que consumidores tenderiam a mudar seu trajeto a fim de procurarem outro ponto de venda que ofertasse sua marca favorita. Ademais, a Souza Cruz afirmava que não havia barreiras à entrada no mercado de cigarros. Assim, exclusividade na propaganda não deveria ser considerada comportamento anticompetitivo.

Em 2011 a SDE emitiu relatório sugerindo a condenação da Souza Cruz e da Philip Morris. De acordo com a SDE, a possibilidade de ganhos competitivos no mercado de cigarros, resultante da implementação de cláusulas de exclusividades com pontos de venda, não seriam suficientes para induzir a entrada de novos agentes no mercado a jusante. Ainda, outros canais de distribuição que não os pontos de vendas, como bares, padarias e centros comerciais, onde não haveria exclusividade, exigiriam investimentos financeiros e tempo. Do que se conclui que cláusulas de exclusividade de propaganda deveriam aumentar as barreiras à entrada no mercado de cigarros, aumentando de maneira desproporcional os custos da concorrência. No caso do Brasil as disparidades entre os grandes produtores e outras empresas acentuavam os efeitos da prática.

Segundo ainda a SDE, sob o ponto de vista da demanda, no caso de a exclusividade de propaganda resultar ainda em exclusividade de vendas, um consumidor teria que desviar de sua rota para achar a marca de sua preferência, ou adquirir uma marca secundária que não reflete sua preferência. Logo, a distribuição era de extrema importância 
uma vez que cigarros são produtos baratos e de consumo rápido, e portanto consumidores não estariam dispostos a dispender tempo e dinheiro para procurarem suas marcas favoritas. Disponibilidade seria um aspecto de vital importância, portanto, concluindo a SDE que exclusividade de propaganda poderia prejudicar a livre concorrência, uma vez que inibia exposição de produtos concorrentes.

Interessante notar que a SDE avaliou que no mercado de cigarros o poder de mercado estaria mais ligado à capacidade dos agentes de aumentarem seus preços do que às suas respectivas participações de mercado. ${ }^{555}$ Assim, a SDE alegou que a Souza Cruz e a Philip Morris teriam posição dominante, podendo agir de forma independente de seus concorrentes, em razão de suas respectivas capacidades financeiras, gama de produtos ofertados e da fidelização de marcada encontrada nos produtos.

A SDE entendeu que as práticas traziam potencial de fechamento de mercado de até $40 \%$ em certos mercados regionais, e de até $65 \%$ em outros mercados. Igualmente, entendeu que as barreiras à entrada no mercado seriam altas em razão do alto grau de investimento necessário em propaganda e canais de distribuição, em razão do baixo valor agregado do produto, que deveria ser ofertado a um grande número de pontos de vendas para se tornar lucrativo. Ademais, havia fidelidade de marca e custos irrecuperáveis relacionados ao mercado.

Após remissão do caso ao CADE, em razão da alta probabilidade de condenação, a Souza Cruz firmou TCC com o CADE em julho de 2012, com validade de 5 anos, pelo qual a empresa se comprometeu a não assinar quaisquer acordos com cláusulas de exclusividade de venda, propaganda ou exposição, bem como alterar os contratos vigentes que possuíssem tais cláusulas. Ainda, não poderia interferir na decisão de armazenagem ou exposição dos pontos de venda, na colocação de displays de concorrentes ao lado do seu, bem como obstruir a visibilidade de displays de seus concorrentes, permitindo a armazenagem de produtos concorrentes em seu display. Da mesma forma, a Souza Cruz se comprometeu a enviar correspondência a todos os pontos de vendas explicando os compromissos acima. Vale mencionar que a Souza Cruz se obrigou ao pagamento de uma contribuição em torno de R \$ 3 milhões.

\footnotetext{
${ }^{555}$ De acordo com a SDE, as participaçoes de mercado à época das Representadas giravam em torno de $80 \%$ para a Souza Cruz e 15\% para a Philip Morris.
} 
Diversas ainda foram as investigações arquivadas pelo CADE que discutiam exclusividade, mas cuja materialidade ou efeitos anticompetitivos não restaram demonstrados. ${ }^{556}$

\subsubsection{Outras Infrações de Destaque}

Tratamos acima daquelas que entendemos ser as mais relevantes e recorrentes condutas unilaterais envolvendo agentes com posição dominante, a fim de tentarmos extrair um padrão de aplicação por parte das autoridades de defesa da concorrência na sua atividade sancionatória. Outras modalidades, contudo, podem contribuir para este exercício, merecendo com isso breve referência.

Neste sentido, alguns casos levados à tutela das autoridades brasileiras envolveram questões de litígio vexatório, ou "sham litigation", e que mereceram modulação pelas autoridades. Vale neste sentido mencionar o caso envolvendo a Box 3 Vídeo e Publicidade Ltda. e Léo Produções e Publicidade, em que a primeira tentou dominar o mercado através de diversas ações judiciais descabidas, muitas com pedidos de liminares baseados em direito autoral inexistente. ${ }^{557}$ Todas as ações, quando analisado o mérito, foram revertidas. O Conselheiro Relator reconheceu a necessidade de dois requisitos para caracterização do ilícito: o primeiro objetivo, envolvendo a ausência de um direito plausível nas ações; e um segundo subjetivo, envolvendo a tentativa de interferir nos negócios de um concorrente diretamente. Assim, foi a Box3 condenada pelo CADE. Outro caso envolvendo práticas de sham litigation envolveu a Siemens, que possuía participação de $85 \%$ no mercado de tacógrafo. ${ }^{558}$ Segundo foi relatado, a empresa teria atuado junto a órgãos administrativos e judiciário para impedir comercialização dos produtos da SEVA, seu concorrente. A suposta ilicitude viria da cumulação de interesses questionáveis, de medidas inapropriadas e de efeitos negativos sobre o mercado. Verificou o CADE, neste sentido, que a conduta seria potencializada em presença de uma empresa dominante no mercado, de um concorrente entrante e com o objetivo de retardar sua

\footnotetext{
556 Averiguação Preliminar 08012.005307/2002-40. Representada Sabre International Inc.; Averiguação Preliminar 08012.003009/2006-49; Averiguação Preliminar n. 08012.007813/2006-05.

${ }^{557}$ Processo Administrativo n. 08012.004283/2000-40. Representadas: Box 3 Vídeo e Publicidade Ltda. e Léo Produções e Publicidade.

${ }^{558}$ Processo Administrativo n. 08012.004484/2005-51. Representada: Siemens VDO Automotive Ltda.
} 
entrada ou forçar saída por meio de ações. Não obstante, entendeu o CADE não terem se verificado práticas de sham litigation, arquivando o caso com relação a esta acusação. ${ }^{559}$

Merece ainda menção decisão do CADE de 2013, em que a empresa SKF fora condenada por fixação de preço de revenda. ${ }^{560}$ Até o referido julgamento, teriam sido esporádicas as avaliações do CADE em cláusulas de fixação de preços de revendas, porém das quais se poderia inferir inexistirem preocupações concorrenciais em casos envolvendo (i) fixação de preços máximos; (ii) mera sugestão de preços; e (iii) fixação ou sugestões de preços de revenda sem que a empresa detivesse poder de mercado, inclusive com relação a preços mínimos.

Na recente decisão de condenação da SKF o CADE, de certa maneira, reviu sua jurisprudência, utilizando-se de critério mais objetivo para avaliação da conduta anticompetitiva. Neste sentido, por maioria entendeu o plenário do CADE que a imposição de preços ou margens mínimas de revenda seriam condutas ilícitas por objeto, conforme permite interpretar o artigo 36 da Lei n. 12.529/11. Em outras palavras, o CADE decidiu que a imposição de preços mínimos e condutas cujo objeto teriam a capacidade e propósito de restringirem a concorrência e, somente em casos excepcionais, dependentes de análise caso a caso, poderiam ser consideradas cláusulas auxiliares à outra conduta racional e, consequentemente, lícita.

Entenderam os Conselheiros, por maioria, que a imposição de preços mínimos seria presumidamente ilegal, cabendo às partes, e não às autoridades, provarem a ausência de poder de mercado, ou alternativamente, eficiências geradas que superassem os efeitos anticompetitivos, invertendo-se desta forma o ônus da prova para os administrados. Às autoridades caberia tão somente provarem a ocorrência do fato, através da existência tácita ou expressa de um acordo de fixação de preço de revenda ou imposição de preços mínimos. Diante da prova material do fato, incidiria presunção relativa de seu caráter ilícito, cabendo à parte rebater tal presunção.

\footnotetext{
559 Outra investigação envolvendo sham litigation se deu no caso 08012.004055/2005-84. Representada: ANGIS - Associação Nacional dos Organismos de Inspeção. Neste caso, a Associação Nacional dos Organismos de Inspeção foi representada por supostas práticas de sham litigation, além de cartel no mercado de serviços de inspeção de veículos com histórico diferenciado. Para que empresas possam atuar neste mercado, faz-se necessário cadastro no INMETRO. Neste sentido, a ANGIS moveu ação declaratória de inconstitucionalidade face à resoluções do Inmetro, com pedido de tutela antecipada, o que impediu o Inmetro de cadastrar novas empresas. Segundo a representante, seria a maneira encontrada pela representada de excluir concorrentes. Porém, o plenário entendeu que havia amparo de direitos constitucionalmente garantidos, arquivando a denúncia de sham litigation, bem como as demais denúncias.

${ }_{560}$ Processo Administrativo n. 08012.001217/2001-44.
} 
Para tanto, o Conselheiro Relator estabeleceu que a presunção restará refutada no caso de: (i) nem o fabricante, nem os distribuidores envolvidos, deterem mais de $20 \%$ de um mercado relevante; e (ii) nenhum dos fabricantes ou distribuidores envolvidos na conduta, conjuntamente considerados, estarem entre os quatro maiores agentes do mercado, se a participação conjunta destes agentes estiver acima de $75 \%$ do mercado relevante. Caso não seja a parte capaz de demonstrar ausência de poder de mercado, deverá provar que a conduta gerou eficiências econômicas (i) que não poderiam ser alcançadas por outros acordos verticais ou através de maneiras menos restritivas, e (ii) que são claramente mais significativas que o potencial negativo por elas gerado; e (iii) que resultem em maiores benefícios aos consumidores, comprovadamente, sem prejuízo ainda de outras eficiências que venham a ser demonstradas.

Mais importante para o presente estudo do que a própria linha de raciocínio trazida pelo CADE neste caso seria a possibilidade de aplicação da teoria dos ilícitos por objeto, algo muito próximo à regra per se norte-americana, porém que admite prova em contrário. 


\section{CAPÍTULO 8}

\section{ANÁLISE APLICADA DA TEORIA DAS RESPONSABILIDADES ESPECIAIS}

\subsection{Análise Comparativa da Teoria do Abuso de Posição Dominante como Elemento de Apoio}

Ao longo dos capítulos anteriores, pretendemos trazer ao conhecimento comum todos aqueles elementos que se reputam de indispensável instrumentalidade para a análise da disciplina do abuso de poder de mercado, procurando apresentá-los na sua essência, por vezes ressaltando pontos de divergência e convergência entre as jurisdições analisadas. Da mesma forma, procuramos identificar precedentes e análises doutrinárias relacionadas ao tema para cada jurisdição, de forma a sistematizá-los, quando possível, a fim de se reconhecer áreas comuns de subsunção dos elementos fáticos ao direito, bem como princípios divergentes de aplicação.

Este exercício inicial se faz de vital importância ao tema, na medida em que se propõe a complementar a teoria das responsabilidades especiais, uma vez que, como vimos, esta não se destina à identificação da concorrência no mérito decorrente da conduta de agentes com posição dominante. Não serve assim ao propósito de isolá-la daquela concorrência predatória ou abusiva eventualmente praticada, razão pela qual nos socorremos de uma análise detalhada da teoria do abuso de posição dominante.

Por certo, ao constatarmos a timidez dos precedentes pátrios com relação à teoria do abuso de posição dominante, incapazes muitas vezes de fornecer orientação clara de atuação, essencial que balizemos uma proposta de aplicação do tema ao ordenamento jusconcorrencial brasileiro levando-se em conta não somente os princípios legais a ele inerentes, mas ainda as diversas especificidades que têm sido utilizadas para orientar a aplicação da lei em outras jurisdições, de forma comparada.

Para que possamos, adiante, sistematizar os testes aplicados pelas autoridades, relevante caracterizar os princípios legais e demais elementos intrínsecos e extrínsecos presentes em cada ordenamento jurídico analisado. Assim, inicialmente trataremos dos seguintes tópicos que, ao nosso entender, contribuem à moldura que é dada por cada jurisdição para aplicação de suas leis concorrenciais: (i) sistema e ordenamento jurídico 
adotados, incluindo preceitos constitucionais e princípios legais aplicados ao sistema jusconcorrencial de cada jurisdição; (ii) organização funcional e estruturação administrativa dos órgãos responsáveis pela aplicação do ordenamento jurídico, incluindo órgãos diretamente envolvidos no processo decisório e no controle de legalidade das decisões; (iii) influência das diversas escolas econômicas na aplicação do direito; (iv) orientação políticopartidária e sua capacidade de influência na aplicação da norma; (v) tradição públicoprivada dos operadores da organização administrativa; (vi) preceitos supranacionais e externos à ótica jus-concorrencial, de integração econômica; tudo sem prejuízo de outras verificações que se insurjam ao longo desta análise.

Primeiramente, com relação ao sistema e modelo de ordenamento jurídico adotados, devemos verificar que os Estados Unidos elegeu, na sua origem, influenciado por sua colonização britânica, o sistema do common law, caracterizado por regras gerais e normativos de tipologia aberta, moldados, contudo, com base em precedentes dos tribunais. Neste sistema, a força dos julgados adquire importância se comparada ao sistema romano-germânico do civil law, mantendo-se maior coerência entre os casos decididos, e exigindo-se debate mais intenso e características particulares para alteração dos julgados consolidados. Verifica-se, assim, ponto de partida para as decisões, e o ônus para alteração dos precedentes é, por vezes, significativamente superior ao verificado na tradição romanogermânica.

Há justificativa para a defesa, portanto, de que o próprio sistema norte-americano do common law é capaz de orientar de forma mais clara a atuação das autoridades, verificando-se mais facilmente um padrão decisório. Parece ainda mais em conformidade com o real propósito das normas de defesa da concorrência, que como já verificamos, trazem tipologia aberta, e consequentemente maior discricionariedade aos operadores do direito.

Dispensável mencionarmos ainda que, em um sistema predominantemente judicializado, tal controle se perpetua de maneira mais natural. Neste sentido, os testes para caracterização do ilícito de monopolização, tentativa de monopolização ou combinação ou conspiração para monopolização tem recebido tratamento coerente por parte dos tribunais americanos ao longo dos anos, de forma evolutiva, até os dias atuais.

Da mesma forma, em razão da modelagem constitucional do sistema norteamericano, sucinta e objetiva, esta não parece influenciar de maneira determinante a aplicação da norma concorrencial. A se mencionar abaixo, a própria influência das escolas econômicas parece emprestar maior significância à atividade das autoridades. 
Na Europa, por sua vez, que adota o sistema continental do civil law no tocante às suas normas supranacionais, vale recordar que a política concorrencial se baseia em cinco pilares tradicionais, consagrados no seu Tratado de origem: (i) a proibição dos contratos entre agentes econômicos que limitem a concorrência; (ii) a proibição do abuso de posição dominante por um ou mais agentes econômicos: (iii) o controle de fusões e aquisições que venha a criar um agente econômico com posição dominante; (iv) o controle de auxílio estatal por Estados-membros a agentes econômicos ou categorias econômicas; e (v) a liberalização de medidas pelos Estados-membros para favorecerem o segmento de infraestruturas nacionais. Ainda, traz relevância singular para a atuação das autoridades na Europa um de seus objetivos reputados primordiais, qual seja o estabelecimento e bom funcionamento do mercado único europeu, que deve primar pela eliminação dos obstáculos para a livre circulação de produtos e serviços.

Recordemos que não obstante os Estados Membros da União Europeia possuam seus próprios sistemas de proteção à livre concorrência, estes devem atuar sempre segundo as orientações da legislação comunitária, não podendo ser empregado qualquer tratamento mais leniente por parte de uma autoridade nacional se comparado ao entendimento da legislação comunitária, salvo especificamente no caso das condutas unilaterais regradas pelo artigo 102 do TFUE, onde não haveria necessidade de convergência. Ainda, permitese que autoridades nacionais possam aplicar legislações locais que protejam interesses outros à proteção da livre concorrência nos mercados, desde que compatíveis com os princípios gerais e demais dispositivos da legislação comunitária.

Com relação ao Brasil, igualmente um sistema de tradição romano-germânica e cuja constituição possui ampla abrangência, vale recordar nosso entendimento acerca do peso empenhado por esta norma fundamental na defesa da concorrência. Como anteriormente discutido, as normas de defesa da concorrência são erigidas à categoria de garantia institucional posta pelo ordenamento jurídico. Seria, portanto, mais do que política pública, merecendo o devido sopesamento quando confrontada com políticas públicas na sua essência. Não poderia, sob esta argumentação, de qualquer maneira dispor o Estado de sua aplicação.

E como garantia institucional que se coloca, reconheçamos ainda a importância da aplicação do princípio da função social aos bens de produção e correlatos. O conceito dos bens de produção viria a substituir a função da propriedade privada, em especial no que tange à realização dos interesses dos indivíduos, reconhecendo, contudo, a organização 
empresarial por detrás da persecução destes interesses, passando a propriedade de bens de produção a ser compreendida como poder de controle.

Aliás, em breve paralelo ao sistema do common law adotado nos Estados Unidos, que coloca grande ênfase na jurisprudência dos tribunais, o tipo aberto da norma de defesa da concorrência no Brasil requer que a autoridade competente, no caso o Conselho Administrativo de Defesa Econômica, exerça fundamental papel na interpretação das normas, trazendo de forma clara e coerente os testes e paradigmas para sua aplicação. $\mathrm{O}$ mesmo se diga com relação à União Europeia, o que nos leva à percepção de que a tipologia aberta, característica das normas de defesa da concorrência, alivia os efeitos que poderiam decorrer da adoção de um sistema de civil law. Por que não dizer, portanto, que as leis concorrenciais trazem aquilo de mais próximo que os sistemas continentais poderiam ter com o common law?

No que tange às diferenças verificadas em razão da organização funcional e estruturação administrativa dos órgãos reesposáveis pela aplicação do ordenamento jurídico, cabe novamente recordar o sistema predominante judicializado norte-americano. Casos são levados ao Tribunal Distrital, revisados por sua vez pelos Circuitos Federais e, finalmente, com relação a pontos legais em disputa, podem ser reexaminados pela Suprema Corte norte-americana.

Conforme já verificado, há uma multiplicidade de atores neste sistema, como os órgãos federais, os órgãos estaduais e partes privadas, todos com competência específica relacionada à tutela da concorrência. Os estados federativos norte-americanos também possuem competência legislativa para editarem norma concorrencial. As duas agências norte-americanas - o Departamento de Justiça e a Comissão Federal de Comércio possuem competência concorrente no que tange à maioria dos diplomas federais. Os estados, governos locais e partes privadas podem, por sua vez, trazer ações tanto no âmbito federal, quanto estadual ou municipal, caso haja legislação neste sentido. Na grande maioria das vezes, as ações judiciais são trazidas por partes lesadas perante o judiciário, ficando a atuação das autoridades concorrenciais especializadas em segundo plano.

Importante ainda se mencionar que, nos casos envolvendo crimes, a decisão deverá se dar pelo tribunal do júri, que se pode arguir, trata-se de decisão menos técnica e mais centrada na percepção pessoal de seus integrantes acerca do caso. A corroborar com esta visão a incrível indústria de seleção de júri existente nos Estados Unidos, com o propósito de trabalhar tais percepções e que tendem a fugir, de certa forma, dos aspectos técnicos da questão. 
No velho continente, por sua vez, há uma atuação mais administrativa do que judicializada num primeiro momento, com a possibilidade de reexame judicial das decisões. A Comissão Europeia é responsável por investigar e decidir os casos dentro de seu corpo administrativo, somente se utilizando do judiciário em questões incidentais e na execução das penas. Contudo, há intenso escrutínio de suas decisões pelo Tribunal de Primeira Instância e pelo Tribunal de Justiça Europeu.

Tal mecanismo revisor, sem qualquer sombra de dúvida, tem sido responsável pela modelagem da atuação da Comissão Europeia nos casos que decide levar adiante, pelo respeito ao devido processo legal, aos direitos humanos fundamentais e ao arcabouço jurisprudencial que determina a correta interpretação dos dispositivos da legislação comunitária ou mesmo das legislações nacionais. Assim, com relação ao controle de legalidade que é efetivamente desempenhado pelo judiciário, vale reconhecer que os tribunais europeus o fazem com maestria, em nosso entender de forma mais apropriada do que verificado nos Estados Unidos, visto que seu próprio sistema difuso dificulta tal revisão quando decisões anteriores já se encontram viciadas na origem, tornando-se, muitas vezes, difícil corrigi-las diante do limitado escopo de revisão das cortes superiores.

Já no Brasil, o sistema encontra-se mais em linha com o verificado na Europa, com uma autoridade administrativa investigando e decidindo os casos dentro de sua própria estrutura, sem que haja atuação substancial litigiosa de partes lesadas perante o judiciário num primeiro momento. A utilização do sistema revisional brasileiro para decisões emanadas das autoridades administrativas, contudo, ainda se verifica bastante disperso e incipiente, com pouquíssimas decisões transitadas em julgado. Assim, o judiciário brasileiro ainda é incapaz de moldar a atividade das autoridades administrativas, verificando-se hoje, não obstante alguma evolução neste sentido, abusos ou desrespeitos a princípios processuais básicos que acabam por influenciar o próprio mérito das decisões.

$\mathrm{O}$ terceiro item a ser analisado diz respeito à influência de escolas econômicas nas jurisdições em questão, principalmente nos Estados Unidos, amplamente por elas influenciado. Natural que o fosse, visto ter sido o berço destas teorias em razão de seu pioneirismo na adoção de normas de defesa da concorrência. A ideia do pêndulo que gravita sobre a atividade concorrencial ainda hoje é defendida, marcada por vezes como política intervencionista que se assemelha ao pensamento de Harvard, outras vezes calcada nas ideias fundamentalmente liberalistas enraizadas nos modelos de Chicago e suas evoluções. Referido pêndulo encontra-se ainda atrelado aos dogmas políticos predominantes em momentos históricos diversos, de certa forma aludindo-se à captura por 
parte da função jurisdicional administrativa, o que, ressaltamos, não deva ser reconhecido como privilégio deste ramo do direito.

No tocante à Europa e mesmo ao Brasil, vale dizer que as escolas econômicas não influenciaram significativamente e de forma direta a atividade concorrencial, a exemplo do ocorrido nos Estados Unidos. Não obstante, entendemos que a efetiva atividade deste último e suas prioridades na aplicação da norma, bem como sua advocacia para a globalização da matéria, tenham por sua vez influenciado a atividade jus-concorrencial brasileira, trazendo com isso, indiretamente, certa carga ideológica de tais escolas econômicas. Já a União Europeia sempre nos pareceu mais fiel ao seu ideal de expurgo dos desvios e dos abusos a fim de proporcionar um bom balanceamento para promoção do mercado comum, menos inclinada aos preceitos das escolas em questão.

No tocante à importância de orientações político-partidárias em exercício, estas são capazes de guinar o foco da exequibilidade da lei, principalmente na medida em que opções estratégicas devem ser feitas por conta de escassez de recursos disponíveis. Assim, em princípio nos quer parecer que a política concorrencial norte-americana pode assumir feição mais liberal ou conservadora, variando com isso o peso que deve desempenhar a mão do Estado, de acordo com a sua orientação política, certamente guiada por sua economia cíclica. Os próprios guias elaborados pelos Estados Unidos parecem permitir que a autoridade foque, e esclareça aos seus administrados, sua política concorrencial. Tal prerrogativa é de vital importância para que possa haver, ainda, sinalização no complemento privado da atividade concorrencial norte-americana.

De certa maneira, o mesmo se verifica com relação à Europa, no tocante à elaboração de seus guias. E não poderia deixar de ser, visto que o mesmo permite alocação mais eficiente de recursos, na persecução daquelas infrações supostamente mais lesivas e que merecem mais imediato reparo. Contudo, parece sofrer menos a influência política, e mais a influência técnica, visto haver significativa isenção da Comissão Europeia para formulação de suas políticas concorrenciais. O Parlamento Europeu, que poderia de fato exercer tal pressão política, possui atuação relativamente tímida neste tocante.

No Brasil, muito se discute a influência política nas autoridades de defesa da concorrência. Ainda que se possa elencar situações em que esta pareça de certa forma se insurgir, ${ }^{561}$ no geral parece haver isenção dos Conselheiros na tomada de suas decisões.

561 Naquilo que se poderia utilizar para discussão acerca da influência política, se discute a tentativa de
recurso ao Ministro da Justiça nos primórdios da atuação do CADE (Pedro Dutra, Conversando com o
$C A D E$ ), as políticas de formação de campeões nacionais do início dos anos 2000, a livre exploração de 
Algo que muito se discute vem no sentido da elaboração de guias que possam direcionar, de forma mais clara, a política concorrencial brasileira. Vislumbramos, contudo, certa divergência no tocante à possibilidade de fazê-lo, visto não dispor a autoridade brasileira de discricionariedade para persecução de infrações ou crimes, sob pena de responsabilidade criminal por prevaricação. ${ }^{562}$

Com relação às questões de maior interação entre os setores públicos e privados, no sentido de se avaliar se haveria rotação com relação aos encarregados da aplicação da lei concorrencial, devemos considerar que tal prática se verifica constante nos Estados Unidos, e praticamente em regime de exceção na Europa, onde os funcionários tendem a ser carreiristas. Já no Brasil, houve tempos em que tal rotação se mostrava mais constante, encontrando-se atualmente rara.

Em nosso entender, se por um lado uma autoridade composta na sua grande maioria de técnicos carreiristas pode contribuir para a continuidade e consistência de sua atuação, que são valores essenciais na atividade em questão, por outro se corre o risco de certo isolamento na sua atuação, promovendo-se muitas vezes dificuldades na atuação dos administrados. Muitas vezes se perde até mesmo a riqueza dos detalhes nas discussões quando ausentes a divergência e o debate.

Por fim, no que tange aos preceitos supranacionais e externos à ótica jusconcorrencial, de integração econômica, recordemos a perspectiva de aplicação da lei europeia segundo objetivo do livre mercado interno comum, preocupando-se com a eliminação dos obstáculos para a livre circulação de produtos e serviços. Conforme anteriormente defendido, as normas de defesa da concorrência europeias, apesar de encontrarem seus pilares e assemelharem-se a diplomas de outras jurisdições, neste quesito assumem feição particular, conforme podemos reconhecer da revisão de seus precedentes. Por vezes decisões parecem demasiadamente restritivas sob o ponto de vista da defesa concorrencial, mas perseguem maior acomodação das práticas para balanceamento de efeitos nos diversos países do bloco.

Todos os elementos acima contribuem para a diferenciação no tratamento das condutas de abuso por parte das autoridades norte-americanas e europeias, e por que não dizer, brasileiras. Aqui, certamente a forma modifica o conteúdo. Um sistema judicializado e descentralizado, muitas vezes organizado por autoridades não carreiristas com

monopólios por empresas com participação estatal, bem como o poder de controle e as políticas públicas desempenhados pelo BNDES.

${ }^{562}$ Artigo 319 do Código Penal. 
experiência na prática privada e muitas vezes decidido de forma menos técnica - por um júri popular -, fortemente baseado em precedentes diante de uma tipologia extremamente aberta e influenciado por teorias econômicas mais liberais, não imune à influência política de seu tempo, tende a sugerir uma orientação mais permissiva nos preceitos executáveis e em termos de política concorrencial do que um sistema administrativo centralizado, civilista na sua essência apesar de também aberto no tocante à sua tipologia, mas organizado por autoridades carreiristas e constantemente modelado pela revisão judicial constante e firme, menos influenciado por teorias liberais econômicas e menos politizado.

O sistema jus-concorrencial brasileiro inegavelmente parece se situar mais próximo ao sistema europeu, ao menos no tocante ao seu diagnóstico. O que equivaleria a dizer que seu padrão de aplicação deveria se alinhar mais aos preceitos europeus do que aos americanos, conforme se discute adiante.

Vale, por fim, ponderação ideológica acerca da existência de eventual crise institucional envolvendo políticas concorrenciais muitas vezes não convergentes aplicadas pelas mais diferentes nações do globo. Ao assumirmos que o seu conceito e princípios deveriam estar ancorados em raízes econômicas, e supondo para tal fim uma influência similar das teorias econômicas - o que já vimos anteriormente não se verifica - , tal convergência seria esperada. Por outro lado, se outros fatores forem trazidos a bordo para seu mecanismo de sistematização, seria plausível esperar-se divergência em temas específicos. E parece ser o que ocorre no caso. Conclusão é que a concorrência passou a representar importante e eficaz instrumento de política desenvolvimentista e social das nações que a adotam. Assim, não nos parece sensato esperar absoluta convergência, pois na prática são diversos os elementos aplicados em cada jurisdição, em razão de divergente natureza de suas realidades.

Feitas as considerações iniciais que pontuam questões de extrema relevância, mas que raramente são consideradas quando se fala ou se cobra convergência ou divergência de atuação entre as jurisdições, principalmente a europeia e a norte-americana, mas incluindose percepção sobre o sistema brasileiro, passemos a tratar do caso Microsoft e suas diversas expressões, que muito bem ilustram os temas acima e contribuem para nossa melhor compreensão sobre os diferentes parâmetros de aplicação da lei de concorrência nos dois lados do Atlântico. 


\subsection{Os Casos Microsoft: Análise Comparativa Aplicada}

\subsubsection{Caso Microsoft nos Estados Unidos}

Três principais casos envolvendo a Microsoft nos Estados Unidos podem ser descritos para fins comparativos de parâmetros utilizados pelas autoridades norteamericanas vis-a-vis os parâmetros reconhecidos em outros casos envolvendo a mesma empresa na Europa e no Brasil. Por vezes, circunstâncias fáticas se repetem ou se assemelham, nem sempre implicando o mesmo tratamento e, mais ainda, o mesmo resultado. Servem, portanto, de precisa base comparativa e que permitirá melhor sistematização dos tratamentos emprestados pelos diferentes sistemas jurídicos.

O primeiro caso envolvendo investigação de abuso de poder de mercado nos Estados Unidos contra a Microsoft se deu no início dos anos 90, com a comercialização de um programa de interface gráfica com o utilizador que se sobrepunha ao sistema operativo, tornando sua operação mais fácil e intuitiva. Vale dizer que para operação dos computadores há necessidade de uma unidade central de processamento ou microprocessador, um sistema operativo e os programas informáticos adequados às tarefas que o utilizador pretende realizar. Cada computador possui ao menos um microprocessador e um sistema operativo, podendo o utilizador optar por diversos programas destinados à realização de tarefas específicas ou aplicações, como processamento de texto.

Anteriormente ao cenário acima, quando a $I B M$ lançou o computador pessoal, recorreu a duas empresas para fornecerem uma plataforma conjunta: a Intel, para processador (Intel 8080), e a Microsoft, para o sistema operativo. O sistema operativo (SO) da IBM baseava-se no CP/M desenvolvido em 1976 pela Digital Research Incorporation, para o processador Intel 8080, sendo que em 1980 a Microsoft adquiriu, por USD 100 mil, os direitos exclusivos sobre um programa derivado do CP/M, chamado Disk Operating System (DOS), que após algumas modificações se transformou no MS-DOS primitivo. Para combater o problema da dificuldade operacional dos computadores, começaram a surgir programas concebidos para tornar a interação do operador mais acessível e intuitiva, o primeiro deles sendo o Windows. ${ }^{563}$

A Digital Research Incorporation, adquirida pela Novels, continuou lançando versões do DOS, conhecidos como DR-DOS, que concorriam com o MS-DOS. Verificava-

\footnotetext{
563 Antes do lançamento do Windows 95 havia versões com utilização do MS-DOS e Windows,
} conjuntamente. 
se à época que o DR-DOS capturava parcela de $10 \%$ de mercado, a $I B M$, através de seu PC-DOS, com 18\%, e o MS-DOS, da Microsoft, com cerca de $70 \%$ do mercado. Para responder ao sucesso momentâneo de lançamento do DR-DOS, a Microsoft anunciou, após um mês de lançamento daquele, o lançamento de nova versão do MS-DOS, o que acabou ocorrendo somente um ano após o anúncio. Um pouco antes disso, a Microsoft lançou ainda nova versão do programa de interface gráfica do utilizador Windows. Nos dois anos subsequentes a Microsoft alcançou participações de mercado que beiravam os $80 \%$, considerando-se o segmento de SO para IBM-PCs.

Uma investigação inicial conduzida pelo FTC teve por objeto analisar: (i) o alegado favorecimento das aplicações da Microsoft através da não divulgação de informações relativas às características do seu sistema operativo; (ii) a prática de vaporware, que consistia em anúncio prematuro de novas versões do seu sistema operativo de modo a dissuadir utilizadores de outros sistemas; (iii) subordinação da licença do seu sistema operativo à licença de seus aplicativos; (iv) a exigência de royalties por cada processador vendido, independentemente de possuir o computador o MS-DOS.

Por decisão da maioria dos Comissários do FTC não foi aberto processo formal de investigação. Porém o DOJ avocou a investigação que acabou com um acordo com a Microsoft em junho de 94. O acordo tinha por objeto estipular as condições contratuais das licenças, as quais permitiam uma manutenção da posição dominante no mercado de sistemas operativos. Verificaram-se ainda acordos de confidencialidade impostos pela Microsoft às empresas que recebiam versões preliminares do MS-DOS e Windows. O mercado relevante foi definido como mercado de sistemas operativos para PCs que utilizavam processadores Intel x86 ou equivalentes, sob a dimensão geográfica mundial, que traziam níveis de participação de mercado da ordem de $70 \%$ para a Microsoft. Este mercado era ainda sujeito a externalidades de rede, caracterizada: (i) por elevado custo de desenvolvimento de um novo sistema operativo; (ii) pela inexistência de um conjunto de aplicações com alta qualidade que concorressem com o novo sistema operativo: (iii) pela dificuldade de convencimento de produtores de aplicações independentes a desenvolvê-las; (iv) pela inexistência de uma base instalada de utilizadores; e (v) pela dificuldade de convencimento dos fabricantes de computadores a oferecerem e promoverem novo sistema operativo que não o da Microsoft. Assim, os efeitos de rede reforçavam as barreiras à entrada neste mercado.

O DOJ reconheceu a posição de monopólio da Microsoft como resultado de vantagens fortuitas e da sua superioridade em termos de estratégia comercial. Ainda, 
segundo uma análise dos efeitos de rede, atribuiu-se importância decisiva a acontecimentos aparentemente insignificantes que fizeram o mercado rumar na direção de determinado sistema. Assim, "as práticas imputadas à Microsoft seriam então o grão de areia que fez pender decisivamente a balança do mercado a seu favor". 564

Neste cenário, o DOJ foi bastante cauteloso nas suas conclusões, considerando que a posição da Microsoft foi resultado de uma decisão da $I B M$, de uma gestão bemsucedida e da qualidade dos seus produtos que decidiram a batalha pelo sistema operativo do IBM-PC. Entendeu que as práticas da Microsoft apenas reforçaram sua posição na medida em que promoveram elevadas barreiras à entrada, dissuadindo a inovação de terceiros.

O objeto da investigação levada a efeito pelo DOJ dizia respeito à adoção de cláusulas restritivas da concorrência junto aos fabricantes de computadores, levando ao encerramento deste canal de distribuição aos seus concorrentes no mercado de sistemas operativos. Assim, havia imposição aos fabricantes para venderem seus computadores com sistema operativo da Microsoft, visto que os royalties se aplicavam por cada processador vendido, independentemente de estarem ou não com o sistema da Microsoft acoplado. ${ }^{565}$ Da mesma forma, investigavam os acordos de confidencialidade firmados com programadores que os inibiam de trabalhar com sistemas concorrentes durante longo período de tempo.

Pelo acordo firmado com o DOJ, a Microsoft ficou proibida de celebrar licenças por processador com seus licenciados, de obrigá-los a pagar quantia fixa por licença, de lhes impor quantia mínima a ser adquirida, de celebrar contratos de licença por períodos superiores a um ano e de subordinar a compra dos seus sistemas operativos a aquisição e distribuição de outros produtos Microsoft. ${ }^{566}$

Já no segundo caso investigado nos Estados Unidos contra a Microsoft, apurou-se a conduta do monopolista que teria começado a exigir dos fabricantes de computadores a instalação do seu programa de navegação na internet, o Internet Explorer, sob a ameaça de não licenciar a tais fabricantes o seu sistema operativo Windows 95. O DOJ decidiu solicitar aos tribunais norte-americanos sua condenação por desrespeito à decisão judicial

\footnotetext{
${ }^{564}$ MOURA E SILVA, Miguel. O Abuso de Posição Dominante na Nova Economia, cit., p. 477.

${ }^{565}$ As práticas em questão tornavam a opção por um sistema de terceiros menos atrativa, na medida em que já pagava pelo MS DOS. As justificativas objetivas apresentadas pela Microsoft não foram suficientes para a descaracterização da conduta, e tratavam do controle da pirataria e discriminação entre fabricantes.

${ }^{566}$ Interessante comparação seria a posição dominante exercida pela IBM vis a vis a exercida pela Microsoft. No último caso, parece mais sólida a posição dominante deste agente por conta dos efeitos de rede que caracterizam o mercado em que opera. Verifique-se, em corroboração com este argumento, que o poder da IBM foi, aparentemente, contestado.
} 
que aprovara o acordo feito em 1995, pretendendo-se obter uma medida judicial que proibisse a Microsoft de obrigar fabricantes de computadores a incluir o Internet Explorer como condição para o licenciamento do seu sistema operativo, bem como obrigá-la a informar consumidores que não eram obrigados a utilizar seu programa de navegação.

Não obstante a decisão em primeira instância favorável à Microsoft, análise mais substancial do caso se deu no Circuito Federal, onde se discutiu se os dois programas constituíam um único produto ou produtos diversos. A Microsoft argumentava que o Internet Explorer era um simples melhoramento do Windows 95, o que foi acolhido pelo Tribunal. O Tribunal ainda reconheceu que, se os produtos pudessem ser integrados pelo próprio licenciado, a integração seria fraudulenta, e os produtos, considerados distintos entre si. ${ }^{567}$

Assim, o acórdão considerou comprovados os benefícios da integração, em termos de ganho de eficiência que beneficiavam o próprio consumidor, admitindo a existência de benefícios decorrentes da integração do sistema operativo com o programa de navegação.

Pouco antes da decisão do segundo caso da Microsoft, acima ilustrado, o DOJ promoveu ação judicial contra a empresa, aduzindo a monopolização do mercado de sistemas operativos para PCs com processadores Intel, através de conjunto de comportamentos de exclusão dirigidos ao programa de navegação comercializado pela Netscape, o Navigator, bem como contra as tecnologias desenvolvidas pela Sun, denominada Java. Segundo o DOJ, a Microsoft há vários anos possuía posição dominante - cerca de $80 \%$ dos sistemas para PCs-Intel - sendo ainda instalada em 90\% das novas máquinas colocadas no mercado. Da mesma forma, o mercado era caracterizado por elevadas barreiras à entrada e por efeitos de rede, sendo que a atratividade de um novo sistema dependeria do número de aplicações compatíveis com este sistema, e vice-versa. Também para se permitir o desenvolvimento de aplicações, produtores de sistemas operativos deveriam divulgam parte do código essencial para a interação funcional entre os dois programas.

O Navigator era programa de navegação de internet que utilizava as próprias APIs - application programming interface - e poderia correr num ambiente próprio, independentemente do sistema operativo em que se situava. A Nestcape contava com cerca de $70 \%$ de participação em termos de utilização, e estava levando a cabo uma estratégia de

\footnotetext{
${ }^{567}$ Interessante notar que o Tribunal se impressionou com a inoperabilidade do sistema uma vez retirado o Internet Explorer. Contudo, deve-se considerar que tal ocorre em razão da programação de códigos da Microsoft, portanto a essência da conduta lesiva.
} 
plataformas múltiplas que, ao expor as APIs para os programadores de aplicações, permitia tornar os consumidores indiferentes ao sistema operativo, criando para a Microsoft o risco de indiferenciação ou comoditização de seu sistema. Assim, a própria Netscape consistia em plataforma alternativa ao Windows na medida em que permitia aplicações próprias capazes de correrem em PCs-Intel, independentemente do respectivo sistema operacional.

Em razão da ameaça, a Microsoft começou por propor à Netscape, em 1995, um acordo de partilha de mercado. Diante da negativa, a Microsoft colocou em prática uma estratégia de combate, sendo que o ponto principal passava pela utilização da posição dominante no mercado dos sistemas operativos para promover seu próprio programa de navegação - o Internet Explorer. Houve até mesmo reconhecimento, por parte de executivos da Microsoft, de que seria muito difícil adquirir participação de mercado de navegação com base no mérito, devendo-se focar numa alavancagem do sistema operativo. Assim, a Microsoft investia de forma pesada no desenvolvimento do Internet Explorer e o distribuía gratuitamente.

Adotou ainda outras estratégias como: (i) pagamentos a outras empresas para distribuição do IE em lugar do Netscape; (ii) exigência aos fabricantes de instalação prévia do IE nos seus computadores, subordinando o licenciamento do SO à distribuição do navegador da Microsoft; (iii) integração do IE com o Windows 98, impedindo ainda os fabricantes de excluí-los; (iv) acordos com fabricantes para que estes não pudessem alterar a sequência de inicialização mediante introdução de outros ícones de produtos que não fossem originários da Microsoft, celebrando acordos com ISPs. Um destes acordos consistia em colocar a Microsoft suas conexões no Internet Wizard Conexion e, em troca, estes distribuiriam quase que exclusivamente o IE. A própria Microsoft possuía um ISP, o MSN, mas negociava com as demais, colocando-os em posição de destaque apenas para prejudicarem seus concorrentes. O mesmo com relação aos prestadores de serviços de conteúdo para a Internet (ICPs), sendo que a Microsoft os promovia incluindo-os no desktop Windows em troca da promoção exclusiva do IE.

Importante ainda consideração sobre os efeitos de rede em mercados da nova economia, envolvendo tecnologias de inovação, como os ora discutidos. Tais efeitos de rede podem ser manipulados de tal forma a gerarem efeito semelhante a uma falha natural de mercado, e que justificam, enquanto não haja evolução e convergência de tecnologia apta a mitigar tais efeitos, intervenção por parte das autoridades de defesa da concorrência.

A tese do DOJ era no sentido de que as práticas da Microsoft reduziam os incentivos à inovação. Assim, o comportamento tinha como efeito impedir a concorrência 
pelo mérito entre os programas de navegação da Internet, impedir a concorrência potencial das plataformas alternativas em face dos SOs da Microsoft, estender seu monopólio no mercado destes sistemas ao mercado dos programas de navegação na Internet e, por fim, preservar o monopólio nos sistemas operativos para PC-s Intel.

Era inegável a presunção de posição dominante exercida pela Microsoft, a qual, em nenhum momento, foi por ela refutada. ${ }^{568}$ A Microsoft, contudo, argumentava que, em mercados dinâmicos e em rápida evolução, deve-se fazer prova direta do poder de mercado, propondo análise do Índice de Lerner, para que se determinasse se o preço estava acima do nível de custos marginais. O tribunal acatou a posição de dominância da Microsoft, principalmente em decorrência de seu poder de aumentar o preço do Windows sem ter em conta os preços dos seus concorrentes.

Os vários comportamentos adotados pela Microsoft de forma a evitar o aparecimento de uma plataforma que fizesse frente ao seu SO constituíam, no entender do Juiz Jackson, conduta tendente a preservar seu poder de monopólio por meios anticoncorrenciais. Após procurar a Netscape para uma composição, a Microsoft promoveu estratégia de retaliação que consistia em acordar com empresas que formavam os canais mais eficazes de distribuição a promoção do IE em detrimento do Netscape. Entre as práticas mais censuráveis estava a subordinação de licenciamento do Windows à distribuição do IE e a limitação da possibilidade de reconfiguração do Windows 95 e 98 de forma a impedir o Navigator como programa preferencial. Some-se a tudo isso a falta de apresentação de qualquer justificativa comercial legítima para as práticas elencadas.

Também se verificou repressão à conduta da Microsoft em limitar a interoperabilidade entre o seu SO e o sistema JAVA, na medida em que esta oferecia uma linguagem de programação que transformaria o Nestscape em plataforma alternativa ao Windows. Esta prática criava incentivos para que os programadores utilizassem somente a execução Windows para seus aplicativos, de modo a garantir maior disseminação de seus produtos. O comportamento da Microsoft era indubitavelmente irracional sob o ponto de vista econômico, sendo a única justificativa para tanto a exclusão de seus concorrentes.

A decisão condenatória em primeira instância chegou ao Circuito Federal, que por sua vez afirmou sua desconfiança em proceder a análises tão exigentes sob pena de

\footnotetext{
${ }^{568}$ Poder de mercado da Microsoft, em SO, sempre se situou acima dos $90 \%$ durante toda a década de 90 . Se alargado a todos os SOs, incluindo Apple, sua cota cairia para $80 \%$. Dois outros fatores considerados eram os efeitos de rede e barreira das aplicações (MOURA E SILVA, Miguel. O Abuso de Posição Dominante na Nova Economia, cit., p. 492).
} 
arrefecimento da concorrência em função da inovação que caracterizava os mercados em tela:

\begin{abstract}
Whether any particular act of a monopolist is exclusionary, rather than merely a form of vigorous competition, can be difficult to discern: the means of illicit exclusion, like the means of legitimate competition, are myriad, The challenge for an antitrust court lies in stating a general rule for distinguishing between exclusionary acts, which reduce social welfare, and competitive acts, which increase it. ${ }^{569}$
\end{abstract}

No esteio da transcrição acima, questiona Miguel Moura acerca dos princípios a se adotar:

\begin{abstract}
Contudo, fica ainda por esclarecer que princípios devemos então aplicar, para realizar essa distinção pretendida pela lei. Em síntese, o Círculo Federal estabelece um requisito probatório pesado e preliminar para quem arguir a ilicitude da prática: deve ser demonstrado um "efeito anticoncorrencial", na acepção de prejudicar o próprio processo concorrencial e, dessa forma, também os consumidores. Sem tal prova o caso deve ser imediatamente decidido a favor da ré: se o tribunal não esta convencido da existência de um dano, direto ou indireto, para os consumidores, não se coloca sequer a questão de distinguir entre "boa" e "má" conduta - o desvalor fica dependente da probabilidade de um resultado contrário ao processo concorrencial. ${ }^{570}$
\end{abstract}

Uma vez ultrapassado o requisito preliminar da verificação de um efeito anticoncorrencial, pode a ré apresentar justificativa objetiva para seu comportamento e, caso aceita, caberia ao autor demonstrar que no balanceamento não supera os efeitos anticoncorrenciais. Em rápida reflexão, podemos admitir trazer o método acima viés de certa forma favorável à empresa monopolista, uma vez que não se exigiria a consideração de outras variáveis geralmente levadas em conta em uma análise antitruste, como a prova de que a restrição seria necessária para atingir tais benefícios e prova da ausência de alternativas menos restritivas. Ainda, nos quer parecer que a prova sobre o elemento subjetivo é deixada, sob este viés, para segundo plano.

Contudo, mesmo com um critério mais exigente para estabelecer-se a existência de um ilícito em termos de integração tecnológica, o Tribunal decidiu pela condenação, nos três casos objeto do recurso: (i) exclusão do IE do comando do Windows, o qual permitiria a adição ou remoção de aplicações; (ii) a concepção do browser supletivo que

\footnotetext{
${ }^{569}$ US v Microsoft (Microsoft III) (DC Cir 2001).

${ }^{570}$ MOURA E SILVA, Miguel. O Abuso de Posição Dominante na Nova Economia, cit., p. 500.
} 
não o IE; e (iii) a integração recíproca do código relativo a outros ficheiros contendo código do IE, o que levaria a pôr em xeque o funcionamento do próprio SO.

Já com relação à investigação de subordinação do IE com o Windows 95 e 98, deve-se recordar que a jurisprudência da Suprema Corte exigia, para a caraterização de abuso nesta seara, a presença de dois produtos distintos, a não disponibilização a clientes da alternativa de aquisição do produto subordinante sem o subordinado, efeito em volume substancial do comércio interestadual e, finalmente, poder de mercado com relação ao produto subordinante. ${ }^{571}$

Assim, o Circuito Federal aceitou justificativa objetiva da Microsoft para a integração. ${ }^{572}$ A subordinação englobava: (i) vinculação dos licenciados do Windows 95 e 98 à licença do IE, cobrando preço único; (ii) recusa em autorizar fabricantes de computadores a retirar o IE ou seu ícone do desktop Windows; (iii) a concepção do Windows 98 de modo a impedir os consumidores de retirarem o IE utilizando o utilitário genérico para estas operações, restando a programação do Windows configurada de modo a se sobrepor à escolha do consumidor em termos de browser supletivo.

Com relação à análise do requisito de distinção dos produtos, devemos notar que uma complementariedade funcional não implica tratar-se de único produto. O que deve ser avaliado é se haveria procura específica para cada um deles, utilizando-se evidências diretas e indiretas para tanto. O Tribunal concluiu que empresas só oferecem bens em conjunto quando as economias resultantes da oferta conjunta ultrapassam os custos de uma escolha individual, porém recusa-se a entrar num debate de ganho de eficiência, restando satisfeita com o resultado da prova indireta, mas admitindo a necessidade de balanceamento dos ganhos e potenciais efeitos lesivos.

O Tribunal tentou ainda excluir a integração tecnológica do âmbito das subordinações, devido aos riscos de erros tipo 1 que venham a dissuadir inovações, sugerindo tratamento mais permissivo ao agente monopolista neste mercado de inovação.

\footnotetext{
${ }^{571}$ Eastman Kodak Co. v. Image Technical Services, 504 US 451 (1992).

572 Segundo o Juiz Jackson em crítica à decisão, não foram provadas as justificativas e não foram balanceados os alegados ganhos de eficiência e potenciais efeitos anticompetitivos. Contrariam, segundo ele, as decisões de Eastman Kodak e Jefferson Parish. Aparentemente no caso Kodak a Suprema Corte rechaçou análises puras de modelos econométricos, frisando a importância de se verificarem as efetivas realidades comerciais presentes. No caso Microsoft, parece haver ignorado que os consumidores mediam os programas pela sua funcionalidade e inovaram como o código do programa é estruturado e subdividido. Segundo ele havia evidência de procura específica dos navegadores descasada dos SOs. Também o volume de comércio afetado era demonstrado com base nos prejuízos da Netscape. Havia ainda imposição do IE aos consumidores, sendo que as OEM acabavam pagando parte do preço. O Juiz Jackson entende as preocupações adjacentes ao acórdão, mas não encontrou justificativas para contradição aos precedentes da Suprema Corte. O Tribunal também não aplicou a regra per se, utilizando-se a rule of reason, em contradição com os precedentes da Suprema Corte.
} 
Com relação à tentativa de monopolização no mercado de browsers, vale lembrar que o Sherman Act não apenas pró́be a monopolização como também a tentativa de monopolização, exigindo-se, além de uma conduta anticoncorrencial ou predatória, dolo específico e uma probabilidade perigosa de o resultado vir a ser alcançado. Neste quesito o acórdão da primeira instância foi anulado por se considerar insuficiente a prova produzida pelo DOJ, em especial a indefinição quanto ao mercado relevante, uma posição um tanto quanto formalista. $^{573}$

Por fim, houve absolvição ainda na primeira instância, pelo Juiz Jackson, quanto aos acordos de exclusividade firmados com vários canais de distribuição, sublinhando a facilidade com a qual a Netscape poderia ser distribuída pela Internet. Aqui seria necessário provar, segundo o juiz, a exclusão da Netscape de todo o mercado e não apenas dos canais mais importantes.

Vale notar ainda que, em primeira instância, o Juiz Jackson proferiu medidas impositivas extremas, como a separação estrutural da Microsoft entre uma empresa de sistemas operativos e outra dedicada ao negócio de aplicações. Houve até mesmo tentativa de mediação através do Juiz Posner, que não foi aceita pela Microsoft. As justificativas para a imposição das medidas vieram na seguinte linha: (i) a Microsoft não reconheceu que infringiu o Sherman Act; (ii) os autos indicavam que a conduta da Microsoft continuava a ocorrer e poderia mesmo vir a estender-se a outros mercados; (iii) o Juiz Jackson considerou que a Microsoft não mereceria confiança, atendendo ao comportamento de pretenso cumprimento das medidas de outros processos; (iv) ampla prova produzida, não havendo razão para delongas no procedimento.

Os problemas encontrados pelo Circuito Federal na sentença do Juiz Jackson foram a ausência de contraditório da Microsoft acerca da medida corretiva aplicada, querendo parecer que haveria inviabilidade na sua implementação considerando-se todas as complexidades técnicas. Da mesma forma, criticou o Tribunal a insuficiência da sentença no que tange à confirmação das acusações, principalmente na ausência de comprovação do nexo causal entre o poder de mercado da Microsoft e a conduta.

Com base nestes argumentos, o caso encerrou-se com um acordo firmado entre DOJ e a Microsoft em que esta se comprometia a divulgar o conjunto de informações de APIs aos vários interessados, dever este limitado ao estritamente necessário para garantir a

\footnotetext{
${ }^{573}$ Uma questão de fundo que se insurgiu passava por questionar se estaria o mercado de browsers sujeito a monopolização, visto que o IE era fornecido a título gratuito. Ainda que o fosse, prática muito comum nos mercados da nova economia, tem sido igualmente comum a obtenção de remuneração em serviços complementares ou junto de fornecedores de conteúdo.
} 
interoperabilidade com o SO Windows. O acordo inibia ainda aquela empresa de exercer pressões sobre os fabricantes de computadores de modo a impedi-los de promover ou distribuir produtos concorrentes.

\subsubsection{Caso Microsoft na União Europeia}

O principal caso Microsoft investigado na Europa envolvia práticas de recusa de fornecimento de informações de interface e venda casada de produtos. Originou-se com base em denúncia da Sun Microsystems, em 1998, de abuso de posição dominante ao recusar o fornecimento de informação sobre interface necessária ao desenvolvimento de produtos capazes de dialogarem com os computadores pessoais inseridos numa rede informática local. ${ }^{574}$ Este comportamento, segundo a Sun, era susceptível de eliminar a concorrência no mercado de sistemas operativos de servidores para redes de trabalho. A investigação foi posteriormente estendida para incluir a venda de pacotes do sistema Windows com vários produtos de software, um dos quais o Windows Media Player (WMP). A decisão condenatória da Comissão Europeia se deu seis anos após, em 24 de março de 2004.

O mercado em que se verificavam as condutas inicialmente consideradas consistia em PCs ligados a uma rede de informática, para os quais são especialmente concebidos sistemas operativos que não podem ser substituídos por produtos com outras características, como sistemas operativos para servidores. Estes últimos, contudo, formavam outro mercado relevante, onde se produziam os efeitos da conduta de recusa de informação de interoperabilidade, tratando-se, assim, de mercados complementares. Este efeito no segundo mercado relevante implicaria a exclusão do mercado de SO para servidores mais exigentes, como os relacionados a tráfego aéreo ou defesa, bem como de SOs e servidores com funções mais especializadas, como proteção de vírus.

Por sua vez, o WMP é um aplicativo utilizado para decodificar, descompactar e reproduzir ficheiros de áudio e vídeo, descarregados ou transmitidos pela internet e outras redes. Diferentemente dos EUA, a Comissão entendia que o WMP e outros aplicativos constituíam mercados relevantes específicos, e não integrados ao $\mathrm{SO}$, valorizando a substituibilidade pelo lado da oferta, uma vez que produtores independentes ofertavam este

\footnotetext{
${ }^{574}$ Decisão da Comissão Europeia de 24.3.2004, COMP/C-3/37.792 Microsoft, C(2004) 900 final, J.O. L 32, de 6.2.2007.
} 
tipo de aplicativo. Também caracterizado como mercado que exige investimentos vultosos, com efeitos de rede.

A Microsoft possuía posição dominante na medida em que controlava um "quasestandard" do mercado há algum tempo - Windows -, possuindo elevadas participações de mercado. ${ }^{575} \mathrm{O}$ argumento da durabilidade reduzida, que geraria oportunidades a novos produtos, seria assim limitado pelos efeitos de rede. O segmento era ainda representado por significativas barreiras à entrada, em especial por barreiras a aplicações, de onde se pode concluir que, quanto maior um SO, mais aplicações são escritas para ele; quanto mais aplicações escritas para ele, mais popular e maior será o sistema operacional.

A primeira investigação, portanto, dizia respeito à recusa de fornecimento de informações necessárias para garantir a interoperabilidade do sistema Windows usado em computadores pessoais e em computadores centrais - os servidores. Isso colocava os seus concorrentes nos mercados de sistemas operativos para servidores em desvantagem, na medida em que mais de $90 \%$ dos sistemas de PCs que interagiam com os computadores centrais eram Windows.

Neste sentido, cabe verificar que, na sua atividade revisora, o Tribunal de Primeira Instância pontuou que se deveria apurar qual o grau de interoperabilidade necessário para assegurar a viabilidade da concorrência, pois somente após esta constatação é que se poderia auferir se a informação recusada é ou não indispensável para atingir este grau de interoperabilidade. ${ }^{576}$

A Microsoft alegava que a informação recusada era protegida por direitos de propriedade intelectual. Segundo a Comissão, a Microsoft teria o dever de fornecer estas informações devido: (i) à alteração do comportamento da Microsoft relativamente ao passado; (ii) à confusão entre "execução" e "especificação"; ${ }^{577}$ (iii) ao nível de informação prestado pela Microsoft, que variava em decorrência da ameaça concorrencial, sendo maior no começo em que só tinha a ganhar com a interoperabilidade entre os sistema para PCs e para servidores, e foi se reduzindo quando mais consolidada no segundo segmento. Constatou-se que o atual grau de interoperabilidade não poderia assegurar a viabilidade da concorrência no médio prazo.

\footnotetext{
${ }^{575}$ Microsoft possuía mais de $90 \%$ de participação de mercado nos sistemas operativos e mais de $60 \%$ para servidores, em 2002 (Decisão da Comissão Europeia de 24.3.2004, COMP/C-3/37.792 Microsoft, considerandos 435 e 499).

576 Acórdão do Tribunal de Primeira Instância (Grande Secção) de 17.09.2007, Proc. T-201/04, Microsoft c. Comissão, Colect. 2007, p. II 3601, considerando 151.

577 Enquanto execução seria o código que corre no computador, protegido pelo direito de autor, a especificação seria passível de várias formas de expressão.
} 
Quanto ao progresso técnico, a Comissão entendia que a prática limitava a capacidade de clientes beneficiarem-se de inovações nos sistemas operativos para servidores trazidos pelos concorrentes da Microsoft, bem como limitava as possibilidades de sucesso destes concorrentes, com o consequente desincentivo da realização de investimentos em novos produtos. A interoperabilidade traria benefícios de forma a se permitir a diferenciação dos produtos e inovação, considerando a concorrência pelo mérito nas características dos diferentes programas e não a vantagem artificial resultante da maior interoperabilidade num ambiente exclusivamente operado com Windows.

Ao invés de a Comissão avaliar se o comportamento abusivo seria justificado objetivamente, ela seguiu uma linha diferente, contrapondo a questão dos incentivos à inovação aos benefícios da imposição do dever de licenciar a informação em causa, sob o ponto de vista da concorrência.

Vale frisar que a Comissão assumia posição essencialmente estática até o final da década de 90, valorizando a eficiência na afetação dos recursos, porém sem ponderar considerações dinâmicas. Neste caso, adotou, contudo, um balanço dinâmico:

\begin{abstract}
Se a função dos direitos de PI é promover a inovação, mediante a atribuição de direitos exclusivos (e direitos morais no caso do direito de autor) que permitam ao criador obter uma recompensa pelo seu esforço, esta motivação estende-se também à difusão dos resultados da criatividade humana. Assim, a recusa de licença poderá, em circunstancias excepcionais, 'ser contraria ao bem publico geral', na medida em que dessa recusa decorram efeitos negativos na inovação e nos consumidores. ${ }^{578}$
\end{abstract}

Assim, a nova ponderação a ser feita passa pelas restrições à livre concorrência verificadas e seu efeito no próprio processo inovativo. Interessante ponto a se debater vem no sentido da difusão e do compartilhamento da inovação promovida, por certo se considerando a devida remuneração ao processo de criação. Ao extremo, a não difusão do processo inovativo implicaria menor inovação subsequente. Importante ainda que a inovação deva ser compreendida de forma global e não isolada. Via de consequência, o potencial de inovação nos sistemas operativos para servidores será seguramente maior com vários concorrentes. Da mesma forma, resultarão maiores benefícios a estes agentes em função dos efeitos de rede. ${ }^{579}$

Com relação ao abuso por subordinação do sistema operativo Windows ao WMP, objeto de queixa do Real Player, concluiu a Comissão que o caso assentava-se sob quatro

${ }^{578}$ MOURA E SILVA, Miguel. O Abuso de Posição Dominante na Nova Economia, cit., p. 537.
${ }^{579}$ Idem, ibidem, p. 539. 
pilares: (i) produto subordinado e subordinante eram produtos distintos; (ii) a posição dominante ocupada pela Microsoft no mercado do produto subordinante; (iii) a Microsoft não oferecia aos consumidores a escolha entre obter o produto subordinante com ou sem o produto subordinado; (iv) a prática excluía a concorrência no mercado do produto subordinado.

Com relação ao primeiro ponto o Tribunal rejeitou a argumentação da Microsoft de "funcionalidade média", na medida em que esta se fundamenta na complementariedade, ou seja, produtos integrados de forma que se caracterizam como um único.

Em rápida digressão, ao nos questionarmos até que ponto seria legítimo considerar abusiva a integração de novas funcionalidades num produto tecnológico, diversos fatores devem ser levados em consideração. No caso em tela havia elemento de coação, visto que fabricantes de PCs eram impedidos de fornecer aos consumidores PCs sem uma versão do WMP. Da mesma forma, foi reconhecida a procura independente de PCs sem o WMP. Por exemplo, clientes corporativos não queriam esta versão nos seus computadores. Da mesma forma, verificou-se a existência de oferta independente, via produtores independentes deste aplicativo. Por fim, a própria Microsoft vendia o WMP para outros sistemas operativos.

A decisão de condenação da Comissão Europeia foi assim confirmada pelo Tribunal de Primeira Instância, não somente com relação à confirmação da multa de mais de EUR 497 milhões aplicada à Microsoft, mas ainda com relação à quase totalidade das medidas corretivas impostas pela Comissão Europeia. ${ }^{580}$

Interessante notar, por fim, que ainda que a Comissão não tenha considerado circunstâncias agravantes no caso - no que foi seguida pelo Tribunal -, este faz breve consideração acerca da conduta da empresa e consequente procedimento enfrentado nos Estados Unidos como justificador da decisão mantida:

Por outro, importa referir que a Microsoft já tinha sido objecto de processos judiciais nos Estados Unidos devido a uma pratica análoga à venda ligada abusiva em causa, concretamente, a venda ligada do seu browser Internet Explorer e do seu sistema operativo Windows para PC clientes, e que existe um

\footnotetext{
580 As medidas determinadas incluíam a disponibilização de informações de interoperabilidade para desenvolvedores de sistemas de operação para servidores, as quais deveriam se manter atualizadas, bem como oferecimento de uma versão de seu SO sem integração do WMP. Vale notar que a Microsoft foi novamente multada nos anos que seguiram à decisão por descumprimento das obrigações impostas pela Comissão Europeia na presente decisão.
} 
risco de que cometa o mesmo tipo de infracção no futuro com outros aplicativos. $^{581}$

\subsubsection{Caso Microsoft no Brasil}

Diversas foram as investigações levadas a efeito no Brasil envolvendo a Microsoft ao longo da última década, porém com repercussão muito aquém da verificada nos casos discutidos na Europa e nos Estados Unidos. E não poderia ser diferente a constatação, até mesmo pelo reduzido nível de sofisticação das discussões locais, comparativamente às demais jurisdições. Tratou-se de casos envolvendo, especialmente, discussões de exclusividade, venda casada e preços predatórios, dentre outras.

Neste sentido, em 2004 o CADE decidiu que a gigante norte-americana havia abusado de sua posição dominante ao restringir a distribuição de software e serviços de computação associados, em um caso que não envolvia, propriamente, restrições tecnológicas em mercados de inovação. ${ }^{582}$ A Microsoft havia estabelecido um sistema de representante para grandes contas, conhecidos como LARs (Large Account Resellers) para vendas a clientes corporativos substanciais, cuja atuação estaria restrita a uma área geográfica específica. Porém, uma dada área poderia ser servida por múltiplos LARs, a depender de quantas distribuidoras atendessem aos parâmetros da Microsoft para obterem status de LAR.

O procedimento foi instaurado baseado em denúncia oferecida pela empresa IOS Informática Organização e Sistemas Ltda., revendedora da Microsoft, para apurar, em especial, a maneira como foram definidos, implementados e fiscalizados os critérios de credenciamento adotados pela Microsoft, bem como a forma com que as representadas deles teriam se utilizado com a finalidade de conferir exclusividade à TBA para atuação no mercado do Distrito Federal e, consequentemente, para comercialização a todo o Governo Federal. $^{583}$

\footnotetext{
${ }^{581}$ Acórdão do Tribunal de Primeira Instância (Grande Secção) de 17.09.2007, Proc. T-201/04, Microsoft c. Comissão, Colect. 2007, p. II 3601, considerando 1363.

582 Processo Administrativo n. 08012.008024/1998-49, representante SDE, representada Microsoft e TBA Informática.

${ }^{583}$ As seguintes condutas no mercado nacional de venda e licenciamento de softwares e prestação de serviços de informática à administração pública federal foram investigadas: (i) divisão do mercado de distribuição e revenda de produtos de informática; (ii) limitação ou criação de dificuldade ao acesso, funcionamento e desenvolvimento de empresa concorrente ou adquirente no mercado de distribuição e revenda de produtos de informática; (iii) combinação prévia de preços ou ajuste de vantagens na concorrência pública ou administrativa; (iv) dificuldade ou rompimento da continuidade ou desenvolvimento de relações comerciais, em razão de recusa da outra parte em submeter-se a cláusulas e condições injustificáveis ou anticoncorrenciais; e (v) imposição, sem justa causa, de preços excessivos.
} 
As condutas praticadas pelas Representadas Microsoft e TBA constituíram lesão às relações concorrenciais no mercado. As restrições à concorrência intramarcas, baseadas em critérios estabelecidos ex post, que eram observados de modo não harmônico e subjetivo, em conjunto com a quase completa inexistência de concorrência intermarcas aos produtos ofertados pela Microsoft, assim como a injustificada exclusividade conferida à TBA representaram elevados prejuízos à concorrência no mercado de vendas corporativas de software, notadamente para a Administração Pública Federal. Ainda, o fato de a Microsoft haver credenciado empresas em outras regiões distintas do Distrito Federal que não se adequavam aos critérios estabelecidos demonstra que serviam para impedir o credenciamento ou justificar o descredenciamento quando conveniente. ${ }^{584}$

Desta forma, a conduta de limitação do acesso de novas empresas ao mercado, que comercializavam produtos concorrentes aos produzidos pela Microsoft, restou configurada pela concessão de exclusividade para a $T B A$, induzindo à renovação de seu contrato sem realização de licitação, o que beneficiava tanto à $T B A$ quanto à própria Microsoft. Quanto ao aspecto da restrição às empresas que atuavam no segmento de manutenção, desenvolvimento de softwares, treinamento e assistência técnica, a conduta restou configurada em razão da divulgação da exclusividade pela $T B A$.

Havia ainda questões relativas à combinação prévia de preços para participação em licitação e ajuste de vantagens. A prova inequívoca deste ajuste de vantagens constou das cartas de exclusividade, que materializaram a indicação da TBA como representante exclusivo no Distrito Federal, situação que impediu a competição entre licitantes e que foi determinante para que a Administração Pública Federal procedesse à contratação direta.

Entendeu o CADE demonstrada infração contra a ordem econômica, condenando a Microsoft e a TBA à multa equivalente a $10 \%$ e $7 \%$, respectivamente, de seus faturamentos.

Outro caso de interesse envolvendo a Microsoft, este sim envolvendo restrições tecnológicas em mercados de inovação, resultou em arquivamento pelo CADE em 2004. Tratou de representação promovida pela Paiva Piovesan Engenharia \& Informática Ltda., acusando a empresa de limitar ou impedir o acesso de novas empresas ao mercado, criar dificuldades ao desenvolvimento de empresa concorrente, impedir o acesso de concorrente

\footnotetext{
${ }^{584}$ Vale também recordar que sem o concurso da TBA não seria possível a implementação dos efeitos da conduta. Assim, quanto à sua imputação de prática de limitação ou criação de dificuldade de acesso, funcionamento e desenvolvimento de empresas concorrentes no mercado de distribuição e revenda de produtos de informática, tal ilícito se deu sob dois aspectos: não só aproveitou-se da exclusividade a ela conferida pela Microsoft, como efetivamente a implementou, dado que em cartas endereçadas a clientes governamentais apresentou-se como revendedora exclusiva do Governo Federal.
} 
aos canais de distribuição e praticar venda casada. ${ }^{585}$ As condutas que em tese produziriam os efeitos em referência implicavam: (i) a inclusão do software de gerenciamento financeiro "Money 97" no pacote de aplicativos denominado "Microsoft Office for Small Business 97", prática que poderia caracterizar venda casada; (ii) venda de 250 mil cópias ao Banco do Brasil e 110 mil cópias à Caixa Econômica Federal do software gerenciador financeiro "Money 97", o que teria restringido a entrada de outros concorrentes no mercado; e (iii) restrição ao acesso dos produtos concorrentes dos maiores distribuidores nacionais de software, que eram também distribuidores Microsoft.

O mercado relevante foi definido como softwares de gerenciamento financeiro desenvolvidos para o ambiente Windows, sendo sua dimensão geográfica restrita ao território nacional. A Microsoft detinha posição dominante neste mercado, através das vendas do Money, com participações superiores a 80\% entre os anos de 1995 a 1997.

Segundo o Conselheiro Relator do caso, para identificar os efeitos econômicos de uma conduta seria necessário verificar por que a empresa denunciada se engajou nesta prática, podendo estar amparado em aumento da eficiência econômica, acarretando ganhos para si e para os consumidores, ou no aumento de seu poder de mercado, com consequente elevação do preço do produto casado, associado com a elevação das barreiras à entrada, no mercado do produto casado, buscando igualmente, condições para a imposição de preços mais elevados.

Ponderou ainda o Conselheiro Relator que produtos integrados representam inovação vantajosa para os consumidores na medida em que permitem seu barateamento, já que a ampliação das quantidades vendidas gera ganhos de escala e possibilita a redução das margens unitárias de lucro. Esta tendência se encontraria amplamente consolidada nos mercados de softwares, sendo seguida pelos principais ofertantes de diversos aplicativos como Lotus, Corel, dentre outros. A própria Representante Paiva Piovesan apresentou nos autos documentação onde comunica planos de venda de pacotes integrados.

Com relação às alegações de venda casada, o Conselheiro Relator esclareceu que:

Os efeitos anticompetitivos desta conduta relacionam-se com a transferência
("alavancagem") do poder de mercado de um produto para outro, elevando
abusivamente os lucros em detrimento dos adquirentes e, em última análise, do
consumidor, ao mesmo tempo em que promove o "bloqueio" do segmento a

${ }^{585}$ Processo Administrativo n. 0812.001182/98-31. 
jusante (em geral, de distribuição) para concorrentes efetivos e potenciais (aumento das barreiras à entrada). ${ }^{586}$

No presente caso, não houve imposição de compra dos pacotes. O Money 97, ao preço de $\mathrm{R} \$ 60,00$, podia ser comprado isoladamente, contra o preço de $\mathrm{R} \$ 520,00$ do pacote Office SBE, com o Money. Assim, conforme enfatizado pela SEAE e SDE, não se verificam no presente caso as condições necessárias para a caracterização de venda casada.

$\mathrm{Na}$ fase final da instrução do processo três outras denúncias surgiram contra a Microsoft: (i) impedir o desenvolvimento de softwares de terceiros, ou seja, de novos aplicativos em português, a partir da disponibilização de uma nova ferramenta para a instalação de programas no Windows 2000, denominada “Visual Studio Installer", a qual não permitia a criação de instruções de instalação em português ou em qualquer outra língua que não o inglês; (ii) inclusão, exclusivamente no "Office", de objetos de programação que permitiam a geração de programas para a Web (internet), de forma que somente o adquirente de uma cópia do "Office" poderia ter acesso a estas novas linguagens de programação; e (iii) prática de preços predatórios, apresentando dados revelando que os preços do Money nos distribuidores foram reduzidos de US\$ 20,25, em 1995, para US\$ 19,51, em 1996, US\$16,08, em 1997, e US\$26,37 em 1998, sendo que aos usuários finais os preços evoluíram de US\$ 53,01, em 1997, para US\$ 56,80, em 1998, US\$ 58,22, em 1999, e US\$ 38,31, em 2000.

Com relação às duas primeiras novas alegações, sugeriu o Conselho a abertura, no âmbito da SDE, de averiguações preliminares para apurar os efeitos destas práticas sobre a concorrência. Quanto às denúncias de preços predatórios, o CADE entendeu que os valores informados pelo Representante não indicavam a ocorrência de predação por três razões principais. Após o retorno dos autos à SDE para aprofundamento das investigações, o CADE concluiu pela insubsistência dos indícios de infração para as duas alegações contidas na Representação. ${ }^{587}$

\footnotetext{
${ }^{586}$ Processo Administrativo n. 0812.001182/98-31, p. 4-5.

${ }^{587}$ Em recurso de ofício encaminhado ao CADE referente ao arquivamento da presente investigação, por maioria o CADE determinou os autos de volta à SDE para investigação das condutas em referência, instaurada como Averiguação Preliminar n. 08012.002034/2005-24. No tocante à primeira conduta, concluiu o CADE que o Visual Studio Installer não possuía poder de mercado, existindo diversas alternativas a ele no mercado, nunca tendo existido versão em português. Com relação à alegação de deslocamento de componentes do Windows para o Pacote de Aplicativos Office, concluiu-se também pela existência de alternativas ao ActiveX no mercado, e que exigem que ao menos o usuário tenha instalado em seu computador o aplicativo Office, ressaltando-se ainda que o Office Web Components nunca foi componente do Windows e nunca foi gratuito, exigindo-se uma licença do Office para sua utilização. Já com relação ao Internet Explorer, verificou-se igualmente alternativas no mercado e a funcionalidade de aplicativos - no
} 
Em primeiro lugar, porque embora os preços do Money aos distribuidores, determinados pela Microsoft, tenham sido reduzidos seguidamente de 1995 a 1997, elevados apenas no ano de 1998, os preços cobrados aos usuários finais, fixados pelas revendas, não acompanharam estas reduções. De fato, os preços praticados pelas revendas experimentaram aumentos sucessivos até 1999, vindo a cair somente no ano de 2000. Constata-se, portanto, que as revendas não acompanharam as variações de preço praticadas pela Microsoft, o que indica que efetivamente não houve fixação de preços de revenda do Money, conforme informado nos autos pela própria Microsoft. Este fato, por si só, inviabiliza qualquer estratégia predadora, já que revendas mantiveram os preços aos consumidores em patamares elevados, provavelmente ampliando suas margens de comercialização. Ademais, a partir do mês de julho de 1998 e nos anos seguintes, as vendas do Money caíram substancialmente, revelando ser implausível a possibilidade de recuperação de prejuízos decorrentes de preços predatórios.

Em segundo lugar, a comprovação do preço predatório nos mercados de software é extremamente difícil. Conforme definição dada pela Resolução CADE n. 20, de 09 de junho de 1999, o preço predatório consiste na "prática deliberada de preços abaixo do custo variável médio, visando eliminar concorrentes para, em momento posterior, poder praticar preços e lucros mais próximos do nível monopolista". Entretanto, os custos de reprodução do programa (cópia), após o desenvolvimento do software, são desprezíveis. Quando se trata de softwares desenvolvidos em outros mercados geográficos e adaptados para o mercado nacional, como é o caso do Money, os custos envolvidos nas atividades de concepção, desenvolvimento do software já foram cobertos na comercialização do produto em outros mercados. Nestas circunstâncias torna-se praticamente impossível a avaliação real das condições efetivas de custo. Por outro lado, o comportamento dos preços ao longo do tempo, como visto acima, não sinaliza para a necessidade de análise detalhada de custos, já que não revela indícios de que tenha ocorrido queda de preços aos consumidores ou vendas abaixo do custo.

Em terceiro lugar, a adoção racional de uma política predatória em preços pressupõe que a empresa infratora tenha capacidade para manter antigos e novos ofertantes fora do mercado após o período de predação. Desta forma, após o afastamento dos concorrentes, poderá recuperar os prejuízos causados pela manutenção dos preços abaixo dos custos com a sua elevação posterior. Entretanto, em razão das características do 
produto (software de gerenciamento financeiro) são reduzidas as possibilidades de bloqueio à entrada de novos ofertantes, já que empresas que ofertam este produto em outros países ou antigos concorrentes, os quais configurariam concorrência potencial, podem ingressar no mercado atraídas pela elevação dos preços após o período de predação, sem grandes custos de adaptação e atualização do software.

Em outro processo ainda, a Microsoft fora acusada de: (i) venda casada de seu sistema operacional com seu navegador e alguns aplicativos; (ii) cobrança de preços excessivos para atualização de seus softwares; (iii) fixação arbitrária de sua margem de lucro; (iv) concessão de licenças de uso restrito, em especial com relação ao programa "Exchange"; (v) imposição de cláusulas anticoncorrenciais em seus contratos de treinamento. ${ }^{588} \mathrm{O}$ CADE, da mesma forma, decidiu ao final por arquivar esta representação contra a Microsoft em 2007 baseado na ausência de evidências apresentadas pelas Representantes e por tratar-se de disputa privada entre as partes relativa a concessões contratuais e patentes. Contudo, em razão de condenações verificadas em casos similares em outras jurisdições, o CADE determinou à Secretaria de Direito Econômico que investigasse a conduta da Microsoft, acarretando a abertura de nova investigação, que desde então se encontra parada no CADE. ${ }^{589}$

\subsection{Sistematização dos Testes para Determinação de Abusos}

A aplicação do artigo 102 do TUFE, seção 2 do Sherman Act ou artigo 37 da Lei n. 12.529/11 às práticas de agentes econômicos dominantes potencialmente excludentes da concorrência requer um balanceamento extremamente cuidadoso de seus possíveis efeitos. A existência de um poder que permite a tais agentes econômicos independência nas suas práticas comerciais não deve, por si só, cerceá-los de competir de forma eficiente. De onde podemos inferir que, se ao conceito de abuso é dada uma interpretação muito restrita, agentes com posição dominante podem usar de seu poder para prejudicar o processo competitivo e, se por outro lado for interpretado de forma muito ampla, pode-se verificar

\footnotetext{
${ }^{588}$ Averiguação Preliminar n. 08012.004570/2000-50. Representada: Microsoft Informática Ltda.

589 Averiguação Preliminar n. 08012.010027/2007-68. Representada: Microsoft Informática Ltda. A investigação visava a ocorrência e efeitos de possível discriminação, em relação ao momento e condições comerciais em que forem disponibilizadas ferramentas essenciais para o desenvolvimento de aplicativos compatíveis com as últimas versões do $\mathrm{SO}$; o provimento regular e em bases não discriminatórias de recursos eficientes para a adaptação de aplicativos existentes às novas versões de seu sistema operacional; e os efeitos concorrenciais das práticas de transferência de tecnologia. A Representação foi arquivada pela Superintendência Geral em 2007 por ausência de indícios de infração.
} 
arrefecimento do processo competitivo, uma vez que tais agentes podem restar impedidos de competir de forma eficiente no mercado. Trata-se dos intensamente debatidos erros tipo 1 e erros tipo $2 .^{590}$

Inegável a existência de tênue linha divisória entre comportamentos pró e anticompetitivos praticados por agentes econômicos com posição dominante, visto que seus efeitos econômicos geralmente são de difícil previsão e constatação. Uma mesma conduta pode apresentar efeitos diferentes sob circunstâncias diferentes, ou mesmo condutas diferentes podem apresentar efeitos similares. Ademais, a mesma conduta pode implicar, como de fato se verifica na maior parte das vezes, efeitos pró e anticompetitivos, especialmente sob uma visão dinâmica de curto ou longo prazo. Por esta razão em especial é que se torna difícil advogar por testes formais ou regras de infração por objeto ou per se, quando tratamos de abusos de posição dominante.

Repisemos que a teoria do abuso de posição dominante não deveria, em princípio, ser aplicada de forma a prevenir agentes com poder de mercado de competirem de forma vigorosa e efetiva, mesmo que concorrentes menos eficientes sejam prejudicados.

$\mathrm{Na}$ esteira de muitos comentários verificados, seria irrealista assumirmos que não haveria erros resultantes da aplicação desta teoria do abuso, até mesmo pelo nível de conhecimento que se tem acerca dos efeitos das condutas unilaterais. Como visto, há posições divergentes sobre a habilidade dos mercados de se autocorrigirem, sobre a probabilidade de geração de efeitos anticoncorrenciais de diversas práticas e sobre como se devem balancear efeitos pró e anticompetitivos. Outro problema se relaciona com a assimetria informacional que as autoridades possuem com relação às condutas e à estrutura de muitos mercados, dificultando qualquer previsão com maior grau de certeza dos efeitos econômicos resultantes. Daí também a divergência entre jurisdições de tradição concorrencial sobre o padrão de aplicação das normas antitrustes.

De extrema dificuldade, portanto, a fixação de único teste aplicável para todos os tipos de conduta. Não obstante, a evolução histórica dos diplomas concorrenciais norteamericanos e europeu, bem como de seus precedentes legais, sugere que nos seus primórdios imaginou-se um teste universal capaz de identificar condutas que deveriam ser reputadas ilegítimas sob o ponto de vista concorrencial. Tanto na acepção do controle prévio de concentrações quanto no controle repressivo das condutas.

\footnotetext{
${ }^{590}$ Neste sentido, e para as considerações que seguem no capítulo, vide ØSTERUD, Eirik. Identifying Exclusionary Abuses by Dominant Undertakings under EU Competition Law, cit., p. 2.
} 
O Tribunal de Justiça Europeu, como vimos, articulou dois conceitos gerais que poderiam ser considerados norteadores da identificação de abusos de exclusão, consistentes na noção de que empresas dominantes possuem uma "responsabilidade especial" de não distorção da concorrência, bem como na descrição ou definição básica de abusos de posição dominante por exclusão, conceitos discutidos em mais detalhes no capítulo seguinte.

Da mesma forma se propõe a teoria econômica a racionalizar testes neste sentido, sob a bandeira de um único capaz de se aplicar sobre todas as condutas, as quais a própria lei não tentou exaurir. Para tanto, economistas têm desenvolvido teorias de aplicação geral e irrestrita, exemplos das quais seriam os testes do competidor tão eficiente, o teste da falta de racionalidade econômica e o teste do bem-estar do consumidor.

Em brevíssima síntese, pelo primeiro temos que somente aquelas práticas capazes de excluir do mercado concorrentes tão ou mais eficientes que a empresa dominante seriam anticompetitivas. Com relação ao teste da falta de racionalidade econômica, temos que somente as práticas que não possuem uma justificativa racional que as suporte, a não ser pela exclusão de seus concorrentes, seriam anticompetitivas. Por fim, com relação ao teste do bem-estar do consumidor, teríamos que somente as práticas que resultassem em efeito líquido negativo aos consumidores deveriam ser censuradas pelas autoridades.

Não obstante os testes acima, de relevância irrefutável para as análises levadas a efeito pelas autoridades, devem-se verificar os diversos testes específicos operacionais que têm sido desenvolvidos pelos tribunais de diversas jurisdições, para categorias individuais de condutas abusivas. Assim, sob a perspectiva dos testes não universais, sua aplicação seria determinada por categorização ou classificação das formas de conduta em questão.

Devemos reconhecer, contudo, aspectos positivos e negativos na aplicação dos dois tipos de testes. Os universais se aplicariam a todos os tipos de condutas de forma isonômica. Contudo, poderiam gerar problemas visto que algumas categorias de abusos possuem maior probabilidade de geração de efeitos, e deveriam ser tratadas de forma menos leniente que outras com menor potencialidade abusiva. Também poderiam representar altos custos de implementação por conta da sua extensão.

Por sua vez, os testes não universais permitem que as especificidades das formas de condutas sejam levadas em consideração quando de suas respectivas aplicações. Verificamos certa dificuldade para seu esgotamento, contudo, na medida em que não possuímos no direito concorrencial rol taxativo de condutas. Assim, tendem a ser modalizadas as condutas mais comumente verificadas nos mercados. 
Outro ponto de discussão se refere ao debate da forma versus efeito que deve ser considerado pelas autoridades na escolha do teste apropriado para subsunção do fato à norma. Enquanto as regras baseadas na forma da conduta distinguem comportamentos abusivos de legítimos através da aplicação de regras rígidas, sem a necessidade de uma análise específica dos mercados, regras baseadas nos efeitos aplicam um critério aberto de padrões que permitem uma avaliação caso a caso. No tocante ao primeiro viés, a crítica que podemos fazer quando a legalidade de determinada conduta depender de sua forma e não de seus efeitos vem no sentido de que formas diferentes de condutas com efeitos semelhantes não serão tratadas de forma isonômica. Interessantes ainda as soluções intermediárias que combinam as perspectivas de aplicação de testes universais com as especificidades dos testes customizados, em especial aqueles de aplicação formal. ${ }^{591}$

Uma precisa postulação para identificação da teoria dos abusos de posição dominante deveria distinguir uma concorrência eficiente - concorrência no mérito - de uma conduta ilegítima tendente à exclusão de agente mais eficiente de mercado. A dificuldade reside em desenvolver uma perspectiva que leve em conta os corretos resultados econômicos para as mais diversas condutas e, ao mesmo tempo, traga clareza e previsibilidade jurídica. Como elucidado na decisão envolvendo a Microsoft:

whether any particular act of a monopolist is exclusionary, rather than merely a
form of vigorous competition, can be difficult to discern: the means of illicit
exclusion, like the means of legitimate competition, are myriad. The challenge
for an antitrust court lies in stating a general rule for distinguishing between
exclusionary acts, which reduce social welfare, and competitive acts, which
increase it. 592

Neste sentido, defendem autores que regras claras e simples tendem a aumentar a segurança jurídica se comparadas a padrões probatórios mais complexos. Estas regras simples e claras, em que a aplicação da lei é determinada por um conjunto de fatos predefinidos pode, de fato, aumentar a segurança jurídica, uma vez que facilita sua compreensão ao mesmo tempo em que limita a discricionariedade na sua aplicação. ${ }^{593}$

Para se desenhar regras que distingam condutas pró e anticompetitivas há trocas necessárias. Por um lado, erros podem ser reduzidos ao se permitir uma análise extensiva dos impactos de determinada conduta às expensas de maior custo de exequibilidade das

${ }^{591}$ ØSTERUD, Eirik. Identifying Exclusionary Abuses by Dominant Undertakings under EU

Competition Law, cit., p. 17.

${ }^{592}$ United States vs Microsoft.

593 ØSTERUD, Eirik. Identifying Exclusionary Abuses by Dominant Undertakings under EU Competition Law, p. 15-16. 
regras e reduzida certeza jurídica. Por outro lado, os custos de exequibilidade podem ser reduzidos ao se adotar um critério baseado na forma, mas em detrimento de probabilidades maiores de erros na avaliação da prática. ${ }^{594}$

De toda forma, ainda que nos queira parecer que em algumas decisões analisadas na Europa e nos Estados Unidos exista tentativa de utilização de conceitos universais para a conduta em questão, não há como fugirmos da aplicação de testes não universais, permitindo o trato de especificidades das formas de condutas. Assim, na maioria das vezes em que tais testes universais são utilizados, há tentativa de sua aplicação junto a outros elementos que acabam por criar testes específicos. O que talvez não seja tão claro, atualmente, seria a opção preferencial por testes baseados em efeitos ou formas.

Importante, portanto, que tentemos sistematizar os testes específicos verificados ao longo do presente trabalho para as modalidades tratadas, cujas conclusões encontram-se na tabela a seguir, a fim de embasarmos nossa conclusão em dose considerável de empirismo. 
Tabela de Testes de Abusos - Estados Unidos, União Europeia e Brasil

\begin{tabular}{|c|c|c|c|}
\hline Conduta & Estados Unidos & Europa & Brasil \\
\hline $\begin{array}{c}\text { Recusa de } \\
\text { Contratação }\end{array}$ & $\begin{array}{l}\text { Para caracterização da recusa de } \\
\text { contratação (segundo a teoria das } \\
\text { infraestruturas essenciais), deve-se } \\
\text { verificar: (i) infraestrutura controlada por } \\
\text { um monopolista; (ii) concorrente incapaz } \\
\text { de construir infraestrutura da mesma } \\
\text { natureza por incapacidade prática ou } \\
\text { razoável; (iii) recusa de acesso a um } \\
\text { concorrente; e (iv) exequibilidade do } \\
\text { acesso à infraestrutura (MCI vs AT\&A). } \\
\text { No tocante ao item (iv) pode haver } \\
\text { justificativas objetivas legítimas para a } \\
\text { recusa, como (i) necessidade de } \\
\text { investimentos (por parte do monopolista); } \\
\text { (ii) falta de capacidade para o acesso (sem } \\
\text { que isso venha a afetar os negócios do } \\
\text { monopolista) e a defesa dos interesses } \\
\text { comerciais do monopolista, caso o acesso } \\
\text { implique modificação da organização ou } \\
\text { lese as relações comerciais com seus } \\
\text { clientes (Chicago Bulls). }\end{array}$ & $\begin{array}{l}\text { Para caracterização da recusa devem } \\
\text { estar presentes três condições } \\
\text { cumulativas: (i) que essa recusa obste a } \\
\text { aparição de um novo produto para o } \\
\text { qual exista uma potencial procura por } \\
\text { parte dos consumidores; (ii) que ela } \\
\text { careça de justificação objetiva; e (iii) } \\
\text { que seja susceptível de excluir toda a } \\
\text { concorrência no mercado derivado } \\
(I M S) \text {. }\end{array}$ & $\begin{array}{l}\text { Não há sistematização verificada nas } \\
\text { decisões do CADE. As decisões } \\
\text { discutindo recusa de contratação não } \\
\text { trazem à tona critérios relativos ao } \\
\text { reconhecimento de infraestrutura } \\
\text { essencial. }\end{array}$ \\
\hline
\end{tabular}




\begin{tabular}{|c|c|c|c|}
\hline & $\begin{array}{l}\text { Decisões posteriores dos Tribunais } \\
\text { confirmam a tendência de tornar ainda } \\
\text { mais excepcional a obrigação de contratar, } \\
\text { relegando tais hipóteses para casos onde já } \\
\text { existisse uma relação comercial } \\
\text { preexistente. }\end{array}$ & & \\
\hline $\begin{array}{c}\text { Venda } \\
\text { Casada }\end{array}$ & $\begin{array}{l}\text { Para caracterização da venda casada } \\
\text { (tying): (i) deve-se verificar a existência de } \\
\text { dois produtos ou serviços separados; (ii) } \\
\text { deve haver o condicionamento de } \\
\text { aquisição de um produto a um segundo } \\
\text { produto, sendo que quando houver a } \\
\text { possibilidade de aquisição de produtos de } \\
\text { forma separada, a subordinação não } \\
\text { imporia restrição não razoável (reprimível } \\
\text { portanto o elemento de coação existente); } \\
\text { (iii) deve-se verificar poder de mercado } \\
\text { como elemento que permite ao agente } \\
\text { implantar a conduta de subordinação; e } \\
\text { (iv) deve-se verificar substancial volume } \\
\text { de comércio no produto subordinado. } \\
\text { A análise deve se dar ainda sobre a regra } \\
\text { da razão, balanceando-se efeitos pró e } \\
\text { anticompetitivo (Eastman Kodak). }\end{array}$ & $\begin{array}{l}\text { Para caracterização da venda casada } \\
\text { (tying/bundling), se faz necessário que: } \\
\text { (i) os produtos sejam distintos; (ii) que } \\
\text { se verifique poder de mercado ao nível } \\
\text { do produto subordinante; (iii) que } \\
\text { esteja presente o elemento de coação; e } \\
\text { (iv) que haja produção de efeitos } \\
\text { anticoncorrenciais (Tetra Pak). }\end{array}$ & $\begin{array}{l}\text { Não há sistematização verificada nas } \\
\text { decisões do CADE. Contudo, da } \\
\text { análise dos casos citados podemos } \\
\text { verificar alguns critérios de } \\
\text { caracterização dos elementos do tipo. } \\
\text { Assim, para configuração de venda } \\
\text { casada ilegítima devemos reconhecer: } \\
\text { (i) existência de poder de mercado (a } \\
\text { fim de se configurar alavancagem de } \\
\text { poder de mercado de um produto ou } \\
\text { serviço para o outro); e (ii) deve } \\
\text { haver elemento de coação ou ainda } \\
\text { incentivo econômico à aquisição } \\
\text { conjunta. }\end{array}$ \\
\hline
\end{tabular}




\begin{tabular}{|c|c|c|c|}
\hline $\begin{array}{c}\text { Preço } \\
\text { Predatório }\end{array}$ & $\begin{array}{l}\text { Para caracterização do preço predatório: (i) } \\
\text { o preço deve situar-se abaixo de uma } \\
\text { medida adequada dos custos do } \\
\text { concorrente; e (ii) deve haver } \\
\text { probabilidade razoável ou perigosa de } \\
\text { recuperação do investimento em preços } \\
\text { abaixo do custo (Brooke Group). } \\
\text { A medida de custo utilizada não foi } \\
\text { pacificada pela Suprema Corte, tendo o } 10^{\circ} \\
\text { Circuito considerado custo médio variável } \\
\text { como um bom parâmetro de utilização } \\
\text { (AMR Corp.) } \\
\text { Ainda, defesas baseadas em eficiências, } \\
\text { quando suportadas por evidências, devem } \\
\text { ser consideradas. }\end{array}$ & $\begin{array}{l}\text { Para caracterização do preço predatório } \\
\text { deve-se levar em conta que: (i) preços } \\
\text { inferiores ao custo variável médio } \\
\text { serão considerados abusivos, enquanto } \\
\text { que preços inferiores ao custo médio } \\
\text { total, incluindo custos fixos e variáveis, } \\
\text { mas superiores ao custo variável } \\
\text { médio, serão considerados abusivos } \\
\text { quando fixados no quadro de um plano } \\
\text { que tem como finalidade a eliminação } \\
\text { da concorrência (ECS/Akzo). } \\
\text { Dispensa-se prova da possibilidade real } \\
\text { de recuperação de perdas. Ressalte-se } \\
\text { que o fato de uma empresa em posição } \\
\text { dominante acompanhar os preços dos } \\
\text { concorrentes não é per se abusivo, } \\
\text { porém a redução para enfrentar a } \\
\text { concorrência poderá ser abusiva } \\
\text { dependendo da intenção. } \\
\text { Deve-se, desta forma, sempre apreciar } \\
\text { as circunstâncias específicas de cada } \\
\text { caso, que demonstrem um } \\
\text { enfraquecimento da concorrência. }\end{array}$ & $\begin{array}{l}\text { Para caracterização do preço } \\
\text { predatório se faz necessária a } \\
\text { verificação de: (i) poder de mercado; } \\
\text { (ii) existência de barreiras à entrada; } \\
\text { (iii) recuperação das perdas } \\
\text { incorridas; (iv) possibilidade de } \\
\text { rápida expansão da oferta; e (v) } \\
\text { capacidade de financiamento da } \\
\text { conduta (Guia de Preços Predatórios } \\
\text { e Daimler Chrysler). }\end{array}$ \\
\hline
\end{tabular}




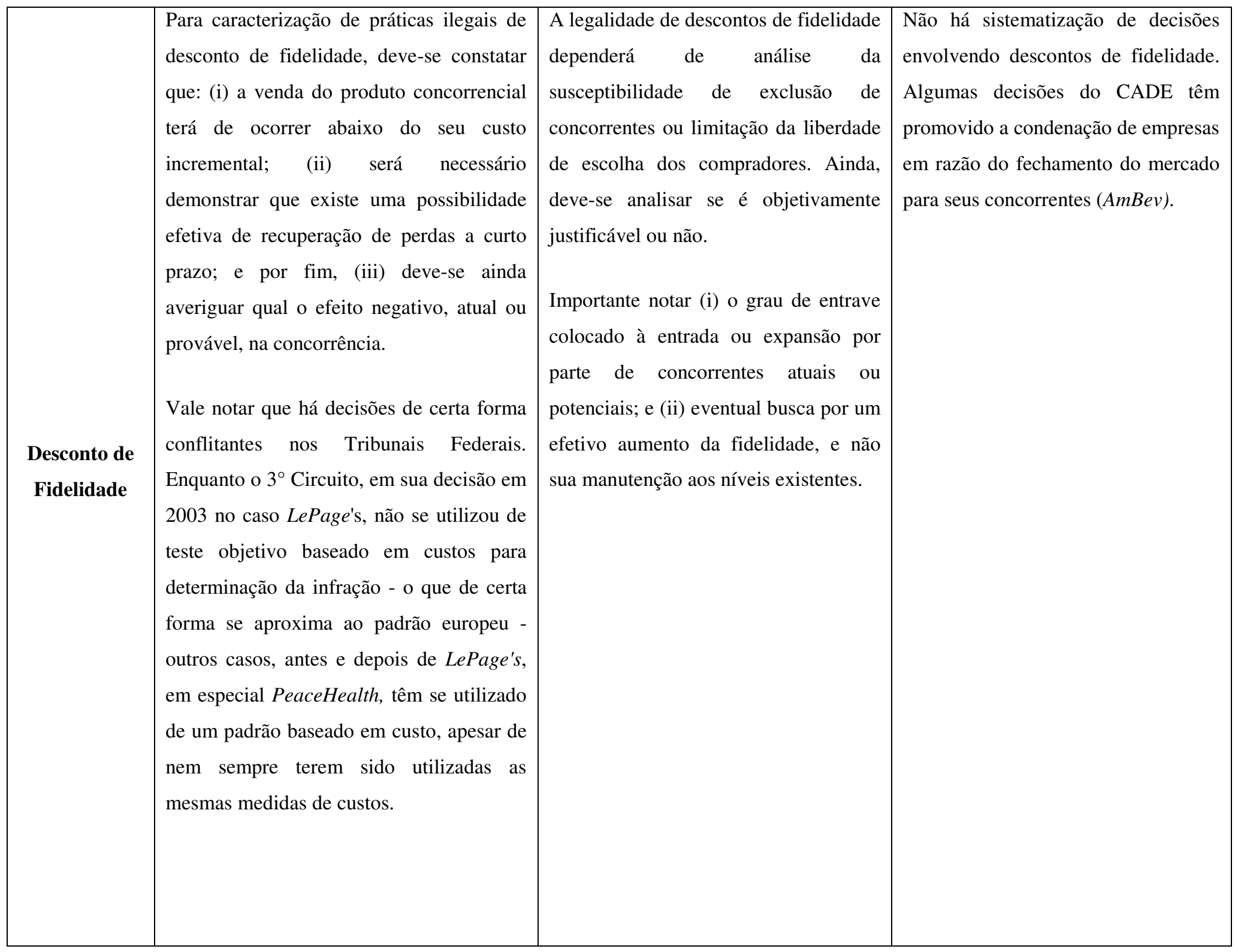




\begin{tabular}{|c|c|c|c|}
\hline Exclusividade & $\begin{array}{l}\text { Para caracterização de práticas ilegítimas } \\
\text { envolvendo exclusividade, deve haver } \\
\text { balanceamento dos prováveis efeitos } \\
\text { concorrenciais do contrato, considerando- } \\
\text { se: (i) a força relativa das partes, (ii) o } \\
\text { volume proporcional de comércio } \\
\text { envolvido em relação ao volume total de } \\
\text { comércio na região relevante e (iii) o } \\
\text { provável efeito imediato/futuro que aquela } \\
\text { participação de mercado poderia gerar na } \\
\text { concorrência. } \\
\text { Assim, o foco da análise centra-se na } \\
\text { probabilidade de exclusão de rivais do } \\
\text { mercado. Os tribunais passaram a } \\
\text { considerar ainda o período do arranjo e } \\
\text { justificativas pró-competitivas, tais como } \\
\text { estável fonte de fornecimento e preços, } \\
\text { promoção mais vigorosa da marca e } \\
\text { prevenção dos caronistas nos esforços de } \\
\text { vendas. }\end{array}$ & $\begin{array}{l}\text { Não parece haver precisa } \\
\text { sistematização dos elementos a serem } \\
\text { considerados nos precedentes } \\
\text { existentes sobre a conduta. Contudo, o } \\
\text { Guia de Restrições Verticais aponta } \\
\text { que a Comissão deverá focar sua } \\
\text { análise no possível efeito de } \\
\text { fechamento do mercado à entrada ou } \\
\text { expansão da concorrência. } \\
\text { Teste trazido pelo Tribunal de Justiça } \\
\text { Europeu requer demonstração de que } \\
\text { agente econômico que detém posição } \\
\text { dominante vincula compradores através } \\
\text { de uma obrigação ou promessa por } \\
\text { parte destes a obter toda ou a maior } \\
\text { parte de suas necessidades de maneira } \\
\text { exclusiva (Hoffmann-LaRoche). } \\
\text { Pode haver ainda justificativas } \\
\text { objetivas para a exclusividade, como } \\
\text { investimentos específicos para } \\
\text { fornecimento. }\end{array}$ & $\begin{array}{l}\text { Infere-se da análise de alguns casos } \\
\text { decididos pelo CADE que, para } \\
\text { caracterização de uma infração } \\
\text { resultante de acordo de } \\
\text { exclusividade, deve-se verificar: (i) } \\
\text { detenção de posição dominante por } \\
\text { parte do fornecedor; (ii) criação ou } \\
\text { aumento de barreiras à entrada no } \\
\text { mercado relevante; e (iii) } \\
\text { possibilidade real de fechamento de } \\
\text { mercado para concorrente, ou } \\
\text { aumento impeditivo do custo de } \\
\text { operação da concorrência (Souza } \\
\text { Cruz/Philips Morris). }\end{array}$ \\
\hline
\end{tabular}


Em breve síntese do quadro acima, verificamos, primeiramente, no tocante à recusa de contratação, que os requisitos trazidos pelo critério erigido nos Estados Unidos e na Europa em muito se assemelham, parecendo convergir, em algum momento. Em especial, os dois lados do Atlântico parecem reconhecer a existência de justificativas objetivas para a recusa. Contudo, enquanto a Comissão Europeia trata do obstáculo criado para aparição de novo produto como requisito, os Tribunais norte-americanos mais recentemente reforçaram a tendência de tornar ainda mais excepcional a obrigação de contratar, limitando tais hipóteses para casos onde já existisse uma relação comercial preexistente. Assim, se em algum momento se cruzaram as teorias, parecem agora caminhar em sentidos opostos.

E com relação ao Brasil, vale notar que os casos de maior relevância analisados pelas autoridades não nos permitem sistematizar uma teoria consistente de aplicação da norma, visto apresentarem-se mais focados em aspectos fáticos pontuais, extraindo-se destes algumas percepções que se tornam conclusões, acerca da probabilidade da produção de efeitos deletérios ao mercado.

Com relação às práticas de venda casada, os critérios recentemente elencados pelos tribunais da Europa e Estados Unidos parecem mais alinhados. Ainda que nominalmente os critérios se distingam, na sua essência buscam o mesmo fim. Novamente com relação ao Brasil parece haver rasa sistematização destes elementos, que transitam ao redor da necessidade de verificação de poder de mercado com relação ao produto subordinante, para que se configure uma alavancagem deste poder para um produto ou serviço em outro mercado - e no elemento de coação - onde também parece ser analisada pelo CADE a existência de incentivos econômicos para a aquisição conjunta.

Contudo, grande divergência entre os requisitos aplicados pelos tribunais nos Estados Unidos e Europa se encontra no campo das práticas de preços predatórios. Ainda que ambas as jurisdições exijam análise de preços para comparação com os custos incorridos, os tribunais Europeus evoluíram para uma dispensa de prova da possibilidade real de recuperação de perdas. Foram ainda além ao exigir apreciação das circunstâncias específicas de cada caso que possam demonstrar enfraquecimento da concorrência. Neste sentido, quer nos parecer que o ônus e a prova exigidos para uma condenação pela Comissão Europeia são significativamente inferiores se comparados à prática norteamericana justamente em razão da necessidade de demonstração do elemento de recuperação. 
O Brasil parece se aproximar à teoria e prática dos Estados Unidos ao exigir, igualmente, prova de recuperação das perdas incorridas. $O$ requisito adicional de verificação da possibilidade de rápida expansão da oferta, encontrado no Guia Brasileiro que trata de preços predatórios e replicado em alguns precedentes das autoridades, nada mais é do que elemento de demonstração da possibilidade de recuperação. Igualmente se poderia afirmar que o elemento trazido da capacidade de financiamento da conduta parece requisito intrínseco à demonstração da possibilidade de recuperação. Aqui vale notar, a exemplo do que foi pacificado nos padrões europeus, que nem sempre se observam condutas racionais por parte de agentes monopolistas, sendo real a possibilidade de sinalização à concorrência desprovida de probabilidade de recuperação de perdas incorridas, no que poderia merecer maior reflexão por parte das autoridades brasileiras. Porém, para tanto, o requisito da capacidade de financiamento da conduta se faz essencial.

As práticas de descontos de fidelidade, por sua vez, também têm se verificado bastante controversas dos dois lados do Atlântico. Enquanto nos Estados Unidos o procedimento adotado para verificação dos efeitos no mercado tem levado em consideração testes baseados em custos, a exemplo do verificado nas modalidades de preços predatórios, na Europa estes testes tendem a avaliar a susceptibilidade de exclusão de concorrentes ou limitação da liberdade de escolha dos compradores em razão dos incentivos artificiais criados pela prática. Dispensável a conclusão de que a linha seguida pelos Estados Unidos coloca, igualmente, maior ônus probatório ao reclamante da conduta, reduzindo de maneira sensível as chances de sucesso na condenação das empresas. Exceção ao tratamento reconhecido nos Estados Unidos foi o caso LePage's, o qual não se utilizou de teste objetivo baseado em custos para determinação da infração, aproximandose ao padrão europeu.

No Brasil, apesar de uma falta de sistematização dos elementos a serem reconhecidos, parece haver maior aproximação com a perspectiva europeia, visto que o foco das análises parece transitar em torno da potencialidade de fechamento da concorrência no aspecto atinente aos incentivos artificiais gerados pela prática, sem necessidade de análise detida de custos.

Por fim, as práticas de exclusividade de compra parecem suscitar semelhantes preocupações nas três jurisdições analisadas, não existindo grande divergência de requisitos para identificação dos seus elementos, ainda que não pareça haver consistente sistematização nos precedentes europeus e brasileiros analisados. De forma semelhante ao verificado na conduta de descontos de fidelidade, a preocupação gira em torno do 
fechamento de oportunidades à concorrência, exigindo-se, para tanto, a presença de poder de mercado que gere a potencialidade lesiva. Admitem-se ainda justificativas objetivas para a prática, contanto que no seu balanceamento não reste o instituto da livre concorrência prejudicado pela excessiva lesividade da conduta adotada.

Concluída breve análise acerca das tendências de divergência ou convergência entre as três jurisdições verificadas, no tocante às condutas em questão, vale recordar alguns elementos decisórios acerca das práticas de mercado da Microsoft. Tal avaliação promete bem ilustrar os parâmetros utilizados por cada sistema jurídico durante as investigações, bem como a ideologia por detrás de cada sistema, restando explícita e, confirmada, nossa percepção acerca das diferentes formas de interpretação da lei concorrencial e de sua aplicação por cada uma das autoridades. Assim, a análise comparativa destes parâmetros visa a testar as conclusões até então alcançadas como resultado da extensa análise doutrinária jurisprudencial levada a efeito.

Neste sentido, podemos verificar que os tribunais norte americanos têm seguido linha mais permissiva, preocupados com erros tipo 1, estabelecendo requisito probatório pesado para quem arguir a ilicitude de uma prática de abuso de posição dominante, em especial quando se trata de temas da nova economia e cujos remédios podem vir, alegadamente, a dissuadir inovações. Parece trazer consigo uma visão predominantemente Schumpeteriana, que valoriza a eficiência dinâmica, a concorrência pela inovação, a esperada destruição criativa, na medida em que lança a semente da inovação para os que ainda não alcançaram tal posição.

Para tanto, parecem elevar os padrões probatórios para configuração de um ilícito, através de análise mais formalística, restando claro o referido tratamento mais permissivo ao agente monopolista, especialmente para mercados de inovação. Vale referência à sua decisão sobre venda casada ou subordinação do Windows 95 e 98 com o IE da Microsoft, em que o tribunal, ao avaliar um dos critérios de verificação do abuso - o requisito de distinção dos produtos -, concluiu que empresas só oferecerão bens em conjunto quando as economias resultantes da oferta conjunta ultrapassarem os custos de uma escolha individual, recusando-se, contudo, a entrar no debate de ganhos de eficiência.

Da mesma forma se verifica perspectiva mais formalista com relação aos testes envolvendo tentativa de monopolização no mercado de browsers. Vale lembrar os requisitos firmados na jurisprudência norte americana no sentido de que a tentativa de monopolização requer, além de conduta anticoncorrencial ou predatória, dolo específico e probabilidade perigosa de o resultado vir a ser alcançado, tendo sido o acórdão da primeira 
instância em Microsoft III anulado por se considerar insuficiente a prova produzida pelo DOJ, em especial a indefinição quanto ao mercado relevante.

E novamente, com relação aos acordos de exclusividade firmados com vários canais de distribuição, ainda em Microsoft III, a empresa foi absolvida em razão da facilidade com a qual a Netscape poderia ser distribuída pela Internet, tendo sido afirmado que a prova da exclusão deveria ter se dado com relação a todo o mercado e não apenas dos seus canais mais importantes.

Por sua vez, a investigação levada a efeito na Europa contra a mesma empresa em muitos aspectos se assemelhava às investigações norte-americanas, envolvendo práticas de recusa de fornecimento de informações de interface para interoperabilidade de sistemas e venda casada de pacotes do Windows com vários produtos de software, como o Windows Media Player. Em clara divergência com a decisão alcançada pelos tribunais norteamericanos, a Comissão entendeu que o WMP e outros aplicativos constituíam mercados relevantes específicos, e não integrados ao $\mathrm{SO}$, valorizando a substituibilidade pelo lado da oferta, uma vez que produtores independentes ofertavam este tipo de aplicativo.

Ainda, a Comissão entendia que as práticas em questão limitavam a capacidade de clientes beneficiarem-se de inovações nos sistemas operativos para servidores trazidos pelos concorrentes da Microsoft, gerando desincentivo a investimentos em novos produtos. Assim, ao avaliar que a interoperabilidade traria benefícios de forma a se permitir a diferenciação dos produtos e inovação, seguiu a Comissão uma linha diferente, contrapondo a questão dos incentivos para inovação aos benefícios da imposição do dever de licenciar a informação em causa, sob o ponto de vista da concorrência.

Adotou assim balanço dinâmico, estendendo a função dos direitos de propriedade intelectual à difusão de seus resultados, reconhecendo que a recusa de licença poderia, em circunstâncias excepcionais, ser contrária ao bem público geral quando decorrerem efeitos negativos na inovação e nos consumidores.

Portanto, ao analisar a questão da distinção entre os produtos subordinados e subordinantes, a Comissão rejeitou a argumentação da Microsoft de "funcionalidade media", na medida em que esta se fundamenta na complementariedade, ou seja, produtos integrados de forma que se caracterizassem como um único.

Verifica-se assim análise menos formalística por parte da Comissão Europeia, procurando avaliar, segundo as teorias da economia comportamental, os reais incentivos em jogo e prováveis efeitos das condutas, se preocupando menos com erros tipo 1 e gerando percepção de atuação menos permissiva, ainda que tenha empregado análise tão 
ou mais focada na avaliação das eficiências dinâmicas em mercados de inovação, comparativamente aos Estados Unidos.

Já no Brasil, as investigações promovidas contra a Microsoft pouco podem acrescentar à identificação de um padrão de interpretação da norma. Na investigação trazida pela Paiva Piovesan, que avaliava, principalmente, a prática de venda casada resultante da inclusão do aplicativo Money 97 no pacote de Microsoft Office for Small Business 97, não houve, segundo o CADE, imposição de compra dos pacotes, visto que o aplicativo podia ser comprado isoladamente, portanto ausentes as condições necessárias para a caracterização do abuso.

Ainda, em outros processos julgados pelo CADE com relação à mesma empresa, vale menção à investigação de práticas de preços predatórios. Em especial, uma das análises levadas a efeito dizia respeito à possibilidade de recuperação de perdas, cuja negativa impactou no arquivamento da investigação, além da alegação de dificuldades de avaliação real das condições efetivas de custo.

E ainda vale menção à conclusão das autoridades brasileiras com relação à racionalidade de uma política predatória de preços por parte da Microsoft, que na sua visão não seria possível em razão das características do produto que reduziam as possibilidades de bloqueio à entrada de novos ofertantes, já que empresas concorrentes localizadas em outros países ou antigos concorrentes poderiam ingressar no mercado atraídos pela elevação de preços pós-período de predação, sem grandes custos de adaptação e atualização do software. Tal assertiva não parece tecer maiores considerações, contudo, acerca dos efeitos resultantes das externalidades de rede verificadas no segmento, que como vimos trazem dinâmica diferenciada ao mercado. Concluindo-se, portanto, no sentido de uma ausência de reconhecimento de elementos sistematicamente aplicados às condutas de abuso de posição dominante nos casos investigados.

Reitere-se que os testes promovidos pelos diversos tribunais nas diferentes jurisdições e no tocante às condutas ora tratadas requerem, na grande maioria das vezes, análise substancial com relação aos seus efeitos prováveis. Esta perspectiva baseada em efeito deve ser avaliada com relação à estrutura do mercado para concluir-se acerca da sua ilicitude. Trata-se, por certo, da aplicação da regra da razão, que reiteramos deva ser empregada em toda análise que envolva práticas supostamente anticoncorrenciais.

Grande parte da doutrina e jurisprudência defende a existência de condutas necessariamente abusivas e desprovidas de quaisquer justificativas, como os cartéis. Estas, sob a perspectiva de uma análise formalista, simplesmente requerem a prática de 
determinada conduta para caracterização de sua ilicitude, sem que se exija verificação de seus efeitos. Há ainda testes que requerem análise da intenção do agente, trazendo consigo a ideia de dois elementos cumulativos, a conduta e a intenção, como as práticas de preços predatórios em que se deve caracterizar a intenção de exclusão da concorrência do mercado.

Assim, diferentemente do que se pode pregar com relação às condutas colusivas, que trazem no seu âmago, indiscutivelmente, uma presunção quase absoluta de lesividade nos seus efeitos, a avaliação de condutas unilaterais parece ser muito mais sensível aos argumentos de eficiência, razão pela qual se pode dizer que agentes com posição dominante deveriam ter sempre uma oportunidade de demonstrar justificativa objetiva para suas condutas. Tal implica empregar na análise dois passos obrigatórios: a determinação do abuso prima facie e a justificação objetiva desta conduta.

A defesa dos agentes econômicos com base em justificativas objetivas geralmente fundadas em eficiências parece ser uma ponderação das autoridades diante da necessidade de moderação na avaliação de condutas unilaterais, a fim de se reduzir o risco de resultados não razoáveis ou contraproducentes que venham a conflitar com os objetivos da garantia institucional de livre concorrência. Ainda, nos parece relacionar-se ao princípio da proporcionalidade nas decisões.

Com isso, chegamos à conclusão de que a tão discutida convergência na aplicação do direito antitruste, em especial entre a Europa e os Estados Unidos, não parece se verificar para algumas modalidades de abuso analisadas, ao mesmo tempo em que é percebida para outras situações. Para se chegar a tal conclusão devemos observar o tratamento emprestado pela legislação, doutrina e jurisprudência às diferentes modalidades de condutas praticadas em abuso de posição dominante. Destarte, ao que nos parece, há clara preferência por parte das autoridades de testes específicos não universais para o tratamento do abuso, ainda que possam pesar argumentos favoráveis e desfavoráveis em ambos os sentidos.

Verificamos distanciamento de conceitos e testes construídos para verificação de abuso de posição dominante para práticas envolvendo recusa de contratação, preços predatórios e descontos de fidelidade, certamente as mais controvérsias práticas dentre as analisadas e, provavelmente, no universo das práticas de abusos cometidos por agentes com poder de mercado no dia a dia. Presente a polêmica e, portanto, reconhecidas maiores chances de erros tipo 1 ou falsos positivos, têm os Estados Unidos optado em erigir critérios que permitam aos seus participantes o benefício da dúvida, na esperança, ou 
melhor, na crença de que o próprio mercado discipline a situação. Por outro lado, a Europa parece menos preocupada com os erros tipo 1, sendo menos exigente no tocante ao ônus probatório necessário para configuração dos abusos, chamando a si a responsabilidade de disciplinar condutas as quais não vislumbra tratamento pelo próprio mercado. Já o Brasil necessita se posicionar, conforme discutimos na sessão seguinte.

\subsection{Ausência de Sistematização nas Decisões do SBDC e Influência dos Princípios Aplicáveis: o Dever-Ser do Sistema Jus-Concorrencial Brasileiro}

De todo acima exposto no tocante ao Sistema Brasileiro de Defesa da Concorrência, especialmente em comparação com a evolução jurisprudencial verificada nas demais jurisdições em comento, não nos quer parecer, em absoluto, que haja real identidade da prática nacional no tocante à repressão das condutas de abuso de posição dominante.

Determinados modelos parecem ser privilegiados, por vezes em decorrência da conveniência do julgador, mas poucas são as ocasiões em que precedentes são colhidos, analisados, tentativamente sistematizados e por fim utilizados para fundamentação jurídica decisória, a fim de que se dê aplicação consistente, com algum ponto de identificação. Na maior parte das vezes em que isso ocorre estamos diante de condutas colusivas e questões processuais, porém raramente verificamos algo neste sentido em sede dos investigados abusos praticados por monopolistas.

A ausência de guias que tratem de forma mais estruturada os elementos a serem avaliados contribuem para esta causa, ao contrário do que se verifica nas demais jurisdições que adotam guias em que há clara indicação destes parâmetros, os quais trazem ainda previsibilidade aos administrados. Os guias contribuem ainda à formação de uma identidade ao dificultar que julgadores fujam à sua aplicação por convicções pessoais, o que se verifica com bastante frequência em sistema de menor tradição concorrencial.

Como afirmado, a prova do efeito ou de sua potencialidade lesiva para esses temas, nas decisões trazidas pelas autoridades nacionais, na maioria das vezes se dá de forma casuística, desvinculada de critérios objetivos comuns a cada modalidade de conduta. Novamente, a importância destes critérios vem no sentido da previsibilidade da conduta infrativa e sua consequente prevenção, sendo que a ausência de critérios esclarecedores contribui para uma zona cinzenta de caracterização dos abusos que resulta 
em aumento de custo para os agentes econômicos na implementação e monitoramento de suas políticas de compliance.

Em se tratando a norma brasileira de tipologia aberta, inegável a dificuldade para sua sistematização, ao mesmo tempo em que é correto reconhecer a essencialidade desta característica quando tratamos do tema de abuso de posição dominante. E como visto, não se trata de privilégio da realidade brasileira, mas da dinâmica crescente da atividade empresarial que não permite antecipar todas as situações fáticas que possam implicar lesividade da livre concorrência.

Dessa forma, quer nos parecer que a aplicação da norma relacionada aos abusos de posição dominante no Brasil, por razões diversas expostas ao longo do presente trabalho e salvo raras exceções, segue uma linha de preocupação mais focada nos erros tipo 1, ou seja, no temor de condenação equivocada de condutas que venham a efetivamente beneficiar o instituto da concorrência. Ao que se debata tal perspectiva mais permissiva, portanto, resultar em subaplicação do direito concorrencial e proliferação de erros tipo 2.

Recorde-se o sistema norte-americano que, como visto, apresenta-se bastante influenciado por ideologia predominantemente liberal, com fortes raízes econômicas firmadas na confiança da autorregulação dos mercados, bem como traz sua organização funcional descentralizada, com decisões judicializadas. Poucos pontos de convergência ideológica e funcional com o sistema brasileiro, portanto.

Em alguns momentos podemos verificar a incorporação de testes e práticas de origem norte-americana sem os devidos cuidados à realidade diversa da economia nacional, algo como uma mera tradução das soluções aplicadas naquele país, que por vezes presta péssimo serviço à prática local e nefastos efeitos à livre concorrência. Certo é que não se pode negar a realidade principalmente econômica dos dois países, assim como entre Brasil e os países da União Europeia.

O estágio de maturidade verificado na concorrência exercida entre agentes econômicos para os mais diversos setores da economia verifica-se mais ou menos avançado, por vezes prematuro, a depender do segmento em questão, exigindo-se reconhecimento desta realidade para a devida adaptação de critérios. Em situações de maturidade concorrencial parece ser menos lesiva a ocorrência de erros tipo 2 comparativamente a situações em que se verifique reduzida concorrência entre os agentes econômicos.

Neste sentido, deixando-se inicialmente de lado todos os princípios legais inerentes ao ordenamento jurídico brasileiro que, igualmente, contribuem com um 
esperado afastamento de tratamento da norma com a ótica norte-americana, percebemos que o sistema jus-concorrencial brasileiro possui mais elementos intrínsecos e extrínsecos de convergência com o velho continente.

Esta análise se apresenta confusa e conflitante. Do pouco de sistematização que podemos extrair da jurisprudência nacional com relação aos abusos, verificamos que o tratamento trazido no Brasil para determinadas práticas, como preços predatórios, ensaia seguir testes aplicados segundo a linha norte-americana. Por outro lado, nos quer parecer que a prática punitiva de outras modalidades tratadas parece trazer simpatia a testes europeus, a exemplo do que verificamos com os descontos de fidelidade. Não há identidade ideológica clara do sistema jus-concorrencial nacional.

Não obstante o conflito acima identificado, a ausência dessa sistematização de precedentes locais, ainda que em determinadas ocasiões pareça haver simpatia a preceitos europeus, tende a gerar resultados mais liberais ou permissivos, e novamente a percepção de uma maior proximidade com a técnica norte-americana. O que pretendemos reforçar, assim, é que tal resultado não é consequência direta da ideologia e dos princípios atinentes ao ordenamento jurídico brasileiro, mas resultado da subutilização do direito como meio de repressão às condutas de abuso de posição dominante.

Em outras palavras, não há que se falar que o sistema jus-concorrencial pátrio é essencialmente liberal com relação à repressão das condutas de abuso de posição dominante por convicção ideológica das normas postas, resultado de um processo legislativo de amplo debate que desta forma optou. É sim resultado da inexperiência no trato da questão e da ausência de recursos para seu exame no nível de detalhamento exigido em razão da sua complexidade, dentre os demais fatores já elencados, e que por fim gera subutilização do direito para fins da persecução destas práticas.

Descaracterizada, portanto, a mística de um sistema mais permissivo de aplicação das normas de repressão ao abuso de posição dominante como resultado de uma escolha legislativa e jurisprudencial firmada em dogmática econômico liberal, passemos a analisar, de forma detida, quais os princípios do ordenamento jurídico que devem reger a aplicação das normas de defesa da concorrência no tocante aos abusos de posição dominante.

Primeiramente, devemos recordar os princípios consagrados na análise antitruste brasileira, segundo artigo 170 da $\mathrm{CF}$, como o princípio da livre iniciativa, princípio da livre concorrência, princípio da liberdade de contratar, princípio da propriedade privada e princípio da proteção do consumidor. Quanto ao último, entendemos que a proteção pelo direito concorrencial deve ser mediata, não merecendo tutela direta sob esta bandeira. Já 
com relação ao princípio da propriedade privada, tratar-se-ia de vetor instrumental da ordem econômica, direito individual a ser exercido dentro dos ditames da função social.

Assim, os princípios constitucionais que devem reger a ordem econômica nacional são relativamente amplos, sendo que a exata medida de sua aplicação, um tanto quanto incerta, deve necessariamente conviver, sendo deixada ao trabalho interpretativo do aplicador do Direito.

De vital importância recordarmos ainda que a proteção da concorrência traz garantia institucional mínima, portanto valor imprescindível a ser perseguido, garantindo a liberdade de escolha e disseminação da informação. As normas de defesa da concorrência no Brasil implicam fim sem si mesmas, e garantia de que abusos de poder de mercado serão reprimidos através dos instrumentos jurídicos pertinentes. Consequentemente, haveria poder-dever do Estado de sua preservação, através da aplicação de regras estruturais e comportamentais que assegurem interação mais justa entre os agentes econômicos. A concorrência visa, portanto, não somente a manutenção, mas ainda a promoção de um ambiente concorrencial que atenda aos princípios legais da ordem econômica estabelecida, regulando-se, de forma a prevenir, o exercício do abuso de poder econômico. A função social reconhecida à propriedade privada é elemento essencial para que cheguemos a esta conclusão.

Para tanto, recordemos ainda que, além dos bens de consumo e dos bens de produção, existiriam também bens de cuja utilização depende a possibilidade de concorrer em determinado mercado, os chamados bens de acesso necessário. A função social nesta seara não somente consistiria na boa utilização destes bens, mas ainda na sua disponibilização a terceiros. Portanto, com relação a estes bens de acesso, encontramos clara a função-dever do agente dominante.

O que implica dizer que um agente monopolista possui dever de fomento da livre concorrência em determinadas situações, quando sua atuação for essencial para a inserção ou manutenção esta mesma concorrência - visto que garantia institucional a ser perseguida pelo Estado - e quando desta não resultar prejuízo injustificado ${ }^{595}$ ou impedimento de sua atividade comercial. Esta obrigação de acesso deve, por certo, se dar de forma não discriminatória. Devem assim ser providas, naquilo que dependa do agente monopolista,

\footnotetext{
595 Especificamente com relação ao critério de prejuízo injustificado, ressalva se faça que a consideração deve abarcar não somente resultado para o agente econômico monopolista, mas essencialmente o bem-estar final do consumidor afetado positivamente com a introdução de novo concorrente.
} 
todas as condições necessárias para introdução ou manutenção de concorrência efetiva no mercado.

Em paralelo à justa remuneração pelo ativo licenciado, cedido, compartilhado ou serviço prestado pelo agente monopolista que provê acesso, devemos discutir ainda eventual direito indenizatório eventualmente pleiteado. Aqui dois cenários devem ser considerados: sugestivamente, o monopolista-herdeiro e o monopolista-inovador.

No primeiro caso, teríamos essencialmente os detentores de posição dominante decorrente de monopólios naturais, na grande maioria das vezes resultante de processos de desestatização de setores em que o Estado atuava excepcionalmente e diretamente na economia. Geralmente há forte presença do interesse público na regulação destes setores, devendo-se sempre contratar com as empresas adquirentes - via regulação - obrigações de acesso não discriminatório ao mercado e seus elementos, que resulta em claro dever de fomento à concorrência. Tais obrigações devem ser colocadas via regulação setorial, tratando-se de normas cogentes que não ensejam qualquer direito indenizatório, salvo pela justa remuneração do uso dos ativos. Ainda que não haja previsão neste sentido, torna-se questionável qualquer indenização, uma vez que a condição monopolística fora alcançada em decorrência de regulação e posterior disposição dos ativos pelo Estado, e não decorrente de maior eficiência de agente econômico. ${ }^{596}$

Já no caso do monopolista-inovador a questão se torna mais complexa. O mérito concorrencial de suas ações parece mais claro, assim como o direito de seu devido ressarcimento pelo seu dever de acesso. Conforme anteriormente discutido, o direito de propriedade intelectual possui como principal objetivo a busca por um equilíbrio adequado entre o grau de proteção necessário para incentivar inovações socialmente úteis, por um lado, e a garantia da disseminação e utilização ótima dessas inovações.

Para tanto, salvaguardas a certa margem de concorrência geralmente são aceitas, devendo ainda o direito da concorrência desempenhar papel de controle quanto à necessidade de se manter um mercado competitivo em matéria de inovação. Direitos de propriedade intelectual permitem ao seu titular impedir que terceiros produzam, utilizem ou coloquem no mercado produtos que incorporem o objeto protegido.

Intuitivamente, o próprio dever de fomento da concorrência poderia trazer impacto negativo na inovação ao permitir concorrentes de se apropriarem livremente da

${ }^{596}$ Dois exemplos do tema tratado em matéria regulatória seriam a Lei Geral de Telecomunicações (Lei n. 9.472/97), que em seu artigo 73 estabelece o direito de utilização da infraestrutura de prestadores de serviços de interesse público, e a Lei do Petróleo (Lei n. 9.478/97), que em seu artigo 58 faculta o uso dos dutos de transporte e dos terminais marítimos existentes ou a serem construídos, mediante remuneração adequada. 
inovação sem incorrerem nos seus respectivos custos (free-ridding). Nesta linha, monopolistas possuem fortes incentivos de não permitirem que seus concorrentes se beneficiem da inovação sem suportarem os custos de pesquisa e desenvolvimento.

Assim, a questão nos parece focada no tocante ao último requisito clamado pelo direito de propriedade intelectual: a garantia da disseminação e utilização ótima dessas inovações. O direito de propriedade intelectual não deixa de ser propriedade e, consequentemente, sujeito à análise de uma função social. O que implicaria dizer que o direito de fomento da concorrência por agente monopolista-inovador a seu concorrente deve atender à análise da disseminação eficiente dos bens de acesso.

Ainda que se possa arguir eventual possibilidade de atendimento pleno pelo agente monopolista-inovador de toda demanda de mercado, não haveria garantia de que novo agente seria incapaz de suplantá-lo em decorrência de sua maior eficiência. Importante, somente, que a remuneração ao agente monopolista, não discriminatória, considere todo o custo de pesquisa e desenvolvimento por este incorrido, a fim de que se atinja o devido equilíbrio com o grau de proteção necessário para incentivar inovações socialmente úteis. A esta remuneração permitida pelos institutos trazidos pelo direito de propriedade intelectual, e que devem abarcar todo o custo de pesquisa e desenvolvimento, podemos reconhecer natureza indenizatória em contrapartida ao reconhecido dever de acesso.

No tocante às demais condutas ora tratadas, bem como de forma mais geral à aplicação das normas de defesa da concorrência relativas aos abusos de posição dominante, resta claro que não há como se punir a conquista de mercado resultante de processo natural fundado na maior eficiência de agente econômico em relação a seus competidores. ${ }^{597}$ Assim, a eficiência, em princípio, se coaduna no limite à aplicação da função social justaposta aos meios de produção.

Certo que no caso dos bens de acesso, ausente estaria o elemento de comparação de eficiência a justificar a aplicação da função social, uma vez inexistente qualquer concorrência. Nesta realidade se torna mais claro o dever de fomento da concorrência, com o acesso ao bem jurídico tutelado, exceto quando disso, conforme exposto, puder resultar prejuízo injustificado ou impedimento de sua atividade comercial.

Superada a discussão sobre os princípios do ordenamento jurídico brasileiro aplicados à análise concorrencial, vale reconhecer a maior proximidade de elementos

$\overline{597}$ Artigo 36, § 1 ${ }^{\circ}$, da Lei n. 12.529/11. 
intrínsecos e extrínsecos de convergência com o velho continente, verificados no início do presente capítulo. Para tanto recordemos a adoção do sistema continental do civil law tanto na Europa - com relação ao direito comunitário - quanto no Brasil, ainda que não pareça ser este elemento preponderante em razão da tipologia aberta das normas de defesa da concorrência. Da mesma forma, há maior similaridade na organização funcional administrativa com possibilidade de reexame judicial das decisões; na ausência de uma influência direta das escolas econômicas tendencialmente mais liberais, como Chicago; na maior independência de atuação dos órgãos com relação a influências político-partidárias; e na ausência de participação da iniciativa privada constante no tocante à rotação dos cargos de direção das autoridades brasileiras e europeias, tendo sido mais recente a consolidação brasileira neste sentido.

Portanto, com exceção do preceito supranacional de aplicação da lei europeia segundo objetivo do livre mercado interno comum, e que trata de especificidade fática que torna ainda menos permissiva a conduta de agentes com posição dominante, todos os demais elementos extrínsecos ao regime jus-concorrencial parecem mais alinhados à experiência europeia. Consequentemente se presumindo, portanto, maior acerto por parte das autoridades de defesa da concorrência brasileiras na persecução de testes e elementos de análise encontrados na doutrina e jurisprudência europeia para as mais diversas modalidades de abuso de posição dominante, aplicando-se sobre estas ainda os princípios trazidos pelo ordenamento jurídico pátrio, acima tratados.

\subsection{Análise Comparativa do Tratamento da Responsabilidade Especial}

Inicialmente, notamos que a ausência de reconhecimento de uma responsabilidade especial nos Estados Unidos remonta às ideias mais liberais difundidas pela escola de Chicago, muito ao redor da tese da capacidade de os mercados se autocorrigem, bem como em razão da predileção de uma perspectiva de repúdio aos falsos positivos.

Especificamente sobre o assunto, a noção de que cabe ao monopolista a obrigação de cooperar com seus rivais, de exercer pressão especial ou ater-se a um padrão de comportamento que difere de outros concorrentes, foi afastada pelo juiz Posner em Olympia Equipment:

Opinion about the offence of monopolization has undergone an evolution. Forty years ago it was thought that even a firm with a lawful monopoly ...could not be 
allowed to defend its monopoly against would-be competitors by tactics otherwise legitimate; it had to exercise special restraint... Later, as the emphasis of antitrust policy shifted from the protection of competition as a process of rivalry to the protection of competition as a means of promoting economic efficiency, it became recognized that the lawful monopolist should be free to compete like everyone else; otherwise the antitrust laws would be holding an umbrella over inefficient competitors. A monopolist, no less than any other competitor, is permitted and indeed encouraged to compete aggressively on the merits. $^{598}$

Como enfatizado por Posner na decisão, monopolistas são livres para concorrerem, quer seja contra seus concorrentes efetivos quer seja contra concorrentes em potencial, desde que isso não resulte em práticas excludentes, entendidas como aquelas aptas a excluírem rivais igualmente ou mais eficientes. ${ }^{599}$

No caso Intel Corporation, o Tribunal de Apelação do Circuito Federal determinou que abusos de monopolização e a teoria das infraestruturas essenciais não se aplicavam ao caso em razão da ausência de concorrência nos mercados a jusante e a montante, não havendo evidências nos autos de que a Intel deseja obter vantagem competitiva no mercado a jusante de estações de trabalho gráficas:

\begin{abstract}
A non-competitor's asserted need for a manufacturer's business information does not convert the withholding of that information into an antitrust violation... The notion that withholding of technical information and samples of pre-release chips violates the Sherman Act, based on essential facility jurisprudence, is an unwarranted extension of precedent. ${ }^{600}$
\end{abstract}

Essas diferenças na abordagem dos deveres especiais de monopolistas no direito comunitário europeu e nos Estados Unidos ajudam ainda a esclarecer por que a recusa da Microsoft em fornecer informações sobre interoperabilidade não fora considerada elemento relevante do processo para os norte-americanos, embora tal elemento tenha sido mencionado no acordo firmado. Da passagem acima podemos perceber que o resultado do caso Intel Corporation parece ter se baseado bastante no fato de que a empresa não teria incentivos para monopolização do mercado a jusante, tendo sido a recusa de fornecimento mais uma tentativa de proteção de seus direitos de propriedade intelectual. ${ }^{601}$

Não nos parece, contudo, que isso seja uma resposta absoluta para a indagação acerca do dever de imposição de responsabilidade sobre as empresas dominantes com

\footnotetext{
${ }^{598}$ Olympia Equipment Leasing $v$ Western Union Telegraph 797 F.2d 370 (7th Cir. 1986), em 375. ${ }^{599}$ Olympia Equipment Leasing $v$ Western Union Telegraph 797 F.2d 370 (7th Cir. 1986), em 250. ${ }^{600}$ MCMAHON, Kathryn. Interoperability: - Indispensability and Special Responsibility in High Technology Markets, cit., p. 52.

${ }^{601}$ Idem, ibidem, p. 52.
} 
relação à recusa de fornecimento de informações sobre a interoperabilidade, devendo-se avaliar a indispensabilidade da cooperação:

\footnotetext{
If 'some cooperation' is indispensable to competition in interoperability cases, surely a duty to deal will be imposed regardless of a finding with respect to $=$ special duties', simply as part of basic application of antitrust law principles. ${ }^{602}$
}

No mínimo, esta comparação da abordagem entre os dois sistemas com relação à teoria da responsabilidade especial corrobora nosso entendimento de que o conceito em si é, em grande parte, sem conteúdo, não ensejando qualquer padrão para distinção da concorrência no mérito de uma concorrência abusiva.

Já na Europa, Amato aponta que o conceito continental de responsabilidade especial das empresas dominantes aparentemente impõe um ônus legal de natureza pública e não privada. Da mesma forma, a Comissão tende a focar mais sua decisão nos preceitos de livre iniciativa, prejuízo ao consumidor e incentivos adicionais à inovação não quantificáveis no longo prazo. A questão do agente tão eficiente deve, assim, ser examinada com maior profundida. Não basta que qualquer agente igualmente eficiente seja capaz de entrar no mercado, mas deve ainda ser capaz de permanecer no mercado e fazer frente à pressão do agente monopolista.

A Comissão assim tem reconhecido e defendido, de certa forma, o interesse público na questão. Parece ainda reconhecer a importância de questões outras além da performance da própria empresa, como elementos que ampliem esta proteção ao agente econômico, no sentido de que este seja capaz de trazer produtos ou serviços ao mercado sem ser prejudicado pelo agente monopolista. Prega assim pela livre escolha do consumidor e pela consideração da inovação na sua perspectiva completa. Adquire um caráter, não podemos negar, de proteção institucional da concorrência.

Portanto, a responsabilidade especial de não distorção da livre concorrência no seu mérito não pode se basear, sob a perspectiva europeia, em avaliação exclusivamente econômica de desempenho, merecendo expandida consideração. Critique-se ainda, que talvez isso possa parecer um tanto quanto inconsistente com a reforma do artigo 102 que clama por uma aplicação mais forte da perspectiva econômica e de efetiva avaliação de efeitos das práticas.

\footnotetext{
${ }^{602}$ MCMAHON, Kathryn. Interoperability: Indispensability and Special Responsibility in High Technology Markets, cit., p. 53.
} 
No que diz respeito a descontos de fidelidade, por exemplo, podemos reconhecer que, nos Estados Unidos, tais descontos, mesmo que promovam a lealdade do cliente, não seriam necessariamente anticompetitivos. Efeitos pró e anticoncorrenciais têm que ser demonstrados e, em seguida, balanceados. Na prática, tem se verificado excepcionalmente que os esquemas de descontos ou mesmo exclusividades simples são proibidos.

Já na União Europeia, há uma tendência geral para simplesmente presumir efeitos anticoncorrenciais sistemáticos em caso de qualquer sistema de descontos de um agente dominante e para subestimar seus efeitos pró-concorrenciais. No caso Michelin II, o Tribunal de Justiça Europeu reconheceu que a empresa falhou em demonstrar que os descontos espelhavam economias de escala, tendo inclusive, na visão de alguns autores, invertido o ônus probatório:

\begin{abstract}
It is striking that the Court in Michelin II requests the defendant company to prove that linear quantitative rebate schemes are cost justified; it thereby reverses the current case-law, which traditionally puts the burden of proof in this respect on the authority. Paradoxically, the former case-law is correctly summarized by the Court, in para. 58 of its Michelin II judgment, when it stresses that quantitative rebates are normally not abusive as they are 'presumed' to reflect cost-savings or other economies of scale and are 'considered as having no foreclosure effects. 33 The Court then however condemns Michelin's quantitative rebates for having failed to demonstrate that the rebates reflected economies of scale. 34 In doing so, the Court reverses the current presumption of legality of quantitative rebates by assimilating quantitative rebates totally to loyalty rebates, and puts the burden of proving the justification of the rebate on the dominant company. ${ }^{35}$
\end{abstract}

Já os tribunais norte-americanos sempre foram enfáticos em sua conclusão de que um agente econômico não deveria ser constrangido no seu direito de livre exercício da sua decisão de fazer negócios, observando, contudo, ocasiões em que agentes dominantes podem incorrer em responsabilidade decorrente de sua conduta unilateral. Na mesma linha, Eastbrook defende:

In a number of circumstances, it is beneficial for the economy and for consumers if firms holding monopoly power compete hard with other firms. In other circumstances, the conduct of those firms can be exclusionary. Since it is hard to distinguish between competitive and exclusionary conduct, it is better to allow firms to compete hard and put the burden upon authorities, in exceptional circumstances, to show that the conduct was in fact exclusionary and in breach of $\S 2 .{ }^{603}$

${ }^{603}$ EASTERBROOK, F. H. On Identifying Exclusionary Conduct. 61 Notre Dame L. Rev. 972. 1986. 
O trecho acima reflete, em nosso entender, de forma precisa, a ideologia da política concorrencial norte-americana, cujos princípios basilares, clara e expressamente, defendem uma concorrência feroz, cabendo às autoridades, em circunstâncias especiais, demonstrar que esta concorrência teria ultrapassado os limites da legitimidade.

Talvez uma constatação omissa no trecho acima se refira ao padrão probatório necessário para esta demonstração, e ainda mais à dificuldade de exercício deste padrão probatório em razão da assimetria informacional comumente verificada nos mercados, principalmente quando tratamos de mercados de inovação.

Sob o regime europeu esta distinção é mais tênue. As empresas dominantes seriam permitidas a concorrer no mérito, devendo se abster de outras formas de concorrência que, em tese, não possuem tais méritos, reconhecendo-se, desta forma, uma responsabilidade especial.

\subsection{Abuso de Poder e Responsabilidade Especial: Reconhecimento da Interdependência das Teorias}

As questões trazidas ao longo deste trabalho visaram, inicialmente, pavimentar a análise do seu objeto principal, introduzindo aqueles elementos essenciais à sua completude. Para tanto, foram tangenciados temas como o escopo das leis antitruste, a essencialidade da teoria econômica como instrumento de previsibilidade da aplicação das normas concorrenciais de tipologia aberta, as falhas de mercado e formas encontradas pelo sistema jurídico para sua correção e a importância da regulação dos mercados. Em seguida, discutimos temas como a importância dos mercados relevantes, a teoria dos monopólios, do poder de mercado e da posição dominante, tecendo, finalmente, considerações sobre uma realidade mais contemporânea, ligada à ideia da Nova Economia e os desafios por ela trazidos. Todos os temas identificados constituem o universo de elementos vitais para efetiva aplicação da teoria das responsabilidades especiais proposta, ainda que alguns tragam elementos mais diretos de apoio que outros.

Para então entrarmos na análise comparativa da identidade dos três regimes estudados, no tocante à sua origem e evolução histórica, seu arcabouço jurídico, a doutrina e jurisprudência desenvolvida por suas instituições ao longo dos anos, com uma análise tentativamente sistematizada acerca de seus precedentes, a fim de que fosse possível chegarmos à conclusão sobre o atual estágio de maturidade verificado no Sistema 
Brasileiro de Defesa da Concorrência e seus necessários ajustes, em especial tratando da teoria dos abusos de posição dominante.

As teorias do abuso de posição dominante e das reponsabilidades especiais se completam. Não há como se cogitar da aplicação de qualquer delas de forma isolada, conforme pretendemos demonstrar. A responsabilidade especial é decorrente de uma situação fática - poder de mercado - que requer uma atuação segundo o grau de responsabilidade que esta situação coloca.

A teoria do abuso, conforme desenvolvida nos capítulos anteriores com foco nas práticas ora elencadas, serviria de orientação para efetiva aplicação da teoria das responsabilidades especiais, naquilo que a última se propõe: uma inversão do ônus probatório promovida pela autoridade diante do reconhecimento desta responsabilidade especial. Contudo, observamos que a teoria do abuso de posição dominante serviria ainda a indispensável função de elemento procedimental de admissão da ação por parte das autoridades de defesa de concorrência e mesmo judiciais, conforme abordado adiante.

A novidade da teoria das responsabilidades especiais que se propõe discutir para o Brasil é ainda um tanto quanto incipiente no berço de sua concepção. Ao mesmo tempo, há negativa de seu reconhecimento nos Estados Unidos, onde certamente imperam as teorias mais liberais da Escola de Chicago. O que nos coloca algumas questões.

Uma inicial reflexão, fruto do resultado de todo conteúdo analisado no presente trabalho, nos leva à conclusão de que agentes econômicos com posição dominante possuem responsabilidades especiais em contrapartida ao seu poder de mercado, e que impõem sobre estes agentes o dever de conduzirem-se sob os ditames de um não impedimento ou manutenção da livre concorrência e da livre iniciativa, e por vezes mesmo da promoção ou fomento de tais princípios, como intensamente debatido.

O conceito de responsabilidade especial que tem sido aplicado pelos tribunais europeus sinaliza para uma atenção especial às condutas comerciais praticadas por agentes em posição dominante, na medida em que parece sugerir a existência de atitude suspeita destes. No que não nos parece equivocado, na medida em que quanto maior o poder de mercado verificado por um agente econômico, maior seria a probabilidade de produção de efeitos deletérios ao instituto da concorrência em razão de tentativa de manutenção ou aumento deste efetivo poder de mercado.

Conforme mencionado, a fim de que se dê completude à teoria da responsabilidade especial dos agentes com posição dominante e se permita sua aplicação, um passo atrás na presente análise se fez necessário justamente para identificação ou 
sugestão do tratamento a ser dado pelas autoridades brasileiras à teoria dos abusos de posição dominante.

O segundo diagnóstico apresentado acerca de nosso sistema jus-concorrencial é a ausência de identidade ideológica da teoria dos abusos de posição dominante, em razão, principalmente, do padrão casuístico de análise. Há, claramente, subapliação e debate insuficiente desta teoria no nosso ordenamento jurídico. Como consequência, desenvolvemos aquilo que poderíamos chamar de uma base do dever-ser do normativo concorrencial brasileiro no tocante às modalidades de abuso tratadas. Somente mediante esta base caracterizada é que poderemos passar a tratar dos efeitos da imposição de responsabilidades especiais aos agentes econômicos dominantes. A teoria dos abusos de posição dominante reconhecida pelos sistemas jurídicos analisados é, portanto, elemento intrinsecamente relacionado ao tema das responsabilidades especiais reconhecidas aos agentes econômicos.

\subsection{Teoria do Abuso de Poder Econômico: Concorrência no Mérito}

Ao longo desta análise é inegável o fato de prestar a teoria econômica serviço de essencial importância para avaliação da legitimidade das condutas levadas a efeito pelos agentes econômicos com posição dominante. A teoria econômica é capaz de trazer maior previsibilidade com relação às normas de tipologia aberta do sistema jus-concorrencial, prestando papel essencial em combinação com a jurisprudência. Principalmente, é de se reconhecer que os preceitos econômicos ligados à eficiência das atividades comerciais das empresas é elemento essencial a pautar qualquer análise por parte das autoridades.

No tocante às próprias regras postas, defendem autores que clareza e simplicidade podem ser mais prováveis de aumentarem a segurança jurídica do que padrões complexos estabelecidos. Uma regra simples e clara, em que a aplicação da lei é determinada por um único, ou um conjunto limitado de fatos predefinidos, pode aumentar a segurança jurídica uma vez que limita a discrição na sua aplicação. Também diminuem os custos relacionados ao monitoramento do cumprimento da lei e o custo de sua exequibilidade.

Fato, contudo, é que as normas referentes à defesa da concorrência sempre serão de tipologia aberta, em razão da dinamicidade das relações comerciais no atual mundo globalizado. Caberá à teoria econômica embasar os precedentes, estes sim elencados 
critérios simples e claros para constatação de abusos quando incumbir ao agente econômico uma responsabilidade especial de não limitação da livre concorrência.

Da mesma forma, a teoria dos abusos de posição dominante, intrinsecamente ligada ao conceito das responsabilidades especiais, traz indispensável contribuição. Visa estabelecer, juntamente com os testes especiais que podem ser utilizados para cada modalidade de abuso, parâmetros gerais de análise de distinção de uma concorrência no mérito daquele tipo de concorrência abusiva resultante de conduta unilateral. Tal papel não caberia, portanto, à teoria da responsabilidade especial, razão pela a qual as duas teorias são complementares. Como frisado, é impossível tratar de uma sem reconhecimento da outra.

Neste sentido, ainda que pareça intuitiva uma conceituação de concorrência no mérito, há grande dificuldade não somente no consenso de seus elementos avaliadores e conclusivos, mas ainda na valoração do tema. Não há consenso, e provavelmente nunca haverá, no seu significado. E diversos seriam os fatores para tanto.

Inicialmente, poderíamos cogitar de uma concorrência no mérito como sendo aquela "concorrência normal" reconhecida no acórdão Hoffmann-La Roche ${ }^{604}$ Contudo, nos parece trazer insuficiência de critério em ambientes de concentrações econômicas relevantes. $\mathrm{O}$ que seria prática comum em um mercado competitivo adquire nova feição em mercados concentrados. Nestes casos, a concorrência no mérito assume caráter diferenciado para empresas com pouco ou nenhum poder de mercado, comparativamente àquelas em posição dominante.

No relatório da OECD de 2005 tentou-se conceituar a concorrência de mérito:

Typically, use of expression "competition on the merits" implies that when a dominant enterprise is confronted with rivals or the prospect of their entry, it cannot lawfully counter the competitive challenge with conduct that falls outside an area circumscribed by that phrase.

Contudo, verificamos que tal assertiva não traz maiores esclarecimentos. Interpretações diversas de seu conceito são, desta forma, comumente verificadas, corroborando com o receio de agentes dominantes de receberem tratamento arbitrário por parte de autoridades concorrenciais.

\footnotetext{
${ }^{604}$ Acórdão do Tribunal de Justiça de 13.2.1979, Proc. 85/76, Hoffmann-La Roche \& Co. AG c Comissão das Comunidades Europeias, Colect. 1979-I, p. 217.
} 
Um conceito mais próximo ao consenso sobre "concorrência no mérito" e parâmetros por ele trazidos deveria servir ao propósito inicial de auxiliar a separação daquelas condutas lesivas à livre concorrência de uma concorrência saudável. Inevitável, contudo, que para construção destes conceitos se passe pela discussão acerca dos objetivos inerentes à aplicação das normas concorrenciais por um sistema jurídico específico.

Ainda, com relação ao Brasil, como asseverou a própria autoridade brasileira no relatório da OECD de 2005, a discussão da concorrência no mérito encontrava-se, à época, e insistimos ainda se encontra, bastante incipiente:

\begin{abstract}
The competition on the merits concept is something that is still very incipient in Brazil. As said, CADE has never taken a decision that explicit the concept "competition on merits". As a matter of fact, it can be said that there are not enough decisions in order to reach a definition under jurisprudence. The very few antitrust cases dealt by the Brazilian judiciary do not also allow building a definition. However, the number of cases in what the idea of this concept has come up is growing up, as it can be noticed by the different analyses made on the Paiva Piovesan/Microsoft case (when the aggressive conduct adopted by Microsoft was not considered illegal) and the Microsoft/TBA (condemned by discriminatory practices). ${ }^{605}$
\end{abstract}

A concorrência no mérito poderia implicar afastamento do mercado ou na marginalização de concorrentes menos eficientes ou menos atrativos a consumidores sob o ponto de vista de, entre outras coisas, preços, possibilidade de escolha, qualidade ou inovação.

Importante a comparação, novamente, entre as perspectivas norte-americanas e europeias. O artigo 102 do TFUE parece se aplicar para condutas que, através de recursos a métodos diferentes daqueles que governam a concorrência normal baseada no desempenho de operadores comerciais, teria o efeito, em detrimento de consumidores, de impactarem na manutenção do grau de concorrência existente no mercado. Por sua vez, os norteamericanos parecem um pouco mais tímidos em qualquer intervenção relativa ao tema por conta dos referidos erros tipo I - falsos positivos - decorrentes da dificuldade de diferenciação entre concorrência saudável e predatória.

Ao final, nos quer parecer que nos Estados Unidos uma empresa mais eficiente que seus concorrentes pode justificadamente empreender conduta comercial que terá como

\footnotetext{
${ }^{605}$ Relatório OECD. Policy Roundtables. Competition on the Merits, 2005. O relatório ainda se refere ao Caso dos Operadores Portuários, que ilustrou como a autoridade da concorrência brasileira aborda a questão da separação de concorrência no mérito de práticas exclusionárias. Apesar da ausência de dispositivo formal aplicado, o relatório aponta alguns critérios adotados de forma regular pela jurisprudência do CADE. Por exemplo, a identificação de posição dominante, o incentivo à adotar comportamentos, a capacidade de realizar a estratégia e, finalmente, os danos para rivais, clientes ou consumidores.
} 
efeito a exclusão de todos os agentes menos eficientes do mercado. Já para os Europeus, tal condição não justifica a exclusão de concorrentes, na medida em que se preocupam ainda com a estrutura da concorrência e do mercado como um todo. Mesmo que se pregue mais análise econômica nas decisões europeias, o que tem sido ainda sinalizado por aquelas autoridades, ainda assim, poderia haver a manutenção da política de concorrência para preservação das estruturas do mercado.

Em que pese tal discussão, aplicando-a ao nosso sistema jus-concorrencial, por todo exposto anteriormente com relação ao caráter de garantia institucional da concorrência no Brasil, resultado impositivo de nossa Carta-Magna, e consequente função social dos meios de produção, a preservação da concorrência no mercado e das suas estruturas para ser um objetivo do sistema, conforme tratamos a seguir. Assim, agentes econômicos devem encontrar, no mercado, uma estrutura de concorrência que lhes permita competir livremente com relação aos agentes que se encontram em posição dominante, ainda que, ao extremo, isso implique dever de acesso.

\subsection{Reconhecimento de Livre Concorrência como Garantia Institucional}

Naquilo que se refere à ineficiência dos monopólios, o conceito econômico que, em nosso entender, merece destaque, vem sob a ótica de Kaldor-Hicks, ou da maximização de bem-estar social. Como visto, o movimento de uma situação de monopólio para uma situação de concorrência perfeita estaria justificado sob a ótica econômica na medida em que o excedente do consumidor - consumer surplus -, somado ao excedente do produtor producer surplus -, verifica-se maior em decorrência desta troca, considerando ainda o peso morto gerado ao consumidor no caso de monopólios. Segundo tal modelo econômico ora privilegiado, deveriam as autoridades encarregadas da tutela concorrencial agir de forma a incentivar o atingimento da concorrência perfeita em tantos mercados quanto possíveis.

Este raciocínio encontra-se perfeitamente alinhado ao reconhecimento do caráter da garantia institucional que a proteção à livre concorrência incorpora como resultado da análise do nosso ordenamento jurídico, portanto, muito além de condição de política pública de Estado.

Mesmo em situações de monopólios naturais, defendemos que a concorrência pode ser fomentada pelas autoridades reguladoras e concorrenciais, gerando bem-estar 
adicional ao consumidor. A teoria das infraestruturas essenciais vem neste sentido, com seu respectivo dever de acesso. E ainda, não podemos nos esquecer da inovação tecnológica e consequente convergência gerada, capaz de alterar parâmetros definidores do alcance de mercados relevantes. Em outras palavras, mesmo monopólios naturais não devem restar imunes à análise da possibilidade e benefícios da introdução ou aprofundamento da concorrência, devendo ser objeto de constante estudo e reflexão por parte de autoridades reguladoras e concorrenciais.

Quando da revisão do Tratado na União Europeia para implementação dos ditames do mercado único, percebeu-se que setores específicos, como energia, transporte e telecomunicações, permaneciam imunes à pressão da concorrência e integração das atividades econômicas. Este fato parece ter influenciado de forma significativa a postura aparentemente intervencionista da Comissão para pressionar Estados-Membros na liberalização dos setores. A ideia de seus idealizadores era permitir a existência de empresas em posição dominante, dotadas de direitos especiais ou exclusivos, mas impondo-lhes ônus de serem sujeitos de deveres especiais de conduta que as levasse a atuar como se submetidas à disciplina do mercado via concorrência.

A regulação pode, deve, e de fato desempenha, portanto, papel essencial de introdução da livre concorrência nestes setores regulados. O faz em situação clara, muitas vezes sob natureza contratual, em contrapartida à efetiva concessão a particulares da possibilidade de exploração de lucros monopolísticos.

Devemos ainda ter em mente que, simplesmente, esta perspectiva de lucros monopolísticos pode criar incentivos necessários para empresas desenvolverem, melhorarem e baratearem produtos ou tecnologias. Logo, as decisões das autoridades devem se pautar de todo cuidado necessário para não gerarem incentivos protecionistas, como efeitos de carona ou free riding, em concorrentes menos eficientes, desestimulando o processo inovativo.

Caso sejam impostas responsabilidades que proíbam o agente com posição dominante de levar a efeito conduta economicamente eficiente em detrimento de agente não dominante menos eficiente, poderíamos entender que o benefício de proteção gerado ao agente não eficiente teria natureza de compensação trazida pelo Estado, ou ainda caráter redistributivo, à custa do agente dominante mais eficiente.

Incentivos criados segundo uma política de privilégio a agentes econômicos menos eficientes podem levar ao acomodamento e ausência de dispêndio de seus esforços de inovação, com propósito de tornar-se mais eficiente. Tratar-se-ia de escolhas públicas 
obviamente equivocadas, tendentes a gerar redução do bem-estar social. E não é isso que pretendemos ao defender a concorrência como garantia institucional, mas simplesmente um ambiente de livre concorrência na sua completa acepção.

Ao extremo, poderíamos reconhecer a impertinência de eventual chancela de legitimidade de condutas envolvendo maior eficiência produtiva alcançada com base, exclusivamente, em economias de escala, porém ausentes as progressivamente relevantes eficiências dinâmicas.

Tal assertiva parece mais verdadeira ainda nos chamados mercados de inovação. A relação entre a concorrência e a inovação, neste tocante, tem promovido constante embate teórico na literatura econômica, absorvido pela jurisprudência de diversos sistemas jurídicos. De um lado aqueles que defendem uma negativa relação entre concorrência e inovação, na medida em que o aumento da concorrência diminui as potenciais rendas auferidas pelo inovador, reduzindo, portanto, os incentivos à inovação. De outro lado, aqueles que defendem que a concorrência em si seria suficiente para criação dos necessários incentivos à inovação, uma vez que agentes econômicos tendem a ganhar mais com a inovação se se encontram em ambiente de livre concorrência, comparativamente à situação de lucros supracompetitivos segundo um cenário de monopólio. Fato é que a política de concorrência deve ser cuidadosamente calibrada. ${ }^{606}$

Portanto, a inovação não deve ser considerada de forma apequenada, limitada ou restrita, mas em toda sua extensão. Haveria, assim, dois elementos a serem considerados, o segundo deles constantemente ignorado por correntes mais filiadas às teses de Chicago: a ideia da invenção e a sua implementação, ou seja, sua introdução no mercado. A inovação que não gera efetiva introdução do produto ou serviço no mercado de pouco adianta. Portanto, apesar de relevante a questão do investimento, e consequentemente a sinalização à proteção destes investimentos que o arcabouço jurídico deve garantir, este não seria o único fator determinante a ser considerado sob o prisma da inovação.

Devemos garantir que o arcabouço jurídico de um ordenamento, no caso o brasileiro, traga todos os elementos de garantia à plena introdução da invenção no mercado, obviamente remunerando, a justo título, o inventor. Introduzir invenção no mercado passa por questões, portanto, de acesso, tanto sob a ótica da oferta quanto da demanda.

606 LAROUCHE, Pierre e SCHINKEL, Maarten Pieter. Continental Drift in the Threatment of Dominant Firms. Article 102 TFUE in Contrast to $\S 2$ Sherman Act. In TILEC. Discussion Paper. Maio 2013. Disponível em: <http://ssrn.com/abstract=2293141>. 
Para que haja incentivos completos à inovação se faz necessário que agentes econômicos tenham a habilidade de introduzir novos produtos e serviços a potenciais clientes e, consequentemente, que potenciais clientes possam efetivamente a eles ter acesso a fim de avaliarem se estes novos produtos atendem suas preferências. A política concorrencial implicaria a manutenção de liberdade do processo competitivo, inclusive no tocante à possibilidade de buscar novos clientes. Se tais invenções não puderem percorrer seu caminho no mercado, não haverá inovação.

Neste tocante, a concorrência no mérito toma uma nova dimensão, enxergada na sua perspectiva dinâmica:

From a dynamic perspective, competition on the merits can be seen as the ability to present new products and services to customers and have customers decide whether these products and services, as opposed to what is already on the market or to alternative novelties, find their favour. ${ }^{607}$

Deve-se ainda observar que a inovação não parece ser um processo isolado, mas dependente, em muitas ocasiões, do ambiente em que se insere, com uma construção a partir de outra inovação, de interações com seus clientes ou, ainda, interações com seus concorrentes decorrentes da cadeia de fornecimento. A criação de padrões tecnológicos nos quer parecer um grande balão de ensaio para melhoramento ou desenvolvimento de novas tecnologias.

Especificamente com relação ao ordenamento jurídico brasileiro, o interesse público, visto que a concorrência é garantia institucional do sistema, deve prevalecer sobre os interesses privados dos agentes monopolistas. O balanço correto deve levar em consideração, portanto, os devidos incentivos para que se dê a concorrencial dinâmica, e não meramente estática, promovendo inovação. A opção de escolha que é dada aos consumidores também se faz de vital importância. O interesse público ainda se coaduna com as obrigações resultantes da função social dos meios de produção.

Portanto, qualquer conceituação de concorrência no mérito sob a ótica do ordenamento jurídico brasileiro deve levar em consideração os elementos indispensáveis à introdução ou proteção da concorrência residual no mercado, com o objetivo de aumentar o bem-estar do consumidor e promover alocação eficiente de recursos.

607 LAROUCHE, Pierre e SCHINKEL, Maarten Pieter. Continental Drift in the Threatment of Dominant Firms, cit., p. 21. 
Não podemos nos olvidar que o bem-estar do consumidor passa ainda pela opção que este tem com relação a produtos e serviços. E ainda que o direito concorrencial se proponha a estudar a real percepção do consumidor com relação a estes produtos e serviços, a fim de avaliar a efetiva substitutibilidade entre eles, o que o faz através das longas discussões de mercado relevantes com base em metodologias econômicas nem sempre incontestáveis, esta percepção não é absoluta. Consumidores não possuem, e jamais possuirão, padrões absolutos e retilíneos de consumo. Exemplificativamente, um consumidor $\mathrm{X}$ pode ter uma percepção de melhor tecnologia de um produto $\mathrm{Z}$ e decidir pagar preço a maior se comparado ao produto $\mathrm{W}$ que, comprovadamente, possui tecnologia mais moderna. Este consumidor, defendemos, não pode ser privado de acesso ao produto de sua preferência. Opção na escolha de diferentes produtos e serviços também se reflete como bem-estar do consumidor.

O conceito de concorrência no mérito é, como visto, núcleo central da teoria, implicando em melhor qualidade, menor preço, melhor desempenho, melhor produto ou inovação. A todos deve ser garantido o direito da livre concorrência, sem interferências artificiais que venham a distorcer as pressões concorrenciais existentes nos mercados.

Como garantia institucional da correção e equilíbrio da interação econômica dos diversos agentes, a justificativa da regulação passaria a ser a criação de uma igualdade material entre todos os agentes econômicos, para que possam desenvolver suas atividades em iguais condições. Para que se dê uma igualdade material haveria a necessidade de uma difusão forçada do conhecimento econômico entre os indivíduos, que só poderia ser assegurada através de uma garantia firme de existência de concorrência.

A presença constante de concorrência em um mercado deve, portanto, ser tratada como presunção de bem-estar social. É isso que visam as leis concorrenciais ao serem tratadas como garantia institucional. Sempre ao respeito da função social dos meios de produção. Tal conclusão se torna bastante clara quando contrapostos os direitos de propriedade intelectual e a função social, elencando-se como ponto de chegada o bem-estar social, sem prejuízo, contudo, da discussão do prêmio ao agente inovador:

Se a função dos direitos de PI é promover a inovação, mediante a atribuição de direitos exclusivos (e direitos morais no caso do direito de autor) que permitam ao criador obter uma recompensa pelo seu esforço, esta motivação estende-se também à difusão dos resultados da criatividade humana. Assim, a recusa de licença poderá, em circunstâncias excepcionais, "ser contrária ao bem público 
geral", na medida em que dessa recusa decorram efeitos negativos na inovação e nos consumidores. 608

Circunstâncias especiais surgem se a recusa de fornecimento envolve direitos de propriedade intelectual. Nestes casos, o tribunal deve equilibrar o incentivo para inovar, protegido pelo direito de propriedade intelectual, através da promoção da concorrência no mercado. A maneira pela qual esta tenha sido tratada no âmbito do direito europeu, em linha com outras jurisdições, é que não seria a posse, mas o abuso, da propriedade intelectual, que atrai a aplicação da norma. Se o direito é exercido de tal forma a prosseguir uma finalidade manifestamente contrária aos objetivos do artigo 102, então ele não está mais sendo exercido de acordo com a sua função essencial e direito comunitário prevaleceria sobre qualquer uso da propriedade intelectual. ${ }^{609}$

Ainda no tocante aos temas atrelados à nova economia, mais precisamente àqueles que dizem respeito aos mercados de inovação, vale redobrada atenção com relação, principalmente, à importância da flexibilização das definições de mercados relevantes observados e o foco na análise dinâmica dos comportamentos e da estrutura de mercado.

Vale recordar que mercados mais fortemente ligados a tecnologias quebram parâmetros, permitem convergência, destroem fronteiras e criam outros mercados com velocidade assustadora. Assim, não se deve limitar uma análise com base em definições estanques de mercados relevantes, devendo-se flexibilizá-las, entendendo os comportamentos que uma conduta possa gerar de forma mais ampla.

$\mathrm{O}$ embate identificado parece refletir-se de forma bastante clara nos sistemas jurídicos ora analisados. Por um lado, verificamos uma visão predominantemente Schumpeteriana nos Estados Unidos, que valoriza a eficiência dinâmica, a concorrência pela inovação, a esperada destruição criativa, e reconhecendo nas empresas com posição dominante a matriz da inovação. Por outro lado, mais conservador parece ser o tratamento seguido pela União Europeia segundo o seu Tratado de Funcionamento, caracterizando mais facilmente como abusiva a exploração de posição dominante para obter vantagens que não seriam possíveis se o agente estivesse sujeito à disciplina descentralizada e anônima da concorrência. O Brasil parece dever se situar mais próximo às perspectivas europeias.

${ }^{608}$ MOURA E SILVA, Miguel. O Abuso de Posição Dominante na Nova Economia. Teses de Doutoramento, cit., p. 537.

609 MCMAHON, Kathryn. Interoperability: Indispensability and Special Responsibility in High Technology Markets, cit., p. 6-7. 


\title{
8.9. Aplicação Sugerida da Tese de Responsabilidade Especial
}

A primeira constatação com relação à aplicação de uma teoria das responsabilidades especiais que devemos fazer refere-se ao posicionamento de diversos autores, por este corroborado, que são enfáticos em reconhecer que o termo não parece identificar qualquer critério para se determinar se um agente com posição dominante praticou ou não ilícito aos ditames das normas concorrenciais relevantes, devendo esta responsabilidade especial ser ponderada em vista das circunstâncias fáticas de cada caso. Não traz, portanto, qualquer parâmetro de reconhecimento de concorrência de mérito ou abusiva e, consequentemente, de qualquer teste substantivo.

Assim, poderíamos reconhecer inicialmente que este conceito geral de responsabilidade especial pouco ajuda na identificação das formas de conduta que podem constituir abuso de posição dominante, ou naquilo que seria ainda uma restrição à livre concorrência. ${ }^{610}$ Neste sentido, observa Richard Whish:

\begin{abstract}
This statement is routinely repeated in the judgments of the Community Courts and the decisions of the Commission on Article 82. In a sense it is a statement of the obvious: it is clear that Article 82 imposes obligations on dominant firms that non-dominant firms do not bear. (...) An issue that will be explored (...) is whether this special responsibility has led the Commission and the Community Courts to apply Article 82 too widely: do dominants firms labour under a handicap that prevents them from competing fiercely as their non-dominant competitors? ${ }^{611}$
\end{abstract}

Justamente em razão da ausência de critérios trazidos pela teoria das responsabilidades especiais no tocante à diferenciação da concorrência no mérito daquela concorrência abusiva, propusemos, ao longo do presente trabalho, analisar de forma detalhada os testes utilizados pelas diversas autoridades para identificação destas situações abusivas, de forma comparativa. Serviu tal análise prévia justamente ao papel de elucidação, ou mesmo proposição, de elementos de análise que permitiriam isolar a concorrência predatória, justamente ao propósito de se somar à teoria das responsabilidades especiais. Portanto, sem a primeira parte deste trabalho não haveria como se aplicar a tese das responsabilidades especiais, reiteremos.

\footnotetext{
${ }^{610}$ Vide LANG, J. Temple e O’DONOGHUE, R. The Concept of an Exclusionary Abuse under Art. 82 EC. In GCLC Research Papers on Article 82, julho 2005.

${ }^{611}$ WHISH, Richard. Competition Law (7. ed.), p. 192.
} 
Ainda em resposta à provocação de Richard Whish no trecho acima, em nossa visão é permitido aos agentes dominantes que concorram de maneira agressiva, extraindo participação de mercado de seus concorrentes, desde que o façam com base em superior eficiência, e não como decorrência de abuso de sua situação concorrencialmente privilegiada em relação aos seus concorrentes, sempre diante de uma estrutura de mercado que garanta igualdade de oportunidades entre os agentes econômicos.

Por certo, agentes econômicos com posição dominante tendem a apresentar, na maioria dos mercados em que atuam, melhor estrutura competitiva fruto do desenvolvimento de suas políticas comerciais. Mas aos novos entrantes ou já presentes concorrentes, desprovidos da mesma condição comercial de seu concorrente dominante, deve ser garantida uma liberdade de atuação que lhe permita difundir suas ideias, seus produtos ou seus serviços aos consumidores. Se este irá alcançar tais anseios não é, na maioria das vezes - salvo situações em que haja responsabilidade especial de fomento da concorrência como discutido na teoria das infraestruturas essenciais -, problema do agente dominante. Mas deve ter o pretendente de acesso ao mercado possibilidade de fazê-lo sem que haja interferência não relacionada diretamente à eficiência dos produtos ou serviços do agente econômico dominante.

A segunda constatação é que se a responsabilidade decorre desta condição de dominância ou mesmo superdominância, os atuais agentes dominantes podem nem sempre estar nesta posição, retornando à permissibilidade de uma prática padrão da indústria uma vez que percam tal condição. A natureza dinâmica da inovação significa que este poder de mercado pode ser corroído rapidamente. Isto é especialmente verdadeiro se a interoperabilidade alcança seu objetivo, por exemplo.

Da mesma forma, o exercício de poder de mercado só dá lugar à responsabilidade pela conduta subsequentemente à aquisição desta posição dominante, só podendo ser sujeito de responsabilidade especial inerente ao conceito de posição dominante aquele que tem o dever de se comportar de forma diferente.

A terceira constatação, esta sim já entrando mais a fundo naquilo que se propõe delinear como uma teoria da responsabilidade especial, passaria pela perspectiva institucional, que impõe uma responsabilidade diferenciada para um agente dominante de autoaplicação dos limites permitidos para sua conduta comercial. Assim, diante de uma 
realidade de posição dominante, ao agente econômico caberia a cuidadosa promoção de uma autoavaliação da legitimidade de sua conduta. ${ }^{612}$

Sugerimos, portanto, uma perspectiva institucional para a teoria das responsabilidades especiais, em linha com o que se verificou na Europa com o "Modernization Regulation de 2003". ${ }^{613}$ Naquela ocasião, a nova legislação dispensou a obrigatoriedade de notificação de determinadas naturezas de contratos, cuja avaliação caberia aos próprios agentes econômicos. Sempre com a ajuda de instrumentos de soft-law, como guias, relatórios e resoluções preparados pela Comissão Europeia, além da clara sinalização jurisprudencial trazida.

O mesmo se propõe para a teoria das responsabilidades. Empresas com posição dominante carregam consigo uma responsabilidade especial de autoavaliação do impacto concorrencial de suas próprias condutas, com todos os riscos inerentes a esta análise.

Da mesma forma, se a posição dominante em que se encontra o agente econômico gera o ônus da responsabilidade especial de autoavaliação de suas condutas comerciais, seu desrespeito deve gerar presunção relativa de efeito anticoncorrencial no mercado (iuris tantum), admitindo, portanto, prova em contrário para descaracterização da conduta.

Portanto, suposta falha nesta autoavaliação, que se materializaria por alegados efeitos no mercado decorrentes da conduta, ainda que potenciais, ensejando representações ou mesmo investigações perante autoridades concorrenciais ou poder judiciário, geram efeitos de inversão do ônus da prova em detrimento do agente econômico que produziu a conduta sob suspeita.

Contudo, se faz de vital importância para garantia, em especial, do princípio do devido processo legal, que haja breve análise inicial desta conduta por parte das autoridades ou de eventuais representantes, segundo os critérios trazidos pela teoria dos abusos de posição dominante. Se constatados elementos de convicção que sugiram a potencialidade lesiva da conduta, segundo os padrões probatórios próprios ao sistema jusconcorrencial brasileiro, decorrente de uma aplicação sumária dos testes, haverá condição de ação para abertura de procedimento investigatório perante o SBDC, restando autorizada a inversão do ônus probatório. Haveria, neste cenário, presunção relativa de lesividade da prática.

\footnotetext{
${ }^{612}$ Neste sentido vide LAROUCHE, Pierre e SCHINKEL, Maarten Pieter. Continental Drift in the Threatment of Dominant Firms: Article 102 TFUE in Contrast to § 2 Sherman Act, cit.

${ }^{613}$ Regulação da Comissão Europeia n. 1/2003.
} 
A teoria do abuso de posição dominante, no tocante a cada particularidade de conduta sob exame, segundo a proposta do dever-ser do sistema jus-concorrencial brasileiro, deve ser utilizada pelas autoridades para este exame sumário da condição da ação. Some-se a tais testes a percepção geral acerca da natureza de garantia institucional da norma. Como concluído, a concorrência cuja legitimação se busca é a concorrência no mérito, e a eficiência trazida pelo agente econômico dominante, por sua vez, não deve extrapolar os seus limites, de forma a afetar a igualdade material de concorrência que impacte o acesso aos mercados.

Concluímos, neste tocante, que a teoria das responsabilidades especiais também impinge atribuições àqueles que desafiam a legitimidade da conduta do agente com posição dominante. Funcionaria, desta forma, como verdadeira condição da ação a necessária avaliação, segundo os testes sugeridos, da conduta do agente. Esta avaliação deve se dar de forma sumária, com base nas evidências que tenham sido trazidas suportando a desconfiança de efeitos anticoncorrenciais gerados, ainda que potencialmente.

Não pode, desta forma, se furtar a autoridade - ou mesmo qualquer concorrente ou cliente que represente tal conduta às autoridades - em promover esta avaliação sumária dos elementos em questão, cabendo motivação adequada e suficiente, segundo princípio da motivação, que garanta o direito ao contrário e ampla defesa do agente econômico. Deve haver elementos de convicção nos autos que direcionem à conclusão de ilegitimidade da conduta, de uma prática predatória ou abusiva, nos termos já discutidos acima.

Tal inversão, segundo entendemos, se faz permissiva no nosso ordenamento jurídico em razão ainda da assimetria informacional que existe nas modalidades de abuso. É claro que um dos principais desafios que a autoridade da concorrência enfrenta para identificar uma concorrência no mérito é a assimétrica e falta de informação. As estruturas de custos e os preços, bem como a política comercial mais ampla da empresa, tendem a não ser transparentes. Da mesma forma que devem, em grande parte, provir dos investigados, o que reduz os incentivos a qualquer contribuição. Além disso, informações sobre a dinâmica do mercado e detalhes da disputa concorrencial raramente são bem compreendidos pelas autoridades e precisam ser incorporados à análise.

Uma inversão do ônus probatório da autoridade para as próprias empresas investigadas, uma vez que estas possuem mais informações sobre sua estrutura de custo, preço e da própria eficiência de seu modelo econômico, da dinâmica do mercado e dos parâmetros de concorrência, permitiria uma inversão dos incentivos de produção destes 
elementos comprobatórios ou excludentes da desconfiança de ilegitimidade das condutas. Cuida, portanto, da questão da assimetria informacional para avaliação do caso.

Portanto, a proposição ora formulada passa por autorização da aplicação da presunção relativa de efeitos anticompetitivos, uma vez que a autoridade concorrencial, em sua análise da conduta, segundo os testes ora sugeridos para as modalidades em comento, entenda haver fortes indícios de efeitos anticompetitivos. A teoria da responsabilidade especial dos agentes em posição dominante é aplicada diretamente no instituto jurídico do ônus probatório, invertendo-o em favor da autoridade, porém dependente da indispensável verificação da condição da ação ora tratada.

Importante ressaltar que não se trata da criação de qualquer regra per se ou de conduta por objeto que independe da produção de efeitos, mas sim de real inversão do ônus probatório decorrente do dever especial que é suportado pelos agentes econômicos com posição dominante. Vale lembrar que já defendemos a impossibilidade de regras per se no sistema jus-concorrencial brasileiro, em especial com relação à teoria do abuso de posição dominante, no sentido da necessária comprovação da lesividade de uma conduta, ainda que potencial.

Devemos considerar também os riscos decorrentes desta responsabilidade de autoavaliação dos efeitos de cada conduta por parte dos agentes econômicos. Primeiramente, o agente dominante pode não ter incentivos para uma autoaplicação das normas ou mesmo recusar-se a fazê-lo. Justamente por este fator é que a criação de uma presunção relativa pode trazer significativos incentivos de autoaplicação das normas de defesa da concorrência.

Segundo, a própria empresa poderia cometer algum erro tipo I ou II, uma vez que ela própria carrega alguma medida de assimetria informacional, principalmente com relação aos seus concorrentes, e poderia avaliar de forma imprecisa as condições da conduta. Essa visão distorcida poderia decorrer ainda de uma interpretação mais ou menos ampla dos limites trazidos pela norma concorrencial. Acresça-se a tais fatores a necessidade de manutenção de um sistema norteador de condutas praticadas, o qual veríamos, de certa forma esvaziado, em decorrência da ausência ou diminuição de investigações e decisões por parte das autoridades públicas.

Um exemplo de uma bem-sucedida política de autoavaliação, como já brevemente mencionada, foi a edição da Regulação da Modernização Europeia. ${ }^{614}$ A questão dos

${ }^{614}$ Regulação da Comissão Europeia n. 1/2003. 
recursos disponíveis, ou mais precisamente indisponíveis, para movimentação da máquina pública, bem como as prioridades estabelecidas pelos diversos sistemas jurídicos, são de relevância singular neste sentido.

Em linha com o exposto acima concluem Pierre Larouche e Maarten Pieter Schinkel:

In this respect, the special responsibility of dominant firms under Article 102 TFEU might find the most meaning when it is explained in institutional terms. Indeed, on substance, the special responsibility does not usually add much to the analysis.

(...)

When seen as a signal to dominant firms that they are expected to contribute actively to enforcement by selfassessing their conduct, however, it is sensible to mention that special responsibility time and again, to emphasize that dominant firms are expected to internalize the substantive analysis set out by the competition authority. ${ }^{615}$

Não cogitarmos de uma autoaplicação completa da norma sem que haja a devida tutela do ambiente concorrencial por parte das autoridades, o que nos parece bastante utópico. Contudo, em vista da responsabilidade especial que lhes é imposta, e do dever institucional que possui de maior cuidado na avaliação de efeitos de suas políticas comerciais em razão da posição de domínio que exerce, restaria justificada a adoção de uma presunção relativa de ilegitimidade da conduta, observadas as condições de ação, e cabendo aqui inversão do ônus probatório da conduta ilegítima. ${ }^{616}$

Alguma dificuldade talvez se estabeleça em razão da legislação brasileira punir a potencialidade lesiva da conduta. As autoridades devem ter bastante claro o padrão probatório apropriado que permita, efetivamente, aos agentes econômicos, demonstrarem que sua conduta não produziu efeitos anticompetitivos no período investigado, e ainda que

\footnotetext{
${ }^{615}$ LAROUCHE, Pierre e SCHINKEL, Maarten Pieter. Continental Drift in the Treatment of Dominant Firms: Article 102 TFUE in Contrast to $§ 2$ Sherman Act, cit., p. 14.

${ }^{616}$ Idem, ibidem, p. 13: "In fact, viewing the special responsibility of the dominant firm in institutional terms helps to explain two recent cases where such responsibility was more central to the reasoning, namely Deutsche Telekom (price squeeze) and AstraZeneca. In both cases, the Commission faulted the dominant firm for its conduct in regulatory processes, invoking its special responsibility under Article 102 TFEU. In Deutsche Telekom, the German telecommunications regulatory authority had approved a set of wholesale and retail tariffs for DT, which put its competitors in a price squeeze. The Commission found that DT could not rely on the regulatory outcome, and that its special responsibility under competition law dictated that it go back to the authority to petition for new tariffs in order to remove the price squeeze. In AstraZeneca, AZ systematically took the most favorable interpretation possible of medicines regulation, in order to extend its patents to the maximum. The Commission found, here as well, that AZ's special responsibility should have led it to take a more mainstream interpretation, to avoid excluding potential competitors. While on substance both cases seem to take the special responsibility of the dominant firm very far, from an institutional perspective the reference to the special responsibility underscores that these two dominant firms were bound to continue to self-assess their conduct, even when regulation came in the picture."
} 
sua conduta não permitiria, ainda que potencialmente, a produção destes efeitos. Novamente nos remeteríamos à teoria do abuso de posição dominante desenvolvida, para as modalidades tratadas.

A responsabilidade especial funcionaria para aquelas situações de dominância, bem como às situações identificadas envolvendo superdominância de agentes econômicos quase monopolistas, em que abusos se tornam mais prováveis de acontecerem. Tais situações foram identificas, por exemplo, nos tratados casos Tetra Pak, ${ }^{617}$ Compagnie Maritime Belge, ${ }^{618}{ }^{2} S^{619}$, Deutsche Post $A G^{620}$ e Microsoft. ${ }^{621}$

Richard Whish identifica a discussão em pauta, no contexto de situações envolvendo infraestruturas essenciais, e reconhecendo que a expressão superdominância ensejaria uma responsabilidade ainda maior, não tendo sido referida expressão ainda utilizada ainda pelos tribunais europeus e tampouco pela própria Comissão:

\begin{abstract}
The idea that firms with a position of dominance approaching a monopoly may be subject to particularly onerous responsibilities would also help to explain why firms that control "essential facilities" have an obligation in certain circumstances to provide access to them, since their market power is particularly strong. It may be helpful, therefore, to identify a concept over and above dominance, that we might call "superdominance" where the risks of being found to be acting abusively are correspondingly higher: if a dominant undertaking has a "special" responsibility, a super-dominant has one that is even greater. The expression super-dominance has not been used by the Community Courts, nor by the Commission, and it remains to be seen whether is will be. ${ }^{622}$
\end{abstract}

Não nos parece, contudo, que existam níveis de participação a se considerar, de forma universal, a partir do qual possa resultar uma responsabilidade "mais" especial para o agente com posição quase monopolista. A análise que deve ser feita implica a avaliação dos mesmos elementos encontrados na análise dos abusos de posição dominante, sem qualquer diferenciação. O mesmo se diga com relação à aplicação da teoria das responsabilidades especiais.

Por certo que, em razão do poder de mercado verificado em tais situações de superdominância, as chances de produção de efeitos excludentes de concorrência são

${ }^{617}$ Acórdão do Tribunal (Quinta Secção) de 14 de novembro de 1996. Processo C-333/94 P. Tetra Pak International SA contra Comissão das Comunidades Europeias.

${ }^{618}$ Acórdão do Tribunal (Quinta Secção) de 16 de março de 2000, Processos apensos C-395/96 P e C-396/96 P, Compagnie Maritime Belge Transports SA (C-395/96 P), Compagnie Maritime Belge SA (C-395/96 P) e Dafra-Lines A/S (C-396/96 P) c. Comissão das Comunidades Europeias.

${ }^{619}$ Decisão da Comissão Europeia de 3.7.2001, IV/38.044 - NDC Health/IMS Health: Interim measures.

${ }^{620}$ Decisão da Comissão Europeia de 25.7.2001, IV/ 36.915 - Deutsche Post AG - Intercepção de correio transfronteiriço.

${ }^{621}$ Vide SPEECH/07/539, 17 de setembro de 2007.

${ }^{622}$ WHISH, Richard. Competition Law, cit., p. 185. 
exponencializadas; porém devem restar demonstrados os mesmos elementos de convicção da prática ilegítima, seja qual for a participação de mercado do agente quase monopolista. Evidências a serem apresentadas por agentes econômicos em posição de superdominância deverão ser tanto mais robustas quanto seu poder monopolista verificado, na exata proporção necessária para que sejam afastadas quaisquer preocupações relativas a mais alta probabilidade de exercício abusivo, segundo os parâmetros apresentados. Isso porque qualquer avaliação de potencialidade de fechamento do mercado encontra-se diretamente relacionada com o grau de poder de mercado.

\subsection{Defesas Disponibilizadas aos Agentes com Posição Dominante}

Verificada a existência das responsabilidades especiais e avaliada sua extensão para as mais variadas condutas e situações, deve ser aplicada a teoria dos abusos de posição dominante acima discutida para o exercício inicial de avaliação das condições de ação por parte das autoridades. Igualmente, deve ser utilizada a própria teoria como parâmetro para a demonstração da legitimidade das condutas praticadas pelos agentes econômicos com posição dominante. Com base na teoria ventilada, devemos ainda tentar a customização dos elementos específicos a serem verificados para configuração de cada modalidade de abuso, ainda que para tal exercício possamos nos socorrer de alguns conceitos mais universais desenvolvidos ao longo do presente trabalho.

O mesmo deve ser observado para práticas resultantes de dominância coletiva, quando possível a demonstração de uma atuação conjunta de empresas que, individualmente, seriam simplesmente reconhecidas como tomadoras de preços.

Caracterizada a responsabilidade especial, percorrida a análise procedimental de condição de ação por parte das autoridades e autorizada a inversão do ônus probatório, caberia ao agente com posição dominante a apresentação de sua defesa, a fim de expurgar a desconfiança acerca da ilegitimidade da conduta.

Repisemos ainda a posição alcançada de que a concorrência é um valor institucional a ser protegido. A concorrência é, assim, sempre desejável, mesmo em algumas situações de monopólios naturais, se demonstrado que o arranjo competitivo pode trazer benefícios ulteriores aos consumidores finais. Os valores da concorrência, neste sentido, não admitem, em especial, o abuso de poder econômico. Seria tarefa mínima da 
regulação garantir as condições básicas de concorrência, de forma ativa, em especial diante da existência de condições estruturais que impeçam o estabelecimento da concorrência.

Temos aqui que o contraponto da responsabilidade especial seria o limite da permissibilidade de suas condutas, a ser avaliada por cada agente econômico em posição dominante segundo a dinâmica concorrencial do seu mercado de atuação. A eficiência deve representar um destes limites de atuação. Uma empresa em posição dominante poderia justificar seu comportamento com base em ganhos de eficiência que sejam suficientes para tornar pouco provável um prejuízo aos consumidores.

Igualmente, temos como limite a ser igualmente considerado o direito à livre concorrência, sem interferências artificiais que venham de alguma forma distorcer as pressões concorrenciais existentes nos mercados, consequentemente com a criação ou manutenção de uma igualdade material entre todos os agentes econômicos, para que possam desenvolver suas atividades em iguais condições.

E diversos seriam os fatores a se considerar neste sentido. De toda análise proferida, podemos elencar a necessária demonstração que a conduta implicou ou implicará a concretização de ganhos de eficiência, não devendo existir alternativas menos anticompetitivas que permitam produzir os mesmos ganhos. Ainda, os ganhos de eficiência gerados pelo comportamento devem compensar os efeitos negativos sobre a concorrência e bem-estar dos consumidores, não devendo ainda o comportamento em questão eliminar concorrência efetiva, através da supressão de todas ou parte das fontes atuais ou potenciais de concorrência.

Eventuais efeitos deletérios da conduta praticada não deve alterar a estrutura da concorrência no mercado em questão, de forma a dificultar a atuação de concorrentes não dominantes. Recordemos o binômio trazido pela inovação: produção e implementação. Assim, não se deve admitir defesa de eficiência que traga perda líquida de bem-estar social ao consumidor.

Neste sentido, cabe recordar que o próprio acesso ao produto e sua possibilidade de escolha pelo consumidor representa, em si, valor de significância ao direito da concorrência, especialmente quando nos filiamos à tese de que sempre haverá incentivos à inovação em ambientes de concorrência. O mercado, ou as autoridades encarregadas de tutelarem seu funcionamento diante de falhas de mercado, deve sempre regrar as relações de concorrência de forma a aproximá-las de uma concorrência perfeita. Por sua vez, os agentes econômicos tenderão sempre a buscar a diferenciação e um isolamento na percepção do consumidor com relação ao seu produto, como algo diferenciado e, portanto, 
justificador de um preço supracompetitivo. Este é o princípio universal que rege a relação entre administrador e administrados, e entre concorrentes.

Portanto, nos quer parecer que o sistema jus-concorrencial brasileiro encontra-se alinhado com uma preocupação mais sistêmica de preservação das estruturas de concorrência do mercado, além, obviamente, do ulterior benefício ao consumidor, a exemplo do que verificamos na União Europeia. Permitir-se livre atuação, seja na entrada ou manutenção de concorrência residual, parece uma situação apropriada para, tentativamente, promover-se equiparação das forças competitivas. Sem interferências o funcionamento do mercado, o melhor produto ou serviço, segundo uma concorrência no mérito, deverá prevalecer, ou ao menos, deverão ter claramente definidos seus nichos de consumo.

Posta a regra geral que deve ser perseguida pelos agentes econômicos com posição dominante para demonstração da concorrência no mérito resultante de suas condutas comerciais, devemos considerar outras situações mais pontuais. Destarte, questão intensamente discutida na doutrina se baseia no conceito da equiparação de concorrência ("meeting competition"). Vale recordar que no Discussion Paper elaborado pela Comissão Europeia se discutem tais critérios, tendo sido estabelecido que uma defesa somente se aplicaria a abusos que, de outra maneira, constituiriam abusos de preços, e que só deveriam se aplicar a comportamentos unilaterais e não coletivos:

The Community Courts have considered that defending its own commercial and economic interests in the face of action taken by certain competitors may be a legitimate aim. In other words, to minimize the short run losses resulting directly from competitors' actions can be a legitimate aim. ${ }^{623}$

Tal implicaria dizer que uma justificativa objetiva não seria possível se a empresa dominante não fosse capaz de mostrar que sua conduta configura-se como clara resposta à redução de preços praticados por seus concorrentes, ou caso as autoridades sejam capazes de demonstrar que o objetivo da conduta seria o fechamento direto da concorrência.

$\mathrm{Na}$ linha das discussões sobre as justificativas objetivas acima tratadas vem o teste de proporcionalidade exigido pelo Tribunal, em que a empresa deveria provar que sua conduta seria uma forma apropriada de atingir um fim legítimo. Assim, uma justificativa objetiva não seria possível se, por exemplo, a conduta também envolvesse investimento

${ }^{623}$ DG Competition Discussion Paper on the Application of Article 82 of the Treaty to Exclusionary Abuses. Brussels, 2005. 
adicional em capacidade, mas que não viesse a proporcionar redução de perdas em decorrência da ação de seus concorrentes, configurando-se irracional sobre o ponto de vista econômico.

Um agente econômico poderia, desta forma, justificar seu comportamento afirmando que fora forçado a esta conduta, a fim de minimizar as perdas que sofreria decorrente da competição de seus rivais. Vale notar que, de acordo com a lei antitruste norte-americana, empresas dominantes poderiam defender-se, simplesmente, afirmando a probabilidade de transferência de eficiências aos consumidores, os quais não seriam os ulteriores lesados pela sua conduta.

Sob os parâmetros acima elencados, agentes dominantes não estariam impedidos de tomar medidas razoáveis para proteção de seus próprios interesses comerciais, devendo agir, contudo, de forma proporcional à sua força. Neste sentido declarou o Tribunal de Justiça europeu: "Even if the possibility of a counter-attack is acceptable that attack must still be proportionate to the threat taking into account the economic strength of the undertakings confronting each other". ${ }^{624}$ Portanto, não deve haver impedimento para que empresa dominante tome os devidos passos para proteção de seus investimentos e seus mercados, contudo, que não gerem perda de bem-estar social ao consumidor, inclusive no tocante à proteção das estruturas de mercado, e que estes passos sejam proporcionais à sua força.

$\mathrm{Na}$ sua tarefa de refutar uma presunção operada de abusividade de sua prática comercial, além da demonstração da proporcionalidade de sua conduta, a empresa dominante deve ainda demonstração que sua conduta é indispensável, ou seja, que seus efeitos não poderiam ser atingidos na extensão pretendida por qualquer alternativa menos restritiva, e que a conduta seria limitada no tempo ao seu mínimo absoluto.

No exemplo europeu, sugerem-se ainda considerações sobre eventuais precificações predatórias, devendo-se avaliar se estas se situam abaixo de certa medida de custo e que, desta forma, não justificariam uma defesa de equiparação de concorrência. Caso não se situe abaixo da medida de custo em questão, se preenchidas as demais condições poder-se-ia reputar justificada a conduta praticada. ${ }^{625}$

Uma questão identificada e que persiste seria eventual concorrência predatória por parte de um agente não dominante no mercado, promovida por empresa ou grupo com

\footnotetext{
${ }^{624}$ United Brands v Commission [1978] ECR 207, parág. 190; cf. BBI/Boosey \& Hawkes: Interim Measures [1987] OJ L286/36, [1988] 4CMLR 67.

${ }^{625}$ DG Competition Discussion Paper on the Application of Article 82 of the Treaty to Exclusionary Abuses. Brussels, 2005.
} 
capacidade ampla de financiamento. Nesta situação não se poderia cogitar de poder de mercado por parte do praticante da conduta, o que, em princípio, sugeriria ausência de potencialidade lesiva. Contudo, a prática financiada poderia implicar ulteriormente na redução de participação de mercado do agente mais eficiente, devendo assim ser tratada pontualmente, ainda que não se possa reconhecer racionalidade na conduta do agente não dominante.

Diante desta situação, deveria merecer o agente mais eficiente 'autorização' para extrapolar os parâmetros de sua própria eficiência a fim de promover equiparação de forças competitivas no mercado, sem prejuízo da punição do agente econômico com alto poder de financiamento da conduta, porém não possuidor de poder de mercado. Tratar-se-ia de prática de entrada predatória ineficiente de curto prazo amparada em alto poder de financiamento, mas potencialmente lesiva no médio ou longo prazo. 


\section{BIBLIOGRAFIA}

ADAMS, William James; YELLEN, Janet L. Commodity Bundling and the Burden of Monopoly. Q.J. of Econ., vol. 90, n. 3, 1976, p. 475.

AGUILAR, Fernando Herren. Direito Econômico. Do Direito Nacional ao Direito Supranacional. 1. ed. São Paulo: Atlas, 2006.

AHLBORN, Christian; ALLAN, Bill. The NAPP Case: A study of Predation? World Competition. Vol. 26. No. 2. 2003, p. 233.

AHLBORN, Christian; BAILEY, David. Discounts, Rebates and Selective Pricing by Dominant Firms: A Trans-Atlantic Comparison. European Competition Journal. Vol. 2. N. Special Issue, 2006, p. 101.

AKMAN, Pinar. Searching for the Long-Lost Soul of Article 82EC. Oxford Journal of Legal Studies (2009).

ALMEIDA, Marcus Elidius Michelli de. Abuso do Direito e Concorrência Desleal. São Paulo: Quartier Latin, 2004.

ARAUJO, Luiz Alberto David. Curso de Direito Constitucional. São Paulo: Saraiva, 1998.

AREEDA, Phillip. Essential Facilities: An Ephithet in Need of Limiting Principles. Antitrust L.J. Vol. 58. No. 4, 1990, p. 841.

The changing contours of the per se rule. v. 54. 1985.

ASCARELli, Túlio. Abuso de poder econômico - Agrupamento de empresas Concorrência - Sociedade por quotas - Gestão de negócios - Ratificação. Revista Forense, p. 61-73, 1949.

ASQUINI, Alberto. Perfis da Empresa. Trad. port. de Fábio K. Comparato. Revista de Direito Mercantil 104 (1996). 
AZEVEDO, Paulo Furquim de; FARINA, Elizabeth Maria Mercier Querido; SAES Maria Sylvia Macchioni. Competitividade: mercado, Estado e organizações. São Paulo: Singular, 1997.

BAGATIN, Andreia Cristina. Price Squeeze e os mercados recém-liberados. Boletim de Ciências Econômicas, vol. XLX, 2007.

BAILEY, Davide. Standard of Proof in EC Merger Proceedings: A Common Law Perspective. CML Review, vol. 40, n. 4, 2003.

BALDWIN, CAVE e LODGE. The Oxford Handbook of Regulation. Oxford Univ. Press, 2010.

BARBIERI FILHO, Carlo. Disciplina jurídica da concorrência: abuso do poder econômico. São Paulo: Resenha Tributária, 1984.

BAUMOL, William J. Predation and the Logic of the Average Variable Cost Test. J.L. \& Economics, vol. XXXIX, 1996.

BECKER, Gary. Nobel Lecture: The Economic Way of Looking at Behavior. Journal of Political Economy. University of Chicago Press, 1993, vol. 101(3), p. 385-409.

BOBBIO, Norberto. Teoria do Ordenamento Jurídico. Brasília: Universidade de Brasília, 1996.

BORK, Robert H. The antitrust paradox: a policy at war with itself. New York: Basic Books, 1978.

BOWMAN, Ward. Tying Arrangements; Patent and Antitrust Law - A Legal and Economic appraisal. Chicago: University of Chicago Press, 1973.

BUCCI, Maria Paula Dallari. O Conceito de Política Pública em Direito. In BUCCI, Maria Paula Dallari (org.). Políticas Públicas: Reflexões sobre o conceito Jurídico. São Paulo: Saraiva, 2006.

BUCHAIN, Luiz Carlos. O Poder Econômico e a Responsabilidade Civil Concorrencial. Porto Alegre: Nova Prova, 2006. 
CAMPILONGO, Celso Fernandes; ROCHA, Jean Paul Cabral Veiga. Concorrência e Regulação no Sistema Financeiro. São Paulo: Max Limonad, 2002.

CANOTILHO, José Joaquim Gomes; MOREIRA, Vital. Fundamentos da Constituição. Coimbra: Coimbra, 1991.

CARLTON, Dennis W.; WALDMAN, Michael. The Strategic Use of Tying to Preserve and Create Market Power in Evolving Industries. Rand J. of Econ., vol. 33, 2002.

CARLTON, Dennis W.; PERLOFF, Jeffrey M. Modern Industrial Organization. 3. ed. Addison Wesley Longman.

CARSTENSEN, Peter C. Remedying the Microsoft Monopoly: Monopoly Law, the Rights of Buyers, and the Enclosure Movement in Intellectual Property. Antitrust Bull., vol. XLIV, n. 3, 1999.

CARVAlHOSA, Modesto. Comentários à Lei de Sociedades Anônimas. 4. ed. São Paulo: Saraiva, 2008. v. 2.

CHIRILlO, Eduardo J. Rodríguez. Privatización de la empresa pública y post privatización: analysis jurídico. Buenos Aires: Abeledo-Perrot, 1995.

COASE, Robert. The Nature of the Firm. Economica, N.S., vol. 4, n 16, 1937, p. 386.

COELHO, Fábio Ulhoa. Direito Antitruste Brasileiro: Comentários à Lei 8.884/94. São Paulo: Saraiva, 1995.

Lógica Jurídica: uma introdução. São Paulo: EDUC, 1992.

COHEN, William E. Competition and Foreclosure in the Context of Installed Base and Compatibility Effects. Antitrust L.J., vol. 64, n. 3, 1996.

COMANOR, William S. Is there a Consensus on the Antitrust Treatment of Single Form Conduct?, 2007.

COMPARATO, Fabio Konder. Função Social da Propriedade dos Bens de Produção. In Revista de Direito Mercantil Industrial Econômico Financeiro. São Paulo: Ed. Revista dos Tribunais. Ano XXV (Nova Serie). n. 63. julho/setembro de 1986. 
COMPARATO, Fábio Konder. Direito público: estudos e pareceres.

COMPARATO, Fabio K.; SAlOMÃO, Calixto. O Poder de Controle na Sociedade Anônima. 5. ed. Rio de Janeiro: Forense, 2008.

COPI, Irwing. Introdução à Lógica. Tradução de Álvaro Cabral. São Paulo: Mestre Jou, 1981.

COPPI, Lorenzo. Aftermarket monopolization: the emerging consensus in economics. Antitrust Bull, vol. 52, n. 1, 2007.

DALLARI, Dalmo de Abreu. Elementos da teoria geral do estado. 11. ed. São Paulo: Saraiva, 1985.

DEMARET, Paul. Patents, Territorial Restriction, and ECC Law. Weinheim: Verlag Chemie, 1978. v. 2.

DENOZZA, Francesco. Antitrust: leggi antimonopolistiche e tutela dei consumatori nella CEE e negli USA. Bologna: Il Mulino, 1988.

DIKSON, Peter R. Evolutionary theories of competition and aftermarket antitrust law. Antitrust Bull., vol. LII, n. 1, 2007.

DOLMANS, Mauritis; GRAF, Thomas. Analysis of Tying Under Article 82 EC: The European Commission's Microsoft Decision in Perspective. World Competition, vol. 27, n. 2, 2004.

DUTRA, Pedro. Conversando com o CADE. São Paulo: Singular, 2009.

EASTERBROOK, Frank H. When is it Worthwhile to use Courts to Search for Exclusionary Conduct. Colum. Bu. L. Rev., n. 2, 2003.

EASTERBROOK, Frank H. On Identifying Exclusionary Conduct. 61 Notre Dame L. Rev. 972. 1986.

ECONOMIDES, Nicholas. The Economics of Networks. Int. J. Ind. Organ., vol. 14, n. 6, 1996.

ECO, Umberto. Como se faz uma tese. 14. ed. São Paulo: Editora Perspectiva, 1977. 
EDLIN, Aaron S. Stopping. Above-Cost Predatory Pricing, Yale L. J, vol. 111. No. 4, 2002.

EVANS, David. Lightening Up on Market Definition. In Research Handbook on the Economics of Antitrust Law. New York: Edward Elgar, 2011.

(org.). Microsoft, Antitrust and the New Economy: Selected Essays. Boston: Kluwer Academic Publishers, 2002.

; PADILLA, Atilano Jorge. Tying Under Article 82 EC and the Microsoft Decision:

A Comment on Dolmans and Graf. World Competition, vol. 27, n. 4, 2004.

FAGUNDES, Jorge. Fundamentos Econômicos das Políticas de Defesa da Concorrência - Eficiências Econômicas e Distribuição de Renda em Análises Antitrustes. São Paulo: Editoria Singular, 2003.

FARINA, Elizabeth Maria Mercier Querido; AZEVEDO, Paulo Furquim de; SAES, Maria Sylvia Macchione. Competitividade: Mercado, Estado e Organizações. São Paulo: Singular, 1997.

FARRELL, Joseph; KATZ, Michael L. The Effects if Antitrust and Intellectual Property Law on Compatibility and Innovation. Antitrust Bull., vol. XLIII, n. 3-4, 1998.

FEDERICO, Giulio. When are Rebates Exclusionary. E.C.L.R., vol. 26, n. 9, 2005.

FERRAZ JR., Tércio Sampaio. Da abusividade do poder econômico. Revista de Direito Econômico 21/23.

Introdução ao Estudo do Direito. São Paulo: Atlas, 1991.

FERREIRA, Waldemar Martins. História do Direito Constitucional Brasileiro. São Paulo: Max Limonad, 1954.

FONSECA, João Bosco Leopoldino da. Direito Econômico. 5. ed. Rio de Janeiro: Forense, 2007.

(org.). Temas de Direito da Concorrência. Belo Horizonte: Faculdade de Direito UFMG, 2005. 
FORGIONI, Paula A. Direito Concorrencial e Restrições Verticais. São Paulo: Revista dos Tribunais, 2007.

Os Fundamentos do Antitruste. São Paulo: Ed. Revista dos Tribunais. 3. ed. 2008 / 6. ed. 2013.

Análise econômica do direito: paranoia ou mistificação. Revista de Direito Mercantil Industrial, Econômico e Financeiro, v. 139.

A evolução do direito comercial brasileiro: da mercancia ao mercado. São Paulo: Ed. Revista dos Tribunais, 2009.

FOX, Eleanor M. In Search of a Competition Law Fit for Developing Countries. Law \& Economics Research Paper Series. Working Paper No. 11-04. 2001.

Monopolization, Abuse of Dominance, and the Indeterminacy of Economics: The US/EU Divide. Utah Law Review 725, 2006.

. Is There Life in Aspen After Trinko? The Silent Revolution of Section 2 of the Sherman Act. Antitrust L.J. vol. 73, n. 1, 2005, p. 153.

FRANCESCHINI, Jose Ignácio Gonzaga. Introdução ao Direito da Concorrência. Revista de Direito Econômico 21/88.

Disciplina jurídica do abuso do poder econômico. RT 640/255-262, fev. 1989.

; FRANCESCHINI, José Luiz Vicente de Azevedo. Poder Econômico: Exercício e Abuso. Direito Antitruste Brasileiro. São Paulo: Ed. Revista dos Tribunais, 1985.

FREITAS, Herculano de. Direito Constitucional. São Paulo: s.c.p., 1965.

FRIEDMAN, David D. Law's Order. Princeton, 2000. C. 2.

GABAN, Eduardo Molan; DOMINGUES, Juliana Oliveira (coords.). Estudos de Direito Econômico e Economia da Concorrência. Curitiba: Editora Juruá, 2009.

GARCIA PÉREZ, Mercedes. Collective Dominance Under the Merger Regulation. E.L.Rev., vol. 23, n. 5, 1998. 
GEISST, Charles R. Monopolies in America - Empire Builders and Their Enemies from Jay Gould to Bill Gates. Oxford: Oxford Univ. Press, 2000.

GERADIN, Damien. Limiting the scope of Article 82 EC: What can the EU learn from the US Supreme Court's judgement in Trinko in the Wake of Microsoft, IMS and Deutsch Telekom? C.M.L. Rev., vol. 41, n. 6, 2004.

The Decision of the Commission of 13 May 2009 in the Intel Case: where is the Foreclosure and Consumer Harm. Versão eletrônica disponível em http://www.intel.com/pressroom/legal/docs/Damian_paper.pdf.

GEROSKI, Paul; GRIFFITH, Rachel. Identifying Anti-Trust Markets. In: NEUMANN, M.; WEIGAND, J. (eds.). International Handbook of Competition. Edward Elgar, 2003.

GILBERT, Richard J.; SHAPIRO, Carl. Unilateral refusals to licence intellectual property and international competition policy. In HOPE, Einar; MAELENG, Per (orgs.). Competition and Trade Policies - Coherence or conflict? Londres: Routledge, 1998.

GILBERTO, André Marques. O Processo Antitruste Sancionador - Aspectos Processuais na Repressão das Infrações à Concorrência no Brasil. São Paulo: Lex Editora, 2010.

GOldBerg, Daniel K. Poder de Compra e a Política Antitruste. São Paulo: Singular, 2006.

GRAU, Eros Roberto. A ordem econômica na Constituição de 1988. 15. ed. São Paulo: Malheiros, 2012.

Direito, conceitos e normas jurídicas. São Paulo: RT, 1988.

Elementos de direito econômico. São Paulo: RT, 1981.

; FORGIONI, Paula A. Lei Antitruste e leis que autorizam práticas restritivas de concorrência. A Lei Ferrari. O Estado, a empresa e o contrato. São Paulo: Malheiros, 2005 .

A ordem econômica na Constituição de 1988. 3. ed. São Paulo: Malheiros. 
Elementos de direito econômico. São Paulo: RT, 1981.

GRINOVER, Ada Pellegrini. O controle de políticas públicas pelo Poder Judiciário. Revista Brasileira de Estudos Constitucionais, Belo Horizonte, v. 2, n. 8, out. 2008.

HOVERNKAMP, Herbert. Antitrust. St Paul: West Publishing Co., 1986.

IP Ties and Microsoft's Rule of Reason. Antitrust Bull., vol. XLVII, n. 2\&3, 2002.

Federal Antitrust Policy. 3. ed. St. Paul. Minn. West Group, 2005.

IRTI, Natalino. L'ordine giuridico del mercato, 3. ed. Roma: Laterza, 1998.

JONES, Alison; SUFRIN, Brenda. EC Competition Law. Text, Cases, and Materials. 2. ed. London: Oxford University Press, 2004.

. Left Behind By Modernization? Restrictions by Object Under Article 101(1). European Competition Journal: at [2010] European Competition Journal 649.

KANT, Immanuel. Crítica da razão pura. Tradução de Manuela Pinto dos Santos e Alexandre Fradique Morujão. Lisboa: Calouste Gulbenkian, 1994.

KATZ, Michael L.; SHAPIRO, Carl; Network Externalities, Competition and Compatibility. American Economy Review, vol. 75, n. 3, 1985.

KAYSEN, Carl; TURNER, Donald. Antitrust Police, 1959.

KELSEN, Hans. Teoria Pura do Direito. Tradução de João Batista Machado. São Paulo: Martins Fontes, 2000.

KOLASKY, William. What is Competition? Department of Justice. Speech on October 28, 2002. Disponível em: <http://www.justice.gov/atr/public/speeches/200440.htm>.

KORAH, Valentine. Concept of a dominant position within the meaning of article 86. Commom Market Law Review, v. 17, n. 3, p. 395-414, ago. 1980. 
The Interface Between Intellectual Property and Antitrust: The European Experience. Antitrust L.J., vol. 69, n. 3, 2001, p. 801.

KRATTENMAKER, Thomas G.; e SALOP, Steven C. Anticompetitive Exclusion: Raising Rivals' Costs to Achieve Power Over Price. Yale Law Journal 209, 1986.

LANG, J. Temple; O’DONOGHUE, R. The Concept of an Exclusionary Abuse under Art. 82 EC. In GCLC Research Papers on Article 82, julho 2005.

LAROUCHE, Pierre; SCHINKEL, Maarten Pieter. Continental Drift in the Threatment of Dominant Firms: Article 102 TFUE in Contrast to $§ 2$ Sherman Act. In TILEC. Discussion Paper. Maio 2013. Disponível em: <http://ssrn.com/abstract=2293141>.

LEIBENSTEIN, Harvey. Allocative Efficiency vs. X-Efficiency. Am. Econ. Rev., vol. 56, n. 3, 1966, p. 392.

LEVY, Stephan M. Should 'Vaporware' Be an Antitrust Concern? Antitrust Bull., vol. XLII, n. 1, 1997, p. 33.

LIEBOWITS, Stan J.; MARGOLIS, Stephen. Network Externality: Na Uncommon Tragedy. J. Econ. Persp., vol. 8, n. 2, 1994.

MARSDEN, Philipp. Exclusionary Abuses and the Justice of "Competition on the Merits." Chapter 14. In The Reform of EC Competition Law: New Challenges, p. 411-418.

MATtOS, Cesar. A Revolução do Antitruste no Brasil - A Teoria Econômica Aplicada aos Casos Concretos 2. São Paulo: Singular, 2008.

MCMAHON, Kathryn. Interoperability: Indispensability and Special Responsibility. In High Technology Markets. Tulane Journal of Technology \& Intellectual Property. Vol. 9, 2007. Cópia eletrônica disponível em: <http://ssrn.com/abstract=1523146>.

MENDES, Gilmar Ferreira; BRANCO, Paulo Gustavo Gonet. Curso de Direito Constitucional. 9. ed. Brasília: Saraiva, 2013.

MOURA E SILVA, Miguel. O Abuso de Posição Dominante na Nova Economia. Teses de Doutoramento. Coimbra: Almedina, 2010. 
NALEBUFF, Barry J. Bundling, Tying, and Portfolio Effects. Department of Trade and Industry Economics Paper n. 1, 2003.

NASH, J. The bargaining problem. In KUH, H. Classics in Game Theory. Econometrica, vol. $18,1950$.

NEUmann, J. Von; MORGEnSTERn, O. The Theory of Games and Economic Behaviour. Princeton University Press, 1944.

NORTH, Douglas. Institutions, Institutional Change and Economic Performance. Cambridge: Cambridge University Press, 1990.

OECD Policy Roundtables. Competition on the Merits, 2005.

OLIVEIRA, Gesner de. Direito e Economia da Concorrência. Rio de Janeiro: Renovar, 2004.

ØSTERUD, Eric. Identifying Exclusionary Abuses by Dominant Undertakings under EU Competition Law: The Spectrum of Tests. International Competition Law Series. Great Britain. Wolters Kluwer Law \$ Business. 2010.

PERLOFF, Carlton. Modern Industrial Organization. 3 Edition.

PITOFSKY, Robert. The Essential Facilities Doctrine Under the United States Antitrust Law.

POSNER, Richard A. Antitrust Law. 2. ed. Chicago e Londres: The University of Chicago Press, 2001.

Antitrust in the New Economy. Antitrust L.J., vol. 68, n. 3, 2001, p. 925.

. Economic analysis of Law. 4. ed. Boston: Little-Brown, 1992.

_. Essays in Law and Economics. In Michael Faure e Roger Van den Bergh (Eds.). 1989.

The economics of justice. Cambridge: Harvard University Press, 1983. 
PRADO JUNIOR, Caio. Formação do Brasil Contemporâneo; . História Econômica do Brasil.

RAMSEY, F.P. A Contribution to the Theory of Taxation. Econ. J., vol. 37, n. 1, 1927, p. 47.

RATHENAU, W. Vp, Aktienwesen, Eine geschaeftliche Betrachtung, Berlim, 1917; tradução italiana La Realtà della Società per Azioni.

RIBEIRO, Marcia Carla Pereira. Sociedade de economia mista e empresa privada. Curitiba: Juruá, 1999.

RULLI NETO, Antonio. Função Social do Contrato. São Paulo: Saraiva, 2011.

SAlOMÃO FILHO, Calixto. Direito Concorrencial - As estruturas. São Paulo: Malheiros, 2007.

Direito Concorrencial - As condutas. São Paulo: Malheiros, 2003.

Regulação e Concorrência - Estudos e Pareceres. São Paulo: Malheiros, 2002.

SCHERER, Ross. Industrial Market Structure and Economic Performance. 3. ed. Boston: Houghton Mifflin, 1990.

SCHUMPETER, Joseph A. Capitalism, Socialism and Democracy. 5. ed. Londres: Routledge, 1976.

History of Economic Analysis. Reimpressão da edição de 1954. Londres: Routledge, 1994.

SELZNICK, P. Focusing Organization Research on Regulation, Regulatory Policy and the Social Sciences (Berkley, CA, 1985), R. Noll (ed.) 363.

SILVA, Jose Afonso. Curso de Direito Constitucional Positivo. 34. ed. São Paulo: Malheiros, 2011. 
STIGLER, J. G.; SHERWIN, R. The extent of the market. Journal of Law and Economics, V.28, N. 3, p. 555-585, Oct. 1985.

SZTAJN, Rachel. Teoria Jurídica da Empresa: atividade empresária e mercados. São Paulo: Atlas, 2004.

Direito e Economia. In Revista de Direito Mercantil, vol. 144. Malheiros, 2006.

SUlLIVAN, Lawrence A.; GRIMES, Warren S. The Law of Antitrust. An Integrated Handbook. Saint Paul, Minn: West Group, 2000.

SUMMERS, Lawrence H.; Competition Policy in the New Economy. Antitrust Law Journal, vol. 69, n. 1, 2001, p. 353.

TALADAY, John M.; CARLIN, James N., Jr. Compulsory Licensing of Intellectual Property Under the Competition Laws of the United States and European Community. Geo. Mason L. Rev., vol. 11, n. 2, 2002, p. 442.

TEMPLE LANG, John. Monopolization and the Definition of Abuse of a Dominant Position Under Article 86 EEC Treaty. C.M.L. Rev., vol. 16, 1979, p. 345.

O’DONOGHUE, Robert. Defining Legitimate Competition: How to Clarify Pricing Abuses Under Article 82 EC. Fordham Int'l L.J., vol. 26, 2002, p. 83.

VATIERO, Massimiliano. Power in the Market: On the Dominant Position.

VILANOVA, Lourival. Lógica Jurídica. São Paulo: José Bushatsky, 1976.

Estruturas Lógicas e o Sistema no Direito Positivo. São Paulo: Max Limonad, 1997.

WARAT, Luiz Alberto. O direito e sua linguagem. Porto Alegre: Fabris, 1984.

WARLOUZET, Laurent. The Rise of European Competition Policy, 1950-1991: A CrossDsiciplinary Survey of a Contested Policy Sphere. EUI Working Papers. RSCAS 2010/80.

WHISH, Richard. Competition Law. 6. ed. Oxford: Oxford University Press, 2008. 
; BAILEY, David. Competition Law. 7. ed. Oxford: Oxford University Press, 2012.

WILKS, Stephen; Competition Policy - Towards an Economic Constitution. In WALLACE, Helen; POLLACK, Mark A.; YOUNG, Alasdair R (coord.). Policy-making in the European Union. Sixth Edition. Oxford Univesity Press.

YAZBEK, Otavio. Regulação do Mercado Financeiro e de Capitais. 2. ed. São Paulo: Elsevier, 2008.

ZANOTTA, Pedro. Desafios Atuais do Direito da Concorrência. 1. ed. São Paulo: Editora Singular.

ZYLBERSZTAJN, Décio; SZTAJN, Rachel (orgs.). Direito e Economia. Rio de Janeiro: Elsevier, 2005. 